

\section{THE UNIVERSITY}

\section{OF ILLINOIS}

\section{LIBRARY}

$$
\begin{aligned}
& 557 \\
& \text { C } 12 \\
& \text { v. } 2^{\prime}
\end{aligned}
$$


The person charging this material is responsible for its return to the library from which it was withdrawn on or before the Latest Date stamped below.

Theft, mutilation, and underlining of books are reasons for disciplinary action and may result in dismissal from the University.

To renew call Telephone Center, 333-8400

UNIVERSIS OF ILLINOIS LIBRARY AT URBANA-CHAMPAIGN

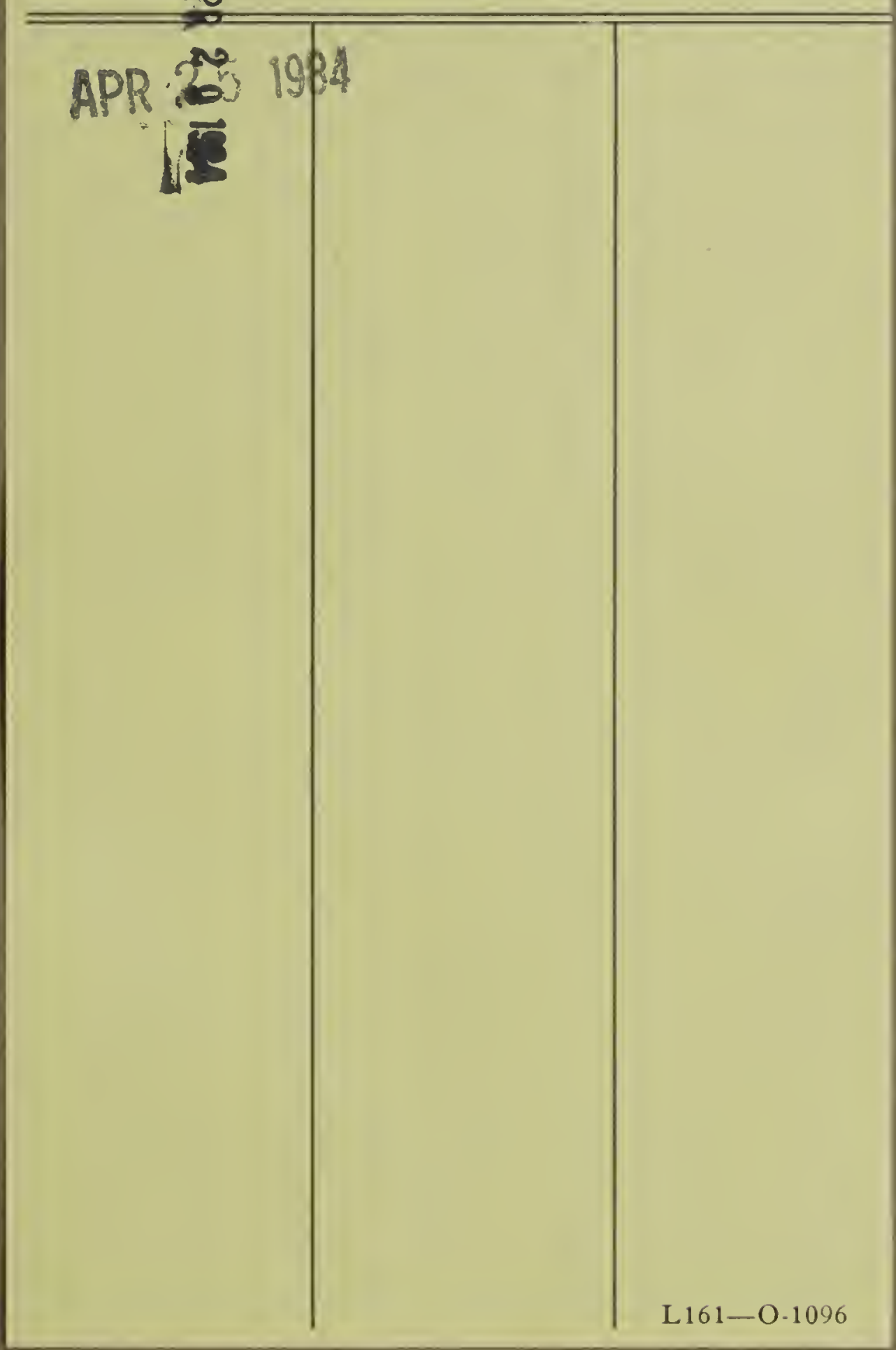


단.

in

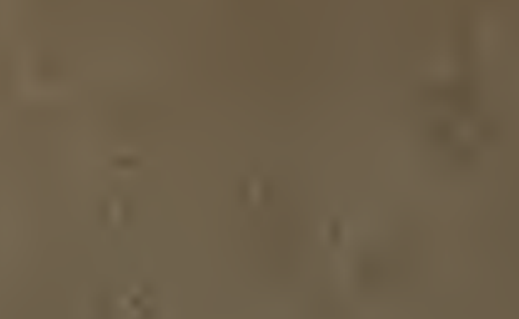

$$
\begin{aligned}
& 4
\end{aligned}
$$

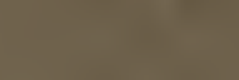

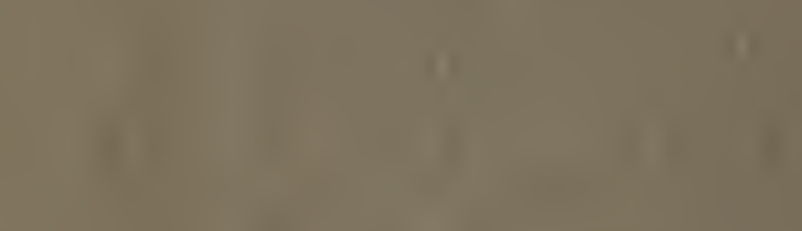

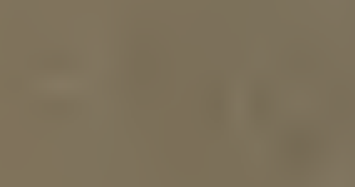

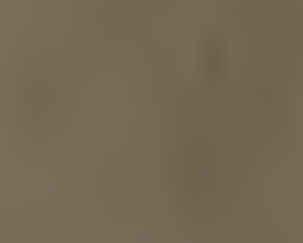

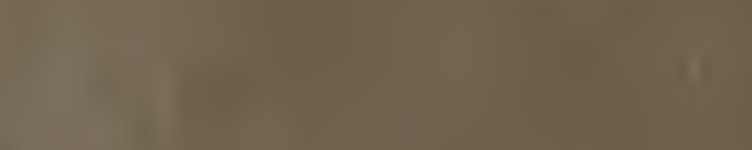

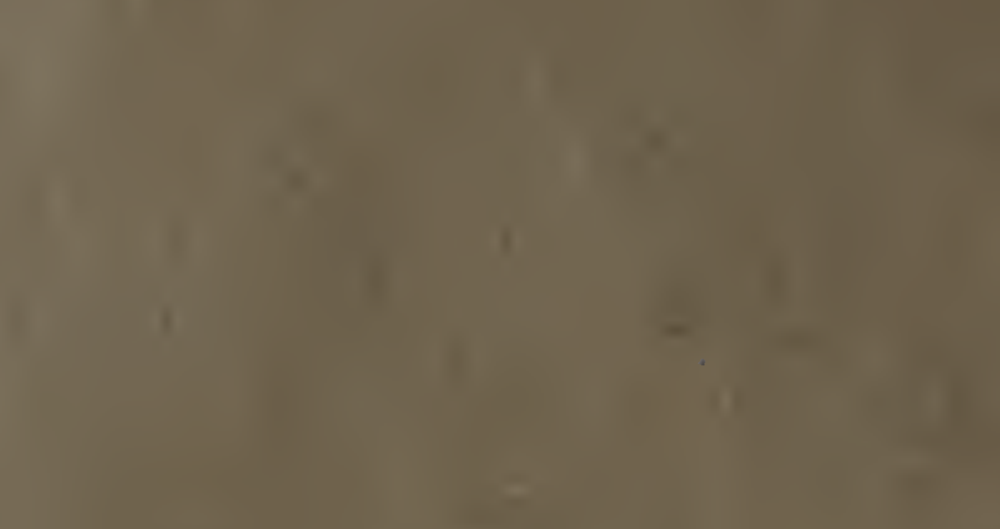$$
\text { - } 1 .
$$

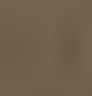

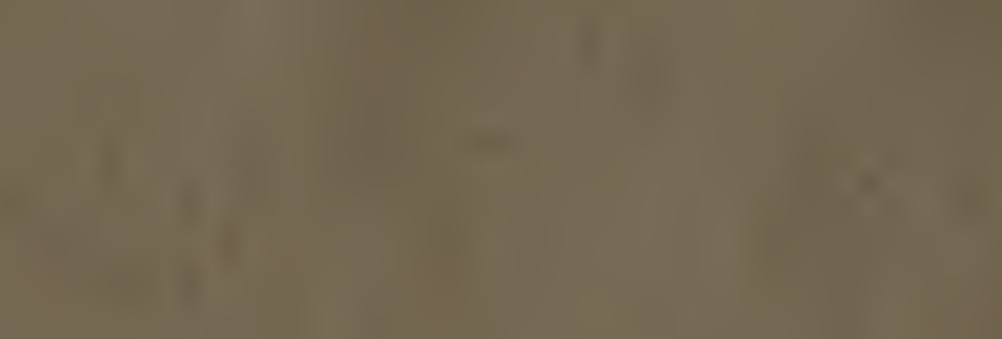$$
\text { a) }
$$$$
x^{2+2}
$$ 


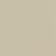





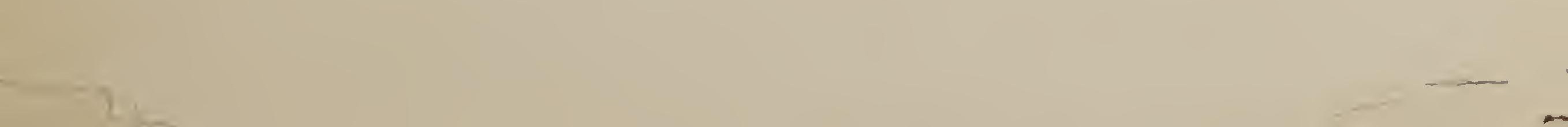


GEOLOGY OF CALIFORNIA.

V O L. I. 


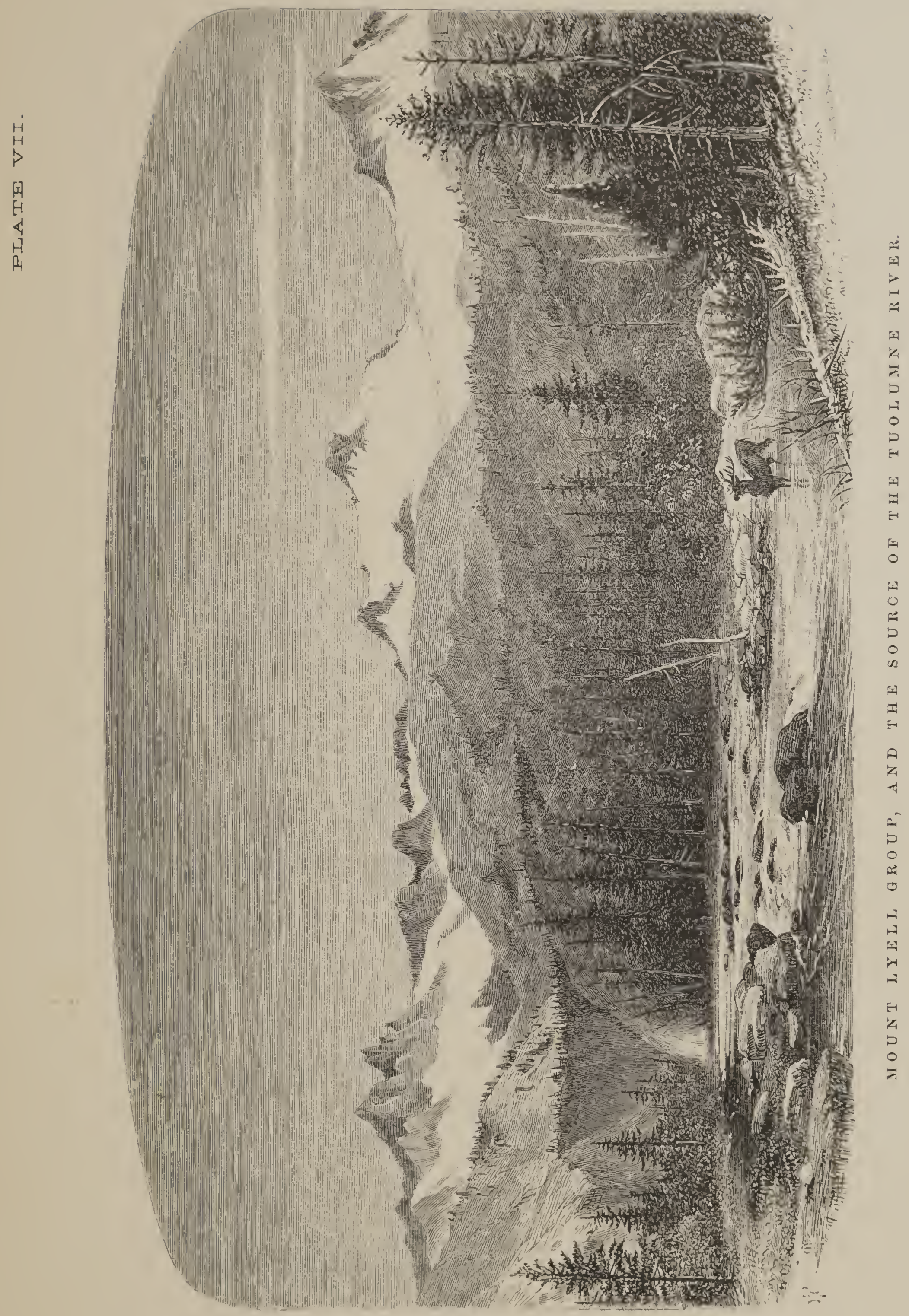




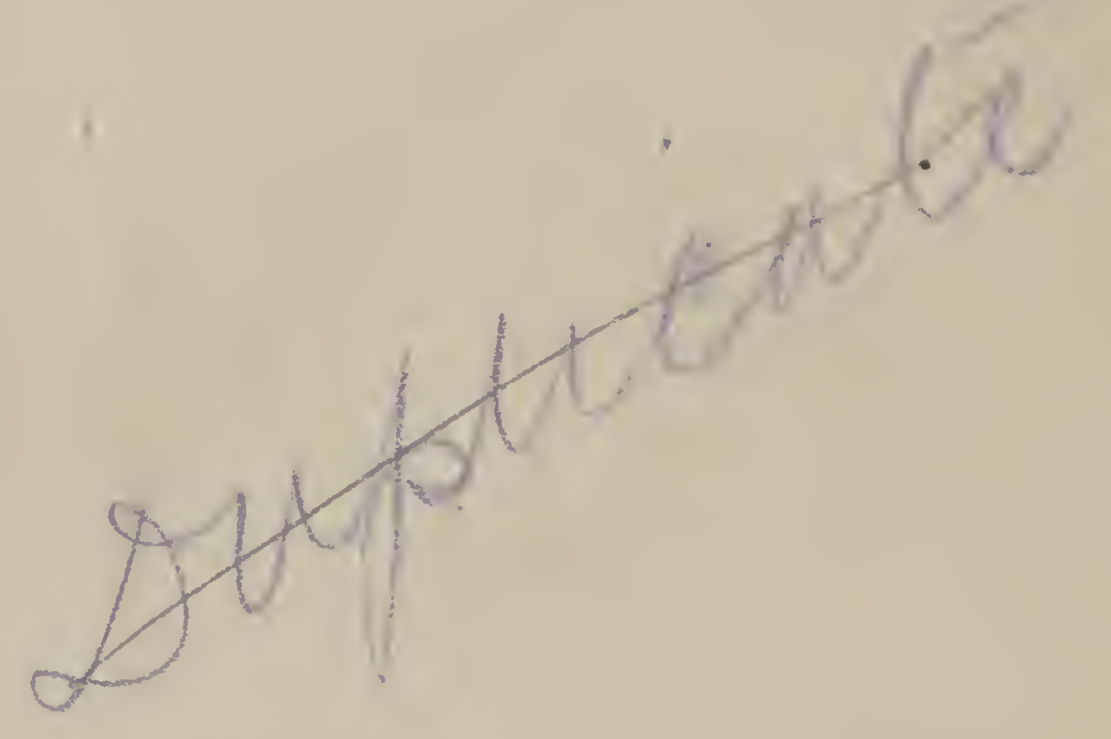

\author{
LIBRARY \\ OF THE \\ UNIVERSITY OF ILLINOIS
}




\title{
GEOLOGICAL SURVEY OF CALIFORNIA.
}

J. D. Whitney, State Geologist.

\section{G}

\author{
V O L U M E I.
}

REPORT OF PROGRES AND

SY NOPSIS OF THE FIELD-W OR K,

From 1860 to 1864. 


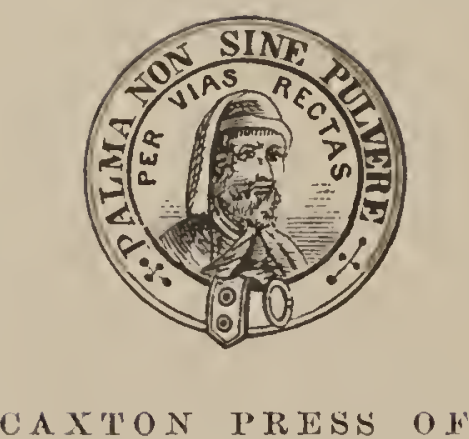

SHERMAN \& CO., PHILADELPHIA 


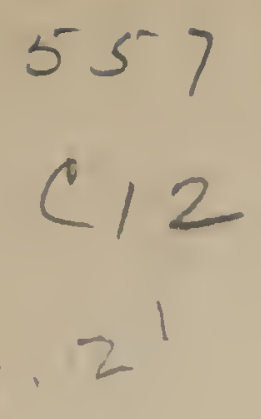

\title{
MEMBERS OF THE CORPS
}

\author{
From 1860 to 1864.
}

Professor J. D. Whitney, . . . State Geologist.

Professor W. H. Brewel, . . . . Principal Assistant, 1860-64, in charge of Botanical Department.

J. G. Coopkr, M.D., . . . . . . Zoologist, 1860-64.

W. Ashburner, . . . . . . . Assistant in the Department of Economical Geology, 1860-61.

C. F. Hofmans, . . . . . Principal Topographical Assistant, 1861-64.

V. Wackenteuder, . . . . . . Topographical Assistant, 1862, 1863.

W. M. Gaвв, . . . . . . . . Palæontologist, 1862-64.

A. RÉmond, . . . . . . . . Volunteer Assistant in the Geological Field-work, 1862, 1863.

Clarence King, . . . . . . Volunteer Assistant in the Geological Field-work, 1863-64.

J. T. GArdnek, . . . . . . . Tolunteer Assistant in the Topographical Field-work, 1864.

C. AvermL, . . . . . . . . Clerk, Commissary and Barometrical Observer, 1860-63.

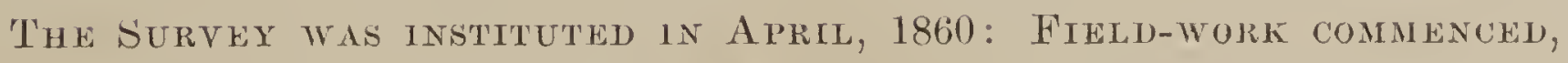
November, 1860. 



\title{
TABLE OF CONTENTS.
}

PREFACE,

\author{
PART I. \\ GEOLOGY OF THE COAST RANGES.
}

CHAPTER I.-INTRODUCTORY, . . . . . . . . . . . $1-7$

Chapter II.-The Monte Diablo Ranee, . . . . . . . . 8-60

SECtion 1. Introductory, . . . . . . . . . . 8-11

2. Contra Costa Hills, . . . . . . . . . 11-19

3. Monte Diablo Group, . . . . . . . . 19-39

4: Mount Hamilton Group, . . . . . . . . 39-52

5. Monte Diablo Group, south of Pacheco's Pass, . . . . $52-60$

Chapter III.-The Peningula of San Francisco, including the Regron fron the Bay of MoNterey to the Golden GATE, . . . . . . 61-79

CHapter IV. - The Coast Ranges vorth of the Bay of San fraxCISCO, . . . . . . . . 80-108

Chapter V.-The Coast Ranges south of the Bay of Monterey, . 108-166

SeCtios 1. Introductory Remarks, . . . . . . . . 108-119

2. The Region from San Fernando Valley north to the Bay of

Monterey, . . . . . . . . 119-158

3. The Gavilan Range, . . . . . . . . . 159-160

4. The Vicinity of the Bay of Monterey, . . . . . 160-166

Chapter vi.-The Coast Ranges from the vicinity of Los Angeles, SoUtri, . . . . . . . . . . 166-186

Section 1. Preliminary Remarks, . . . . . . . . 166-168

2. Sierra Santa Monica, . . . . . . . . . 168-171

3. San Gabriel Range and the Vicinity of Los Angeles, . . 171-175

4. Santa Anna and Temescal Ranges, . . . . . . 175-181

5. Islands off the Coast of Southern California, . . . . 182-186

CHap'ter ViI.-The Region betwena the Cã̃ad de las Utas and

Soledad Pass, . . . . . . . . 186-197 


\section{PA卫I II. \\ THE GEOLOGY OF THE SIERRA NEVADA.}

PACF:

Cha PTeR VIHI.-The Undisturibe Marine Semmentary Rocks along THE Foot-hills of the SHqR $\Lambda$, . . . . 199-212

Citapter ix.-The Mining Region of California; embracing the great Auriferous Belt along the Weatkre Slope of the Sierra NeYADA, . . . . . . 212-363

Section 1. Preliminary Remarks, . . . . . . . . . 212-216

2. From Téjon Pass to Mariposal, . . . . . . . 216-2222

3. Mariposa County, . . . . . . . . . . 223-231

4. Tuolumne County, . . . . . . . . . . 232-253

5. Calaveras County, . . . . . . . . . 253-268

6. Amador County, . . . . . . . . . 269-278

7. El Dorado County, . . . . . . . . . 279-283

8. Placer County, . . . . . . . . . . 283-287

9. Nevada County, . . . . . . . . . 287-298

10. Sierra County, . . . . . . . . . 298-304

11. Plumas County, . . . . . . . . . 304-316

12. The Northern Counties, . . . . . . . 316-363

Chapter X.-The High Sierra, . . . . . . . . . 364-450

Section 1. Preliminary Remarks, . . . . . . . . 364-365

2. The Region about the Head of Kern and King's Rivers,. . 365-391

3. The Head of the San Joaquin River, . . . . . 391-40?

4. The Region about the Heads of the Nerced and Tuolumne Rivers,. . . . . . . . . 403-437

5. The Sonora Pass, . . . . . . . . . 437-443

6. The Head of the Mokelumne River. The Rond from the

Calaveras Big Trees to Silver Mountain, . . . . 443-450

CHAPTER XI.-The Eastern Slope, . . . . . . . . 450-474

Section 1. Mono Lake and its Vicinity, . . . . . . . 450-455

2. Owen's Valley, . . . . . . . . . . 455-460

3. The Great Basin, . . . . . . . . . 461-474

APPEndix A.-Tajular Statement of the Operations of the principal Quartz Mills running in Califoriata in 1861. BY W. Ashburner, . . . . . . 475-476

A PPEndix B.-Dencription of Fossils from the Aurifferous Slates of Catifornia. By F. B. Meek, . . . . 477-483 INDFi: 


\section{P R E F A C E.}

'The Geologicar Survey of Calmfornia was instituted, in 1860, by the passage of the following Act of the Legislature of that State:

\section{AN ACT TO CREATE THE OFFICE OF STATE GEOLOGIST, AND TO DEFINE THE DUTIES THEREOF.}

The People of the State of California, represented in Senate and Assembly, do enact is follows:

SeCtion ONE. J. D. Whitnky is hereby appointed State Greologist, whose duty it shall be, with the aid of such assistants as he may appoint, to make an accuratc and completc Geological Survey of the State, and to furnish, in his Report of the same, proper maps and diagrams thereof, with a full and scicntific description of its rocks, fossils, soils, and minerals, and of its botanical and zoological productions, together with specimens of the same, which specimens shall be properly labelled, and arranged and deposited in such place as shall be hereaftcr provided for that purpose by the Legislature.

Section Two. Said State Geologist shall, as near as may be, at the beginning of cach session of the Legislature, present to the Grovernor, who shall lay the same before the Legislature, a report of progress, in which the operations of the Geological Survey during the preceding year shall be set forth, and its more important practical results made public. Hc shall also furnish such estimates as he shall deem proper of the amount of appropriation which shall be required for the continuance of the Survey. His report shall also embrace the amount of expenses incurred up to that period.

Section Three. On the completion of the Survey, the State Geologist shall prepare and present to the Governor a full and comprehensive Report, embodying the results of the cntire Survey, with proper maps, diagrams, and drawings of the same; and the Sccretary of State is hereby directed to obtain the copyright for the same, as also of the annual reports of said Geologist, for the benefit of this State.

Secrion Four. Whenever one or more volumes of the Greological Survey herein provided for shall be published, the Governor and Secretary of Statc may causc such books to be sold upon the most advantagcous terms to the Statc; and any moneys derived from such sales shall be placed in the Common School Fund of the State.

Sectios Five. The said Geologist shall prepare and superintend the publication of his reports of the final results of the Survey provided for in this act, and he shall present to the Lcgislature an estimatc of the costs of such publication.

Skctiox Six. The State Geologist shall receive for his compensation the sum of six thousand dollars per annum, payable monthly; and his assistants shall receive such compensation as shall be detcrmined upon by the Governor and said Geologist, which, together with the salary of the State Geolugist, shall be audited by the Statc Controller, and paid

GEOL. YOL. I. - I3 
out of the amount herein appropriated, or out of such appropriations as shall be hercafter made for that purpose; provided that the compensation hercin allowed shall be paid only from the time they shall enter npon the performance of their duties.

Section Seven. Whenever the said J. D. Whitrey shall notify the Governor of his accptance of the appointment hercin made, the Governor shall cause to be issucd to said Whitney his commission under the seal of Statc; and if the said Whitver shall decline to scrve as said Gcologist, or die, or bccome mable to prosecute said Survey, the Governor of this State is hereby authorized to appoint some suitable person to prosecute said Survcy.

Section Erght. The sum of twenty thousand dollars is hereby set apart out of any moneys in the State Treasury, not otherwisc appropriated, as a special fund for the payment of cxpenses incurred by said Survey.

Section Nine. This Act shall take effect from and after its passage.

PHIL. MOORE, Sperker of the Assembly.

J. N. QUINN, President of the Senate.

Approved April 21, 1860.

\section{JOHN G. DOWNEY,}

Governor.

At the time my commission as State Geologist reached me I was engaged in making a survey of the Lead Region of the Northwest, under authority of the Legislature of Wisconsin. This work was completed, and the Report written, so that I was able to sail for California on the $22 \mathrm{~d}$ of the following October. Prof. W. H. Brewer and Mr. William Ashburner accompanied me; the former as Principal Assistant, in charge of the Botanical Department; the latter as Assistant in the Geological Field-work.

We landed at San Francisco, November 14 th, and proceeded at once to organize our party for the commencement of the explorations, which of course could only be carried on in the Southern part of the State during the winter. Mr. C. Averill was engaged as clerk, commissary, and barometrical observer, and we were also accompanied by Mr. F. Guirado, who was well acquainted with the region we proposed visiting. Onr labors commenced, after the completion of the necessary preparations, on the 12 th of December, and the party did not return to San Francisco, where our office was established, until the 15th of the next November, having been uninterruptedly occupied in the field-work during a period of nearly a year.

This first year was almost exclusively devoted to the Coast Ranges. We first made a reconnaissance of a portion of Los Angeles and San Bernardino Counties, then proceeded north through Santa Barbara, San Luis Obispo, and Monterey Counties, spending the summer chiefly in the Monte Diablo Range, then crossing over to the north side of the Bay of San Francisco, and reaching the Geysers just at the commencement of the rainy season. From the time of our taking the field up to February 7 th I was with the party uninterruptedly; and after that, at various times, spending from a few days to several weeks with them, at places of particular interest, or when other duties did not interfere. Professor Brewer had eharge of the party at times when I was unable myself to be with them. 
Mr. Ashburner was detached from the general field-work on the 21st of February, 1861, and was engraged, from that time up to Norember 20th, in an examination of the auriferous quart $z$ mines of the Sierra Nevada, from Marriposa to Plumas Counties.

While absent from the main party, I spent a portion of the time in attending to the general business of the Survey, a portion with Mr. Ashburner, and the remainder in examining; by myself, certain districts, my object being, during the first year, to initiate my assistants into their work, and to obtain a general idea of the geological structure of the State over as large an extent of surface as possible, so that I might be enabled to lay my plans for the future conduct of the Survey with a better understanding of what there was to be done, and what it was likely to be in our power to accomplish.

Mr. C. F. Hoffmann joined the corps as Topographical Assistant, March 26th, 1S61, and was immediately employed in compiling, at the United States Surveyor-General's Office, such geographical information as could be obtained. The Department of Zoology was also organized, by the appointment of Dr. J. G. Cooper to the place of Zoologist to the Surrey, July 1st of the same year.

At the beginning of the year 1862, Mr. W. M. Gabb arrived in California, having been selected by me for the post of Palæontologist to the Survey. His duties were entered on at once, by commencing with the collcctions of fossils made by us during the previous year.

Deferring the fitting up of a laboratory, and the engaging of a special assistant in the chemical department, until a suitable permanent place could be provided in the State Museum building, I sent Mr. Ashburner east in the spring, to commence the examination of some of the ores and minerals of the State in the laboratory of the Sheffield Scientific School of Yale College, under the direction of Professor Brush, who has charge of the metallurgical department of that institution. The reduction of the appropriation to $\$ 15,000$ for the next year made it necessary to suspend this work soon after it was commenced, in order that the whole force of the Survey might be concentrated on the field operations, and Mr. Ashburner's connection with the Survey was terminated.

In 1862, the field-work was much delayed in its commencement by the almost cntire destruction of the roads and bridges throughout the State, consequent on the unprecedented storms of the preceding winter. Our wagon being at San Francisco, and our mules at Clayton, in Contra Costa County, we were unable to commence operations with the whole party until the creek at Pacheco was made passable; this was in the latter part of April. Previous to this, however, the geology and topography of Marin and a part of Sonoma County were worked up by Messis. Brewer and Hoffmann, during the months of March and April.

The explorations of 1861 . having revealed the presence of Cretaceous rocks in the Monte Diablo Range, and various circumstances making it 
apparent that the vicinity of Monte Diablo itself, by a detailed and careful study, would throw much light on the structure of the Coast Ranges, and furnish a key to what had been previously more or less obscure in the stratigraphical position of the rocks south and west of the San Joaquin, I determined, having especially in view the economical importance of the coal of that region, to make first a thorough examination of the vicinity of the mountain, and a topographical map, on a large scale, of the coal-mining district. This work occupied about a month, during which time I was with the party.

This accomplished, the party, in charge of Professor Brewer, continued their explorations along the east side of the Monte Diablo Range, as far as Pacheco's Pass, mapping an extensive district, of which hardly anything had been previously known. This occupied the month of June.

After this was accomplished, it had been my intention to have the party cross the San Joaquin and meet me at Snelling's on the Merced, and then to derote our whole strength, for the remainder of the season, to working up the geology of the foot-hills of the Sierra Nevada, going as far north as time would permit, and then returning on the west side of the Sacramento, in the foot-hills of the Coast Ranges. It appeared, however, that all the ferries of the San Joaquin had been broken up by the winter's storms; and up to August, there was no possibility of crossing at any point, the river continuing greatly swollen by the melting of the snow of the Sierra until late in the season. This made a great change necessary in our plans. The party had to return up the San José valley, and cross at Benicia. I then determined to continue our surveys up the Sacramento, along the Coast Ranges west of that river, and to reach Mount Shasta not too late in the season to make the ascent, and, if possible, to get some idea of the geology of the nortbern portion of the State. The party had proceeded as far as Rag Cañon, and were about to explore Bereyessa Valley, when the severe sickness of Professor Brewer put a stop to our operations in that quarter. After his recovery, it became necessary to move up the Sacramento Valley quite rapidly in order to reach Mount Shasta in season to make the ascent that year. At Shasta City, however, three of the party were attacked by fever, and another serious delay was occasioned. I joined them at that place about the first of September, and leaving Mr. Rémond there to observe the barometer, with the rest of the party went up the Upper Sacramento Valley, ascended Mount Shasta with Messr's. Brewer and Averill, and determined its height. The party continued their work in Shasta, Siskiyou, and Trinity Counties, until October, although during the whole time some of them were suffering more or less from bilious attacks.

During the month of October, the work was continued down the east side of the Sacramento Valley, for the purpose of settling the relations of the Cretaceous strata of that region to the auriferous slates of the Sierra Nerada. Near the end of the month the party was broken up, and the animals sent into winter quarters, the explorations being continued in the 
counties adjacent to the Bay of San Francisco, by small parties on foot, or by single indiriduals, in different sections, to gain additional topographical and geological information for our map of that region. 'These explorations occupied the whole of the month of November, during which the weather continued highly favorable. During this season, Messirs. Brewer, Hoffmann, Gabb, Arerill, and Remond participated in the field-work, the lastnamed gentleman rendering efficient service as a volunteer in the Geological Department for sereral months.

In 1863 the field-work was commenced, on the 1st of April, by a visit of Messrs. Brewer and Gabb to the region about Fort Tejon and the Cañada de las Uvas. After a month spent in that portion of the State, they travelled up the east side of the San Joaquin to Mariposa County, from which point Mr. Gabb returned to San Francisco, to go on with the palæontological work at the office. Mr. Hoffmann and I then joined Professor Brewer, and we together made an examination of the High Sierra at the head of the Merced and Tuolumne Rivers. The months of June,.July, and a part of August, were occupied in exploring the mountains between the Mono Pass and the Silver Mountain district, M[r. Hoffman, however, returning to San Francisco and resuming his office-work before the end of July. The rest of the season was spent by Professor Brewer, accompanied by Mr. Clarence King as a volunteer assistant, in continuing the reconnaissance of the High Sierra to the north. Working along the most elevated portion of the range, and cross. ing over nearly all the important passes, they made their way around the eastern side of Mount Shasta, examined the vicinity of Yreka, and finally came down to Crescent City, late in November. From this place, Professor Brewer returned to San Francisco by boat, and Mr. King by stage. During the time that this small party was thus engaged, I was employed in examining the geology of the lower portion of the western slope of the Sierra, in the region of the most important mines.

Up to this time the following sums had been appropriated for the continuance of the Survey:

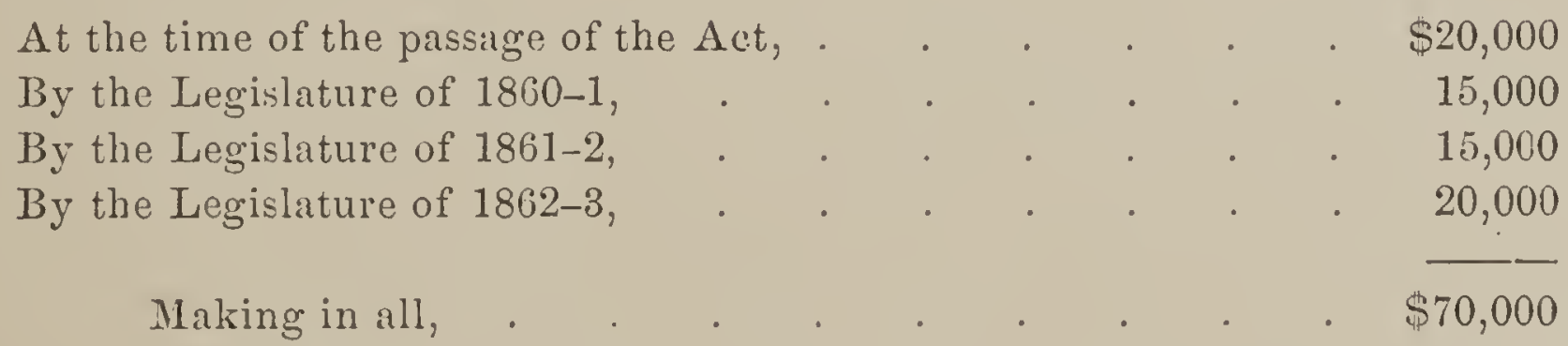

Besides this, $\$ 3000$ was appropriated by the Legislature of 1861-2 for printing one volume of the Report.

As, by the Constitution of the State, no office can be created by the Legislature which shall last over four years, and as, under this provision, the office of State Geologist would cease to exist in April, 1864, of course a discontinuance of the Survey at that time would be inevitable, unless a new Act should be passed. It will be noticed, however, that the Survey had, at 
the beginning of the winter of $1863-4$, been going on only three years, owing to the necessary delay in commencing the work.

At the time the Legislature of 1863-4 met, the new Constitution of the State was in operation, and the sessions being now biennial, instead of annual, it was necessary to provide funds for continuing the Survey for two years. Unfortunately, the State was at this time in great trouble, the drouth of the two previous winters having most seriously affected both the agricultural and the mining interests, and given rise to a wide-spread feeling of a!arm. It was with difficulty that any appropriation could be secured for the Survey, especially as it was necessary that an act shou?d be passed creating the office of State Geologist anew. This was, howerer, accomplished, and the following enactment became a law :

\section{AN ACT TO CREATE THE OFFICE OF STATE GEOLOGIST, AND TO DEFINE THE DUTIES THEREOF.}

The People of the State of California, represented in Senate and Assembly, do enact as follows :

Section One. J. D. Whitrey is hereby appointed State Geologist. He shall be commissioned by the Governor, and it shall be his duty, with the aid of such assistants as he may appoint, to complete the Geological Survey of the State, and prepare a Report of said Survey for publication, and superintend the publication of the same. Such Report shall be in the form of a geological, botanical, and zoological history of the State, and the number of volumes, and the number of copies of each volume to be printed, and the style, form, maps, diagrams or illustrations to be contained therein, or to be published separately, shall be determined by the State Geologist, and said Report, when published, shall be sold upon such terms as the Governor and Secretary of State may decide upon, and the proceeds of such sales shall be paid into the Conmon School Fund of the State.

Section Two. It is hereby made the duty of the State Geologist and his assistants, to devote the time not necessarily required in the preparation and superintendence for publication of the Reports provided for in Section One of this Act, to a thorough and scientific examination of the gold, silver, and copper producing districts of this State, and to make such seientific and practical experiments as will be of value in the discovery of mines and the working and reduction of ores.

Section Three. The following sums of money are hereby appropriated, out of any money in the State Treasury not otherwise appropriated, for the prosecution of the Geological Survey of the State, and for the sixteenth and seventeenth fiscal years: For salary of the State Geologist, nine thousand dollars; to be drawn monthly on the last day of each month. For salary of two assistants, six thousand six hundred dollars; to be drawn in the same manner as the salary of the State Geologist. For publication of two volumes of Report, six thousand dollars. For office rent and expenses of Survey in mining districts, and experiments on ores and all incidental expenses of work, ten thousand dollars; to be drawn one-half each fiscal year.

Section Four. This Act shall take effect immediately.

\section{R. BURNELL,}

President of the Senate, pro tem.

WM. H. SEARS,

Approved, April 4, 1864.

Speaker of the Assembly.

FREDERICK F. LOW,

Governor. 
'The appropriation for the Survey in the above Act, added to those of previous Legislatures, make the total amount provided for the field-work and salaries in all departments, from the commencement of the Survey up to June $30,1866, \$ 95,600$, or a little less than $\$ 16,000$ a year, on the average. Besides this, there has been $\$ 9000$ appropriated for publication; which, howerer, should not be debited to the Survey, as this amount will be refunded to the State by the sale of the volumes published, it being provided, in both Acts, that our publications shall be sold, and the money paid in to the Common School Fund.

Since the passage of the new Act, by which only $\$ 12,300$ a year were appropriated for the Survey, our field operations have necessarily been very much cut down, most of our time and money having been absorbed in the preparation and publication of portions of our results. The field-work done has all been in the Sierra Nevada, in accordance with the provisions of the Act reconstituting the Survey.

In 1864, a small party, consisting of Messi's. Brewer and Hoffmann, accompanied by Messrs. King and Gardner as volunteer assistants, commenced operations in the southern portion of the Sierra, it being my intention to work up the geology and topography of that great chain, from the south towards the north, as thoroughly and accurately as our means should permit. The interesting results obtained by the party will be found in Sections 2 and 3 of Chapter $\mathrm{X}$ of this volume.

In May, of the same year, I left California for the East, to commence the publication of a portion of our results in the different departments, agreeably to the provisions of the Act, and in accordance with my understanding with the "Committee on Mines and Mining Interests" of the Legislature. What progress bas been made in the publication, up to the present time, will be specified under the appropriate heads, farther on in this Preface, in connection with a statement of the amount of work accomplished by the Survey in each department.

At the end of the campaign of 1864 , Professor Brewer relinquished his position as Principal Assistant, leaving California to enter on his duties as Professor in the Sheffield Scientific School of Yale College. He still remains, however, charged with the Botanical Department of the Survey; as will be noticed farther on under the head of Botany.

During the year $1865, \mathrm{Mr}$. Gabb has been employed for a portion of the time in completing the revision of our palæontological materials, and $\mathrm{Mr}$. Hoffmann in compiling our geographical materials relating to the central portion of the State. Field-work has been carried on-not on a large scale, as it is hardly necessary to add-by $\mathbf{M r}$. Rémond, who is now connected with the Survey as Geological Assistant, and who has been employed in continuing the detailed explorations of the mining region of the Sierra, from the south towards the north, in accordance with the plan of operations indicated above.

Having thus given a brief sketch of the progress of the field-work of the 
Survey, in connection with the notice of the action of the Legislature at various times, it remains to add a statement of what has been accomplished in each department of our work, with especial reference to the preparation and publication of the "geological, botanical. and zoological history of the State," provided for by the last Legislature.

\section{Topography.}

Recognizing most distinctly, from the first, the great importance to the State of the topographical work of un Survey, and the absolute necessity of maps at least approximately correct, if we would do anything satisfactory in the Geological Department, I have done all that was possible-and sometimes more than the Legislature has provided the means for-towards the increase of our geographical knowledge of the vast area comprised within the boundaries of California. It is not necessary, at this time, to go into a minute account of our operations in this department of the Survey; it need only be briefly stated that at the time our work was commenced nothing was accurately, and very little eren approximately, known in regard to the topograpliy of the mountainous regions of the State; and, when we consider that the plains and broad ralleys do not together occupy more than one-fifteenth of its area, it will be evident that the task before us was truly one of no common magnitude. The surveys made under authority of the United States by the General Land Office are never carried into the mountains; their lines stop at the base of the hills, except where there are only very moderate elevations. This is true even for the Coast Ranges; and, in the Sierra Nevada, the United States linear surveyors have done no work worthy of notice. In short, there was not a map of any portion of the State sufficiently correct in its details to allow of our laying down even the outlines of the geology upon it.

In commencing our topographical work, we first compiled at the United States Surveyor-General's Office, at San Francisco, all the geographical information which could be obtained. on a series of over fifty skeleton maps, on a scale of half an inch to the mile; these have been used by us in the field, especially in the Coast Ranges and along the edge of the foot-hills of the Sierra, and we have sketched in the topography upon them, whenever we explored the regions which they covered. In the elevated portion of the Sierra Nerada we have done work enough to enable us to give a general idea of the topography of the great chain from Walker's Pass north to Mount Shasta, with the exception of a few blanks, the most important of which is the region between the Henness Pass and Lassen's Peak. A hasty reconnaissance has been made of that part of the Sierra which lies between the parallels of $36^{\circ}$ and $37^{\circ} 30^{\prime}$, comprising an area of over 10,000 square miles, of which not even the outlines of the topography were known previous to our visit. The exploration of this region disclosed the interesting 
fact that the highest mountains of the State are included within it, as well as the grandest scenery.

Mr. Wackenreuder has also been employed by us during portions of two seasons in surveying the High Sierra between Silver Momtain and the Downieville Buttes. His map, four and a half feet by four in size, contains a large amount of original information, obtained by the most arduous and persevering exertions.

The following maps have been prepared for publication or are in progress:

1st. A map of the vicinity of the Bay of San Franciseo, on a scale of half an inch to the mile, and four feet by three in dimensions. It extends from near Santa Cruz on the south to Napa on the north, and from the Pacific to Corral Hollow east and west, and covers an area of four thousand two hundred and forty-eight square miles of land, which is just twice that of the State of Delaware, and only lacks two hundred square miles of equalling that of Connecticut: It embraces a region far more densely inhabited and thriving than any other district of equal size within the borders of the State. As near as could be ascertained from the census of 1860 , the district included on this map contains over one-third of the population of California, and a considerably larger proportion of its wealth. This map has all the topography correctly represented on it, in as much detail as the scale will allow. It is now ready for the engraver, and we only await the necessary appropriation for that purpose to have it put in hand. It will either be colored, so as to represent the range and extent of the different geological formations; or else an outline, on a reduced scale, will be used for this purpose.

2d. A detailed topographical map, on a scale of two inches to the mile, of the vicinity of Monte Diablo: this is about two and a half by three feet in dimensions, and includes the most important coal mines yet known to exist in the State. It is now ready for publication, and it is my intention to have it reproduced by the photolithographic process, which, there is reason to beliere, will soon be in successful operation in this country.

3d. A map of the Coast Ranges, from the Bay of Monterey south to Santa Barbara: this is about three feet by two and a half in dimensions, and is on a scale of six miles to the inch. It cmbraces about sixteen thousand square miles of territory, chiefly within the counties of Monterey, San Luis Obispo, and Santa Barbara. Considerable more field-work will be required to complete this map.

4th. A map of the vicinity of Virginia City, three and a half by two and a half fect in size, and on a scale of two inches to the mile, has been drawn by $\mathrm{Mr}$. Wackenrender from his own accurate topographical surveys. This was intended to form one of our series of map publications; but its cost has been refunded to the State, and I have placed it at the disposition of Baron Richthofen, the eminent geologist, who has been engaged for some time in making a detailed survey of the region which it covers, the results of which will be of the greatest value.

GEOL. VOL. I. -C 
5th. A map of the Comstock lode was prepared from the joint surveys of Mr. Wackenreuder and myself; but this will be superseded by the more accurate and detailed onc of Baron Richthofen.

6th. A map of Central California has been for some time in progress at the office of the Survey; it embraces the region between the parallels of $36^{\circ}$ and $40^{\circ} 30^{\prime}$, and extends from the 118 th to the $123 \mathrm{~d}$ meridian: this includes the whole Sierra from Owen's Lake north to Lassen's Peak, the Washoe mining region, and the Coast Ranges from Clear Lake on the north to Point Sur and New Idria on the south. This will be a bighly valuable map, but at least two years more of field-work are required to collect the materials necessary for its completion.

All the above maps were drawn by Mr. Hoffmann, when not otherwise specified.

The preparation of a map of the whole State, on a scale of ten or twelve miles to the inch, is one of the objects we have had in view from the commencement of the Survey. Whether this desirable crowning of our topographical labors will ever be reached, it is of course impossible to say.

Small, detailed maps, of particularly interesting districts, will be furnished as the Survey progresses. One of the environs of San Francisco, and another of Monterey and its vicinity, are in preparation. The more important mining districts will also be illustrated by special maps, provided this is in our power.

In regard to our methods and the relative degrees of accuracy of the different parts of our topographical work, it is not necessary to go into detail at the present time. It is sufficient to remark, that our results in this, as well as all other branches of the Survey, are necessarily proportioned to the means at our command. We are extremely desirous of making our work as accurate as possible, but are also of opinion that an approximation to the truth is better than no knowledge at all. Hence we have drawn on all the sources accessible to us for information in regard to the geography of districts we have not ourselves been able to visit, and all our anthorities will receive due credit whenever any of our geographical materials are published.

\section{Physical Geography.}

It is intended to devote a separate volume of the Repart to this subject, and we have been constantly collecting materials in this department. The barometrical measurement of heights among the numerous mountain ranges of the State has received especial attention, and the results of a thorough working over of our hypsometrical data will form one of the most important chapters in this volume of our publications. In this connection we await with much interest the appearance of the report of Major Williamson to the Topographical Bureau of the United States, of his investigations into the subject of the laws governing the fluctuations of the barometer on the 
Pacific coast. This work will be of great importance to science, and of especial value to us, as enabling us to use our own observations more intelligently than would be possible, unless we had the means of carrying on a series of investigations similar to those of Major Williamson, and on which a great amount of time and labor would have to be expended. The subject of the distribution of the forest vegetation in the State will occupy a chapter in our volurne of Physical Geography; and it is hoped that we shall be able to illustrate it with a map showing the range of the different groups of species.

\section{General Geology and Paleontology.}

'The present volume, which is chiefly deroted to a synopsis of our geological field-work, will be a sufficient exhibit of our progress in the investigation of the geological structure of the State.

It is to the department of General Geology that, up to the present time, by far the greater portion of our attention has been given, since the first thing required in a geological survey is a knowledge of the general geological structure of the State, the age of the various formations which occur in it, and their range and extent, or the position which they occupy on the surface, and their relations to each other. Each group of strata, thus determined by its lithological peculiarities and by the fossils which it contains, is then to be laid down upon the map, in the position which its outcrop occupies on the surface. The general character of the minerals and ores which occur in each formation or group of strata having been thus determined, the details of their mode of occurrence, their relative abundance, and the facilities which may exist in each separate district for making then economically available must, after the preliminary general work has been done, be the object of more special and detailed examinations. It is not, however, the business of a geological surveying corps to act, to any considerable extent, as a prospecting party; to do this would require that we should confine our operations to a very limited area; the labors of the whole corps for an entire season would not suffice to thoroughly prospect more than a few hundred square miles in a very rich mineral region, and we should have often to engage in expensive mining operations to decide what was really of permanent value. It is our task, rather, to limit the field of research, and to show to others where their labors will be best bestowed, preventing foolish expenditures of time and money in searching for what our general geological investigations have determined not to exist in sufficient quantity, in certain formations, to be worth working. Especially in the first years of our work, in a State of such an immense area as California, our labors have more the character of a geological reconnaissance than of a detailed survey.

In the department of Palæontology, one volume has already been published. This contains in the first section a description of the Carboniferous 
fossils of Bass's Ranch; the only locality where any well-preserved organic remains of that age have been found within the State. The second section is devoted to the fossils of the Triassic rocks, including all which have thus far been discovered in California and on its borders. While we have abundant evidence that a formation equivalent in geological age to the Alpine Trias, or the beds of Hallstadt and St. Cassian, occurs over a vast area, and forms an important part of the metalliferous belt of the Pacific coast, on both sides of the Sierra, and while fossils of this age have been found at several localities within the borders of California, our most ample supply of well-preserved specimens has come from the Humboldt Mining District, in Nevada. Hence we have included in our description of the Triassic fossils those of that region, although some among them have not yet been found in California.

The third section of the volume of Palæontology is devoted to the Jurassic fossils of the Sierra Nevada; or, rather, to such as had been discovered at the time of its publication. These fossils are all from the localities in Genesee Valley, noticed in Section 11, Chapter IX, of this volume. At the end of this volume (Appendix B.) a paper will be found containing descriptions of the Jurassic fossils of the auriferous slates in Mariposa County, from the localities discovered by Mr. King, and in close proximity to one of the great quartz veins of the mining region proper. This paper by Mr. Meek, which is also illustrated by a steel plate (Plate 1), is published in this volume, to prevent delay, as the question of the geological age of the auriferous slates is one of great interest, and as some time will necessarily elapse before the second volume of the Palæontology will be ready for publication.

The fourth section is devoted to the Cretaceous fossils, and forms considerably the larger portion of the volume, as the rocks of this geological age occupy a very extensive area on the Pacific coast, and are rich in fossils at many localities. A reference to the section in question will show how large an amount of material new to science has been derived from this series, the existence of which in California had, previous to the commencement of our work, been only surmised.

The first and third sections of the volume have been prepared by $\mathrm{Mr}$. Meek; the second and fourth by Mr. Gabb. The plates are thirty-two in number, partly engraved on steel and partly on stone, from drawings furnished by the authors of the text.

Another volume of the Palæontology is now partly ready for the press. It will be devoted chiefly to the fossils, both animal and vegetable, of the Tertiary rocks of the Pacific coast. It will also contain such additions to our knowledge of the palæontology of the lower members of the series as we may have been able to accumulate since the preparation of the first volume was completed. For this, the Tertiary mollusca have already been worked up by Mr. Gabb, and the figures for ten or twelve plates are drawn. The vertebrate remains have been referred to Dr. Leidy, who has made a 
preliminary report on them, and will prepare a more eiaborate one on those already collected and such as we may hereafter be able to add, for the second volume of the Palæontology. The plants will be worked up by Dr. Newberry, and the diatoms and other microscopic forms have been submitted to Mr. A. M. Edwards, of New York. The engraving of the plates for this volume can be commenced as soon as provision has been made therefor by the Legislature.

\section{Economical Geology, Mining, and Metallurgy.}

In the present volume a considerable amount of information will be found in regard to the economical geology of the State; but all the detailed descriptions of mining regions and mining processes have been reserved for the volume of the Report especially deroted to these subjects. We have now arrived at a stage of the Survey when, the preliminary reconnaissance of the State being well advanced, we can take up the mining districts and work up the details of their geology, investigate the quality, quantity, and mode of occurrence of their ores.

We need, however, a laboratory, where the necessary chemical work of this and other branches of the Survey can be done under my immediate personal supervision. Mr. Ashburner's investigations of the quartz mines and mills of the State were the commencement of work in this department; and, as far as they go, they form an important contribution to an understanding of the mining interests of the State. The tabular statements prepared by him, to show the principal facts connected with the auriferous quartz mills running in 1861, will always be valuable for reference. It has been given in this volume (Appendix A.), as that devoted to Economical Geology, Mining, and Metallurgy may be long delayed, or, possibly, entirely fail of publication.

The work of investigating, in detail, the geology of the mining region of the State has been begun, but will require some years for its completion, so vast is the field and so important are the interests with which this branch of our work is connected. We can do much for the benefit of the people in this direction, if properly supported by the Legislature; but hasty and superficial work will be of little use. 'l'oo large a portion of the resources of California has already been thrown away in foolish mining enterprises, and it is fully time that a stop should be put to a course which has already materially retarded the progress of the State, and which, if persisted in, will bring utter financial ruin upon the people.

\section{Botany.}

The Botanical Department of the Survey has been, and still continues, under the charge of Professor Brewer. From his investigations, it appears 
that about 1600 species of flowering plants (including the higher orders of the flowerless), and 100 species of mosses, have been found growing naturally within the limits of the State, or on its immediate borders. In the orders below the mosses in the scale of organization, the data are still too imperfect to allow a probable estimate to be made of the number of species.

The collections made by the Survey contain about seventy-four per cent. of all the species known to exist in this State. About five per cent. of them are new to science, and eleven per cent. new to the State; that is, not before found within its borders.

Professor Brewer is now engaged in preparing a report; which will be, in fact, a "Manual of the Botany of California," with as full descriptions of all the plants of the State as can be given in one volume; of this the general plan and arrangement will be similar to those of the "Colonial Floras" issued under the auspices of the British Government. Full references and synonyms will be given of all the species peculiar to the Pacific States and which occur in California, and a chapter will be added on the general distribution of the plants of the State and their economical valtie. This volume will form a suitable text-book to be used in the schools of the Pacific coast, in connection with "Gray's Lessons in Botany," or some other work of a similar character; and it may be added that this science cannot be taught in California until such a manual as the one proposed has been prepared, since the descriptions of the plants of the State are, at present, scattered through hundreds of volumes, most of which are quite inaccessible to any except the few who are furnished with costly and extensive botanical libraries.

In preparing this volume-a task in which considerable progress has been made by Professor Brewer-he will have the aid of several of the most eminent botanists of the country. Professor Gray has kindly offered to work up the large and difficult family of the Compositoe; he has also determined most of the species in the collection, and has given every facility for consulting the collections and library of the "Gray Herbarium" of Harvard University. Professor Torrey will describe certain orders of the Apetala, of which he has made a special study. Dr. Engelmann, of St. Louis, will prepare the descriptions of the Cactacece, and render assistance in several other orders to which he has particularly devoted himself. Professor Thurber, of New York, will also describe the grasses; and Professor Eaton, of New Haven, the ferns and higher cryptogamic plants. The carices collected during the first two years of the Survey were examined and determined by Dr. Boott, of London, just before his death. The herbarium of Dr. Torrey, so rich in Pacific coast specimens, and those of the Academy of Natural Sciences of Philadelphia and of the Smithsonian Institution have also been freely opened to Professor Brewer for comparison and consultation. The plants in the State collection will all be carefully named, and it is hoped that the Legislature will make suitable provision for having them placed 
where they will be accesssible for comparison to all students of this science on the Pacific coast.

It is belicved that the botanical volume will be ready for the press before the close of the year 1867.

\section{ZOOLOGY.}

The extensive acquaintance of Dr. Cooper with the Fauna of the Pacific coast, obtained previous to his connection with the Geological Survey, has enabled him to prepare a large amount of material for the press, forming the basis of at least four volumes of our Report. The illustrations for three of these have been in hand for several months, and it is hoped that they will be entirely ready, so that the volumes can go to press, towards the close of the next year.

Of these volumes, two are devoted to the Mammals and Birds, and they will be thoroughly revised by Prof. Baird, of the Smithsonian Institution, who will also have charge of the execution of the illustrations. We propose to give a figure of one of the species in each genus; those species which have never before been figured or described will be illustrated by large colored figures on steel or stone; those which are not new, by woodcuts. The different species of each genus will be distinguished from each other by diagrams of the head, claws; wings, and other characteristic parts. The Mammals will also be fully illustrated, the object of this volume, as well as of all the others of the zoological series, being to furnish manuals, or text-books, which shall not only have a permanent scientific value, as containing in a condensed and systematic form all that is known of the Fauna of the State of California and its borders, but which shall be practically useful to those persons who desire to ascertain the names and habits of the animals they may meet with on the land or in the waters of the Pacific coast.

The description of the fishes will form a separate volume, and will be prepared by $\mathrm{Mr}$. Theodore Gill, who will be able to use, not only the materials and notes furnished by Dr. Cooper, but also the extensive collections of the Smithsonian Institution, accumulated during many years of labor, by the various naturalists who have devoted themselves on the Pacific coast togathering specimens in this department. Each species will be illustrated by a carefully drawn and engraved figure, the work being done under Mr. Gill's immediate superintendence.

The shells will also afford the material for another volume, Dr. Cooper's collections of Mollusca being very extensive, and comprising nearly two hundred new species. As the eminent conchologist, Mr. P. P. Carpenter, has been for a long time specially devoted to the study of the shells of the Pacific coast, Dr. Cooper's collections have been intrusted to him for scientific use, and it is expected that he will prepare one of the volumes of our zoological series, in which each species will be illustrated by a carefully drawn figure. 
The maps and sections, with perhaps some of the more important illustrations of the scenery of the State, should be placed together in one vol. ume or atlas, and will form the proper conclusion of our series of publications.

As thus planned, it will be seen that we contemplate issuing from eleven to thirteen volumes, as follows:

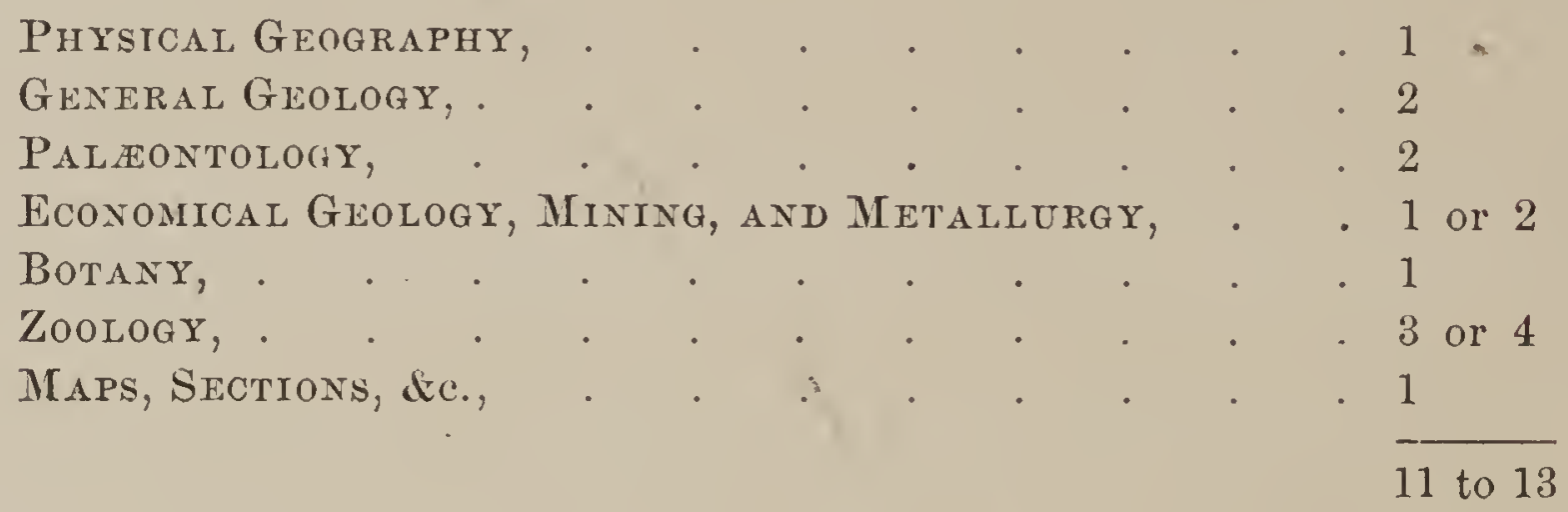

The time required to complete this series will depend of course on the amount of the appropriations made for the Survey by the Legislature. It is hoped that the importance of continuing our work, so as to enable us to finish up the volumes already in progress, as given in the above schedule, will be appreciated by the people of the State, and that we shall have the means necessary to enable us to push the work with rapidity, in which case it is believed that all can be completed within the next four years.

Some hesitation was felt in regard to including the present volume in the permanent series of the Report, since it is properly a synopsis of our fieldwork, and a provisional report, rather than a portion of a final one. It was finally concluded to allow it to be considered as the first volume of the Geological series; but, the number of copies printed being small, it is probable that a revised and enlarged edition may be issued at a future time, after the completion of the field-work of the Survey. The second volume of the General Geology will contain a systematic review of the different formations of California and the adjacent States and Territories, together with all the generalizations, and such matters as cannot be properly prepared until we have accumulated as large a store of facts as possible. Had we the materials for such a volume now in readiness, it could not properly be issued until our maps and sections had been prepared, as these would be alnost indispensable for use in the study of our final geological results.

No provision has yet been made by the Legislature for the arrangement and exhibition of the collections made by the Survey, as was contemplated in the original Act of the Legislature. These collections are already very extensive, embracing many thousand specimens of rocks, fossils, minerals, and ores, as well as the extremely valuable suites in the Zoological and Botanical Departments. All these specimens are of great importance as illustrating the natural history, the geological structure, and the mineral resources of the State. Such of them as bave not been required for use 
in the preparation of our Report remain packed in boxes and stored away in the office of the Survey. Unfortunately we were obliged, fiom want of room, to store a portion of our specimens in a so-called fire-proof building in San Francisco, and these have already been burned, entailing a serious loss on the Survey and the State. In view of this calamity, it will not be necessary to enlarge on the necessity of providing a permanent and thoroughly fire-proof building for our collections, as has already been repeatedly ulged by me in my annual communications to the Legislature.

The only official step thus far taken towards the establishment of a State Museum is the passage of the following resolution by the Legislature of 186-ㅜㅇ :

"Resolved, By the Assembly, the Senate concurring, 'That Professur J. D. Whitney, State Geologist, John Swett, State Superintendent of Public Instruction, and J. F. Houghton, Surveyor-General, be and they are hereby constituted a Board of Commissioners, to report to the Legislature, on or before the second Monday of Decenber, one thousand eight hundred and sixty-three, upon the feasibility of establishing a State University, embracing an Agricultural College, a 'School of Mines,' and a Museumincluding the Geological collection of this State; and that said Board report such facts and considerations as they may deem important in connection therewith.'

In obedience to this requisition of the Legislature, an elaborate Report was submitted by the Board of Commissioners, as above constituted, at the session of $1863-4$, in which Report the whole subject of the organization of a State University was thoroughly discussed, and the requirements of the Constitution, in this respect, duly set forth. The establishment of a "State Polytechnic School," baving for its object "the professional training of young men in the exact and natural sciences and their application to arts, manufactures, mining, and agriculture," was strongly recommended to the Legislature. It was also proposed that the entire collections of the Geological Survey should be placed in a suitable fire-proof building, in which should be ample accommodation for displaying and storing them, as well as room for a library, a laboratory, and an office for the Survey, together with lecture-rooms and other conveniences necessary for a Scientific School, for which purpose the building was to be used after the completion of the Survey. This would have been the first step towards the establishment of a State University, provided for long since by the Constitution, and for which the funds have been furnished by the United States. The interest on the money given by Congress for the establishment of a University has thus far been applied to another object; but it is evident that the people, through the Legislature, are bound in honor to see that the trust accepted by the State, and incorporated in their own Constitution, should be sacredly complied with.

For the details of the organization of the Polytechnic School proposed by the Commissioners, reference. may be made to their Report, contained in the Public Documents of the State for the year 1864.

GEOL. VOL. I.-D 
To those gentlemen in California, as well as in the Eastern States, who have aided me. in various ways, in the prosecution of the arduous undertaking in which I have been engaged for the last fire years, my warmest thanks are due; but especially to my assistants, who have all laboled zealously for the interests of the State and the Survey, regardless of hardships or dangers.

In closing this preface, I will simply add an extract from my address before the Legislature, in 1862, in which the reasons why the Geological Survey of California should be continued on the broad basis of the original Act under" which it was organized, are succinctly set forth.

"I submit, therefore, that California needs a Geological Surrey, for" the following good and sufficient reasons:

First. 'To furnish a basis for detailed explorations for farther deposits of metallic and mineral treasures, by limiting the field of research for the numerous prospectors always engaged in the search for useful ores; so that every man will be working where his labor will tell, and not throwing it away on undertakings which a comprehensive view of the mode of occurrence and geological position of our economically valuable materials will show to be a mere waste of money, time, and energy.

"Second. To insure permanent working and economical development of what is discovered, by giving every one the means of knowing beforehand how his discoveries may be turned to the best account, how much it will cost to open his mine, how much to reduce his ores, what form to give his products, and where and in what quantity they can be disposed of. On subjects of this kind, we are constantly applied to for information, and are always ready to advise to the best of our ability. And, if not now, we shall, as we become more fully acquainted with all the necessary conditions, be able to render essential service in this line, as our statements will be recognized as being based on extensive researches, and entirely disinterested; and in our final report we shall throw all possible light on these subjects, so that it will not be onr fault if the man about to embark in any enterprise connected with ores or mineral substances will not find in our work something which will materially aid him in his undertaking, or at least prevent a foolish waste of money on the impracticable.

"Third. We need a Feological Survey in ordel that the resources of the State may be made known to the world, under official guaranty of correctness, and in detail, so that not only our own capitalists, but those of other countries, may have opened to them a field for investment, in regard to which they will be possessed of such definite information that they may feel that they are not entering on a blind speculation when putting their money into a mine.

"Fourth. We need such a Survey as was contemplated by the Act under" which we commenced our work, in order that the educational interests of the State may be advanced-our schools, colleges, and University furnished with a scientific basis for instruction in the different branches of Geology and Natural History, and with text-books in which the necessary informa- 
tion may be found as to the forms of animal and vegetable life occurring on the Pacific coast.

"Fifth. We need a Geological Survey in order" to show to the world that the State is willing to contribute something towards the adrancement of science, and that we may not be subjected to the mortification of having the rich harvest of facts which California spreads out before us, left ungathered, or only partially reaped, for the benefit, and by the efforts of other States and countries."

November 1st, 1865.

J. D. Whitney. 



\section{PART I. \\ GEOLOGY OF THE COAST RANGES.}

\section{CHAPTER I。}

\section{N T R O D U C T O R Y.}

The term "Coast Ranges" is one which will be frequently employed in this Report, as it is one in common use in California. It is the designation of a great group of mountain ranges, naturally, and almost necessarily, applied to distinguish them from the ranges of the Sierra Nevada, and for this purpose familiar to all residents on the Pacific coast. When, however, we seek to define the term Coast Range with the precision desirable in a scientific work, we soon discover that an exact definition of it is a difficult matter, and that a discussion of its meaning will soon lead us into regions where a knowledge of both the geography and geology of the State will be necessary for understanding all the elements which are involved in what is apparently so simple a question. The first part of this Report will be occupied with the geology of the Coast Ranges, the second with that of the Sierra Nevada, and it will not be until we have passed over this ground, that we can enter understandingly upon a discussion of the question, how and why shall the line be drawn separating the two systems of mountain ranges from each other. In the meantime, however, some general considerations on the topography of the Coast Ranges will be convenient as an introduction to what is to follow in regard to its geology, reserving the consideration of the more difficult theoretical portion of the subject for a future chapter.

GEOL. VOI. I. - 1 
Between the parallels of $35^{\circ}$ and $40^{\circ}$ there is no difficulty in separating the Coast Ranges from the Sierra Nevada. The traveller, passing up the valleys of the Sacramento or the San Joaquin, observes at a distance of twenty or thirty niles, on either hand, a continuous wall of mountains, which may appear in the dim distance to the inexperienced eye as a simple and narrow range, but both of which in reality are broad belts of elevated ranges, the one averaging forty, the other seventy miles in width, of which the detailed structure is exceedingly complicated, and whose grand dimensions can only be appreciated by those who have penetrated to their deepest recesses. Suffice it to say, for the present, that in the Sierra Nevada on the one hand, and the Coast Ranges on the other, we have two groups of mountain chains, which for length and average elevation are but little, if at all, inferior to the Alps and the Appalachians, those grand features of the earth's surface which have for so many years occupied the attention of a host of scientific observers, and lovers of natural scenery. Of the eastern series of ranges, the most distant and loftiest elevations are never entirely bare of snow, and for a large portion of the year are extensively covered with it; while the western ones, in the central portion of the State at least, are only occasionally and rarely whitened on their highest summits, and for a brief period of the winter. Hence the eastern heights were long since known to the Spaniards as the "Sierra Nevada," or Snowy Range; sierra being almost the exact equivalent of our word range or mountain-chain. The group of mountains on the western side, and nearer the ocean, naturally received the designation of "Coast Ranges," although this appears to be a term of natural Anglo-American growth, and not a translation from the Spanish, those using this language having, so far as noticed, no word in general use equivalent to "Coast Range," but calling the different groups of mountains, or minor chains separated by narrow valleys, after the names of various saints; indeed, nearly exhausting the calendar. In many cases these names are uncertain, and frequently the same range is known to residents along different portions of it by different names, which are generally the same as those given to the dominating peak in the immediate vicinity. Thus the Monte Diablo Range is so called from the conspicuous point of that name, which, although not as high as 
other summits of the same range, from its peculiar isolated position is a sort of natural landmark over a large part of Central California.

Between the 35th and 40th parallels, as before remarker, there is no difficulty in distinguishing the Coast Ranges from the Sierra, as the broad valleys of the Sacramento and the San Joaquin form a complete separation of the two systems of mountain-chains; but if we go north or south of these limits, the condition of things changes greatly, as will be evident to any one inspecting a map of the State. In the neighborhood of the Tejon Pass; which is in about $35^{\circ}$ of latitude, the ridges of the Sierra and the Coast Ranges become continuous, and it is only on geological considerations that the line of division between the two systems can be drawn, the topography alone giving no clue as to where the one ceases and the other begins. Thus the question has been repeatedly asked during the continuance of the survey:- What is the proper name to apply to the ranges south of Fort Téjon? Do they belong to the Sicrra, or to the Coast Mountains? The same is the case with regard to the mountains north of the head of the Sacramento Valley. Above Shasta City (latitude $40^{\circ} 35^{\prime}$ ) the ranges close in on all sides, and to the traveller threading the innumerable cañons there seems to be no clue to the labyrinth of chains and no possibility of preserving the distinction between Coast Range and Sierra. Farther on in this Report this question will be discussed, in the light of the geological information which has been previously laid before the reader; at present such general topographical considerations need only be presented as shall render the systematic division of this volume intelligible. For a complete review of the physical features of the State, a future volume of this Report, exclusively devoted to physical geography, must be awaited.

In order to bring vividly before the mind the grand simplicity of the topographical features of California, we may draw on the map of the State five equidistant, parallel lines, having a direction of N. $31^{\circ}$ W., and 55 miles apart. Let the middle one of these be drawn at the western base of the Sierra Nevada, touching the edge of the foot-hills, as it will be found to do with the given direction, from Visalia to Red Bluff, the first parallel line east of this, drawn at 55 miles distance, will pass through or very near the highest points of the Sierra, begin- 
ning with Mount Shasta, on the north, and tonching in succession towards the south, first Lassen's Butte, then Spanish Peak, Pilot Peak, the Downieville Buttes, Pyramid Peak, Castle Peak, Mount Dana, and beyond this, keeping close along the main crest of the Sierra, across the culminating points of the chain which lie to the south of Mount Dana, of which the position has only recently been determined, and which have not yet been laid down on any published map. Indeed there is no map of the Sierra, as yet, on which the main ridge is accurately given, and the determination of the more or less precise accordance of the line indicated above with all the dominating peaks must await the completion and publication of our topographical work. It is sufficient, for the present, to say that the line drawn through the culminating peaks of the Sierra, for a distance of almost 500 miles, is very nearly a straight one, and that its direction is $\mathrm{N} .31^{\circ} \mathrm{W}$., and that we may call this the main axial line of California, while it will be interesting to notice to how considerable an extent the great topographical features of the State will be found to be subordinate to it.

The next parallel line east of this, still at the same distance of 55 miles, crosses a series of depressions, mostly occupied by lakes, which we may consider as representing the eastem base of the Sierra. These lakes are the Klamath, Wright, Pyramid, Walker, Death Valley, and Soda Lake, the sink of the Mohave. At its southern extremity, it marks the confluence of the Colorado and Gila Rivers.

The first line to the west of the central one, or that drawn at the western base of the Sierra, will be found to follow very closely the eastern edge of the Coast Ranges, from the neighborhood of Kern Lake to that of Clear Lake, a distance of over 300 miles. The second line west of the central one, and the last of the series of parallel, equidistant ones, represents, as nearly as possible, the coast line of the Pacific; or, in other words, the western base of the Coast Ranges. By this curious arrangement, which must be due to the working of great cosmical forces, and which is evidently not the result of chance, we have the State, at least that portion of it between Fort Téjon and Red Bluff; divided into four belts of nearly equal width (a portion of the most easterly one, however, falling within the limits of the State of Nevada), which are designated as follows, naning them in order from east to 
west: the Eastern Slope, the Sierra, the Great California Valley, and the Coast Ranges.

This arrangement of the physical features of the State holds good for a length of 400 miles, in the direction of the main axial line, and this division of California is the largest and by far the most important, comprising almost the whole of the agricultural and the greater part of the mining districts, and may be designated as Central California; that portion to the south of a line drawn at right angles to the main axial line, or N. $59^{\circ}$ E.-S. $59^{\circ}$ W., through Fort Téjon, may be called the Southern Division; that north of a parallel line passing through Fort Reading, may be also designated as the Northern Division of the State. This perhaps is the most simple and convenient division into a small number of parts which can be made, and it approximates pretty closely to the general and natural recognition, among the people, of a Northern, Central, and Southern California. So peculiar, however, is the detailed structure of the State, that it is difficult to find any thoroughly satisfactory arrangement of its parts; and in view of our as yet imperfect knowledge of all the conditions influencing the decision of this question, the matter will be left in abeyance until the publication of a final volume on geology or physical geography. In the meantime a more or less artificial system will be followed, based however on the well-marked division of the mountain chains into Sierra and Coast Range systems.

As the Coast Ranges in the vicinity of the Bay of San Francisco have been more carefully studied by the Survey than any other portion of the State, and especially more so than the continuations of the same ranges north and south, it will be proper to take up the description of this region first, since its geological structure can be made out in a more detailed manner than that of other districts, where of necessity less labor has been expended.

Two difticulties beset us constantly in the study of the Coast Ranges: one is, the similarity in lithological character of rocks of different geological ages; the other, the comparative paucity of fossils by which the different sets of strata might be identified and traced over the wide extent of territory they occupy, where lithological characters were insufficient for this purpose. It may also be noticed that the preva- 
lence of metamorphic or chemical changes in the rocks has often obliterated all the evidences of stratification, while the thorough mechanical crushing which the beds have undergone, over many extensive districts, has often rendered the deciphering of their stratigraphical position a task of extreme difficulty. In consequence of these conditions, while our general conclusions may fairly be accepted as making a reasonable approach to correctness and as furnishing a sound basis for future explorations, we cannot avoid great deficiencies in the details, which only the patient labor of many years, on the part of future students in this region, will be able to supply.

As the geographical basis on which this portion of our work is founded, and as the necessary guide in its perusal, we refer to the topographical and geological "Map of the Region adjacent to the Bay of San Francisco," drawn by Mr. Hoffmann, and compiled from all the sources within our reach, the topography being almost exclusively original, and the result of his own labors.* This map embraces the region from near Santa Cruz north to Sonoma, Napa, and Petaluma, and it extends east and west from Punta de los Reyes to Corral Hollow. The area of land which it covers is about 4248 square miles, which is just twice that of the State of Delaware, and only lacks two hundred square miles of equalling that of Connecticut. As near as can be ascertained, from an examination of the results of the census of 1860 , it contains one-third of the population of the State, and has about thirty inhabitants to the square mile, the average density of the population of California being but little over two to the square mile.

The region adjacent to the Bay of San Francisco may, without hesitation, be called the garden of California; it includes her most fertile valleys and her richest and best watered farming lands. Its climate, tempered by the proximity of the Golden Gate, through which enter

* This map will be issued by itself as soon as the engraving, whieh is neeessarily the work of mueh time, has been eompleted. It will also form one of the series of maps embraced in a volume of the series of the publieations of the Geological Survey, whieh volume will be especially devoted to maps, seetions, and other illustrations whieh eannot well be bound up with the text. The various maps issued by the Survey will be furnished either plain, or with the geology eolored upon them, as may be desired, so that they may be used either as geographical or geological guides in the regions whieh they embrace. 
the moist and cooling ocean breezes, is as near perfection as ean be desired. That portion represented on our map contains less than onefortieth of the area of the State, but has one-third of its population; and, so rapid is the growth of San Francisco, that it will soon comprise one-half, and probably in time a considerably larger proportion. Hence the propriety of preparing a map of this region on a scale greater than that which we shall be able to use for other portions of the State; and hence, also, the convenience and possibility of working up its geology more in detail than that of other districts, of which our maps are much less complete, for without accurate maps accurate geology is simply impossible.

On examining the map, it will be seen at once how large a portion of the region in question is of a mountainous character. With the exception of the Bays of San Francisco, San Pablo, and Suisun, and the valleys adjacent, which are in reality all parts of one connected whole, only not entirely covered by water, there are no extensive plains. The most superficial glance at the map will also reveal the fact, that the ranges of mountains have a predominant trend in one direction, namely, about northwest and southeast, and that the main features of the surface, such as the position of the hills, valleys, plains, and watercourses, are closely dependent on the fact of the folding of the surface having taken place in this direction. The topographical elements are in the line of northwest and southeast, or nearly at right angles to it. This, indeed, is mainly true throughout the Coast Ranges.

There are many general considerations with regard to the Coast Ranges which cannot well be entered upon until after their geological structure has been explained, and these will, consequently, be deferred to a later portion of this volume, and we may now commence with the Monte Diablo Range. 


\section{CHAPTER II.}

THE MONTE DIABLO RANGE.

\section{SECTION I.-Introductory.}

The group of mountain chains to which the name "Monte Diablo Range" is applied, extends from the Straits of Carquines and San Pablo Bay in a southeastern direction to about latitude $36^{\circ} 30^{\prime}$. It is limited on the east by the plain of the San Joaquin, and on the west it has the Bay of San Francisco and the Valley of Santal Clara to isolate it from the other division of the Coast Ranges. In its northern extension, the Monte Diablo Range is easily defined; but to the south it widens and inosculates with other ranges, or spurs, falling into it from the northwest, until finally uniting with the extreme western members of the great group of the Coast Ranges it forms the broad region of high rolling hills, intersected by a labyrinth of narrow valleys, which lies between the parallels of $35^{\circ}$ and $35^{\circ} 30^{\prime}$, and where distinctness of nomenclature for the different groups of elevations is almost entirely lost. For convenience, and as representing as nearly as possible a natural division of the Coast Ranges, the Monte Diablo Range may be considered as terminating to the south in the low ridges running out into the San Joaquin plain at the head of Las Gatas Creek, in latitude $36^{\circ} 20^{\prime}$. As thus defined, the range is about one hundred and fifty miles long and from twenty to thirty broad. For fifty miles on its southwestern edge it is with difficulty separated from the Gavilan Range, the two having only the narrow valley of the San Benito between them for nearly that distance, and finally uniting in the most unbroken comnection with each other.

The Monte Diablo Range is made up of a complicated series of ridges, mountains, and valleys, when examined in detail, and part of it is exceedingly rough and very little traversed by any class of men, not even by hunters or explorers. How little was really known of the geography of the chain may be inferred from the fact that there existed in it peaks higher than Monte Diablo and in sight from the 
elevated portion of the city of San Francisco: this fact was made known by the explorations of the survey.

That portion of the Monte Diablo Range which lies north of Alameda Cañon and west of the Valley of San Ramon, is usually called in San Francisco the Contra Costa Range, or the Contra Costa Hills, these being the elevations which rise behind the Bay of San Francisco, and which are so conspicuonsly in view from the city itself. The mass of the range north of Livermore's Pass, and east of the San Ramon Valley, is that particular portion of the range to which the name of Monte Diablo, that of its culminating point, is most usually applied. To that extensive and rugged mountain district, which lies south of the Contra Costa Hills and the Corral Hollow Pass, it will be convenient to give names corresponding to the various subdivisions into which it may most naturally be broken. To the region between Corral Hollow Pass and Pacheco's Pass the name of the Mount Hamilton Division may be given, from that of its culminating point. That portion which lies between Pacheco's and the Panoche Passes may be designated as the Panoche Division; of this, Pacheco's and the Santa Anna Peaks are the most conspicuous points. The next more southerly division of the main range, or that between the Panoche and Estrella Passes, may be called the San Carlos Division, from its dominating peak, which is also the highest point of the whole Monte Diablo Range. Finally, the most southerly division lies between the Estrella and Roble Passes, and to this the name of Estrella may be given, from the pass and river of that name.

In traversing the plain of the San Joaquin, issuing from Pacheco's Pass, or, better still, from Livermore's Pass, and taking the road to Visalia, the various masses of the Monte Diablo Range are well seen and may be studied and compared in their general outline and magnitude. The Livermore Pass is much lower than either of the others, there being no such break through the chain anywhere to the south. The high mass of Mount Hamilton is conspicuous, and it is evident that the ridges in that part of the chain run out into and sink beneath the plain. Pacheco's Peak and the other high points in its vicinity are conspicuous, but less so than from the westem side of the chain. Low sandstone hills stretch along in front of them and south to beyond GEOL. VOI. I. -2 
San Carlos Peak, looking like a wide and elevated terrace in the distance, much eroded into cañons, and very dry and bare, except in the early spring after a winter of abundant rain. The mass of San Carlos seems the highest and grandest of the whole chain, the most elevated point being a few miles south of the mine of that name, near New Idria; this high mass, however, extends south fifteen or twenty miles, the southern portion having a very rough outline, crowned with a battlement of rock, which is conspicuous from a long distance. South of this is the depression, through which is the Estrella Pass, the trail ascending Chelone Creek, from the Estrella Ranch, and crossing over the Arroyo las Gatas; this depression, however, is not a low one. South of this is another mass of mountains of considerably less elevation than the San Carlos, and the chain sinks very low again as we approach Paso Roble.

The following table shows at a glance the principal facts known with regard to names and elevations of the various subdivisions of the Monte Diablo Range, the highest peaks and the passes:

$$
\text { Subrlivision. }
$$

Monte Diablo.

Mount Hamilton.

Panoche.

San Carlos.

Estrella.

$$
\begin{aligned}
& \text { Name and elevation of } \\
& \text { dominating peak. }
\end{aligned}
$$

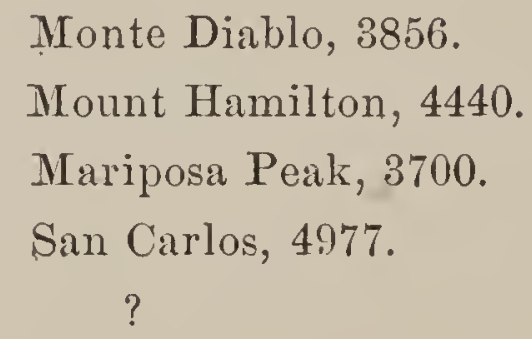

$$
\begin{aligned}
& \text { Name and height of pass, } \\
& \text { separating it from next } \\
& \text { more southern division. }
\end{aligned}
$$

Livermore Pass, 686.

Pacheco's Pass, 1470.

Panoche Pass, 2500.

Estrella,?

Paso Roble, ?

The Estrella and Roble Passes have never been instrumentally explored.

In describing each of these divisions it will be convenient to begin with the Monte Diablo group, and to proceed southward. The explorations on which our information is based and the lines of section examined in working out the geology of the Monte Diablo Range were as follows:

In 1861, the chain was passed through in a southeast direction from San Juan to the New Idria mines, the road traversing the range diagonally for a distance of fifty or sixty miles. The most southerly point visited was San Carlos Peak, which is about one hundred and fortyfive miles from the northwest extremity of the chain. Another excursion was made to Pacheco's Pass and its vicinity, and thence the party 
travelled along the east side of the San Jose Valley and the Bay of Siln Francisco for a distance of seventy miles, making frequent offsets into the chain to the east. Thence a line of section from Oakland to Monte Diablo itself was examined and the vicinity of the mountain as far south as Corral IIollow, as well as the region adjacent to Calaveras, Livermore's, and San Ramon Valleys. In 1862 the vicinity of Monte Diablo was again visited and explored more in detail than the year before, so much so as to admit of an accurate topographical map being constructed. This work was participated in by all the corps, and afterwards the east side of the Monte Diablo and Mount Hamilton groups were explored with some care by Messrs. Brewer and Gabb, and the principal points in the topography of that before utterly unknown region determined. by Mr. Hoffmann. This party returned north through Pacheco's Pass, on their way re-examining some of the points left unvisited on the previous journey up the valley. Many short excursions were made at various times into the vicinity of Monte Diablo and the Contra Costa Hills by all the members of the corps.

\section{Section II.-Contra Costa Hills.}

The subordinate group of elevations lying west of Martiñez and the San Ramon and Livermore Valleys, is known as the Contra Costa Hills; they extend through the county of that name into Alameda and Santa Clara Counties, and finally become merged in the Mount Hamilton Division of the Monte Diablo Range. These hills are separated from the principal mountain mass of Monte Diablo by a system of valleys extending for about forty-five miles, and preserve a somewhat distinctive character for some fifteen miles farther, losing their identity entirely about the head of Calaveras Valley. They are made up of Tertiary and Cretaceous strata, usually but little metamorphosed, although a belt extending along their western side is considerably altered from its original character.

Beginning at the northwest extremity of the group, at Martinez, we have in the immediate vicinity of that place Cretaceous strata, well exposed in the bluffs along the Straits of Carquines. Here the rocks observed are sandstones, shales, and argillaceons limestones, the latter 
forming bands and lenticular masses in the shales, generally but a few inches thick, although sometimes as much as three feet. Their strike is usually about $\mathrm{N}$. $42^{\circ} \mathrm{W}$., varying, however, from $\mathrm{N}$. $39^{\circ} \mathrm{W}$. to $\mathrm{N}$. $44^{\circ} \mathrm{W}$, and they dip southwest at an angle of from $35^{\circ}$ to $60^{\circ}$.

The rocks near Martiñez have furnished a large number of species of Cretaceous fossils, having been most diligently examined by Mr. E. Matherson. Over a hundred forms, mostly new, have been obtained here by this gentleman and the members of the survey, for a list of which see the table of localities of Cretaceous fossils in the volume devoted to the Palæontology of these rocks. Both divisions of the Cretaceous are represented here.

In passing along the shore of the Straits of Carquines, west of Martiñez, the Cretaceous strata occur for about seven miles, and are made up of shales and sandstones, the former containing frequent thin layers of hydraulic limestone. These rocks, however, exhibit but few fossils. The dip and strike are variable, but generally about east and west magnetic, and the dip is also irregular, but almost always to the southwest, and at almost every angle from nearly horizontal to vertical; the strike is nearly parallel with the line of the. Straits. Near the upper limit of the Cretaceous, are sandstones very like those of Monte Diablo which accompany the coal, and they contain a considerable quantity of carbonaceous matter, but no regular coal-bed, so far as yet discovered. Near these carbonaceous strata, and above them, is a narrow belt, partly altered and folded, and from one hundred and fifty to two hundred feet in width. The Rodeo Valley marks the limit of the Cretaceous, going west from Martiñez, the Tertiary succeeding in that direction, and resting conformably on the strata beneath, and having the same general southwestern dip. South of Martiñez the Cretaceous strata have a higher dip, but in the same direction.

Southwest of the Rodeo Valley lies a broad belt of Tertiary rocks, which extends from San Pablo Bay to Amador Valley, forming the mass of the Contra Costa Hills, for a distance of about thirty-five miles northwest and southeast, and having a breadth of from six to eight miles. The rocks are chiefly sandstones, and in places highly fossiliferous. San Pablo Creek heads in this belt, and flows between two parallel ridges, in the line of the strike of the rocks. On the west side 
of the creek, about four miles a little south of east from San Pablo, the rocks contain considerable bituminous matter, and a well had been bored here in 1862 to the depth of eighty-seven feet, at which point oil was struck, which it was proposed to purify by distillation, and works were erected for this purpose, as also to obtain oil from the highly saturated sandstone.* At these springs the rock has a high dip northeast; but a mile farther northwest it dips to the southwest, while the hills in the vicinity are too deeply covered by soil and decomposed rock to admit of the general position of the strata being determined satisfactorily.

To the north of San Pablo are low hills of very recent strata, which are nearly horizontal and which rest unconformably on the edges of the Tertiary. Whether these beds contain any extinct species of shells has not yet been determined; at all events, they are no older than the Post Pliocene.

In the valleys between San Pablo and Walnut Creeks, many sections made by the rains of 1861-62 in the superficial detritus were observed. The beds are horizontally stratified, and made up of light and darkercolored materials, the lighter ones being darker near their upper surfaces, and growing lighter downwards to the depth of from six to twelve inches; as beds usually do when acquiring a color from decaying vegetable substances. This would indicate that the rate of deposition of this detritus has been exceedingly irregular, long periods having sometimes elapsed without much addition to the detrital deposits, and then, again, a heavy mass of materials being suddenly spread over the surface, just as takes place at present during a winter of extraordinary storms, like those of 1861-62. The appearances indicate sometimes a heavy deposit during one year only; at others, a succession of them for several years. The same or similar facts were observed at many points in the Coast Ranges.

The whole range under consideration is denuded into a great number of hills and valleys, the latter running parallel with the strike of the strata, as will be seen by referring to the map. The valleys are

* The quantity of oil obtained scems to have been too small to pay, as the work was not profitable, and had been discontinued previous to the oil exeitement of 1865 ; whether resumed or not we have not been informed. 


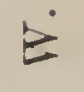 \\ $\dot{i s}$}

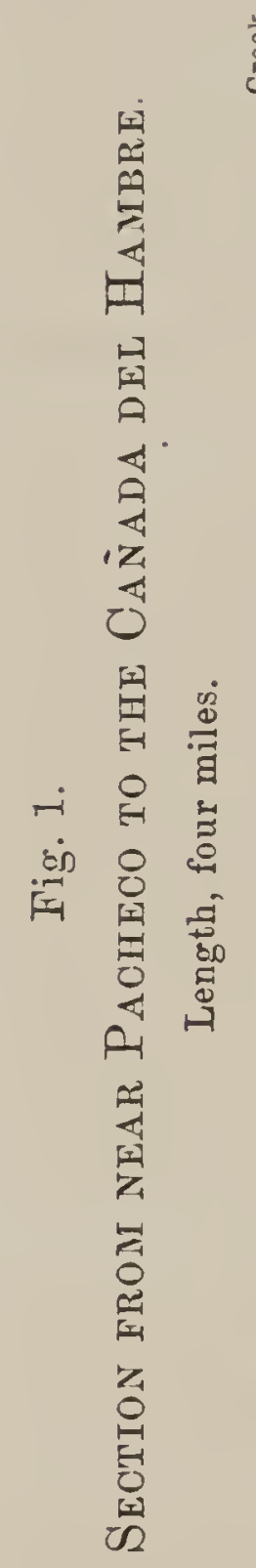

excavated in the softer materials, and are frequently drained by streams running in two opposite directions, which connect at their sources by very low divides, so that one hardly recognizes the fact that he is passing over them. When streams cut across the strike of the strata, as they occasionally do, the valleys become mere cañons, or narrow rocky defiles.

To the southeast of Martinez there is a good exhibition of the folding of the strata exhibiting a synclinal axis, as will be seen from the annexed section (Fig. 1), by Mr. Gabb, which runs from a point one mile north of Pacheco, southwest to the Cañada del Hambre, a distance of about 4 miles.

Walnut Creek (Arroyo de las Nueces) heads in the divide between the valley of this name and that of the San Ramon; it separates the Contra Costa Hills from the Monte Diablo group proper. High hills of 'Tertiary sandstone rise to the west of it, attaining an altitude of from 1800 to 2000 feet. The high group of hills north of the head of the San Ramon is also of sandstone, and has about the same elevation. The strike of the strata here is about $\mathrm{N} .50^{\circ} \mathrm{W}$. to $\mathrm{N}$. $55^{\circ} \mathrm{W}$, and the $\operatorname{dip} 65^{\circ}$, to the southwest. The San Ramon, heading in this group of hills, runs southeast, then turns and runs parallel with its former course in the opposite direction, having a high 
and steep range of fossiliferous sandstones between the two parallel portions.

The foothills along the eastern base of these higher ridges are of strata very much broken, with every possible dip and strike, the latter frequently at right angles to that of the strata in the main ridge, and standing vertical. There are indications of a line of quite recent disturbances of the rocks through the San Ramon and El Hambre Creeks, which line crosses the general direction of the stratification at an angle of $35^{\circ}$. There are fissures in the soil along the west side of the San Ramon Valley, which were formed during the earthquake of June, 1861, and which may be considered as strengthening the probability of the recent formation of this valley. That extensive disturbances have taken place in the Monte Diablo chain within the most recent geological epoch will be seen farther on.

Near the head-waters of the San Ramon, the hills of Tertiary sandstone rise to the height of about 2000 feet; the strata have a strike of about $\mathrm{N} .39^{\circ}$ to $41^{\circ} \mathrm{W}$., and they have a high dip to the southwest. The same strata, as followed along a few miles farther to the northwest, near Maragua Valley, become more nearly vertical, and the strike curves around more to the west. The same belt of rocks extends southeast from the head of the San Ramon, through the range of hills west of Amador Valley, and they have a lower and more uniform northwesterly dip. These hills sink into the plain near the eastern end of the pass leading from Hayward's to Amador Valley.

Near the "Wahnut Creek House," a small patch of Cretaceous occurs, extending over a few acres, from which the overlying Tertiary, forming the crown of a low anticlinal, has been denuded.

A belt of metamorphic rock may be traced along the western side of the Contra Costa Hills, beginning near San Pablo, thence following the west side of Wild Cat Creek, and appearing in a southeast direction along the foot-hills of the range, for a distance of about thirty-five miles. It generally forms a narrow belt, not over two miles wide, and often not half that; but in some places there is more or less metamorphic action observable over a width of four miles. The northwestern portion of this band of altered rock curves to the northwest, and seems to form the isolated metamorphic hills lying near the bay and west of 
San Pablo and islands of similar rock in the Bay, apparently connecting with the range of high hills which run out at Point San Pedro and extend back of San Rafael.

Near San Pablo a great variety of the results of metamorphic action may be observed; as, for instance, in following a line extending from the house of $V$. Castro back to the top of the ridge. The original rock seems to have been a more or less bituminous slate or shale, and patches of it have almost entirely escaped metamorphism, while other's in the immediate vicinity are very much altered and converted even into mica slate. The dip of the strata, when it could be made out, was to the northeast, $30^{\circ}$ at the base of the hill and gradually getting higher towards the crest of the ridge, where the metamorphism is most complete. Here the rock is traversed by small quartz veins, and has evidently been acted on by water containing silica in solution, as it is to a large extent converted into that mixture of ferruginous, jaspery, and chalcedonic material, which is so well known as frequently containing cinnabar, that we have become accustomed to call it the "quicksilver rock." Considerable masses of actinolite have been found lying on the surface in this vicinity, evidently derived from the rocks of this ridge. The specimens resemble exactly those obtained from the very much older metamorphic rocks of New England.

The widest and highest portion of this metamorphic belt lies near the pass leading from Oakland to La Fayette, the summit of which is 1311 feet above high tide. About a hundred rods west of the summit metamorphic slates stand vertical, having a close lithological resemblance to rocks elsewhere known to belong to the Cretaceous system; a short distance northwest they have a high dip to the northeast. A sharp ridge, half a mile in a direction N. $32^{\circ}$ W. from the "Summit House," is of hard metamorphic sandstone, of which the strike is $\mathrm{N}$. $64^{\circ} \mathrm{W}$, but curving more to the south as we go southward; the dip is to the northeast, about $70^{\circ}$ in amount. Hand specimens of this rock have a very trappean look; but they appear to be of metamorphic origin.

About one mile farther north is the highest point north of the pass, called on our map "Rocky Mound;" it is 1921 feet high, forming a rounded hill, having a distinct stratification, although very trappean in 
its appearance, and a dip to the northeast. Between this point and the ridge spoken of in the last paragraph, there is a mass of trappean rock, finely crystalline and very hard, in which no planes of stratification can be observed. On the northeast of San Pablo, the unaltered strata rest on these metamorphic rocks and dip northeast.

The ridge between Wild Cat and San Pablo Creeks is made up of strata dipping northeast from $30^{\circ}$ to $35^{\circ}$, and having a strike of about N. $52^{\circ} \mathrm{W}$. The north end of this ridge is of quite unaltered strata, while the southern portion is highly metamorphosed.

On the east side of Carlisle Creek, a metamorphic limestone occurs, in which all traces of stratification have been obliterated, the mass of the rock being traversed by veins of quartz, resembling semi-opal in appearance.

South of the pass from Oakland to La Fayette, several high domeshaped hills rise, having an elevation of about 1850 feet, made up of highly metamorphic rock having a trappean aspect, but stratified and dipping northeast. Intruded in this are masses of rock which appear to be of decidedly eruptive origin, as the metamorphic strata are displaced in their vicinity. Here, as in many other localities in California, it is difficult to draw the line between eruptive and sedimentary, as both have undergone extensive metamorphism since their formation.

A short distance south of the pass the metamorphic strata suddenly contract to about one and a half miles in width, an arm of unaltered sandstone and slates extending up between two branches of the metamorphic. In this region the slates are little metamorphosed, appearing white and easily decomposed, although much contorted. Portions are highly silicious, but soft and friable, and, under the name of "kaolin," are used to mix with clay in making pottery at San Antonio. This belt of slates and shales may be traced southeast as far as Suñol Valley, beneath which they dip, rising again probably and appearing in a highly metamorphic form in the mass of the Mount Hamilton Group. In the places where they are not metamorphic they have all the lithological character of the strata known to be of Cretaceous age, which have been described as occurring near Martiñez, and which will be noticed farther on as so well developed near Monte Diablo.

Lying to the west of this are massive sandstones, entirely unaltered, GEOI. VOT. I. - 3 
which as yet have furnished no fossils, but which are believed to be of Cretaceous age. They form an elevated ridge, of which the culminating point is Redwood Peak, 1635 feet above the level of the bay. The strike of these sandstones at this point is about N. $69^{\circ} \mathrm{W}$.; but they curve more to the south on the southeastern side of the ridge. Their usual dip is to the northeast; but near Redwood Point the strata are much broken, and three miles southeast they sometimes stand vertically, or have a very high dip to the northeast.

Beneath this mass of sandstones, and extending to the southwest, there is a body of coarse conglomerate, forming a series of ridges of considerable altitude. Northeast of San Leandro it appears in the range of hills forming the eastern boundary of the San Antonio Ranch. Ten or twelve miles farther to the southeast it appears in Suñol Peak, which rises to an elevation of over 2000 feet, on the southeast side of which it dips to the southwest. It passes through the Suñol Valley and becomes a portion of the great metamorphic belt of the Mount Hamilton Range.

Although no fossils have been found in place in the belt of slates and shales alluded to above as exhibiting so well-marked a resemblance to rocks elsewhere determined to be of Cretaceous age, yet a few boulders have been picked up which contained shells undoubtedly of this epoch. A more careful search will hardly fail to furnish some farther evidence on this point. One of these boulders was found near the entrance of Suñol Valley, in a locality wherè it is hardly possible that it should have come from any other belt of rocks than that indicated above.

The metamorphic band, before alluded to as beginning near San Pablo, after narrowing near Redwood Peak, extends along the western slope of the hills, forming the lower ridges at their base. It does not, however, form a well-defined belt parallel with the strike of the strata, nor does it appear to represent an axis of elevation. In a section examined from San Leandro across the summit of Monte Diablo, it was seen conformably underlying the conglomerates and sandstones before spoken of; but farther south its relations to the adjacent rocks become very obscure, owing to the almost entire obliteration of the lines of stratification consequent on the increased metamorphism of the mass. 
As observed in the foot-hills of the range between San Antonio and Alamedia Creek, this metamorphic belt has all the characters which are so often exhibited by the altered Cretaceous rocks. Serpentine is abundant in it in large irregular masses, and jaspery slates like those of Monte Diablo. East of San Antonio large patches are to be secn, having all the character's of the quicksilver-bearing rock of New Almaden and New Idria, exactly like those noticed as occurring near San Pablo. Considerable masses of chromic iron occur in this position, one of which was formerly worked to some extent. Stains of copper are not unfrequent, and have led to several attempts at mining, none of which have proved successful, or are likely to repay the labor and capital invested.

In the neighborhood of Alameda Cañon this metamorphic belt appears to be almost lost; but traces of chemical action, commenced and partially completed, are exhibited in narrow streaks visible among the highly inclined and broken strata; these, however, do not appear to connect through with the metamorphic mass of Mount Hamilton.

\section{Sectiton III.-Monte Diablo Group.}

Under this head, as a subdivision of the Monte Diablo Range, I shall describe the region which naturally groups itself about the dominating peak of Monte Diablo; namely, all that series of ridges and mountain elevations north of Livermore Valley and Corral Hollow Pass, as far as the San Joaquin River and Suisun Bay, and separated on the west from the Contra Costa 'Hills, just described, by the valleys of Amador, San Ramon, and Walnut Creek. For an idea of both the geography and geology of the region in question, the "Map of the Region adjacent to the Bay of San Francisco" may be consulted; as also, for a more detailed exhibition of a portion of the group, the "Map of the Vicinity" of Monte Diablo," which is on a scale of two inches to the mile, and which comprises an area extending from four miles south of Monte Diablo to twelve miles north, and having a breadth of about eleven miles east and west. This includes what, up to this time, has proved to be by far the most important coal-mining district in the State, and 
one which on this account was well worthy of a representation on a larger scale than any other portion of the Coast Ranges. The region about Monte Diablo, moreover, from its convenience of access and consequent facility of exploration, was at an early stage in the progress of the Survey deemed peculiarly fitted to be selected for a more detailed study than could be given to any other considerable area of the Coast Ranges, and it would be difficult to find in any part of the State a more interesting field for geological investigation. To the Survey it has served as a sort of key for unlocking the stratigraphical difficulties of the whole line of upheavals from Los Angeles to Clear Lake, and it was here that the existence of the Cretaceous formation in the State was first clearly recognized.

Monte Diablo itself is one of the most conspicuous and best known landmarks in California. But few persons in the State can have failed to recognize it from some point either of the Coast Ranges or of the Sierra Nevada. It is not its great elevation which has given it its preeminence among the imnumerable peaks of the Coast Ranges; it is just the height of Mount Bache near New Almaden, a point hardly known by name to those who have not made a special study of the geography of California, and it is overtopped by Mount Hamilton, San Carlos, and some nameless peaks to which no public attention has ever been attracted. The reason why Monte Diablo has so marked a pre-eminence among the peaks of the Coast Ranges is, that it is, comparatively speaking, quite isolated, especially on the northwest, north, and northeast, the directions from which it is most likely to be seen. To the traveller passing up Suisun Bay and the Sacramento or San Joaquin Rivers, it presents itself in all its symmetry and grandeur, rising directly from the level of the sea, and easily recognizable from a great distance by its double summit and regular conical outline, resembling that of a volcano, which it was generally supposed to be by the early settlers.

If the mountain is made such a conspicuous landmark by its isolated position, it becomes itself, in turn, a point from which a vast area of the State may be observed and studied. Rising as it does among the Coast Ranges, these may be traced from its summit from Mount Hamilton on the south to unnamed peaks in the vicinity of Clear Lake on the north, and from the plains of the Sacramento and the San Joaquin to 
the P'acitic, east and west. The great interior Valley of California lies spread out like a map, extending as far as the eye can reach. To the east, the view seems illimitable, and it is believed that there are few, if any points on the earth's surface from which so extensive an area may be seen as from Monte Diablo. This is due to the peculiar form of the Great Valley of California and the gradual rise of the Sierra, which brings higher and higher points to view as the distance becomes greater. The eye can range over an extent of 400 miles from north to south, and back to the east, or towards the summit of the Sierra, as far as the crest of this Range, the farthest northern point visible being Lassen's Butte, and the most extreme southernsome point near Owen's Lake probably, thus aftording a range along this snow-crested line of mountains of over 300 miles in length. The whole area thus spread out before the eye can hardly be less than $40,000^{\circ}$ square miles, not much less than that of the whole State of New York.

In describing the geology of Monte Diablo and its surroundings, it will be convenient to begin with the central mass of the mountain itself as a starting-point. This central mass is made up of metamorphic rocks; it is about six miles long, and one and a half miles in width, and is surrounded on all sides by entirely unmetamorphosed strata. It is of an irregular crescent form, the concave side turned to the northnortheast. The material of which it is composed is extremely variable in its lithological character; but it consists essentially of a central portion of very hard metamorphic sandstone, containing considerable epidote, flanked on both sides by jaspers, silicified shales, and slates. The former constitutes the north peak, the latter the main peak, or Monte Diablo itself. The central crescent-shaped mass of altered saridstone commences on the northeast, about a mile and a half in that direction from the north peak, sweeps around to the sonth and passes with its southern limit about a quarter of a mile north of the main peak, then bends around to the north so as to include the precipitous spur which runs off to the northwest, lying to the east of the head of Mitchell's Creek, and to the highest point of which we gave the name of Eagle Point; this is 2393 feet above the bay. Extending still farther to the northwest it crosses the creek, and forms the high north and south ridge which makes up the most northwesterly portion of the mountain 
mass. The southern extrenity of this ridge we name Black Point; the northern, Pyramid Hill: the former is about 1800 feet in elevation, the other a little less. The rocks of this ridge are, in part, an exceerlingly dark-colored, fine-grained, crystalline material, destitute of traces of stratification in the central portion of the mass; but which appears to be a metamorphic sandstone, although at first sight it might be taken for an eruptive rock. Its relations to the surrounding rocks indicate rather a metamorphic than an eruptive origin. It would be difficult to consider this part of the mountain as being of purely igneous origin, without including with it the rest of the crescentic mass, which, however, we know from its connection with the adjacent sedimentary strata, and from the fact that portions of it have partially escaped the metamorphic action, to be made up of detrital materials deposited from water.

Between the north peak and the main peak, or Monte Diablo itself, along the narrow ridge of a little more than a mile in length which connects the two summits, the variable character of the metamorphic rock of the mountain may be well observed. Portions of it consist of jaspery material, or silicious slate, distinctly stratified; these have resulted from the metamorphism of the purely silicious strata. Here and there are patches of imperfect serpentine, formed from the more argillaceous sandstones; while in places the rock becomes so highly metamorphosed as to be converted into a well-characterized mica-slate, in which numerous small garnets occur, and also zircons of minute size. The north peak has an elevation of 3593 feet, or 263 feet less than Monte Diablo proper. Here all traces of stratification are lost; but a careful examination of the rock, where it is well exposed in all its relations to the surrounding strata, led irresistibly to the conclusion that it was not of eruptive origin. The gap between the two peaks is excavated in the soft, imperfect serpentine; it is about 800 feet below the summit of Monte Diablo.

One of the best points for observing the gradual passage of the argillaceous sandstone into the hard dioritic or trappean rock, is along the flanks of the ridge of which Eagle Point is the culmination. The strata here may be traced in all stages of passage, from the soft sandstone to 
the hardest and most crystalline rock, to which in hand specimens an eruptive origin would have readily been assigned by most geologists.

On the outside of this great central metamorphic mass, both on the north and south, but not entirely surrounding it, are heavy accumulations of jaspery rock, one of the most peculiar features of the mountain, and the material of which the culminating point itself is made up. On the north side of the North Peak, these beds are finely exposed, forming a lenticular mass about two miles long and half a mile wide. They have a nearly east and west strike and dip to the north. They are here, as elsewhere, of a red color, varying from a dull brick-red to a brilliant vermilion hue. The strata are usually thin, an inch being about their average thickness, and they are much folded together and twisted. These jaspery strata on the north side of the North Peak do not extend around so as to pass to the north of the Eagle Point Ridge, but may be traced in the ravines in which Bagley Creek heads, passing into the unaltered shales of undoubted Cretaceous age, in which Ammonites, Inoceramus, and other fossils have been found, and which are largely developed to the north of the mountain as well as to the south. On the north side these may be traced high up into the mountain mass along the branches of the Arroyo del Monte Diablo. No one making an examination of this part of the mountain could doubt that these jaspers are the result of the alteration of the Cretaceous shales.

The rock of the summit of Monte Diablo is the same jaspery material, filled with fine reticulations of quartz, running through it in every direction; but, in some places, containing a large amount of epidote, which has been formed where the shale contained originally more lime than usual. The dip of these metamorphic strata is distinctly to the north, and the strike along the ridge leading to the summit is nearly east and west. "At many points on the south side of the mountain near the summit, and for a thousand feet below, these masses of contorted jaspery strata may be seen. At one locality, just two miles west of the summit, there is, in a narrow ravine, a most beautiful exposure of this kind. The strata of jasper are alternately brilliant red and light green, contrasting finely with each other, and are folded together in a manner which is rendered very attractive from the thinness and regularity of the different layers. The strike here is, in general, about N. $54^{\circ} \mathrm{W}$., 
and the dip to the north from $50^{\circ}$ to $70^{\circ}$. In tracing these strata to the west, they appear to give place to other metamorphic varieties of rock, of which serpentine is the most prominent, and we soon reach the entirely unaltered shales as on the north side of the mountain.

Serpentine is found, on both the north and south sides of the mountain, in considerable quantity. The largest mass is met with on descending the North Peak torrards the north, where it forms a lenticular deposit about two miles long and half a mile wide, lying next to the jaspery shales. It also occurs in the gap between the two summits, and around the head of the Arroyo del Cerro, two and a half miles west-northwest of the summit. Here, as in other localities, the serpentine is seen in every stage of passage from the argillaceous sandstone to the perfect serpentine itself. The boundaries are very irregular in all these localities, especially on the Arroyo del Cerro, where we come into the unaltered shales and sandstones on going a short distance in either direction.

The metamorphic region, thus indicated as forming the central mass of Monte Diablo, covers about twenty square miles, and from. it a great variety of rocks might be obtained. The red and green jaspery rocks, however, are the most characteristic forms, and having been here so unmistakably traced to their origin as Cretaceous shales, they have been of great service to us in recognizing this formation in other locali-

- ties, where the facilities for tracing it out in all its connections, and of determining its age by fossils were less than they were found to be in this vicinity.

This metamorphic region has been, at various times, assiduously explored for minerals and metalliferous ores of various kinds. Gold is reported to have been obtained in small quantities, and was at one time the object of expensive mining research. Cinnabar occurs at several points, especially on the northeast side of the North Peak, where quite handsome specimens have been obtained, associated with the silicious rock in which this ore usually occurs; it is also found on the ridge of Eagle Point. Copper ore has been also the object of much excitement in this region, as it is frequently found in small quantities, and occasionally in rather large masses, in the dioritic variety of the metamorphic rock. In and about Mitchell's Cañon, where this kind of 
rock is most developed, a considerable number of companies were at work in 1862 and 1863; but nothing had been discovered which could properly be called a regular vein, or worked with profit. It is interesting to notice, however, the occurrence of these ores in a rock of so late a geological epoch, so evidently associated as they are with the existence of metamorphic action in this region.

Near the northwestern extrenity of the metamorphic mass, about two miles northwest of the summit of Black Point, is the largest mass of travertine or calcareous tufa which we have yet observed in the State. It extends north and south for a distance of over half a mile, forming low ridges running northwest and southeast, and having sandstone both to the north and the south. Its width east and west is fully 1000 feet. It is almost white, much of it quite so, marle up of a very pure carbonate of lime, and possessing the concentrically-aggregated structure so often exhibited by masses of stalagmite. It undoubtedly owes its existence to deposition from a hot spring, which once came to the surface at this point. This deposit has been quarried and burned for lime; but was not in use for that purpose at the time of our visit, there not being at this locality the same facilities for fuel and transportation that the lime-kilns at Santa Cruz have, so that it could not sustain a concurrence with the establishmentoat that place.

It may be mentioned that there are other deposits of this calcarcous material in this region. The most extensive, next to the one just noticed, is on the other side of the San Ramon Valley, near Mr. Russell's house, where it forms a very heavy mass on the side of the hill, about 500 feet above the valley.

Flanking the whole north side of Monte Diablo are unaltered Cretaceous strata, having everywhere a northerly dip, and a general strike of about cast and west magnetic; the dip of the mass is irregular, in some places vertical, but usually from $45^{\circ}$ to $35^{\circ}$. These Cretaceous strata consist of shales and sandstones, the former containing frequent beds of argillaceous limestone, which are generally less than a foot in thickness and rarely continuous for any great length. The shales are very soft and disintegrate easily, hence they are usually found occupying valleys between the ridges of sandstone, which latter rock resists the weather better. The valley at the base of Monte Diablo, which sepa- 
rates the mass of the mountain from the hills farther north, in which are the coal-mines, is occupied by these shales, which may be traced in the beds of the two branches of the Arroyo del Monte Diablo, which unite at the village of Clayton.

The same shales may be observed on the south side of the mountain, especially in the cañada leading to Curry's house, and in the ravines rumning up to the south from this cañada. As on the north side, so here, quite a number of characteristic Cretaceous fossils were found in this belt of rocks, among which are:

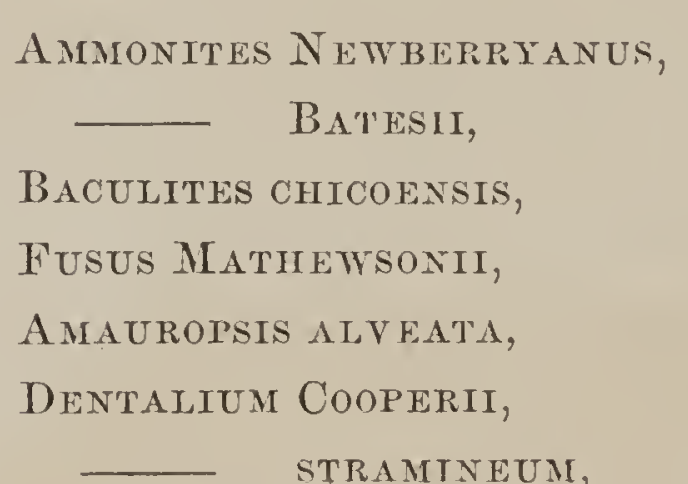

Ammonites Newberryanus,

BaCUlites CHICOENSIS,

Fusus Matiewsonit

Dentalium Cooperit,

STRAMTNEUM,

\author{
Venus VARIANS, \\ Cardium annulatum, \\ ERIPHYLA UMBONATA, \\ Pinna BreweriI, \\ Trigonia Evansit, \\ Cucullata truncata, \\ PeCten operculiformis.
}

These strata, as exposed in the bed of the creek in Curry's Cañada, have a very irregular dip, although usually at a high angle, and to the southeast, south, or southwest, near the mouth of the cañada. Near Curry's, the dip is from $80^{\circ}$. to vertical, and the strike nearly east and west magnetic.

Next above the Cretaceous shales with argillaceous limestones intercalated, as just noticed, comes a very thick and heavy-bedder mass of sandstones which, on the north side of the mountain, form the elevated ridge just south of and facing the coal-mines. These sandstones contain a few Cretaceous fossils, such as Axincea, Natica, and Dentalium.

These Cretaceous strata curve around to the south as they pass to the east of the mountain, running out into the plains of the San Joaquin in long, low, and almost exactly parallel ridges, as will be observed on the Bay map; although, to the eye, the parallelism seems more extraordinary than it would appear to be from an examination of the map. The counterpart of these Cretaceous sandstones of the north side is found also on the south side of the mountain, forming an elevated and conspicuous ridge, sweeping around parallel with the general strike of the rocks in this vicinity, but not forming so distinct a feature of the 
topography of the region as the Tertiary ridge next south of it. Its culminating points rise to the height of from 2000 to 2200 feet. To one of these points or ridges where the white soft sandstone was, at the very summit, curiously worn into cave-like hollows, we gave the name of "Cave Point." This is 2070 feet in elevation. Although these sandstones, in this vicinity, are very barren of fossils, enough were found to determine the fact that they belong to the Cretaceous series.

A. little south of Cave Point, in the depression between that and the next ridge south, the sandstone is worn into curious tower-like forms; a group to which we gave the name of "Tower Rocks," is represented in the annexed woodcut. (Fig. 2.)

Fig. ㄹ.

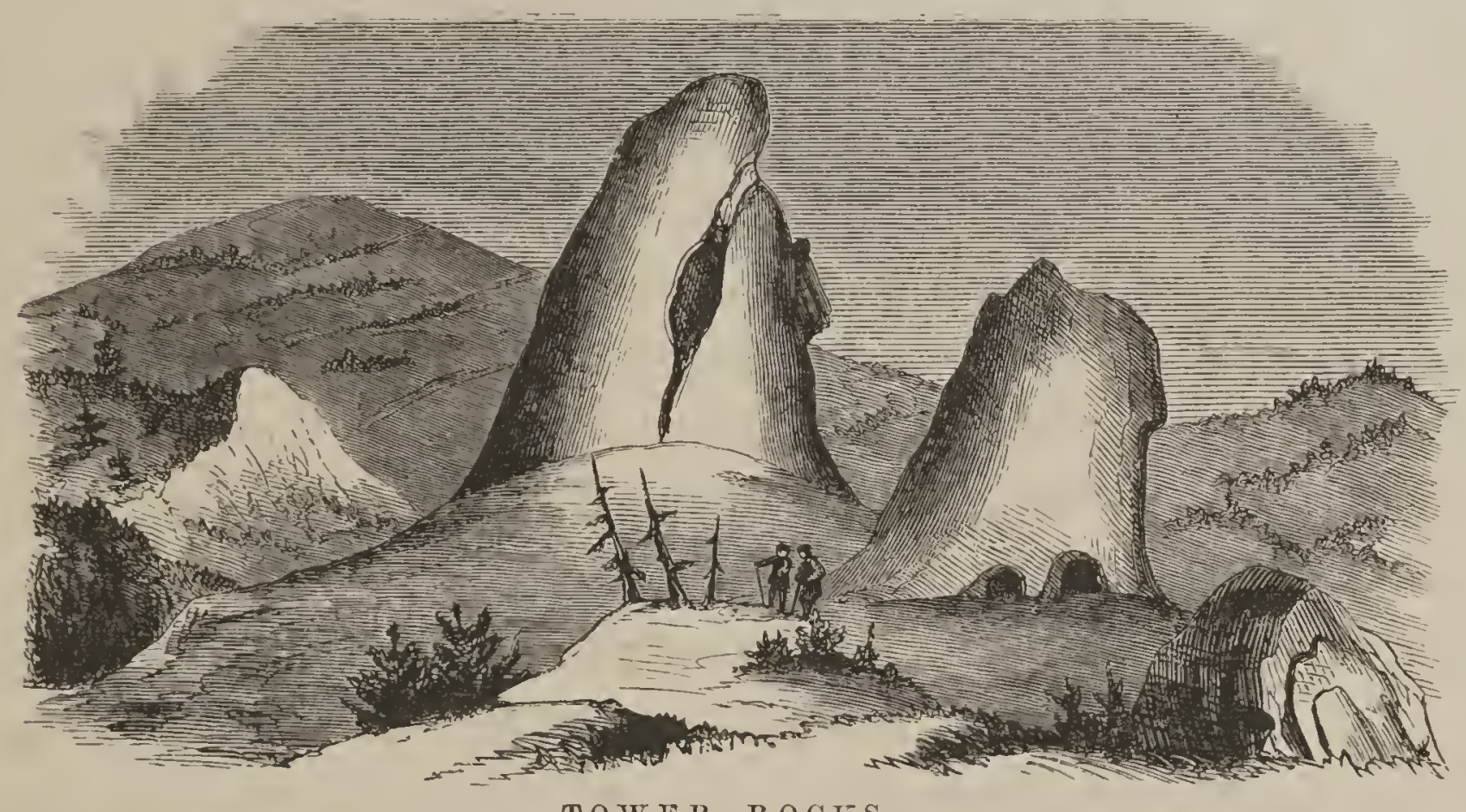

TOWER ROCKS.

Coal has been found in the Cretaceous shales noticed above as lying under the sandstone; but the only extensive workable beds yet discovered are included in the sandstones belonging to the upper part of the Cretaceous.

Of the Monte Diablo coal-beds, the only workable deposits of this invaluable material yet discovered in the State, a full account, illustrated by sections and diagrams, will be given in the volume devoted to Economical Geology. At the time of our last visit to this region, in 1862, the workings were not sufficiently advanced to enable us to obtain all the data desirable for forming an opinion of the exact num- 
ber and extent of the beds which occur there, and a detailed investig:ation was postponed until a later period. A few facts may, however, here be stated, which will show that these deposits are extremely interesting and of great economical importance to the State, especially as we have reason to fear that no coal of the Carboniferous period proper will ever be found on the Pacific coast.

The coal-mines in question are situated on the north side of Monte Diablo, about five miles south of the San Joaquin River, by means of which water conmunication may easily be had with the Bay of San Francisco and the Sacramento Valley. The outcrop of the coal-beds was traced by us for nearly six miles, in an easterly and westerly direction, from a point about one mile due north of Clayton, to near Cochran's, nearly six miles N. $87^{\circ}$ E. from that place. The line of outcrop is irregular, curving to the north in going west from Cochran's, and showing itself on the north slope of the hills until the Mine Hill divide is passed, when the principal outcrop is in the face of a high bluff facing the south, as at the Peacock Mine, beyond which to the west it is irregular, and can be traced with difficulty. There are abundant proofs that the ground has been uplifted and broken, and the coal-beds dislocated since their deposition, so that only underground exploration will render it possible to fix with certainty their exact number, position, and longitudinal extent. This is unfortunate, as necessarily leading to considerable expense in fully developing the resources of the region.

The dip of the beds is highest at the westernmost mine; at the Peacock it was $45^{\circ}$, as measured when the mine was first opened; towards the eastern extremity of the outcrop, as at the Clark and Cruikshank and Adams Mines, the inclination was from $26^{\circ}$ to $30^{\circ}$, and here, as through the whole region, to the north. At the time of our last visit, there were known to be two workable beds; but whether the two were sufficiently developed to admit of their both being protitably worked in any one locality had not been demonstrated. The lower of the two, or the "Peacock Vein," was four feet thick, as opened by an inclined shaft, going down at an angle of $33^{\circ}$ to $35^{\circ}$, and striking the coal at a depth of 195 feet on the incline. Several small seams were cut in this shaft, one of which was 14 inches in thickness, indicating irregularity in the deposition of the strata, and rendering probable the conclusion, 
that at no two points on the line of outcrop will the sections of the strata and the included coal-beds be found exactly the same, a conclusion also arrived at from an inspection of the surface. Tn the Peacock shaft, the coal was found to be so much broken by a dislocation a little to the west, that work was abandoned, and we are not aware that it has been resumed.

At the Cumberland Mine, three-fourths of a mile N. $70^{\circ} \mathrm{E}$. from the Peacock, this rein was also four feet thick, with a considerable thickness of dark shale, with much coaly matter in it, both above and beneath. The Black Diamond Mine, a little over a quarter of a mile to the east of the Cumberland, afterwards purchased by the company owning this last-mentioned mine, showed, in 1862, the bed of coal to be from three feet six inches to four feet thick, averaging three feet nine inches. There are several inches of shale under the coal, and a thin layer above. 'This locality had only just been opened when last examined by us; but it has since been extensively worked.

At the Clark Mine, when first opened, the bed of coal was three fect six inches to four feet two inches thick, and it had a dip of from $24^{\circ}$ to $26^{\circ}$. The roof was of shale from six to twelve inches thick, and the bottom of the coal rested directly on the sandstone. At the Cruikshank and Adams Mine the bed of coal was two feet nine inches thick, dipping $30^{\circ}$, and without clay or shale either above or below.

Since our examination of this region, many changes have been made in the ownership and working of the mines, and it is said that six or seven companies are taking out coal, or making preparations for so doing, and the produce of all the mines in 1864 is given at 37,453 tons. It is said that the companies now at work might produce 50,000 tons a year without difficulty, if there was a sufficient demand for it. And this demand is constantly increasing, as the Monte Diablo coal can be delivered at San Francisco, and sold at a profit, at a lower price than that from any other locality. As soon as a railroad is built to the San Joaquin, and the proper arrangements made for shipping the coal, without handling it over so many times as is now necessary, it will be delivered in much better order, and at a lower price than can now be done.

The quality of the Monte Diablo coal is such as to adapt it for use in 
families and on the river steamers. Like other coals of a later geological period than the true Carboniferous, it contains considerable water, which is driven off on drying at the temperature of $212^{\circ}$. It also parts with this moisture, although more slowly, after being taken from the mine and exposed to the ordinary temperature of the air. In thus losing its moisture, the coal slacks or crumbles to some extent. These same defects, however, are found in some of the Carboniferous coals of the Mississippi Valley, the percentage of water in some samples of Iowa coal being as great as in some of those from Monte Diablo. In other respects, the coals of this region resemble the highly bituminous coals of the true coal-measures, as will be seen from the following analyses of some of the principal varieties of Cretaceous and Tertiary coals used on the Pacific coast, among which specimens of the principal Monte Diablo mines may be found. More complete analyses will be given hereafter.

\begin{tabular}{|c|c|c|c|c|c|c|c|c|c|}
\hline & $\begin{array}{l}\dot{0} \\
\dot{0} \\
\ddot{z} \\
\dot{3} \\
\dot{3}\end{array}$ & 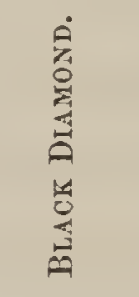 & 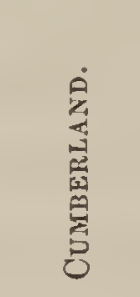 & 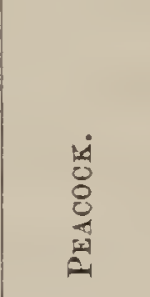 & 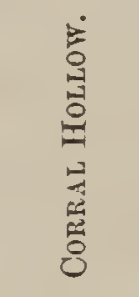 & 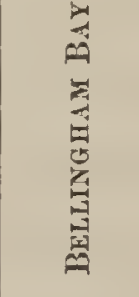 & 竞紊 & 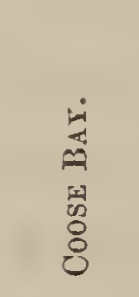 & 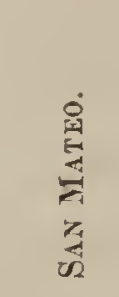 \\
\hline Water, & 13.47 & 14.69 & 13.84 & 14.13 & 20.53 & 8.39 & 2.98 & 20.09 & 17.54 \\
\hline Bituminous substances, & 40.36 & 33.89 & 40.27 & 37.38 & 35.62 & 33.26 & 32.16 & 32.59 & 35.93 \\
\hline Fixed Carbon, . & 40.65 & 46.84 & 44.92 & 44.55 & 36.35 & 45.69 & 46.31 & 41.98 & 43.00 \\
\hline Ash,. . & 5.52 & 4.58 & .97 & 3.94 & 7.50 & 12.66 & 18.55 & 5.34 & 3.53 \\
\hline
\end{tabular}

It must be remarked that these analyses were made in 1861 and 1862 , and are of specimens taken at no very great depth.

The Monte Diablo coals all contain about the same amount of water, namely about fourteen per cent., while the Bellingham Bay and the Nanaimo coals have much less, the Nanaimo less than three per cent.; yet these coals are of the same geological age as those of Monte Diablo; hence it may prove that the quantity of moisture in the California Cretaceous coal will be diminished as the mines are worked to a greater depth. The Monte Diablo coal is remarkably free from mineral and stony matter, one specimen leaving less than one per cent. of ash, 
and no other as much as six. In this respect they are equal to any coals in the world, and greatly superior to those of Nanaimo and Bellingham Bay. They are also but little contaminated with sulphur, at least the better qualities are comparatively free from this deleterious material.*

The exact limit of demarcation between the Cretaceous and the Tertiary, in this vicinity, has not been exactly made out. Resting on the coal-bearing strata above described, there is a heavy mass of sandstone, with some shales interstratified, which, however, are more silicious than the truly Cretaceous beds of otherwise similar character. These beds appear to be beds of passage between the Cretaceous and the Tertiary; but fossils are so extremely rare in them that it is not easy to come at their precise relations. They hold the position which should be occupied by the Eocene Tertiary; but have yielded no forms recognized elsewhere as of this particular age. This mass of sandstones occupies, on the north side of the mountain, a considerable width on the surface, apparently not less than a mile, to the north of Mine Hill. On the south side it appears less distinctly marked; in fact, there seems to be but little room for this body of strata between those of undoubted Cretaceous age at Tower Rocks, and the high ridge of Miocene Tertiary directly south of it.

Rocks of both Pliocene and Miocene age are extensively developed to the north of the strata just spoken of, on the northern slope of the range in which are the coal-mines. Those which we refer to the Miocene division of the Tertiary consist chiefly of sandstones, which are very heavy-bedded towards the base of this part of the series. They are succeeded above by thinner and more fossiliferous strata, which not only contain large number's of marine fossils, but also impressions of leaves and considerable fossil wood, the latter silicified and lying upon the surface, the rock having decomposed around it. These upper strata are referred by Mr. Gabb to the Pliocene division of the Tertiary, from a consideration of the number of living species which they contain, as well as from their stratigraphical position. The

* The coals and coal-deposits of the Pacific coast will be fully investigated and reported on, in the volume of this Report devoted to Economical Geology. 
following species were collected, from this group of strata, near the east end of Kirker's Pass:*

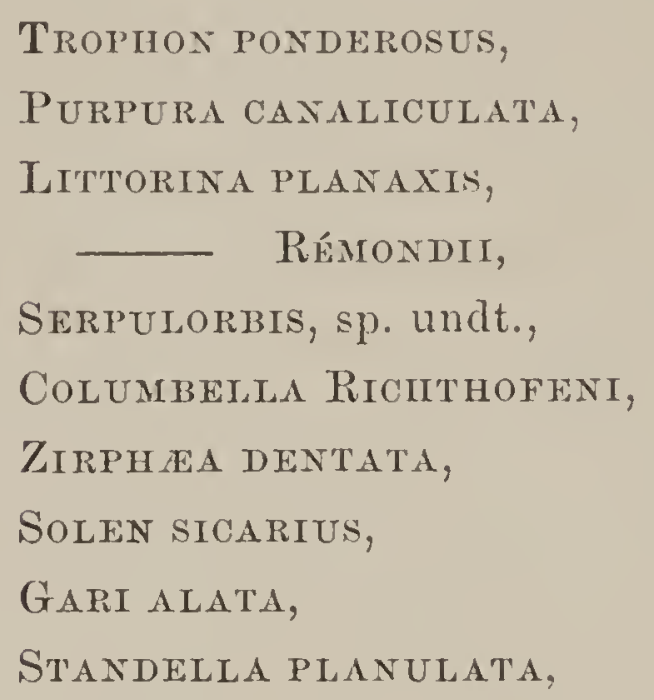

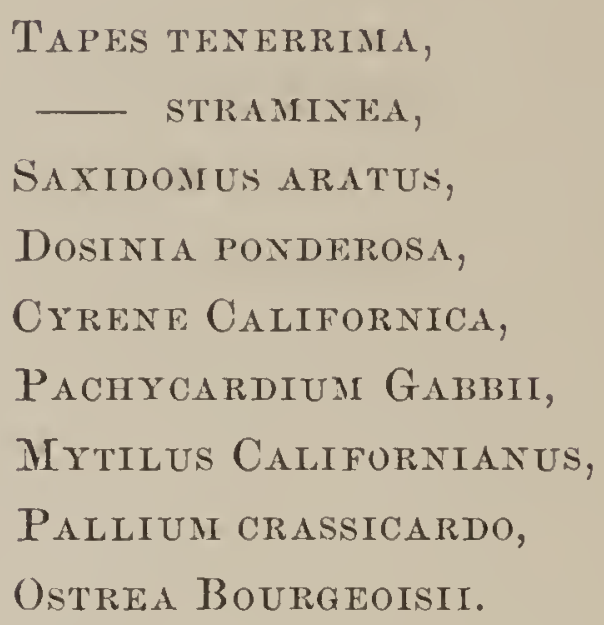

Resting upon these are strata of volcanic materials, such as ashes and pumice, which have evidently been ejected or washed into water and deposited in a stratified condition. These beds to the west of Kirker's Pass have a thickness of several hundred feet, and rise into considerable hills. Their dip is usually about $25^{\circ}$ to $30^{\circ}$; but, in some places, they are elevated at as great an angle as $50^{\circ}$. Their strike is also somewhat irregular, and they form a series of rounded and bare hills, stretching along near the edge of the San Joaquin plain.

Above the sedimentary volcanic beds just noticed are beds of gravel and loase materials, probably of Post-Pliocene age, which also have a considerable but variable thickness, and which pass gradually into the modern deposits of the valley. All these strata, from the Cretaceous up to the Post-Pliocene, appear to be perfectly conformable with each other, and they all have a northerly dip, although it is variable in amount.

The Pass called after Mr. Livermore, an old settler in the valley, is on the west side of the eastern division of the Monte Diablo Group, and about sixteen miles southeast of the summit of the mountain, and here the chain is more completely broken through than at any other point in its whole extent; this Pass has, for that reason, been selected for the passage of a railroad from San José to Stockton, for which the preliminary surveys have been made, and which is now in process of

* For a description of such of these as are new, see Palreontology, Volume II, of the Report of the California Survey. 
construction. The western division of the chain, the Contra Costa Hills, already described in this chapter, are entirely broken through by the cañon through which the Alameda Creek, which drains a Frge region in the interior of the range, finds its way to the Bay of San Francisco. This cañon, therefore, in connection with the Livermore Pass, furnishes a good and easy ronte for a railroad entirely across from the bay to the plains of the San Joaquin ; it is, indeed, the only feasible one. As we issue from the Alameda Cañon, going towards Livernore Pass, we come into a valley or plain some twelve miles in length, but of irregular width, which extends to the western entrance of the pass. The western portion of this is called "Amador Valley;" the easter'u, "Livermore Valley." 'These valleys are formed by the sinking down of the Tertiary ranges of hills which lie along the southwestern slope of Monte Diablo. The portion of the range which continues to the southward, and which connects the Monte Diablo group with the Mount Hanilton group, and over which the Livermore and Corral Hollow passęs cross, is made up of a very irregular belt of hills about ten or twelve miles wide, most elaborately wrought out by denudation into a labyrinth of ridges and cañons, the minute exhibition of whose details would require a map on a very large scale. These ridges are nearly destitute of trees, with but a scanty supply of feed, in the shape of grass or forage, and poorly provided with water, what there is being generally alkaline. The hills in the vicinity of the pass are seldom over 1200 feet high, but they rise higher a little farther north, and "Bushy Knob," or "Las Cuevas," may be considered as the culminating point of this division of the group; it is 1742 feet above tidewater.

The pass itself is, according to the Pacific Railroad Surveys, 481 feet high at its western entrance, and 686 feet at its summit; by our measurement, the eastern entrance, at "Zimmerman's Nountain House" (Camp 60), is 223 feet above the sea.

The rocks near the pass are sandstones, which are soft and easily disintegrated. 'They are of 'Tertiary age, but contain few fossils. Along' the eastern sicle of the range the dip is to the northeast, and on the western side it is in an opposite direction, there being a low axis running through the region from southeast to northwest, and passing a GEกT. VOI. T., - 
little to the east of Bushy Knob. The dip in both directions is quite small, in keeping with the comparatively small elevation of this portion of the chain. At Bushy Knob it was only $15^{\circ}$, the direction of the strata being N. $69^{\circ} \mathrm{W}$.

South of Livermore Valley the hills rise in altitude, but exhibit in the main the same features as on the other side, until we approach Corral Hollow. They are rounded in outline, and the rock is rarely seen, except in the cañons. As we reach Corral Hollow we find the strata more disturbed, and all the indications of an approach to another great metamorphic centre.

The pass or cañon usually known as Corral ILollow extends back from the San Joaquin plain and opens into Livermore Valley; it crosses the hills about ten miles south of the Livermore Pass, but is more elevated than that, and traverses a greater variety of rocks, as it intersects both the altered and the unaltered Cretaceous strata in its upper portion.

This upper region of the pass, which has a northwest and southeast direction, is a deep, precipitous cañon, extending across to the Livermore Valley from the bend in Corral Hollow Creek. This creek, as is so often the case with the streams in this region, runs towards the northwest, parallel with the stratification, for a considerable distance, and then turus suddenly, and, crossing the strata, runs at right angles to its former course, The change in direction is just at the point where the unaltered strata are intersected. The general strike of the strata in this region is nearly magnetic east and west, or $\mathrm{N} .70^{\circ}$ to $75^{\circ} \mathrm{W}$.; the dip is usually to the north, at a pretty high angle, but very variable. The metamorphic region in which Corral Hollow Creek heads will be noticed farther on, as it forms a part of the Mount IIamilton group. The division between the metamorphic and unaltered rocks in the angle of the creek is well marked and easily recognized at a distance, from the varied character which the difterent rocks give to the landscape. The metamorphic hills are covered with a darker and thinner soil, and are more bountifully supplied with trees, especially the Quercus agrifolia and Q. Garryana, while the outlines of the ridges are sharper and the outcrops of rock more numerous. Near the junction with the unaltered strata, the metamorphosed beds preserve their origi- 
nal lines of stratification, and are perfectly conformable with the overlying beds of rock, which have undergone no change. These metamorphic rocks are of Cretaceous age, and are identical in appearance with the jaspery rocks noticed as occurring so abundantly near Monte Diablo. The jasper bands are from a fourth of an inch to several inches in thickness, sometimes very much contorted and of various colors-red, rose-colored, green, gray, and white; the whole presenting, especially on the weathered surfaces, the most brilliant and beautiful appearance. There are also reticulations of quartz crossing the mass in small, irregular veins and threads, such as have already been described as occurring near Monte Diablo, forming the peculiar rock which we have followed from this region north as far as Clear Lake. Serpentine is also abundantly distributed through this metamorphic region.

Between the metamorphic and the Tertiary there is a narrow belt of unaltered rock, of Cretaceous age, the metamorphic action not having penetrated through the whole mass of the strata. But few perfect fossils were found in these unaltered rocks, and these were distinct from any obtained elsewhere in the Cretaceons, to which formation, however, they were referred, with some doubt, by Mr. Gabb, who described two species from this locality, namely, Cyprinella tenuis and Corbula primorsa; besides these, Anomia and Mytilus were observed, as also three other bivalves, too imperfect to be referred with certainty to any genus. Mr. Gabb considers that these fossils, which overlie rocks known to be of Cretaceous age, and which dip under the Miocene Tertiary, may probably prove to belong to a brackish-water deposit of the Cretaccous, although it is possible that the formation in which they occur may represent the Eocene division of the Tertiary.

The dip and strike of these unaltered rocks are variable, but they usually incline at a pretty high angle to the north. Two sections were made across the valley in this region, which will serve to show the position of the strata and also of the coal-beds, which are found here, and which have been worked to some extent. The first crosses Corral Hollow at the "Pacific Mine," and runs N. $20^{\circ}$ E.; it represents a length of five miles, and is on an equal scale of horizontal and verticat distances. The other one crosses at the Almaden Mine, and is of about 
the same length as the other. On comparing these two sections it will be seen at once how great a disturbance of the rocks has taken place in this region, within so short a distance, as the whole series of sandstones on the north side of the hollow has in one. section a position exactly the reverse of that in the other. In the section at the Pacific Nine the mass of unaltered strata north of the hollow lies nearly conformable with the metamorphic; and, like that; dips to the north for a distance of a mile and a half; then we have a mass of disturbed strata and a reversal of the dip. In the Almaden Mine section the reversal of the dip takes place in the strata immediately connected with the coal, which of course has an unfavorable influence on the working of the bed. Indeed, the disturbances in this district are so extensive that it is to be feared these coal-beds will not be made available; and up to the present time, at least, they have not been, although the quality of the coal is good as compared with other Pacific coast coals, and the thickness of the beds sufficient for profitable working, if they had not been so much disturbed by the movements of the strata.*

From Mr. Brewer's notes the following notice of these mines is taken. The Pacific Mine is situated near the upper

* For an analysis of the Corral Hollow coal, see page 30 . 
curve of the stream, on the south side, is about nine miles from the mouth of the valley, and 950 feet above the sea. The stratum of coal is in sandstones and shales; the strike is $\mathrm{N} .80^{\circ} \mathrm{W}$, and the div $50^{\circ}$ to $70^{\circ}$ to the north. The strata are much broken, and frequent slips and faults occur, while the dip is quite variable. A drift cuts the bed from the lower side and follows it for a distance of three or four hundred feet. The bed shows at its eastern end a thickness of fifty inches of workable coal. It was stated that, up to October 15th, 1861, from two hundred to four hundred tons had been mined here. When visited again in 1862, but little farther work had been done here. The drift had been extended a few feet, and the thickness of the coal was found to be sixtysix inches. Many facts were noticed, showing how great a disturbance had taken place here. In the strata beneath the coal are many angular fragments of the coal itself, which appear to have slipped out of place and to have been caught between the strata while undergoing these convulsions, which in one place have cut the seam entirely oft and brought it squarely up against the broken edge of the sandstone.

The Coast Range Company was the first one to mine in this district. Their. shaft is one and a half miles below that of the Pacific Company, in the bottom of the valley, on the south side. The coalseam was perpendicular, and a shaft was

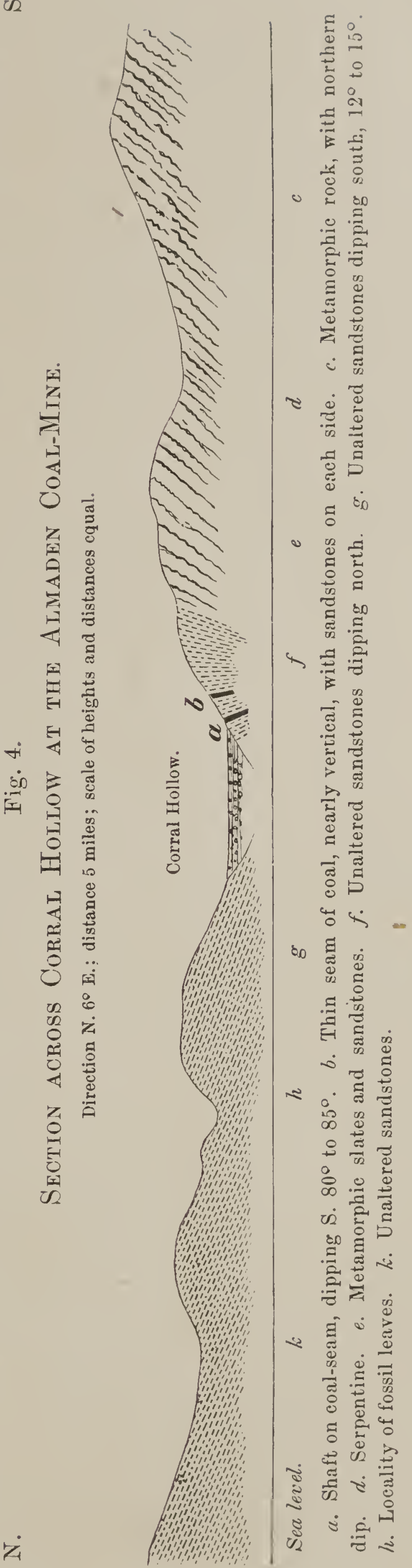


sunk in it to the depth of 100 fect; but little good coal was found, and it is now abandoned.

Some explorations and attempts at mining at the Almaden Company's, on the south side of the cañon, gave equally discouraging results, the strata being much broken, so that the bed could not be followed continuously in the shafts, one of which had been sunk to the depth of one hundred and fifty feet in 1861. In this shaft, as will be noticed on the section, the strata dip to the south at a high angle, there being a complete overturn of the strata here. The bed of coal exposed in this shaft was about two feet thick, and of good quality, although much crushed and therefore easily disintegrated. As far as can be ascertained, no coal has been shipped from these mines of late, and they are probably abandoned. Unless the quality and quantity of the Corral Hollow coal were quite superior, it would be in possible for it to come in competition with the product of the Monte Diablo mines, the latter being so much more favorably situated with reference to a market.

To the north of the belt of Cretaceous strata just described, there is an extensive region of Tertiary hills, extending towards Livermore's Pass. The highest of these are from 2400 to 2500 feet in altitude; the highest point measured was two and a half miles north of the Pacific Mine, and its altitude was found to be 2198 feet. The rock in these hills is deeply covered with soil, but is sufficiently exposed in the cañons to show that it has a very variable strike and dip, being much affected by the fault or disturbance which passes through Corral Hollow. On the hills north of the mines there are several localities of the large fossil oysters (Ostrea Titan), where these occur in great numbers.

About one mile north of Camp 61, the impressions of leaves and silicified wood were found in great abundance in a soft sandstone, supposed to be of Pliocene age. The strata had a dip to the southeast, and the leaves were chiefly found in a stratum about two feet thick. They were very pumerous and beautifully preserved, and represented several genera of deciduous trees. These leaves will be fully described in the second volume of the Palæontology of this Report. In one case a stump was found still upright, its roots in the leaf-bearing stratum, and its top projecting into that next above. These indications of a terrestrial 
Flora were observed over an area of several square miles, but the exact relations of the strata to the oyster-beds could not be made out, owing to the fact that the exposures of the rocks are so poor in this region.

\section{Sretion TV.-Mount Hamiton Group.}

The region south of Corral Hollow, as far as Pacheco's Pass, may, as has already been stated, be conveniently considered as a subdivision of the Monte Diablo Range. The separation of it, for the purpose of geological description, from the Monte Diablo and San Carlos subdivisions of the range on the north and the south respectively, although somewhat artificial, is not wholly unfounded. The great break to the north in the chain, at and near Corral Hollow and Livermore's Pass, caused by the absence of metamorphism and the easy denudation of the soft sandstones of Tertiary age, makes a well-marked line on that side, and south from there to Pacheco's Pass the mass of ranges forms one comnected whole, unbroken by any depression. It is a great area, fifty miles long by thirty wide, entirely covered by mountains, many of them very high and rough, scantily supplied with water, and as little traversed, even by hunter or explorer, as any portion of the State. No map at all approaching to accuracy or even givings the outline of its geography has ever appeared. The explorations of the Geological Survey have not extended all over this forbidding region, yet our parties have penetrated it on all sides, and especially from the eastern,-Messi's. Brewer, Gabb, and Hoffimann having devoted about six weeks of the early season of 1862 to exploring it on that side, returning through Pacheco's Pass, and making several excursions into it from the western edge of the mountains.

A portion of the geography of this region is to be found on the Bay Map, namely the northwestern corner, as far south as Mqunt Hamilton; but the connected geography of the whole district will not be given until the publication of our Map of Central California, which is now in preparation.

The description of this district will be best entered into by taking 
up the region adjacent to Corral Hollow and proceeding southward along its eastern edge, following Mr. Brewer's notes chiefly.

Lone Tree Cañon lies about seven miles southeast of Corral Hollow, the stream or creek of the same name rising in several cañons in the metamorphic rocks, about ten miles back from the plain. The lower four miles of this cañon are cut through the unaltered strata, supposed to be of Cretaceous age, and consisting of shales and sandstones, of which the lower two miles dip to the south, and the portion above and next to the metamorphic in the opposite direction. The interstratified sandstones have a strike of $\mathrm{N} .74^{\circ} \mathrm{W}$., and the shales between them have about the same position, except that they are more subject to local disturbances. The shales contain beds of argillaceous limestone similar to. those observed in the Cretaceous near Monte Diablo, but rather more silicious; they also contain many flakes of selenite, and occasionally considerable carbonaceous matter, which has given rise to some prospecting for coal. In several places masses of sandstone were found in the shales, in the same position with reference to the surrounding rocks as would be occupied by dykes. These dyke-like masses seem to have originated in the filling of fissures by sand, which has since become indurated. They run parallel with the strike of the strata and nearly perpendicular to their dip. From their superior hardness, which enables them to resist weathering better than the shales, they sometimes stand out from the surface in long lines like walls. The tendency of the rock of which these pseudo-dykes are formed to weather in nodules, or with a concentric structure, adds to the resemblance to artificial masonry.

At about four miles from the mouth of the cañon the metamorphic begins quite abruptly, the entire change taking place within a distance of a few hundred feet, and within this range rocks may be found in every stage of alteration. In this vicinity and position, a little serpentine occurs, but it was not seen farther up the cañon, and no boulders of it were observed in the stream. Its dark color has led to its being "prospected" for coal, and the same is the case with regard to the dark jaspers a little farther up the cañon.

The several ridges that lie between the nearly parallel branches of Tone Tree Creek, above this point, run almost parallel with the strike 
of the altered strata. Jaspers abound in them and mica-slate oceurs in boulders in the cañon. Lying south of the cañon, and about four miles back from the plain of the San Joaquin, is a series of high sandstone ridges, haring a strike of $\mathrm{N} .70^{\circ}$ to $75^{\circ} \mathrm{II}$, and rlipping to the northeast, sometimes nearly rertically. These same strata on the southeast form the high ridges lying between Mount Oso and the plain, and rising to the height of 2000 to 2100 feet.

'The outer edge of the hills, extending from two to three miles abore the mouth of Lone 'Tree Cañon to Hospital Cañon, forms a table-land about tro hundred feet abore the plain, and from one to two miles wide. This appears to be the remains of an ancient terrace, rising as we go back towards the hills, and cut into many irregular arroyos, or gullies; it is underlaid by soft Cretaceous shales, and covered with a deposit of gravel, in some places from one hundred to two hundred feet in thickness, having a gentle dip away from the mountains, and composed chiefly of pebbles of the metamorphic rocks above. When seen from the valley, at a distance of a few miles, this terrace seems to be a regular, even plain; but, on examination, it is found to be eroded into innumerable rounded hills and ridges; it is about six hundred feet abore the sea-level.

Hospital Cañon is parallel with Lone Tree Cañon; it is about two or three miles southeast of it, and resembles it in its geological characters. The strata are, however, better exposed, and everywhere dip to the northeast at an angle of from $40^{\circ}$ to $60^{\circ}$; the strike curves around gently towards the meridian as we approach the plain. These rocks are all Cretaceous, consisting of sandstones and shales; the sandstone bands are less contorted than the shales, as was observed in Isone Tree Cañon.

The summit of Mount Oso, which lies between the Hospital Cañon and Arroyo del Puerto, is 3383 feet above the sea-level; it is composed of jasper's, generally dull-red, but often gray and green, with reticulations of quartz like the rocks of Monte Diablo. On the north slope, the shales, as well as the interstratified sandstones, were less altered, yet all partly metamorphosed. About two miles north of the summit the stratification can be easily traced, the beds dipping north and having a nearly east and west trend, hut cupring as we pass GEOS. VOI. I. - ri 
to the east. Mere, as elsewhere in this region, the beginning of the metamorphism is distinctly marked by the presence of forest trees, scattered over the surface much more abundantly than on the unaltered rocks; some species, as Quercus Garryana, occurring only on the metamorphic. On the northeast of Mount Oso, a depression extends along in a line very nearly marking the edge of the metamorphic, in which are the sources of the Arroyo de las Piedras on the south, and a branch of Hospital Creek on the north. Between this depression and the plain are high ridges, the most elevated of which is about 2100 feet above the sea. They are all made up of unaltered sandstones, having a strike of $\mathrm{N} .60^{\circ}$ to $65^{\circ} \mathrm{W}$, and dipping at quite a high angle to the northeast. These strata everywhere curve more to the south as they are traced eastward towards the plain.

The Arroyo del Puerto is the next considerable cañon south of Hospital Creek, and is distant about two miles from it. Like the others in this vicinity, it breaks through the strata at nearly right angles to their strike, and it extends back into the high metamorphic region in the centre of the chain, to a distance of about sixteen miles from the plain in a direct line. The strike of the strata bends to the south some $15^{\circ}$ or more where the cañon breaks through. The belt of unaltered strata between the metamorphic and the plain is about six miles wide, and consists of steep, dry ridges, nearly destitute of trees. The ravines are dry; or, if water is found in them in the summer, it is alkaline, and the alkaline salts effloresce on the exposed surfaces of the sandstones. The water from the metamorphic is less contaminated, but not wholly free from alkali. The hills rise to an elevation of from 2000 to 2400 feet, and there are inany points above 2000 feet; these high ridges are generally made up of sandstone, the depressions between them being hollowed in the softer shales. These rocks closely resemble the Cretaceous shales and sandstones seen near Monte Diablo, and the shales contain similar beds of hydraulic limestone, but of a more silicious variety than that noticed farther north. From the peculiar wearing away of these strata, the sandstones have a less dip on the summits of the ridges than they have in the cañons; thus giving a curved appearance to the stratification, as seen in section. A few Cretaceous fossils were found here, both in place and in boulders; but, on the 
whole, these strata are remarkably destitute of organic remains. All the rocks exposed in this cañon are of Cretaceous age, as was shown both by lithological characters and by the fossils, unless it be the extreme outer band of strata next the plain; this consists chiefly of a conglomerate, which rises about 1000 feet above the plain and 1300 feet above the sea, forming a marginal ridge, behind which is a series of cañons, on both sides of Puerto Creek, excavated in the soft shales. The conglomerate which forms the crest of the ridge is of a coarse variety, containing many kinds of pebbles, mostly of metamorphic rock different in character from that of the Monte Diablo chain. The strike is $\mathrm{N} .45^{\circ} \mathrm{W}$., north of the Puerto, and N. $30^{\circ} \mathrm{W}$. south of it; the dip is to the northeast, $40^{\circ}$ to $45^{\circ}$. The strean breaks through this ridge by a narrow gorge or gate, which gives the name to the cañon.

The most noticeable feature of these strata is, as Professor Brewer remarks, their enormous thickness. The horizontal distance across the section, at right-angles to the strike, is six miles. The dip is invariably to the northeast, often as high as $70^{\circ}$, and never, so far as seen, below $40^{\circ}$, and this only near the margin of the plain. At $50^{\circ}$ dip, this would represent a thickness of 23,700 feet, while the average dip seemed higher. The whole of this section was passed over twice, and the outer half four times, yet no indication of folds were observed. If this be so, it is indeed extraordinary; but other facts collected in this region justify us in the belief that the strata are indeed developed to an almost incredible thickness.

On ascending the cañon the metamorphic is first met with at about six miles from the margin of the plain. Here the sandstones become more nearly vertical, and the metamorphism begins suddenly. The principal varieties are metamorphic sandstones, jaspery slates, and serpentine; the latter the least abundant. Patches of rock which have entirely escaped the metamorphic action lie enclosed in the altered strata, and exhibit the usual characters of the Cretaceous shales and sandstones. The metamorphic mass is exceedingly broken, forming a series of ridges nearly thirty miles across, many points rising to above 3500 feet, and some to over 4000. Of these Mount Hamilton is the culmination, being 4443 above high tide. These hills have a very complicated topography, and the region is one which has been but 
little explored; in fact, few portions of the State are less frequently trodden by the foot of either hunter or explorer. It is rendered forbidding by its dryness as well as its ronghness, and the thick growth of chamisal over portions of it, which renders it extremely unpleasant to traverse; as there is no reason to believe that it will ever be valuable for its mineral productions, it will probably remain for an indefinite period what it now is, - a barren wilderness.

Orestimba Cañon is the next considerable opening in the range towards the southeast, and it is eleven miles distant from the Puerto; like the other cañons mentioned, it gives passage to a stream heading in the metamorphic mass of mountain above, and flowing down and breaking through the unaltered strata nearly at right angles to their strike.

In passing along the plain, as well as from the elevations back, it is seen that the high marginal ridge, mentioned as occurring at Arroyo del Puerto, sinks into the plain to the southeast of that cañon, long before reaching Orestimba. At the last-named cañon a number of successive ridges lie back of each other, the highest rising to 2360 feet, and many to over 2200 feet, all made up of unaltered strata, having a northeast dip. The outer portion of these was referred to the Tertiary and the remainder to the Cretaceous, on the evidence of fossils found.

At the mouth of the cañon the Tertiary extends back about three miles, having a dip of about $45^{\circ}$, where it lies upon the Cretaceous and perfectly conformable with it, the inclination diminishing towards the plain and becoming very low at the outer margin of the hills. This margin is not sharply defined where the Tertiary forms the edge; in such cases the ridges become low and rounded and gradually die out, being covered more or less extensively with very modern deposits as they disappear. This condition of things contrasts in a decided manner with the abrupt termination of the Cretaceous, when it meets the plain without any intervening Tertiary.

Between the 'Tertiary and the metamorphic lies a belt of unaltered Cretaceous, about four miles wide in its narrowest place, the strike of the strata averaging about $\mathrm{N} .30^{\circ} \mathrm{W}$. to $\mathrm{N}$. $33^{\circ} \mathrm{W}$., but often curving round to as much as $\mathrm{N} .45^{\circ} \mathrm{W}$. A change of about $15^{\circ}$ in the direction of the strata occurs at the entrance of the cañon, where they bend 
more to the sonth and run out into the plain with a direction of $\mathrm{N} .15^{\circ}$ W. At the onter edge of the Cretaceous it has a dip of $45^{\circ}$; but, for at least three miles, it is from $50^{\circ}$ to $60^{\circ}$, averaging at least $55^{\circ}$, indicating, as at the Arroyo del Puerto, an enormous thickness of the strata of this age. The predominating roeks are sandstones, but shales are frequently interstratified with them. No evidence of any folds in these beds could be obtained here. The hills formed by the Tertiary are very unlike those made up of Cretaceous rocks; they are less regular, more rounded in their outlines, and they sink very gradually into the plain; they are also quite destitute of trees, while the Cretaceous hills have seattered oaks upon them (Q. Garryana), chiefly on their northern slopes.

Pacheco's Pass is the most considerable depression in the chain to the southeast of Livermore's Pass. A wide valley extends back from the San Joaquin Plain, entirely across the unaltered strata and some distance into the metamorphic, forming a basin of several square miles in extent, with a rim of hills of unaltered rocks in front. This valley or basin is known as the San Luis Gonzaga Ranch.

North of the mouth of San Luis Creek several steep ridges form the rim, the strata consisting of conglomerates, sandstones, and shales, apparently all Cretaceous, with a strike of $\mathrm{N} .30^{\circ}$ to $34^{\circ} \mathrm{W}$. and a dip to the northeast, but the latter very variable, from $40^{\circ}$ to $80^{\circ}$, or even sometimes vertical. The conglomerates generally form the erests of the ridges and are very coarse, containing numerous boulders as large as one or two cubic feet in size, and great numbers of them are over six inches in diameter. These consist of porphyry, granite, and various forms of metamorphic rock, entirely unlike, however, to the metamorphic Cretaceous of the centre of the chain. These boulders weather out from the rock in immense numbers, often entirely covering the ground; they are all much worn and thoroughly rounded and polished.

The strata on the north of the valley have a strike of $\mathrm{N} .30^{\circ} \mathrm{W}$.; on the south, N. $37^{\circ} \mathrm{W}$, with a dip to the northeast of $42^{\circ}$, diminishing towards the plain.

The following species of Cretaceous fossils were obtained on the San Luis Gonzaga Ranch : 


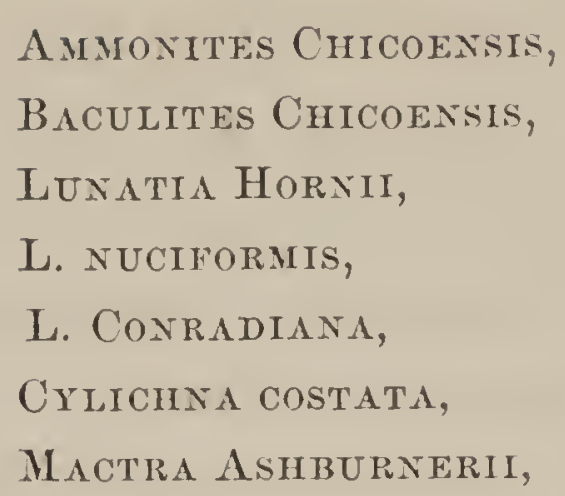

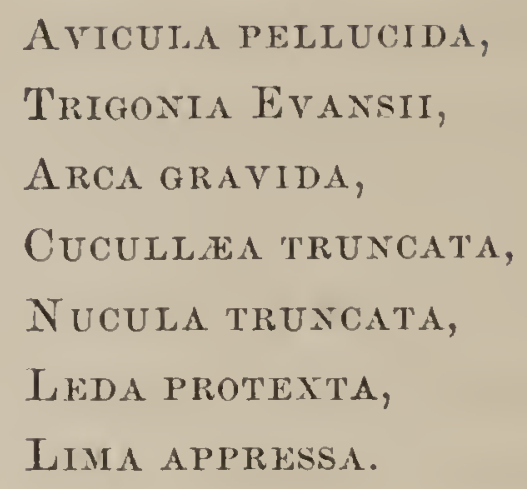

In following this belt of unaltered Cretaceous rocks southeast along the margin of the chain from Corral Hollow to this point, it appears evident that the mass of strata increases in thickness, while the shales gradually diminish, the sandstones predominating more and more; the interstratified limestones in the shales also disappear to a considerable extent, and become more silicious in character than they were observed to be near Monte Diablo. There is also a great increase in the development of the conglomerates, both in the frequency and the thickness of the beds, and in the size of the pebbles of which they are made up, as we go towards the north. The unaltered beds of Cretaceous and Tertiary extend along the eastern edge of the Monte Diablo Range to the north as far as where it joins the Sierra Nevada, although the region south of Pacheco's Pass has only been very cursorily examined by our parties.

The metamorphic region in the vicinity of the pass is marked by a depression across the whole chain, the ridges rising to about 1600 feet in the vicinity of the summit, which itself is 1472 feet above the sealevel. These hills rapidly rise in elevation as they extend towards the south, while to the north their increase of altitude is more gradual. Near Butterfly Peak, about eight miles from the plain and four miles north of the pass, there is an abundance of jasper and other evidently metamorphic Cretaceous rocks, which are much disturbed in position, but have a general strike of about $\mathrm{N}$. $45^{\circ}$ to $55^{\circ} \mathrm{W}$, and a northeasterly dip. Across the centre of the chain, along the line of the pass, the rock appears to be all metamorphic Cretaceous, which in places is not highly altered, but still in the whole so much so that no satisfactory section can be given. In circumscribed localities the stratification can be clearly made out, but in general the beds are broken, twisted, and contorted, as if acted on by pressure from several different directions. 
The the south of the pass there are several high peaks, one of which, without a name, was ascended and found to be 3412 feet above the sea; this one is two miles northwest by north from Mariposa Peak. A little south of west from this is another high point, about 3550 feet in elevation, and the Mariposa Peak, or what was supposed to be that, is about 3800 feet high. Pacheco's Peak, 2845 feet high, and three miles southeast of Hollenbeck's house, in the pass, is a conspicuous landmark from the San José Valley, as it rises about five hundred feet above the surrounding ridges and terminates in a very sharp point. These high points form a belt of trachyte running across the chain in a direction of about N. $55^{\circ} \mathrm{W}$. It is supposed to run through to the Panoche Plain, but was not explored farther than the peak noticed above as 3412 feet high. As far as could be made out, this eruptive volcanic mass has had no influence on the upheaval or metamorphism of the surrounding strata; it seems to have been poured out after the surface had assumed nearly its present condition; it cannot by any means be considered as forming an axis of upheaval.

The region lying oft to the northwest of Hollenbeck's for six or eight miles, as far as a point visited and found to be 2362 feet in elevation, is all of metamorphic rock. Near the point measured, fine specimens of actinolite were found and mica-slate occurs. No satisfactory section was obtained in this region, as the rocks are too much disturbed and metamorphosed to allow of their dip and strike being determined. Contorted jasper's were observed near Hollenbeck's.

A characteristic outcrop of the metamorphic rock in this vicinity is figured in the annexed wood-cut (Fig. 5). It is called Hollenbeck's Rock, and it rises to about eight hundred feet above the pass at that point.

Having thus given a sketch of the geology of the eastern edge and the adjacent interior region of the Mount Hamilton group, and having made our way across it through Pacheco's Pass into the San José Valley, we may now follow up its western side, giving such observations as were made by the corps in passing up the valley, and making occasional excursions into the heart of the region from its western edge.

The most noticeable feature of this side of the range is that there is 
an onter or marginal range of hills all along the interior mass of mountains, the valleys of Coyote Creek, the Penitencia (Cañada de Pala), and

Fig. 5.

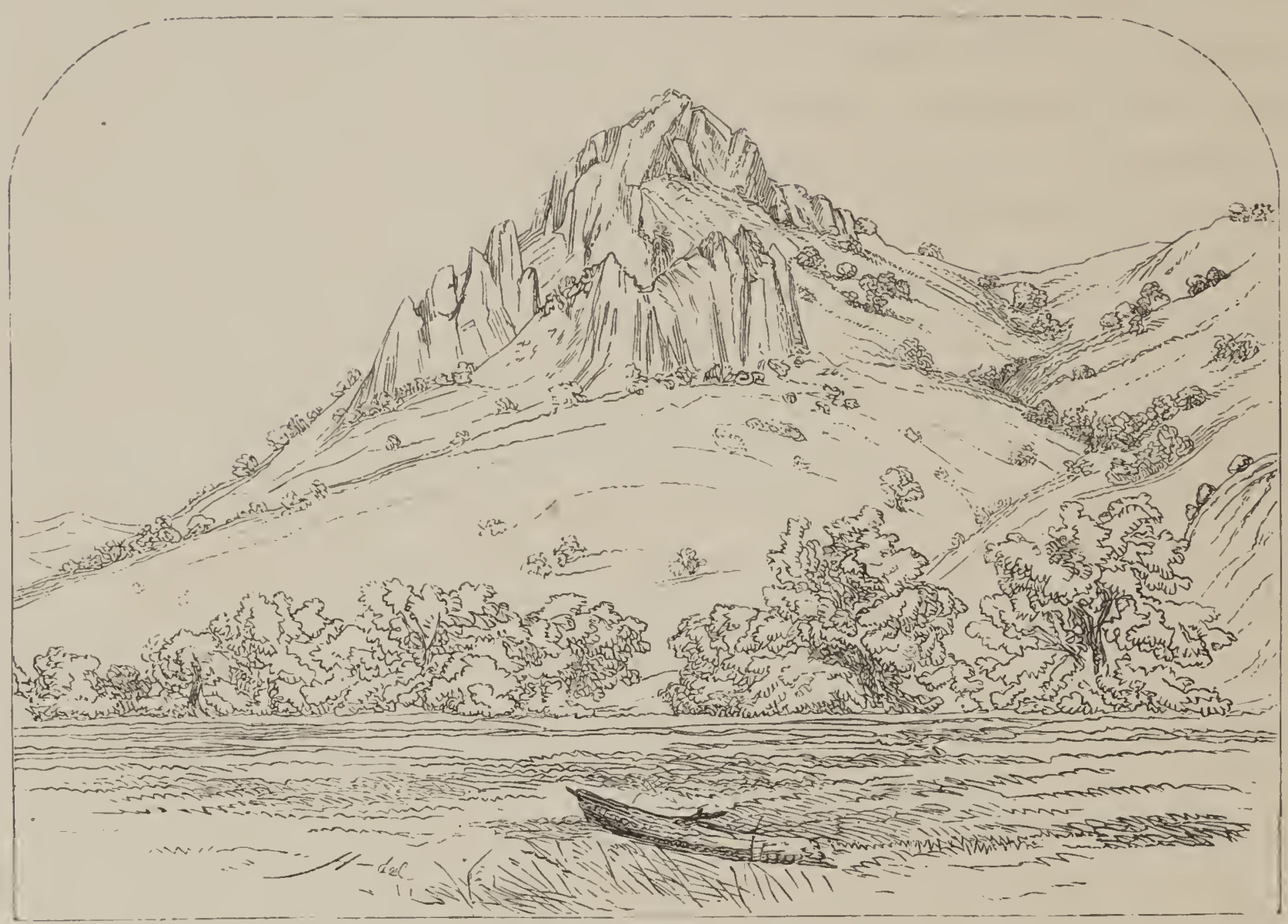

HOLLENBECK'S ROCK-PACHECO'S PASS.

of Calaveras Creek, marking this division. The course of the Coyote and of the Penitencia Creeks offers a good illustration of the peculiar geography of the Coast Ranges. They head together in or near a sort of lagoon in the centre of the Cañada de Pala. The Penitencia flows northwest a few miles in a narrow valley between high ridges, and then turns suddenly, breaks through the western one, and emerges into the San José Plain; the Coyote flows northeast from its source for about eight miles; it then breaks through a high ridge and enters the Las Animas Valley, resuming its former southeast course and keeping it for about six miles, when it again cuts through a ridge to the west, and after issuing from it turns and runs parallel with its former course but in the opposite direction, and finally unites with the Penitencia near the lower end of the San José Valley. The ridge just mentioned as the one the Coyote breaks through to issue on to the San 
Jose Plain is continuous for many miles, with the exception of this break. It rises about a thousand feet above the plain, and, when seen from the hills on the opposite side of the valley, appears like a terrace, having a darker brown color than the hills beyond. It is composed entirely of metamorphic rocks; the most of it a sort of diorite, very hard and crystalline. Some of it is decidedly amygdaloidal, having its cavities filled with carbonate of lime. This rock was considered by $\mathrm{Mr}_{\mathrm{r}}$. Brewer as probably of metamorphic origin, although it had in places quite the appearance of an eruptive mass. The deep brown color of this range, as noticed when seen from a distance, is due to the multitude of boulders or loose pieces of the dark-colored rock scattered over the surface.

The ridge back or next east of the one just noticed is made up of sandstone mostly unaltered, but occasionally a little metamorphosed, and having a strike parallel with the direction of the ridge, about $\mathrm{N}$. $30^{\circ}$ to $34^{\circ} \mathrm{W}$., but sometimes as much as $\mathrm{N} .45^{\circ} \mathrm{W}$.; its dip is to the northeast, but not high, generally less than $25^{\circ}$. Some serpentine was seen at the base of the ridge. These hills supported a much heavier growth of wild oats than the metamorphic ridge to the west.

This marginal ridge was again visited at a point due north of our camp (No. 47), at the Ojo de Agua de la Coche, and about five miles northwest of the place where the Coyote Creek breaks through it. As when examined farther south, so here it was found to be made up of metamorphic rock, with some masses possibly of eruptive origin. Serpentine occurs also, but chiefly at the base of the ridge. In connection with these serpentine rocks near the summit, there is a large deposit of carbonate of magnesia, which occurs scattered through the rocks in masses of considerable size, irregular in their form and not connected into a vein. The thickest of these were from two to three feet through; and their surface often weathers in large botryoidal masses, showing a distinct concentric structure pervading the material. This variety of the carbonate of magnesia is a peculiar one, as it is extremely hard and compact, breaking with difficulty and with a conchoidal fracture, and ringing under the hammer like a piece of metal; it is white and exceedingly pure. This same material occurs in other places in the Monte Diablo Range; it is often supposed to FEOA., VOL. I. -7 
be of value for the manufacture of porcelain, and is called porcelain earth, with which, however, it has no affinity, nor is it of any value at present.

Spurs of this metamorphic range of foot hills extend out into the San José Valley, and appear to nearly cross it, as low rounded hills with a dark brown soil stretch along in a line a few miles south of San José, partially closing up the valley, which expands into a plain both to the north and the south of them. At all events, this metamorphic ridge does not follow the western edge of the Monte Diablo Range continuously, for on exploring the hills bordering the valley directly east of San José they were found to consist of sandstones unaltered, or only slightly metamorphosed in places. These sandstones have a strike nearly parallel with the chain and a high dip to the northeast, sometimes standing nearly vertical. They contain numerous fossils, although mostly in a bad state of preservation; enough were collected, however, and determined, to fix the age of this ridge as Tertiary. Its elevation is from 1000 to 1200 feet above the valley at its base, and its culminating point, Master's Hill, is 1604 feet above the sea,

Passing east, after crossing this ridge and the valley at its eastern base, called "Cañada de Pala," we come to a region of highly metamorphic rock, which in some places might almost be called mica-slate. On its eastern side is a deep valley, in which Calaveras Creek heads, and crossing this we strike the ridge which leads to the summit of Mount Hamilton, in a direction nearly transverse to the main chain, or northeast and southwest. This ridge is of metamorphic sandstone, although not so highly altered as are portions of the great mountain mass to the east. The strata are much broken, often standing nearly vertical, and having a strike from northeast to southwest, indicating great disturbances in this region. Mount Hamilton, the highest point of the group, and the highest peak north of San Carlos, as far as Clear Lake, is 4448 feet above the level of the sea. From its summit, which is very easy of access, there is a fine view, not only of the beautiful and fertile valley of San José, but of the wild and entirely uninhabited and unknown region to the east, northeast, and southeast. To any one desirous of forming an idea of the character of the mountains in this part 
of the Coast Ranges, a trip from San José to Mount IIamilton may be recommended. It can be made in a day, although a long one is required, as the distance from San José to the summit of the mountain is about thirteen miles in a straight line, and there are two high ridges to be crossed before arriving at the base of the mountain itself. The valley of the Calaveras, called here the "Arroyo Hondo," offers a pleasant camping ground to those who wish to devote more than one day to the excursion. No other peak in the Coast Ranges, of anything like the same elevation, offers so easy an ascent.

The western edge of this portion of the chain was again examined at the Arroyo de la Penitencia, or "Arroyo Aguage," as it is also called, which is about six miles northwest of the place where this ridge was crossed in going to Mount Hamilton. At the entrance of the cañon there is a slight development of conglomerate, made up chiefly of pebbles of the metamorphic rock, and having a dip to the southwest. Above this, for three or four miles, nothing was seen but metamorphic sandstones and slates. The so-called "Alum Rock" is a soft, slightly metamorphosed sandstone, on the surface of which various sulphates, derived from the decomposition of iron pyrites and a little copper pyrites, effloresce. Near the "Upper Alum Rock" there are sulphur springs, containing carbonate of soda and some sulphuretted hydrogen. They are somewhat warm, but the volume of water is not large. Near these springs there is a metamorphic slate which is jet black, and hence has been mistaken for coal; it has a dip to the southwest, and a strike of about N. $60^{\circ} \mathrm{W}$., but both strike and dip are variable. Some copper, in the native state, has been found here. The specimens which we saw were in the form of small grains, in a hard silicious rock; the quantity is too small to be worth working, although some "prospecting" has been done here and a copper excitement started.

The most interesting feature of this ridge is the manner in which it has undergone local metamorphism. Although quite metamorphosed, as has been stated, in the Arroyo Aguage, yet to the north and the south, at a short distance, the same strata are in their original condition, soft and fossiliferous. Although not as thoroughly metamorphosed as some or most of the altered Cretaceous, yet these Tertiary strata show 
that the same kind of action has taken place in rocks of this very recent epoch, which we have already so often had occasion to notice as having effected such extensive changes in the condition of the older underlying strata.

The next point where this range of hills was examined was back of the Milpitas Ranch, nearly north of San José and east of Alviso. There is a high mass of hills here, between the head-waters of the Coyote and Calaveras Creeks, exceedingly broken, and divided into subordinate ridges, with many knobs more or less connected, rising from two hundred to four hundred feet above the general level of the mass, and so nearly of a height that it would be difticult to make out which is the most elevated. These hills are made up of strata of sandstone, standing vertically or having a high dip to the northeast, rarely in the opposite direction. The strike is very much broken, as can easily be recognized at a distance by inspecting the long lines of outcropping strata; it varies between N. $55^{\circ} \mathrm{W}$. and N. $35^{\circ} \mathrm{E}$., but is usually from $\mathrm{N} .15^{\circ} \mathrm{W}$. to N. $45^{\circ} \mathrm{W}$. Tertiary fossils were obtained in considerable quantity in this range of hills, but usually in a very poor state for determination, owing to the hardness of the rock in which they were imbedded.

This Tertiary ridge extends along to the northwest, between the San José and Calaveras Valleys. Back of San José Mission rise hills of unaltered sandstone with very abrupt sides, in which the strata dip to the northeast. In the hills near the "Seventeen Mile House," one mile northeast of the mission, the strata are fossiliferous, the species being the same Tertiary ones found along the ridge at various points to the southwest. Back of this range of hills the Calaveras Creek flows to the northwest, and after uniting with Alameda Creek they break through the ridge by a very deep and abrupt cañon.

\section{Section V.-Monte Diablo Range, south of Pacheco's Pass.}

Of the geological structure of the chain to the south of Pacheco's Pass, only some general ideas can be given, as our investigations in that region were of necessity quite limited. We passed through the chain diagonally in a southeast direction from San Juan to the New 
Idria mines, the road giving us an opportunity to observe the geology at various points for a distance of about sixty miles.

We first followed up from San Juan the San Benito River, a branch of the Pajaro. The hills on the north side are of metamorphic rock, and presumed to be a continuation of those described as existing near Pacheco's Pass. The San Benito exhibits fine terraces along its course. At a point about ten miles from San Juan two of them were measured; one near the stream and fifteen feet above it, and another twenty rods farther back and twenty feet in height. The valley of the San Benito is narrow and marks the division between the Gavilan and the Monte Diablo Ranges; the different ranges, as has been before remarked, gradually approaching and inosculating as we proceed southward, so that the distinction between them becomes almost entirely an artificial one. This whole region was extremely dry at the time of our visit (July, 1861), no water being obtainable on the route except at a few stations, usually from ten to fifteen miles apart; and when obtained it was often so alkaline as to be very disagreeable to the taste.

From Tres Pinos, thirteen miles from San Juan, to Booker's (Camp 39), a distance of about thirteen miles in a direct line, the road follows the Arroyo Joaquin Soto, a branch of the San Benito, which runs parallel with it at a distance of three or four miles. Soon after leaving the Tres Pinos we came upon vast deposits of gravel, or entirely unconsolidated detritus, which appears to be of Post-Tertiary age, and which forms a large portion of the series of ridges between the Gavilan on the one side and the Monte Diablo Range on the other. At the first exposure, about two miles beyond Tres Pinos, the stratified detritus forms a steep bluff about four hundred feet above the creek. The gravel is made up of pebbles of granite, red and green jaspers, and silicious slate and other metamorphic materials; the granite is composed almost exclusively of red or flesh-colored feldspar and quartz, with but little mica or hornblende. At this point the detritus, or gravel, hr a nearly horizontal position. As we pass up the valley, however, we find it very much disturbed, at some places dipping almost vertically. This was especially observed at a point where the cañon narrows, a few miles below Booker's. In the vicinity of that place these unconsolidated deposits were examined in some detail on both sides of the road. The 
strata here are worn into precipitous cañons, with bare bluff banks or almost perpendicular walls, regularly stratified, and varying in fineness from a coarse gravel to fine sand, with here and there a thin band of consolidated materials, the remainder entirely in the original condition in which it was deposited, as far as being held together by any cement is concerned. As near as could be made out, these strata fill the valley between the two ranges, dipping towards the centre from both sides, forming a sort of basin some six or eight miles across. The thickness of these deposits was enormous; one hill measured, south of Camp 39, was found to be 1274 feet above the valley at Booker's, or 2330 feet above the sea; while another hill, on the other side of the camp, having a dip in the opposite direction, was estimated at 1800 feet above the valley or 3000 feet above the sea. Of both these hills the entire mass was evidently made up of this unconsolidated material, which so far as observed was entirely destitute of organic remains. It must, however, be newer than the Miocene, and is probably of Post-Pliocene age; yet it has evidently undergone great disturbance since its deposition, for although we might suppose the material to have been washed into a deep and narrow basin and deposited in beds inclined at a considerable angle, yet it is impossible that it should be supposed to have had originally the vertical position which it now has in some places. This region gives one a most vivid idea of how recently geological changes of magnitude have taken place in this part of the State, and furnishes most impressive testimony, to add to that obtained in other places, in relation to the lateness of the geological epoch during which this portion of the chain was elevated. Beautiful exhibitions of terraces were noticed in this cañon, a few miles below Booker's. In some places as many as five can be seen, in others three or four; the elevation of the highest above the valley was estimated at about 225 feet. It would appear that the basin in which these Tertiary strata were deposited was drained of the water at successive intervals by the elevation of the basin itself, judging from the disturbed position of the strata it contains, and not by the gradual wearing away of a barrier at its lower end.

A little above Booker's this gravel deposit is passed, and we enter into a region of sandstones and slates, which gradually assume a 
thoroughly metamorphic character as we approach Camp 40, at the sheep-wells, about ten miles in a direct line nearly east from Booker's. Here we are near the divide, or summit of the range, at the head of the Little and Big Panoche Creeks. The rocks here are entirely of a dark metamorphic, almost trappean material, the soil dry and supporting a thin crop of forage plants, with a few scattered oaks and pines. The altitude of this camp was about 2200 feet, the nights clear and cold, the thermometer sinking to $40^{\circ}$; the days, on the other hand, were extremely hot, the temperature remaining at some point between $90^{\circ}$ and $100^{\circ}$ from 9 A.м. to 4 P.M. A hill several miles north of this camp was visited, and its elevation found to be about 3750 feet above the sea. The rocks passed over in going to it were chiefly of metamorphic sandstone, with a granular-crystalline texture; mica-slate was also observed, forming a ridge, of which the strata stood almost vertically, and had a very variable strike, but usually somewhere near northwest and southeast. The texture of this mica-slate was very variable, at times fine and again very coarse, with numerous small quartz veins traversing it, and some imperfect serpentine or other magnesian mineral disseminated through it. Well-crystallized actinolite was also noticed as occurring in this rock.

The culminating points of the chain, in a section across on this line, are probably from 3850 to 4000 feet, as the view from the point which we measured, and found to be 3750 feet high, was a commanding one on all sides, although a few somewhat higher points were visible in the vicinity. The summit of the pass, about four miles southeast of the sheep-wells, was about 2700 feet in elevation, and here considerable timber was observed, Quercus agrifolia being the predominant tree. From this divide we sank rapidly to the Panoche Plain, which is a level tract, some fifteen miles in length and six in width, through which runs the Big Panoche Creek; it was very dry and destitute of vegetation at the time we passed through it. It is surrounded on all sides by high ranges of hills. Those on the north are of a darkcolored rock, evidently the metamorphic mass of the central chain over which we have just passed. To the east the hills were perfectly bare of trees, and were distinctly seen in the distance to be made up of stratified rock, probably sandstone, tilted up at a considerable 
angle and having an exceedingly arid appearance. The sides of the Panoche Valley are distinctly terraced in many places, the plain having once evidently been occupied by a lake. The range of hills to the east of the Panoche Plain are, in all probability, of Tertiary sandstone; while the metamorphic rock on the west is presumed to be the continuation of the great belt of Cretaceous which we have traced down from Monte Diablo.

From our limited knowledge of the geography of this region, no portion of it ever having been laid down on a map with any approach to accuracy, it will be difficult to give a clear idea of its geology. From the Panoche Plain we turned off at a sharp angle to the south and entered a narrow and abrupt cañon worn in the unaltered sandstone rocks which leads up towards the New Idria mine. This cañon is about six miles in length, and it presents a picture of perfect aridity, having no drinkable water at the time we passed through it, and no vegetation except a few parched undershrubs. But in some of the side-valleys and over the low hills in this vicinity sufficient herbage grows to support a few cattle, and a ranch house is found a little above the south end of the cañon, which is called "Griswold's;" but what the inducements could be to live in such a place it was beyond our power to determine. In the cañon the sandstone has a general southerly dip; at three miles from the entrance it is inclined at an angle of $35^{\circ}$, and the dip gradually increases in amount as we go towards Griswold's. In one place this rock presents a very curious appearance, from the occurrence in it of numerous hard nodules of a few inches in diameter, which project like cannon-balls from the weathered surface. Sometimes these projecting nodules are arranged in regular lines, which, in connection with their color and form, gives them the appearance of rivet-heads joining sections of the rock together. Near the head of the cañon there are several-bands of black bituminous shales in the sandstone, dipping about $55^{\circ}$. They are a few inches in thickness, and contain impressions of leaves and stems of plants, but these are too much impreguated with sulphur for preservation. The locality has been opened and some rock excavated, apparently under the idea that a valuable deposit of coal might exist there. There is, indeed, some coaly matter, but no indication of enough to pay for working. 
Quite a number of well-preserved Tertiary fossils were found near Griswold's, of which Mr. Gabb notices the following:

\begin{tabular}{|c|c|}
\hline TRIPTERA CLAVATA, & VENUS ASTARTAFORMIS, \\
\hline Nassa INTERSTRATA, & Tapes truncatum, \\
\hline STANDELIA FALCATA, & DOSINIA PONDEROSA, \\
\hline HEMIMACTRA LANTICULARIS, & LUCINA BOREALIS, \\
\hline CHIONE SUCCINCTA, & ARCA TRILINEATA. \\
\hline
\end{tabular}

The formation is referred to the Miocene.

The road from Griswold's to New Idria keeps along pretty near the line between the Tertiary unaltered rocks and the metamorphic Cretaceous. Large masses of the former are seen in the hills on the eastern side, dipping at an angle of $45^{\circ}$ to the north and northeast. A broad belt of country on this side of the range is evidently made up of Tertiary sandstones.

The New Idria furnace or "hacienda" is situated just within the borders of the metamorphic. The sandstones occur in great force along the road from Griswold's, but we had small opportunities to examine them for fossils. From specimens obtained a few miles east of the furnace, Mr. Gabb was inclined to the belief that the Eocene period of the Tertiary was there represented; if so, it would be the only locality in the State where this formation has been detected. Everything indicates a very considerable widening of the Tertiary belt, forming the eastern edge of the chain, as we proceed southwards, and the mass of these sandstones appears to dip towards the plain of the San Joaquin.

The top of the San Carlos Peak, which is 4977 feet above the sea, gives a fine view of the structure and topography of the region. The peak appears to be nearly in the centre of the chain east and west, and is the highest point in the Monte Diablo range, with the exception of a ridge a short distance to the south, which is about 250 feet higher. The chain is here seen to be broken into subordinate ranges, which have a direction nearly parallel with that of the whole group taken together, namely, $\mathrm{N} .35^{\circ} \mathrm{W}$. The strike of the strata in this portion of the range is almost exactly east and west, magnetic, or $N$. $75^{\circ}$ IV.-S. $75^{\circ}$ E., and the general dip is to the north and northeast. G EOLL. VOL. I. -8 
Three parallel ridges may be seen to the east, the two first of nearly bare rock, witl a little chaparral; the one next the plain shows no rock, although absolutely bare of vegetation. To the west the ranges of mountains are lofty and broken, and the region occupied by them a sterile, arid, and forbidding one. These ranges are irregular and broken, but they have a general parallelism with the axis of the chain; their sides are often precipitous and worn into deep cañons. The ridges nearest the plain of the San Joaquin are the most barren, and they are entirely destitute of trees; the central ridges have considerable forest vegetation in places; the trees are chiefly pines and oaks and the white cedar (Librocedrus), which is the best timber in the region.

What little life there was in this region at the time of our visit was due to the working of the New Idria quicksilver mine, which, during the time of the stoppage of the New Almaden, in consequence of legal difficulties and a judicial injunction, was of considerable importance, and the main source of this metal in the State. This mine was discovered, in 1855 , by some persons who were prospecting for silver ore, and who, having discovered a large vein of chromic iron, considered their fortunes made; this led to a great excitement and the thorough examination of the region, the principal result being the discovery of cinnabar at the New Idria Mine. There are several openings or mines, extending over a line about three miles long, in a direction of N. $50^{\circ}$ W. from the San Carlos Mine. to the New Idria, which are the names given to the two principal workings, of which the latter was much the most important. At the San Carlos Mine, which is a little way from the summit of the peak of the same name, the rock is a whitish granular sandstone, in some places considerably metamorphosed, in others in almost its original condition. The ore, cinnabar, is most irregularly diffused through the rock, so much so that there is no system or regularity to be traced in the workings, which extend through a little over one hundred feet of vertical height, and are scattered over several square rods of surface.

The Aurora Mine is situated on the north side of a steep mountain side, about a mile S. $50^{\circ} \mathrm{W}$, from the summit of San Carlos, and at an elevation of about 1500 feet above the furnace. The rock here is an exceedingly hard, silicious material, colored green in places by nickel, 
with ferruginous portions, and a little cinnabar scattered through it in specks. There is a large amount of serpentine in this vicinity, between the San Carlos and New Idria Mines, and on the ridge to the west. In this serpentine occurs the deposit or bed of chromic iron, mentioned before as having been mistaken for silver ore. It is near the summit of a ridge, to the west of the cañon rumning from San Carlos to the furnace, and which divides Monterey and Fresno Counties. The workings in this deposit have all fallen in and are covered by disintegrated serpentine, but a large amount of the chromic iron lies on the surface; not less than thirty or forty tons of the pure material being piled up near the holes from which it was taken. In one place a block of chromic iron, entirely free from any admixture with the serpentine, projects from the ground to a height of four feet, and is seven feet four inches long and five feet six inches wide; how extraordinarily large the mass of ore must be, of which this is a projecting fragment, is easily to be inferred. The excavations were made here under the mistaken idea that this was silver ore, and a furnace was erected for smelting it; in the whole, many thousand dollars must have been wasted in this enterprise. The locality, however, is very interesting, as being the largest and most important deposit of chromic iron known to exist in the State, and we are not aware that any locality has ever been discovered where so large and pure masses of this ore are found.

A variety of interesting magnesian minerals were obtained in this vicinity, including marmolite, hydromagnesite, and a fibrous-radiated and concentrically-laminated variety of serpentine, of interest as showing the unquestionably metamorphic origin of this substance.

The rocks at the New Idria Mine are very varied in character, consisting of sandstones and slates in various stages of metamorphism. In these the cinnabar is very irregularly diffused, and the workings of the mine are proportionately irregular. The only symmetry which could be noticed was an apparent radiation from a centre of the masses of quicksilver-bearing rock, and a concentric band of ore-ground connecting these radiating masses, which was in some places very productive. Thus, in the "Sleeman Tunnel," a chamber of ore was opened running nearly east and west for a distance of seventy-five feet, and extending from fifteen to twenty feet below the level of the tumnel, and to seventy- 
five feet above it. The sides of this excavation are left very rough, as if no regular vein had been followed, showing here and there occasional threads of ore rumning oft at right-angles, and forming thin deposits on the sides of the joints by which the rock is divided. The rock in this tumnel is a dark, somewhat bituminous, silico-argillaceous slate, much fractured and fissured, filled with slickensides, and so disturbed that it would be impossible to make out its average dip and direction. Another large body of ore was taken out from a cavity near the one lastmentioned, running in a northeast direction, and quite straight, for a distance of one hundred and twenty-five feet, and about seventy fect ligh. Here the rock is very silicious and broken up into a sort of breccia, the cimnabar filling the spaces between the fragments; the width of the productive ground was from two to three feet. There is a large amount of iron pyrites in connection with the cinnabar and throughout the mine; this readily decomposes and adds to the high temperature of the workings. The difficulty of following the ore is everywhere evidenced in this mine by the irregular character of the workings, which seem as if almost entirely governed by chance.

It is stated that a large deposit of cimnabar occurs in a mountain called the Picacho, about twelve miles west of New Idria. Some attempts were making, or had been made, at the time of our visit, to develop this and erect a furnace; they do not appear to have been successful.

We have thus traced the Monte Diablo Range nearly to its southern extremity, and have arrived at the point beyond which our investigations have not extended in this direction; the little we know of the geology of the Gavilan Range which adjoins the region just described on the west, will be most conveniently given in connection with the description of the Salinas Valley and the mountains to the west of it, as our explorations were all made from that side. Owing to the incompleteness of onr work, we must necessarily follow a somewhat arbitrary arrangement in a report of progress; it would only be possible to arrange a thoroughly systematic division of the various regions described, after the whole ground had been thoroughly gone over and a much nearer approach to a complete map of the country obtained, than we have now in our power to compile. 


\section{CHAP'TER III.}

THE PENINSULA OF SAN FRANCISCO, INCLUDING THE REGION FRON THE BAY OF IIONTEREY TO THE GOLDEN GATE.

Having gone over the geology of the Monte Diablo Range as completely as our observations permit us to do, it will be convenient next to take up the region on the west side of the Bay of San Franciseo and the Santa Clara Valley. In doing this we shall start at the north end of the Bay of Monterey and trace the formations along the coast from the southeast towards the northwest, thus following a geographical order, and necessarily a somewhat artificial one, as it is impossible to avoid doing at the present stage of our work.

As on the east side of the bay, so on the peninsula bordering its western shore and separating it from the Pacific Ocean, the hills and mountainous portions of the surface predominate greatly over the plains. Mountains cover the whole region north of the Bay of Monterey, with the exception of a strip along the Bay of San Francisco, which widens out as we go south, commencing at Point 'San Bruno, and which joins with the Valley of Santa Clara or San José at the southern extremity of the bay. Along the Pacific coast the mountains come close down to the ocean ; or, at least, are separated from it only by a narrow strip of table-land. Portions of this mountain region, with the very narrow valleys which it includes, and especially the lands along the base of the hills on the bay side, are among the most delightful and desirable sites in California, both on account of soil and climate, and, it may be added, for picturesque beauty of situation. San Francisco, the metropolis of the Pacific coast, comprising fully onequarter of the population of the State, and a much larger proportion of its wealth, stretches her arm down the peninsula, and the numerous fine country-seats along the foot-hills, far beyond San Mateo, tell of the prosperity of the commercial capital.

What has been said of the geology of the Contra Costa IIills will in a considerable degree apply to the ranges on the east side of the bay. 
There are, on this side as well as that, a number of parallel ranges, which extend for a certain distance and then come together in to great masses of mountains, in which no definite trend of the subordinate parts can be traced. For these ranges there are no particular designations in general use, and it is very difficult to give them satisfactory and appropriate names. Beginning at the north, however, we find the name "San Bruno Mountains" given to the short range which extends in a direction diagonal to the peninsula from Sierra Point nearly across to the Pacific, being separated by a low divide from the group of hills on the San Miguel Ranch, to which the name of San Miguel Hills may be giren. The ranges extending through San Mateo County and their continuations through Santa Cruz, may conveniently be designated by the names of the counties through which they pass, since there is no general well-known name for them.

In these hills and mountains of the peninsula we have in many respects the counterpart of those on the opposite side of the bay. They belong to the same Tertiary and Cretaceous systems, and exhibit the same general lithological characters, yet with many local peculiarities. Fossils are much less abundant in these ranges than in those on the Monte Diablo side, and the geology is rendered more complicated by the presence of intrusive granitic rocks, which appear in several places on the peninsula.

The entire system of elevations between the Bay of Monterey and the. Golden Gate is sometimes included under one name, and called the Santa Cruz Range, which is, however, properly the term for the southern and middle portions of the hills in question, or those included in Santa Cruz County. Here, in fact, are the highest mountains and the broadest belt of elevated country, the chain diminishing in height and breadth as it runs north, until it finally sinks beneath the ocean at the Golden Gate. The entire range, from the Bay of Monterey to the end of the peninsula, is about sixty-five miles in length, and its greatest breadth is about twenty-five miles. The eastern ridges are highly netamorphic, and constitute the main portion or backbone of the range, Mount Bache being the highest point; this has an elevation of 3780 feet, being less than a hundred feet lower than Monte Diablo; this mountain-nuass, to which Mounts Choual (3530 feet) and Umunhum 
(3430 feet) belong, is the dominating one of the range, although there are points farther north which rise to over 3000 feet.

Taking up the description of these mountains, which are collectively designated as the Santa Cruz Range, we commence near the town of that name and proceed in a northerly direction, grouping the subdivisions of the range in as natural a manner as is possible.

In crossing over from Santa Cruz, in a northerly direction across the chain, to the Santa Clara Valley, before reaching the metamorphic, a mass of rocks is traversed, which is much broken and elevated, some of the ridges being fully 2000 feet high. In rising on to this elevated ridge, however, we first pass over a belt of unaltered strata, which near the town lie nearly horizontal, and which appear to have escaped the action of the elevating forces by which the main chain has been raised. There appears to be no doubt that these horizontal strata are the same ones which are tilted up in the mountains, and that they belong to the Miocene Tertiary.

At about six miles from Santa Cruz are some singular examples of weathered sandstone, which are known as "the Ruins," or the "Ruined City." Here perpendicular tubes or chimneys of rock are found, from one to three feet in diameter, the sandstone appearing to have been hardened in concentric layers by the infiltration of ferruginous solutions, and this hardened portion has withstood the action of the elements, while the softer bands and the interior columnar or cylindrical masses have weathered away, leaving a pile of rocks behind, which, by some exertion of the imagination, can be construed into a resemblance to a ruined city on a very small scale, as may be seen from the annexed sketch (Fig. 6) of one of the most prominent of these castellated piles. These rocks contain quite a number of fragments of echinoderms.

In the more broken and higher ridges farther north, near the summit of the pass, the rock is chiefly sandstone, in places interstratified with slates, and at the highest part of the road these strata are somewhat metamorphic.

- From an elevated point near the summit an extensive view was had of the southern part of the range of the high and deeply eroded ridges of Mount Bache, to the east, and of the ranges to the northeast, which are also lofty and rugged, rising in some places to nearly 3500 feet in eleva- 
tion. The scenery on this road from Santa Cruz to San José is hardly surpassed in grandeur and beauty by anything in the Coast Ranges. There are heavy forests of pines, firs and oaks, which almost vie with

Fig. 6.

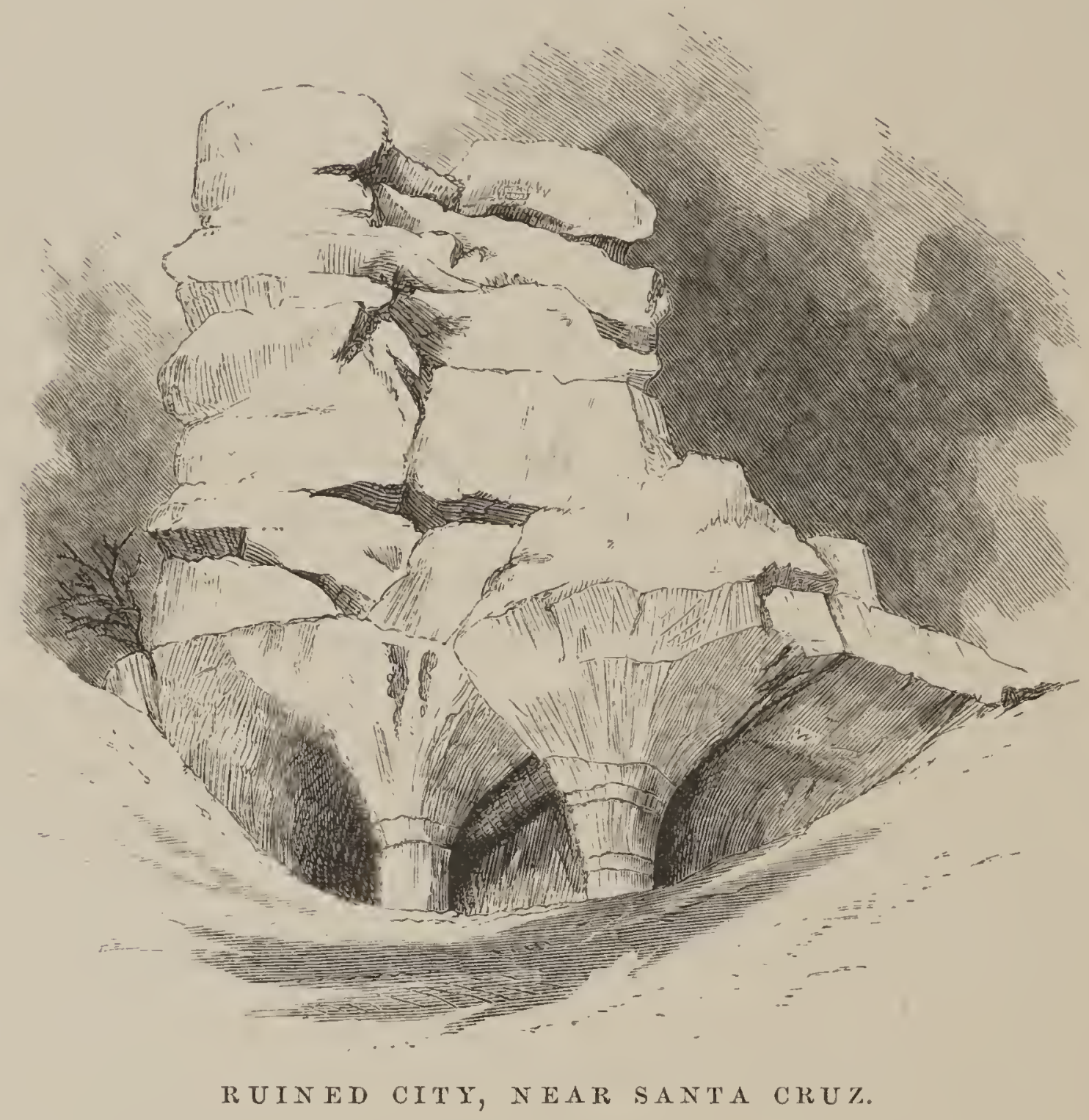

those of the Sierra in size and vigor of growth. In the Valley of the San Lorenzo, above Santa Cruz, there are magnificent groves of redwood, the finest which can be seen within easy distance of San Francisco, and well worth a journey to examine, as they are little inferior to the Big Trees in size or beanty. One measured fifty feet in circumference at the base, and is said to be two hundred and seventy-five feet high, as determined by the United States linear surreyors.

Gold occurs on the eastern slope of this ridge, but probably not in paying quantity, although a considerable amount of ground has been washed over.

The metamorphic belt, before spoken of as occurring on the east side, forms the highest ridges of the range. The higher masses extend from 
a point back of Redwood City, southeast for about forty miles. The most northerly portion of this metamorphic ridge visited was that which lies back of Momntain View, and of which Black Mountain is the culminating point, being about 3000 feet high.* Here are several parallel ridges, haviug a direction of about N. $54^{\circ} \mathrm{W} ., \mathrm{S} .54^{\circ} \mathrm{E}$., which appears to be nearly the strike of the rock; but the stratification is very obscure, owing to the metamorphic character of the rock. These ridges run out into the plain to the southeast, their strike taking them to the north of Mount Bache, the range being broken and irregular in the intermediate region, where cut through by the Los Gatos and Quito Creeks. All these ridges have steep slopes, and are very dry in the summer and covered on their northeastern sides with dense chaparral, composed more exclusively of the Adenostoma fasiculata, or "chamiso," $†$ than were similar tracts farther south, where various species of Ceanothus predominate in the dense, thorny, and almost impenetrable undergrowth, to which the name of "chaparral" is universally given. The slopes on the southwest sides of the mountains were less inlospitable, being covered to a considerable extent with wild-oats, as were also the foot-hills. The rock in the Black Mountain mass is almost exclusively metamorphic sandstone, with but little serpentine or mica-slate, scarcely any of either of them being seen. At the summit is an outcrop of metamorphic limestone, very compact and hard, but not crystalline. The foot-hills in this region extend several miles into the San José Plains, and are covered with a fertile soil; they form some of the most delightful and attractive farming lands of the State.

On the northwest side of the high metamorphic ridge before spoken of as forming the mass of Mounts Bache, Choual, and Umunhum, and lying parallel with it, is a lower ridge in which occur the quicksilver mines of Santa Clara County; the culminating point of this lower

* This is the Black Mountain of the United States Coast Survey; the name "Loma Prieta" is very commonly given by the Spanish-Mexican population to any high chaparral-covered point which looks black in the distance. Mount Bache is one of these "Black Mountains."

$\dagger$ Where the chamiso predominates, the thick undergrowth is usually designated as "chamisal:" the proper meaning of "chaparral" is a dense undergrowth of shrubby ouks.

GR.กI. VักI. I.—! 
ridge is Mount Chisnantuck, which is 1790 feet high, and there are several points in it which rise to over 1600 feet.

A belt of metamorphic limestone occurs in this ridge, and is evidently the same as that noticed on Black Mountain. It is seen on the Jus Gatos Creek, about one-fourth of a mile above Forbes's Mill, where it has a distinct stratification and a dip to the northeast, and is less altered than near New Almaden. It is seen again a short distance above the "Ranchita," about one or one and a half miles north of the Guadalupe Mine, where it is more altered, so much so that no dip or strike is distinguishable. Another locality noticed was half a mile sonth of the Guadalupe Mine, on the west side of the creek, where it is quarried and burned for lime, supplying all the mines of the vicinity. It crops out again on the same side of the creek, about a fourth of a mile above. the Enriquita Mine; also on the ridge stretching between Mounts Choual and Chisnantuck, where it is distinctly stratified, and contains impressions of the scales of fishes; a whole fish, in an imperfect condition, has also been found here. The rock at this locality contains black silicious nodules, Another locality is about one mile S. $37^{\circ} \mathrm{E}$. of Chisnantuck, where it is highly altered and no stratification visible; from here it may be traced a mile and a half farther to the southeast. Although all these limestone masses appear evidently to belong to the same belt, it is not now a continuous one, as it must in all probability have been when first deposited; it forms detached masses, separated from each other by intervals of other kinds of metamorphic rock. Isolated masses of limestone occur off the line of this belt, on both sides; one of these, on the east side of the Capitancillos, between the Guadalupe and the Enriquita Mines, was quarried for burning into lime until it was exhausted. The same rock also occurs in patches between the New Almaden Mine and the furnaces. Other localities were noticed on the opposite side of the main belt, on the ridge at the west base of Mount Choual, near the spring.

The higher points on the outer ridge are composed of silicified shales, generally in the form of red jaspers. These are lithologically identical with the metamorphic Cretaceous of Monte Diablo, so that hand specimens from the two localities could not be distinguished. These jaspery shales form the crest of Mount Chisnantuck, and extend southeast to- 
wards the Uvas Creek, and also to the northwest, cropping out in at pretty well-defined belt near the furnaces, and passing near the mouth of the new tumnel at the New Almaden Mine; the same rock was also traced along the ridge of Mine Hill for several miles. This is the most extensive development of these jaspers found, along this belt of metamorphic strata, although rocks of the same character are seen in many places on this line, in more limited quantity.

The quicksilver mines are essentially in this principal belt of altered slates, generally nearer its western edge, and there are extensive beds of serpentine on both sides of it, not entirely continuous, but sufficiently so to be considered as one stratum, while isolated patches also occur off the line.

Nount Chisnantuck is composed of red and green jaspers, haring an eastern dip, and this rock extends uninterruptedly to the furuaces, containing some serpentine. On the east of this is a belt of serpentine, which runs by the school-house below New Almaden. On the ridges between Cañada de las Uvas* and Chisnantuck, are jaspery rocks and altered sandstones, the latter having occasionally retained their original condition. To the west and southwest of Uvas Creek are high ridges covered with dense chaparral, which appear in the distance to be the continuation of the metamorphic belt of Mount Bache. Between the New Almaden and Enriquita Mines, metamorphic slates occur, and are sometimes a good deal decomposed.

On the ridge that extends back from Mine Hill to Mount Umunhum, there occurs a limited patch of unaltered sandstones, which contains a number of Pectens and other Tertiary fossils, and which is surrounded on all sides by metamorphic rocks. This Tertiary occupies the summit of a low ridge, and it appears to be the remains of a folded mass caught in and compressed between the Cretaceous strata, as a distinct synclinal structure was traced through it, not without difficulty, owing to the broken and metamorphic character of the surrounding beds, in which it is almost impossible to distinguish the real lines of bedding.

Although no fossils were found in the quicksilver-bearing beds themselves, we have little hesitation in referring them to the age of the Cre-

* Not to be confounded with the Cañda of the same name near Fort Tejon. 
taceous. The jaspery beds of Chismantuck are the exact counterpart of those of Monte Diablo, which we know to be Cretaceous, and those of Mine Hill, in which are the deposits of cinnabar, are evidentiy the continuation of those of Mount Chisnantuck. And as we trace them farther north, to the extremity of the peninsula, we find them still retaining the same lithological character, while we have there the evidence of fossils to prove them to belong to the Cretaceous epoch. In regard to the geological position of the cinnabar deposits of California, it may be added, that this ore has been found by us in many localities, and in formations of nearly every age. It occurs in the Sierra Nevada and in the southern part of the State in strata of Triassic age, and on the eastern slope of the Sierra, probably in rocks of the same age. In the Coast Ranges it has been found in the Tertiary; but, as far as yet known, there are no large and valuable deposits cxcept in the Cretaceous, in which position the localities which have been discovered, and where the ore is known to exist, in small quantity at least, are very numerous, extending in a line with the metamorphic Cretaceous from New Irria to Clear Lake.

The only mine of cinnabar which has been extensively worked in the State, and with large profit, is that of New Almaden; indeed, this mine is the second in importance in the world; it is only inferior in productiveness to the Almaden Mine itself, the average monthly produce of quicksilver for the half year ending December, 1864, being 4118 flasks, or about 300,000 pounds, equal to over three and a half millions of pounds per annum. The present capacity of the reduction works is equal to a production of 5000 flasks monthly, or four and a half millions of pounds per annum. With the New Almaden, the Enriquita Mine is now united, and the total production of the two, since July, 1850, is given in the published statements of the company at 371,880 flasks, of which the Enriquita furnished 10,571 only.

The ore from which the larger portion of this amount of metal has been taken occupied a series of irregular cavities, mostly confined within a space about one hundred feet square and extending downwards for about four hundred feet. This ore-ground dips to the north at an angle of $30^{\circ}$ to $35^{\circ}$, with the formation, and the masses or chanbers of ore are scattered through it without any approach to regularity, 
as is shown by the fact that there have been times when there was no ore in sight in the mine, in spite of its great average productiveness.

The ore-ground extends for some five miles to the northwest, in the line of strike of the strata, and has been opened and worked at intervals, although no one locality has at all approached in productiveness the New Almaden Mine itself. The Enriquita Mine, two miles northwest of the Mine Hill, was opened in 1859; but was closed from May, 1861, to May, 1863; it has produced about 1,300,000 pounds of quicksilver, but has not been worked with profit, owing to the irregular distribution of the ore. The same is true of the Guadalupe Mine, two miles beyond the Enriquita, where, up to 1862, nearly half a million of dollars had been expended in prospecting.

Quicksilver is one of the important articles of export from California; a large portion of it (in 1864, just one-half) goes to China, the remainder chiefly to Mexico and the South American States. The average amount shipped from San Francisco for the last five years has been 33,168 flasks, or nearly two and a half million pounds per annum.

In passing from the Guadalupe Mine to Forbes's Mills, Tertiary rocks are seen in the low foot-hills, having a gentle dip to the northeast. The relations of this deposit to the metamorphic were not satisfactorily made out; but it appeared to rest unconformably on the edges of the altered strata. The same rocks were again observed near McCartysville, where they also have a low dip to the northeast, and in one place they were seen resting unconformably on the metamorphic beds of the quicksilver-bearing series. This locality was about one mile up the cañon from McCartysrille.

Along the Los Gatos Creek, above Forbes's Mill, towards Lexington, the rock is entirely metamorphic, often much contorted, and in places broken into angular fragments, but the large masses dip to the northeast; these rocks evidently belong to the metamorphic mass of Mount Bache and Black Mountain. From observations made in two places, where it was crossed, and as seen from the heights between Los Gatos Creek and Black Mountain, this belt appears not to be over three or four miles wide. The general dip of the mass appear's to be everywhere to the northeast. Up the cañon from McCartysville, this rock was observed in several places to have a strike of $\mathrm{N} .65^{\circ} \mathrm{W}$, and to dip at a 
high angle to the north. Fossils are reported to occur on the old trail from Lexington to Forbes's Mill; they are probably in the unaltered Tertiary, resting unconformably on the metamorphic, as was seen near McCartysville.

Along the west side of this metamorphic belt there is a series of high ridges of unaltered Tertiary strata. These form a broad range of mountains, extending from near the summit of the road from Santa Cruz to Lexington, northwest into San Mateo County, and covering a region but little explored and hardly inhabited. This ridge is very much furrowed by eañons, especially on the southwest side, from which flow the tributaries of the San Lorenzo Creek, and the whole region to the west of it, as far as the Ocean, is a labyrinth of hills and cañons. There are some ranches along the coast, and settlements have extended themselves some way up the San Lorenzo and Pescadero Creeks; but all the interior of the mass of hills is otherwise uninhabited, and not traversed by any trails, between the one leading from Pescadero over to the Corte de Madera Ranch, and the road which crosses from Santa Cruz over the mountain to Santa Clara Valley. The culminating point of this ridge lies about five miles a little south of west from McCartysville, and rises to the height of 3269 feet above tide. In the absence of any name for this mountain, it was called Mount Bielawski.* Another point two miles sontheast of this was found to be 2886 feet high; and a third, four miles farther on, in the same direction, 2431 feet high.

In passing up the Los Gatos (reek to explore this region, shales were met with in the bed of the creek, near Howe's Mills, standing vertical, or having a high dip to the northwest; but their strike was observed to be more east and west than the general direction of the mountain mass. Large bodies of strata were seen with a strike of $\mathrm{N}$. $45^{\circ} \mathrm{W}$. to N. $55^{\circ} \mathrm{W}$. Sandstones were the most abundant rock seen here, but shales were often met with, especially in the low divides.

The region to the northwest of the mountain range just noticed, and west of Black Mountain, including the Corte de Madera Ranch and

* In honor of the chief draughtsman of the Surveyor-General's Office, Mr. C. Bielawski. 
the country from there west to Pescadero, was also traversed and some examinations made. About Searsville there are some exposures of metamorphic sandstone, and between there and Redwood City a light brown sandstone was noticed, in which Mr. Gabb detected a fucoid, similar to one observed in the beds of Cretaceous rock overlying the coal at Monte Diablo. From Searsville, a metamorphic rock, principally an altered conglomerate, containing large pebbles of. jasper, continues along the road to a little beyond the southern boundary of the Corte de Madera Ranch. A portion of this conglomerate has escaped the metamorphic action, as boulders of this rock, unaltered, were found in the San Francisquito Cañon, which were said to have come from just below the coal; but it was not found in place. This rock closely resembles a conglomerate observed in the Monte Diablo Range, a little north of Pacheco's Pass, and which is there found in various stages of alteration.

The boundary between the unaltered and the metamorphic rocks extends along the west side of the ridge, in which the "coal-mine" is situated, although the exact line of contact is concealed. In a sidecañon, about a mile northwest of the mine, and running from the next ridge to the west, the Cretaceous shales crop out in a few small exposures at the base of the hill; here the strike is $\mathrm{N} .42^{\circ} \mathrm{W}$., and the dip about $45^{\circ}$ to the northeast. The upper portion of this ridge is made up of a highly fossiliferous shale, with some sandstone, which rocks are of Tertiary age, and are referred to the Miocene by Mr. Gabb. In the bed of the creek were, among the boulders of sandstone, some fragments of syenitic granite and of a basaltic rock, which latter is said to cap a few of the highest points of this ridge.

The "coal-mine" is just on the edge of the metamorphic strata, and in the excavations made there considerable masses of lignite, showing. the original fibre and annual rings of the wood, have been found. From the workings a gray, sandy clay has been taken, which contained some fossil shells and a few impressions of leares, too imperfect for determination.

Quite extensive "prospecting" has been carried on here for coal, and also for quicksiker, on the opposite side of the ridge, in the metamorphic rocks. There was a shaft sunk to the depth of seventy-five fect 
in a vein or bed of red clay, which was said to contain cinnabar, but there was none of this metal or its ore visible to the eye; it was stated, however, that assays made of this material had given from three to ten per cent. of quicksilver. There are several veins of this red clay, close together and varying from a few inches to a foot and a half in thickness. The formation is one in which this metal might be found; but if the clay contained more than a trace of cinnabar, it would be a different mode of occurrence of this ore from any that we have hitherto observed in California.

Following the same ridge to the south, the conglomerate becomes covered with soil, and before reaching the highest point of the road exposures of Tertiary rocks are met with. The first of these is of a lightcolored sandstone without fossils; but a little farther on is a white sandstone full of irregular grains of calcareous spar. This rock is highly fossiliferous, containing shells belonging to the genera most commonly found in the Miocene Tertiary of the Coast Ranges, such as Mytilus, Pallium, Pecten, Venus, and the large oyster (Ostrea Titan) so abundant and characteristic of this division of the series.

From this point to Lambert's, sandstones and shales occur, but no fossils were observed. The hill west of Lambert's consists of a lightbrown unaltered sandstone on the summit and, so far as was seen, on the east side. On the west side, however, fragments of shales and limestones resembling those of the Cretaceous formation were observed; but these rocks were not found in place. In a hill two and a half miles southeast of Lambert's, shales and sandstones were also seen, but apparently not of Cretaceous age. In the "Devil's Cañon" there is a fine exposure of sandstone, overlaying the shales just mentioned, and having a strike to the northwest, and a dip of $55^{\circ}$ to the southwest.

In the region to the southwest of the Tertiary and metamorphic Cretaceous belt which has just been described as extending along from Mount Bache to Searsville, and forming the centre and eastern edge of the Santa Cruz Range, there is a high range of granite hills, of which the southern termination is near the town of Santa Cruz, and where a great deal of prospecting for gold has been done. It is stated, on what is believed to be good authority, that at least one quite rich mass 
of auriferous veinstone has been obtained here. There does not, however, seem to be any prospect of permanent profitable working for this metal at this point, as no well-defined vein could be traced.

This ridge of granite extends oft to the northwest from Santa Cruz, but disappears before reachịng Pescadero Creek. Its highest point is between 2800 and 2900 feet in elevation. Unfortunately the opportunities for observing the relations of this rock to the surrounding strata are very poor. The coast was followed up from Santa Cruz to Pescadero by our party, and some examinations made inland. Along the trail travelled to the mouth of Scott's Creck, there are numerous outcrops of bituminous shale, always horizontal, or so nearly so as to indicate that no disturbance has taken place in this rock since its deposition. About eight miles from Santa Cruz, near the road, on a small creek, a bed of coarse gray sandstone was seen, which is curiously weathered into small irregular cavities over its entire surface. This bed is horizontal, intercalated in the bituminous shale, and from twenty-five to thirty feet thick; it was destitute of fossils. An attempt was made to ascend the granite ridge from Scott's Creek, but it was not reached, on account of the thickness of the chaparral. A high point was attained, however, which was made up of white shale or slate, with a very gentle dip of about $8^{\circ}$ in a direction a little south of west and away from a high ridge just west of the San Lorenzo Creek; this ridge appeared to be of granite, as boulders of this rock were seen in the creeks at its base.

Just north of the New Year's Point ranch house, an exposure is seen in the bluffs, on the coast, of fine-grained sandstone, referred by $\mathrm{Mr}$. Gabb to the Pliocene. This deposit seems to form a small basin, cut through by the coast-line, and extending for about a mile along the shore.

At Pigeon Point, a bluish-gray, very compact sandstone was found, containing Natica, Mactra, and Mytilus, and belonging to the great Miocene Tertiary of this portion of the peninsula. The coast, for nearly the whole distance between Pescadero and Santa Cruz, shows two well-marked terraces, of variable height, and often interrupted by the coming down of the hills quite to the shore. The whole region traversed by the trail from Pescadero to Searsville, as far as the metaGEOL. VOT. I. -10 
morphic on the eastern edge of the range, is bituminous shale of Miocene age, with occasional beds of interstratified sandstone, of which the dip is irregular but not high.

From Lambert's along the ridge north of Pescadero Creek, the rock is a shale or slate, of a light cream-color passing into gray. It contains, towards the east, occasional seams of sandstone, which disappear within a few miles of Lambert's. The general strike of these strata is nearly northwest and southeast; they have a dip which indicates that the surface has been thrown into a series of low arches since the deposition of this bituminous shale. No other fossils were found than a few small splinters of opalized wood and an impression of a fish-scale; but, from lithological characters and general position, it can hardly be anything else than the Miocene bituminous slate of the Coast Ranges. The same rock is seen in the high hills between the Pescadero and Butano Creeks, and near the beach west of Pescadero; going north from the last-named place it continues, as far as three miles northeast of Spanish Town, where it caps a mass of granite which forms the body of the ridge.

Another line of section across the peninsula was examined, namely, from San Mateo to Half-Moon Bay, at Spanish Town.

Near San Mateo, and a little to the north of the road to Crystal Springs, there is a good exposure of the metamorphic rock which forms the eastern edge of the mountain belt of the peninsula. The rock here is a red jaspery mass, quite resembling that of Monte Diablo, distinctly stratified, and passing into brown argillaceous sandstone; it dips east, at an angle of $35^{\circ}$. As we proceed west along the Crystal Springs road, the ground rises and finally assumes the form of a rolling plateau, of which the summit is about 1200 feet high. In thus passing west, the rocks become more and more metamorphic, and serpentine makes its appearance. On the ridge fronting San Andreas Creek, to the north of Crystal Springs, there is serpentine, intermixed with white quartz, and red and green jaspers.

In the cañon of the San Andreas, on the west side, there is a heavy mass of limestone, which may be traced high up in the side gorges coming down from the west. It dips to the northeast, at a varying angle, nsually not less than $35^{\circ}$, but in some places stands nearly ver- 
tical. The upper layers are thin-bedded, and some strata are lightcolored, others dark; below, the stratification is less distinct, the layers heavier, and the rock more crystalline. The thickness of this belt of limestone must be over 1000 feet; but it was not seen in its full width. A little distance south of Crystal Springs, this rock was formerly qualried and burned for lime.

Between the limestone mass and the head of Pilarcitos Creek, there is a series of heary-bedded sandstones, brown in color, but so much broken and so irregular that their position could not be made out, although they appeared in some places to be conformable with the limestone belt, which dips to the east. This sandstone forms a ridge, which rises to about 2500 feet above the sea, and is the backbone of the peninsula in this region, occupying a belt of high rolling country for two or three miles in width. No fossils could be found in this rock.

West of this is a range of granitic hills, to which the Cumbre de las Auras belongs, and which runs northwest and dies out just before reaching Point San Pedro. This granitic mass occupies an elliptical area, and consists of high, rounded, almost bare ridges, rising in their highest peaks from 2500 to 3000 feet above the sea. The granite decomposes readily, and the sides of the hills are in places covered by heavy masses of disintegrated rock. The region is dry and uncultivated.

Beyond this, to the west, is first a low ridge of heavy-bedded friable sandstone, with a dip of $40^{\circ}$, away from the granite, or to the west; proceeding a little farther west, however; the same strata are seen again with an easterly dip of $50^{\circ}$, and this continues to be the direction of the dip all the way to the sandy plain on which Spanish Town is built. The strata, however, have a less and less decided inclination as we recede from the granite, and finally, before reaching the coast, become nearly horizontal; they also pass gradually from sandstones to shales, very thinly-bedded and a good deal broken. The fossils found in these strata show that they belong to the Miocene Tertiary. They are the continuation of the bituminous slate series which extends all along the coast from Santa Crum to Spanish Town, forming a gradually narrowing belt of rock, which is slightly disturbed near the granite; but, at a little distance from it, retains its original position. 
The belt of limestone noticed above, as occurring between San Andreas and San Mateo Creeks, runs out to the sea-shore about one and a quarter miles north of Point San Pedro, forming a low ridge or headland. Here it has to the south of it a red and green jaspery rock, distinctly stratified, and having the same northeasterly dip as the limestone. The granite range of the Cumbre de las Auras disappears beneath the ocean, but rises again to the north of the Golden Gate, in the promontory of Punta de los Reyes.

The great regular ranges of mountains which form the peninsula appear to run out, to the north of San Pedro, and no more granite is seen on its northern end after passing the mass of the Cumbre de las Auras. The extremity of the peninsula is occupied by short and broken ranges, or low hills, in which the regular trend to the northwest can be no longer detected, but where the influence of the east and west line of depression, by which the Golden Gate has been opened, and access given to the interior, is manifested in the most chaotic jumble of strata which it is possible to find in the State.

The larger portion of the rocks which make up the north end of the peninsula are of Cretaceous age, and are more or less metamorphic in character, being in fact the continuation of the strata which form the eastem edge of the belt of mountains, which have just been noticed as extending through Santa Cruz and San Mateo Counties. The principal varieties are the brown argillaceous sandstone, in all stages of passage, from the entirely unaltered rock to the hard, dark-colored, almost dioritic material; then the metamorphic shales, or the silicious slates passing into jaspery rock, as is so often seen in the metamorphic Cretaceous. Besides these, which make up the greater portion of the surface in this region, there are large masses of serpentine and occasional beds of the peculiar locally-metamorphosed silicious rock, which is so often accompanied by ores of mercury. There are no eruptive rocks on the peninsula, to the north of San Mateo, so far as our observations extend.

Owing to the near approach of the rocky hills to the shore, and the great number of points where the ocean has cut into them, there is no lack of good exposures of the strata in the vicinity of San Francisco. Extensive artificial excavations within the city for opening new streets 
have also furnished excellent sections of the rocks, at a heary expense to the property-holders. But, so crushed and broken are the strata thus revealed to view, and so few and indistinct the fossils which they contain, that it was a long time before their real age could be clearly made out, and it was not until after we had decided, on stratigraphical and lithological grounds, that the so-called "San Francisco sandstone" must be of Cretaceous age, that the timely discovery of a single shell, undoubtedly of this epoch, in the rocks of Alcatraz Island, gave the additional desirable assurance of the correctness of our vicws. We now feel justified in asserting that the whole of the upper end of the peninsula, with the exception of a few patches of limited extent on the western side, belongs to the Cretaceous epoch.

Where least metamorphosed, the Cretaceous sandstone is distinctly scen to be made up of fine rounded grains of silicious material, cemented together by carbonate of lime. Its color is a decided grayishblue in the interior of the strata; but on the surface of beds which have been exposed to the weather it is a yellowish-brown, from the decomposition of the protoxide of iron which appear's to be contained in the cement which holds the particles together. This rock is quarried to a considerable extent as a building material, especially on Angel Island; it is used chiefly for purposes where beauty and strength are not absolutely required, for this rock possesses. neither qualification in a high degree, although it answer's very well for ordinary uses in the mild and equable climate of San Francisco. At the quarries on Angel Island, the rock is very heavy-bedded, and so intersected by joints that it was extremely difficult to make out the real position of the strata. The dip appeared, however, to be to the northwest, at an angle of $65^{\circ}$. The sandstone on the islands about the city is more silicious and better adapted for a building-stone than that on the main-land; the quarries on the islands have also greater advantages of approach, and superior facilities of working.

The rock on the main-land in and about the city of San Francisco is what may be called an argillaceous sandstone, that is to say, a rock formed from a deposit of sand and mud intermixed. Many portions of it are made up of thin layers of silicious material, with shaly partings between them, while other portions are rather homogeneous in 
texture and heavy-bedded. Nost of it decomposes gradually on exposure, and hence has but little value as a building-stone. Through much of this rock metamorphism has hardly proceeded farther than the first stage, which is one as much of mechanical preparation as of chemical action, the strata having been so broken up as to allow the easy access of moisture and air from above, and hence the rock is pretty thoroughly decomposed to a considerable depth. This kind of slightly metamorphosed sandstone is well seen in the excavations around Telegraph Hill, of which it forms the mass, and also in the high ridge of which Russian and Clay Street Hills form a part. The more silicious and thinnerbedded layers, so peculiar to the Cretaceous series, are well seen about the end of Rincon Point, and thence to Steamboat Point. These thinner strata often show, by the intricacy and closeness of their foldings, how thorough, as well as how irregular, the action of the uplifting forces has been in this region.

The serpentinoid rocks occupy much less space around the city of San Francisco than do the less metamorphosed sandstones. They resemble the masses of this material which occur elsewhere so frequently in connection with the Cretaceous sandstones, as has already been frequently noticed in describing the geology of the Monte Diablo Range. The principal outcrop of this rock in the neighborhood of San Francisco extends across from Fort Point, by Lone Mountain and Mission Dolores, to the Potrero. The material known as the "red rock," and which is so much used for ballasting the roads about the city, is apparently an imperfect serpentine. A chemical examination of these rocks, in their various stages of progress from the unaltered to the thoroughly metamorphosed material, is much to be desired. A map of the city and its vicinity, on a large scale, has been commenced by the Survey, on which all the varieties of strata and of the superficial covering of . soil and sands will be laid down.

Considerable patches of the quicksilver-bearing rock occur in the hills around the Mission, and both the native metal and the sulphuret (cinnabar) have been found in small quantities; but no workable deposit has yet been discovered. The only other mineral of economical value found in the metamorphic Cretaceous of this vicinity is the oxide of manganese (pyrolusite), which has been obtained in considerable 
quantity and in a high degree of purity on Red Rock, near Point San Pablo, and which also occurs on the main-land near Hunter's Point. If extensive deposits of this mineral can be found, they will be of great value to the State.

Although the Miocene Tertiary sandstones which form so conspicuous a member of the Coast Ranges are not exposed in the vicinity of San Francisco, there are somewhat extensive outcrops of rocks of a later 'Tertiary, in the low hills extending along the sea-shore southwest of Merced Lake, nearly as far as Mussel Rock. According to the observations of Messrs. Rémond and Gabb, there are two sets of strata here, which belong to the Pliocene and Post-Pliocene epochs, and which are unconformable with each other. Both these formations rest also unconformably on the metamorphic Cretaceous, as does also the Miocene in the region north of the Golden Gate, while that formation appears to be wanting throughout the northern end of the peninsula of San Francisco.

The Pliocene beds between Merced Lake and Mussel Point are made up of a bluish sandstone, of which the grains are cemented by carbonate of lime, interstratified with hard, fine conglomerates, of which the pebbles are evidently derived from the adjacent jaspery rocks of Cretaceous age. These strata contain Scutella interlineata, Crepidula princeps, both of which are extinct, together with several species still living on this coast. The Post-Pliocene series consists of beds of gravel, sand, and clay, with some soft sandstones, and contains only shells of recent species, among which the genera Tellina, Mytilus, and Buccinum are represented. Of these two sets of beds, the lower, according to $\mathrm{Mr}$. Rémond, have a northwest strike, and dip to the northeast at an angle of $35^{\circ}$, while the upper ones have an inclination of only $10^{\circ}$. This is only one of a numerous class of facts, which show that there lave been quite extensive disturbances of the rocks along the coast within a very recent geological epoch. 


\section{CHAPTER IV.}

TIIE COAST RANGES NORTH OF THE BAY OF SAN FRANCISCO.

In continuing our sketch of the geology of the region adjacent to the Bay of San Francisco, it remains for us to take up that portion of the Coast Rauges which lies north of the Bays of San Francisco, San Pablo, and Suisun. Owing to various causes, among which want of time was the most important, we have not extended our explorations in this direction beyond Clear Lake, the geology of the extensive area comprised in Mendocino and Humboldt Counties, and belonging to the Coast Rariges, being only known to us from the examination of a few specimens furnished to the Survey by chance collectors, and from reasoning on general principles of stratigraphy, based on our information with regard to the geology of the Coast Ranges, by the aid of which we are enabled to form a tolerably correct idea of what formations we may expect to find in that region, whenever we have the opportunity of exploring it. The little we have to say in regard to the most northern portion of the Coast Ranges, or that lying between Trinity River on the east and the Pacific Ocean on the west, may, therefore, be conveniently given in another chapter; in this we shall take up the region immediately north of the bay, including Marin, Sonoma, Napa, Solano, Yolo, Colusi, and Lake Counties.

In its general features this part of the State resembles, both geologically and topographically, that region which has just been described as forming the northern extension of the Monte Diablo and Santa Cruz Ranges. We have on the north of the bay, as on the south, the same predominance of hill and mountain over plain and valley, the same parallelism of general trend, and the same intricacy of detail in the minor features of the topography. There is no one valley to the north of the bay which spreads out so fair and wide an extent of fertile soil as that of Santa Clara; but, on the other hand, there are more ranges of low and rolling hills adapted for cultivation, and, with the charming though narrow valleys between them, enabling the counties enume- 
rated above to vie with any portion of the State of equal area in fertility. For picturesque beauty and general salubrity of climate, it would not be easy to decide which of the valleys leading out from the Bay of San Franciseo is entitled to pre-eminence; taken together, they may well claim to be considered as one of the most attractive portions of our country.

The whole of Marin Comnty is thrown up into rolling hills of moderate height, and the depressions between them have little level ground; nor is there much regularity in the distribution of the ridges, a circumstance which is due to the irregular dip and strike of the strata, and the still more irregular manner in which they have undergone a more or less complete alteration by chemical agencies since their deposition. In general character the rocks of this county are similar to those described as occurring on the peninsula south of San Francisco; of these they are in reality the continuation, although apparently separated from them by the Golden Gate.

The culminating point of the county is Tamalpais, ${ }^{*}$ which rises to the height of 2597 feet, forming a portion of a ridge which extends across the peninsula in a nearly east and west direction; in this ridge there are three summits of nearly equal height, all being over 2550 feet. One of these points is a Coast Survey station, and is called "Table Mountain." These are all of hard, metamorphic sandstone, not so much altered, however, as to obliterate the granulation or the lines of stratification. Near the eastern summit, veins of quartz occur, portions of which are distinctly banded, as if deposited from water. Some of these are said to contain gold, and they have been worked but found too poor to pay for the labor. The summit has been, and is perhaps now, held as a quartz claim. The eastern summit is very sharp, the slope, as scen in the sky-outline from San Rafael, being $25^{\circ}$ on both

* Tamalpais is the name by which this mountain is now universally known in San Francisco, from which it is so conspicuous and beautiful an object. It was called "Mount Palermo" by the United States Exploring Expedition, and "Table Mountain" by Beechy and the United States Coast Surrey. The Coast Survey station is not, however, on the highest point, but is about a mile to the west of it. The elevation of the station is given at 2597 feet; that of Tamalpais itself at 2604 feet. The name is said to have originated in the fact that this region was formerly the residence of the Tamal Indians: see Davidson's Directory of the Parific Const, in Coast Survey Report for 1862.

GEOT. VOI. I. -11 
sides, and the whole mountain is deeply furrowed by denudation. About three-fourths of a mile west from the highest point, serpentine occurs in large quantities, as also on the northern slope. On the northwestern side there are immense masses of this rock, forming the ridge between the Tomales y Baulines, San Geronimo, and Cañada de Herrera Ranches, and rising to the altitude of 1829 feet. This belt, which is almost entirely of serpentine, extends several miles to the northwest. On the north slope of Tamalpais altered slates occur, at the altitude of about 1200 feet, and have a northwest strike and a rery high but irregular dip to the southwest.

Between Petaluma and San Rafael on the east and Tomales Bay on the west, the rock is entirely metamorphic or eruptive, with the exception of very limited deposits of unaltered Tertiary along the northern part. The whole region is broken up into ridges, of which the higher ones are generally of metamorphic sandstone, usually very much altered, but not always so. There are also slates and shales in various stages of alteration, sometimes assuming the form of the jaspery rock so characteristic of the summit of Monte Diablo; some mica-slate was also noticed, although it does not oceur in large quantity.

Eruptive rock occur's in various places. About one and a half miles west of San Rafael, at Sugar Loaf Hill, there is a mass of trachyte of a light brownish-gray color, which extends for a short distance east and west. Near Rudesill's Landing a very hard, compact, and fine-grained basalt occurs and is seen in several hills. It forms a belt or dyke, extending about north-northwest, and is well exposed about threefourths of a mile southrvest of Petaluma, where it is about two hundred yards wide. It has here a columnar structure, the columns being very regular, usually six-sided, and about two feet in diameter, although sometimes as much as three. The joints or columms are from one to three feet long, and generally dip to the sonth at an angle of from $60^{\circ}$ to $80^{\circ}$, although occasionally rertical. This rock is quarried for building, for which purpose it is well adapted, breaking equally well in all directions, and rough-dressing easily; of course it is extremely durable. At the quarry the dyke has a direction of N. $65^{\circ} \mathrm{W}$. Eruptive rock was also seen in the high hills on the Olampoli and Santa Margarita Ranches, hut was not exposed so that it conld be well examined. 
Among the varieties of metamorphie rock in this region, silicious and jaspery masses are predominant. In a hill about a mile north of San Rafael, there is an immense outcrop of quartz, approaching flint in appearance; it is mostly of a light-green color, although portions are white, gray, and black. It has a conchoidal fiacture, and a tendency to separate into prismatic and cubical fragments, with which the whole surface of the hill is covered.

'The hills of the peninsula three miles northeast of San Rafidel have been the scene of considerable gold excitement. They are made up of metamorphic sandstone, including reins of quartz, some of which probably do contain a little of the precious metal, but they are not regular enough to pay for working. There are some slates in this vicinity, with a northeasterly dip.

In crossing the peninsula from San Rafael to the head of Tomales Bay, metamorphic rocks were everywhere met with, the only exception being the small outcrop of trachyte before noticed. These rocks seemed to be of Cretaceous age, and at seven miles from San Rafael shales occur, scarcely altered at all, and precisely similar in character to the shales of that age near Monte Diablo. In close proximity to these unaltered strata, and in the same direction, masses of jasper were observed, eridently the restilt of the metamorphism of the shales, and this jaspery rock occurs at intervals along the whole line explored across the peninsula. Metamorphic sandstones also occur in abundance, containing epidote; other forms of altered Cretaceous rocks, which have already been noticed as observed near Monte Diablo, also occur here. Serpentine appears in considerable quantity, and the peculiar silicious rock, which is usually associated with cinnabar, is found about nine miles from San Rafael.

Between Petalunia and the entrance of Tomales Bay, the hills are much lower, quite a well-marked depression extending across the penimsula. The rock exposed on this line is mostly metamorphic, the strata highly altered and much contorted and broken. In various places patches of Tertiary sandstone rest unconformably upon these altered strata. These are best seen at Estero San Antonio, about three miles north of Tomales, where a section two hundred and fifty or three hundred feet thick may be studied. The rocks here are soft, yellow 
sandstones, with large nodules of hard blue calcareous sandstone imbedded in them. These beds are quite fossiliferous, and appear to belong to the Miocene division of the Tertiary.

Patches of these sandstones, in all cases nearly horizontal, occur at various points between 'Tomales and Petaluma, and several of these were seen "near the first-named place, especially two miles west of it, where they form large outcrops. The metamorphic rocks had suffered extensive denudation before the deposition of these Tertiary strata, which have themselves been extensively denuded since their formation, but not otherwise disturbed.

West of Tomales Bay lies a series of ridges having a direction of about $\mathrm{N} .36^{\circ} \mathrm{W}$., and extending from Tomales Point to Baulines Bay, a distance of about twenty-eight and a half miles. The principal ridge is on the western side, and is separated from the ridges east by a nearly straight valley, the northern portion of which, for about fifteen miles, is occupied by Tomales Bay, the remainder by the swamps at the head of the bay and the valley of the Arroyo Olemus Loke, terminating on the south in Baulines Bay, thus forming a well-marked and continuous depression through the entire distance.

The extremity of Tomales Point is entirely of granite, mostly soft and decomposed. About three and a half miles from the Point, at White's Gulch, sandstone occurs, resting on this granite nearly horizontally, or with a slight northeastern dip. On these sandstones rest white, argillaceous slates, in places somewhat silicified, and resembling the bituminous and infusorial strata at Santa Cruz and Monterey. Farther south, near Abbott's Ranch House, the sandstone occur's in large masses, having a low dip to the southwest, from $5^{\circ}$ to $8^{\circ}$, usually. No fossils were found in these; but they appear to be of the same age as the sandstones found at Estero San Antonio, near Tomales. Between the highest points near the head of Tomales Bay and Punta Reyes, there are some minor ridges made up entirely of sandstone, having a low southwest dip; these are probably all Miocene. The granite rises in high ridges near the head of the bay, and in places is accompanied by mica-slate, which latter rock is too much broken for any satisfactory idea to be obtained of its position. Metamorphic limestone also occurs associated with these rocks; it undoubtedly runs through in nearly a 
straight line to Tomales Bay, and has been burned quite extensively for lime at several places. It is too much metamorphosed to show wellmarked lines of stratification, being quite crystalline, and containing thin plates of graphite. It appears to be the continuation of the limestone belt of Santa Cruz and San Andreas, in San Mateo County.

Punta de los Reyes is of granite, rising in a ligh promontory, but it is separated from the ridge of Tomales Point by a deep depression, which is partly occupied by Tertiary sandstones. Granite also occurs at Bodega Head, probably a continuation of the mass of Tomales Point.

Napa Valley extends north from Napa City, about twenty-five miles, to the base of Mount St. Helena. From the village of that name to the head of the valley is about twelve miles, and in this portion it is about a mile wide. It is one of the most beautiful and fertile valleys of the State. High ridges of metamorphic rock enclose it on both sides, and in the central portion, especially near Sebastopol, or Yount's, a number of low isolated hills of the same formation rise from the bottom; otherwise, it is a nearly level tract, with a gently descending slope from its head to the marshy region at the head of San Pablo Bay. The upper part of the valley has many trees, among which are several species of oaks, pine, spruce, madrona, and an occasional redwood. The following are the altitudes, above tide-water, of some of the points in this valley.

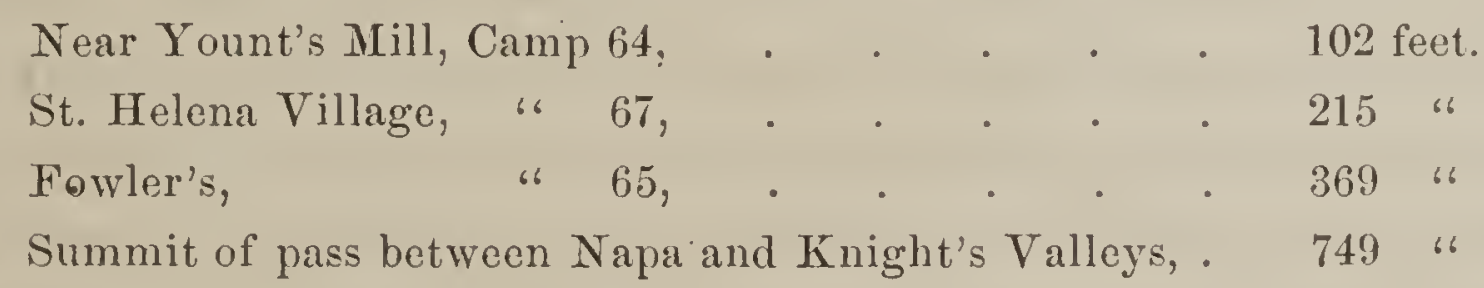

At the head of the valley, the western ridge becomes quite depressed and connects with the St. Helena Mountain by a low divide, from which we descend to the northwest into Knight's Valley, which is drained into Russian River Valley. All through this region the small sidevalleys on the numerous creeks are most charmingly situated, few portions of the State being able to show more attractive and valuable farms and ranches.

A high, sharp ridge on the west of Napa Valley, between Sebastopol and St. Helena, was ascended; our time not permitting us to make 
anything more than a very general examination of this region. This ridge is covered, near its summit, with low chaparral, and is a very conspicuous point in passing up the valley. The rock of which it is chiefly made up is a metamorphic sandstone, having a strike of about N. $50^{\circ} \mathrm{W}$. A few outcrops of serpentine were seen in the hills to the west. The summit commanded a fine view of Napa Valley and the ridges to the east of it, as well as of the broken region to the northwest, between Napa and Russian River Valleys. All this portion to the west seems to be made up of metamorphic sandstones, the volcanic rocks of the eastern side not crossing over to this. The point ascended being without a name was called Mount Henry, in honor of the distinguished secretary of the Smithsonian Institution. Its height was found to be 2398 feet above the sea, and the highest points of the ridge were estimated at 2600 feet. A ridge to the northwest, connected with Mount Henry by a low divide of 1600 to 1800 feet in elevation, was found to be about 150 feet higher than the one ascended. Another ridge to the south-southeast was also somewhat higher, and is conspicuous for a great distance, on account of a few scattered pines upon its summit. These ridges have a general northwest and southeast direction, but there are no continuous and well-defined valleys between them like that of Napa.

Mount St. Helena is the culminating point of the ridges between the Bay of San Francisco and Clear Lake, and is, with the exception of Mount Hamilton, the highest mountain between San Carlos and the high region west of Colusi County, where are many points which have not yet been measured and of which little or nothing is known. The height of Mount St. Helena is given by the Coast Survey at 4343 feet, or about one hundred feet less than that of Mount Hamilton. It was ascended by Wosnessensky, a Russian naturalist, in 1841, and named in honor of the Empress of Russia, and a copper plate, with an inscription, was fastened on the summit, which was afterwards removed by thoughtless or malicious persons, and is now preserved in the Museum of the Geological Survey.* This mountain, from which the volcanic

* Wosnessensky, a naturalist attached to the Zoological Mluseum of St. Petersburg, was sent out to the Pacific by the Academy of Sciences in 1839, and spent ten years in travelling through the countries bordering its northern shores, from California to Kam- 
materials spread over the country to the east and southeast appear to have originated, is a part of the voleanic belt which extends from near Napa through to Clear Lake at least, and how much farther is not yet known. It is a grand object with its steep and rocky sides, although it does not tower above the surrounding ridges to a sufficient height to make it very prominent at a distance. As seen from Napa, it has a flat, table-like summit. Mr. Hoffman ascended to within three hundred feet of the top, and saw nothing but volcanic rocks on the side on which he climbed.

It is not certainly known that this voleanic range extends through uninterruptedly to Clear Lake; but rocks of this class, including trachytes, basaltic lava, obsidian, and pumice, which extend along the southwestern side of Clear Lake, are in a line with the volcanic belt on the east of Napa. The existence of hot springs in the valley, at several points, is connected with this volcanic range. The "Hot Springs" seven miles southeast of the summit of Mount St. Helena, in a sidevalley running out from Napa Valley to the northeast, have quite a reputation for their curative qualities. The waters had a temperature (November, 1861) of from $157^{\circ}$ to $168^{\circ}$, and they issue copiously around the base of a low conical hill of metamorphic sandstone. The "Napa Springs," or the "Sulphur Springs," in a side-cañon two miles southwest of St. Helena, are much resorted to by patients and pleasure-seekers.

Another fact, connected with the volcanic character of the rocks of Mount St. Helena, was testified to by a number of independent and reliable witnesses at different places in this vicinity. This is, that in December, 1859, a tremendous explosion was heard in the mountain, like the discharge of heavy artillery, causing a distinct vibration of the ground like an earthquake, except that the cause seemed to be local and was referred by all to the mountain itself, where the noise seemed to originate and from which in all directions, for many miles, it was distinctly heard. It is not unlikely that it may have been caused by the falling of heavy masses of rock in some of the subterranean cavities which we know to exist in these volcanic regions.

schatka. The plate bears his name and that of a companion ('Tschernich), with the date of their ascent (June 12, 1811), and the word "Russians" twice repeated, once in their native tongue and again in Tatin. It was presented to the survey by Dr. I. A. Veateh, 
A hasty exploration was made of the region to the northwest of Mount St. Helena, as far as the Geysers, and including most of the localities where, in 1861, quicksilver-mines were being opened or prospected for; but our work in the field was put a stop to just as we arrived at the Geysers, by the setting in of the severe winter storms of 1861-2. Afterwards, in 1863, a few days were devoted to an examination of the region around the southern end of Clear Lake, during which we passed up the Napa Valley as far as St. Helena, and then crossed the range and went north by the Locoallomi Ranch and Pope Valley, and returned from the lake by way of Bereyessa Valley to Suscol.

The country to the north of Knight's Valley and McDonald's is a rough and mountainous one, and no map of any portion of it has yet been made. The ridges, as well as the rocks, are very much broken, and the country in general elevated and abounding in picturesque scenes; with its great facility of access from San Francisco and the attractions of the Geysers, it cannot fail to become, in time, a place much resorted to by tourists.

In the vicinity of McDonald's no other rock was seen than metamorphic sandstone, in various stages of alteration; where most changed, it passed into mica-slate and contained large masses of actinolite, like those found near San Pablo. To the north of McDonald's rises the high ridge known as Pine Mountain, having an elevation of from 3200 to 3500 feet. This was crossed in two places, and found to be made up of metamorphic rocks resembling those seen. farther south and known to be of Cretaceous age. Some mica-slate was observed, with much serpentine and large bodies of granular, quartzose metamorphic sandstone. The summit of this ridge is magnificently wooded with pitch pine, sugar pine, Douglas spruce, and, on the northwest slope, the nutmeg tree (Torreya); the sugar pine was only seen on the higher ridges.

A few miles northwest of Pine Mountain rises a still higher ridge, pine-clad on its summit, and known as Mount Cobb; this was not visited, but was estimated at about 3800 feet in height. The ridges which intervene between these are from 2800 to 3000 feet high. This region is made up of highly metamorphic rocks, inchuding serpentine in im- 
mense quantities and other rocks similar in association and in lithological character to the mercury-bearing rocks of New Almaden and New Idria; in fact the resemblance is quite complete, and extends to the associated minerals, a large number of deposits of cinnabar having been discovered here, although none have yet proved sufficiently extensive to be worked continuously with profit.

The locality of these mines and explorations, which were most actively pursued in 1861, is in the serpentine belt noticed above as occurring between Pine Mountain and Mount Cobb, a single claim only (the "Pine Hill") lying south of the crest of Pine Mountain. This quicksilver belt, as it is called, extends in a general northwest and southeast direction, and about 33,000 feet of claims had been taken up on it in 1861. The peculiar quicksilver rock occur's at intervals along this belt, and there is no doubt that the number of points where cinnabar may be found is very great, and it is not at all unlikely that some large deposit of this ore may be struck eventually. The following claims were examined: "Cincinnati," "Dead Broke," "Pittsburg," "Pioneer," and "Denver;" these being the only ones where any work of consequence had been done at the time of our visit.

The "Cincinnati" is on the hill-side near a steep cañon, northeast of Pine Mountain ; from it Mount St. Helena bears S. $32^{\circ}$ E., and the mine was estimated to have an altitude of about 2500 feet. The prevailing rock is serpentine filled with threads and veinlets of quartz, running through it in every direction, presenting rather a peculiar appearance, as some of the quartz is in a crystallized form. Both cinnabar and native mercury have been found here; but there was little appearance of regularity in the deposit, and no large mass of ore had been discovered, although a drift had been r'un in two hundred feet or more "to strike the lead."

The "Dead Broke" lies about a mile west of the Cincinnati. The rock here consists of alternating layers of a dark and light-colored and partly decomposed quartzite; the strike of these is about N. $5^{\circ} \mathrm{W}$.S. $5^{\circ} \mathrm{E}$., and their dip, which is to the west, about $45^{\circ}$. On the east side of the ridge imperfect serpentine was seen, and a level had been driven in it for 265 feet. The cinnabar, of which rich specimens had 
been procured, was contained in a stratum about four inches wide and parallel with the formation.

The "Pittsburg" Claim is one-half a mile N. $15^{\circ} \mathrm{W}$. from the Dead Broke, and some cinnabar has been found here in serpentine; but nothing regular or permanently valuable.

From this last-mentioned claim several ridges were crossed, which were estimated at about 3000 feet above the sea-level, in going towards the Pioneer Claim, which is about four miles from the one last-mentioned, in a northwesterly direction. A great variety of metamorphic rocks were passed over on this line, consisting of sandstones in every stage of metamorphism, and serpentine, with its varieties marmolite and chrysolite, and quartz veins ramifying through it. The serpentine, however, is the predominating rock.

The "Pioneer" Clain is the one on which the most mining had been done at the time of our visit to this region. Work was commenced here in June, 1861. The rock most nearly associated with the ore is the same peculiar silicious variety usually seen at the cinnabar-mines of California, and it is enclosed, on both sides, by serpentine. The strike of the metalliferous lode or vein was nearly northwest and southeast, and the $\operatorname{dip} 46^{\circ}$ to the southwest. The metal exists here both in the form of the sulphuret, as cinnabar, and in the native state; indeed, so far as we know, it is one of the most remarkable localities of native mercury ever discovered. The metal occurs disseminated in fine globules through the veinstone, or in larger quantities in the interior of quartz geodes or "pockets." Over six pounds have been saved from a single pocket, and one of the first cavities broken into yielded four pounds three ounces of the metal, besides what was unavoidably lost in collecting; these facts are stated on the authority of Mr. B. C. Wattles, the superintendent. Large masses of rock, with the mercury exuding from them and standing in drops all over the surface, especially of a fresh fracture, were obtained for the State collection. Considerable bituminous matter occurs here, as in most of the other mercury-mines of the State, and some of the quartz geodes contain bitumen.

A furnace was erected here, in a cañon to the northeast of the mine, and some attempts made to extract the metal from the ore, but these had not been pecuniarily snceessful at the time of our visit, and it is 
believed that the mine is now abandoned, quite a large sum of money, probably not less than $\$ 40,000$, having been expended here.

On the south slope of the same ridge in which the Pioneer Claim is situated, and in a southeast direction from it, is the Denver Claim, which consisted of a drift run in over two hundred feet through serpentine, without a trace of mercury or cimnabar, so far as could be perceiverl. Some interesting specimens of hydromagnesite were obtained here, in fibrous, stellated forms.

For convenience, reference will be made here to the other localities where quicksilver ores have been mined, north of the Bay of San Francisco; although they are not in the immediate vicinity of those which have just been noticed.

One locality of considerable importance is in Pope Valley, three or four miles northeast of Mount St. Helena. The rock here shows all the characteristics of the quicksilver-bearing rock of the other districts where this metal occurs. The same variety of half-formed serpentine, or sandstone in process of metamorphism, of a dark-brown color, of which a large mass occurs a little west of the summit of Monte Diablo, is seen here. There appears to be a considerable quantity of cinnabar disseminated through the rock, but, as in many other localities of this mineral, it is extremely irregular in its mode of occurrence, so that the workings cannot be considered as having been successful (up to the year 1863), as they have failed to develop any large body of ore.

A company called the "Hamilton Quicksilver Mining Company" put up six retorts near this, and smelted the ore, paying a royalty of seven cents for every pound of quicksilver obtained. This conceru had suspended operations in the autumn of 1863, after having produced, as near as could be ascertained, about 17,000 pounds of the metal. The locality of the furnace is on the stage road (as it was in 1863) from St. Helena to Clear Lake; the mine was about a mile to the west of it, and explorations were still making here at that time by Mr. Billings, the proprietor, in the hope of striking a more concentrated body of the ore.

About eighteen miles from Lower Lake, a small settlenent near the southern end of Clear Lake, on the road to Suisun, is a locality where mining for quicksilver was carried on in 1863. This is called the 
"Lake Mine;" and about two miles farther down the valley is another, the "Excelsior Mine." At the Lake Mine the rocks are slightly altered, impure calcareo-argillaceous shales. The ore, which has not yet been proved to exist here in large quantity, is quite distinct from any seen elsewhere in the State, on account of its being associated with the sulphuret of antimony, which occurs in needle-shaped crystals and crystalline-granular masses. It appears to form lenticular bodies in the shales, and was not observed to be associated with the usual silicious rock seen in other localities where cinnabar is found. The rocks in this vicinity have all the appearance of belonging to the Cretaceous series, and immense masses of serpentine occur a little to the north and extend for a long distance in that direction. The Excelsior Mine has been worked to a considerable extent, the ore here being a good deal mixed with iron pyrites; reduction works have been in operation here, and were yielding a little quicksilver in September, 1863; the amount produced was not ascertained, nor are we informed whether the furnaces are still in operation.

The trouble with all the deposits of cinnabar just noticed is, that they are too irregular, and that the ore is not sufficiently concentrated, or in large enough masses. There is no reason why heavy deposits of valuable ore should not be met with, in sinking upon the outcrops in which small quantities of it are exhibited; but it is far from being a matter of certainty; and, as the result of actual experience, it may be stated, that in the only instance where a deposit of ore has been discovered sufficiently large to pay for continuous working, there was a correspondingly large display at the surface; this was at the New Almaden Mine, which was undoubtedly known to the natives for a long time previous to the arrival of the whites on these shores.

Very peculiar and interesting specimens of cinnabar were shown us at Clear Lake, the locality of which we were unable to visit. These consisted of rounded and water-worn masses of pure cinnabar, with specks of native gold enclosed in them, which were said to have come from near Sulphur Springs, four miles south of Bear Valley, on the trail from Clear Lake to Colusi. Considerable quantities of this remarkable combination of ore and metal are said to have been washed out from the bed of a creek in the cañon at that place. 
The hot springs, known as the Geysers, are situated about half way between IIealdsburg and the southern end of Clear Jake, and are approached by a road from Ray's Ranch, or by a trail from MeDonald's, the route being in either case extremely picturesque, the excursion from San Francisco to the Geysers forming one of the pleasantest and most attractive ones that can be made from the city with small expenditure of time. We visited the locality in question from the Pioneer Mine, and, the winter rains having already set in, were only able to make a hasty examination of the place and no topographical survey, so that our notice of it can only be of the briefest kind.

On our way to the Geysers we passed along the high ridge that connects Sulphur Peak, or Geyser Peak as it is also called, with Pine Mountain. It is probably about 3000 feet high and commands a most extensive view both to the north and the south. The rocks are all metamorphic Cretaceous, with very heavy beds of serpentine, similar to the other ridges in this region. Sulphur Peak is one of the stations of the primary triangulation of the Coast Survey, and is given in their report as 3471 feet high; it is said to be the finest point of view in this part of the State, commanding a large part of the Russian River Valley, and of the wild mountainous region to the northwest between the Geyser's and Clear Lake.

There are two localities of hot springs in this vicinity, one known as the Geysers, the other as the Little Geysers, although it must be allowed that there is no real analogy between the California Geysers and those in Iceland, where the name originated. The principal locality is in a side-gorge, known as the Geyser Cañon, opening into the cañon of Pluton River, itself a tributary of Russian River. Its elevation was not measured by us, but it is said to be 1700 feet above the sea-level. Along this cañon for a distance of about a quarter of a mile, and over an area of several acres, numerous springs and steam jets occur, the water having a temperature of from $200^{\circ}$ to $207^{\circ}$ in the various openings into which the thermometer could be inserted. In many localities there is no water running, but jets of steam issue, which appear to have been under high pressure; from one hole about two feet in dianeter, it escapes with a loud noise, like that from the escape-pipe of a high-pressure steamboat, and it is hence called the Steamboat Geyser. 
Both the water and the steam are highly charged with sulphuretted hydrogen and sulphurous acid, and the waters hold in solution a great variety of salts, especially sulphates of iron, lime, and magnesia; these salts, as well as crystallized sulphur, are deposited over the rocks in the cañon, giving them a peculiar and vivid coloration, which is perhaps the most striking feature of the place. Quite extensive deposits of sulphur occur farther down the cañon and are known as the "Sulphur Banks."

The surrounding rocks are entirely metamorphic sandstones, and silicious slates of the Cretaceous series, and these are constantly undergoing a variety of chemical changes caused by the action of the hot water and steam. The iron held in solution by some of the springs comes in contact with water holding sulphuretted hydrogen and an inkblack precipitate of sulphuret of iron takes place, which fills one reservoir in the rocks known as the Witches' Cauldron, and boils and seethes with a most unearthly smell and appearance. The rock, in some places, appears as if so thoroughly leached by the hot water that only the silica remains behind as a sort of skeleton, while large deposits are formed of silicious matter, resembling putty in appearance and consistency. These changes have the appearance of taking place quite rapidly, and we were informed by Mr. McDonald that the ground has slacked away and sunk several feet (twenty-five or thirty, he thought) around the largest spring within the past ten years. All the deposits around the springs are charged with acid salts and free sulphuric acid, and a visit to the place is, as may be supposed, ruinous to boot and shoe leather.

The most exaggerated accounts have been published of this cañon and its springs; but the reality is sufticiently interesting to well repay a visit, especially from those to whom phenomena of this kind are new. It is said-that the quantity of water and steam is increased, and the general effect of the scene much enhanced, by the saturation of the ground with water from the winter rains; and, as we saw it at the end of the dry season, we were probably there just at the time when the plienomena were least striking. Certainly there were no jets of water rising high in the air, as has been asserted, and nothing like the quantity of water delivered which issues at the Steamboat Springs near Washoe Lake, in Nevada. 
The "Little Geysers" are in character like the larger ones, except that, instead of issuing along the bottom of a cañon, they occur scattered over a gently sloping side-hill. They are about four niles farther up the Pluton Cañon, at an estimated height of 2100 to 2200 feet above the sea, and near the furnace of the Pioneer Mine. All of the effects seen at the larger springs may be observed at the Little Geysers. A great variety of metamorphic sandstones occur here, in all stages of decomposition and chemical change; of these rocks a careful examination should be made.

There will be no difficulty in understanding the origin of these phenomena when we consider that they are displayed along a line of former volcanic activity, and where even now the igneous forces are not entirely dormant. A belt of eruptive rock, of which Mount St. Helena is the culminating point, extends through on the west side of Clear Lake down to Suisun Bay, and a line of more recent volcanic action may be traced from near the Geysers to Clear Lake, and thence transversely across the Coast Ranges to the Sacramento Valley, along which great accumulations of pumice, scoriæ, and obsidian, or volcanic slag, may be found, as well as numerous hot springs like those at the Geysers, only on a smaller scale. The dependence of the Geysers for their activity, in part, on the recurrence of the rainy season, as is stated on good authority, indicates clearly that the water, percolating down through the fissures in the rocks, meets with a mass of subterranean lava not yet entirely cooled off, and becoming intensely heated, under pressure, finds its way to the surface again along a line of tissure connecting with the bottom of Geyser Cañon; in this heated condition it has a powerful action on the rocks and the metallic sulphurets which they contain, especially on the sulphuret of iron everywhere so abundantly diffused through the formation, and so dissolves them and brings them up to the surface, to be again partly redeposited as the solution is cooled down by contact with the air. Phenomena of the same kind as those observed at the Geysers, and sometimes even on a larger scale, are exhibited all throughout the now almost extinct voleanic regions of California and Nevada; eren on Mount Shasta the last expiring efforts of this once mighty volcano may be traced in the solfatara action still going on near the summit, and which is mondoubtedly dne to the 
melting snow finding its way down to the heated lava or other voleanic materials below, in the interior of what was once the crater, from and around which a mass of erupted matter has been poured forth and piled up to the height of several thousand feet.

In spite of the heated and acid character of the ground in the immediate vicinity of the hot springs at the Geysers, a species of grass grows there, and the same has been noticed elsewhere in similar localities. It has been described by Mr. Bolander as the Panicum thermale. Several low forms of vegetation grow in the hot water and on the surfaces ex-. posed to the hot steam. One species, of a vivid green color, a sort of conferva, was found on surfaces exposed alternately to the intensely hot steam and the cold air, as the former was blown away by the wind. It was seen in the water at the temperature of $200^{\circ}$, and abundantly where it was exposed constantly to a temperature of $190^{\circ}$ to $195^{\circ}$, and several low forms of algre, as well as the former species, were abundant in the acid waters of the stream, where the temperature ranged from $120^{\circ}$ to $180^{\circ}$, although thriving best at from $125^{\circ}$ to $130^{\circ}$. A farther notice of these plants will be found in the Botanical Report of Professor Brewer.

Some explorations have been made around the lower end of Clear Lake, more particularly for the purpose of getting an idea of the very interesting locality of borax, which is found in this region.

Clear Lake is about sixty-five miles northwest of Suisun Bay, and about thirty-six miles from the Pacific. It is believed to be about twenty-five miles long, but has never been surveyed, so that its shape and size are not accurately known. It lies so that its greatest longitudinal extension is nearly parallel with the strike of the strata in this region, or northwest and southeast; the lower half, in length, is comparatively narrow, being not over two miles wide for a distance of eight miles from its southeast end. Beyond this, it expands out into a broad, almost circular area, surrounded on all sides by high hills, which on the northeastern side come close down to the water; on the west and northwest there is a plateau of rolling land between the lake and the mountains, which, although dry, has a pretty good soil, and where there is a small settlement.

At the angle where the narrow part of the lake opens out to the west 
is a high mountain, which comes down with a precipitous front to the water, and which is supposed to be about 2500 fect above the lakelevel. It is called the "Uncle Sam Mountain," and, as seen from the opposite side of the lake, it appears to be made up of a closely folded synclinal mass, probably of somewhat metamorphic Cretaceous sandstones. On the southwest side, and to the southeast, rolcanic materials and rocks occupy the surface, as is well seen in a crater-like depression on the southwest side of the narrow arm of the lake, called "Thurston's Lake," which is partly covered by water, and surrounded on all sides by high cliffs of volcanic rocks, appearing as if it might have been one of the vents from which the eruptive matter, obsidian, ashes and pumice, so abundant in this region, were ejected. On the eastern side of the narrow arm of Clear Lake, nearly opposite to, and about four miles distant from, Thurston's Lake, is a large accumulation of volcarlic materials, with much obsidian and pumice. In fact, all through the chain of the Coast Ranges in this direction, down Grizzly Cañon to Bear Valley, on the trail to Colusi, there are hot springs and the remains of solfatara action, indicating strongly a cross-fracture in this region, through which the volcanic agencies have made themselves perceptible, and which probably comnects on the southwest with the Geysers, thus forming a line of rolcanic action nearly if not quite across the chain.

Among the evidences of the former working of volcanic forces in this region, there is nothing more interesting and remarkable than the so-called "Borax Lake" and its vicinity. This lake occupies a depression on the east side of the narrow arm of Clear Lake, from which it is separated by a low ridge of volcanic materials, lying loosely heaped together, and consisting of scorix, obsidian, and pumice. The Borax Lake is of variable dimensions, according to the scason of the year and the comparative dryness of the scason. When examined (September, 1863), the water occupied an area about 4000 fect long, and 1800 feet wide in the widest place, and its shape was irregularly oval, its longer axis being turned in the direction of east and west, magnetic; it has once extended nearly twice as far to the southeast, as the ground is hardly raised above its present level in that direction for nearly a mile. The lake is said to have been entirely dry during the summer before 
the great rains of 1861-62. In 1863 the water was about three feet deep.

The existence of this lake was first made known to the world by Dr. J. A. Veatch, who examined it in September, 1856, and detected the presence of borax in its waters; but it was not until some months afterwards that the existence of a large bed of crystals of this valuable material in the bottom of the lake was discovered. The land about here has been located by the "California Borax Company," the agents of which have caused explorations to be made, have had the waters carefully analyzed, and were, in 1864, preparing to manufacture borax on a large scale.

The water collected from the Borax Lake, in September, 1863, as analyzed by G. E. Moore, contained 2401.56 grains of solid matter to the gallon, of which about one-half was common salt, one-quarter carbonate of soda, and the remainder chiefly borate of soda, there being 281.48 grains of the anhydrous biborate, equal to 535.08 of crystallized borax, to the gallon. Traces of iodides and bromides were also detected. A sample of water taken from the interior of a coffer-dam sunk in the middle of the lake, and which had been allowed to fill by percolation from the bottom upwards, was found to be more concentrated, yielding 3573.46 grains of solid matter to the gallon; but it contained nearly the same ingredients, and in the same proportions, as the water of the lake itself. The bonax, being the least soluble substance contained in any notable quantity in the water, has in process of time crystallized out to a considerable extent, and now exists in the bottom of the lake in the form of distinct crystals, which are of all sizes, from microscopic dimensions up to two or three inches across. These crystals form a layer inmediately under the water, intermixed with blue mud, of varying thickness; as observed in the coffer-dam sunk in 1863, the layer of crystals was about eighteen inches thick, and beneath it was mud without crystals. The thickness, however, of the deposit is undoubtedly very variable, and there are, in places, several layers of them separated by beds of clay or mud. It is believed, by those who have examined the bottom of the lake, that several million pounds of borax may be obtained from it by means of movable coffer-dams, at a moderate expense, and so as to yield a handsome profit to those en- 
gaged in the enterprise. Tow much of a supply of water could be oltained by boring, and what its quality would be, can hardly be settled in any other way than by actual experiment.

Lying about a mile beyond the ridge which borders the Borax Lake on the northeast, and at the foot of a shorter arm of Clear Lake which extends off to the southeast parallel with the longer one, is an interesting locality where solfatara action is still going on, and where a large amount of sulphur has accumulated. This is called the "Sulphur Banks." It consists of a much decomposed volcanic rock, fissured in innumerable places, through which fissures steam and gas are constantly issuing, and all over and through which large quantities of sulphur have been deposited, so as to give the mass, from a little distance, the appearance of being entirely composed of this material. Into some of the cavities a pole may be inserted for several feet, and they are often lined with fine crystallizations and stalactites of sulphur. No doubt a large quantity of this material could be obtained here, and the time will probably come when it will be made available. It is the largest deposit which we have seen in the State, covering several acres of ground; but to ascertain its value and determine the quantity of pure sulphur it contains, it would have to be dug into at various points.

Near the sulphur bank just at the edge of the lake is a hot spring, of which the outlet is, even at low water, partly beneath the lake, so that the amount which flows from it camnot be ascertained without some expenditure to keep out the surrounding water. The flow of this spring seems to be quite variable at different seasons, and probably the amount of materials it holds in solution is far from constant. Dr. Veatch found the area over which hot water was percolating through the sand to be 150 by 75 feet in dimensions; at the time of our visit it was much less; nor was the estimated yield anything like as great as he made it, namely, three hundred gallons per minute.

The water of this spring, as analyzed by Mr. Moore, is found to be of a remarkable character; his analysis is subjoined:

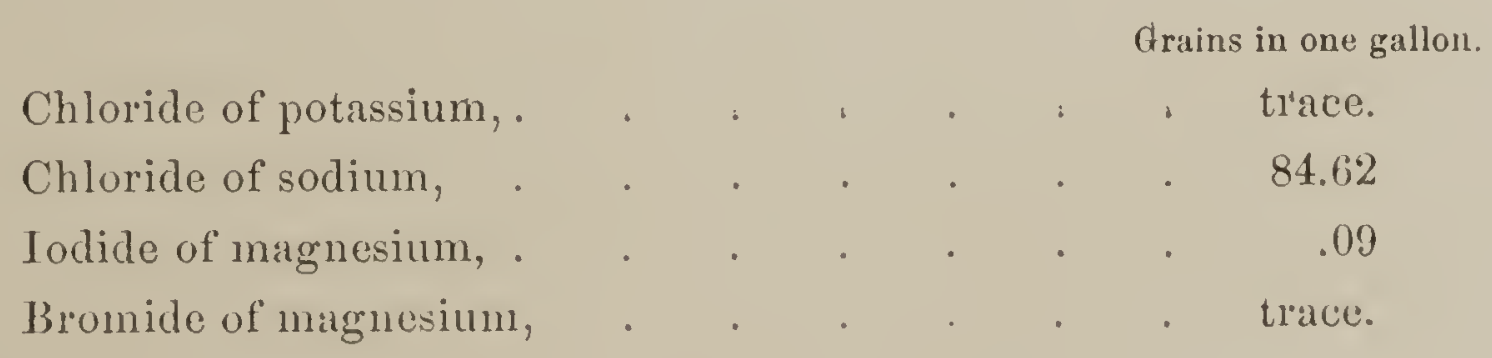




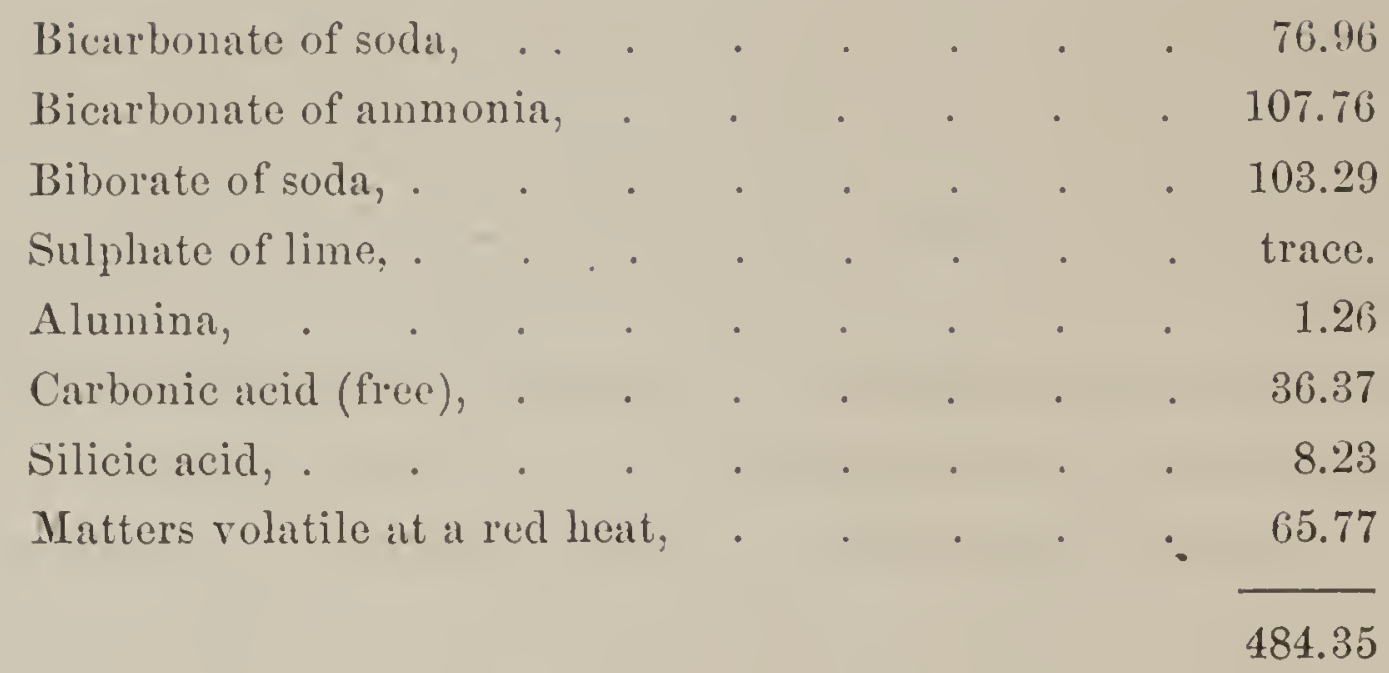

In this table the constituents are necessarily calculated as anhydrous salts; the biborate of soda, however, contains about 47 per cent. of water when crystallized, and the 103.29 grains given above correspond to $\mathbf{1 9 5 . 3 5}$ of crystallized borax. The most extraordinary feature in the above analysis is the very large amount of ammoniacal salts shown to be present in this water, in this respect exceeding any natural springwater which has ever been analyzed. Mr. Moore thinks that, as in the case of the boracic acid waters of Tuscany, this ammoniacal salt may be separated and made available for economical purposes. This locality is worthy of a most careful examination to ascertain how considerable a flow of water can be depended on.

The rocks in the vicinity of Clear Lake, when not of volcanic origin, belong to the Cretaceous system, and are the continuation of a great belt of strata of this age, which commences at Benicia and stretches off to the northwest for an indefinite distance, apparently coming out to the ocean in the neighborhood of Cape Mendocino. Having followed up Napa Valley, by Mount St. Helena, to the Geysers and Clear Lake, giving what information we possess in regard to the western portion of the Coast Ranges north of the Bay of San Francisco, it remains to add some observations on the eastern side of the region in question.

A system of ridges begins at Benicia and stretches northwest along the eastern side of Napa Valley, but the chain is not known by any general name. Mount St. Helena belongs to this range and is its culminating point south of Clear Lake. These mountains are a continuation of the Monte Diablo Range, and the mass of them is probably of Cretaceous age; but volcanic rocks are also extensively developed 
here, both in the form of solid lava and of sedimentary materials, or such as have been thrown out in the form of ashes, pumice, and the like, and, having fallen into water, have assumed in their deposition a stratified appearance.

The termination of this range at Benicia is of unaltered Cretaceous strata, much broken, and forming rounded hills, destitute of trees. Here, as in Contra Costa County, the Cretaceous is well represented, both by the bluish clay shales, with interstratified beds of argillaceous limestone, and by the overlying masses of blue and yellow sandstones, the latter in very heavy beds. The shales are seen everywhere along the shore and in the deeply eroded valleys. As usual, this member of the series is very poorly supplied with fossils, but a few characteristic forms were discovered by Mr. Rémond near the arsenal; among then Ammonites Batesii, that common and characteristic species of the older beds of the Cretaceous.

On rising into the hills back of Benicia the sandstones are met with, the outcropping of the strata being plainly indicated by the lines of weather-worn blocks extending over the rounded ridges. The strike is very irregular, as if the formation had been extensively faulted; it varies from $\mathrm{N}$. $15^{\circ} \mathrm{W}$. to $\mathrm{N}$. $60^{\circ} \mathrm{W}$, and the dip is usually to the southwest. Intermediate between these two sets of strata, the sandstones and shales, are beds of passage, consisting of interstratified layers of both kinds of rock, and it appears to be in this position that the beds of hydraulic limestone occur, which have been so extensively worked near Benicia.

Although fossils are so infrequent through the whole series of Cretaceous beds of this region, in comparison with the widespread areal which the formation covers, yet the sandstones are much better supplied with these than the underlaying shales. Mr. Remond discovered a locality, about half a mile north-northeast of Benicia, where a bed of conglomerate occurred, several feet thick, and filled with fragments of shells, among which Trigonia Evansï was the most abundant; this is a very characteristic and widely distributed fossil in the Lower Cretaceous of the Pacific coast, ranging from Central California to Vancouver's Island. This Trigonia stratum was traced from Benicia to Suisun Bay, 
and was afterwards found on the opposite side of the Straits of Carquines, at Bull's Head Point.

Nearly the whole of the peninsula on which Benicia is situated, for some twelve miles towards the interior, is made up of these quite unaltered Cretaceous rocks, forming low, rounded hills which are quite bare of trees. There are, however, two belts of metamorphic rock extending through this region, one of them forming low hills on its eastern edge, the other and principal one beginning about three miles north of Benicia, and extending in a direction of $\mathrm{N} .53^{\circ} \mathrm{W}$. This latter belt widens to the northwest and disappears at the edge of the hills, in that direction, which is that of a high metamorphic ridge west of Carnero Creek. The rock is very tine-grained and durable, and forms sharp ridges when denuded.

The unaltered Cretaceous strata in the vicinity of Benicia and Vallejo, and on the west side of the metamorphic belt just noticed, have a strike of $\mathrm{N} .55^{\circ}$ to $58^{\circ} \mathrm{W}$, and dip to the southwest at an angle of from $30^{\circ}$ to $60^{\circ}$. On the east side of the metamorphic the rocks are tilted up at a higher angle, and have an inclination to the northwest and a more northerly direction.

A Post-Tertiary deposit, made up of beds of gravel, sand, clay, and oyster-shells, rests horizontally upon the upturned edges of the Cretaceous at several localities around Benicia. These are similar to the beds noticed as occurring on the shore between Martiñez and Bull's Head Point, which contain fragments of bones of large animals and rolled Tertiary shells. Similar beds, with oysters, were observed on San Pablo Bay between Point Pinole and the Embarcadero; at this locality the beds containing oysters, which rest horizontally on upturned strata of the Tertiary, are elevated twenty feet above the level of the water in the bay. At Benicia also there has been an elevation of several feet since these oyster-beds were deposited. With the shells of oysters, those of other species, all now living in the waters of the bay, are found. These deposits evidently belong to the Post-Pliocene, and they are of the same age as the beds of gravel with boulders of gray. sandstone, containing the bones of the mastodon and horse, which occur at Bottle Hill near Benicia. Tertiary sandstones also exhibit themselves in very limited exposures near Suscol. 
At abont twelve miles north of Benicia, the older rocks become covered with voleanic materials, which are mostly stratified, and which appear to rest conformably on the Cretaceous. Between the voleanic and the Cretaceous there is, in some places at least, and perhaps all through this region, a deposit of Tertiary rocks exclusively of sedimentary origin, as is distinctly seen at Suscol, but the exact range and extent of these various formations, and how far the Cretaceous has been elevated and denuded before the deposition of the newer groups, remains to be investigated. It is probable that the most extensive disturbances of the Cretaceous, as also the larger portion of the metamorphic action upon it, had taken place before the Tertiary marine and volcanic beds were deposited.

In the range of hills to the left of the road from Benicia to Suisun, a few miles north of the former place, the volcanic beds are darkcolored and have a texture varying from compact to cellular. They dip, near the road, at an angle of about $40^{\circ}$ to the southwest; but are, in general, irregularly disturbed, and the adjacent Cretaceous beds are broken and bent, the two formations being so intermixed that it is not easy to trace out their boundaries. These rocks closely resemble the altered volcanic rocks seen near Kirker's Pass, in Contra Costa County.

In the vicinity of Rockville, the same formation oceurs; but here consists of heavy beds of stratified voleanic ashes, which have a nearly horizontal position. Their color is white or light-yellowish, and they often are brecciated in structure, and have many fragments of pumice and darker-colored trachytic material scattered through their mass.

The unaltered Cretaceous rocks extend from Benicia, on the west of this volcanic range, to a point three miles southwest of Rockville, where they are seen cropping out at the base of Elkhorn Peak. Beyond this, to the northwest, all along between this peak and the 'Twin Sisters, and comnecting still farther in that direction with the range of Mount St. Helena, the volcanic beds form the mass of the hills. The region occupied by these eruptive rocks is very broken and rugged, and the ridges rise higher as we go northwest. A great variety of roleanie materials may be observed here, and especially of those which have been ejected moder water, or which have fallen into water and have 
thus been made to assume a stratified form. Not only has the true character of these materials been thus masked by their deposition from water, but they have undergone still farther changes by the metamorphic action of hot water, steam, and gases on them since their formation; and the result has been a most complicated series of rocks, which offer every possible variety of texture and color, and require a most careful investigation of their chemical composition before they can well be classified or named. These strata appear also to have undergone mechanical disturbances since their deposition, their inclination being usually to the west. They may be well studied around the head of Green Valley.

North of Suisun commences another series of hills, which has received the name of the "Pelevo Hills," at their southeastern end, but which extend northwest and become merged in the chain known as the "Vacca Mountains," which is the name given to the ridges here bounding the Sacramento Valley on the western side.

The Pelevo Hills form a kind of spur or side-range, extending southeast from the main ridge of the Vacca Mountains; they are destitute of trees and shrubs. These hills are made up of Cretaceous strata, unaltered and containing but few fossils; the strike of the beds is generally about northwest and southeast, and the dip to the northeast and variable in amount.

The well-known "Suisun marble" occurs in these sandstones, and is evidently a deposit from calcareous springs. It is of a deep brownish-yellow color, with a banded structure, and is a very elegant ornamental stone, which would be much sought for if it could be obtained in masses of any considerable size, which does not seem to be possible; it has also been burned for lime to some extent. A short distance from the quarry springs occur, which hold much lime in solution, and are now forming an extensive deposit of tufa; these springs have evidently been at a former time much more copiotis than they now are.

From the Twin Sisters the voleanic range extends northward for many miles, bending a little to the west; it forms a thick mass of hardcned ashes, dark-colored scorix, and peculiar feldspathic rocks, interstratified with beds of basaltic lava, all having a slight dip to the west. 
These various beds are finely exposed on the west side of Wooden Valley.

The Cretaceous formation, which is seen cropping out near the northeastern base of the Twin Sisters, is continuous from that place as far north as Capel Valley, at which point it becomes metamorphic and broken. The hills lying between the Sacramento and Suisun Valleys are also Cretaceous, and they appear to form a line of foot-hills along a high Cretaceous ridge, made up of unaltered shales and sandstones, running nearly northwest and southeast, and extending from Suisun Bay to Puta Creek. This range is about 3500 feet high, and the ridge along the summit is formed by heavy-bedded sandstones; it is quite a remarkable feature in this part of the Coast Ranges, that so high and extensive a ridge should be made up of unaltered rocks. The road leading from Suisun Bay to Puta Creek, through Gordon Valley and Rag Cañon, skirts this ridge on the western side. The dip of this mass of strata is to the northeast, and the strike, which is $\mathrm{N} .35^{\circ} \mathrm{W}$. to the east of Gordon Valley, gradually becomes more northerly as we approach Puta Creek, where it is about N. $50^{\circ}$ E.; the dip varies from $35^{\circ}$ to $80^{\circ}$.

Near the head of Wooden Valley, there is a mass of serpentine, some two or three miles in length, which appears to occupy the summit of an anticlinal axis, as the strata dip to the west, on the other side of Suisun Creek. The rocks around Capel.Valley are also considerably metamorphosed, and contain some beds of conglomerate.

Puta Creek cuts its way through the great Cretaceous ridge noticed above, nearly at right-angles with the strike of the beds, thus presenting a fine section of the strata from Rag Cañon as far as the northern end of Pleasant Valley. In following this section from the west, several hundred feet in thickness of clay-shales and slaty sandstones are crossed, with thin layers of calcareous and ferruginous sandstones, but the usual argillaceous limestones are comparatively rare. These strata have been twisted and faulted, but not chemically changed. Beyond this, we meet an enormous thickness of sandstones, the strata standing nearly vertical, and forming on each side of the creek grand and almost perpendicular cliffs, which rise to the height of from 1200 to 1500 feet. Here and there occurs a thin layer of conglomerate, made GEOT. VOL. I. -14 
up of rounded pieces of the argillaceous limestone found in the lower member of the series, with small pebbles of jaspery rock, mixed with a few broken shells, the whole cemented by sand and clay. Generally through this region the Cretaceous rocks are almost destitute of fossils.

At the head of Pleasant Valley, the strata are overlaid by beds of volcanic ashes, interstratified with gravels, the whole series being conformable and dipping at a low angle to the east. They appear to be of Pliocene age, and identical in most respects with the sedimentary-volcanic beds to the north of Kirker's Pass. A dyke of fine-grained, compact, black, basaltic lava cuts through these beds; from this enormous blocks have rolled down into the bed of the creek. This same dyke is seen crowning a hill, about 1500 feet high, a little eașt of Thurber's Ranch in Pleasant Valley (Camp 85). It follows a zigzag course, the general direction of which is about N. $15^{\circ} \mathrm{E}$. It is fractured in every direction and gradually weathers into angular fragments. This dyke cuts through the Cretaceous strata without changing their dip, and producing but slight alteration of the adjacent rock along the line of contact. The magnetic needle is very irregularly and extensively affected by this rock. Just below the summit of this hill, and a little to the north of it, is a bed of gravel, twenty-five feet thick, chiefly made up of pebbles of basalt, porphyry, and jasper; those of the basalt are from the size of a nut to that of the fist, the others very small; this deposit has been formed since the eruption of the basaltic dyke, and is quite anomalous in character and position,

It is an important question, whether the unaltered. Cretaceous strata, which, as we have seen above, extend along the east edge of the Coast Ranges from Benicia northwards for a considerable distance, contain workable beds of coal, Deposits of coaly matter, fragments of plants, and masses of lignite were observed by us; but no regular and welldeveloped beds of coal, like those at Monte Diablo. The following section, taken on Suisun Bay, a little north of the arsenal, by Mr. Rémond, will show how these imperfect coal-beds are connected with the formation:

Shales,

6 inches.

Sandstone, .

Thin-bedded argillaceous sandstone, .

2 feet 6 "

11 "6 
Hard calcareous sandstone, .

3 feet.

Shales,

Thin-bedded sandstone with fragments of plants,

6 inches.

Light yellow sandstone,

8 "

Shaly parting,

1 foot.

1 inch.

Thin-bedded sandstones witl plants, .

Soft sandstones, .

10 ․

Clay shales,

Lignite,

36

Sandstones and shales, thickness not determined.

This is a specimen of many sections observed, where thin beds of lignite and strata containing remains of plants were intercalated witl the shales and sandstones of the Cretaceous series. A good deal of exploration for coal has taken place along this range; but, from all that can be learned, it would appear that the rocks are too much broken up, where such deposits have hitherto been found, to admit of their being successfully and continuously worked. The region has not, however, been explored with sufficient detail by the Survey, to enable us to decide positively that valuable beds of coal may not yet be found here. The absence of any map of this region renders it impossible to work out the details of its geology.

The ridges lying between Petaluma and Sonoma, and between Sonoma and Napa, are made up of metamorphic rocks, with some unaltered strata, and also large quantities of materials of volcanic origin.

Between Petaluma and Sonoma, the mass of the ridge is of highly metamorphic strata, which are supposed to be of Cretaceous age. Sandstones occur along the western base, near Lakeville, very highly inclined, and destitute of fossils, so far as observed. These are altered in some places and form a ridge to the west of the higher metamorphic, from which they are separated by a valley in which is a small "laguna."

The higher metamorphic ridge is composed of rock of a great variety of different characters. Columnar basalt occurs in a spur about five miles northwest of Sonoma. The eastern slope of these ridges is covered by volcanic-sedimentary materials.

About eight miles due north of Petaluma, coal occurs in a ridge, at the base of which there is much very hard and probably volcanic rock; 
above this are shales, not at all metamorphosed, in which is the coal. These shales are very light, when dry, and resemble those seen near the coal, at the Clark Mine near Monte Diablo, and also near Marsh's; they appear to be of Cretaceous age. The strata have a direction a little to the east of north, and dip to the east from $40^{\circ}$ to $50^{\circ}$, showing indications of irregular disturbances since their deposition.

The Valley of Petaluma extends through to the Russian River, being separated from that of the Santa Rosa Creek by hills so low that the divide can hardly be recognized. This valley is in the direct line with the Tertiary strata of the Contra Costa Hills, and is probably an excavation in that belt, with metamorphic Cretaceous and eruptive rocks on both sides.

What little remains to be said with regard to the continuation of the Tertiary and Cretaceous formations over the vast area of the Coast Ranges, to the north of the point at which our explorations have ceased, will be added in another part of this volume.

\section{CHAPTER V.}

THE COAST RANGES SOUTH OF THE BAY OF NONTEREY.

\section{Section I.-Introductory Remarks.}

Having given, in the preceding chapters, an outline of the geology of the region adjacent to the Bay of San Francisco, which portion of the State was taken up first, for reasons which have been already stated, we pass on to the consideration of another extensive area embraced within the Coast Ranges, namely, that which lies north of Santa Barbara Channel and the Santa Monica Range, and extends to the southern end of Monterey Bay.

This portion of the Coast Ranges embraces an extensive territory, about 250 miles long and from 40 to 50 broad, including between 10,000 and 12,000 square miles, an area considerably greater than that of the State of Vermont. The whole of this region is of a mountainous cha- 
racter, the valleys not being of sufficient dimensions to be considered as anything else than subordinate to the mountains, as they always appear very narrow when compared with the extent of the elevated regions on each side of them. The only possible exception to this is perhaps the Salinas Valley, which at its lower end, for a distance of about twenty-five miles from the mouth of the river, has an average brearth of from six to eight miles. West of the Salinas and a line drawn to the southeast in continuation of its direction, there are no valleys which are wide enough to be represented on any map drawn on the small scale of those commonly in use as State maps of California.

Of the whole of this extensive area we know but little more than the general features of the geography, and of course are equally deficient in the details of its geology. A map of the region in question has been commenced by Mr. Hoffmann, on a scale of six miles to the inch, partly to bring together all that was known of its geography, and partly that we might lay down our own work upon it, which makes some approach to completeness in the northwestern corner, around the Bay of Monterey; but elsewhere is only in detached fragments. To complete this map, so as to show the main features of the topography on the scale adopted, would require at least two years' work; but the results would certainly prove a valuable contribution to the geography and geology of the State.

The inaccuracy and incompleteness of our maps prevent us from giving any complete view of the systems of mountain-ranges existing within the area we now propose to take up. Some generalizations, however, may be permitted, before entering into details, as they are based on facts observed, and will be useful as preliminary to what follows.

It may first, however, be stated, that our explorations in the portion of the Coast Ranges which lies between Santa Barbara and the Bay of Monterey, were made chiefly during the early spring of 1861, and that they were necessarily of a very superficial character, although it may be fairly claimed that the most was done which could be, with the limited amount of time and means at our command. The party left Los Angeles, on their route northward, on the 11th of February, 1861, 
and reached Monterey Bay on the 15th of May; about a fortnight was afterwards spent in that vicinity, and this was all the time which we have been able to give to this extensive region. During the larger part of this exploration the party was in charge of Professor Brewer, from whose notes the details incorporated in the following section have been chiefly drawn.

The first thing which strikes the geologist, in examining the maps of the region in question, is the presence of at least two lines or systems of upheaval, which have made themselves very manifest in the topography; one is the northwest and southeast system, with which we have already become acquainted in the Monte Diablo Range, and have noticed as predominating all around the Bay of San Francisco; the other is an east and west system, which, if it exists at all in the districts described in the preceding chapters, has but a very subordinate importance.

The region of northwest and southeast trends, in this part of the Coast Ranges now under examination, is especially that which lies north of San Luis Obispo, and a glance at the map wili show that here the main features of the topography are strictly and almost exclusively dependent on this system of upheavals. The Salinas River, by far the largest in this portion of the State, has a northwest course, and the ranges of mountains, on either hand, are parallel with it in their general direction.

The east and west system is indicated at once by the trend, in that direction, of the coast of Santa Barbara Channel, and of the shore to the east of Point Duma. This east and west coast line is the expression of a great fact in the geology of the country, which makes itself perceptible in the topography far into the interior. The main mountain-ranges which have been upraised by this system are the Santa Monica, the Santa Susanna, and the Santa Iñez, and the trend of the line of islands on the south side of the Santa Barbara Channel is strictly in accordance with that of the above-named mountain-chains.

Between the region of east and west, and that of northwest and southeast, trends is a wide area, where the effects of both these systems are clearly perceptible, the broken and disjointed ranges, with a very complicated topography, giving evidence of the interference of two lines of 
upheaval; while it is probable, from geological considerations, as will be seen in a future chapter, that one of these systems is, in fact, to be divided into two, chronologically, although the direction of two is very nearly, if not quite, coincident. Of the geological age of these systems of uphearal, it will be more convenient to speak in another part of this Report; an indication of the names and positions of the different ranges included within the area of their influence is all that will be required, as preliminary to such a sketch of the geological structure of the region as it is in our power to give.

The main east and west ranges of this district have names of universal recognition; they are the Sierra Santa Iñez, which rises close to the shore of Santa Barbara Channel, the Sierra Santa Monica, which extends from the Cahuenga Pass west to the coast at Point Mogu, and the Sierra Santa Susanna, which lies north of the San Fernando Valley and the Semi Pass and River.

The main northwest and southeast chains are less unmistakably designated. The name Sicrra Santa Lucia is that which is best known and most frequently applied to what may be called, with more propricty than any other, the dominating range of this region. It extends in an almost unbroken series of high mountain-crests from northeast of San Luis Obispo to Carmelo Bay, a distance of nearly a hundred miles. From the Piedras Blancas to Point Sur it meets the Pacific with so steep and rough a descent, that no trail, even, has erer been carried through along its base; and its lofty and precipitous heights, covered with chaparral and haunted by wild beasts, are as little traversed as any portion of the State of equal area. The southeastern continuation of the Santa Lucia chain is less distinctly marked; it may, perhaps, be as well to consider it as terminating at the Arroyo Grande.

The eastern edge of the Santa Lucia chain, consisting of a group of elevations parallel with that range, and separated from it by the valleys of the Carmelo and San Antonio Rivers, and the tributaries of the Arroyo Seco, is locally known as the Palo Scrito Hills at its northern end, and as the San Antonio Hills to the southeast of the Soledad Mission. The whole chain is called, on the Pacific Railroad Map, by Lieutenant Parke, the "Sierra de las Salinas." The range to the east of the Salinas Valley, at its northern termination, where well-defined and lofty, is 
known as the Garilan Range, and its close connection on the east with the Monte Diablo group, has already been noticed. As continued to the southeast of the head of the San Benito, it sinks down into a high, rolling region, the various subdivisions of which are known by the same designations as the streams and ranches in their immediate vicinity; of these the San Lorenzo and the Estrella are the most prominent.

In the region of short, broken ranges, between those just mentioned and the distinctly-marked east and west ones, the names locally in use are numerous; but as there is no predominating chain, so there are no general terms for groups of minor elevations. The two most prominent ranges are, perhaps, that of the San Rafael Hills, which lie between the Santa Iñez and Santa Maria Rivers, and the Cuyamas Range, which runs between the last-named river and the Cuyamas. The direction of these chains, which are nearly parallel, so far as we have been able to ascertain is about $\mathrm{N} .60^{\circ} \mathrm{W}$. One or both of them may, perhaps, be considered as the prolongation of the Santa Lucia chain. This direction of $\mathrm{N} .60^{\circ}$ to $65^{\circ} \mathrm{W}$., is also that of the line of upheavals which marks the northeastern limit of the Coast Ranges, along the line of the desert, southwest of the Cañada de las Uvas and the ridges which unite the Sierra and Coast chains of mountains together.

The whole region embraced in and between the above ranges of hills and mountains is essentially of one character. It is sparsely inhabited and generally very poorly supplied with water. Such favored districts as can be irrigated are fertile in the highest degree, and may be adapted to almost any semitropical culture. The most attractive localities were selected by the monks of the Franciscan order for the missions which they began to establish, throughout this portion of Upper California, in 1769. Of these, no less than eleven were included within the limits of the region between San Fernando Valley and Monterey. These were the Missions of San Fernando, San Buenaventura, Santa Barbara, La Purisima Concepcion, Santa Iñez, San Luis Obispo, San Miguel, San Antonio, La Soledad, Carmelo, and San Juan Bautista. The situation of most of these were admirably selected, and the ruined and deserted buildings are still prominent and picturesque objects.*

* For a full account of the foundation of these missions, and of their condition iwentyfive years ago, sce Duflot de Mofras, "Exploration de l'Orègon, des Californies, \&c.," Paris. 1844 . 
If the valleys throughout this region are dry, the mountains are still more so; they are usually covered more or less with chaparral, which effectually keeps off intruders. In the vicinity of the Ocean, and, especially, near the summits of the higher mountain-ranges and in the deep and shaded cañons on their sides, where the moisture brought in by the winds from the sea is not too rapidly evaporated, there is a considerable growth of forest trees; the number of these increases as we go towards the northwest. Pines and oaks greatly predominate in number over the other genera. Of the pines, Pinus Coulteri, P. insignis, and $P$. monticola are the most characteristic species; of the oaks, Quercus lobata (called also Q. Hindisii), Q. Douglasii, Q. Garryana, Q. agrifolia, Q. Sonomensis (synonyms, Q. Californica, Q. tinctoria, and Q. Kelloggii) are the most abundant. Of the cedars, the redwood, Sequoia sempervirens, is found in limited patches near the sea, from Point Concepcion north; the Cupressus macrocarpa (Monterey cedar) is a magnificent tree, resembling the cedar of Lebanon, but very restricted in its range. Of other prominent trees, which give a character to the scenery of this part of the Coast Ranges, the following may be mentioned: Tetranthera Californica (laurel or bay), Arbutus Menziesï (madrona), a characteristic and beautiful tree, Populus monilifera (cottonwood), flourishing everywhere in the Coast Ranges, in the valleys along the sides of the streams, Platanus racemosus (sycamore), growing chicfly along. the river banks. Of the shrubs, Adenostema fasciculata (chamiso), Arctostaphylos glauca (manzanita), and the Ceanothus, called "wild lilac" by" settlers from the Eastern States, on account of the resemblance of the delightful perfume of its flowers to that of the common lilac, are the most abundant and prominent. Mingled together, and associated with a variety of species of shrubby oaks, each furnished with as many thorns as there are points to leaves or branches, this vegetation makes up that horrible undergrowth, with which we have become intinately acquainted, on almost every mountain slope from San Diego to Siskyou, to the great detriment of skins, clothes, and tempers.*

Almost all the really valuable land in this part of the Coast Ranges

* For a complete account of the distribution of trees and shrubs throughout the State, sce the volume of Physical Geography, in the series of the Final Report.

GEOI.. VOL. T. - 15 
is occupied by Spanish grants, or ranches, some of which are of immense size, containing from forty to fifty thousand acres; these are located along the valleys of nearly all the principal streams, and although these ranch-grants do not probably cover more than one-eighth of the surface, yet the owner of the valley has, in point of fact, undisturbed possession of the adjacent mountains. The raising of cattle was, in former times, almost the exclusive business of the rancheros; but, of late years, sheep-growing and the cultivation of the vine have been of rapidly increasing importance.

There are no mines of any value in this part of the Coast Ranges, so far as is yet known; nor has the result of our explorations been such as to lead to the belief that this will ever become a mining region. Cinnabar is the ore which is most likely to be found in deposits of sufticient extent to be valuable, in the region of the metamorphic Cretaceous. Within a short time, this ore is reported to have been discovered in the Tertiary strata, not far from San Luis Obispo, but the locality has not been examined by any of our corps. Small quantities of argentiferous galena, found on the Alisal Ranch, a few miles northeast of Monterey, have given rise to stories of silver mines of great richness, which have been handed down from author to author, and have led to much exploration, but always without success. The broken and semimetamorphosed condition of the rocks, through this region, as also their recent geological age, renders it improbable that veins or deposits of valuable metalliferous ores (with the exception of those of quicksilver) will be found here with sufficient development to be capable of being continuously and permanently worked. Chromic iron may, however, be discovered, sufficiently near to a place of shipment to become of value in time. The deposits of asphaltum, on and near the coast, are well known, and all such as have been visited by our corps will be found described in this chapter. These are very extensive and have been utilized to a considerable extent, for some years past, for local consumption, the material being much used for covering the roofs of houses in the vicinity of the deposits. The asphaltum has also been shipped to San Francisco and used for roofs and pavements, and the business has been profitable in a small way.

Within the last year the "oil-excitement" of the Atlantic States has 
penetrated to the Pacific coast, and the presence of a small proportion of a more fluid oil, in connection with the solid asphaltum, has led to unbounded hopes of a vast production of petroleum in the Coast Ranges of California, creating an excitement which has been skilfully made use of by unprincipled speculators, for their own purposes, by the creation of stock conpanies with an immense number of shares, which have been disposed of to a credulous public, nearly the whole proceeds of their sale being clear profit to the promoters of these enterprises, while it is certain that, even under the most favorable conditions, the luckless stockholders will never receive even a moderate return for the money invested.

Our line of exploration, through the asphaltum region in Santa Barbara and Los Angeles Counties, did not happen to lead us to those ranches which have become celebrated by the formation of monster oil companies on them, although we examined carefully all the localities where, at that time, the asphaltum was being made practically available; in none of these did it happen that more than a trace of a really fluid oil could be seen. In forming an opinion of the probable truth of recently published statements of the occurrence of vast quantities of liquid petroleum in this region, we have relied to some extent on the observations of Dr. Antisell, one of the geologists to the Pacific Railroad Survey, and the author of a work on "Photogenic Oils," who visited all the known localities of asphaltum and bituminous substances in the counties of Santa Barbara and Los Augeles, and whose observations have the merit of being entirely disinterested. The examination of his chapter "On Bituminous Effusions," in Volume VII of the Pacific Railroad Report, and the comparison of his accounts with those which have since been given by interested parties, will serve to convince every unprejudiced person that these latter have not been distinguished for a strict adherence to truth—to use a mild form of expression for a very ugly fact.

At an early period of the Survey, a considerable quantity of the asphaltum of this region was forwarded by us to an Eastern city, where it was examined by a highly skilful chemist, well acquainted with this class of substances, to see if it could be made available as a source of burning oil, under the present conditions. The auswer to this question 
was in the negative, and subsequent trials, on a somewhat larger scale, in California, have confirmed this result. We consider it a settled question, that with the facilities and conditions which now exist, the asphaltum cannot be profitably used for the manufacture of burning or lubricating oil. It is not necessary, in this place, to go into a detailed statement of facts to prove this; that may be more properly reserved for the volime of Economical Geology. Those who doubt the statement can, if they see fit, devote their time and money to proving it to be incorrect by actual practical results.

The next question which arises in this connection is, whether a fluid oil exists on the surface in sufficient quantity to pay for collecting in the large way. It has been stated, in the published prospectuses of some of the California oil companies, that rivers of oil were flowing through the ranches of which they were the lucky proprietors, which only required to be conducted down to the sea-shore in pipes, or canals, to furnish for shipment a boundless supply of material. It seems hardly possible that anybody should be found sufficiently credulous to be imposed on by these statements. Apart from Dr. Antisell's descriptions, which show most clearly that the thinner tarry material, as it oozes from the rocks, everywhere soon hardens into asphaltum, it is evident from the operations of those who have, in years gone by, endeavored to distill oil from the material obtainable here, that no great quantity of a fluid material could be secured, as they used the solid asphaltum, or the sand inpregnated with it, for distillation, and, as it need hardly be added, without being successful pecuniarily. Besides, the fact that the company in whose prospectus conduits and canals to convey off the liquid oil figure most conspicuously, actually commenced operations by boring (if any credence can be given to the statements of the newspapers on this point), is sufficient evidence that the originators of these schemes knew that they were deceiving, when they put forth their advertisements and pamphlets.

The question resolves itself, then, in to this: Is it probable that flowing wells will be struck by boring, as in the oil region of Pennsylvania, and that these will deliver a liquid oil, or petroleum, in sufficient quantity to make it worth while to take up the business and carry it on, in the large way? We say "in the large way," because it is self-evident 
that, to pay dividends to incorporated stock companies with heavy nominal capitals, the business must be done on a large scale. A delivery of a fer barrels a day would not amount to enough to pay the rent of the office of the company in New York or Philadelphia, much less the salaries of the office-holders. A few lines will be devoted to answering the question, whether the geological structure and conditions in the Coast Ranges south of San Francisco Bay are such as to justify a large expenditure of money in the expectation of striking copiously-flowing wells by boring to a considerable depth.

The great bituminous slato formation, of Tertiary age, extends through California, from Los Angeles as far north as Cape Mendocino. No doubt it contains bituminous matter enough to supply the world for an indefinite period, could this be made available without expense. But it will be observed that the strata of this formation, all through the region south of the Bay of San Francisco, are turned up at a high angle, in this respect occupying a very different position from the oil-producing beds in the Eastern States. There, the strata in which petroleum is found in abundance, and in which all the wells which yield any considerable quantity of this material are sunk, are horizontal or inclined at a very moderate angle. Nowhere is oil obtained in large quantity, where the stratum in which it originates is exposed to the air by being turned up on edge, or is only covered by light and porous accumulations of detritus. The reason of this is very evident: the oil is slowly elaborated or brought together in a certain bed, or set of beds; and, unless confined in some way, so that it cannot escape, it must be forced to the surface by capillary attraction, hydrostatic pressure, or that of gas generated at the same time, when it escapes and is lost; to allow it to accumulate, there must be an impervious covering of rock over the oilstratum proper, which will confine the fluid material within limits, and allow it to accumulate, away from the influence of the air. For this reason, a large flow of oil on the surface cannot be considered as a favorable indication for boring wells, and much less can heavy accumulations of asphaltum be so regarded. If, then, flowing wells are struck in California, it is more likely to be in those portions of the region north of the Bay of San Francisco, where the bituminous slates are less disturbed, and not set up on edge, and where they may perhaps be cov- 
ered by formations of later age, which will act as covers and receptacles for the elaborated oil. In the Coast Ranges south of the Bay of Monterey, as the bituminous shales are everywhere turned up on edge and have no cover of impervious rock, the inference is unavoidable, that flowing wells, or at least those delivering any considerable quantity of liquid petroleum, cannot be expected to be got, by boring to any depth; the probabilities, at least, are decidedly against it. While, therefore, we would not object to a reasonable and prudent expenditure of small amounts to test the question whether fluid oil can be obtained in California in sufficient quantity to pay a moderate profit on a bon $\hat{a}$ fide investment, we would caution all against paying to speculators an immense premium for the privilege of making these experiments on lands which they have secured for a small sum, and where there are no better, if as good, chances of success as on many other tracts which have not yet fallen into the hands of these monster stock companies.

Whether the asphaltum of California is derived from the thickening, or oxidation, by exposure to the atmosphere, of exactly the same substance, chemically speaking, as that which is called petroleum in Pennsylvania, is a matter for chemical investigation. In the light of the facts and considerations just presented, it does not appear to be economically important that it should be settled at once. How large a portion of the numerous hydrocarbons which are originally contained in the bituminous slates of California evaporate on exposure, and how many of them become oxidized into asphaltum, is a delicate subject for investigation. From the well-known fact that there are few, if any, deposits of asphaltum or asphaltic material existing on the surface in the oil region of Pennsylvania, although the oil itself appears to have been escaping at numerous points for an indefinite period of time, it appears to be probable, at least, that the original chemical constitution of the mass of bituminous matter in the oil-bearing shales of Palæozoic age is different from that material which occurs in the Tertiary rocks of California, and of which at least much the largest part does, on exposure, become consolidated into a hard and brittle material, which certainly no longer contains more than a very small percentage of light oil.

In view of the above facts, it will not be necessary to discuss the 
question how far the greatly increased expenses of obtaining and working machinery, of barrels, of transportation, and of labor, would render it difficult for California oil-wells, if any did exist, to compete with those in the Eastern States, where the conditions are so much more favorable in these respects.

Many facts will be presented in this chapter which have come under our own observation, in regard to the occurrence of asphaltum in the region in question, and from these some aid may be obtained in forming an opinion as to the correctness of the statements which have been made in these few preliminary remarks.

We proceed now to the consideration of the geological structure of the Coast Ranges north of Santa Barbara, commencing with the San Fernando Valley and the Sierra Santa Susanna, and proceeding northward, as being the more convenient way of giving our observations, which were taken in that order. The Santa Monica Range will be included in the next section, or that devoted to the Coast Ranges south of Santa Barbara Channel, as being closely connected with the San Gabriel Range, and therefore more conveniently taken up at the same tinie with that.

Section II.-The Region from San Fernando Valieit nortil to the Bay of Monterey.

This valley, or plain, occupies the depression between the Santa Susanna chain on the north, the Santa Monica on the south, the San Gabricl on the east, and the low ridges and hills rumning transversely between the Santa Susanna and the Santa Monica on the west. It is about twenty miles long and twelve miles wide, and is drained towards the south by the Los Angeles River. The soil of most of the plain is sandy, and the streams running into the valley from various directions sink when they strike it, and do not flow on the surface, except during seasons of heavy and long-continued rains. A warm spring occurs on the south side of the plain, at the base of the Santa Monica, on the Encino Ranch. The water had, in February, 1861, a temperature of $83^{\circ}$, and a slightly alkaline taste, and appeared to contain car- 
bonate of soda and the sulphates of soda and magnesia, in so considerable a quantity as to be unfit for irrigation.

The Sierra Santa Susanna lies on the north side of this plain, and extends west as far as the valley of Santa Clara; this range is also familiarly known as the "Scorpion Hills." From the plain, the hills to the north present a bold and precipitous front, as the strata of which they are made up are heavy-bedded sandstones, dipping to the north, and presenting their broken edges, in the form of high cliffis of nearly naked rock, to the south; these cliffs rise in bold escarpments, so that their stratification is distinctly visible from a great distance, and from the very massive character of the strata, their position is much easier made out by an observer several miles off, than by one on the spot. The material is coarse, often passing into conglomerates, and generally red in color; it has a marked tendency to weather into fantastic forms, the angular masses becoming rounded in outline by the disintegration of the rock, and having many irregular cavities worn in it; detached fragments, originally angular, finally assume, under the influence of the weather, the appearance of enormous boulders. To the northwest of our camp at the base of Scorpion Hills (Camp No. 14), the sandstone in the higher ridges had a strike of S. $46^{\circ} \mathrm{W}$., with a dip to the north of from $20^{\circ}$ to $30^{\circ}$; the highest of these ridges rise from 1800 to 1900 feet above the plain, or about 3000 feet above the sea. Along the foot of the range, west of Camp 14, were several hills near the base of the main range, but isolated from it. Those near camp were of sandstone with highly inclined, sometimes vertical, strata; farther west, along the western edge of the valley, they were found to be of bituminous slate. Three or four miles west of the Scorpion Ranch, there is a stratum of white, crystalline limestone running through the foot-hills, and rising in sharp steep hills to the height of 300 to 400 feet. This limestone is burned in the vicinity and appears to make good lime.

The annexed section from the Santa Monica Range, in a northwesterly direction across the San Fernando Plain, to the summit of the Santa Susanna Range, a distance of about forty miles, shows the position of the rock in this region; but only in an approximative way, as far as the Santa Susanna Range is concerned, since no minutely-detailed examination was made. 
The structure of the Santa Monica Range has already been described, and nothing farther need be added here. There is no doubt that the sandstones of the Santa Susamma Range are of the same age as those of the Santa Monica, namely, Miocene, at least in considerable part. A series of beds of later age, referred by Mr. Gabb to the Pliocene, was discovered by Baron Richthofen to the north of the east end of the San Fernando Plain; but we have not the exact position of the locality, nor are the relations of the strata to those exhibited in the section above known.

The section shows that there is evidently an immense fault or break in the strata at the southern base of the Santa Susanna Range, by which the rocks to the north have been uplifted at least 3000 feet, and perhaps much more. To the north, the Santa Clara Valley appears to occupy the bottom of a synclinal curve, but the range to the north of that stream is but little known; it is possible that the strata there may be horizontal, and resting unconformably on the rocks below, and that they are the Pliocene beds noticed above.

At the western end of the San Fernando Valley, among the rounded foot-hills which connect the Santa Susanna and Santa Monica Ranges, there is some coarse conglomerate, probably GEOT. VOT. I. -16

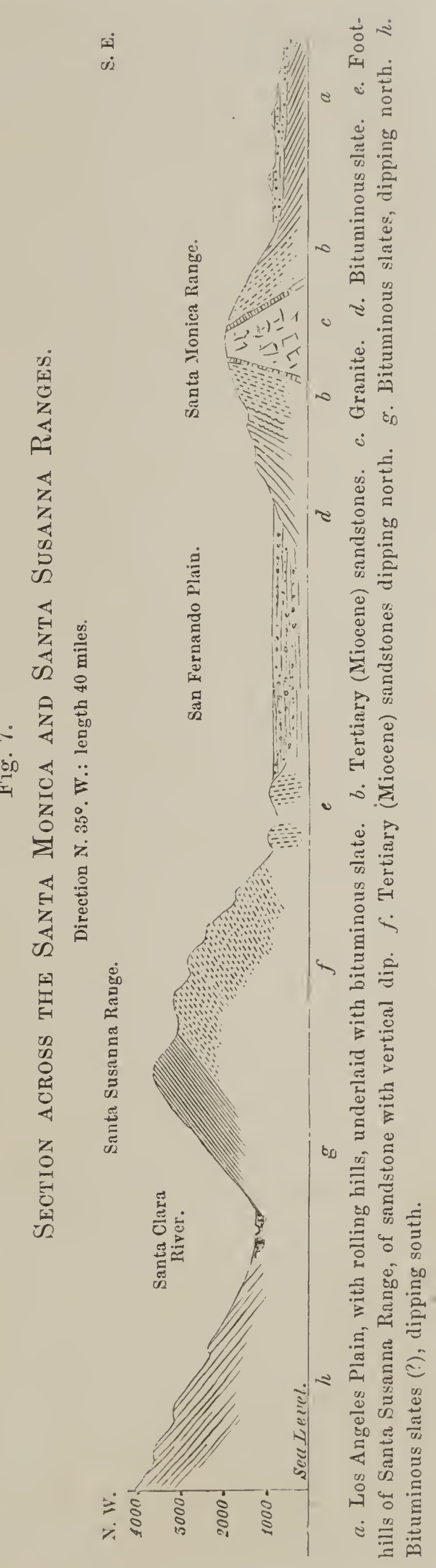


of later Pliocene age, like that on the south side of the last-named range. In this region the strata are exceedingly broken, having a general northeast and southwest strike, and a dip at every possible angle intermediate between southeast and northwest, and varying in amount from $20^{\circ}$ to $70^{\circ}$. In some places the strata are bent into immense arches; but usually the force of the upheaval has broken them off abruptly, and they are now left in a condition of indescribable confusion, jammed together and piled up into a labyrinth of hills and cañons. Portions of these sandstones are here well filled with fossils, of Miocene age, but they are in a very poor state of preservation, from the coarse, friable character of the rock in which they are imbedded. The strata containing these fossils most abundantly formed a high ridge, with a strike of N. $64^{\circ} \mathrm{E}$, and a dip of $20^{\circ}$ to the southeast, the northern slope being very steep and rough. These strata were covered on the east side by conglomerates, destitute of fossils, which were made up of pebbles of jasper, quartz, and other rocks similar to those seen by us in the Santa Anna Range.

Still farther to the north and northeast, high hills rise, which command an extensive view of the bituminous slates and fine-grained sandstones to the northwest. The height of this ridge, above our camp on the edge of the San Fernando Plain, was 2735 feet, or 3950 feet above the sea.

The ridges bounding the San Fernando Valley on the southwest are made up of light-colored bituminous slates, dipping generally to the east or northeast; they form rounded hills, bearing the marks of extensive erosion. A higher range to the west of these hills connects the two chains, and rises to a height of 3000 feet above the sea, being made up of Miocene sandstones, highly inclined and in some places metamorphosed. Between the lower rounded hills of slate and the hight sandstone ridge, there is a series of valleys in which are the Virgenes, Triunfo, and other ranches. The Virgenes Creek breaks through the Santa Monica Range and runs south, emptying into the sea a little east of Point Duma.

Five or six miles southeast of the Triunfo Ranch (Camp 15), rise the high sandstone ridges of the Santa Monica. These were examined to the east of Virgenes Creek, where they have a strike of S. $24^{\circ} \mathrm{W}$. to 
S. $49^{\circ} \mathrm{W}$., and dip to the north at an angle of from $40^{\circ}$ to $70^{\circ}$, the strata presenting their broken edges to the east and southeast in steep precipices. These ridges are extremely rough and rocky, as may be seen in the amnexed section (Fig. 8).

liig. 8.

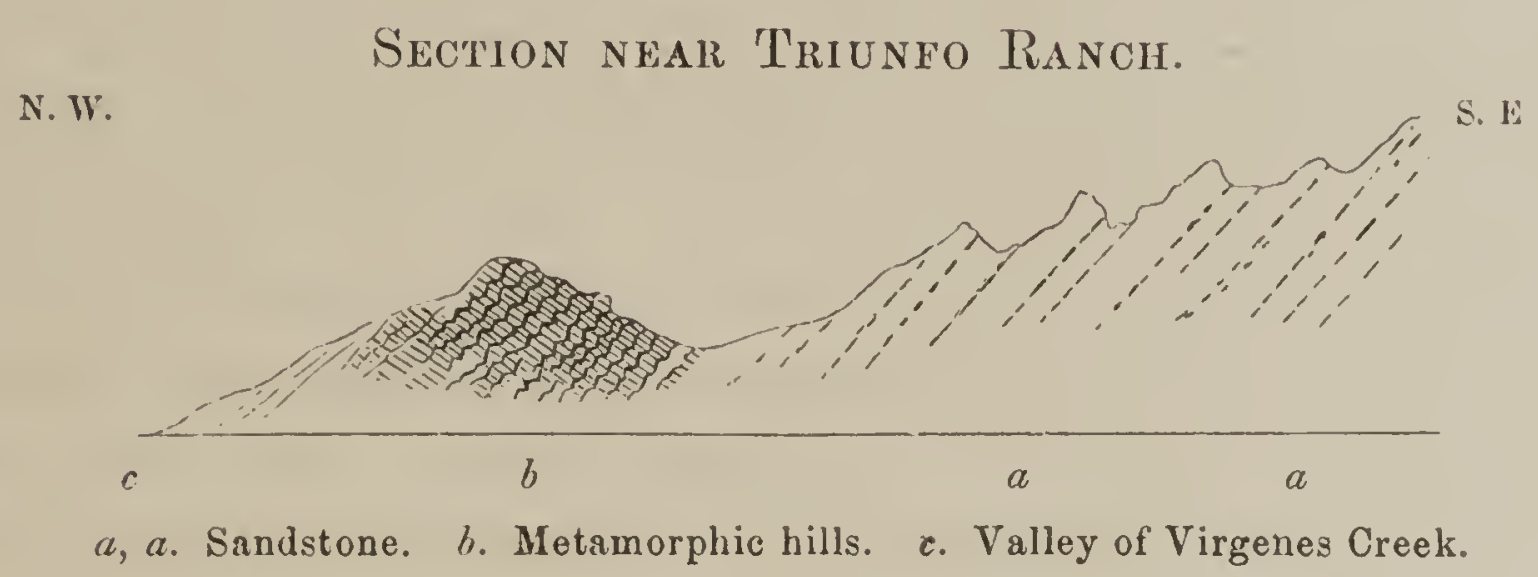

Extending along the base of these ridges of very slightly metamorphosed sandstone, which rise to the height of 2000 feet, there is a low range of sharp ridges, from 400 to 600 feet high, of which the strata have the same dip and strike as those in the higher mountains south, but which are highly metamorphosed, and perhaps intrusive, although no rock was seen which could be recognized as positively eruptive. Some portions of these low ridges were of a dark, compact, or semicrystalline rock, apparently diorite; others were amygdaloidal, having the cavities filled with carbonate of lime, and disintegrating rapidly, forming a dark, reddish-brown soil. Some traces of metamorphism were observed in the higher ridge of sandstones, the granite coming to the surface in one place, as it does farther east in the range on an extensive scale.

Between the Triunfo and Cayeguas Ranches several low sandstone ridges were crossed, and about six miles north of Triunfo, a very steep one, also of sandstone, having an east and west direction and a northerly dip, the strata being much metamorphosed at the base of the ridge on the southern side. This ridge was examined, in its western continuation, from our camp at the Cayeguas Ranch (Camp 16), where it was found to rise to the height of 1000 or 1100 feet above the valley, commanding a good view of higher and rougher ridges, apparently of the same sandstone, lying off to the south and southwest, the strata in some places appearing quite vertical. Where examined, these strata 
were found to be extensively metamorphosed, so that it was not easy to decide whether they were accompanied by intrusive or eruptive rock. From Professor Brewer's notes, however, it appears that he inclines to the belief that the amygdaloidal rock seen by him, and which had so trappean an appearance, was in reality a metamorphic sandstone. The strata in this region have a general east and west direction, and dip to the north at an angle of from $30^{\circ}$ to $45^{\circ}$. On the hills north of the Cayeguas Ranch there are beds of light-colored sandstones, containing considerable numbers of Pliocene fossils. These hills, at a point a mile and a half north of the ranch, were found to be from 600 to 700 feet high above the valley; here the ridge runs east and west and the strata dip to the north, having the Cayeguas Valley on the south, and Las Posas on the north. The topography of the region is very complicated, and could hardly be represented at all except on a map on a large scale. The ridge near which the best fossils were obtained is furrowed by cañons, with exceedingly steep sides; namely from $40^{\circ}$ to $60^{\circ}$, as measured by the clinometer. All through here the strata bear the marks of great disturbance and of extensive metamorphic agencies at work below, although the presence of volcanic or trappean rock on the surface seems not to have been settled beyond a doubt. At all events, the metamorphosed strata, if such they were, occupied a position conformable in dip and strike with the beds in which they were intercalated. Some of these altered beds were very friable, decomposing readily into a dark-brown soil, very different from that produced by the disintegration of the ordinary sandstones. Of these latter, some were made up of coarse, clean, white beach-sand, closely compacted together and containing numerous fragments of shells, broken and water-worn. Some of the strata were very fossiliferous, many species being represented; but they were in such a frail condition that but few good specimens were collected. Many fragments of sea-weeds and a vertebra of a fish were also noticed, as well as some remains of corals. These beds are considered by Mr. Gabb as being of Pliocene age, as will be seen in another part of this Report.

The San Buenaventura, or Santa Clara Plain, as it is called on the -Pacific Railroad Map, forms a triangular area inclosed between the Santa Susanna, Santa Monica, and the transverse connecting range 
noticed above on the east, the San Buenaventura hills on the north, and the Ocean on the southwest. All the water seen on the plain was alkaline, except that of the Santa Clara River. Hills of the white bituminons slate lie to the northeast of this plain, in which the strata, as indicated in numerous exposures, dip to the sonthwest, or south-southwest. These hills approach the sea at the Mission. To the east and northeast, at some distance in the interior, were high mountains, snowcovered on their summits at the season of our visit (March, 1861), and apparently 5000 or 6000 feet above the sea; in these the strata of bituminous slate were very conspicuous from a distance, evidently dipping to the south and southwest, and presenting their broken edges to the south. The soil derived from the decomposition of these slates, where seen in the plain or on the low hills, was of clay, producing at this season an abundant growth of forage, chiefly Medicago and Erodium.

The same bituminous slates appear at San Buenaventura; and Mount Hoar, a high mountain near the sea, a little to the northwest, was found to be made up of the same rock, as far as examined along its flanks. To the north and northeast of the Mission, the hills are deeply and extensively furrowed by cañons, with very steep sides; the slopes of one near the sea were found by actual measurement to be as much as $60^{\circ}$ to $65^{\circ}$. Near the San Buenaventura River the strata have a dip of $25^{\circ}$ to $30^{\circ}$; but two or three miles northeast of the Mission the strike is N. $64^{\circ}$ E., and the dip from $35^{\circ}$ to $50^{\circ}$. Everywhere on the inclined strata is a deposit of more modern sand and gravel, nearly horizontal, and in some places as much as twenty-five feet thick.

Nearly all the boulders in the San Buenaventura River are of sandstone, sometimes metamorphic; but a few were of granite, gneiss, and a dark hornblendic or trappean rock. On the sea-shore, boulders of asphaltum were seen, nearly as hard as anthracite, and large deposits are found in place, on the surface, in the vicinity, as will be more fully noticed farther on. Valuable beds of sulphur are reported to exist a few miles up the river.

The road followed by our party, from Camp 17, at Buenaventura, to Camp 18, at Carpinteria, was along the coast and the base of Mount Hoar, which appeared to be entirely made up of the bituminous slates. IIigh bluftis or steep liills skirt the coast, showing everywhere inclined 
strata, dipping from $25^{\circ}$ to $30^{\circ}$ to the southwest, with a few feet of horizontal beds of detrital material on the top. The slates are interstratified with fine-grained sandstones, and the formation is undergoing rapid denudation from the action of the resistless surf of the Pacific. The worn edges of the strata, planed oft and polished by the waves, may be seen for some distance out from the shore at low water. The strike of these rocks is here from $\mathrm{N} .45^{\circ}$ to $55^{\circ} \mathrm{W}$. No eruptive rock was seen here, and only a few granite boulders were observed on the beach; but immense number's of sandstone pebbles were seen, some of which were quite fossiliferous.

About five miles southeast of Carpinteria, the rock presents exactly the appearance of having had the bituminous matter burned out of it; it assumes varions colors, such as bright-red, rose, brown, yellow, and cream-color, and it appears to have been partially fused in some places. These colors are made very conspicuous by the washing and smoothing of the rocks by the Ocean.

The slates are black and highly bituninous where the outerop strikes the sea, three miles to the southwest of Carpinteria, and large quantities of tarry asphaltum flow from them. For a mile or more along the shore the banks abound in it, and it saturates the beach-sand and flows down into the sea. Sand, pebbles, shells, and wood are cemented into a hard mass by it, the cement being nearly as solid as the rock itself. Near the "oil-works" the strata are almost vertical, and have a strike of" N. $66^{\circ} \mathrm{W}$.; but half a mile farther south they are much disturbed and contorted. They are broken, bent, and twisted, so as to lie at every possible angle of dip and strike, and in the bent strata many of the curves are very short and abrupt. The rocks at this point are more or less metamorphosed, and the strata have assumed elegantly contrasting alternations of black and white, which are rendered more conspicuous by the action of the waves. In places the rocks have been broken up into large masses, and these again reunited, still preserving their lines of stratification with perfect distinctness, as shown in the annexed figure, which represents a fragment of rock, perfectly solid, but with the stratification plainly marked in the different pieces of the mosaic, as is shown in the wood-cut (Fig. 9).

An establishment for distilling oil from the asphaltum was started 
shortly before the time our party visited the place (March, 1861); but access to it was not allowed, nor information given. It is believed, however, to have been a failure, both as regards the quality of the oil produced and the profits of obtaining it.

These bituminous slates extend along the base of the Santa Iñez Range to the east, and were explored by our party as far as the Gaviota Pass, about forty-five miles from Carpinteria; they continue beyond this, but, it is said, not as far as Point Concepcion. The general dip along this line is to the Fig. 9. south; but the strata are exceedingly contorted, being bent and twisted into every possible variety of curve. They are also metamorphosed and hardened, and the variations of hardness and color, as well as the elaborate curvings of the beds, are beautifully displayed in the broad level surface worn off by the sea, and left visible at low tide. These contortions seem to be limited to a rather narrow belt near the shore. As we recede inland they become less conspicuous, and the strata regain gradually their regular southern inclination.

The chain of the Santa Iñez rises to the north of Santa Barbara, a conspicuous object to those approaching this place by water. As far as known, it takes its origin at a point due north of Buenaventura, and running a little north of west $\left(\mathrm{N} .84^{\circ} \mathrm{W}\right.$.) for a distance of over sixty miles, it meets the sea at Point Concepcion. The chain has its greatest elevation apparently near Santa Barbara, where it is about 3800 feet high. To the west of the Gaviota Pass it has an elevation of about 2500 feet. The main ridge is entirely composed of Tertiary (Miocene) sandstones, without any appearance of eruptive rock, and also with very little metamorphism.

When examined towards its eastern end, north of Carpinteria, the chain has the form of a great anticlinal arch, of which the northern portion has remained, while the crown and the southern half have been removed, irregularly, but with a gradual increase of the denudation towards the sea, so as to leave three distinct ridges, as shown in the annexed diagram (Fig. 10), which represents a section across the hills at this point. 
This chain was climbed by our party, at two points between Carpinteria and Santa Barbara; namely, above the Hot Sulpluur Springs, five

Fig. 10.

Section across the Santa Iñez Range, north of Carpinteria.

$\mathrm{s}$.

N.

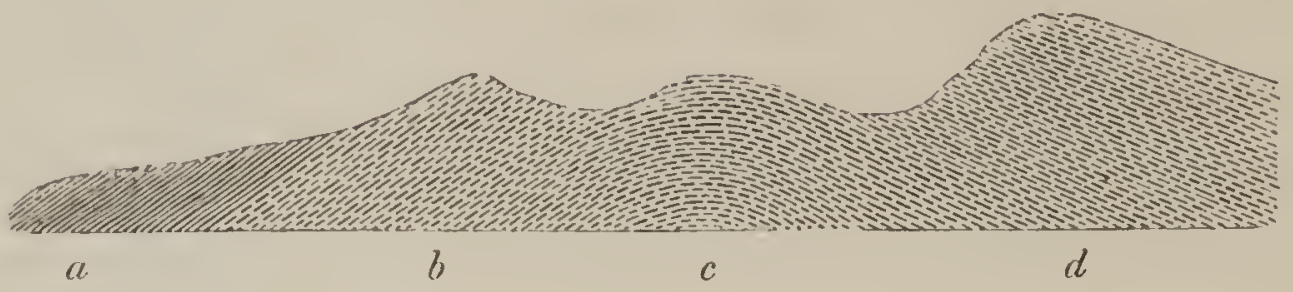

a. Bituminous slate. b. Front ridge of sandstone, dip S. $30^{\circ}$. c. Central ridge of sandstone. r. Main ridge, sandstone with dip of about $30^{\circ}$ to the north.

or six miles east of Santa Barbara, and on the 'Tejon trail, three or four miles still farther east. At both these points nearly the same section was obtained. The foot-hills are of slate, the highest about 800 feet in altitude, and the strata much broken; the main ridge is of sandstone, 3700 to 3800 feet high, with the dip always to the north and the strike about east and west, magnetic (N. $76^{\mathrm{c}}$ W.-S. $76^{\circ}$ E.) ; the summit is rather broad, or made up of several (usually three) distinct elevations, more or less connected by transverse ridges; these sandstones are overlaid on the north by slates and tine grits, sometimes a little metamorphosed.

The Hot Springs are in a precipitous cañon on the side of the range, at an elevation of 1426 feet above the sea, near the base of steep precipices of unaltered sandstone. The waters are highly charged with sulphur, and the springs had the temperature (March 18, 1861) of $112^{\circ}$, $115^{\circ}, 115^{\circ}, 114^{\circ} .5$ and $118^{\circ}$, the larger ones being usually the warmer ; but the most copious one, at the bath, was $115^{\circ}$. In ascending the ridge back of this, the slopes are very steep along the broken edges of the strata, until the crest is attained, which is of sandstone, covered with weathered boulders of the same material. The rock is red, rather coarse-grained, and appeared quite destitute of fossils. About two miles back, along a transverse ridge, and over a small elevation or knob, the northern and highest ridge was reached, and was found to be made up of fine sandstones and slates, generally somewhat metamorphosed. The dip is always to the north, and at an angle of from $50^{\circ}$ to $70^{\circ}$, while in places the rocks stand nearly vertical. The highest 
point measured was 3638 feet above the sea; but higher points were seen both east and west, the most elevated of which was estimated at 3800 feet above the sea.

On an excursion made to the "Coal Mines," by way of the "Téjon trail," a disused and almost impassable bridle-path, the north slope of this range was passed over a little east of the point just noticed, and about six miles east of Santa Barbara. Metamorphic rock and conglomerate were seen on that side, as also serpentine at the north base of the ridge. An idea of the structure of the chain at this point may be obtained from the annexed section. (Fig. 11.)

The horizontal distances are approximate only. At the point where this section was taken, and as far east as the chain can be seen from the summit, all the strata of the main chain have a dip to the north; but, about two or three miles west, the dip changes, and the large masses of sandstone have a southern dip.

The chain was again examined in the cañon back of the Mission of Santa Barbara, where the strata all have a southern dip, as mentioned above, the broken edges of the uplifted beds forming a very ragged outline against the sky. At the base, the dip is very high, sometimes almost vertical, but not a trace of either eruptive or metamorphic rock was seen on this section.

Figure 12 will serve to give an idea of the position of the rock in this section of the Santa Iñez, and will also exhibit the rient. YnT. T. - 17

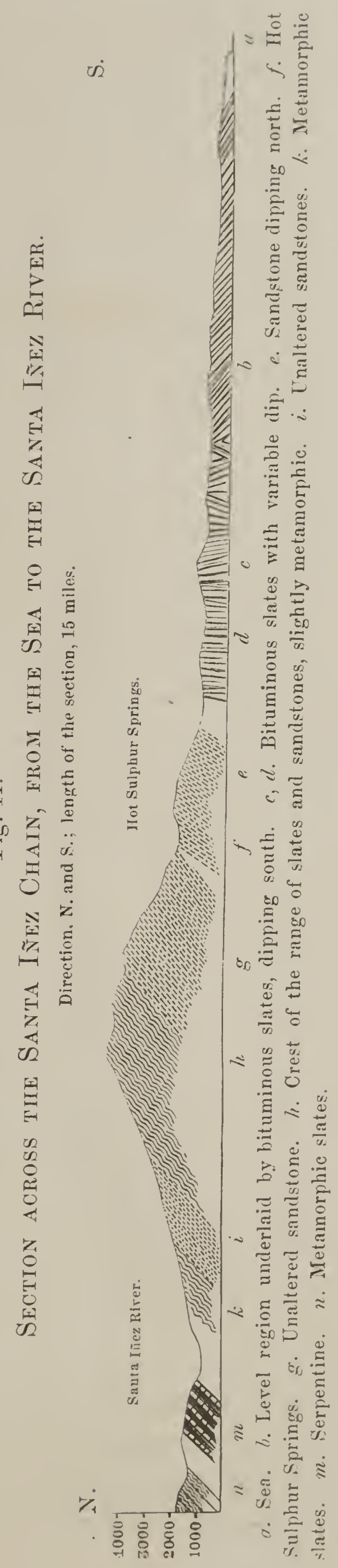


relations of the newer strata near the shore, of which more will be said farther on. Near the shore, the bituminous shales and slates may be seen, in a highly contorted position, and somewhat metamorphosed.

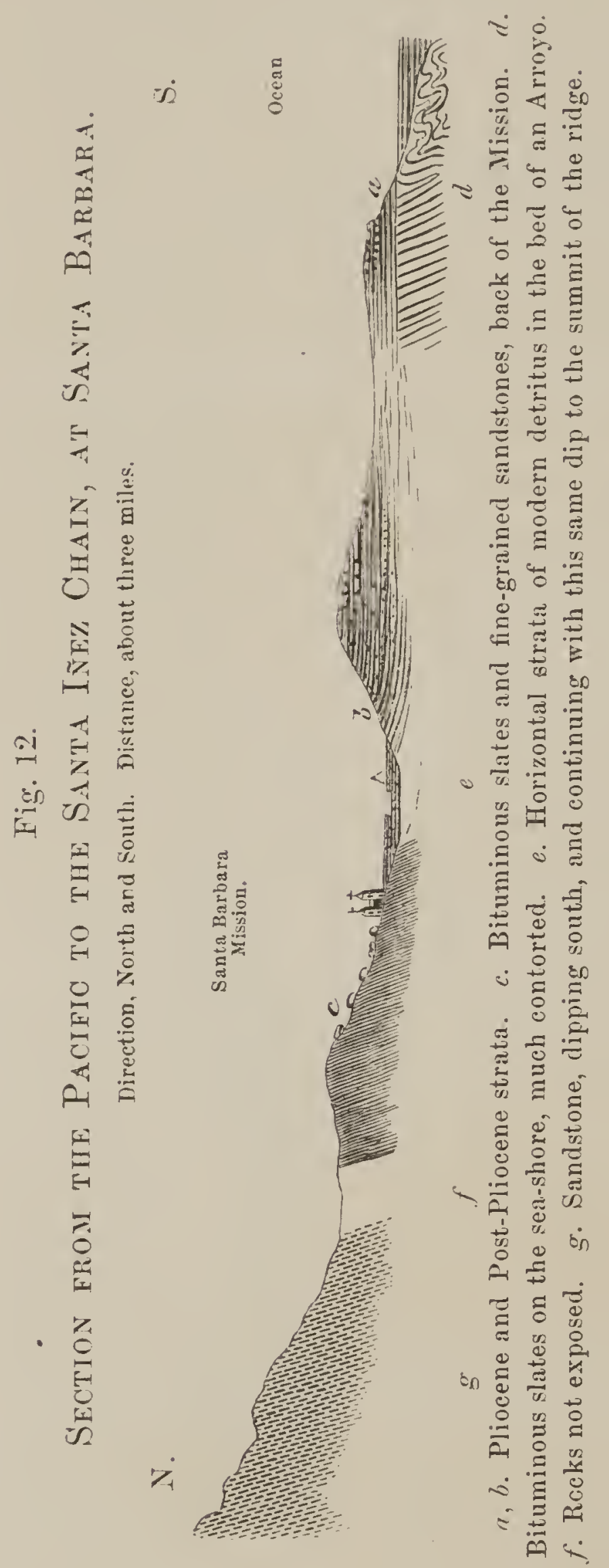

Gradually they acquire their regular sonthem dip, and lose their metamorphic character. The Old Mission is built on these slates, and the slopes behind it are covered with large loose boulders of the sandstone, which have been washed down from the heights above.

Farther up the mountain, as seen in this section, we come to the sandstone, first red and then gray, with very high northerly dip, quite heavybedded, and presenting a very grand appearance with its lofty battlemented edges turned up to the sky. This saudstone continues to the summit of the ridge, which was not crossed at this point. The very highest points of the Sierra Santa Iñez cannot be much less than 4000 feet, as estimated from the point measured, and found to be 3638 feet high, and as the diameter of the chain from north to south is only about six miles, an idea may be formed of its precipitous character, the southern slope being often as high as $30^{\circ}$, and in some places as much as $37^{\circ}$.

The reversal of dip in the chain occurs about four miles northeast of Santa Barbara, where it appears that the axis crosses the ridge diagonally from northwest to southeast; but it was not possible to examine this line satisfactorily. It was certain, however, that this extraordinary change of dip was not connected 
with any alplearance of intrusive or disturbing rock on the surface. This change of the dip of the whole mass of the strata of the mountain is the more remarkable, as being not evidenced by any break in the ridge itself. On this question some remarks will be made farther on in this Report.

Wherever the chain was examined to the west of the section last given, as far as a point a few miles to the west of Gaviota Pass, the rock had always a dip to the south, at a high angle, the crest consisting of the broken edges of the sandstone, the bituminous slate resting on its flanks in the foot-hills, and both formations appearing entirely conformable with each other.

The bituminous slate is admirably exposed all along the sea-shore for several miles to the west of Santa Barbara. At a point one mile in that direction, where the shales were planed down to the level of the ocean, and the stratification could be most beatififully seen, the strike was noticed to be N. $79^{\circ} \mathrm{E}$., and the $\operatorname{dip} 60^{\circ}$ to the south. In some places the slate forms low cliffis by the edge of the ocean; in other's it has been denuded, and it is now covered by a more recent deposit. The complication of the disturbances in these strata may be well seen in the annexed cut, which represents a length of seventy-five feet along

Fig. 13.

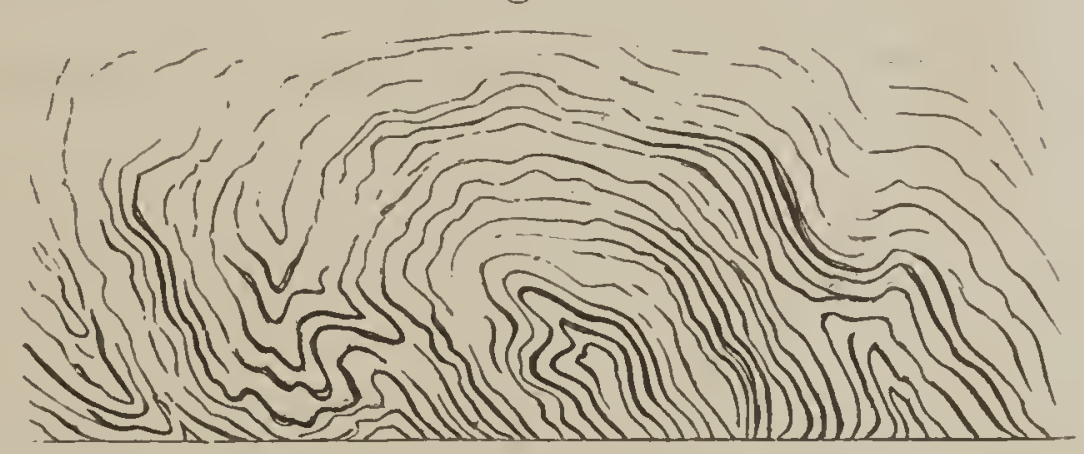

FOLDINGS OF BITUMINOUS SLATE NEAR SANTA BARBARA.

the base of the bluft, and in which the foldings of the strata are accurately copied, in their principal curves, so far as is possible on so small a scale. These disturbances seem particularly common in the immediate vicinity of Santa Barbara. In some localities the rock has evidently been on fire, and the bituminous matter having been burned out-the operation continuing for several years, as it is said-the slates are left of various shades of red, produced by the oxidation of the iron. 
The asphaltum, or hardened bituminous matter, occurs in the greatest abundance on the shore at Hill's Ranch, about six miles west of Santa Barbara, and lies along the beach for a distance of a mile, in large masses. The bituminous slate is here covered unconformably, as at Santa Barbara, by a heavy deposit of Post-Pliocene age, which here attains a thickness of from eighty to one hundred feet.

Fig. 14.

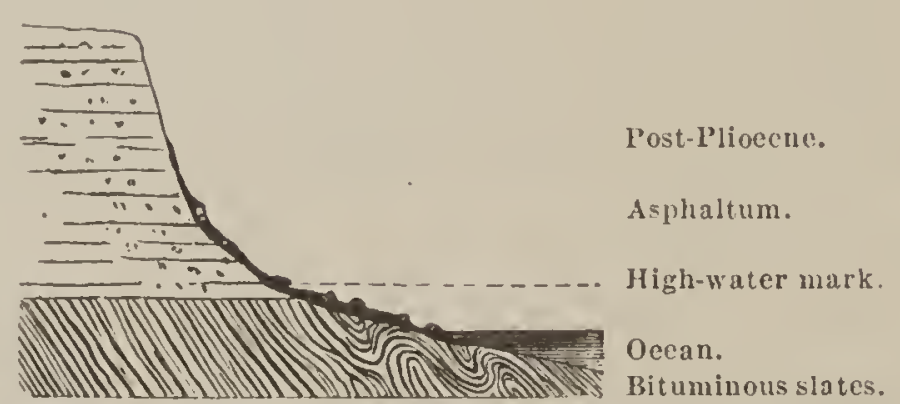

CROSS-SECTION OF ASPHALTUM LOCALITY AT HILL'S RANCH.

The two sections (Figs. 14 and 15) exhibit the relations of the formaltions here, and the position of the asphaltum. The bituminous slates, which are highly contorted and turned up on edge, lie nearly on a level with the ocean. On their edges rests a body of soft arenaceous, and loose gravelly, materials, sometimes very slightly consolidated, in which are long fissures filled with asphaltum; this in some cases has risen to the surface of the formation and become accumulated, in large masses, in the overlying recent or alluvial formation. The gradual erosion of the cliff has exposed large masses of the asphaltum, which have fallen

Fig. 15.

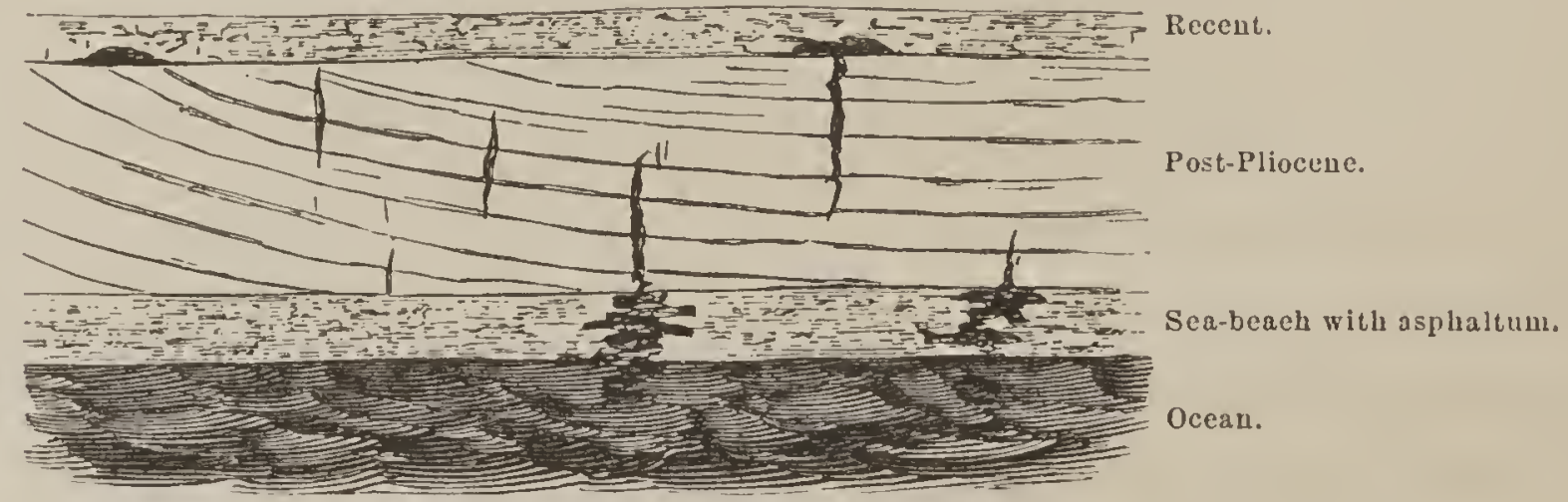

FRONT VIEW OF ASPHALTUM LOCALITY AT HILL'S RAYCH.

down and accumulated in considerable quantity on the beach, as represented in the longitudinal section. This locality has, for a long time, furnished all the asphaltum used for roofs and pavements in San Francisco, as it lies most convenient to the sea. In 1861 this material was 
sold in the city for $\$ 15$ per ton, the chief expense of obtaining it being that arising from the difficulty of getting it on board the ressel, on it coast exposed to the Pacific swell. It will be noticed that the asphaltum lies in the arenaceous rock or sandstone, over the bituminous shales, from which it was derived, and from which it has been foreed out probably by heat and pressure. Through the slates themselves, the bituminous material appears to be uniformly diffised, and not concentrated into pure masses. The asphaltum, as it lies on the shore, is necessarily much mixed with sand: specimens selected as of fair quality contained about sixty per cent. of that material. No appearances of any soft, liquid, or tarry matter were noticed at this locality.

Extending west from Hill's Ranch, the bituminous slate occupies a strip from one to three miles wide, between the rugged Santa Inez Range and the sea. It forms rounded hills, very green and grassy, the soil being fertile and retentive of moisture. The junction of the slates and sandstones could be accurately traced on the surface by the character of the soil and vegetation, as well as by the form of the hills. In ascending from the sea towards the interior, the chaparral, indicating a dry soil, is first met with on striking the sandstone. The ocean fogs help to supply this region with moisture, and few ranches in California can equal in beauty and fertility those situated on the bituminous slates along this part of the coast. Of these, the ranches of Mr. Hill and Dr. Denn (Dos Pueblos) and the Rancho El Capitan are the most noted. At the Tortegas Ranch the belt of slate is narrower, appearing to be about one and a half miles wide, which width it holds as far as we traced it, to beyond the Gaviota Pass. Throughout the whole of this extent it has a strike nearly parallel with that of the chain, and everywhere a southern dip, conformable to that of the sandstone which underlies it. At one locality, a short distance west of Camp 20, in the cliffs at the base of the ranch called El Capitan, the sea has made a section very nearly at right-angles to the strike, and the dip is seen to be quite uniform, being everywhere from $30^{\circ}$ to $40^{\circ}$. A portion without apparent break or fault was measured along the bluff on the beach, which represented a perpendicular thickness of about 1300 feet of slate. The actual thickness is, however, much greater, probably more than twice as great; but, owing to breaks and faults, this is the 
greatest thickness measured in any one place, where the rocks were unquestionably not folded, and where the whole could be minutely examined. This portion of the slate seemed less bituminous than that at Santa Barbara, but still it was, in places, highly charged with this substance.

On referring to the section on page 130 , it will be seen that the strip of land between the Ocean and the Mission of Santa Barbara is occupied by low hills; these rise to the height of 433 feet in the highest place, and they are made up of strata which are nearly horizontal, or have only a slight seaward dip, and which rest on the upturned edges of the bituminous slates. This formation is well exposed in the clifts along the shore west of Santa Barbara, and in some places attains a thickness of a hundred feet. It consists of strata of coarse gravel and sand, some of which are consolidated into the hardest sandstones, while others are still quite soft and easily disintegrated. These strata, themselves unconformable with the slates below, are again overlaid unconformably by the recent or modern alluvial deposits, as will be seen on the section at Hill's Ranch, page 132. Along the sea-shore the beds in question have been very irregularly worn and denuded by the action of the sea, as may be noticed on the section in the wood-cut annexed

Fig. 16.

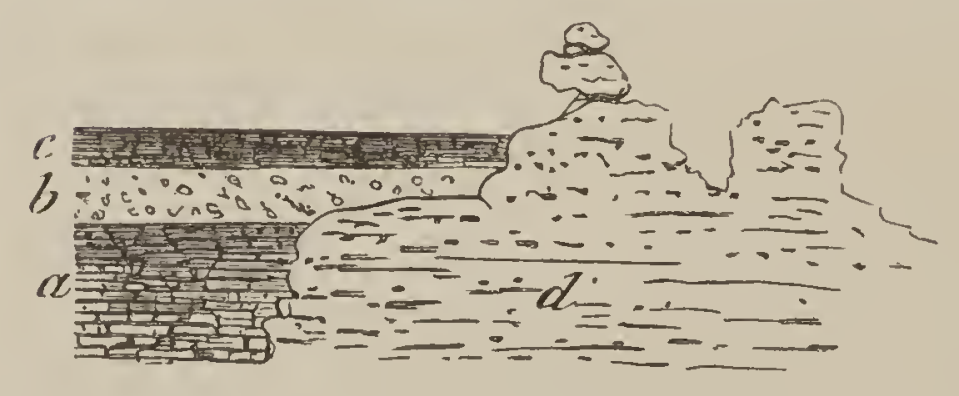

BEACH SECTION, NEAR SANTA BARBARA.

a. Soft beach sand. b. Rolled beach pebbles. ' Fine detritus and sind, with soil on top. $d$. Hard sandstone.
(Fig. 16), taken about a mile west of Santa Barbara, and showing the junction of the recent beach deposits with the denuded and irregularly-worn mass of the older formations.

This formation thus exposed on the beach at Santa Barbara is extremely rich in fossils, nearly all of which are of living, while a small number are of extinct species. The mollusca collected here have been referred to P. B. Carpenter, for comparison with the now living Pacific coast species, and the results of his investigation will be given in the second volume of the Palæontology, forming a part of the publications of the Survey. The fossils of the locality near the town, from the locality at $b$, Fig. 12, and which are referred to the Pliocene epoch by Mr. Gabb, will also be noticed and described in the same volume. 
In crossing the Gaviota Pass, a tooth and some bones of a mastodon were found, on Dr. Denn's ranch, in the superficial detritus, at the bottom of a layer of clay about four feet thick, and resting on a stratum of fine sand. These remains were in too friable a condition to admit of their being removed. The summit of the pass is about 1000 feet above the sea, and the clevation of the mountains to the west of it nearly 2500 feet. Descending the chain on the north side, by the Gaviota Pass, we come to the Valley of Santa Iñez, which is several miles wide at the Mission de la Purisima; but narrower above and below it. There is but little level ground in the valley; but it consists rather of low rounded hills of fossiliferous strata, of Miocene Tertiary age. A section across the Santa Iñez chain, taken one mile east of the Gaviota Pass, is given in the annexed wood-cut (Fig. 17).

Fig. 17 .

Section of Simrra Santa Iñez, east of Gaviota Pass.

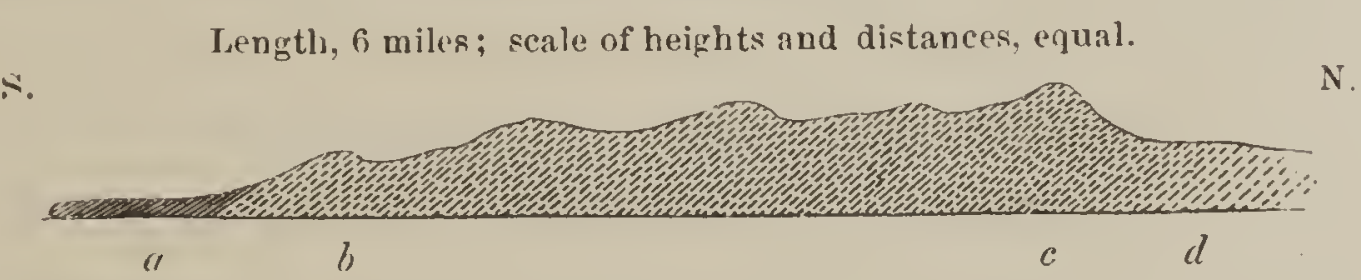

a. Bituminous slates. $b$ to $c$. Unaltered sandstones of Miocene age, with southerly dip. $d$. Low hills of Santa Inez Plain.

The following species, referred by $\mathrm{Mr}$. Gabb to the Miocene, were found in the Santa Iñez mountains and valley, and in the hills north of Camp 29, at the Najohui Ranch:

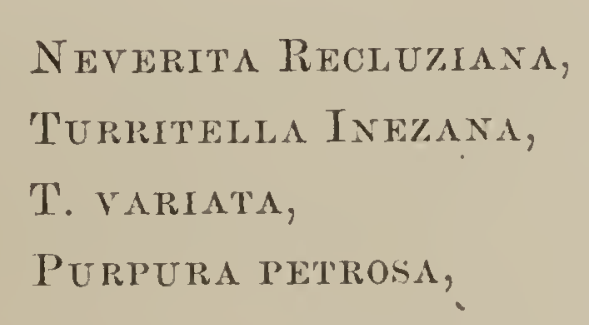

The three chains, Santa Iñez, San Rafacl, and Cuyamas are nearly parallel, and succeed each other from south to north in the order named. The Santa Iñez is the highest and best defined, and has already been described in sufficient detail. The San Rafacl occupies the region between the Santa Iñez and Santa Maria Rivers, and the Cuyamas ehain has the river of the same name on the nortl. These 
ridges were traversed by our party at a point about 15 miles above the Santa Iñez Mission, and in a direction nearly transverse to their trend. The San Rafael chain, where crossed, north of the Santa Iñez River, was from 3800 to 4000 feet high. The rocks seen were sandstones alternating with slates, the latter often dark-colored. Mountains five or six miles east and northeast had much snow on them (March, 1861), and were probably fully 5000 feet high. On the north side of this range, the rocks were examined more particularly in the neighborhoor of a supposed coal-bed, where some explorations had been made in search of that substance. The strata here were slates and sandstones, interstratified, having a strike of about east and west, magnetic, or $\mathrm{N}$. $76^{\circ} \mathrm{W}$., S. $76^{\circ} \mathrm{E}$, and standing nearly vertical. The carbonaceous matter formed thin lenticular masses, which were seldom over an inch thick, where examined by us; but some were said to have been found as much as fire or six inches thick in places.

No eruptive, and but few metamorphic, rocks were seen on this line of section. Serpentine was noticed, however, near the Santa Iñez River, as shown in the section given on page 129; this mass was about 200 feet in thickness, and extended over a mile in length.

As seen from the higher ridges, between the Santa Iñez and Santa Maria Rivers, the surrounding country appears to present two principal higher ridges, running nearly east and west; of these, the southern is the Santa Inez, and the northern was supposed to be the Santa Lucia or Cuyamas Range, although no generally recognized name could be obtained for it; the space between these ranges, which is twelve or fifteen miles wide, is entirely occupied by lower ridges, not continuous, but much broken, the higher ones parallel with the Santa Iñez, the others transverse, or having a general northwest and southeast direction. The strike of the sandstones in these intermediate ridges seemed as variable as the direction of the ridges themselves.

The region to the west of the San Rafael Range, between the Santa Iñez and Cuyamas Rivers, was cursorily examined by our party, which camped once (Camp 22) at Alamo Pintado, four miles north of the Mission of Santa Iñez, and again (Camp 23) at Foxin's Ranch, about twenty-five miles due east of. Point Purisima. The region is occupied by hills of moderate height. No metamorphic rock was seen; but 
peblbles of serpentine and metamorphic sandstone were noticer, especially for three or four miles north of Alamo Pintado. The road travelled over by the party led up a valley in a northerly direction to about eight miles from the Santa Iñez Mission; thence it crossed low hills, following a northwesterly course for eight or nine miles. These hills were covered with gravel derived from the bituminous slates. At times, especially near the Santa Maria River, the hills were capped by a modern horizontal deposit (Post-Pliocene?). The underlying rock, when seen, was the bituminous slate, sometimes dipping to the north, and sometimes to the south. The valley in which Foxin's Ranch (Camp 23) is situated has a course at that place of N. $56^{\circ} \mathrm{W}$. Following this valley down towards the ranch, the elevations on the north were found to be of bituminous slate, dipping north; on the other side, the hills were lower, and generally capped by horizontal strata of semiconsolidated materials, forming tables.

Near Foxin's, on the south side of the valley, there were hills of nearly horizontal strata from 200 to 300 feet high, the north slopes of which were very steep, usually about $35^{\circ}$, but sometimes as much as $37^{\circ}$, yet perfectly grassed. Beneath the soft sandstone which made up the principal part of these hills was a stratum of infusorial rock, resembling chalk in appearance, excecdingly light, its specific gravity not being more than .6 or .7 ; the thickness of this stratum was over twenty feet. The age of this formation is not yet definitely ascertained.

North of the valley, at Foxin's, the bituminous slate occurs, with a high dip to the north, and asphaltum is found in several localities near. In places the slates are altered and silicified, sometimes resembling semi-opal in appearance, the finest laminæ of the original structure being preserved. On this ranch, in the bed of a spring, which disappeared a few years since after an earthquake, the bones of a whale had been found, but only a few fragments could be secured by our party; these bones were obtained about three fect beneath the surface.

There seems to be considerable uncertainty in regard to the names "Cuyamas" and "Santa Maria," as applied to the river running north of the San Rafael chain, and its branches; the lower part of the river' seems to be known by those living in that vicinity as the Santa Maria, and the northern and larger branch as the Cuyamas, the smaller branch 
in this case giving its name to the main river. There is quite an extensive plain at the mouth of the Santa Maria, called "Guadelupe Largo," on which are situated the Nipoma and Guadelupe Ranches. On the south side of this plain there are several well-marked terraces. On the north, near the Nipoma Ranch (Camp 24), there are high, sharp hills, of strata more or less metamorphic and having a high northern dip. A series of tables or terraces lies between the main ridges and the plain, through which run lines of highly metamorphic rock, sometimes silicified, so as to be converted into almost pure quartz, while other portions are more argillaceous, but the whole very hard and ringing like iron under the hammer. The stratification, however, is not at all obliterated in these metamorphic rocks, except in the case of the serpentine; but it is much more evident in the large masses than it would be in hand-specimens. Near the base of the ridge was some very hard and trappean-looking rock; but it appeared, on examination, to be only altered sandstone. The altered slates had the appearance of having been silicified by hot water, which had left them in the condition of a semi-opaline mass, but with the fine lines of stratification distinctly preserved. The annexed wood-cut(Fig. 18) is intended to represent an approximate section of the hills at Nipoma, and especially to convey an

Fig. 18.

\section{Section near Nipoma Ranch.}

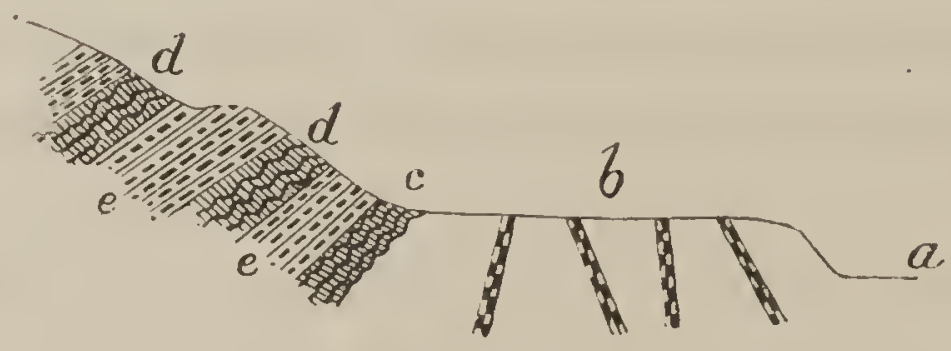

1. Cuyamas Plain. b. Table, at base of hills, with lines of metamorphic rock. C. Highly altered sandstone. 1. Metamorphic beds. e. Unaltered slates.

idea of the way in which these lines of strata have become metamorphosed in parallel bands, showing clearly that these altered rocks are not intrusive masses, disturbing or elevating the chain. In some of the foot-hills, the metamorphic and harder strata alternated with the softer ones, giving a beautiful terraced appearance to the surface. This ridge has about the same direction as the strike of the strata, namely, 
N. $56^{\circ} \mathrm{W}$., their direction being quite regular; the elevation of these hills is from 1800 to 2000 feet above the valley.

Between Niporna and the Arroyo Grande, these metamorphic hills continue, some of them very sharp in outline and rising to the height of 1000 feet. The ridges are much eut up by cañons with precipitous sides, and have a peculiar appearance, from the alternations of the hard metamorphic strata with the softer unaltered ones.

Near Camp 25, on the Arroyo Grande, about three miles below Branch's house, on the Santa Manuela Ranch, the bituminous slate was observed, having a dip to the north of from $40^{\circ}$ to $80^{\circ}$, and a strike of $\mathrm{N} .56^{\circ} \mathrm{W}$. to N. $76^{\circ} \mathrm{W}$. Large deposits of asphaltum occur on this ranch, which is one of those recently acquired by oil-speculators, and on which it is claimed that oil-wells may be bored with every probability of success.

The Valley of San Luis Obispo extends in a nearly northwest and southeast direction from Estero Bay, on the Pacific, nearly to the Arroyo Grande, a distance of about twenty miles; it has a width of from three to five miles. It embraces the San Luis Valley, so called, and the Cañada de los Osos, as well as the Cañada de las Piedras. Between this valley and the sea there is a range of hills, rising to the height of over 2200 feet at its northwest end, but decreasing in elevation towards the southeast, and finally connecting with the Santa Lucia Range, a little to the south of the Arroyo Grande. The Santa Lucia Mountains extend along the northeast side of the Valley of San Luis Obispo, having a range of sharp, conical hills, called "The Buttes," at their base. The valley opens out to the sea, forming a wind-gap, like the Salinas Valley; but it is chiefly drained by the San Luis Creek, which cuts through the chain of hills on the southwest, emptying into the Ocean at the Bay of San Luis. Near the centre of the valley is a swamp or lagoon, which in very wet weather is drained to the northwest.

The San Luis Valley is covered with a superficial deposit of detritus, in places twenty or thirty feet thick, in other's less. The underlying rock is sandstone, occasionally metamorphic, especially near the edge of the valley, the elevation of which, at Camp 26, two miles southeast of San Luis village, was found to be 198 feet above the sea. 
There being $n$ o designation in current use for the chain of mountains on the west and sonthwest of the San Luis Valley, it may for convenience and with propriety be called the San Luis Range. It was examined by our party along two lines of section, one where the San Luis Creek cuts through it, and the other eight or nine miles to the northwest of this, at Wilson's Ranch, where is a well-known locality of the gigantic fossil oysters (Ostrea Titan). At and near the San Luis Creek, and on the road to the bay, the highest points in the range are about 2000 feet above the sca, and the chain is deeply eut into ridges, by erosion chiefly, although the strata are much broken by upheaval. Much light-colored slate exists in the mass of the chain, and it was supposed to belong to the bituminous slate series. The strike of these rocks is variable, but, in the main, nearly that of the chain itself. The dip is still more variable, being generally to the south on the northern side, nearly vertical in the centre, and to the north on the southern edge, the range having a decided synclinal structure, as may be seen from the section given on page 144. Near the northern edge of this range several masses of serpentine were seen, and some metamorphic rock, as also a belt of very compact limestone, containing fossil oysters. No metamorphic rock was seen on the Pacific side of these mountains. At the bay, the rock was light-colored and highly argillaceous, having a strike of $\mathrm{N} .21^{\circ} \mathrm{W}$.; and a dip of $33^{\circ}$ to the north.

Where visited, near Mr. Wilson's, at the locality of the large oysters, the structure of the chain was much less regular, there being frequent developments of highly metamorphic rock, and possibly some eruptive masses. Professor Brewer, however, is decidedly of the opinion that these eruptive-looking rocks are, in reality, indicative of fissures along which metamorphic action has taken place, as has been noticed in so many other localities in the Coast Ranges. These lines of altered or eruptive rock do not run parallel with the strike of the strata, but cross them in an east and west direction. They are certainly not the cause of the upheaval of this chain, and do not form what could by any possibility be called an "axial rock."

The principal locality of fossil oysters is near the summit of a ridge, about 2000 feet high, and three miles S. $40^{\circ} \mathrm{W}$. from Mr. Wilson's house. There are three outcrops of fossiliferous strata, running in a 
nearly east and west direction, and which have been traced for a distance of about a mile. The western ontcrop is at the summit of the hill, where the shells are contained in a very compact linestone; the other fossiliferous beds are in a more or less calcareous sandstone, having a high dip to the south. The oysters are very numerous, adhering together in large masses, as in their natural beds, and weathered specimens were formerly so abundant that they were gathered up and burned for lime. It is said that single ones have been found, weighing thirty pounds; the largest collected by us weighed about sixteen. The annexed section (Fig. 19) shows the position of the rocks in this vicinity.

Fig. 19 .

Section across the Caf̃ada de los Osos.

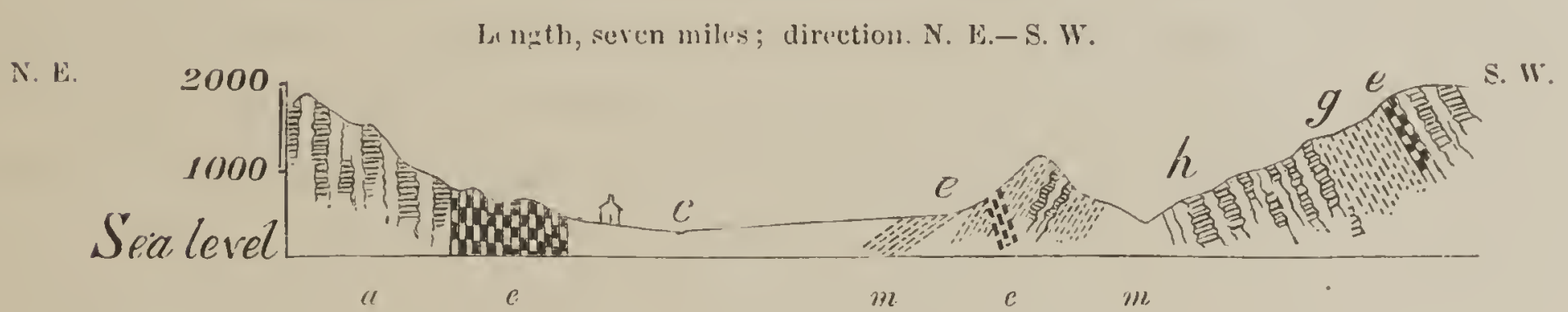

a. Metamorphic rock. e, e, e. Serpentine. c. Stream and swamp in the Cañada de los Osos. $m, m$. Hill of sandstone, somewhat metamorphic on the south side, with a band of serpentine passing through it at $\varepsilon$. h. Metamorphic. g. Oyster-shell beds.

In this section the elevations are only approximate; the Butte, or hill in the valley, $m, m$, is about 1800 feet high. Owing to the broken character of the strata, however, no section can be made which shall be anything more than an approximate and somewhat ideal one.

Skirting the Sierra Santa Lucia on the southwest side, and extending into the San Luis Plain, in a southeast direction, is a chain of sharp, more or less isolated hills, called "the Buttes." These terminate on the northwest in the Moro Rock, a precipitons mass of rock in the Estero Bay; and, on the southeast, gradually sink in low, scattered hills on the San Luis Plain. The higher ones rise to from 1500 to 1800 feet. As seen from the summit of the Santa Lucia, northeast of San Luis, they appear to lie in a nearly straight line, and from that point twenty-one peaks can be seen in this range, of which eight or nine are predominant. So far as examined, these Buttes are made up of lightgray trachyte or trachytic porphyry. A belt of serpentine lies along 
their southern base, becoming wider as we go towards the southeast, and the Buttes south of the town of San Luis are almost exclusively of this rock. The serpentine Buttes are more rounded in outline than the trachytic, and these latter are very rocky and steep, with many rounded boulders on the surface.

Metamorphic slates and sandstones were seen near where the San Luis Creek passes between the Buttes; and, at many points on the plain or in the valley about San Luis, there were outcrops of rocks, and sometimes rocky masses of several acres in extent, of metamorphic sandstone, sometimes porphyritic, sometimes quartzose, and occasionally passing into serpentine. The Sierra Santa Lucia was climbed, at a point about due northeast of the town of San Luis Obispo. Here there are foot-hills, of various elevations, intervening between the main chain or ridge and the valley; these consist mostly of serpentine and other metamorphic rocks, while unaltered stratified sandstones were seen in the hills west of the San Luis Pass road, the dip and strike being very variable, the strata broken up, and occasionally a little metamorphosed. To the east of the road, in the line of the section on page 144, the rock in the foot-hills is mostly metamorphic, with large quantities of serpentine, and the same serpentine skirts the base of the main chain. On ascending the principal ridge, however, the metamorphic rock ceases, and the slope is of unaltered strata, chiefly light-colored and fine-grained sandstones and slates, sometimes bituminous, and, at the altitude of about 1800 feet, a stratum of impure bituminous limestone occurs, enitting a decidedly fetid odor when struck with the hanmer. These rocks probably belong to the bituminous slate series. The slope is covered with soil and grassed over, although steep, the average inclination of the 2000 feet being from $23^{\circ}$ to $26^{\circ}$, while portions are from $45^{\circ}$ to $47^{\circ}$. On nearing the top of the ridge, the slates become more silicious, as if metamorphosed, and the soil is lighter, being covered with manzanita and other shrubby plants, conspicuous among which was a lupine in full flower. The summit consists of several ridges, more or less nearly parallel, and connected by transverse elevations, which appeared to be the result of extensive erosions, effected in the chain after its upheaval. The strike is, in the main, parallel with that of the chain, but varies somewhat in the different 
ridges. The dip, along the entire southern slope, is to the north, the angle increasing towards the summit, and near the central axis of the range it is generally vertical. The northern slope of the chain was not examined; but, as seen from a distance, the dip seemed to be to the south, at a high angle; it was certainly to the south in some of the ridges on that side. The altitude of the highest point reached was found to be 2803 feet; but, at the distance of six or eight miles to the southeast, the mountains rise to a height of about 3000 feet, and the same was true at a distance of twelve or fourteen miles to the northwest.

The rock on these summit ridges is entirely slate, more or less silicified. In the vertical strata, the laminæ, which are from half an inch to three inches thick, are very brittle, and are cleaved and weathered at right-angles to the stratification, the fine weathered lines and creases being very beautifully marked, large surfaces presenting the appearance shown in the annexed diagram (Fig. 20). In some places the rocks are semi-opaline in appearance and small pieces of chalcedony are abundant, as often noticed in other localities where the slates have been subjected to this silicification. The thin soil on these silicious rocks produces no wild oats, neither does the clay on the unaltered slopes of the range. On the southern side of the range this plant formed the prevailing herbage.

Fig. 20

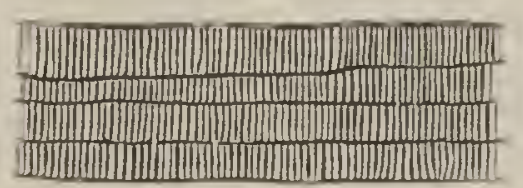

LAMINATION OF SILICIFIED BITUMIYOUS SHALES.

A section across the Santa Lucia Range, through the San Luis V alley, and across the chain of that name, to the Bay of San Luis Obispo, is annexed (Fig. 21).

The San Luis Pass, across the Santa Lucia Range, runs nearly north and south, and the summit is about 2000 feet high. The road passes up a cañon, on the west side of which was much serpentine and other metamorphic rock. The strata exhibited in the pass, after leaving the altered rocks at the base, are slates, occasionally a little changed, and having a north or northeastern dip. The summit is of sandstone, and on the northern slope, where there were fewer outcrops and less opportunity of examining the strata, they appeared a good deal broken, and dipping to the sonthwest. 


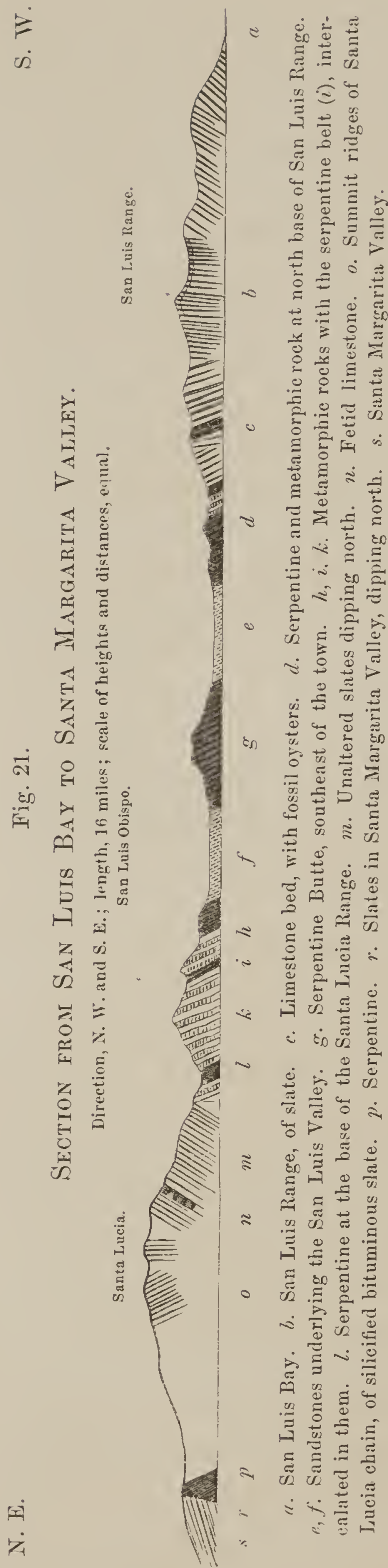

The Santa Margarita Valley, which lies to the east of the Santa Lucia Range, is much higher than the San Luis Plain; its altitude is given in the Pacific Railroad Reports at 1200 feet. The strata, so far as seen, were much disturbed and often metamorphosed, and generally dipped to the southwest, or towards the Santa Lucia. A white quartzose sandstone, with an abundance of oysters and pectens, was the prevailing rock, until the party left this valley and entered that of the Salinas; it decomposes in places into a very dry and barren soil. This formation was observed to the west of Camp 27, at the Atascadero Ranch, where it contained a few fossils, supposed to be of Pliocene age. To the east of the same camp, a light clay slate oceurs, with a very variable strike and dip; this was presumed to belong to the bituminous slate series. These slates were, in places, much silicified, and were associated with the light, infusorial rock, although the relative position of the two sets of strata was not determined.

On crossing the Santa Lucia, a most marked change occurred in the vegetation of the country, not so much an actual change of species, as a greater predominance of certain conspicuous forms, especially of the arboreal. The number of trees was greatly increased in Santa Margarita Valley, oaks and pines of several species became abundant, and the whole appearance of the region was that of one where more rain falls, and where there 
are fewer excessive drouths than to the south of the Santa Lucia. The Salinas Valley was entered by following down the Santa Margarita Creek to the old mission of that name. Locally, the name Santa Margarita is given to the valley, for an indefinite distance down, at least as far as the Atascadero Creek. The Salinas River heads considerably to the south of this; but it only becomes a stream of importance after receiving the waters of the San Antonio and Nascimiento Rivers, which drain the interior of the rough and unknown range extending down the coast from Monterey to San Luis Obispo, and there finding its southern extension in the Santa Lucia Range, to which it is generally considered to belong. The main source of the Salinas proper is the San Juan, which rises in the lofty mountains to the west of the Cañada de las Uvas.

The Salinas Valley is divided by the San Antonio Hills into two portions. These hills stretch across diagonally, at about 75 miles from the mouth of the river, and the region above is a sort of table-land of low, rolling hills, while below there is a valley gradually opening out to what, in California, is a very remarkable width, as much as 12 or 15 miles in its lower extension. The party passed rapidly down this valley, as, owing to the want of time and scarcity of feed here, the season being an unusually dry one, it was impossible to stop at more than a few points for detailed examination.

The valley from Paso el Roble to the San Antonio River is occupied by low rounded hills, in which but few outcrops of rock could be seen, the soil being mostly a fertile clay, retentive of moisture, well adapted to pasturage, and producing an abundance of wild oats and clover. Rounded lills of nearly horizontally stratified gravel were seen near the river in places; but most of the rock observed was a light-colored slate, supposed to belong to the bituminous slate series. Between the A tascadero Ranch and the Nascimiento River a hot spring was seen, of which the temperature was $100^{\circ}$, and the character similar to that of the other springs already noticed. It has considerable local reputation for its curative effects.

To the south-southwest of Camp 28, at the Nascimiento River, the hills were examined for a distance of six or eight miles. In this region there is an immense development of stratified rocks, having a strike of GEOT. VOT. I. -19 
from N. $45^{\circ} \mathrm{W}$. to $\mathrm{N}$. $70^{\circ} \mathrm{W}$. The general dip of the mass of rock is to the northeast, although some portions were seen inclined in the opposite direction. Nearest the valley is a group of sandstone strata, over 1000 feet in thickness, generally rather soft, and in some places calcareous; some of the strata are much altered by the infiltration of calcareous matter into them. A few of the beds are fossiliferous, and the strike of these is from $\mathrm{N} .45^{\circ} \mathrm{W}$. to $\mathrm{N} .50^{\circ} \mathrm{W}$., or nearly parallel with the direction of the ridges. The genus Pecten was most abundantly represented among the fossils, especially the species $P$. Pabloensis, belonging to the Miocene. Beneath these strata, and apparently conformable with them, were heavy masses of the bituminous slate, apparently from 1500 to 2000 feet thick, having generally a northeastern dip; but there was one large wave in the strata, with a reversed dip, or to the southwest. This slate formed rounded hills, many of them of considerable height, covered with a clay soil, and supporting a vigorous growth of wild oats, with some oaks, chiefly Q.agrifolia. The general direction of these ridges was N. $60^{\circ} \mathrm{W}$. From the highest point reached, high and broken mountains were seen to the west and southwest. To the east, and at a distance of six or eight miles, a "mesa," or table mountain, was seen, which appeared to be made up of horizontal strata left in the position by denudation. All the mountains in this region bear marks of deep and long-continued erosion, and the detailed topography is exceedingly complicated; no map gives any idea of it. The names of important water-courses are not even fixed, or given in the same way on any two maps, or located with any pretence to accuracy. All the region to the northeast of the San Juan River, and between that and the Chelone, seems to be of this table-land, deeply cut by ravines; of these there are a great number which are nearly parallel, running from northeast to southwest, and in the rainy season carrying off the water to the San Juan.

To the north and northeast of Camp 28, on the Nascimiento, the region between the San Antonio and Nascimiento Rivers is occupied by hills, some of them rising 500 to 600 feet above the river, and composed entirely of horizontal beds of gravel and sand. This gravel is generally not very coarse, and consists of sand mixed with numerous fragments of the bituminons slates, jasper, and other metamorphic rock, 
and with a few pebbles of granite. No fossils could be found in these beds, although they were carefully sought for. This formation occupies the space between the two rivers, and extends beyond them in places, being seen also on the east bank of the Salinas, forming, at many points, high bluft's.

Far ther to the southwest are high mountains, containing much metamorphic rock, as was ascertained from their appearance, and from the boulders brought down in the Arroyos. The horizontal beds noticed above extend down the Salinas for some 20 miles, and they were also seen along the San Antonio, forming high blufts.

Both banks of the Nascimiento present a fine exhibition of terraces, of which those on the north are the best defined, and were most carefully examined. Above Camp 28, and nearer the hills, there are two remarkably well defined terraces, besides the flats elevated a few feet above the river on each side of the wide sandy bed. The lowest is about 54 feet above the base, two measurements a mile apart giving 52 and 55 feet; its surface is a nearly level plain, varying in width from a few rods to three-fourths of a mile, and very plainly marked for a distance of four or five miles down the river. The second terrace is 65 feet above its base, and is more cut by Arroyos, but is perfectly well defined; the two, as seen from the opposite side of the river, their tables being covered with scattered oaks, present a

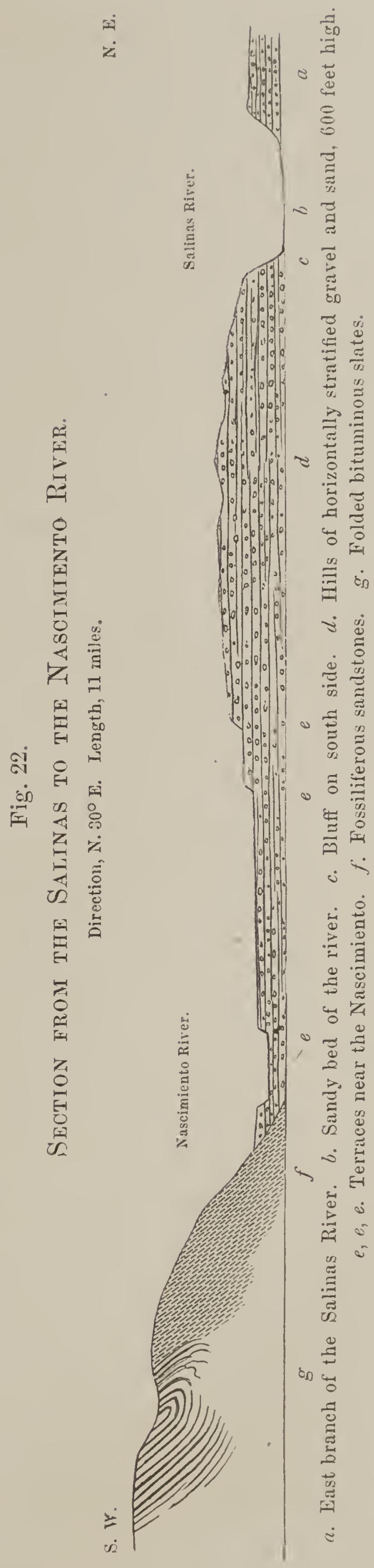


very regular and beautiful appearance. These terraces are underlain by the horizontal gravel-berls on the lower part of the river; but, near the hills, they extend into the inclined strata of sandstone.

Below our camp, near Mr. Thompson's house, the terraces are three in number, the first twenty feet high, the next sixty feet above the first, and the third one hundred and seven feet above the second. On the first one stands the house; the second corresponds with the first one nientioned above as occurring above the camp, and it can be traced from the hills to the high bluff's of horizontal strata, a distance of about six miles; the third and highest is much eroded, and forms a row of hills or ridges, of uniform height.

At this place, and below as far as the San Antonio Hills, the Salinas Valley is entirely occupied with rounded hills, while the upper part, as far to the southeast as the eye can reach, seems one wide and immense plain, the low hills in the valley being too insignificant to be marked features in a distant view.

In continuing the route towards Monterey, from the Nascimiento, the road taken led up the San Antonio River for about twenty miles, to Jolon, a few miles below the San Antonio Mission. On this road the bituminous slate was struck a little before reaching the San Antonio River. The rock is generally a cream-color, but is sometimes almost white. It is very fine-grained, and not highly bituminous, although in one place sufficiently so to have given rise to a flow of this material, which has covered the road with the hardened asphaltum. In some localities the slates are considerably silicified. The strata have generally a dip to the northeast, but not uniformly so. There were several sections examined, all of which indicated an immense thickness for this formation.

The San Antonio and Nascimiento Rivers run, throughout the upper part of their courses, in a direction opposite to that of the Salinas, or in a nearly southeast direction. For more than thirty miles they are nearly parallel, and about five or six miles distant from each other. The region between them is occupied by high ridges, of which the culminating points are of the bituminous slate, having a general direction of northwest and southeast, which is that of the strike of the rock. But portions of this rock have a considerably more western strike, in some 
calses as much as $\mathrm{N} .65^{\circ}$ or $70^{\circ} \mathrm{W}$. It is underlaid by sandstone, which crops out on the south erge of the ridges, and also extends near to the Nascimiento River, sonthwest of our camp. It lies against the heavier mountain masses behind, and is very extensively metamorphosed.

To give an idea of the structure of this region, a section is appended (Fig. 23), from the Nascimiento to the San Antonio River, passing through the Los Ojitos Ranch near Jolon. In the bituminous slate ridge $(d)$ there appeared to be three folds; but the larger mass had a dip of over $40^{\circ}$ and all of over $20^{\circ}$. The thickness of the formation was estimated at from 2500 to 3000 feet. This rock is frequently silicificd and partially altered; but no metamorphism was observed among the sandstones on the northeastern slope of the ridge $(f)$. Near the cañon of the Nascimiento River the strata are much broken, and near the river, at $g$, there are extensive lines of the projecting edges, which stand out sometimes to the height of 300 to 400 feet, with remarkably grand and impressive forms (sce wood-cut, Fig. 24). These outcrops extend along the river for several miles.

With the beginning of the metamorphic rocks of the Santa Lucia, the mountains begin to assume a very rugged appearance, the slopes becoming very stecp, with few trees and much chaparral, and the rocks very various in character. One rocky slope has an inclination, as measured, of $47^{\circ}$, and many others are equally steep. The mountains back of this rise to the height of 4000 fect or more, and appear to be almost inaccessible. The rock, as far as coukd be seen from the ridge ascended, was entirely metamorphic, containing much serpentine, the

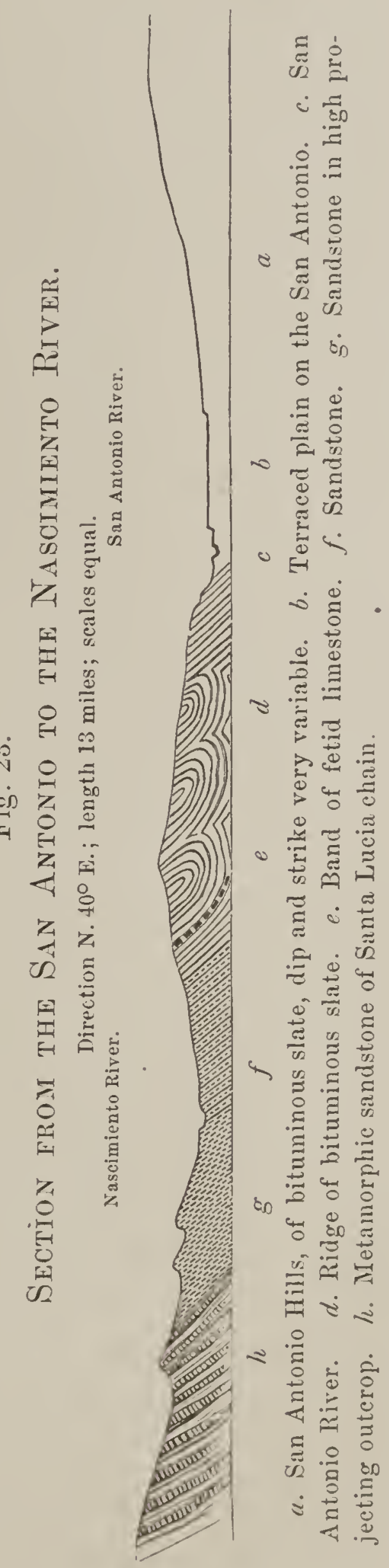
whole mass weathering to a deep-brown color. In a cañon which 
issues from the heart of the chain there are an enormous quantity of boulders, many of several cubic feet in size; among these a great variety of rocks were noticed, such as porphyry, serpentine, jaspery slates, mica-slates, gneiss, quartz, \&c. The varieties of serpentine were the

Fig. 24.

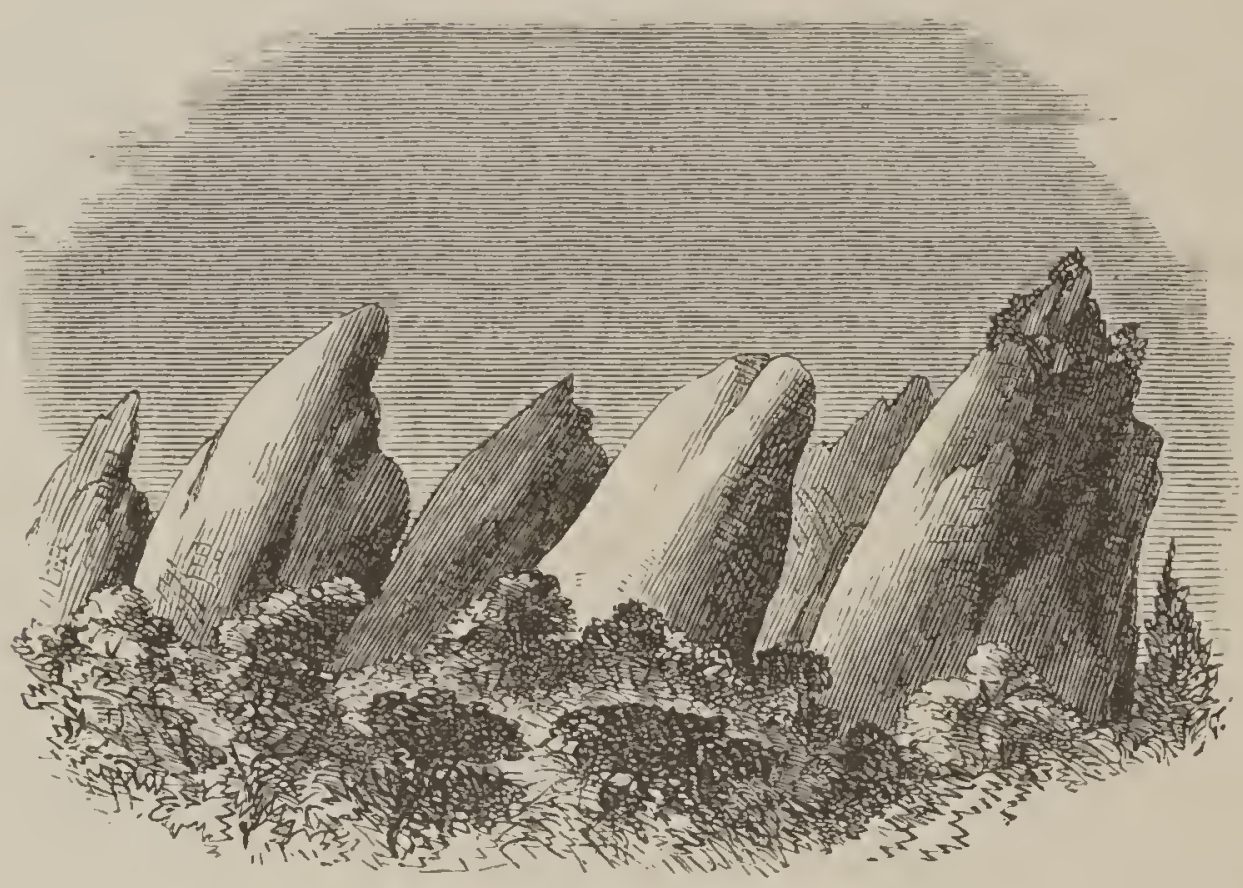

SANDSTONE OUTCROP, NEAR THE NASCIMIENTO RIVER.

most interesting, there being many specimens which showed it in every stage of metamorphism.

Over the front ridges, where the slope is not high, especially on the bituminous slate, the soil supports a good growth of oats, and there are some trees, chiefly oaks and pines. The drier portions of the surface are covered with chaparral.

Along the San Antonio River and extending back among the hills are terraces, well marked in character; they were not measured.

The San Antonio Hills, where crossed, were entirely of bituminous slate, the strata much broken, and their dip and strike so irregular that it was impossible to make out what the average might be. When crossed on the Monterey road, the highest point of the pass is perhaps 1000 feet above the Salinas River, and the most elevated portions of the adjacent ridges from 1500 to 1800 feet; some points between the pass and the Salinas, on the southeast, are perhaps 2000 feet high.

From these hills to the Bay of Monterey, a distance of about eighty miles, the Salinas Valley forms an uninterrupted plain, of from six to ten miles wide, entirely without water during the summer, excepting 
what flows in the river, as the streams coming down from the momtains on either hand sink on reaching the valley. The surface of this plain is remarkably unifor'm, and it has a gentle but decided and regular slope on either side from the hills to the river, the angle being greatest where the river approaches the mountains most nearly, as it does below Soledad, on the west side. Through most of the distance, especially in the upper part of the valley, the Salinas flows in many shallow channels, over a sandy bed from half a mile to a mile and a half in width, which is more or less fringed with trees, and considerably below the level of the plain, generally from 100 to 150 feet. This descent is sometimes in one bluff; generally, there is a succession of terraces. At Camp 30, northwest of Espinosa, there were three, wellmarked ones. These terraces form a noticeable feature of the valley, as they not only skirt the river, but extend across the plain in various places, marking a descent in the valley from a higher to a lower level, as it opens out to the northward.

Near Mission Soledad, below where the Arroyo Seco joins the Salinas, the bluff bank is at the base of the foot-hills, and was found to be from 125 to 150 feet high, the steep slope being covered with angular boulders of mica-slate. These terraces extend nearly to the Bay of Monterey. The soil of the plain is very dry; with water it would be extremely fertile, as is shown at Salinas, and at a few other points where the ground has been cultivated. The conformation of the valley and the dip of the strata on the western slope (the eastern side was not examined) would seem, according to Professor Brewer's opinion, to indicate that artesian wells might be successfully bored in many places, although water would not probably rise to the surface at all points. There are few trees in the plain, execpting the belt which skirts the river. The only species noticed was the evergreen oak ( $Q$. agrifolic), no white oaks (robles) being seen in the plain after passing the San Antonio Range, although they occur on the hills. The fierce winds which blow up the valley would probably act as a drawback to the cultivation of trees on the plain. The forage consisted chiefly of bunch-grass and pin-grass, of which the latter is by far the most valuable.

A chain of hills-or mountains, as they might be called-commences 
a little to the northwest of Monterey, and extends in a nearly southeast direction, skirting the Santa Lucia Range on its castern side. This chain is about seventy-five miles long from Monterey to where the Salinas River cuts it. In the Pacific Railroad Maps, on both Parke's and Warren's, it is called the "Sierra de Salinas;" but it is known on the spot by different names: the southeastern end, as before noticed, is called the "San Antonio Hills," while the northwestern portion, or, rather, the hills lying west and southwest of the Soledad Mission, is known as the "Palo Scrito Hills." This chain skirts the Salinas Valley and the Bay of Monterey on one side, and is separated from the Santa Lucia Range by the valleys of the Carmelo and San Antonio Rivers and the lateral tributaries of the Arroyo Seco.

The hills lying between the Bay of Monterey and the Carmelo Valley have a height in places of near 2000 feet; the central part of the chain, especially the mountains between the Tularcitas Ranch in the Carmelo Valley, and the Guadelupe, Paraje de Sanchez, and Soledad Ranches in the Salinas Valley, has an elevation of from 3000 to 3500 feet, while the southeastern extremity of the chain, or the San Antonio IIills, seldom rises above 2500 feet.

Both ends of this chain are almost entirely made up of bituninous slate, but slightly metamorphosed, while the higher central portion contains much highly altered rock, with some slate, in its original condition, on the western slope.

As has already been remarked, the San Antonio Hills were only hastily examined; but, as far as seen, they were found to be made up of bituminous slate, which is there developed to an immense thickness, the strata being much broken, and indeed so much so, that no definite knowledge of their general position could be obtained.

From Mission Soledad to the Guadelupe Ranch, the mountains rise very abruptly, the slopes being steep and covered with chaparral. The rocks on the east side are nearly all metamorphic, consisting chiefly of mica-slate, in places interstratified with gneiss, while the western slope is made up partly of metamorphic rocks and partly of the unaltered bituminous slate. The boulders seen at the base were mostly of micaslate. The ridge was ascended from Camp 31, at the Guadelupe Ranch, the ascent on that side being very steep for 2500 or 3000 feet, 
and the rock mica-slate, with a general northeast dip, and traversed by veins of quartz. The soil was found to be light and dry, supporting a dense growth of chaparral. The summit was several miles wide, worn into rounded hills, all of mica-slate, the highest points being about 3500 feet above the sea, and covered with wild oats and scattered patches of chaparral, with here and there a few oaks. On the western side the descent was much more gradual. Several beds of highly erystallized limestone were noticed in ascending on the eastern side, at an elevation of from 2500 to 2800 feet. This limestone, as well as the mica-slate, contained many minute crystals of graphite, which were most perfect in the calcareous rock; these crystals were usually arranged along certain lines in the limestone, so as to give it a stratified appearance, and, in the weathered portions of the rock, marks of the original planes of deposition could be traced in the highly crystalline material. This rock had been "prospected" for silver wherever the graphite was abundant, as had also the metamorphic slates under the same circumstances.

The west slope of these hills was seen on a trip up the Carmelo Valley and through the Arroyo Seco. It consists of the white bituminous slate, traversed by bands of mica-slate and gneiss. Professor Brewer thinks there is no doubt that these rocks have resulted from metamorphic action on the bituminous slates, the carbon of the bitumen appearing in the altered rocks as graphite. No traces of an eruptive axis were observed in this chain, and there was everywhere a complete conformability between the altered and unaltered rocks as to dip and strike.

The chain of the Palo Scrito Hills trends more westerly as we leave the Guadelupe and Buenavista Ranches, going towards Monterey. Where examined near that town, and between it and the Mission Carmelo, the bituminous slate was found to be entirely unaltered, and to dip northeast at a low angle, forming a range of hills with rounded outlines. Near Monterey it is very light in texture, and contains some fossils, the first obtained from this rock, although it had been closely examined at many points, for a distance of 300 miles along its outcrop. The only good locality found was one about two miles southeast of the town, at some old quarries, where a sufficient number of species were GEOL. VOT. I. -20 
obtained to enable us to fix the age of this extensively developed formation; it belongs to the Miocene Tertiary.

The rock is soft and can easily be cut with an axe, yet it is sufficiently durable, in that climate, to be used for building purposes; walls laid 50 or 60 years ago still show the marks of the tools used in dressing the stone. The Mission Carmelo is built of this material, and has withstood exposure well. Both sandstone and limestone, more or less impregnated with bitumen, occur in the slate. The sandstone is in thick strata, and has been used for a building material. The slate crosses the Carmelo River and forms high hills, best seen in the "Potrero de Sar Carlos" Ranch, about three miles from the sea, where it rises to the height of about a thousand feet, the strata having a general dip to the northeast, and being in places more or less silicified. After ascending the Carmelo some six or eight miles, this formation is found to be entirely confined to the northeastern side of that stream.

Extending east from Monterey to the Salinas Valley, at the Buenavista Ranch, a group of rocks, newer in age than the bituminous slate, is seen resting on the north flank of the Palo Scrito Hills; they were examined on the Toro and Laguna Seca Ranches. The rocks of this formation are sandstones and conglomerates, and, in one place, a limited outcrop of argillaceous limestone was seen. The strata have a thickness of several hundred feet, and some beds are quite fossiliferous. The following species were collected here:

NePTUNAA RECURVA,

MODIOLA RECTA,
MODIOLA CAPAX,

ARca CANALIS.

These sandstones and conglomerates are either horizontal, or inclined at an angle of less than $20^{\circ}$ to the north and northeast; but nearer the main chain of the hills they are somewhat broken, and dip at a higher angle. They have been much denuded since their elevation, and a number of good sections can be obtained in the Cañada of El Toro. Some portions of this rock disintegrate into a soil of sufficient firmness to support a tolerable growth of wild oats; but it is generally much inferior to that produced by the bituminous slate, and large portions of the region underlaid by it are covered by a dry sand, which is over- 
grown with thickets of low chaparral, and is of little value for agriculture. These rocks appear to belong to the upper division of the Miocene Tertiary; but a more careful investigation is necessary, to determine exactly the relations of the group to the underlying beds of bituminous slate. A map of the vicinity of Monterey, on a large scale, has been begun; but it is not yet completed.

To obtain further information with regard to the rough and unknown region lying between the Salinas Valley and the Ocean, an excursion was made up the Carmelo Valley to the Arroyo Seco. In passing up this valley, intrusions of granite are seen occurring near the coast, which will be noticed farther on. For six or eight miles, the bituminous slate is found on both sides of the river, forming rounded hills of from 1200 to 1800 feet in height. Beyond this, the river, for a few miles, follows a break between the sandstones and the bituminous slates, the left bank being occupied by the sandstones, and metamorphic patches begin to be seen. Near the river are heavy beds of sand and detritus, chiefly derived from the decomposition and wear of micaslate. At the distance of fifteen or eighteen miles from its month, the valley assumes the character of a cañon, and leads back into the heart of the mountain with a more southerly direction. It was not possible to follow it any farther, but a route was taken which led diagonally across from the Carmelo Valley to that of the Arroyo Seco. On this line of travel rounded hills of bituminous slate were crossed, covered with wild oats and affording good pasturage. In passing through the valleys between these hills, frequent localities of sandstone, slate, and metamorphic rock were noticed, the strata being much broken, and the sandstones generally on the south side of the road and the slate on the north. Near the Arroyo Seco, however, the sandstones retreat, and the slates pass farther up into the San Lucia chain. The only fossils seen were some fragments of bone in a boulder near Finch's Ranch, and a single vertebra (cetacean?).

On approaching the Arroyo Seco, the strata are not only much broken, but are often contorted, as if they had been subjected to disturbance and compression while still plastic. They appear to have been caught in and folded between the two axes or lines of upheaval of the Palo Scrito and Santa Lucia chains. The Arroyo Seco heads far 
back in the Santa Lucia chain, breaks through its ridges and again through those of the Palo Scrito Hills, at nearly right-angles to their direction, and issues forth into the Salinas Plain at Soledad Mission, not as a creek, but as a dry, wide, sandy bed of one. The "Arroyo Seco" proper is the dry bed of the creek, or of that portion of it which lies in the Palo Scrito Hills, and where the stream sinks; but above this it is a large and permanent flow of water; this is, however, in a region perhaps as little known or visited as any part of California west of the Sierra.

In an excursion into this wild region, our party struck the river at fourteen miles from Soledad, and pushed up the cañon several miles into the Santa Lucia chain. At the point where the cañon was entered, near Robinson's Ranch, the slate lies at every conceivable angle of dip and strike, but the great masses have a general inclination to the northeast, and are in places considerably metamorphosed. The cañon appears to occupy a break in the strata, in which were large masses of rock highly inclined, and which had suffered much compression and distortion. Some of these folds are on a grand scale, and very interesting, as they are so well laid open for examination in the sections which the stream has cut through them. Among the various exhibitions of contortion and flexure in these strata, the annexed example (Fig. 25) may be selected; it was taken about two miles above Robinson's Ranch, and represents a length of from 800 to 1000 feet, and a vertical elevation of about 300. Many others, on an equally grand scale, were ob-

Fig. 25.

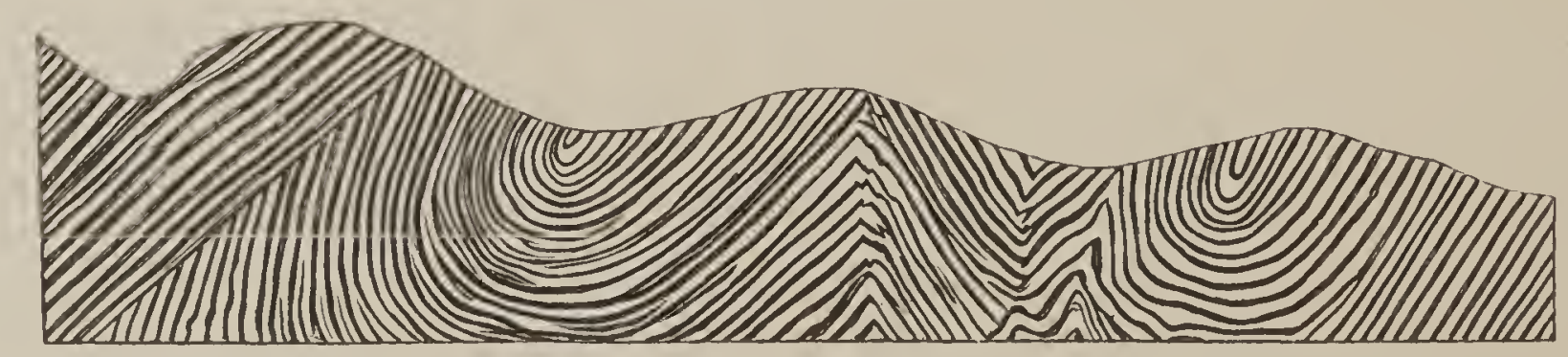

FLEXURES IN THE BITUMINOUS SLATE ON THE ARROYO SECO.

served in this vicinity. Such contortions are most abundant in the cañon; in the great masses of the hills, the dip of the slate is much more regular, the formation overlying the sandstone with a general dip to the northeast. Immense mountain masses were seen in this position. 
Farther up the cañon occur large masses of sandstone, much broken, but still having a general northeasterly dip. Not unfrequently the slate forms ridges displaying great folds and disturbances, and heavy bodies of strata have an inclination in the opposite direction from that of the sandstone strata in the vicinity; this may be seen represented on the annexed section (Fig. 26), in which $a$ and $b$ represent two hills of sandstone, one before and the other behind the ridge of slates, and having

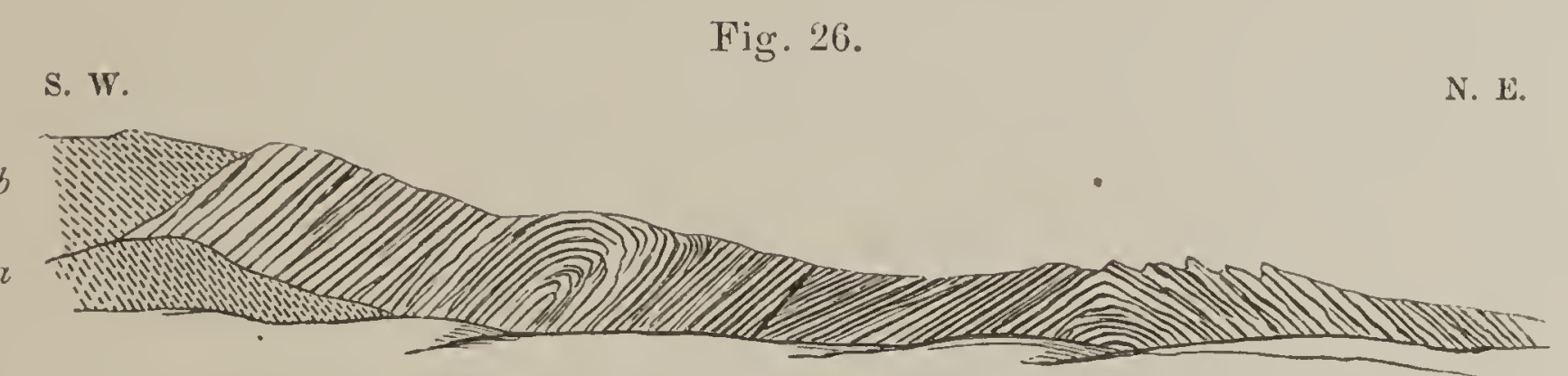

SECTION OF RIDGE IN CAÑON OF THE ARROYO SECO.

a northeast dip, while the great mass of slates between them dips to the southwest.

The Santa Lucia chain has already been spoken of several times, and its structure near San Luis Obispo given in section. It remains to add what little farther information has been obtained with regard to its northern extension.

Beginning at Point Carmelo, the Santa Lucia rises suddenly, and extends along the coast in a range unbroken by any considerable depression, and not crossed by any road, for a distance of fully one hundred and ten miles, namely, to the San Luis Obispo Pass. For at least ninety miles of this distance, the chain consists of the most rugged mountains, and is entirely unexplored; the Coast Survey have made no attempt to carry their triangulation along its craggy ridges, as has been done both to the north and south. A few small ranches exist along the coast, for thirty miles south of Monterey, and are reached by a path along the shore. Three or four trails are said to cross the chain, but little is definitely known in regard to them, except that they are very difficult and very little used.

Wherever this chain was seen from the lesser heights, at various points in the Palo Scrito Hills, it appeared as a succession of very sharp ridges and peaks, furrowed by deep cañons, all the slopes being steep and mostly covered with dense chaparral, while the whole region is 
exceedingly dry during the summer months. Many peaks were seen which were estimated at from 4000 to 4500 feet in height, and some probably reach 5000. Owing to the rugged character of the mountains, the scarcity of water, the extreme density of the chaparral, and the number and ferocity of the wild beasts, which have full possession of the region, it would be a peculiarly difficult one to explore, perhaps more so than any other portion of the State of equal area.

Only the most eastern of the ridges were visited, and these only at a few points. Granite exists in large masses in the interior of the range; it occurs at Point Carmelo and extends along the coast to El Sur, twenty miles from Carmelo Bay, and possibly much farther. Various authorities, among the few mountaineers who know anything about the chain, speak of large quantities of very decomposable granite as existing at various points in the mountains; and boulders in the Nascimiento, San Antonio, and Arroyo Seco Rivers show that this rock is abundant near their sources. Resting on the granite is a sandstone of Tertiary age (probably Miocene), and very extensively metamorphosed. Every variety of form of the metamorphic sandstone, so often spoken of as occurring in the Coast Ranges, is seen here, especially serpentine. Gold has been found at various places, although nowhere in large quantities. Placers are or were worked during a portion of the year near San Antonio, and the precious metal has been found at other places. Small quantities of silver ore, argentiferous galena, have been found at Arroyo Seco, and have caused, at times, much excitement and the expenditure of several thousand dollars, without any prospect of getting back a single one of them. Copper stains are also abundant in the metamorphic rock; but nothing is known of the existence of workable veins.

The greatest width of this mountain region is about twenty-five miles, and the average about eighteen; thus there is here an area of not less than 1500 square miles, entirely unexplored, and which will probably remain so for a long period to come. 


\section{Section III.-The Gavilan Range.}

The Gavilan chain lies between the Salinas Valley on the southwest and the San Juan and San Benito Valleys on the northeast; it extends from the Pajaro River on the northwest, and may be considered as terminating at the San Lorenzo on the southeast. On the northwest, it is connected with the Santa Cruz Mountains by the hills near the Pajaro River, and from this end it has all the appearance of a distinct and independent range; but, as we follow it to the south, we find it gradually becoming merged in the Monte Diablo Range on the east, being separated from it by the very narrow valley, or cañon, of the San Benito. The region around the southeastern extension of this chain remains almost entirely unexplored, especially the portion of it between San Lorenzo and Chelone Creeks. As defined above, the Gavilan chain has a length of about seventy-five miles, and a breadth of ten. The peak at the noith end of the chain, called the "Gavilan Peak," was the only one measured; it is 2932 feet above Camp 38, near San Juan, and about 3381 feet above the sea. The dominating point of the chain, about thirty-five miles southeast of the Gavilan Peak, was estimated at 3800 feet; it is called Mount Chelone.

In crossing the Gavilan Range from the Salinas to San Juan, on the Monterey road, metamorphic limestone is met with on the southern side, the only other rock seen being unaltered sandstone, with sonthern dip, the strata considerably broken, and the hills scarcely over 1500 feet high. But on crossing the range, in the same direction, a few miles farther to the east, and getting a section through Gavilan Peak, nearly the whole series of rocks passed over was found to be metamorphic. The unaltered sandstones extend along the north side, near the San Juan Valley, forming the San Juan Hills, which extend to the Pajaro River; in these hills the strata are very heavy-bedded, and have a dip everywhere to the south. The materials of which they are made up are often coarse, and sometimes large enough to form a conglomerate, among the pebbles of which jasper and other metamorphic rocks predominate. Portions of the formation are fossiliferous; but all the shells found were in such a bad state of preservation that little or 
nothing could be made of them. There is not much doubt, however, that these rocks form a part of the Miocene Tertiary, so extensively developed in the Coast Ranges. Some bones were obtained from the sandstone near our camp at San Juan, but they have not yet been examined.

These rocks become metamorphic near the trail from the Cañon San Juan to Natividad Ranch. Along this trail serpentine was seen; but it was not discovered in the section extending through the peak. Metamorphic limestone exists abundantly in the region; it may be seen in a round, dome-shaped hill, 800 or 900 feet high, near Mr. Johnston's, on the Natividad Ranch; this elevation is a conspicuous object in approaching the chain from the north.

The same limestone forms the culminating points of this part of the range, namely, the Gavilan Peak proper, and those adjacent to it. These peaks, so conspicuous from either side, form a sharp ridge, several miles long, extending from east to west, its general direction from the summit being N. $78^{\circ}$ E.-S. $78^{\circ} \mathrm{W}$, the ridge curving and cutting the chain diagonally. This culminating ridge was examined at its highest point, and also three or four miles west of this; in both places the crest was of metamorphic limestone, with a high southern dip, $75^{\circ}$ to $80^{\circ}$, and in some places vertical. To the northward were metamorphic rocks, quartz, mica-slate, gneissoid granite, and beds of semi-crystalline limestone, the whole having a dip to the south of from $40^{\circ}$ to $80^{\circ}$. The strata on the southern slope of the crest were not passed over, but appeared to dip in the same direction. The gneissoid granite in the centre of the chain was in some places very hard, in others very decomposable, forming a dry, sandy soil, covered with a low chaparral, or chamisal. The whole range is much denuded, and worn into deep and precipitous cañons, which do not coincide in direction with the strike of the strata.

Section IV.-The Vicinity of the Bay of Monterey.

The geology of the region around Monterey and Carmelo Bay is of peculiar interest, owing to the presence of granitic and metamorphic 
rocks in close proximity to maltered strata, and the farorable opportunitios for studying the relations of these formations, afforded by the exposures in the cliftis along the Ocean, will always render this an attractive locality for the geologist.

The country to the east of Monterey is sandy and low, being a continuation of the Salinas plains, and the town itself is built at the point where this sandy plain ceases, and where the granite comes down to the sea, abutting against the hituminous slates, which also just touch the bay at this point.

The granite occupies the promontory, extending from Point Pinos to Cypress Point, and is bounded on the land side by a line drawn from Monterey to the Pescadero Ranch, on Carmelo Bay. It also occurs in several detached patches along the shore of the bay and a short distance in the interior; at Point Carmelo it forms the entire shore line again, and extends down the coast for an unknown distance. It was followed in this direction for eight miles, but is said to form the shore at El Sur, and it probably extends still farther, as has already been noticed, in speaking of the Santa Lucia Range, of which this granite mass forms a part.

This granite is coarse-grained, and contains crystals of feldspar (orthoclase), often two inches in length, and sometimes as much as four. It is frequently traversed by quartzose or feldspathic veins, and sometimes by those of granite of a different character from the principal mass. This rock has been quarried at Feint Pinos, near Monterey, and at Point Carmelo, or Point Lobos; at the last locality a large amount of it has been got out, some of it used, and the remainder left lying on the spot. Where the granite is free from sulphuret of iron, it is of excellent quality, dresses easily and with a handsome surface, and pieces which have been lying here for six years or more remain perfectly sound and retain their natural bright color. Some portions which contained pyrites have become discolored, and partly disintegrated; but the larger part secms to be good. The facilities for quarrying and loading are remarkably fine, and the quarry will probably come into use again. The rock consists of white orthoclase and quartz, with fine scales of black mica disseminated through the mass. A sand of the most dazzling whiteness, apparently formed by the action of the surf GEOL. VOL. I.-21 
on this granite, has accumulated in places along the beach; of this an cnormous pile lies near Cypress Point, and another near the Pescadero Ranch. The material seems suited to the manufacture of glass, at least of the coarser kinds, and should be tried for the finer qualities, as the locality is convenient and the quantity practically in exhaustible.

This granite is flanked by sandstone of Tertiary age (Miocene), and good opportunities were had of examining the junction of the two formations in various places. At the Point Lobos quarry just noticed, the sandstone dips from the granite, at an angle of $35^{\circ}$ immediately at the junction; but its inclination rapidly decreases, and is considerably less at a short distance from the line of contact. Both rocks are considerably altered, for a distance of about twenty feet from the junction; the sandstone is softened and disintegrated, and the granite discolored. At the Pescadero ranch-house, the contact of these two formations may also be examined; here the dip of the sandstone is towards the granite,

Fig. 27.

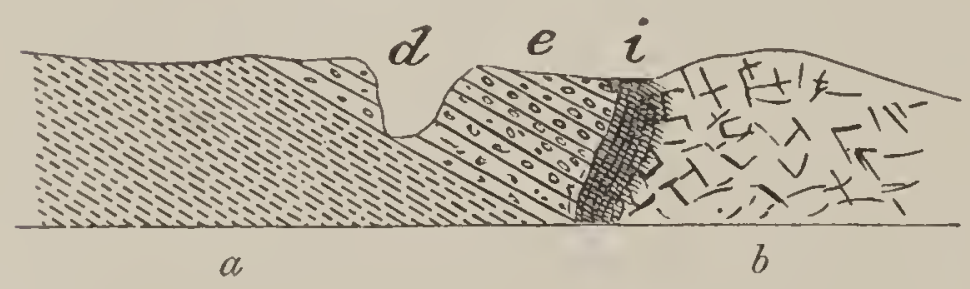

JUNCTION OF GRANITE AND SANDSTONE NEAR PESCADERO.

$a$. Sandstone, dipping south. b. Granite. $e$. Conglomerate. $i$. Junction; the shaded part indicating the extent of the metamorphism. $d$. Arroyo. as shown in the annexed section (Fig. 27). The metamorphism of these formations may be observed here, extending for a distance of twenty feet or thereabouts, and affecting both rocks, so that it would not be easy to say where is the precise line of junction; on both sides of it the rocks are softened, discolored, and more or less disintegrated. At other points the same, or similar, phenomena were observed.

At a small outcrop of granite directly west of the Mission, the sandstones are highly metamorphosed, for a distance of about three hundred feet, along the north side of the junction of the two formations. Through nearly the whole of that width, the granite is so soft that it can easily be crushed in the hand; but this change in structure is not more particularly marked in the immediate vicinity of the line of contact, than it is at some distance from it. The altered strata of sandstone dip away from the granite for a few feet, and then portions become exceedingly hard, and almost basaltic in appearance, although 
the planes of stratification are still evident. Portions of the strata are much twisted and contorted, and cindery in appearance. Although there cannot be much doubt of the proximity of volcanic rocks beneath the surface at this locality, there did not seem to be any visible; portions of the metamorphic strata might, however, be readily taken for eruptive, if they had been seen ont of their connection with the same rock in a less advanced stage of metamorphism.

The most interesting locality of all in this vicinity, for studying metamorphic action, is along the shore of the bay, a little to the southeast of the Pescadero ranch-house, where a long point projects into the water, giving a fine ehance to study the relations of the formations, which are well exposed on all sides. This mass of altered and eruptive rock is entirely inclosed in the sandstone, and has no granite near it, thus showing clearly that it is not the presence of this latter rock, which has effected such great changes in the sedimentary strata at various places around the bay. The cliffs on the north side of the projecting point rise from sixty to eighty, and in some places as much as a hundred, feet above the sea; the rock on this side is in places a hard, compact, dark-colored basaltic material, breaking up into prismatic fragments, apparently an eruptive mass originally, but now itself partially altered by the same causes which have effected so extensive a metamorphism of the adjacent sedimentary strata.

This partial metamorphism of the igneous mass exhibits itself especially on its borders, and, as one result, it is quite impossible to say where one formation commences and the other ends. Near the edge of the water, the eruptive rock is seen to rest on a bed of a brecciated conglomerate, made up of an accumulation of the fiagments of the sedimentary beds through which the volcanic material has forced its way. On the south side of the point, the results of metamorphic action are beautifully displayed along the broken edges of the strata, as seen in the gradual falling off of the clift's to the level of the water. In passing from the entirely maltered beds of sandstone towards the eruptive mass, the first evidence of change is detected in the reddening of the strata; then the lines of stratification become obliterated, which feature is particularly marked in the vicinity of the cross-reins of various mineral substances by which the rocks are intersected; next, 
the mass becomes scoriaceous, or is filled with amygdaloidal carities, growing more and more dark-colored, until it finally passes into what appears to be an unmistakably eruptive rock, although it would be impossible to say where the line separating the two formations should be drawn.

An extraordinary number of veins and rein-like masses of various minerals have been formed in the fissures caused by the uplifting of the intrusive mass through the sedimentary rocks; these are chiefly. seen on the southern side of the point. The material with which they are filled is principally carbonate of lime, having a radiated structure; silica, in the form of crystallized quartz, also occurs, as also some serpentine. Wide spaces of the metamorphic mass are sometimes filled with a network of small veins of these various minerals, and the large reins have many fragments of the wall-rock scattered through them, so as to form, in some places, a regular breccia. Hardly any traces of metalliferous ores are seen in these veins, and no zeolitic minerals were detected; indeed, the volcanic masses, and the sedimentary beds which have been metamorphosed by them, are, throughout the State, remarkably destitute of interesting associated minerals, such as the zeolites. In several respects the appearance of the rocks just noticed strikingly resembles that presented on Lake Superior, at many points along the line of contact of the trap and sandstone, showing that the physical conditions were very nearly the same, during one of the earliest geological periods, when the Lake Superior volcanic beds were poured forth, as those which prevailed at the very recent epoch when the Pacific coast was the scene of the display of these forces. A set of specimens, from the Silurian sandstones and the accompanying volcanic rocks of nearly contemporaneous age, might be made up on the shores of Lake Superior, which would hardly be distinguished from another collection which could be gathered around Carmelo Bay, where the eruptive intrusions and subsequent metamorphic changes have all taken place since the epoch of the Miocene Tertiary.

A map of the vicinity of Monterey, including Carmelo Bay and extending east to the Salinas River, on a scale of two miles to the inch, has been partly prepared by the Survey, on which the details of the geology will be giver. This map will be completed and published, in 
the rolume of maps and sections, forming a portion of our Final Report. There are many things about Carmelo Bay to make it an attractive region; and we may contidently predict that it will, at some future time, become a place of resort, if not for the fashionable world, at least for those who would combine with the enjoyment of the ocean breezes, the pursuit of geological, botanical, or zoological studies; in each of these departments there is much that is interesting, and some things that are peculiar, to be found between Cypress and Carmelo Points and in the adjacent region.

Extending along on the east side of the Bay of Monterey, nearly the same rocks are found which have already been noticed as occurring to the south. From San Juan to the Pajaro Valley, near Watsonville, low hills of sandstone occur, with a gentle dip to the south. The Pajaro Valley is an inclosed basin through which the river of the same name finds its way; the bottom-land is some three miles wide and six or eight long, of extraordinary fertility, and under high cultivation. This valley, as well as the region near Santa Cruz, does not suffer so severely from drouth as the country farther east, being watered by the fogs and dews from the sea. In consequence of this, trees are more numerous, and grain and fruit crops reliable. The rocks are the bituminous slates, nearly horizontal in position. Terraces were observed on the north side of the Pajaro Valley, and also in the vicinity of Santa Cruz, especially to the east of the city. There are two which are well marked and extend for several miles; of these, the first forms a bluff bank along the sea-shore, 64 feet high, near Camp 44, one mile southeast of the town, and extends back in a nearly level table from half a mile to two miles in width, although somewhat cut up by arroyos; on this terrace the town of Santa Cruz stands. The second is 199 feet above the first, or 263 feet above high tide; it was examined in several places, the best locality for that purpose being behind the Mission Church, near the town. This table is not as wide as the other; but is still a marked feature in the landscape.

In the vicinity of Santa Cruz the rock is the bituminous slate, some portions of which are quite light and soft, while others are more silicious; in one case, a stratum of six or eight feet in thickness was noticed as being entirely silicified. The strata are nearly horizontal, 
or have only a slight dip to the south on the shore, but are apparently conformable with the broken and highly inclined beds in the mass of mountains to the northeast of the town, as if the upheaving force had not extended entirely to the coast in this direction.

An extensive outcrop of metamorphic and highly crystalline limestone occur's on the ranch "Cañada del Rincon," about two miles northwest of the town. It was not easy to determine its position with positive certainty; but it appeared to have a dip to the north of from $65^{\circ}$ to $68^{\circ}$. The rock is usually pure white, but portions of it are brown; this color is discharged by burning, leaving an almost perfectly white lime. The discoloration is probably due to bitumen, as the rock emits the odor of this substance when struck. It is extensively burned for lime by Messrs. Jordan and Davis, whose kilns produce about 500 barrels per month. The rock is quarried in a cañon near by, and transported to the kilns on a tram-road, the loaded cars descending by gravity. All the necessary facilities for producing good and cheap lime are found here, and this concern supplied the entire consumption of San Francisco and the adjacent region.

\section{CHAPTER VI.}

THE COAST RANGES FROM THE VICINITY OF LOS ANGELES, SOUTH.

\section{Section I.-Preliminary Remaris.}

In the preceding chapters we have given a general idea of the geological structure of the Coast Ranges in the vicinity of the Bay of San Francisco and to the south of it, as far as the Sierra Santa Susama and the Plain of San Fernando. It now remains, to complete what we have to say before passing to the Sierra Nevada, to take up the southern extension of the Coast Mountains, the portion yet remaining to be described being the ranges from the Santa Monica and San Gabriel chains southward to the border of the State.

Thus far, in our summary of the geology, we have had no difficulty 
in distinguishing the Coast Ranges from the Sierra; but we have now arrived at a point where it is necessary either to draw an artificial line separating one system of mountains from the other, or else to establish some criterion by which they shall be geologically distinguished, as it is evident, from a simple inspection of the map, that below the San Gabriel Range we have no longer any guide to the settlement of this question in the topographical character of the country. Without stopping here to go into a full investigation of the matter, we would simply say that we consider all those chains or ranges of mountains to belong to the Coast Ranges, which have been uplifted since the deposition of the Cretaceous formation; those, on the other hand, which were elevated before the epoch of the Cretaceous are reckoned as belonging to the Sicra Nevada.

In passing from north to south along the foot-hills of the Sierra, we find, at numerous points, the marine Tertiary or Cretaceous, or both, resting in a horizontal position on the upturned edges of the slates and metamorphic rocks of the auriferous series. As we skirt the base of the Sierra, however, in the region where this chain turns to the west, towards Fort Téjon, we pass at once from undisturbed Tertiary to strata of the same age which are elevated at a high angle, and, in so doing, we leave the system of the Sierra and pass over to that of the Coast Ranges. This change takes place about midway between the Téjon Pass and the Cañada de las Uvas; but no break in the mountain ranges indicates this transition. The great lines of disturbance are so closely connected with each other in direction, and they have been so affected in this vicinity by the existence of secondary ones, that the topography of the country does not reveal the geological facts, which not the less do really exist.

Starting then from a point a little to the east of the Cañada de las Uvas, and drawing a line which shall leave on the west all the mountains elevated since the deposition of the Cretaceous, and on the east those which have not been disturbed since that epoch, we find that, according to the present state of our knowledge, this line will pass to the east of the San Gabriel Range, through the Cajon Pass, to the east of the Temescal Range and on the south of the Santa Anna, striking the Ocean in the vicinity of San Luis Rey, which is the most southerly 
point to which the Coast Range system has been traced. The masses of San Bernardino and San Jacinto are included in the Sierra Nevada, which runs south and occupies the peninsula of Lower California, the Coast Range system not having an existence in that region.

The principal group of mountains included in the portion of the Coast Ranges now under consideration are, the Sierra Santa Monica, the San Gabriel, the Temescal, and the Santa Anna Ranges. These will be taken up in this order, and the result of our very hasty examinations in this region given.

\section{Section II.-Sierra Santa Monica.}

The range of mountains, called the Sierra Santa Monica, extends along the coast, west of Los Angeles, beginning to the west of the Cahuenga Pass, and terminating on the Pacific, in a bold headland, called Point Mogu. There are no roads, or passes with travelled trails, across this range, the main channel of land communication between Santa Barbara and Los Angeles being to the north of it, through the Cahuenga Pass. The length of the chain is about thirty-six miles, and its width from north to south about six.

Near the east end of the range, at Hancock's Cañon, about nine miles west of Los Angeles, a dark silicious slate, or slaty sandstone, is exposed along the south flank of the mountains. It has a very considerable thickness, and dips away from the centre of the chain, or towards the south, and is succeeded on the north by the mass of granite forming the axis of this group of elevations, and from which the rocks dip on each side (see section on page 121, across the Santa Monica and Santa Susanna Mountains).

The slates run about N. $70^{\circ}$ W.-S. $70^{\circ}$ E., the trend of the strata being a little more to the north than the direction of the range itself. The granite axis is here perhaps a mile in width, and near it the slates are much hardened and metamorphosed, and penetrated by small veins of quartz. The same formation occurs on the north side of the intrusive mass and also dips away from it, displaying exactly the same phenomena of metamorphism as on the south flank, so that we have here 
one of the best possible examples of a truly anticlinal range of mountains, with a central core of granite, having all the appearance of an intrusive rock which has burst asunder and elevated the slaty strata, producing a highly metamorphic condition of the sedimentary beds along the lines of contact of the granitic mass; these chemical changes, as well as the mechanical displacement of the strata, become less and less conspicuous as we recede in either direction from the intrusive central core.

The rock in place is almost everywhere concealed by a heavy covering of granitic detritus, which is formed by this easily decomposing rock, the harder portion being left, like boulders, on the surface. The slates, on the north side of the range, pass into sandstones, which extend down to the San Fernando Plain. The whole chain is deeply furrowed by cañons, which run at right-angles to its general direction, and give it the appearance, as seen from the high points of the San Gabriel Range to the east, of being made up of a series of parallel north and south ranges. The denudation has, in some places, left the granite in the form of long ridges, ruming north and south, on the summit of which there is hardly more than room for a trail, while the sides slope in each direction from the crest of the ridge with a very steep descent.

The Santa Monica chain was also examined from our camp at the mouth of the Santa Monica Cañon, about fifteen miles from Los Angeles. This cañon runs far up into the range, and a passable wagonroad might easily be made through it across the range.

This cañon is finely terraced at its mouth, where it meets the Ocean. There are four well-marked benches. The first and second of these are close to the beach, and respectively 15 and 25 feet high ; the third is 325 feet behind the second, and 17 feet above it; the fourth 192 feet back of the third, and 91 feet above it, making the total height from the sea to the summit of the highest terrace, 148 feet.

An interesting section was observed on the sea-shore, a little above the month of this cañon. A valley seems once to have existed here and afterwards to have become filled with stratified sedimentary material, as represented in the annexed section (Fig. 28).

The cliff, which rises nearly perpendicularly from the ocean-beach, to the height of about $\mathbf{1 7 5}$ feet, is made up of horizontally stratified ( 
detritus, consisting of coarse and angular materials, chiefly fragments of the bituminous and silicious slates of the vicinity. In this terrace or bed of detritus, there was once a valley, or ravine, extending down

Fig. 28.

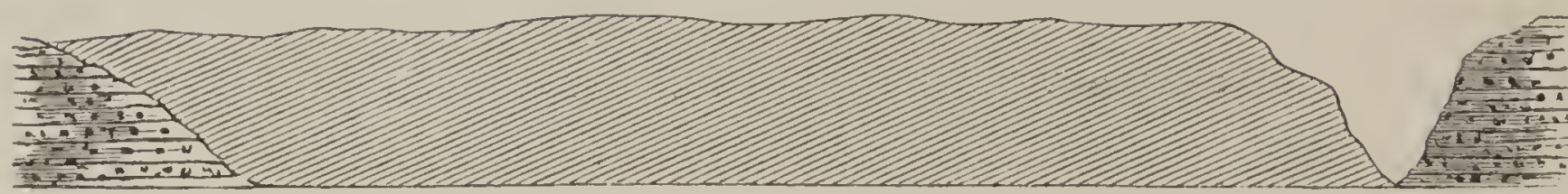

1. . . . . . . . . 560 feet. . . . . . . . . . 1

INCLINED STPATIFICATION IN RAVINE NEAR SANTA MONICA CAÑN.

to the present level of the Ocean, and 560 feet wide, as now shown in the section exposed in the bluff' which has been formed by the action of the sea. The terrace or plain of detrital materials is spread out at the base of the Santa Monica, having a width of three or four miles, and the canon of the same name is cut in it to a depth of about 150 feet. The curious feature in this ancient valley is, that, after its formation, it became filled up again with detrital material, perfectly distinctly stratified, and everywhere inclining at an angle of $23^{\circ}$, as represented in the wood-cut. The material is a fine sandy loam, with a few small, rounded pebbles, and quite different in appearance from the horizontally stratified detritus on each side. This is an interesting section, as showing the possibility of the deposition of a large body of stratified material with perfect regularity at as high an angle as twentythree degrees. What the extent of this mass of inclined strata back into the interior may be, it was impossible to ascertain.

At the entrance of the Santa Monica Cañon into the mountains, there are heavy masses of conglomerate, very coarse, made up of quartz pebbles mixed irregularly with fragments of slate and sandstone, and destitute of any regular stratification, although very thoroughly consolidated. This formation shows itself in nearly vertical cliffs, fully 200 feet ligh, along the mouth of the cañon. It is probably a late Tertiary formation, and of the same age as the conglomerate which occurs near Los Angeles, in the low hills to the south of the town.

Beyond this conglomerate to the north, for the distance of a mile up the cañon, the rock is a coarse, quartzose sandstone, of a brownish- 
yellow color, and much broken up, so that the planes of stratification could hardly be made out. This is suceeded by a dark-colored, slightly bituminous slate, in which no trace of fossils could be discovered. This rock dips to the south, until we reach the centre of the chain, where there is a break and a sudden reversal of the strati, which, for the rest of the way across the canon, dip to the north, forming an anticlinal axis, although there is no intrusive rock visible in this section. The slate, however, is much metamorphosed in the central part of the range, assuming the appearance of a trappean rock and breaking up into small prismatic fragments. Proceeding north, we find this metamorphosed rock gradually reassuming its original appearance of a soft, unaltered slate, with almost exactly the same succession of changes which was observed in Hancock's Cañon, where the intrusive granite has come to the surface and occupies the centre of the chain. The bottom of the cañon is covered with a thick deposit of fragments of blue and black slate, with little soil, but supporting a dense growth of evergreen oaks. It is from the cañons of the Santa Monica Range that Los Angeles is chiefly supplied with fuel.

A sufficient number of fossils were discovered in the unaltered sandstones of the Santa Monica Range to fix their age as that of the Miocene Tertiary.

The following species were noticed by $\mathrm{Mr}$ : Gabb in the collections made in this chain, and chiefly in Hancock's Cañon:

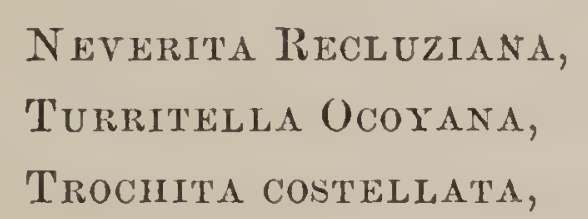

NeveriTA RECLUZIANA,

Trochita costellata,
Cerithidea sacrata,

Cardita SUBTENTA, Mytilus Edulis.

Section III.-San Gabriel Range, and the Vicinity on Los Angeles.

The San Gabriel Range, as we denominate it, is a vast mass of mountains, extending from the Cajon Pass on the east, and joining with the Santa Monica and Santa Susanna Ranges on the west. It is fully 60 miles long, and from 20 to 25 broad from north to south, forming an extensive region of lofty and rugged mountains, of the interior topo- 
graphy of which nothing is yet accurately known. Even the name of its dominating peak, San Antonio, has not yet found its way on to any map. We have given to the whole range the name of San Gabriel, in preference to that of San Antonio, as the latter has been already applied to another chain. San Gabriel is the designation of the principal cañon by which the chain is traversed, and of the only stream of any size which heads in it.

The San Gabriel Range has heretofore been very differently classed and connected with the other mountain ranges of this region, by rarious writers on the geology and topography of this portion of the State. By some, it is considered as a continuation of Mount San Bernardino, and called by that name; by others, it has been made a part of a separate chain, extending from near the San Enidio Cañon down through the Peninsula of Lower California. As, however, we know that the San Gabriel Mountains have been elevated since the deposition of the Cretaceous, and as there are strong reasons for believing, on the other hand, that Mount San Bernardino belongs to the system of the Sierra Nevada, it is impossible to include these two ranges under one name, although they are topographically closely connected with each other, just as are the Coast Ranges and the Sierra near Fort Téjon.

The mass of the San Gabriel Range is of granitic and highly metamorphic rocks, the granite being very extensively developed on the south side of the chain, and appearing to be a part of the same upheaval with that of the central portion of the Sierra Santa Monica. Two high points of granite, without names, nearly north of Los Angeles, were measured and found to be 4760 and 5346 feet above the sea. In this portion of the range, the rock is exclusively granite, except at the base of the monntain, where Tertiary sandstones are seen in the arroyos which have cut down through the heavy masses of Post-Tertiary detritus, which lie piled up against the flanks of the range, to a height in places exceeding 1000 feet.

The San Gabriel Cañon is said to extend nearly through this chain, in a north and south direction. We followed it up a few miles and found its sides very precipitous, and the rocks all highly metamorphic. Boulders of slate, hornblende-rock, and gneiss, were strewn in the 
greatest profusion along the bottom of the cañon, which during the rainy season is hardly wider than the bed of the river. Just after our arrival at the entrance of the cañon, and as we were preparing to explore it more fully; we were entirely cut off from all access to it by the sudden rise of the San Gabriel River, after a three days' rain, which completely filled the gorge, drowning several persons. Specimens of copper ore were shown us, brought from some distance up the cañon; some silver ore has also been found, and much prospecting done for this metal, a few miles from the mouth of the gorge. If we are correct in referring these metamorphic rocks to the Cretaceous epoch, it is not probable that any very valuable veins of copper or silver will be found here. There is more or less washing for gold going on, during the winter, in and about the bed of the creek, as also along the base of the range at various points, especially near the entrance of the Santa Anita Cañon. It was not easy to ascertain whether these washings were very profitable; but it was inferred, from all that was seen, that they were not particularly so.

The highest point of the San Gabriel Mountains is known as San Antonio; it is towards the east end of the range, and is a conspicuous point from all the region to the south. We estimated it to be about 6500 feet high, although not near enough to give a very reliable guess at its altitude. The southern edge of the chain was explored by us, for some six or eight miles to the east of the mouth of the San Gabriel Cañon. There are immense masses of sandstone and conglomerate, probably of Tertiary age, along the foot of the range, which have, in places, been completely overturned, so as to dip to the north, or towards the centre of the chain. These rocks are penetrated by dykes of granite in all directions, and most irregularly and peculiarly metamorphosed. The whole of this side of the chain shows most extensive disturbances and porverful metamorphic action to have taken place, at a very recent geological epoch, or after the deposition of the Miocene 'Tertiary.

At a few miles' distance to the south of the San Gabriel Range, and parallel with it, is a low range of hills, which are made up of sandstones and dark argillaceous shales; these appear in places to have been thoroughly broken up, and recemented by sand forced in between 
the fragments, forming a singular breccia. Other portions of the range have evidently been the seat of extensive hot springs in former times, and have undergone a thorough process of silicification. Large masses of strata consist of fragments of sandstone, each surrounded by a coating of chalcedony, presenting truly a remarkable appearance. Everything would indicate the proximity of voleanic fires to this range of hills; but no rock which could be with certainty classed as eruptive was seen here.

In the vicinity of Los Angeles the rocks exposed are chiefly argillaceous, shaly sandstones, with dark-colored shales interstratified; these rocks are highly bituminous, and have a general southerly dip. In the Arroyo Seco, which comes into the Los Angeles River from the northeast, these strata are well displayed; they there dip to the south at an angle of from $25^{\circ}$ to $45^{\circ}$. The bitumen is seen oozing out, in many places, from the shaly beds, sometimes forming what are generally known as "tar-springs;" this material hardens, on exposure, into "brea," or asphaltum.

The heights bordering the Los Angeles River, two miles north of the city, are made up of this argillaceous sandstone, with occasional pebbles of quartz disseminated through it. The strike of these beds is about $\mathrm{N} .80^{\circ} \mathrm{W}$, and their dip to the south at a high angle. Over 300 feet in thickness of this formation is there exposed. A little farther south the same strata are turned up at as high an angle as $70^{\circ}$. In some places these shales and sandstones are capped by horizontal deposits of coarse conglomerate, made up of pebbles of granite, quartz, and hornblende-rock, and not firmly consolidated. This is evidently a very modern formation, although elevated at least 100 to 125 feet above the plain. There is a thickness of 25 to 30 feet of this conglomerate exposed.

About seven miles due west of Los Angeles is the most important of the numerous tar-springs seen in this vicinity. It is from here that most of the asphaltum used in the town is obtained. Over a space of fifteen or twenty acres, the bituminous material (which when seen by us, in the winter, had exactly the consistency and color of tar) was oozing out of the ground at numerous points. It hardens on exposure to the air, and becomes mixed with sand and dust blown into it, and is 
then known as "brea." The holes through which the bitumen comes to the surface are not large, few being more than three or four inches in diameter. On removing the tarry substance froni the holes, by repeatedly inserting a stick, the empty cavity was very slowly filled up again. At one place there was a pit several yards square, and six or eight feet deep, from which the tar had been taken; but it was filled with water, at the time of our visit, in consequence of late heavy rains. The brea is used almost exclusively for covering roofs at Los Angeles, selling (in 1861) at the springs for $\$ 1$ per barrel, the purchaser collecting it himself, which is done by digging a pit two or three feet deep by the side of one of the koles from which the tar is issuing, and letting it fill up. A very large amount of the hardened asphaltum, mixed with sand and the bones of cattle and birds which have become entangled in it, lies scattered over the plain. Before 1860, the experinent of shipping it to San Francisco, for the purpose of distilling burning oil from it had been tried, withont success, at least in a pecuniary point of view.

The plain on which Los Angeles is situated is celebrated for its beauty and fertility, as well as for the equable character of its climate. The San Gabriel Range to the north of it furnishes the water necessary for its irrigation, from the melting of the snow which accumulates on its highest summits, during winters in which the precipitation of moisture is not below the average. The ranches along the base of the momtains are especially attractive, and the vineyards and fruit orchards have already become quite celebrated. As we rise towards the base of Mount San Bernardino, the plain, which is there a little over 1000 feet above the sea, becomes dry, and in places is covered by desert sand. There are also valuable farming lands on the lower portion of the Santa Anna River.

\section{Section IV.-Santa Anna and Temescal Ranges.}

The Santa Anna Range is an exceedingly broken chain of mountains, covered almost everywhere with the thickest chaparral of oaks and ceanothns, and has been but little explored or traversed even by hunters. It begins, on the northwest, in low rolling hills, not wooder, 
which rise near the San José Creek, and it extends to the southwest for about fifty miles, when it becomes merged in the broken east and west ranges which traverse the country to the north of the Santa Margarita River. The range of the Santa Anna is broken through by the river of the same name, which traverses it nearly at right-angles to the direction of the chain. At the point where it intersects the range, the river has an elevation of 437 feet above the sea, and the mountains rise to an altitude of 3033 feet about three miles south of it, and continue to form an elevated range of from 3000 to 5000 feet as far south as we followed it, which was about twenty miles.

Near the Santa Anna River, and at an altitude of 1500 feet above it, the mass of the mountain was found to be made up of coarse sandstones and conglomerates, the latter containing rounded and polished pebbles of granite, jasper, and quartz. The whole series of beds dips to the northeast at a high angle, being in many places nearly vertical. In the sandstone we discovered a few (cetacean ?) bones, and some imperfect Tertiary shells, believed to be of Miocene age. The strike of these beds is nearly that of the axis of the chain, or about northwest and southeast; the dip becomes more nearly vertical as we approach the summit of the mountain.

An immense accumulation of detrital material lies around the base of the range, and in the cañon of the Santa Anna River. Just below the junction of this stream with the branch coming in from the Temescal Valley, the coarse, unconsolidated gravel forms great tables, 350 feet in height, with precipitous sides and quite bare of vegetation. The same kind of materials occupies the bottom of the Temescal Valley, and slopes from the range of that name up towards the Santa Anna Mountains, forming an accumulation, at their base, of not less than 500 feet in thickness, furrowed in some places by wide cañons fully 200 feet deep. These gravels are the "wash" of the mountains, or the detritus brought down from the disintegrating Tertiary strata, by the storms of successive winters. Several miles farther up the valley, and to the west of the Temescal ranch-house, the same sandstones were seen which have been described as occurring to the south of the Santa Anna River. Here, the strike is $\mathrm{N}$. $72^{\circ} \mathrm{W}$, and the dip nearly vertical. The rock is almost entirely made up of coarse granitic detritus. 
The culminating point of the Santa Anna Range lies about seven miles southwest of the Temescal ranch-house; it can be best ascended from the cañon of Agua Fria, by following that stream up for about a mile, and then striking off to the south, and taking one of the main ridges which leads to the summit. The highest peak, to which we gave the name of Mount Downey, in honor of the then Governor of the State, was found to be 5675 feet above the sea. It was ascended January 26, 1861, at which time there was considerable snow scattered over the north and northeast slope, down to about 1000 feet below the summit.

The view from this mountain is one of the grandest which can be had in the Coast Ranges. The range of vision extends along the coast from Point Duma, near the end of the Santa Monica Range, to the Coronados Islands, a distance of 150 miles. To the north and east the field of view is bounded by the vast ranges of the San Gabriel, San Bernardino, and San Jacinto, all capped with snow during the winter, and frequently, at that season, tinged with the deepest rosy hue at sunset. The plain to the northeast of the Santa Anna River, towards San Bernardino, is seen to rise gradually to the east, and to be traversed by a great number of bare granite ridges, generally quite isolated from each other, deeply furrowed by cañons, and weathering, on the surface, into immense rounded, boulder-like masses. Close at hand, on the east and northeast, are the low, gently sloping, and almost bare ridges of the Temescal Range, the highest of which rises to about half the height of Mount Downey. On the south is what may well be called a wilderness of mountain ranges, having apparently an east and west trend, and closing in on the Ocean north of the Santa Margarita River. These appear to be from 3000 to 5000 feet high, very rough, covered with chaparral, and consequently very little known. The Santa Anna Range, itself, is seen to be intersected by many deep cañons, which run at right-angles to the general direction of the chain. The most southerly point seen, on the main land, is Table Mountain in Lower California.

This portion of the Santa Anna Range is chiefly made up of granitic, trappean, and metamorphic rocks, the unaltered sandstones and conglomerates, which were seen on the point ascended near the Santa ส FคI. VOL. I. - 23 
Anna River, being carried, by the direction of their strike, low down on the slope of the range, in its southern extension; they are seen at the base of the mountain, and appear to cross the ralley and to rise on the other side in the heights of the Temescal Range. At the mouth of the Agua Fria Cañon, granite is seen, and, next above it, a striped jaspery rock, which is a metamorphic slate, such as has often been seen among the altered Cretaceous strata. Above this, again, is another belt of granite, passing into a trappean rock, made up of feldspar and hornblende in fine crystals, the hornblende predominating, so as to give a dark color to the mass; whether this was an eruptive or a metamorphic rock was not ascertained. The thickness of the chaparral on the Santa Anna Range would render the exploration of it extremely difficult. No indications of metalliferous ores were observed by us in these mountains; but it will be a long time before they are thoroughly examined.

The Temescal Range of mountains commences on the south side of the Santa Anna River, and runs southeast in a direction nearly parallel with that of the chain of the same name, from which it is separated by a narrow valley. The northern end of this valley is drained to the northwest by the Temescal Creek, a tributary of the Santa Anna; in the centre there is a lagoon, which is the sink of the San Jacinto River, and south of this heads the Santa Margarita. The whole valley is extremely dry, except during the rainy season, and the adjacent hills still more so, too dry even to allow of the growth of chaparral.

The Temescal Range approaches closely, in its southeastern prolongation, to the San Jacinto Mountains, but there appears to be a wide and low pass separating the two ranges. The whole region to the southeast and around San Jacinto is entirely unexplored, so far as we can learn. The name Temescal seems to be limited in its application to the hills lying between the Santa Anna and the San Jacinto Creeks, and which cover an area of about 300 square miles. These hills are broken and irregular, consisting of short ridges and rounded knobs, which rise from a few hundred to a thousand feet above the Temescal Valley, which at the ranch-house was found to be 776 feet above the sea. Some points in the southern part of the range are probably as much as 2000 feet above tide. 
On the southeast side of the range the rocks exposed are chiefly metamorphic sandstone, which sometimes occurs, forming large masses of nearly pure white quartz-rock. Near the Temescal ranch-house a stratified semi-metamorphic sandstone, passing into quartz, was seen, dipping to the northeast, at an angle of $45^{\circ}$. Farther northeast, the quartz-rock is succeeded on the north by a heavy mass of porphyry; this rock has a base of a deep slate-gray, passing into dark-green and chocolate-brown, with numerous small crystals of white feldspar scattered through it. This porphyry is a material of great beauty, much resembling some of the fine Swedish varieties, which are wrought into vases and other ornamental articles. Beyond this porphyry, granite and syenite occur, and appear to make up the whole eastern and northeastern part of the range. This rock also forms numerous low, isolated ridges and knobs, which rise in the desert plain lying between the Temescal and San Bernardino Ranges. Much of this rock has a concentrically-laminated structure and weathers in such a manner as to give the appearance of ridges covered with drift-boulders, as seen in the annexed wood-cut (Fig. 29), which represents one of these weathered

\section{Fig. 29.}

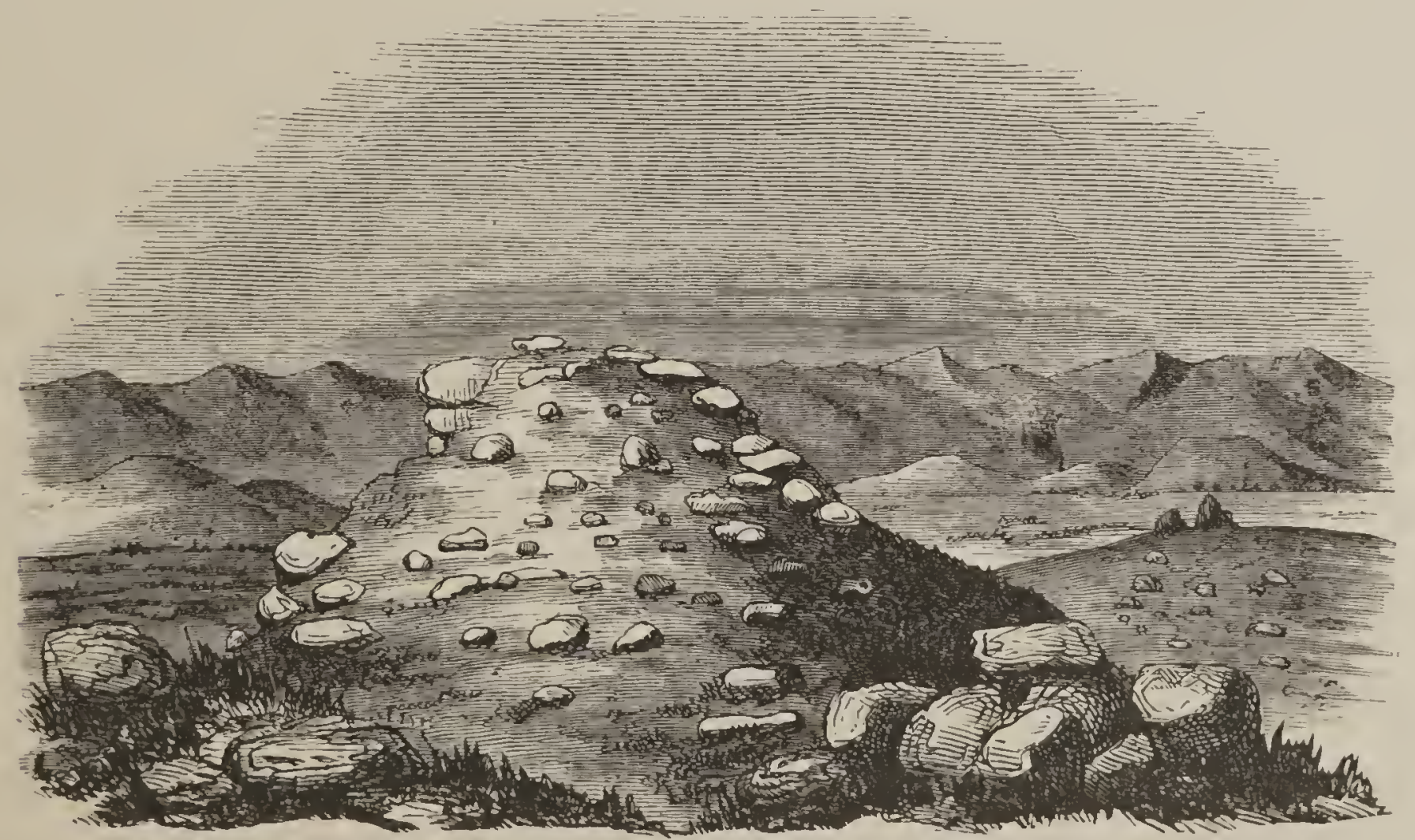

GRANITE RIDGE-TORTI SIDE TEMESCAL RANGE.

granitic outcrops, with the San Bermardino desert beyond, itself covered with similar masses, and the San Gabriel chain in the distance. 
A cañon which traverses the Temescal Range obliquely, and comes out into the valley about three miles southeast of the ranch-house, shows a fine section of the rocks of the southeastern portion of these mountains. The sandstone is seen here in all stages of metamorphism, and finally passing into a rock almost granitic in appearance. It is not easy to say, after our hasty exploration of this region, what is the age of these metamorphic rocks; they are believed to be partly Cretaceous and partly Tertiary. We saw, at the north end of the Santa Anna Range, heavy masses of sandstone strata, between one and two thousand feet in thickness, and perhaps more, forming the flanks of these mountains, and striking across the valley towards the Temescal. It would appear, therefore, that the quartzites and porphyries of the last-named range are these same Tertiary rocks in an altered condition. It would seem probable that this metamorphism was connected with the upheaval of the granite on the northeast side of the range. We have already noticed, in this region, along the Sierra Santa Monica, the occurrence of extensive uplifts of granite, which were raised after the deposition of the Miocene Tertiary, and the consequent metamorphism which extended through a great thickness of the strata of this age. The geological age of these two chains would appear to be the same, although the direction of the lines of upheaval is different, the action of the upheaving force being modified, in the case of the Temescal, by the proximity of the vast masses of the San Jacinto and San Bernardino Mountains. We must expect, in this part of the State, where the geological changes of various ages have been brought to a focus, as it were, that the resulting phenomena shall be found extremely complex and difficult to decipher.

The Temescal Range was, in 1860 and 1861, the scene of a great excitement on the subject of tin, which metal was supposed to occur here in large quantity, hundreds of claims being taken up, covering all the hills and ridges for miles around. Tin ore was undoubtedly found at one locality in these hills and in considerable quantity, as specimens of it have been seen in various collections from San Francisco to New York. The ore, which appears to be a mixture of Cassiterite (tin-stone or oxide of tin), with more or less earthy and mineral matter, resembling a mixture of the hydrous oxides of iron and manganese, is quite 
unlike in appearance to any previously seen, and its true character would hardly have been recognized by the most practised mineralogist. Some specimens, assayed in New York and Boston, gave as much as 60 per cent. of the metal.

The locality from which this ore was obtained was the so-called Cajalco Mine, about three miles north of the Temescal ranch-house. Tere a shaft had been sunk, in the winter of 1860-61, to the depth of thirty-six feet; but it was partly filled with water and inaccessible at the time of our visit. A great number of the "claims" taken up in this vicinity were visited; they seemed nearly all to be located on seams or streaks of dark hornblende rumning irregularly through the granitic and highly metamorphic rocks. Although there was no appearance of tin about any of these, or any signs of regularity in the "leads," a great many specimens were collected and carefully assayed for tin, without there being a trace of that metal found in any one of them. The excitement has undoubtedly long since died away, and it is not probable that the mass of ore in the Cajalco Mine was very extensive, or more would have been heard of it before this time. At all events, it is a singular and interesting occurrence of this metal, and we know of no other locality on the Pacific coast, north of Mexico, where tin ore has been found in place. A single fragment of this substance was given us, apparently under circumstances justifying credence in the discovery, as having been found loose in the soil in the northern part of the State, near Weaverville; but the vein from which it was derived has probably never been discovered, as such a fact could have hardly failed to become widely known.

A belt of limestone crosses through the Temescal Valley, as was recognized from the occurrence of numerous fiagments of this rock on the surface; the bed itself we were unable to discover. It is of a light-brown color, semi-crystalline in texture, and contains minute organic bodies, of which the exact nature could not be made out. 


\section{Section V.-Islands off tile Coast of Southerin Califorina.}

It will not be deemed unsuitable to the purposes of this volume, if we give such information in regard to the islands off the California coast as we have obtained, although we have but few items to communicate, since they have not been risited by any of the geologists of the Survey. Dr. Cooper, however, spent a portion of the spring of 1863 in making zoological collections among these islands, and has furnished some notes on their geology and topography, on which the most of what here follows is based.

There are two groups of islands off the southern coast of California. The four islands Anacapa, Santa Cruz, Santa Rosa, and San Miguel, with the rocks seven miles west by north from the latter, form one group, and these all lie nearly in one line, and have their longer axis parallel with the trend of the shore the other side of the Santa Barbara Channel, which is that of the Santa Inez Range, as already noticed. The other group consists of San Clemente, Santa Catalina, Santa Barbara, and San Nicolas, with John Beggr' rocks, seven miles from San Nicolas. These islands all have a trend of northwest by west, their longer axes being almost exactly parallel with each other and with the line of the coast of the main land opposite.

Dr. Cooper encamped on the island of Santa Barbara for twenty days, with a party engaged in hunting sea-lions. He describes it as composed entirely of vesicular basalt, with very little tendency to a columnar structure, and nothing like a volcanic crater or lava streams. There is an imperfect terraced arrangement due to the action of water in the intervals of successive upheavals, of which three or four seem to have occurred since the island was raised from the sea. The whole surface is covered with a deep and apparently good soil, containing much lime, very light and ashy, and averaging four or five feet deep; it seems difficult to account for its uniformity of composition and depth, except on the supposition that it was, to a great degree, formed from the decomposition of animal remains. The island is about 500 feet high, and has two miles of shore line, everywhere rocky and abrupt, and presenting, on the northeast and south sides, perpendicular clifts exposed to the 
full force of the ocean-swell. The area of the summit of the island is about thirty acres, and near the highest point there is a bed of shells of living species and very fresh appearance, which have been brought there by the Indians, who formerly resorted to this place for eggs and seals. There is also a raised beach, about thirty feet above the sea, on the southeastern face of the island, in which are found shells, one species of which has not been discovered elsewhere on the coast of California. This bed may probably be of the same age as the Post-Pliocene strata at Santa Barbara.

In regard to the animal life of this island Dr. Cooper remarks, that it is now the resort of great numbers of sea-lions, and was also formerly frequented by the sea-elephant, a much larger species of seal, now nearly exterminated along this coast. Myriads of birds, of several species, come to it to lay their eggs, and from these animals the large proportion of lime in the soil is derived; some of this is also washed into the water, thus affording the necessary calcareous material for the shells of great numbers of mollusca, which are found here in an abundance quite unusual on volcanic islands. The land is perfectly alive with snails, of which three new species were obtained, one of which belonged to a new genus (Binneya notabilis). These land-shells appear to have inhabited the island from a very carly period, and fossil forms of the two larger species are found, differing considerably from those now living.

Santa Catalina is seventeen and a half miles long, with an average breadth of four miles to the southern, and two miles to the northern portion, the island being divided into two distinct parts by a transverse break which runs through it; the divide, at this break, is only thirty feet high, while the hills on each side of it rise to an elevation of from 2000 to 3000 feet. Dr. Cooper describes the rocks as being chiefly metamorphic, with frequent volcanic outbursts and lava streams of vesicular basalt. Near the great break in the island is a vein of ferruginous matter, about a foot thick, containing masses of galena, which may be traced for some distance, and which has for some time been known to exist here. On this vein some work has lately been done, and the galena is said to contain silver. There is one good spring on this island, and water has been obtained in places by sinking wells, there 
being several settlers here, engaged in raising sheep. Many new and. interesting species of shells were obtained in dredging about the island, to the depth of 120 fathoms.

San Nicolas is eight miles long and three and a half wide; it is about. 600 feet high, and the summit is a flat, narrow ridge, from which the shores on both sides can be seen. The rock is exclusively sandstone, apparently of a late geological age, but containing no fossils, so far as examined; it dips to the east at an angle of about $25^{\circ}$. The island is distinctly terraced along the northeastern side, having three raised beaches at 30,80 , and 300 feet, the last being near the summit. On these terraces are shells of existing species, few in number on the highest, but more numerous on each succeeding one below, and most of all on the present beach, all being of a rather northern type. The summit appears to have been raised from very deep water containing no shells; but its surface is now strewn with shells and bones left there by the Indians. This island is occupied as a sheep-ranch, and the animals appear to thrive remarkably well, although the vegetation consists wholly of cacti, and other plants apparently unfit for pasturage.

San Clemente is twenty-two miles long, and has an average breadth of two miles. It consists entirely of basalt, which has a somewhat columnar structure, especially towards the southeast end. There is scarcely any soil covering the rock, and the island seems never to have been much resorted to by animals. Its form is that of a terraced table; and although from the nature of the rock and the scarcity of shells but very few fossils have been preserved, yet there is sufficient evidence that each one of the terraces, of which there are about seven, has been at one time the beach of the island. This evidence consists of the fact, that the bluffs forming the steps from one terrace to another are all hollowed out by numerous caves, like those existing in the cliffs along the present shore. Some of the latest upheavals have greatly lengthened the island at the northwest end, from which a reef now extends out about a mile, while along the middle of the eastern side, a depth of 600 feet was sounded by Dr. Cooper within a quarter of a mile of the shore, and no bottom found with a line of 840 feet at a mile distance. The elevation of the highest terrace was estimated at 1000 feet. There is neither wood nor water on this island. 
It will be noticed that the interior island of the group, Santa Catalina, presents no evidence of a recent elevation, being destitute of terraces; from its appearance Dr. Cooper surmises that it may, on the contrary, be sinking, instead of rising. The vegetation of the different islands of the group is quite dissimilar, and so also are the native animals, except in the case of the birds and quadrupeds which have been carried to them by the 'Indians, or borne thither on floating logs, as is the case sometimes. It is a curious fact that sheep thrive on Santa Barbara, although there is no water there during the summer, or for more than half the year; they appear to get moisture enough from the fogs and the succulent plants on which they feed. Even a cat has succeeded in sustaining life there for four years, living on birds and mice, of which there is an abundance.

Of the geology of the more northern group, consisting of Anacapa, Santa Cruz, Santa Rosa, and San Miguel, but little is known, as they were not visited by Dr. Cooper, with the exception of a few hours spent near Prisoner's Harbor, on Santa Cruz. In the "Pacific Coast Directory," drawn up by Mr. Davidson, of the U. S. Coast Survey, and published in the Report of the Superintendent for 1862, some facts are given with regard to these islands. Anacapa, which is in reality a group of three islands extending in a nearly E. N. E. direction, and five miles long, is made up of coarse, dark-gray sandstone, very rotten and crumbling, with perpendicular sides from 250 to 300 feet high. The soil is loose and thin, producing only a few dwarfed species of cactus, and other succulent plants common to the sea-coast in dry, sandy localities. There is no water on this island. Santa Cruz is the largest island of the group, being twenty-one miles long and about four wide, and 1700 feet high. The rock is, like that of Anacapa, a coarse, crumbling sandstone, somewhat metamorphosed in the vicinity of Prisoner's Harbor. Sunta Rosa, fifteen miles long and ten wide, is made up of rolling hills, covered with coarse grass and bushes. The shores are steep and broken, and destitute of a harbor. San Miguel, the most westem of this group, is seven and a half miles long and two and a half broad. These two last-mentioned islands are probably also of sandstone, judging from their position with regard to the others of the group. Some sheep have been placed on San Miguel; the other GEOL. VOI. I. - 24 
is believed to be entirely worthless. No doubt, interesting zoological results would be obtained from a thorough examination of this group; but it has not yet been in our power to have it done. The success of mining enterprises on any of these islands must be looked upon as very doubtful.

\section{CHAP'TER VII.}

\section{THE REGION BETWEEN THE CANADA DE LAS UVAS AND SOLEDAD PASS.}

A RAPID recomnaissance was made, by Messrs. Brewer and Gabb, of the region between the Téjon Pass and the San Emidio Cañon; and, as their observations on this trip were chiefly within the Coast Ranges, they are given in this connection, although they include also a little of the territory which properly belongs to the Sierra, namely, that around the Téjon Pass. Indeed, this region might perhaps be called, with propriety, the debatable ground between Sierra and Coast Range. How far the older rocks of the Sierra may, on the confines of the Coast Range upheavals, have participated in the elevatory movements by which this last-named system has been raised, and whether, in some places, rocks older than the Cretaceous have been brought to the surface in the centre of the Coast Ranges, are difficult questions to answer satisfactorily. At present, we have no evidence that any other than the Tertiary and Cretaceous formations, and the associated eruptive masses, with the metamorphic forms of these two groups of strata, occur in the main ranges of the Coast Mountains; except at their northern and southern extremities, where the two systems are brought into such close contact with each other.

From the Kern River to Cañada de las Uvas is about thirty miles, across a plain, the first twenty miles of which is a low alkaline desert, in some places bare, in others covered with alkaline shrubs. At about fourteen miles from the mouth of the cañon, are the so-called "saltworks," where the soil is impregnated with salt to such a degree that a brine sufficiently pure and strong to preserve meat can be obtained by lixiviation. 
The mountains close entirely around the end of the great plain of the San Joaquin and its continuation in the Tulare Valley, forming a rast amphitheatre, unbroken on all sides except to the north, but lowest to the west at Paso Roble. The momntains south and east are especially high, rising to from 6500 to 8000 feet. From the base of these, a dry, gravelly or sandy slope stretches away with a very gentle inclination into the plain; this is composed of coarser materials, and has a steeper angle near the mountains, gradually becoming more nearly horizontal as it recedes from them. This detrital deposit covers the base of the mountains to the height of a thousand feet above the plain, and is made up of the materials brought down the slopes of the mountains by the wear of the elements. Near the mouth of the cañons which issue from the hills, there are accumulations of boulders, which are also scattered over the plain to some extent, around and near the base of the hills.

The San Emidio Cañon lies about twenty miles west of the Cañada de las Uvas; it has its origin in the high mountains of the Coast Ranges, at Mount Pinos and Mount El Dorado, and runs nearly north, opening into the valley of Kern and Buenavista Lakes. It owes its form to the agency of denuding forces, and has been excavated in places to a depth of over 2000 feet. Towards the head of this cañon, granite, mica-slate, syenite, hormblende-slate, and limestone are found, the formation having a general strike of about N. $75^{\circ} \mathrm{W} .-\mathrm{S} .75^{\circ} \mathrm{E}$, and a dip to the south of from $70^{\circ}$ to $80^{\circ}$. Resting on the elge of these, to the north, are Cretaceous strata, overlain in their turn by Tertiary and Post-Tertiary deposits, chiefly sandstones, quite unaltered and dipping to the north. These newer rocks form a belt about five miles wide at the mouth of the cañon, extending considerably fartler into the plain at that point than they do on either side.

The Cretaceous strata are of inconsiderable thickness compared with the overlying 'Tertiary. They consist chiefly of sandstones; but there are also intercalated masses of shales, with nodular concretions of argillaceous limestone, such as are common in this formation in other parts of the State. But few fossils were found in the Cretaceous of the San Emidio Cañon; but enough were collected to prove conclusively that the strata are of that age. The beds have a strike of $\mathrm{N} .55^{\circ} \mathrm{W}$., and dip north at an angle of from $60^{\circ}$ to $70^{\circ}$. 
These Cretaceous strata are succeeded by 'Tertiary sandstones, which overlie them conformably, and have a great thickness. The lower members of the Tertiary are quite non-fossiliferous, and pass gradually into beds which are undoubtedly of Miocene age. The whole series is upturned at an angle of $60^{\circ}$ or $70^{\circ}$, for a distance of about two miles, the broken strata rising into sharp ridges, having a grandly picturesque appearance. Some of these masses of rock rise to the height of nearly 2000 feet above the bottom of the cañon, and are quite bare of soil and vegetation. Some portions of the Miocene strata are highly fossiliferous, but the fossils are rery poorly preserved, and are chiefly in the form of casts. The upper members of the Tertiary consist of sandstones and conglomerates, the latter abundant and coarse, and appearing to be more recent than Miocene; they are probably of Pliocene and Post-Pliocene age. All these are disturbed and upturned, to the very mouth of the cañon.

Resting unconformably on these, for three miles up the cañon from its entrance, are beds of coarse gravel, forming tables several miles wide, which are cut through by numerous gorges, beautifully displaying their structure. These detrital beds contain immense boulders of granite, of the same character as that found in the mountains to the south; they are rounded on their edges, and often of large size, sometimes as much as six or eight feet in diameter.

The annexed section (Fig. 30), will show the position of the rocks in the San Emidio Cañon. It extends only about ten miles up from the plain, and not as far as the summit of the pass. Farther south, the limestone comes in, beyond the limits of the section. The Miocene strata $(d)$ rise to the height of nearly 2500 feet above the plain, as near as could be estimated. Their dip is from $50^{\circ}$ to $65^{\circ}$.

From the summit of the higher upturned strata, which is between 2500 and 3000 feet above the sea, a wide belt of Tertiary rocks may be seen skirting the Coast Ranges, and worn into rounded hills, which are generally barren, especially on the west side of the Tulare Valley. A spur runs out into the plain to the west and northwest of Buenavista Lake, and widens out near Paso el Roble, extending down the valley as far as the eye can reach. Lying south of the cañon, and about its head, are lofty mountains, of which Mount Pinos, the domi- 
nating peak, is estimated at 7500 to 8000 feet in height.

Passing up the cañon, the Cretaceous strata are seen, resting on the granite and the upturned edges of the nica and hornblende slates. These.metamorphic rocks are dark-colored, and in places almost black ; they are traversed by veins of light-colored granite, having the mica most abundantly segregated in the centre. For several miles granite alternates with gneiss, mica-slate, and silicious metamorphic rocks, among' which some beds of serpentine occur. This formation dips to the south at its junction with the Cretaceous rocks; farther south it is vertical, and at five or six miles from the Cretaceous it inclines to the north at a high angle, indicating a synclinal structure in the range. The strike of the metamorphic beds is about $15^{\circ}$ to the north of west. Limestone occurs, in a highly crystalline condition, about two miles north of Mount Pinos, in heavy masses, which are inclosed in micaslate. Magnetic oxide of iron is also found in this vicinity. Sulphuret of antimony occurs, in the next cañon west of the San Emidio, namely that of the Arroyo Plata, and not in the San Emidio, as previously reported.

The belt of Tertiary extends along the flanks of the mountains eastward for about twenty miles from the San Emidio Cañon, passing out into the plain, and terminating in a range of hills to the northwest of the mouth of the Cañada de las Uvas. These

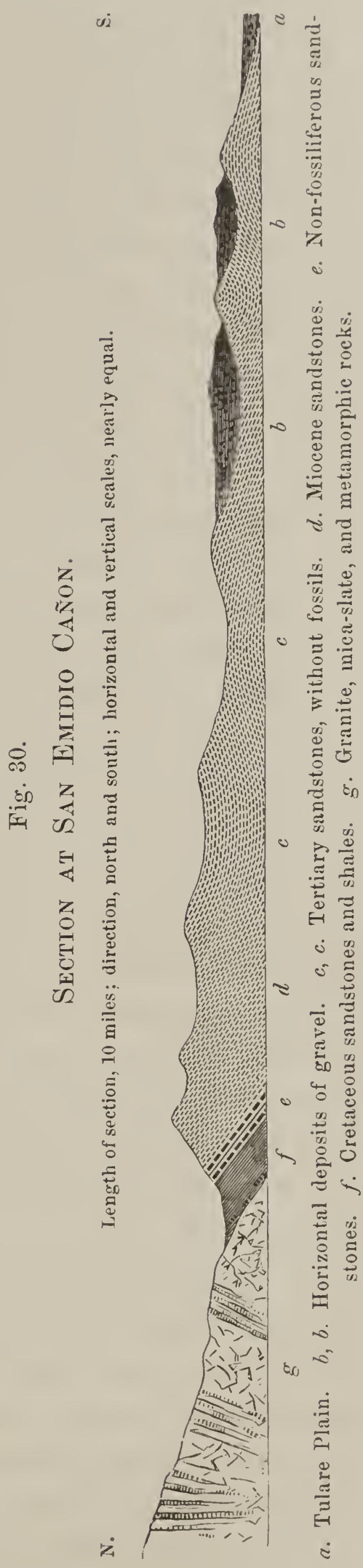
hills are rounded, and deeply furrowed by cañons or gulches, and rise 
perhaps 800 feet above the plain. The appearance and position of these beds would indicate that they belong to a very late Tertiary epoch, although fossils were not discovered in them, during the short stay of our party in that region. The rock is soft, easily disintegrated; and, in places, the sandstone passes into a white shale." This belt of Tertiary ceases altogether at about two miles west of the entrance of the Cañada de las Uvas.

The cañadas called "las Uvas" and "los Alisos" are narrow valleys, through which flow streams or "arroyos" of the same names; they both head in the granitic and metamorphic rocks of the mountain range to the south, opening out to the north in the valley of Kern Lake, and cutting through a narrow belt of Cretaceous rocks as they enter the plain, being in fact the continuation of the series of strata of this age noticed before as occurring in the San Emidio Cañon. At the Cañada de las Uvas, the Cretaceous beds form a belt from one-third to one-half a mile wide, nostly covered with soil, and with many granite boulders, derived from the higher mountains north, strewn over the surface. The exposures are but few, the fossils being the same as those found in the other cañons east; in the one next to the Cañada de las Uvas the Cretaceous belt is somewhat wider than it is in another one still farther in the same easterly direction; but the best locality for examining the strata is at the Cañada de los Alisos, which debouches into the plain four miles east of the Las Uvas Cañon. Here the Cretaceous belt is over a mile wide, the strata being well exposed, although much broken; they form hills about 1000 feet above the plain, and 2500 feet above the sea, the general level of the base of the range between the Cañada de las Uvas and the Téjon being about 1500 feet above the tide-water.

The Cretaceous strata are very much disturbed in this region, both dip and strike being quite variable, the former varying from N. W. and S. E. to N. E. and S. W., while the dip is sometimes to the north and again to the south, and generally at a high angle. The formation consists of sandstones and conglomerates, without any of the shales so characteristic of the Cretaceous in other districts. The conglomerates are very coarse, containing many boulders from three to six inches in diameter, of granite and metamorphic rocks. This rock resembles 
very closely the conglomerate of the Upper Cretaceous, seen near Pacheco's Pass. Portions of the sandstones are very fossiliferous, and the shells in beautiful preservation. About sixty Cretaceous species were found here by Messis. Brewer and Gabb and Br. Horn, who was stationed for some time at Fort Téjon, and collected diligently in the vicinity. It was from this formation that the boulder came, which was picked up at the mouth of the Cañada de las Uvas, and which, containing as it did but few imperfect fossils, led Mr. Conrad to infer the existence of the Eocene Tertiary in this vicinity.

Lying outside of and above these Cretaceous strata, along the margin of the plain, are beds of lava, having a northern dip. This formation begins near the mouth of the Cañada de las Uvas and extends to the east and southeast for a considerable distance. At Alisos Creek, these beds are not over 200 or 300 feet thick; but, at Arroyo Pastoria, they are much more developed, both in width and thickness, and continue to increase in that direction, until, at Arroyo Zapatero, they form a wall of division, as it were, between the Sierra Nevada and the Coast Ranges. The rock is a dark-colored, hard and compact basaltic lava generally; but some portions are full of cavities, and weather out in small, rounded boulders, which cover the surface of the adjacent plain.

The Téjon reservation and plain, on which is the Téjon ranch, lies about twenty miles northeast of Fort Téjon and in the southeastern corner of the Tulare plain. The reservation is at the mouth of the Téjon Cañon, where the plain rises in a gentle slope for ten miles, and at the base of the mountains attains an elevation of 1500 feet above the sea. On the south and east rise high mountains, and on the northeast there stretches along the base of the Sierra Nevada a line of low hills, which extend out into the plains for seven or eight miles, on both sides of Téjon Creek, diminishing in width as they stretch to the northwest. These hills occasionally attain an elevation as great as 600 feet above the plain. They are made up of beds of coarse sandstone and gravel, the debris of granite rocks, with oceasional boulder's of compact, gray lava. They lie horizontally, or have a low dip to the west, and resemble the strata at Posé Creek, and those of the Tertiary hills north of Kern River, of which a description will be given farther on. To the southwest this belt of Tertiary elevations stretches towards, but does 
not connect with, the range of hills of the same geological age, mentioned already as lying to the northwest of the Cañada de las Uvas. In these, however, the strata are disturbed and elevated, and therefore belong to the Coast Range series, while the Tertiary beds about the T'éjon reservation rest in their original position, not having suffered any derangement since their deposition. This is the case with the Tertiary and Cretaceous all along the base of the Sierra, from the Téjon north, as will be seen in the next chapter.

Everywhere around the southern end of the Tulare Valley, and on the slope that rises from it to the base of the mountains, the soil is better than it is on the lower portions of the plain, supporting a luxuriant growth of native forage plants. Boulders from the neighboring mountains are very abundant along the arroyos, and are often of immense size, showing the magnitude of the floods by which they have been brought down from high up in the cañons. In the San Emidio Valley a mass of granite was seen, which was estimated to contain over 1500 cubic feet, being twenty feet long, fifteen wide, and projecting five feet out of the soil in which it is partially embedded. No granite like it occurs in place within four or five miles. On the plain outside of the San Emidio Cañon and the Arroyo Plata, are many boulders of from five to ten feet in diameter; and they are equally numerous, although scarcely as large, about the mouths of the other arroyos coming down from the mountains in this vicinity. At the mouth of each cañon and arroyo the detritus forms a high and wide embankment, which extends far down into the valley, and is made up of sand, gravel, and boulders. The water-courses divide over these, and run down their sides in numerous streamlets, sinking into the plain and disappearing a few miles from the base of the mountains.

The southeastern end of the Tulare Valley is so well closed in by mountains, that there is no low pass leading out of it into the Great Basin; the lowest is that taken by following up the north fork of Téjon Creek, through a narrow cañon, at present without a trail, and crossing a low ridge into the Tahichipi Valley. The summit on this route is about 4000 feet above the sea. The Téjon Pass proper is at the head of Téjon Creek, and is given in the Pacific Railroad Report at 5285 feet above the sea; this route is now but little used. In passing up the 
Arroyo del T'éjon, near the entrance of the cañon, mica-slate is seen, forming a belt one or two miles wide, having a strike of $\mathrm{N} .30^{\circ}$ to $35^{\circ}$ W., and a high dip to the northeast. This rock extends off to the northwest for a number of miles, and is associated with limestone to the east of the reservation. This limestone was not seen in place, but boulders of it were abundant in the arroyo; it is white and has a crystalline texture.

On passing the belt of mica-slate, granite is met with, which, with gneiss and syenite, forms the mass of the mountains between the Téjon and Tahichipi Valley. 'The higher' points were not visited; but they appeared to be of massive granite. The one lying to the south of the pass is given in the Pacific Railroad Reports at 6590 feet; that to the north was estimated at 6000 feet. Granite and gneiss constitute the mass of the chain of the Sierra in the region of Tahichipi Pass.

The same is the case with the higher portion of the mountain range extending west from the Téjon Pass, to beyond the Cañada de las Uvas. In this latter cañon, granite and gneiss are met with, after crossing the narrow belt of Cretaceous, before noticed; the dip of the gneissoid rocks is to the north at a high angle. The hills are very steep and the cañon narrow; but on reaching Fort Téjon the ravine widens out into a sort of valley, which extends up for about six miles and then branches off to the east and west, the mountains on both sides rising to the height of from 5500 to 6000 feet.

Near Fort Téjon are limestones, rumning N. $25^{\circ}$ to $35^{\circ} \mathrm{W}$., highly metamorphic and containing graphite. This mass can only be traced for a limited distance. The western branch of the valley above the Fort extends for twelve miles in a direction about $15^{\circ}$ north of west, where it meets a similar branch of the San Emidio Cañon. On the north side of this east and west valley, a belt of limestone extends along the whole distance; it crosses the San Emidio, and was followed for several miles beyond, without coming to its termination. This limestone is white and crystalline and contains graphite, distributed in layers, so as to give the rock a stratified appearance, as was noticed in the limestone of the Gavilan Range. The thickness of the belt is estimated at 200 fect, but it is not uniform; its dip is at a high angle to the north. Associated with it are mica-slates and some gneiss, togeGEOL. VOI. T. - 2.) 
ther with masses of magnetic iron ore. In the valley the boulders are of every variety of granitic and metamorphic rocks, especially of mica and horublende-slates and quartz; the predominating rock is gneiss, with a very much contorted lamination. Some of the granite contains very large crystals of rose-colored feldspar. This same line of depression is carried across the head of the San Emidio Cañon, which there separates into two valleys east and west. South of these are the highest points of the chain, that to the south of the east branch being known as Mount Pinos, estimated at over 7000 feet, and that south of the west fork is the mountain called El Dorado, which is nearly as high as Mount Pinos. The north slopes of these are of gneiss and mica-slate; the summits are said to be of granite, but for want of time they were not ascended by our party.

In passing down the San Emidio Cañon, from the forks, after crossing the limestone, various forms of metamorphic rock were observed, such as mica and hornblende-slates and gneiss, traversed by large veins of granite. There was also some serpentine and silicious metamorphic rock. This region has been frequently prospected for silver, although no indications of valuable veins were seen. It is said that over $\$ 50,000$ has been expended here.

In passing southeast from the summit of the pass of the Cañada de las Uvas, we follow down a valley for several miles, having on its northern side, a belt of limestone which is often highly crystalline and contains graphite; in places it is accompanied by a belt of a ferruginous metamorphic rock, containing magnetic oxide of iron, and a similar rock was seen associated with the limestone of the San Emidio Cañon.

Four miles east of the summit of the Cañada de las Uvas Pass, are two small salt lakes, dry during a portion of the year, called on the Pacific Railroad maps the Casteca Lakes. Here Tertiary rocks are met with, having a strike of about N. $60^{\circ} \mathrm{E}$., and a high dip to the northwest. These strata form a wide belt which extends off to the southwest, apparently passing through a low gap between the high granite mountains which lie south of the Cañada de las Uvas, and other high (granite ?) ranges to the southeast. It is said, that a low divide extends through to the headwaters of the Cuyamas River, and this Tertiary 
apparently passes through it and connects with the great masses of the same formation along the coast.

This Tertiary extends southeast and east for several miles, then passes under the more modern detritus of the desert and disappears. Near the Liebre ranch-house, the strata are much broken, and were noticed to run in various directions, from N. $35^{\circ} \mathrm{E}$. to N. $60^{\circ} \mathrm{E}$., and to dip sometimes to the north and sometimes to the south, and occasionally to stand vertically. No fossils were detected in these rocks, but they are believed to be undoubtedly of Tertiary age, from their connection with other rocks of this age in the Great Basin. These rocks skirt the desert on the south side to about two miles east of the Iiiebre ranchhouse, where they pass under the plain. Here a belt of volcanic materials makes its appearance, lying immediately south of the Tertiary. This rock is generally very hard, and portions of it have a bedded or stratified appearance; where it has an amygdaloidal structure, the cavities are filled with chalcedony. At the ranch-house it forms a belt at least two miles wide, and extends east, forming the margin of the plain, for eight or ten miles. South of this, is a high granite ridge, covered with chaparral, which extends east and comes out to the plain about ten or twelve miles northeast of Lake Elizabeth, forming the marginal hills up to the point where the road over the San Francisquito Pass crosses, which is as far as was explored by our party in this direction.

To the north of this granite ridge is a vast mass of unexplored mountains, bounded on the south by the Santa Clara Valley, and forming the nucleus, so to speak, from which start out to the west the different ranges of the Coast Mountains. There are two passes across these mountains, leading down into the Santa Clara Valley and thence by the San Fernando Valley to Los Angeles. Of these the Soledad, as it is now called, was discovered by Lieutenant Williamson, and named by him "New Pass." This pass runs nearly east and west, and rises to the height of 3164 feet at its summit. A few miles to the northrest of the head of the pass is Stoneman's Mountain, 6000 feet high, as given by Williamson. The San Francisquito Pass follows up the branch of the Santa Clara of the same name, and comes out to the northeast at Lake Elizabeth, having an elevation of 3718 feet at its summit. This 
pass was once of considerable importance, being on the route of the Orerland Mail from Los Angeles to San Francisco; but, of later years, the coast road has been followed, by Santa Barbara and down the Salinas Valley. The Soledad Pass has been better known, of late, from various attempts made to work copper mines there, large numbers of samples of cupriferous ores, especially of the green carbonate, having been brought from this region in 1862-3. It is not known that any permanent veins have been discovered, and worked with profit. A belt of metamorphic rocks stretches through here, and crosses the San Francisquito, where placer gold mining is carried on at intervals to some extent.* This belt of metamorphic is referred by us to the Cretaceous formation, from general analogy, rather than from any direct evidence of fossils. But little is known either of the topography or geology of the rough and mountainous country lying to the west of the San Francisquito Cañon.

In crossing the desert, from the Liebre ranch-house to the mountains eight or ten miles northwest, between the Téjon Pass and the Cañada de las Uvas, the desert plain is observed to rise with a steeper slope against the mountains on the north than it did on the other side of the desert. At the southern base of the range, between the two passes above-mentioned, there is a narrow belt of marginal hills, covered with thick soil, but underlain by white slates or shales, supposed to be of Tertiary age, and resembling closely the bituminous shales of the Coast Ranges. North of this is soft granite, which rises into mountains over 5000 feet high. This is much cut up into cañons, and furnishes the granitic sand so abundant in the desert. Limestone is said to occur farther northeast, near where the old Frémont trail issues on to the desert. In the centre of the chain, which is here about eleven miles wide, there are said to be pleasant valleys with fine timber and

* It was somewhere in this vicinity that gold was first obtained in California in considerable quantity and from regular washings. This was as early as 1841 . M. Duflot de Nofras says that the loeality was in the mountains six leagues north of the San Fernando Mission, and fifteen leagues from Los Angeles, where the dust was brought for sale. Major J. Bidwell, of Chico, has also given us some particulars as to these early gold-washings, with the details of which he was well aequainted. Work was kept up for several years. 
pasturage, and abundance of water. All the land of any value along the foot-hills is covered by Spanish (?) grants.

The plains on either side of these mountains are destitute of trees, but support more or less shrubby vegetation and a limited amount of forage. The mountains have considerable timber; the drier ridges are covered with chaparral and stinted trees of the species Pinus Frémontiana (the one-leaved pine). Where there is more moisture, there is a larger and more abundant growth of timber, especially of Pinus ponderosa and $P$. Jeffireyi, the latter especially fine. In the valleys there are numerous oaks, among which are Quercus lobata (syn. Hindsii) and Q. crassipocula, but neither of these is fit for timber. These are the principal varieties of forest trees; there are several other species, but not in sufficient abundance to be of importance, nor is their timber of value. The great distance of this region from a market, and from any considerable mines, renders it of much less importance than it would otherwise be. There are no gold washings or quartz veins or any other metalliferous deposits known, which can be made available under the present conditions, any nearer than Kern River. 



\section{PART II. \\ THE GEOLOGY OT THE SIERRA NEVADA.}

\section{CHAPTER VIII.}

THE UNDISTURBED MARINE SEDIMENTARY ROCKS ALONG THE FOO'T-HILLS OF THE SIERRA.

Following the method of arrangement which seems, on the whole, best adapted to the circumstances, we proceed next to take up the Geology of the Sierra Nevada; and, as we have in the preceding pages sufficiently explained what the criterion is by which we separate the Coast Ranges from the Sierra, there is no occasion to dwell farther on it in this place, as it is a subject which will come up for discussion at a future time and place. We need only specify here what will be the order of arrangement in this Part of the present volume.

Our observations have shown us that there is, along the base of the Sierra, a belt of unaltered strata of marine origin, which belongs to the Tertiary and Cretaceous systems; this belt may be traced from Fort Téjon to Fort Reading, no longer forming one connected whole, but occurring in patches, some of which, however, occupy quite an extensive area, especially those near the heads of the Sacramento and San Joaquin Valleys. Denudation has swept off the greater portion of this formation through the central part of the State, a few limited outliers being all that remains along the foot-hills between the Stanislans and the Yuba. These undisturbed sedimentary rocks, to which the present chapter will be devoted, are of marine origin, being in many places abundantly supplied with fossils which afford ample evidence of their geological age, as well as of the nature of the medium in which they were deposited. These marine strata do not rise to a great height on 
the flanks of the mountains, and are not at all to be confounded with the vast sedimentary accumulations of fresh-water origin, which cover so considerable a portion of the Sierra, and extend to so great altitude above the sea-level.

This latter formation, as being chiefly developed in the mining region of the Sierra, and of great importance for the auriferous deposits which it contains or covers, will be taken up in the second Chapter of this Part of the volume (Chapter IX), which will be devoted to the goldmining region proper of the State, or the western slope of the Sierra, especially the lower portion of it, which was, until within the last three or four years, essentially the only mining district of the Pacific States; it is now obliged to divide the honors with other regions north, south, and east.

In Chapter $\mathrm{X}$ of this Part, we will give such information as our limits and means permit, with regard to the Higher Sierra, or the more elevated portions of this range, beyond the region of mining settlements, or, at least, of such as may be considered to be permanently established and pecuniarily successful.

After this will follow, in Chapter XI, a notice of the valleys and ranges beyond the summit of the Sierra, or along the "Eastern Slope," as it is usually called; to this will be appended what little we have to say in regard to the "Great Basin," or "Great Desert" as it is frequently called, meaning that portion of the State which lies to the south and east of the Sierra, towards the Colorado River, and which is covered by a succession of almost unknown mountain ranges, with barren and inhospitable plains between them.

Thus, these two Parts will be found to have included the principal geological facts developed during what may be called a reconnaissance of the State of California. The task of arranging and co-ordinating these facts, so as to draw from them the important general conclusions for which they furnish the material, will still remain to be accomplished. Whether this work will be entered upon at once, as a continuation of this volume, or whether it will be postponed until a farther store of facts shall have been added to those already gleaned from this wide field, will depend on the action of the next Legislature, as will be found fully set forth in the introductory chapter to this Report. 
The base of the foot-hills of the Sierra Nevada is bordered, for a large part of the distance between Téjon Pass and the head of the Sacramento Valley, by a series of beds of stratified materials, resting apparently undisturbed, and in a nearly horizontal position, on the upturned edges of the metamorphic slates and granitic rocks of which the foot-hills are formed. These unaltered strata are all marine deposits, and are, in places, well supplied with the remains of marine shells and other fossils. They are not to be confounded with the stratified masses which occur on the flanks of the Sierra, but, for the most part, higher up in the mountains, and which are also of detrital origin. These contain, however, only the remains of fresh-water or land animals and plants, and are of great importance for the gold they contain; the marine beds, on the other hand, have no such significance, and are nowhere worked for the precious metal.

This belt of marine sediments, in the northern part of the State, is chiefly Cretaceous; but no rocks of this age are seen farther south than Folsom, so far as known; beyond this, to the Téjon Pass, they all belong to the Tertiary age.

Commencing at the southern extremity of the Tulare Valley with our notice of these rocks, we find the greatest development of the Tertiary beds between Kern and White Rivers. This belt begins on the north, three miles beyond White River, and it here forms low hills of very soft sandstone, lying horizontal, or having a low dip away from the mountains. In many places, the denudation of this soft material shows the original flooring of granite on which the Tertiary was deposited.

From White River to Kern River, about 30 miles, the Tertiary sandstones occur all the way, forming rounded hills from 200 to 600 feet high, the rock being soft and chiefly made up of granitic detritus, evidently derived from the mountains to the east, and having a low dip to the west, generally less than six degrees, and often horizontal; there is no reason to suppose that these beds have been disturbed since their deposition. The fossils obtained in these strata were referred by $\mathrm{Mr}$. Gabb to the age of the Miocene Tertiary. The upper portions of some of the hills are, however, of a later formation, and of fresh-water origin, as they contain fragments of bones and wood.

GEOI. VOI. T. -26 
From Kern River to King's River, the metamorphic and granitic rocks continue into the valley, until covered by the recent detritus; but north of King's River, as far as the Stanislaus, there is a belt of low flat-topped and dome-shaped hills of sandstone, rising 100 to 150 feet above the level of the plain. A little north of the Merced River, to the west of the road from Bear Valley to Stockton, a very handsome variety of sandstone was observed, forming low cliffs near the summit of a hill about 150 feet high. This rock was a fine-grained free-stone, elegantly ornamented with fine, waving, and concentric lines and bands of a light rose-red color. For some kinds of architectural purposes, this stone would be a very desirable material.

There is little variety in these Tertiary hills, for a long distance; they are scattered over the plain of the San Joaquin, at the base of the foothills, the deposit never having been very thick, and having been very irregularly denuded, so as to leave many small patches, which could only be laid down on the map after a minutely-detailed survey.

The first exposure of rocks of Cretaceous age along the base of the Sierra, in proceeding 'north, so far as we have observed, is at Folsom. Here, on the north side of the American River, a little below the railroad bridge, is an inconspicuous exposure of sandstones, with a moderate dip down the valley, in which a considerable number of specimens of Exogyra parasitica were found; a single Ammonite (A. complexus?), in the collection of the California Academy of Natural Sciences, was also obtained at this place. There are other localities of Cretaceous fossils in this vicinity; but we have not yet found time to search them out. No doubt there are many scattered patches of strata of this age, which have escaped observation, along the foot-hills from here towards the north.

One of these occurs between Beal's Bar and the Halfway House, near the line of Sacramento and Placer Counties, and not far from Texas Flat. This locality was discovered by Dr. Trask, and a large number of species of Cretaceous fossils collected there by him, and deposited in the collection of the California Academy of Natural Sciences, and thus rendered accessible for scientific description. The grouping of the species at this locality is peculiar, quite a number being found there which have not been discovered elsewhere in the State. 
The following is a list of them, as recognized or described by Mr. Gabb, the species peculiar to this locality being indicated by an asterisk:
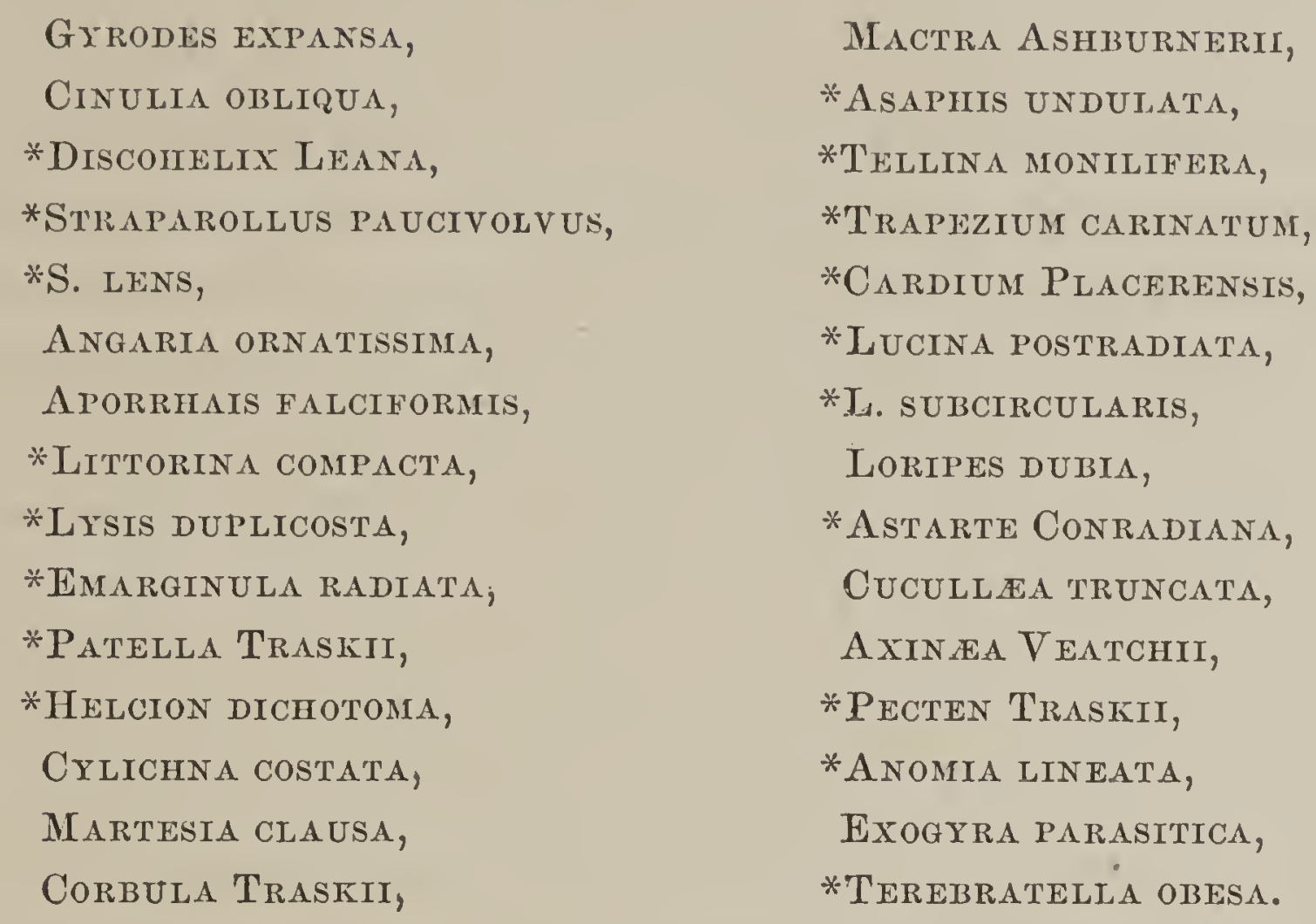

According to Dr. Trask's notes, which he has kindly placed at our disposal, it appears that the fossiliferous bed was struck at a depth of forty feet below the surface, in a mining shaft; the following is a section of the strata passed through in sinking at this place, enumerated in a descending order:

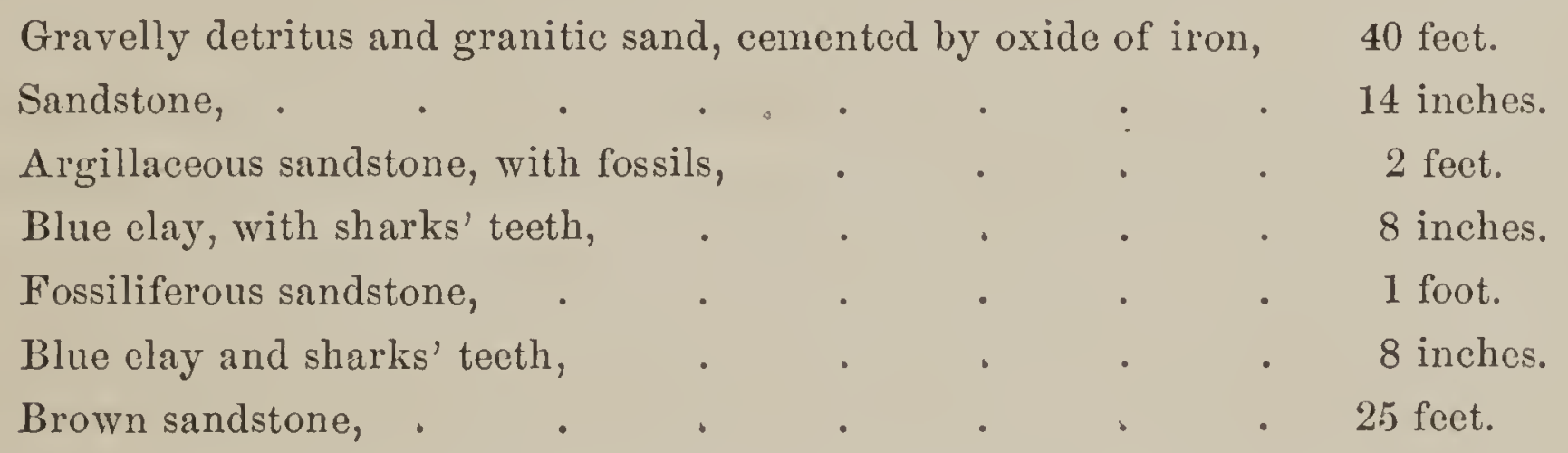

It appears that there are several localities in this vicinity where the same fossiliferous bed might be found, as Dr. Trask remarks that it occurs near Texas Flat, Halfway House, Volcano Ridge, and Mississippi Flat, and he estimates its elevation at from 800 to 1000 feet above the sea.

Quite an extensive belt of Cretaceous rocks occurs in the northern part of the Sacramento Valley, along the slope of the Sicrra Nevada, between Feather and Pit Rivers, although a large portion of the forma- 
tion is covered by an overflow of volcanic materials, so that the underlying sedimentary rocks can only be seen where these have been deeply denuded. The best exposures of the Cretaceous commence a little to the north of Oroville, and they may be seen to advantage on Butte and Chico Creeks. A small area is exposed by the erosion of the lava, near Antelope Creek, but from beyond that as far as Cow Creek, near Fort Reading, the lava comes entirely down to the plain, quite covering the Cretaceous, which, however, is undoubtedly continuous beneath it.

The Cretaceous strata occupy, on Cow Creek and the small streams adjacent to it, an area of about twelve miles long, east and west, and half as much broad from north to south; the best exposures, however, are on the banks of Cow Creek, twelve miles southeast of Shasta City. At this locality, beds of soft, buff-colored sandstones alternate with thin shelly layers, interstratified with argillaceous shales having a good deal of sand mixed with them. The strata are horizontal, or with a low dip away from the mountains, and have evidently not been disturbed since their deposition. At this locality the following fossils were obtained:

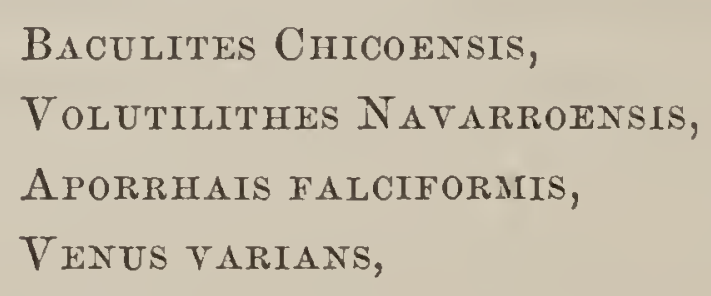

Baculites Chicoensis,

Volutilithes Navarroensis,

VENUS VARIANS,

\section{Eriphyla umbonata, \\ LithopHagUS OVIFORMIS, \\ LEDA TRANSLUCIDA, \\ Ostrea Brewerit.}

Of these, the Baculite was particularly abundant. A single Ammonite was obtained, a remarkable contrast, in this respect, to the beds on the opposite side of the valley so prolific in species of this genus.

A workable bed of coal is reported as occurring on Cow Creek, and between this and Clover Creek. Mr. Sanders, who opened the locality on Clover Creek, speaks of several strata, one of which has one foot of good coal at the surface, associated with three feet of shale. The outcrop extends, it is said, for some ten miles in a northwest direction, and the locality, although probably of little economical importance at present, is interesting as indicating, in connection with many other carbonaceous deposits in the Cretaceous strata of the Pacific coast, a tendency to the formation of coal in this region during the accumulation of a system of rocks which, in other parts of the world, has generally been remarkably barren of this substance. 
Between Cow Creek and Bear Creek, there is a broad plain of volcanic ashes, destitute of trees, and alnost bare of herbage, and as yet hardly at all eroded into cañons. On nearing Bear Creek, more solid lava makes its appearance and increases as we pass south. These volcanic materials are all derived from the great centre of eruptive agencies at and near Lassen's Butte. The examination of the region between that now extinct volcano and the Sacramento River shows, that there were a large number of smaller volcanoes once active there, and that these added extensively to the mass of ejected materials. These consist of layers of ashes and scorix, alternating with hard basaltic lava, and they now cover a district about a hundred miles long from Pit River to Oroville, and nearly seventy-five wide.

Between the mouth of Bear Creek and Red Bluff, the volcanic rocks come entirely down to the river. They may be well studied at Battle Creek, which rises at Lassen's Butte, and has cut a deep cañon in the stratified lavas, which is in places as much as 800 feet deep. The basaltic lava seems to have flowed in sheets over the surface, forming a regular slope from Lassen's Butte to the Sacramento.

On the north side of Battle Creek, and about ten miles east of Fort Reading, there is a conspicuous cone, rising from the slope of lava; this is figured in Dr. Newberry's Report (Pacific Railroad Reports, Vol. VI, Part 2, Fig. 26). Its altitude, as determined by our measurements, is 2633 feet above the sea, or 856 feet above its base. The sides are very steep, and form a regular truncated cone. The rim of the crater is perfect, about 900 yards in circumference, nearly circular, and having its northern edge about 100 feet higher than the opposite one. The crater is funnel-shaped, and about 225 feet deep, the sides steep and covered with trees and shrubs. Scoriæ and pumice are abundantly scattered over the rim and within the crater. Several other cones are visible on the south side of Battle Creek; an outline of two of which is given in the annexed wood-cut (Fig. 31).

Fig. 31 .

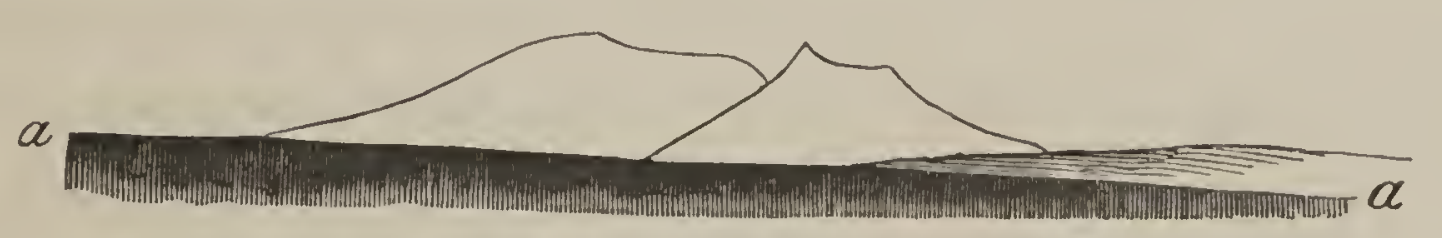

VOLCANIC CONIS, NEAR BATTLE CREEK. 
The volcanic rocks evidently cover the Cretaceous strata, and a single specimen of a fine Ammoirite (Ammonites subtricarinatus), obtained by us in that vicinity, and said to have been found in a boulder in a deep gulch between Battle and Bear Creeks, indicates that, in places, the streams may have cut through the volcanic into the sedimentary rocks beneath.

The Sacramento Valley opens out into a plain again just below Red Bluff, and at a much lower level on the east side, El Primer Cañon Ranch being the first one south of the barren lava slopes. Antelope Creek rises near Lassen's Butte and for many miles cuts a deep cañon into the volcanic, which is in places probably worn through into the Cretaceous, as fossils are reported to have been found in it. The cañon is very deep near its mouth, and the bottom is in places quite inaccessible; it was followed for several miles, without any fossils being obtained, the rock being exclusively volcanic, forming cliffs 800 to 1000 feet high, composed of alternate beds of basaltic lava and ashes. The materials forming the slopes near Tuscan Springs seem to have been poured forth from the two craters noticed above.

At Tuscan Springs, or Lick Springs as it was formerly called, the Cretaceous strata have been bent up into a rather sharp arch, or anticlinal fold, and the volcanic rocks have been denuded in the cañon, so as to expose the sedimentary beds over an area of about one-half a mile from northwest to southeast, and a mile in the opposite direction. The springs are nearly in the centre of this area, the strata dipping away from them in every direction, at an angle of from $35^{\circ}$ to $45^{\circ}$. At the springs the strata are much bent and twisted, and the cracks which have been formed while these disturbances were going on have become filled with carbonate of lime.

The annexed section (Fig. 32) will serve to give an idea of the position of the strata at this locality, as near as it could be made out.

Where the Cretaceous strata were exposed, they had a much greater dip than that of the volcanic beds on each side, but as the two formations could not be examined in actual contact with each other, it was impossible to say decidedly whether they were really unconformable. West of the springs, however, the Cretaceous shales have a dip of $40^{\circ}$; while, but a few feet distant, the beds of volcanic ash were inclined 
only $10^{\circ}$ to $15^{\circ}$; a similar condition of things was observed on the east side also, so that it would appear that the disturbance of the underlying

Fig. 32.

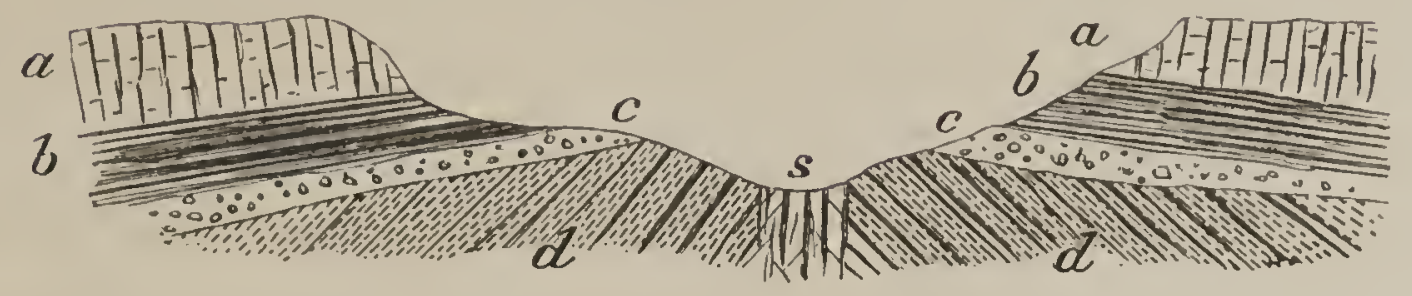

SECTION AT TUSCAN SPRINGS.

$a, a$. Basaltic lava. $b, b$. Volcanic ash and scoria. $c, c$. Conglomerate. $d, d$. Cretacoous sandstone. $s$. Springs.

sedimentary rocks must have commenced before the volcanic materials were deposited on them, and that this disturbance still continued to act in the same direction after that took place.

In several places a bed of conglomerate separates the Cretaceous strata from the volcanic; this bed is made up of smooth pebbles of metamorphic rocks, chiefly quartzose, cemented by a ferruginous and finely pulverized material, as if a thick detrital mass, like that of which the present auriferous beds of gravel are made up, had covered the surface of the Cretaceous before the deposition of the volcanic upon it.

Some of the Cretaceous beds at this locality are particularly rich in fossils, of which a large number were formerly collected by Dr. Veatch, and have been presented to the Survey. Among these the most abundant and characteristic were:

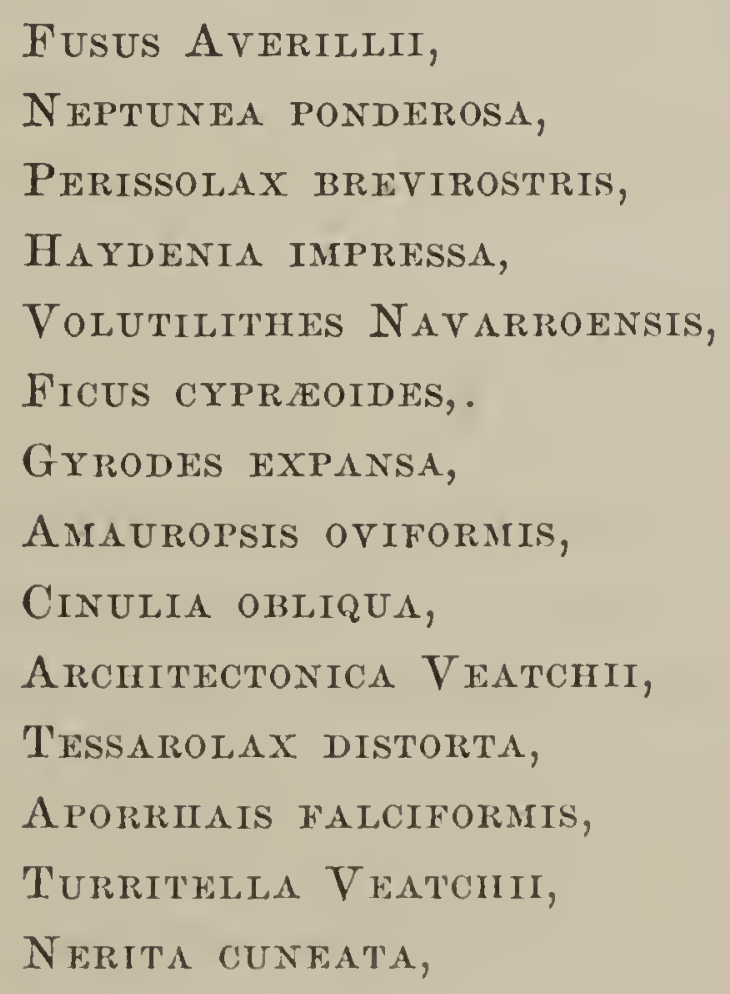

\author{
Martesia cla usa, \\ Corbula Traskir, \\ Mactra Ashburnerit, \\ Venus Veatchit, \\ Astarte Tuscana, \\ MODIOLA CYLINDRICA, \\ Inoceranes Piochit, \\ Trigonia TrYoniana, \\ T. Evansit, \\ Meeria sella, \\ M. RADIATA, \\ Arca Breweriana, \\ Axinda Vhatchi, \\ NUCULA TRUNCATA.
}


The waters of the Tuscan Springs have considerable repute for their medicinal qualities, especially in the cure of rheumatism and syphilitic diseases. The temperature (October, 1862) was $76^{\circ}$. They contain common salt, carbonate of soda, borate of soda, salts of lime, and evolve some sulphuretted hydrogen and a large quantity of carburetted. hydrogen, which is collected, partially purified, and burned for heating the water under the steam baths. A deposit of calcareous tufa is forming here, portions of which are finely banded, and closely resemble the "Suisun marble" and the limestone found on the west side of Monte Diablo.

On passing south from Antelope Creek, the plain widens out in many places and a considerable part of it is a treeless and nearly barren slope of volcanic ash, covered with great numbers of small lava boulders, which extends out for some distance from the termination of the basaltic lavas. Mill Creek, which comes down to the plain between Antelope and Deer Creeks, as seen from the road, appears like these to have cut a deep cañon in the volcanic formation, and emerges from this by a "gate," conspicuous for a long distance.

The cañon of Deer Creek was examined for some distance up, and it was found to be cut deeply into the volcanic materials, which consist of alternating beds of basalt and ashes, forming terraces on both sides. Our party was informed by some "prospecters" who had just made an examination of this cañon to its head, that they had traced it nearly back to Lassen's Butte, and that it was everywhere in the volcanic rocks, and often so precipitous that the stream could not be reached. No trace of gold was discovered in the sands along the creek.

All along between Deer and Chico Creeks the lava terminates with an abrupt edge, and the plain beneath and nearest to it is barren and dry and covered with volcanic fragments; but farther down towards the river the land becomes gradually fertile, and has considerable timber. The proportion of good agricultural land increases as we approach Chico Creek, where the plain is about ten miles wide. This creek, like the others farther north, has worn a deep cañon in the volcanic rocks, extending for many miles back in the mountains. About six miles from the entrance of the cañon, the stream has cut through into the Cretaceous strata beneath; but the point is very difficult of access, 
the gorge being nearly impassable in places below and the volcanic materials on each side having an elevation of 800 to 900 feet.

The Cretaceous strata exposed at this place are chicfly sandstones, and they appear to be quite horizontal. They have not been deeply cut into, but some of the beds are highly fossiliferous, and specimens from this locality have been widely distributed over the country. Among the species found here are: Ammonites Chicoensis, Baculites Chicoensis, a number of the univalve shells mentioned as characteristic species at Tuscan Springs, including Volutalithes Navarroensis, Cinulia obliqua, and Aporrhais falciformis, as well as a more abundant supply of bivalves, among which the following are common: Mactra Ashburnerï, Venus varians, Meretrix lens, M. nitida, Dosinia inflata, Trigonia Eransii, Meekia navis, and some others.

Cretaceous fossils are also reported from the cañon of Butte Creek, below Diamondville, where they are said to be abundant; but the locality is difficult of access.

At Pence's Ranch, about nine miles north of Oroville, and near the southwestern termination of the great volcanic table which comes down from Lassen's Butte, a fine exposition of the geological structure of the northern foot-hills of the Sierra may be seen, and the relations of the volcanic and Cretaceous beds to the auriferous slates of the gold region may be clearly recognized. Table Mountain Creek, or Mesilla Valley, here leaves the volcanic beds, which have been denuded to the southwest, and has worn a valley along the junction between the Cretaceous and the auriferous slates; these latter are seen to the east of the valley, having their usual northwest and southeast trend and a high dip to the northeast.

About one and a half miles northeast of Pence's are large outcrops of limestone interstratified with the auriferous slates; it is, in general, highly metamorphic, although traces of fossils are preserved in it, sufficient to show that it was originally well supplied with them, and that they have since become almost obliterated by the metamorphic action. The best specimens were obtained near the bend of a small cañon called "West Branch." This belt of limestone extends several miles in a northwest and southeast direction, but it appears to be broken, so that it is made up of disconnected masses not exactly in the same line, 
but near enough together to form what may be called, in a general way, one belt. Lithologically it resembles the limestone of the hills at Bass's Ranch, but it is more completely metamorphic than that, although not traversed by trap dykes, as is the case at that locality. Portions of the Pence's Ranch limestone would make good gray marble, and the lime burned from it is of good quality. Another smaller lenticular mass, also highly metamorphosed, occurs about half a mile west of the main belt. The fossils found in these limestones, although imperfect, are sufficient to identify them as of the same age as those of Bass's Ranch, which are pronounced by Mr. Meek to be carboniferous. Productus semireticulatus and Spirifer lineatus were recognized by $\mathrm{Mr}$. Gabb, and a portion of the rock is made up of stems of crinoids, too much obliterated to allow of their generic relations being made out.

Resting on the upturned edges of the auriferous slate and limestone series, is a mass of Cretaceous strata, chiefly sandstones, having a horizontal position, or dipping slightly to the southwest. These have been more or less denuded, and outcrops are found in nearly all the arroyos and ravines. They extend to the height of about 750 or 800 feet above the sea. Some beds are highly fossiliferous and rich in a variety of species as well as in numbers. The following are the most abundant species found in this vicinity:

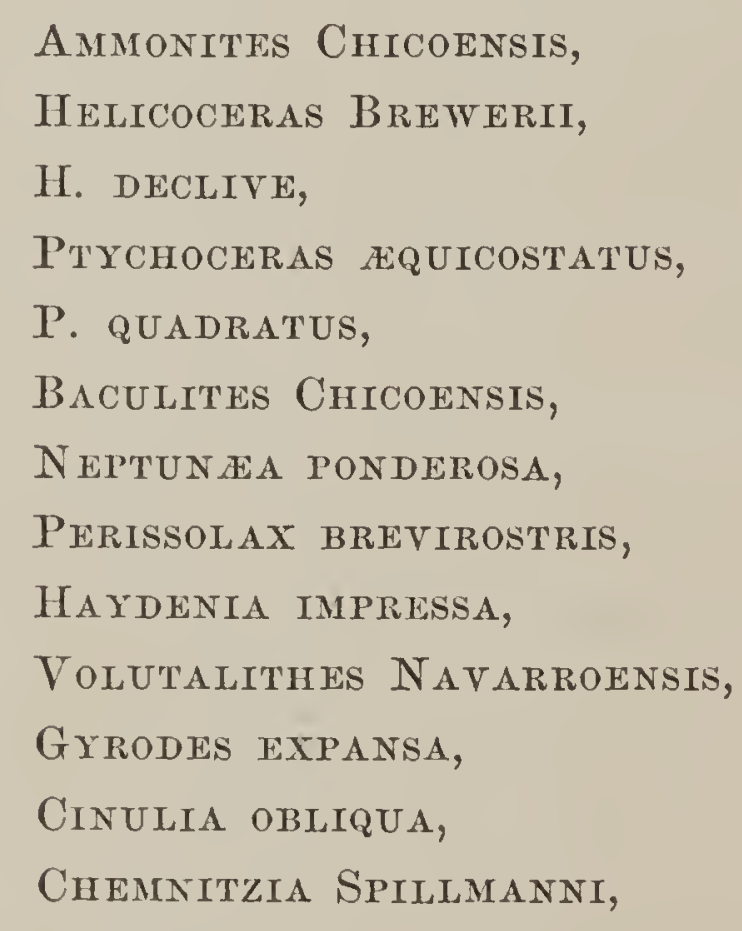

\author{
APORRHAIS FALCIFORMIS, \\ Corbula Traskit, \\ Anatina lata, \\ Pholadomya Breweril, \\ Mactra Ashburnerit, \\ LUtraria truncata, \\ Telifina ooides, \\ T. DECURTATA, \\ 'T. Ashburnerit, \\ Venus Varians, \\ Modiola CYLINDrica, \\ Meekia navis, \\ Axinæa Veatchir.
}

No absolute contact of the Cretaceous with the auriferous slates was observed; but the two formations were seen in close proximity. Rest- 
ing on the Cretaceous is a series of sandstone beds containing blue grains, interstratified with shales in which are a few impressions of fossil leaves. These beds are similar in all respects to the upper Pliocene strata north of Kirker's Pass, and they are, in all probability, of the same age. They are covered, in turn, by accumulations of volcanic ashes, scorixe, and breccia, and over all rests a heavy bed of basaltic lava. The Tertiary and volcanic are perfectly conformable, but whether the Cretaceous is also conformable to these has not been demonstrated; it appears probable that it is not, although the disturbances were not great in the interval between the deposition of the Cretaceous and Tertiary.

The Tertiary beds, in places, contain considerable carbonaceous matter, and at one locality have been prospected for coal. At this place, which is about six miles north of Oroville, there are frequent impressions of the leaves of exogens, in the black shales a few feet beneath the volcanic beds, and a few seams of coal. The latter are not sufficiently thick to be of any value.

The annexed section (Fig. 33) will serve to exhibit the relations of the strata near Pence's Ranch, as described above. This vicinity is not only extremely interesting to the geologist, as showing the relations of two very important groups of strata to each other, but is remarkably picturesque, the numerous table-topped

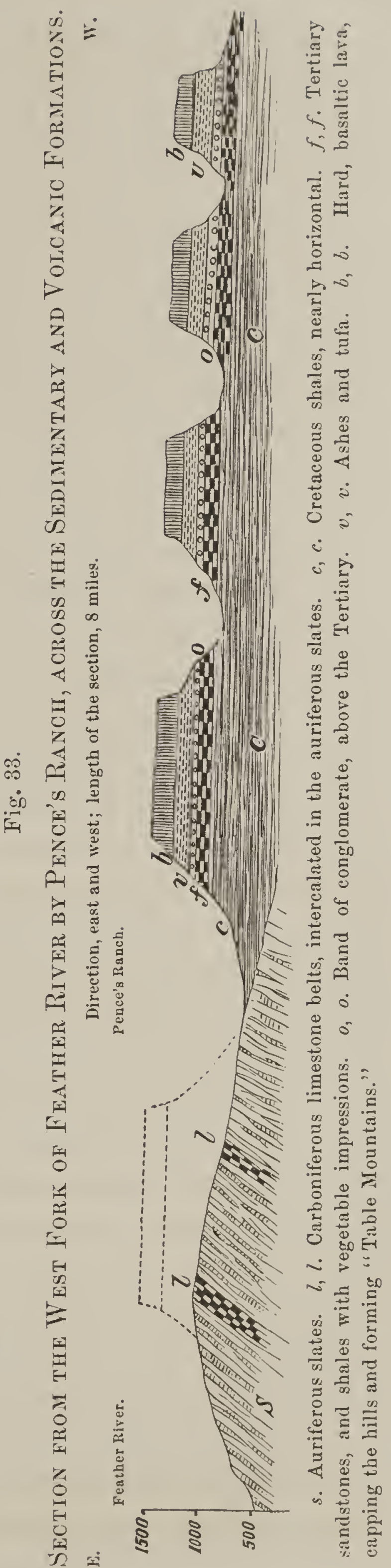


hills, with the deep cañons between, giving a very peculiar character to the scenery.

\section{CHAP'TER IX.}

THE MINING REGION OF CALIFORNIA; EMBRACING THE GREAT AURIFEROUS BELT ALONG THE WESTERN SLOPE OF THE SIERRA NEVADA.

\section{Section I.-Preliminary Remarks.}

We now proceed to take up the great metalliferous belt of California, or the western slope of the Sierra Nevada, this being the portion of the State which was for a long time the field for much the larger part of the successful mining enterprises undertaken on the Pacific border of the United States, and whose development led to the discovery and exploration of many other highly important mineral regions in the adjacent States and Territories, so that now it is difficult to find a range of mountains, within the vast area west of the Rocky Mountain crest, where traces of the "prospecter's" pick may not be detected, while in many places large towns and thriving mining settlements have already sprung up. The gold discoveries on the western slope of the Sierra have led directly to this result, and it is from the mines of California that nearly all the capital has been obtained, which has been applied, with immense energy and perseverance if not always with skill and judgment, to the opening of new mining districts, not only within the limits of the State, but far beyond them, and in all directions, from the Colorado, through the Great Basin, to the Columbia.

The auriferous region of California is not exclusively confined to the western slope of the Sierra, nor can any exact line of division be drawn separating the silver-bearing districts from those which produce gold; but by far the larger portion of the last-named metal has come and is still being obtained from the lower portion of the flanks of that great range, on what may, therefore, with propriety be called the main 
auriferous belt of the State. And, for convenience, this belt will be taken up by itself and made the subject of the present chapter, while the Higher Sierra, or the loftier and almost uninhabited regions of the crest of the mountains, will be described in the succeeding one. Not that mining explorations have failed to extend themselves into these snow-covered and inhospitable regions; but, as yet, their results have rarely been such as to warrant the hope that, under the present condition of things, there can be anything developed in the upper portion of the Sierra which will at all compare in importance with what we know to exist in the auriferous belt proper. For this reason, the chapter relating to the High Sierra will be found to be devoted, not so much to giving the results of mineral explorations and the description of abortive mining enterprises, as to its grand physical features, its stupendous scenery, its geological peculiarities, and to such other considerations as may suggest themselves in connection with the necessity of traversing it at various points with roads and railroads, which are needed to connect California with the great mining region to the east, as well as the still remoter States of the Mississippi Valley and the Atlantic coast.

After giving what information our means and space will permit in regard to the physical geography and geology of the High Sierra, we shall pass, in the succeeding chapter, to a description of those portions of the State which form what is generally known in California as the "Eastern Slope," or which lie to the east of the main crest of the Sierra, including a series of lofty mountain ranges and deep valleys between them, opening out to the southeast into the Great Basin, or the Great Desert of California, a vast region, of whose geological features we can give, at present, only a faint sketch.

The auriferous belt spoken of above, and to which the present chapter is devoted, may be said to begin in the neighborhood of the T'ejon Pass, and to extend through the State to its northern limit. Owing to geological peculiarities, however, different portions of the flanks of the Sierra are of very unequal importance as gold-producing regions.

The principal auriferous district, and that which comprises a large proportion of the population and wealth of the State, occupies the western portion of each of the counties of Mariposa, Tuolumne, Calaveras, Amador, El Dorado, Placer, Nevadia, Sierra, and Plumas, witl 
portions of the eastern sides of Yuba and Butte, and in describing this region this order will be followed for convenience, the counties being taken up in succession, from the south towards the north. It is here that the belt of metamorphic slates and sandstones, which is peculiarly the gold-bearing formation of the State, is developed to its greatest width and least concealed from the miner's exploration by the presence of overlying non-metalliferous formations. It is here, also, that the physical conditions have most favored the concentration of the gold in the detrital formations, so that it could be obtained by simple washing, without the necessity of mining for it in the solid rock, and perhaps more readily and more abundantly than in any region ever opened to seekers after the precious metal. The nature of these conditions, which were so favorably combined in California as to enable the unskilled mining population, which flocked thither from all parts of the world, to carry the production of gold up to between sixty and seventy millions of dollars per annum, within three years after the first opening of the country, will be best explained and understood after the geological structure of the region shall have been described, and they will, at some future time, be thoroughly discussed.

The limitation of the auriferous belt on the north, in Plumas and Butte Counties, is not owing to the thinning out of the proper goldbearing formation; but, rather, to its becoming covered almost entirely, over an immense area in those counties, as well as Shasta and Siskiyon, by a mass of lava of very recent origin, which has been poured forth from Lassen's Butte and other volcanic cones in its vicinity, and has flowed over the older slates and covered them to a great depth with an almost indestructible and entirely non-metalliferous formation. This extends quite down to the Sacramento River, near Antelope Creek, but recedes from it to the east, beyond Battle Creek, passing a little to the east of Fort Reading. The western edge of the great rolcanic plateau may be traced in a line nearly northeast from that point, for a distance of about twenty-five miles; it then bends to the northwest and follows nearly that course to the north line of the State, passing a little to the east of Yreka.

To the west of the volcanic plateau, in portions of the counties of Siskiyou, Del Norte, Klamath, and Trinity, there is a very large area 
covered by the auriferous slates in part; but where granite and granitic or gneissoid rocks are more extensively developed than in the more southern part of the gold region; hence the importance of this northwestern corner of the State as a mining district is less than it would otherwise be, as the granitic formation is, on the whole, considerably less productive in gold than are the slates; so that, while the latter rock may be presumed to be auriferous, until it is proved to the contrary, the granite, on the other hand, camnot be expected as a matter of course to contain rich quartz veins, or to have given origin by its disintegration to a detritus which can be washed for gold with profit; such cases do occur, but they are exceptional, and the auriferous veins in the granite are almost entirely limited to the vicinity of the metamorphic slates and sandstones. Besides, the physical conditions in the northwestern corner of the State are less favorable than they are in the central mining counties, while its extreme roughness, its distance from a market, and the warlike character of the Indians, who have possession of a considerable part of this area, are all drawbacks to its development.

In the extreme southern portion of the gold region beyoud Mariposa County, the slates almost cease to form a continuous belt, and they are more and more encroached on by the granite, as we go towards the Téjon. In fact, there is a gradual decrease in the width of the auriferous formation proper from the north towards the south, and a constant increase in the amount of metamorphism displayed, the granite occupying a larger portion of the mass of the Sierra, and descending lower down on its flanks, while the crest of the mountains becomes more and more elevated, its culminating points being in about the latitude of Owen's Lake.

There is a district there, between the Téjon Pass and the commencement of the gold region proper in Mariposa County, which might perhaps with equal propriety be described in the chapter devoted to the High Sierra, or in this one, which embraces the auriferous belt. On the one hand, the region in question is chiefly granitic, the metamorphic slates occupying but a few patches in the granite, of very insignificant area as compared with the mass of the last-mentioned rock. But, again, as there are both quartz and placer mines at various points 
through this region, and as our remarks are necessarily of the most general character, our opportunities for its exploration having been exceedingly limited, it will perhaps be as well to let what we have to say in regard to the district in question precede the description of the main metalliferous belt of the Sierra, which will be taken up by counties, and in geographical order from north to south.

\section{Section II.-Fron Téjon Pass to Mariposa.}

In entering the Sierra Nevada from the Desert, or Great Basin, by Frémont's Pass, which was the route followed by our party, a low ridge is crossed, and the valley of Oak Creek is reached. After leaving the beds of gravel and detritus which form the edge of the desert, the first rock encountered, at the entrance of the pass, is a white limestone, crystalline, but distinctly stratified, having a north-northeast strike, and a high dip to the sontheast. It seems to form a narrow belt, but was not minutely examined. After crossing the limestone, soft granite was observed, which rock continues, beyond Oak Creek, nearly to the Tahichipi Valley. Frémont's Pass, or that by which Frémont entered the Great Basin, in 1844, is over a low hill and leads out from a sidevalley of the Tahichipi; the name is not used by the settlers, but that of Tahichipi (Tah-ee-chay-pah of the Pacific Railroad Reports) is given to the whole region between the valley of that name and the desert. The ridge between Oak Creek and the Tahichipi Valley is chiefly of granite, with some highly-crystalline, metamorphic rock; it is quite low, being only a few hundred feet above the plain.

Tahichipi Valley is a basin about eight miles long and of irregular width, entirely surrounded by mountains, of which the highest rise to nearly 7000 feet above the sea; the valley itself is 4000 feet in elevation. At its eastern angle, in the lowest part of the basin, is a salt lake, near which, and on its north side, along White Rock Creek, are white strata, supposed to be of volcanic origin. North and northeast of the valley is a chain of high and rugged mountains, estimated at 7000 feet in altitude, and believed from their appearance in the distance to be volcanic. On the southwest is a high granite mountain, which, in May, 1863, was 
covered with snow and was estimated at over 7000 feet high. Some boulders of limestone were found in the arroyos that come down the sides of this ridge, and gold is reported as existing in small quantities. Some of the gravel in the valleys extending west into the granite range is said to be sufficiently auriferous to pay for working. Hydraulic mining is practised here with some success, and ordinary placer washings are carried on, at intervals, during the season when water is to be had. The principal drainage of this valley is by a stream, without a name, which leaves the basin at its southeast angle, and which the Tahichipi Pass follows; but the Tahichipi Creek is a stream rising in the western part of the valley and flowing northwest, through a deep cañon in the granite, to the Tulare Plain. This would be the lowest route across the Sierra Nevada into the Great Basin from the Central Valley of California, if a road were made up Tahichipi Creek; but, up to the present time, there is no communication into the valley from the west, except by means of a road passing over a mountain which is much higher than the main divide itself. Lieutenant Williamson followed down the Tahichipi Creek for fifteen and a half miles through this cañon, and found it to have an average descent of 157 feet to the mile. From his description of this pass, there would seem to be no doubt that it is the easiest one by which the Sierra can be crossed; but it may be considered doubtful, from its geographical position with regard to the mining region of the State, whether it will ever become of any great importance. From the eastern entrance of this pass across to the Colorado is a region very forbidding to settlers and railroad engineers. The elevation of the summit of the pass, which is in the valley, is given by Williamson at 4020 feet.

Tahichipi Valley was covered with excellent grass and forage when visited by our party (May, 1863), affording the best pasturage seen over any area of equal size during the year's journey among the Sierras. There are a few settlers here engaged in raising stock, and it is said that but little snow falls in the valley.*

* In regard.to the orthography of the name which we have written, "Tahichipi," it may be stated that, to avoid confusion, we have followed the spelling of the United States Surveyor-General's Office. It comes pretty near the pronunciation adopted by the settlers; perhaps "Tahachipi" would be still nearer.

GEOL. VOI. I. - 28 
At the northern edge of the valley, and on the east side of Tahichipi Creek, white crystalline limestone occurs, containing some graphite; its trend could not be determined. It is cut through by a wide dyke of basaltic lava, which runs nearly north and south.

From Tahichipi Valley down the creek of the same name, to its junction with Cottonwood Creek, granite and gneiss are the predominating rocks; but some mica-slate was observed, especially near the mouth of the cañon, where it forms rounded hills bordered by the Tertiary of the Tulare Plain. The strike of the gneiss, which makes up the larger portion of the formation, is nearly north and south, and it dips at a high angle to the east, being much contorted and often cut by veins of milk-white quartz, which run at right-angles to the strike of the inclosing rock; some of these quartz veins are of very large size. The trail at present used, in going from the valley over to Cottonwood Creek, is very rough, but affords magnificent views of the surrounding mountains and the Great Valley.

From Cottonwood Creek, our party crossed over to Walker's Basin, "the Park" of the Pacific Railroad Reports. The trail led up Cottonwood Creek and Pass Creek, a branch of the first-named, and then over a sharp and steep ridge, the rocks being exclusively gneiss and mica-slate, the former predaminating. There is considerable soil on the ridge, and a pretty good growth of timber. In the cañon of Pass Creek are many boulders of limestone, indicating a considerable mass of this rock somewhere to the east.

Walker's Basin, or Valley, is a triangular area surrounded on all sides, except a portion of the southeast, by high mountains, the highest peaks east and west being fully 7000 feet in altitude. Cañon Mountain, on the west, has very large exposures of bare rock, consisting of granite and gneiss, beantifully and distinctly bedded or stratified, with a strike of $\mathrm{N} .75^{\circ} \mathrm{E}$, and a nearly vertical dip. The high mountain lying northeast of the valley is of the same character, with rather more granite, having a north-northwest strike and northeast dip. The immense areas of bare and rugged rock on these peaks give a peculiar grandeur to the landscape, especially as contrasting with the green herbage and spring vegetation of the level region below. The soil of the valley or basin is sandy, and chiefly made up of granitic detritus; but 
it produces large crops, in localities where there is a sufficient quantity of water. Boulders of limestone are abundant in this region, and a large ridge of this rock is said to occur four or five miles east of the valley. The outlet of Walker's Basin is at its southeast corner, where the stream enters a deep and narrow cañon, through which it threads its way for twelve or fifteen miles, to reach the Tulare Valley.

A low divide, perhaps 1000 feet above the general level of Walker's Basin, separates it from the valley of Kern River. In the ridge are mica-slate and gneiss, trending about N. $60^{\circ} \mathrm{W}$., and dipping at a high angle, sometimes north and sometimes to the south. These rocks continue along the trail, nearly to Kern River, and some granite is associated with them. Near the foot of the trail, on entering the valley of the Kern, the slates are observed, in decomposing, to form a dark-red, ferruginous soil, like that of the auriferous belt of the Sierra; but this detritus has not proved to contain gold.

On the east side of the trail are high mountains, with bold and precipitous sides, made up of light-colored granite. The higher ridges of this region are very barren, and only thinly wooded. From the summit of the trail there is an extensive view, over a region of rugged granite mountains lying to the north of Kern River, which are very barren and have but little timber on them.

Walker's Pass crosses the Sierra near the point where the Kern River bends from its southerly course, and runs west across the ranges to enter the Tulare Plain. The wagon-road from the valley does not, however, follow the river, but crosses a high mountain range to the north of it, as the river itself flows, for a portion of the distance, in an inaccessible cañon with almost vertical walls.

Keysville is situated at the forks of the river, and two miles above this the cañon opens out into a broad valley, similar to Walker's and the Tahichipi Basins. The North Fork flows into this valley, having pursued a southerly course, between two parallel ranges of the Sierra, from its head, a little west of Owen's Lake. Granite is the predominating rock of the region around Keysville, and no other is seen for six miles east. At this distance, going in that direction, limestone is met witl, associated with mica-slates and quartzites, undoubtedly of metamorphic origin. The limestone is crystalline, and has numerous dark bands 
parallel with the stratification, which give it a very elegant appearance. The strike is $\mathrm{N} .15^{\circ}$ to $25^{\circ} \mathrm{W}$, and the dip vertical, or at a high angle to the southwest. Another locality of metamorphic rock is at "Roberts's," about twenty miles east of Keysville, where there is an exposure of hornblende-slate of limited extent. With this exception, granite was the only rock seen in the region. This has a distinctly bedded structure, so that when seen in large masses it appear's as if stratified; it is also more or less cut by veins of lighter granite of some. what different texture and composition. Mountains rise on each side of the valley to the elevation of about 7000 feet, having sparsely scattered timber on their sides. The soil at their base is made up of granitic detritus.

Walker's Pass follows up a small branch of the Kern, called on the Pacific Railroad Map the Chay-o-poo-ya-pah; the elevation of the summit of the pass is given by Williamson at 5302 feet, and the route is pronounced by him unfavorable for a railroad, as the rise of the last eight miles, in going from the west to the summit, is very steep, averaging over 300 feet, and being for the last mile and a half as much as 428 feet, per mile. The mountains rise on each side of the pass to the height of from 5000 to 7000 feet. Hornblende-slate occurs on the north side, lying on the granite, and dipping to the northeast; but granite is everywhere the predominating rock. From the summit of the pass there is a gradual slope to the desert. A great basin, or open plain, extends between the Sierra and the Coso Mountains, which lie some eighteen or twenty miles to the east. The detrital materials forming this plain sink in a gradual slope towards the centre from the ranges on each side; but the western side, or that reposing on the Sierra, rises much the highest and forms great tables against the mountains, rising to a height of at least 4500 feet above the sea. As far as the composition of this detrital mass could be observed, it appeared to be made up of gravel and coarse granitic sand, but did not contain many large boulders. It is cut by deep gorges, which are occupied by running water only at the time of heavy rains. The gravel is not consolidated into a rock, and whether it belongs to the Tertiary or to a Post-Tertiary formation is not positively known. Along its western border, at the base of the Sierra, many bare and ragged outcrops of 
granite project above the detrital masses for hundreds of feet, giving a peculiarly and grandly picturesque effect to the desolate landscape.

The mining district of "Slate Range" lies about 55 miles, in the direction of N. $79^{\circ}$ E., from the eastern entrance of Walker's Pass, in the second range of mountains to the east. This region has not yet been examined by the Survey.

From the forks of Kern River west, the road does not follow the river, but crosses the mountains to the north. About Keysville the formation is entirely granite, generally very hard; it is traversed by dykes of the same rock, but having a different texture, and also by quartz veins, of which the direction is approximately northeast and southwest. Some of these are worked; one called the "Mammoth Ledge," about one mile southeast of Keysville, is a well-defined vein, running about northeast and southwest, and dipping vertically; it is said to pay well, and has several claims located on it. The wall-rock is exclusively granitic. Another vein is reported, ten or eleven miles northeast of Keysville, which is said to be wide and productive. Rich specimens of auriferous arsenical pyrites have been brought to the office of the Survey from this region, and preparations were making, a year ago, to open extensive mines on the lodes. There are also some goldwashings in the granitic detritus.

The road from Keysville to the Tulare Valley passes over Greenhorn Mountain, and is very steep and difficult. The rock is all granitic, with numerous placer mines, some claims paying very well. There are quartz veins in the granite, generally in the neighborhood of these placers; but occasionally there are gulches, quite productive in gold, and near which no quartz is found. The diggings increase in number as we approach White River. All the streams coming down from the Sicrra pass through narrow cañons before entering the Tulare Plain; this renders it impossible to ascend into the mountains by following up the valleys. But in the interior of the chain, after passing the outside ridges, the cañons open out into comparatively broad valleys, some of which are very charming, as contrasted with the wild and desolate region around them. Posé Flat, Little Posé Flat and Linn's Valley are instances of these openings. The western side of the chain has much more timber than the eastern. Over Greenhorn Mountain and 
to the east of it, three species of oaks and two of pines are common trees; there are many shrubby and herbaceous plants, and an abundance of forage.

The road from Keysville to Tulare Valley does not emerge from the hills until it nearly reaches the Tule River. Between Tulé and White Rivers, it passes for some miles among low, rounded granite knobs, the Tertiary tables being very conspicuous in front, the rounded tops of the almost innumerable hills rising to nearly the same elevation, and gradually declining towards the centre of the Tulare Valley.

On emerging into the plains near Tule River an outer tier of low hills with rounded summits was observed; they were composed of metanorphic rocks, and chiefly of slates. This belt continues to the northwest, rising into hills of considerable height between Tulé River and Four Creeks; but they do not form a continuous ridge, as the plain in some places extends back to the granite. This band of rock appears to be the same which appears in the Téjon Cañon in the form of mica-slate.

From Visalia to Fort Miller, the route of our party was along the line of the horizontal Tertiary beds, which form the lowest belt of foothills at the base of the Sierra; these will be found noticed in the preceding chapter. The region behind these elevations, higher up on the flanks of the mountains, is but little known. The streams have been carefully prospected by explorers, no doubt, as it has rarely happened that even the most insignificant gulch has escaped the notice of the gold-seeker's, along the whole western slope of the Sierra; the absence of mining camps through this region, therefore, is pretty stroug evidence that the rocks, even if auriferous in places, are not generally and sufficiently so to be worthy of continuous working under present conditions. It is desirable, however, that farther explorations should be made by the Survey in this district, not only for geological purposes, but for the sake of getting a better idea of the topography, which is known only in its rudest outlines. Some notices of localities of goldwashings high up on the streams which come down into the plain along this part of the Sierra will be found in the next chapter. 


\section{Section III.-Mariposa County.}

The County of Mariposa comprises the region drained by the Mereed River and its very numerous branches. The line between this and Tuolumne County on the north follows the divide between the Mereed and the Tuolumne Rivers nearly to their heads, an east and west line rumning across to Mono Lake, forming the north boundary; the southeastern is a straight line drawn from the head of the Chowchilla River to meet this at the lake. The county as thus bounded is about sixtyfive miles long in a northeast and southwest direction, and thirty miles wide. Mariposa County does not extend to the San Joaquin River ; it reaches no farther in that direction than the lower edge of the foot-hills of the Sierra, where it meets the line of Merced County.

The settlements in Mariposa County are almost exclusively confined to its lower or southwestern side. There is no wagon-road across the Sierra leading through the county; but there is a trail, over the socalled Mono Pass, which is a goor deal used during the summer by pack-trains. The business is not sufficient to create settlements along this route, as there was not, in 1863, a house, or cabin even, between the Yosemite Valley and the eastern base of the Sierra.

For a description of the magnificent scenery of the upper part of this county, as well as of the physical features of its higher portion, reference may be made to the succeeding chapter. The present one has to do only with the lower mining portion of the county, of which, however, it will be necessary to give only the briefest possible description, as our materials are far from complete, and space, in this volume, is very limited.

The great feature of Mariposa County is the so-called "Mariposa estate," on which are several of the largest mines in the State, and where extensive improvements have been made, a large amount of money expended, and which, on many accounts, has attracted a very considerable share of attention on both sides of the Atlantic. This estate comprises an area of seventy square miles, and extends from the Merced River southeast for about sixteen miles, keeping on the line of 
the great quartz-lodes of this region; this direction is also nearly that of the strata in which the veins are inclosed. Placer mining has been carried on here since the earliest days of mining enterprise in California, and it was here that quartz-mining was first attempted, as early as 1852. The magnitude of the outcrops of quartz and the rich yield of gold of some of the lodes, especially near the surface, might well turn public attention in this direction, and give rise to hopes of boundless wealth to be realized from their working, which have thus far not been satisfied.

The geology of the Mariposa estate has been examined with some detail by Mr. King, from whose notes the following notice of some of the most prominent facts connected therewith is chiefly taken.

The topographical features of the estate are strictly subordinate to the geological structure, the courses of the streams and mountains being all in the main parallel with the normal direction of the strata; the streams, however, as is so often the case on the Pacific coast, do not fail occasionally to show their independence of the ridges, by breaking through them at right-angles to their general trend. The northeastern boundary of the estate is a lofty and precipitous range of mountains, known as the "Mount Bullion Range;" this is a very conspicuous feature in the topography of the country, through the northern half of the estate, but it falls off to the south and runs into several parallel lower ranges, between which flow the branches of Stockton and Mariposa Creeks. Parallel with this range, and next southwest, is the main valley of the estate, Bear Valley, with a stream of the same name, which flows southeast nearly to the centre of the tract and then turns and breaks through the mountains on the southwest, called Juniper Ridge. Crossing the low divide which separates Bear Valley from the Agua Fria, we find the southeastern portion of the estate occupied by short, broken ridges, through which the Agua Fria Creek winds its way, keeping a general southeast direction, with many bends at right-angles to this.

Through the centre of the estate, in the portion occupied by Bear Valley and the Agua Fria, is a broad belt of slates, which is the main geological feature of the region. On each side of this are belts of sandstone, mostly in a highly metamorphic condition; these have again 
masses of slate outside of them, but of which only rery small corners fall within the limits of the Mariposa grant. Subordinate to these belts of sandstone and slate are masses of serpentine and beds of limestone. The extreme southern end of the estate is occupied by granite, which cuts across the other formations and continues westward towards the foot-hills.

The upper or northeastern sandstone range has its maximum of elevation, as well as of metamorphic condition, towards the centre of the estate, in the lofty ridge of Mount Buliion, of which the culminating point is said to be about 5300 feet above the sea. Near the Merced River, and towards the town of Mariposa, the sandstone is in many places very little altered from its original condition. Along the southern edge of the sandstone belt, and separating it from the slates, is a band of serpentine, of varying width, which is seen along the base of Mount Bullion, and from Bullion Knob southeast to Buckeye Ridge and the Crow's Nest. Connected with the serpentine are other magnesian rocks, such as steatite and talcose slates. Two smaller outcrops of serpentine appear near Mount Ophir and Green Gulch Mill; these are within the slate belt, and they pass into it through an intermediate stage of talcose slate. Within the sandstone series are two unimportant outcrops of limestone; one near Oak Springhouse, the other close by the Benton Mills. These are both highly crystalline, and probably contain considerable silica. They coincide in strike and dip with the surrounding rocks.

Mr. King examined the strike of the slates on this estate in a great number of places, and found that all the strata between Mount Ophir and Pine Tree have a direction of $\mathrm{N} .28^{\circ} \mathrm{W}$., not varying anywhere more than a degree and a half from this. But north of Pine Tree and

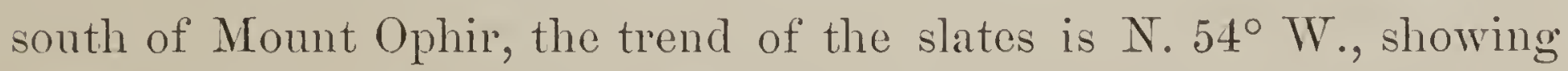
the existence of two great breaks or flexures in the strata, with a change of direction of $26^{\circ}$ at each of them. In the vicinity of these points where the change takes place, the rocks are exceedingly broken and crushed, as would have been expected, the surface rock having every possible direction, and dipping at all angles, although invariably to the east. The length of that southern portion of the belt which has a trend of $\mathrm{N} .5 t^{\circ} \mathrm{W}$, is seren and one-eighth miles; of that which 
strikes N. $28^{\circ} \mathrm{W}$., five and six-eighths miles. The northern trend of $\mathrm{N}$. $54^{\circ} \mathrm{W}$. continues beyond the limits of the estate to an indefinite distance.

Within the slate formation are interstratified sandstones, which are in some cases very distinctly bedded, as, for instance, on the west slope of Hell Hollow. The beds are often several feet in thickness, and, like the slates themselves, in all stages of alțeration, as is made evident by the differences of hardness, color, and texture which they exhibit. The region of least metamorphism seems to have been from the Pine Tree Mine west to the slope of Juniper Ridge, and southward to near the village of Bear Valley. It was in this region that Mr. King found, in situ, fossils by which the age of this formation was clearly made out to be Jurassic.*

As the slates continue southward, they appear to become more altered, and, in the vicinity of the granite, they are very hard, and often contain acicular erystals of black hornblende. Besides the beds of sandstone in this belt of slate, there is a band of conglomerate, which appears west of Hell Hollow, and at various points between there and Green Gulcl. This is made up of pebbles of a slaty rock, with many others of a hard, gray, silicious limestone.

It is in the great slate belt that the larger part of the very numerous gold-bearing quartz veins which occur on the estate are found. Mr. King examined about one hundred and fifty outcrops, and found that, in much the larger number of cases, the veins coincide in dip and strike with the rock in which they are inclosed; although, in a few instances, they appear to cut the slates at a slight angle. Nearly all the veins which occur in the granite, and they are quite numerous, have the same dip and strike as those in the slates; a few, however, run at right-angles to these. Parallel with these cross-veins, in the granite, are dykes of trap, from a foot to fifteen inches in width, which are made

* For the partieulars of this discovery, and a description of the fossils, with figures, by Mr. Meek, see the Appendix to this volume. The geological age of the auriferous slates being one of the most important problems to be solved by the Survey, and everything bearing on this question being of the greatest interest, the publication of the deseription and figures of these fossils, which would properly come in the second volume of the palæontolngieal portion of the Report, will be hastened by giving them in this. 
up of a uniformly fine-grained and compact material, destitute of prismatic or jointed structure.

The granite is a finely-crystalline variety, in which both hornblende and mica are present. The outcrops are smooth and rounded, and exhibit evidence of the concentric structure so often observed in this rock, and which is developed as it undergoes decomposition by weathering. The region along the junction of the granite and slates is covered with a thick accumulation of disintegrated granitic detritus and gravel, which prevented a careful examination of the junction of the two formations.

For a detailed account of the workings on the various quartz veins of this estate, reference is made to the volume devoted to Economical Geology, Mining and Metallurgy.* A few facts may be stated here to give an idea of the magnitude and importance of these veins.

The Pine Tree and Josephine Mines are on the northwestern end of the Mount Bullion Ridge, about a mile and a half from the Merced liver. These mines are in what might be called with truth one of the most extraordinary masses of quartz yet discovered. The average thickness is fully twelve feet, and in places it expands to forty feet, all of solid veinstone. The mass has been opened and worked, chiefly at an elevation of about 1300 feet above the river, by levels run in at four different elevations. Portions only of this vein contain gold enough to pay for working, and the best of the lode is not very rich. The average yield of the Pine Tree quartz worked in the mill was considered to be $\$ 12$ per ton in 1860 ; but the quality of the ore has deteriorated since that time. The processes at the Benton Mill, where this quartz was worked, were so defective, that it was evident that a very large portion of the gold was lost.

The Josephine Mine, a little southwest of the Pine Tree, is on an enormous onterop of quartz, averaging twenty feet in thickness, and from

* Thenever reference is made to other volumes, which are expected to form a portion of the Final Report of the Geological Survey of the State of California, the reader will please understand always, that the publication of such volumes is dependent on the eaprice of a future Legislature; and that, of course, no positive engagement is made that they will ever appear. It is only meant to be understood that they will form a part of the series of our publications, provided our plans are not interfered with. 
which many thousand tons of rock, with a small percentage of gold, have been taken. The appearance of this mine, in 1860, was most remarkable on account of the immense cavities left in the quartz entirely unsupported, and which have probably caved in before this time.

The quartz from the Pine Tree Mine was crushed, together with that from the Josephine, at the Benton Mill, a sixty-four stamp mill, moved by the water of the Merced. The average yield of the rock worked at this mill was, in 1861, $\$ 8.98$ per ton. The total cost of extracting the quartz, conveying it to the mill, and of crushing and amalgamating was $\$ 4.57$ per ton, leaving a handsome profit. The actual percentage of gold in the rock crushed was certainly a good deal higher than this, as an examination of the tailings showed most distinctly. The mill was in every way unfortunate, both in its location and construction. It yet remains to be shown whether by a system of judicious changes at the mill, combined with careful selection of the quartz and skill in following the richer shoots, the Josephine and Pine Tree Mines can be worked with profit, which at present is not the case, as there has been a considerable falling off of the yield of the quartz extracted since 1860. A portion of the Benton Mill has been reconstructed, with improvements, since the present company took possession of the estate; but of the result we are not informed.

It has never been shown by the workings, whether the Josephine and Pine Tree masses of quartz are connected with each other, or whether they unite to the south. Various excavations have been made in the general direction of the supposed continuation of the united veins, and some rich quartz found; but not enough, continuously, to pay expenses.

There is another group of veins six miles southeast of the Josephine, which occupy a space about three miles in length, and which, if not absolutely continuous, are at least closely connected with each other. Of the outcrops in this group, that known as the Princeton Vein is the most important, and the mine of that name has been in former times one of the most productive in California; it is also one of the deepest and most extensive in its workings, having been opened for a length of 1400 feet, and to a depth of over 500. Its direction is nearly that of the inclosing strata, but with many flexures, the courses in the same 
level sometimes making as great an angle with each other as $30^{\circ}$. The dip, which is always to the east, or with the formation, varies considerably; at the surface, in the western shaft, it was $64^{\circ}$; at a depth of one hundred feet, $57^{\circ}$. In the Ridgway Shaft, it was from $48^{\circ}$ to $50^{\circ}$. The thickness of the lode varied from a few inches to eight feet. The rock in which this vein is inclosed is a dark-colored, fine-grained, and rather soft argillaceous shale, which material also often forms fine layers in the veinstone itself. This latter is quite different in its appearance from the veinstone of the Pine Tree and Josephine, containing more pyrites, blende and galena, and less blue carbonate of copper, besides showing free gold in many places, so as to form beautiful specimens, some of which are almost unsurpassed in beauty. The average yield of the quartz from the Princeton Vein, in 1860, was from $\$ 25$ to $\$ 31$, according to the mill in which it was worked. It is said that nearly $\$ 2,000,000$ have been taken from this mine; and it is also understood that at the present depth the yield of the quartz in gold has fallen off very materially, which is one of the prominent causes of the failure of the company now, or at least recently, in possession of this estate, to make their operations profitable.

The Mount Ophir vein is at the northwestern end of the group to which the Princeton belongs. It has not yet been very extensively or successfully worked.

Another group of veins is that near the village of Mariposa, where the first quartz mining on the estate, and, as is supposed, the earliest in California, was done. The principal vein is the Mariposa, which has been traced on the surface for about two miles, a little to the northeast of the village of the same name. This lode has proved to contain several very rich "pockets," and since the giving out of the Princeton Mine, has been the principal hope and resource of the Company.

There are many other outcrops of auriferous quartz on the Mariposa estate, and a great deal of "prospecting" has been done by the Company. High expectations have been excited by this property, and not without reason; its development has, thus far, however, been anything but satisfactory. The causes of this ill-fortune may be examined in the volume of Economical Geology, where full details will be found of the working of the mills and mines, if those who may be in charge at 
the time of publication of that part of the Report permit the necessary examinations and experiments to be made, and the results given to the public.

A large amount of placer mining has been done in other portions of Mariposa County, and many quartz veins worked, not often, however, on a large scale. In 1863 there was considerable excitement in regard to the region of the South Fork of the Merced River, and rich specimens were shown as having come from that district.

There are heavy outcrops of quartz near Coulterville, which are supposed by some to be the continuation of the great quartz vein of the Pine Tree and Josephine. If it cannot be proved to be positively the same vein, it is certain that there-is a series of enormously heavy outcrops of quartz, which run nearly in a straight line, beginning at the Mariposa estate, and continuing as far as Jackson in Amador County, a distance of about 70 miles. It is also certain that the principal quartz mines and heaviest placer diggings are nearly in the line of this series of outcrops, at least in the counties of Mariposa, Tuolumne, Calaveras, and Amador, as will be more fully noticed farther on in this chapter. There are several localities near Coulterville where quartz has been extracted; but none of them appear to have given rise to permanent and valuable mines; at least, none were working in that vicinity in 1863. A number of outcrops were examined, however, and some of them appeared to offer inducements for more careful exploration than they have heretofore received.

There is an interesting quartz lode on the north bank of the Merced, near Horseshoe Bend, on a steep hill-side, at an elevation of some 500 feet above the river. The vein is about six inches wide, as seen at the surface, runs about north and south, and dips to the west at an angle of $65^{\circ}$. It resembles other auriferous quartz veins in most respects; but also carries with it, on its foot-wall, a thin seam of quartz containing cinnabar, in crystalline plates and bunches. The seam is about an inch wide, and appeared to be continuous. There is only one other locality in the auriferous slate formation where this ore has been seen by us in place, and it is a very interesting occurrence, although there is no reason to suppose that the vein can be worked with profit for the 
quicksilver it contains. The rock inclosing this vein is a greenish, highly metamorphic slate.

A few miles northwest of Coulterville there is a fine outerop of the great quartz vein of California in the Peñon Blanco (White Rock), a prominent elevation, of which the crest is a great white mass of quartz, visible from a great distance, and as contrasting with the deep green of the chaparral which covers the sides of the hill, it forms a beautifully picturesque object. A quartz mine has been extensively. worked here, and is understood to pay a very handsome profit. It is known as McAlpine's Lode. The workings are on the back of the great quartz lode on the north side of the Peñon Blanco. Beneath the productive streak, there is an immense mass of white quartz, entirely destitute of gold, and at least forty feet thick. Above it there is also quartz, but of a very different character from that below; being more ferruginous and mixed with metamorphic slate. The great mass of quartz which underlies the lode has been laid bare by stripping, over a length of a hundred, and a height of forty feet, and its smooth and regularly-curved surface is an interesting object to the eye of the geologist. The productive lode has been opened for a length of 1300 feet; and, in places, the workings have reached a depth of 300 feet, where the vein is more nearly vertical and quite regular. These were, in 1863, the only workings on the great quartz vein between Coulterville and Big Oak Flat.

From Coulterville, the most frequented trail leads to the Yosemite; but, as this valley is entirely beyond the mining region, it will be described in the chapter relating to the High Sierra.

Mariposa County differs from most of the mining region of California, in that it has very little of the volcanic accumulations upon its surface which are elsewhere so extensively developed. Hence there are no great hydraulic washings, and the placer mines having very much diminished in yield, the county must look to the development of its quartz lodes for the largest future advance in its prosperity. 


\section{Section IV.-Tuolume County.}

Tuolumne County is one of the most interesting regions in the State, especially on account of the large development of Tertiary, Post-Tertiary and volcanic materials which overlie the older slates, and which are mined extensively in tumnel and hydraulic washings; these are particularly remarkable as containing more of the remains of large animals, such as the mastodon and elephant, than the same formations in any other portions of California.

Tuolurnne County is intersected longitudinally by the river of that name, and has for its southern limit the divide between that river and the Merced; its northern boundary is the Stanislaus. Its shape approaches that of a rectangle, and it is about sixty miles long from northeast to southwest, and forty in the opposite direction. The southwester'u part of the county is pretty thickly inhabited, while the higher portion is almost as much a terra incognita as it was in 1849. A single road crosses the mountains, from Sonora to Aurora and Mono Lake; but south of that, as far as the Yosemite trail to Mono, all is unexplored. Our party passed over the Sonora trail, and such observations as were made in the High Sierra, within the limits of this county, will be found in the succeeding chapter.

The auriferous slate formation occupies a belt of about twenty-five miles in width, in the lower part of this county; all the remainder is underlaid by granite; but extensive deposits of volcanic materials cover both slates and granite, in many places, and over a considerable area of surface. The rocks of the auriferous series exhibit themselves in Tuolumne, as elsewhere in the lower part of the Sierra, with a great variety of lithological characters. The predominating formations are slates, which are argillaceous and silicious, rather than talcose. Besides the slates, there are sandstones in various stages of alteration; but they have almost everywhere been highly metamorphosed since their deposition. They frequently pass into dioritic or trappean varieties, which it is difficult to distinguish from the really intrusive or eruptive masses. They also assume a porphyritic structure, appearing in various forms of hornblende-porphyry, and passing into compact hornblende-rock, or 
amphibolite. Serpentine is also one of the forms of metamorphism of the rocks of the auriferous slate series, and it occurs in large masses in 'T'uolumne, as well as all the other mining counties. Of the exact distribution of all the different varieties of the metamorphic slate and sandstone series, it would be impossible to give any idea without an accurate map, and of the larger part of Tuolumne County there is no map which is even approximately correct. Besides, our investigations in this region are far from having been detailed enough to enable us to lay down the boundaries of the different subdivisions of the auriferous formations. A small party is now in the field, in this very region, making a beginning of this detailed work, which will be continued towards the north, as fast as it can be done with accuracy.

The finely-laminated slates, which appear to constitute that portion of the formation in which the auriferous veins are best developed, apparently occur in the heaviest masses through the centre of the mining: region of the county; these may be traced from near Jacksonville, north through Chinese Diggings to Jamestown, where they pass under Table Mountain, but reappear on the north side, in the gorge of Stanislaus River, and extend towards Angel's, the formation having a more nearly north and south trend here than it has farther north. The hornblendic series of rocks, including the porphyries, are well displayed in a line to the south of this, as near the Crimea House. Interesting outcrops of hornblende-rock are also seen near Texas Flat, above Abby's Ferry, where the hornblende occurs in very largely crystalline masses, sometimes free from associated minerals, but occasionally containing black mica, and crossed by small feldspathic veins. Serpentine occurs in a large outcrop, about two miles from Jacksonville, on the road to Big Oak Flat, near Goddard's Ferry, at Stevens' Bar; it is here associated with black, argillaceous shales. Metamorphic magnesian rocks also occur to the south of the principal belt of slates, and serpentine beds are included with these, and are characterized by the presence of large deposits, or intercalated masses, of chromic iron, as is seen near the Crimea House. The dip of the series of metamorphic slates seems to be everywhere to the east and northeast, and usually at a high angle; the larger number of observations are between $60^{\circ}$ and $80^{\circ}$.

GEOL. VOL. I. -30 
Their strike is also variable, although on the average not far from N. $30^{\circ} \mathrm{W}$.

Of the geological age of the auriferous belt in Tuolumne, we have but little direct evidence other than that of its connection with rocks known to be of Jurassic age to the south, and of both Triassic and Jurassic to the north. A single fossil, an impression on a dark-colored, highly silicious slate, was found by Mr. Alfred Frick, in situ, at the mouth of Mormon Creek, between Robinson's and Knight's Ferries, on the Stanislaus, and by him presented to Mr. Rémond. The fossil, although not in a very satisfactory condition, appears to be identical with the Goniatites lovidorsatus, found also in the rocks of the Humboldt Range, which are known to be of Upper Triassic age. If not this species, it is still almost certainly of Triassic age, and its discovery adds one to the already quite numerous links in the chain of evidence going to prove that the auriferous slates do not belong to the Palæozoic epoch.

The limestone belt included in the Sierra system of rocks is particularly well developed in Tuolumne County, and its surface has been so extensively washed oft in mining, that there are many beautiful exposures of it. Owing to the want of an accurate map, it is impossible to say what are the exact relations of the different masses of limestone observed, as far as position is concerned; this question will, however, be taken up farther on. At all points visited, this rock has very nearly the same lithological characters, being usually quite crystalline and sometimes highly so, of various shades of bluish-gray, passing into white where most metamorphosed, and often showing very distinctly the lines of bedding, either by thin micaceous partings or darker lines in the highly altered portions. The most careful search has failed to reveal the presence of even a trace of a fossil in it through this region, although there are places where it would appear that metamorphism has not been carried far enough to obliterate entirely the impressions of organic remains if any such had existed.

The most southerly point in the county where this belt has been seen by us is at Bull Creek, on the Big Oak Flat trail to the Yosemite, about six miles southeast of Bower Cave, the trail passing over it for a distance of two miles. The rock here is pretty distinctly stratified, and less metamorphic than usual; but no fossils were discovered. 
At Bower Cave, on the north fork of the Mereed, at a point near where the Coulterville and Big Oak Flat trails to the Yosemite come together, and said to be twelve miles from the former place, the limestone is well displayed, and is remarkable as containing a very picturesque and quite unique cave, the peculiar character of which may perhaps be understood from the annexed cross-section (Fig. 34). It is an

Fig. 34.

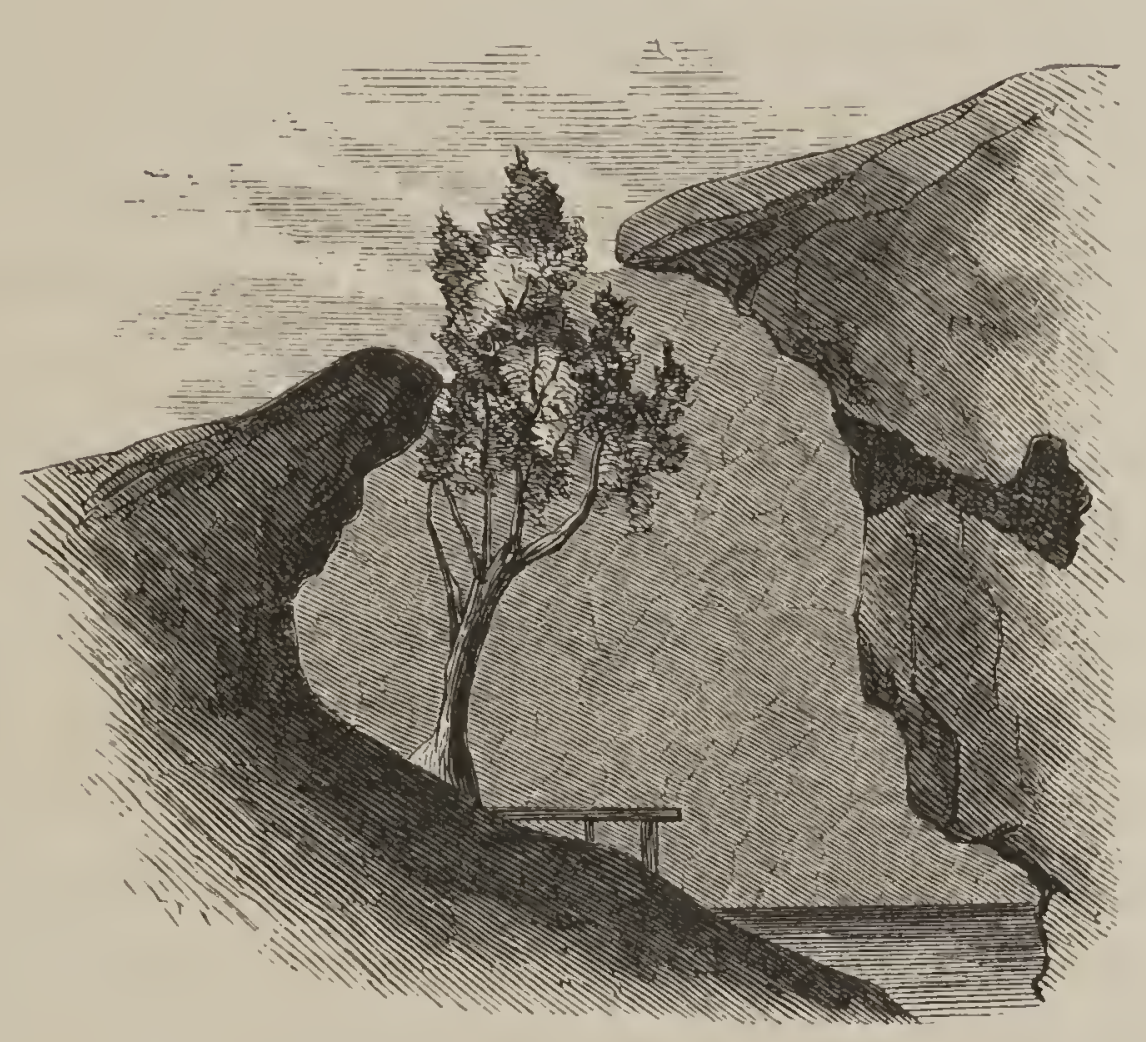

SECTION OF BOWER CAVE.

immense crack in the limestone, open to the air at the surface, and irregularly widened out in a cave-like manner below, by the action of currents of water. On the upper side of the obliquely-descending crevice an overhanging ledge of rock permits the vertical depth of the cave to the level of the water, which partly fills it, to be measured; it is 109 feet. The length of the open crevice is 133 feet, and its width 86. At various heights deep cavities, or small caves, are worn in the rock, some of which may be followed for a considerable distance. The picturesque effect of the cave is greatly heightened by the growth within it of three large maple trees, of which the branches project onit at the top. The water at the bottom is exceedingly pellucid, and permits the ramifications of the crevice beneath its surface to be seen for a depth of at least forty fect. Access can be had to the bottom of the cave by series of ladders, and a boat is provided for the use of visitors, as also a platform, which permits of a comfortable and cool stay 
in this curious place, which seems to be peculiarly adapted for a picnic in hot weather.

The limestone next makes its appearance, towards the northwest, at Kincaid Flat, about three miles from Sonora; it has not been traced or proved to exist continuously over the region between there and Bower Cave. From Kincaid Flat to Abby's Ferry it occupies a broad belt of ground, trending about $\mathrm{N} .25^{\circ}$ to $30^{\circ} \mathrm{W}$., and expanding very much in width just at Sonora, but contracting again rapidly towards Murphy's. The distance across it, at right-angles to the strike, between Springfield and Yankee Hill, is about three and a half miles, which is a considerably greater width than this formation has been observed to have at any other place in the State. Between Kincaid Flat and Abby's Ferry nearly the whole surface of this rock has been washed clean of the superincumbent detritus, and exhibits a singularly curious appearance. It is worn into deep cavities, which are very irregular, but which have their greatest length in the direction of the stratification, and also coincide in their dip with that of the beds of rock between which they occur. These cavities extend down sometimes as much as fifty feet below the surface; but, in general, their depth is from ten to twenty feet. The edges of the ridges between the depressions have a rounded and corroded look, showing that they have been gradually worn away by the action of currents of water, and not

Fig. 35.

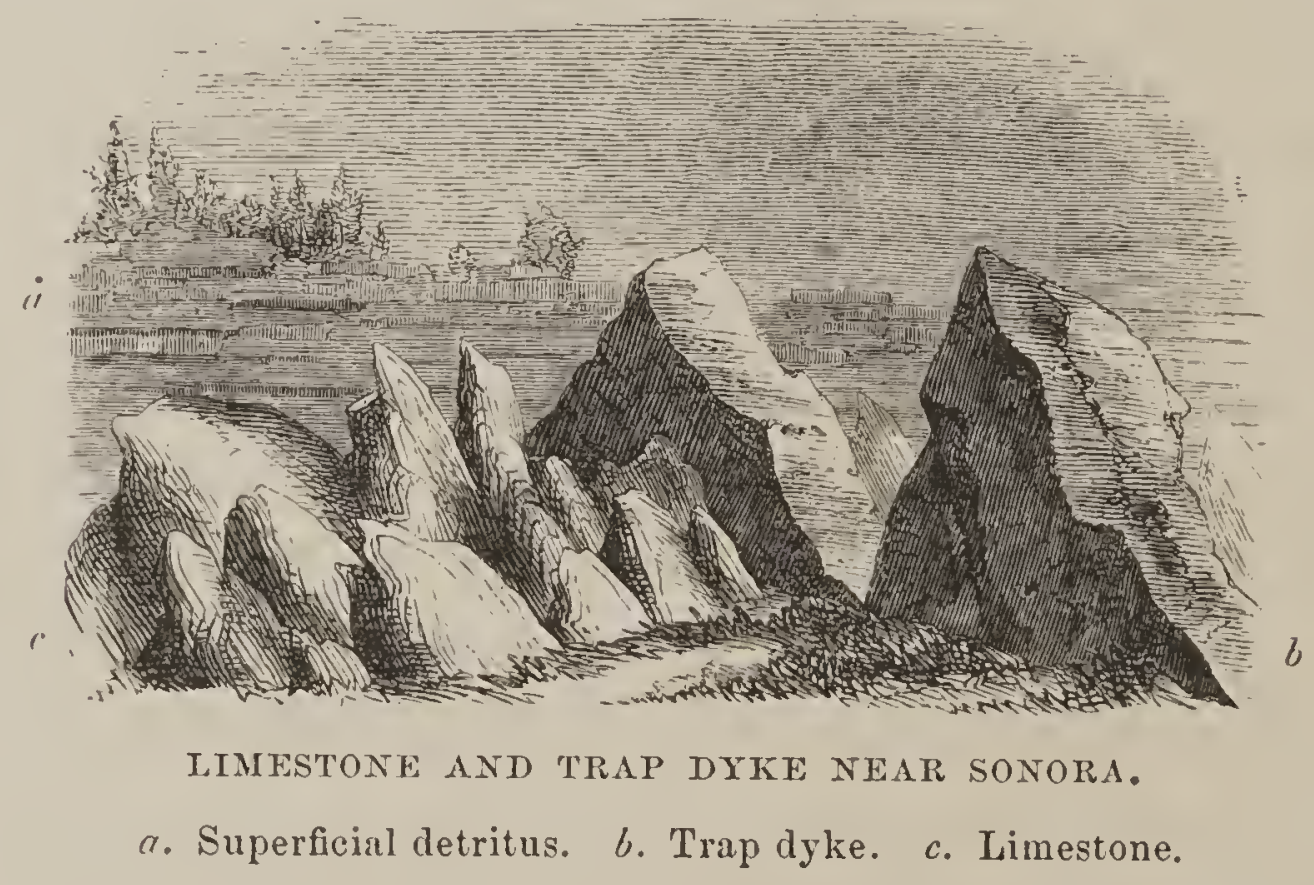

scooped out by the passage of gravel and detritus. The wood-cut (Fig. 35) will illustrate this peculiar surface of the limestone, as well as an- 
other feature which characterizes this belt of rock, namely, that it is intersected by numerous dykes of trap; these run almost always abont at right-angles to the strike of the formation, stand nearly vertical, and are often many feet in thickness. In some parts of the belt of limestones these dykes are surprisingly numerous, as, for instance, near Abby's Ferry. They appear to be almost entirely confined to the limestone formation, and not to extend into the slates which lie next to it, a very curious circumstance, if farther investigations should prove it to be everywhere true. This limestone is quite extensively quarried a little northwest of Columbia, where a good material for gravestones, monuments, and architectural purposes, is readily obtained in large blocks.

In some localities the limestone disintegrates readily, and crumbles into a powder, which on examination is seen to be made up of small crystals. Beds and nodules of chert are observed in this rock, although not frequently. Metalliferous ores are very rarely seen in it; galena is almost the only one found in the limestone about Sonora, and that only in irregular masses, and in too small quantity to be worth working.

Through Tuolumne County the north edge of the great limestone belt nearly marks the line between the metamorphic and granitic rocks. The limestone appears to pass into a quartzose slate, by taking into its composition more and more silica, and a belt of this rock, passing occasionally into gneiss, occupies in some places a considerable area between the limestone and the granite.

Quartz mining has been carried on at many points in Tuolumne County, although most of the valuable veins in this region are worked in the granite and not in the metamorphic slates. A very heavy quartz vein passes a little south of Big Oak Flat, cutting the strata of slate in which it is contained at a small angle, the lines of bedding of the wallrock appearing to run nearly northwest and sontheast, while the vein of quartz has a strike of $\mathrm{N} .30^{\circ} \mathrm{W}$.; it dips to the east at an angle of $30^{\circ}$, the slates themselves standing nearly vertical. This is, perhaps, the most marked instance, hitherto observed in the State, of a hèary quartz vein differing essentially both in dip and strike from the inclosing rocks. There has been considerable mining done at this point; but it seemed, in 1863, to have been stopped, by the burning of the 
mill. There are other localities in this vicinity where quartz mining has been carried on, or where preparations were making at the time of our visit to begin work, the number of veins which contain some gold being quite considerable.

According to Mr. Ashburner's notes, there were in operation in Tuolumne County, in 1859, thirty quartz mills, which had cost over $\$ 200,000$ to erect; but not more than half of these were in existence in 1861 . The scene of the greatest mining activity in this county was, at that time, near Soulsbyville, about eight miles southeast from Sonora. At this place there were three mills, two of which were running on quartz from the Soulsby vein, and the other on custom-work.

The Soulsby vein is inclosed in granite, and stands nearly vertical; it has a strike of almost exactly north and south, magnetic. Its average width is about one foot, the widest place in it being four feet six inches. The granite which forms the wall-rock is exceedingly hard and compact, and the vein perfectly well-defined, and very rich in the sulphurets of iron, lead, copper, and zinc,- the two former, however, in much the largest proportion. Near the surface, where the sulphurets were decomposed, the veinstone was worked with great profit; its average yield, in 1861 , was $\$ 50$ per ton, although some of it has produced six or seven times as much.

Two mines were worked on this vein, one called the Soulsby, and the other the Platt Mine; each of these had a mill, the first one of twenty stamps; the other one of ten. The Gilson Mill, a few rods south of the Platt Mill, was built to run on rock from another claim on the same vein; this was also a ten-stamp mill, and was running, in 1861, on rock from the Draper vein. This vein is one and a half miles from Soulsby's, and is also inclosed in granite, and very nearly of the same character as the Soulsby vein. At Lomberdo's Mill, two miles east of Soulsby's, there are several veins in the granite, nearly parallel with each other, and running about north and south. Of these, the only one worked, in 1861, was the "Louisiana claim," the quartz from which yielded about $\$ 20$ per ton.

There is a group of quartz mines and mills about $3 \frac{1}{2}$ miles from Soulsby's, which were, in 1861, of considerable importance. Of these, the Eureka Mine was worked on a vein in the slates close to their junc- 
tion with the granite, bearing about N. $25^{\circ} \mathrm{W}$., and dipping east at an angle of $50^{\circ}$. The mill has twenty stamps, and is run by a waterwheel fifty-fire feet in diameter. The yield of the quartz was estimated at \$12 per ton. Sower's Mill, near the Eureka, was rum on rock from a vein said to be a continuation of the one worked for that mill; it was doing but little in 1861.

The Confidence Mill is about four miles northeast of Soulsby's, has ten stamps, and was run on rock from a vein in the granite, distant about a quarter of a mile to the east. The quartz is very hard and yielded from $\$ 10$ to $\$ 20$ per ton; its width was from three to twelve feet.

The Telegraph Mill, on the south fork of the Stanislaus, and about thirteen miles from Sonora, was run on a vein inclosed in a belt of slates, which occurs here isolated from the main body of the auriferous slate formation. The vein has the usual course and dip of the inclosing rock, running $\mathrm{N} .25^{\circ} \mathrm{W}$, and dipping east at an angle of $50^{\circ}$. Its width is from a few inches to twelve feet, and it yielded from $\$ 15$ to $\$ 47$ per ton, the average of one thousand tons stamped between September 10th, 1860, and May 29th, 1861, being $\$ 30.80$ per ton.

At Tuttletown, five miles west of Sonora, there were, in 1861, several quartz mills, of which only two were in operation; these were Street \& Co.'s, and Patterson \& Co.'s, both doing a small business, on quartz of a rather low grade of richness.

'The great vein of Mariposa and the Peñon Blanco appears to crop out in Tuolumne County about a mile below Jamestown, where there is a large mass of quartz, which can be seen from a long distance to the east. It forms several eminences, known by the names of Whiskey Hill, Poverty Hill, Quartz Hill, and other equally picturesque appellations. The main vein is very irregular in width, varying from two feet to several rods, and has been repeatedly worked for gold, but never found sufficiently rich to pay expenses. Near the large vein, and nearly parallel with it, are several smaller ones, which have been profitably mined. In 1861, one of the best mines in this vicinity was that of Knox \& Co., on a vein about two hundred feet east of the main one. This averaged about one foot in width, went down perpendicular for the first thirty feet, and then dipped to the east at an angle of $70^{\circ}$. 
The foot-wall also contains gold, in a "casing" of soft slate, from six to ten inches thick, and often very rich. The arerage yield of the quartz from this rein was given at $\$ 20$ per ton. The mill of Knox \& Co. was a small one of only five stamps. The Italian's Mill, of two stamps, was run on quartz from the same vein as that of Knox \& Co. The Yaney Mill, on Wood's Creek, below Jamestown, of six stamps, was run on custom-work, in 1861. Judge Preston's mill, a little below the last mentioned, having eight stamps, was running on quartz from a vein in Quartz Mountain, parallel with the great vein, and twenty or twenty-five feet to the east of it; it was about eighteen inches wide; its yield was not known. Snyder's Mill, on Wood's Creek, has three stamps, and was run on quartz from a vein on Whiskey Hill, which had paid well for several years previous to 1861 .

How many of all these mills have been moved over to Washoe, or have otherwise disappeared, and how many new ones have been built, since 1861, we have no means, at present, of stating.

A new district was opened on Sugar Pine Creek, about twelve miles northeast of Sonora, in 1861, which, when visited in 1863, was found to have some very promising mines, and one which was celebrated over all this part of the State for its richness. This was the Excelsior Mine, owned by Gilliss, Holton \& Gilmore, who commenced operations in December, 1861. The house is at an elevation of 4350 feet above the sea. The vein is inclosed in granite, which is the only rock seen in the region. In the summer of 1863 , the vein had been opened to a depth of two hundred feet, by a shaft sunk on the lode; its inclination was found to be to the northeast, at an angle of $40^{\circ}$ near the surface, and $27^{\circ}$ at the bottom. The vein runs about $\mathrm{N}$. $40^{\circ} \mathrm{E}$., and averages nearly two feet in width. The casings, or selvages of the vein, on each side are rich in gold, and if the veinstone entirely disappears, provicled there is any seam visible in the rock, it is sure to be accompanied by gold on each side. The quartz was said to average from $\$ 50$ to $\$ 75$ a ton, and some had paid as high as $\$ 250$. It was worked in a tenstamp mill, situated on the Tuolumne River, which affords abundant water power, the rock being hauled over the ridge between the mine and the mill by steam power, and descending, on the other side, by 
gravity, on an inclined plane, to the valley of the river, which here forms a gorge over 1200 feet in depth.

A number of other well-defined veins have been discovered in this vicinity, but few of them had been worked up to 1863. The Pirate Mill, built in 1862, is on the Tuolumne River, four miles by the river, and one in a straight line, from the Excelsior. It has ten stamps, but was not running in 1863. It is only three or four miles from this, in a southwesterly direction, to the Confidence Mill, already noticed.

In this county, as in others in California, the quartz-mining interest varies in aspect from year to year; and to kecp the run of it accurately would require that the whole State should be gone over annually. It may perhaps be convenient in another part of this Report to make some general remarks on this branch of the mining business; but it will not be until the publication of the volumes on Economical Geology that the subject will be thoroughly discussed.

As before mentioned, the detrital and volcanic deposits which rest upon the granitic and auriferous slate formations, in this county, are of great interest, for it is in this region that these deposits have yielded a larger number of fossils than have been found in any other part of the State in a similar position. - These detrital strata may be divided into two classes, namely: first, such as rest directly on the surface, without being covered by any other formations; and, second, those which are overlain by more or less extensive accumulations of volcanic materials.

The first of these classes presents the ordinary features of the surface deposits of the gold region, or the usual placer-diggings, so widely distributed over the State, and which, to avoid repetition, will all be treated of at once, in a section devoted to the Post-Tertiary.* Some peculiar features of these deposits in Tuolumne County, may, however, be mentioned here.

The surface of the limestone through the whole region from Kincaid Flat to the Stanislaus has been one of the most productive areas of placer-mining in the State. Nearly the whole of this district has been

* Either in the systematic review of the geological formations of the State, which will be given in another volume of the geological part of this Report, or, else, in the volume of Economical Geology. 
worked over, although in some places the accumulations of detritus are so extensive that considerable masses yet remain to be washed. The deep crevices in the limestone seem to have acted as gigantic riffles to retain the gold when the country was swept over by the currents which have deposited the gravelly and volcanic materials with which they are filled. Where the bottoms of these cavities lie very low, they are worked out by the aid of water-power.

Texas Flat is an interesting locality, where a vast accumulation of calcareous tufa has formed over the auriferous gravel, in an ancient gulch which once emptied into the Stanislaus River, when at a much higher level than it now has. The same tufa formation occurs extensively on the southern bank of the Stanislaus, where it assumes a most picturesque appearance, sometimes rising in cliffs which resemble coral-reefs, and inclosing small caverns lined with stalactitic formations. In this tufaceous deposit many fragments of the bones and teeth of large mammalia have been found, including the mastodon, elephant, and horse, and also both land and fresh-water shells, the latter at the bottom and resting on the amphibolite, which here forms the bed-rock.

All through the region northwest of Columbia, as far as Abby's Ferry, the remains of the elephant and mastodon have been found in greater abundance than anywhere else in the State, unless it may possibly be at Kincaid Flat. At Gold Springs, a mile northwest of Columbia, there is a copious spring of clear water which forms a large pool, a quite exceptional circumstance in the auriferous region, and it is not unlikely that this spring may have existed in former times, during the period of the mastodon, and that it may have attracted to this vicinity the large animals whose remains are found there so abundantly. But few of these relics can now be obtained, as most of them crumble to pieces on exposure, and the others rarely escape the careless handling to which they are subjected, either from curiosity or recklessness. A wagon-load of bones is said to have been destroyed by a fire in a miner's cabin burned near Gold Springs some years ago. A complete review of all the mammalian remains found in the auriferous detritus of this, as well as other portions of the gold region, must be deferred to a future volume of this Report, as our stock of material, in this depart- 
ment, is still scanty; farther investigations will, it is hoped, enable us to add materially to what we have already secured.

One of the most striking features in the topography and geology of Tuolumne County is the so-called "Table Mountain," a name given, throughout the State, to the flat table-like masses of basaltic lava which have been rendered so conspicuous by the erosion of the softer strata on each side, and which now exist as elevated ridges, dominating over the surrounding country, and remarkable for their picturesque beauty, but still more so on account of the important deposits of auriferous detritus which lie beneath them.

The Table Mountain of Tuolumne County is a flow of lava originating in the lofty volcanic region, beyond the Big Trees of Calaveras, which will be described in the chapter on the High Sierra; it comes down on the north side of the Stanislaus, forming a nearly continuous ridge, elevated more than 2000 feet above the river. Just below Abby's Ferry, the Stanislaus has broken through the once continuous basaltic ridge, which has been irregularly worn away for some distance from the river, but which reappears as a continuous mountain a little southwest of Columbia, and continues on the south side of the river, forming a conspicuous feature of the scenery as far as Knight's Ferry, a distance of about twenty miles fro the point where it crosses the river and enters Tuolumne County. As seen from a distance, this Table Mountain reveals its origin at once in the contrast between the long straight line of its upper edge, and the broken and curving ones which the eroded hills of the auriferous slates everywhere exhibit. Its lark color and the comparative absence of trees or shrubs on its top and sides, also indicate very clearly that the material of which it is composed is very different from that of the surrounding hills. The annexed sketch (Fig. 36), taken from a point on the south side of the Tuolumne, and at a distance of about twelve miles in a southeasterly direction from the nearest point of Table Mountain, will serve to show something of its peculiar character. The elevations in the farthest distance are the Bear Mountain Range, near Copperopolis.

On approaching Table Mountain and examining the material of which it is composed, and the position which it occupies, it is seen at once that it is a vast lava flow, of which the upper surface remains very 
nearly at the level and with the form which it originally had at the time of its consolidation, while its edges and the surrounding country

Fig. 36.

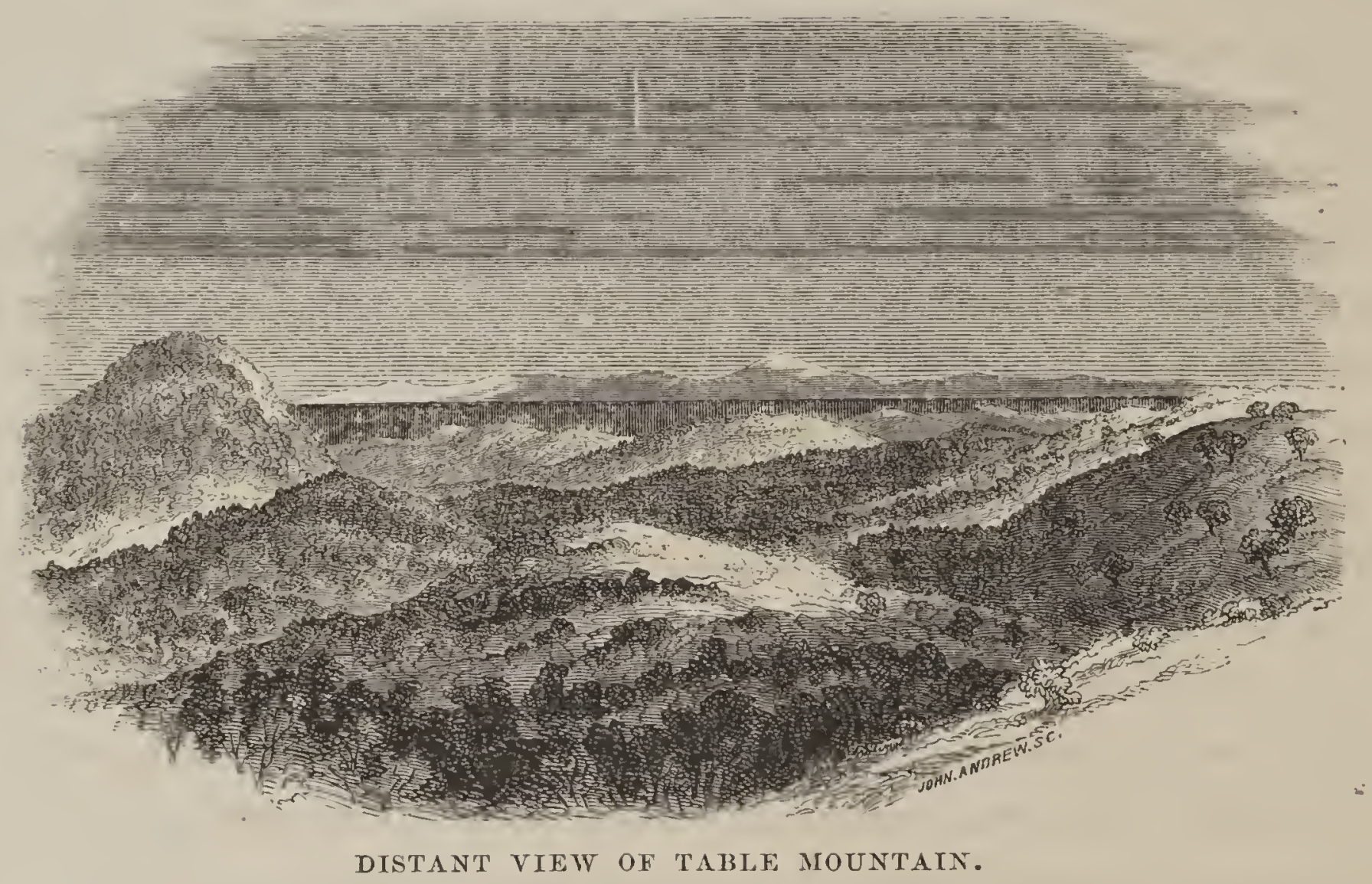

have been denuded and washed away, so that the topography of the region is entirely different from what it once was; in fact, it is almost the reverse of it. No one can deny that a stream of melted lava, running for forty miles down the slope of the Sierra, must have sought and found a depression or valley in which to flow, for it is impossible that it should have maintained, for any distance, a position on the crest of a ridge. Nor could the valley of the Stanislaus, now two thousand feet deep, have existed at that time, for this flow of lava is clearly seen to have crossed it at Abby's Ferry. The whole face of the country must, therefore, have undergone an entire change since the eruption took place, during which this mass of lava was poured out. Directly over the gorge in which the Stanislaus River now runs, there must then have been a range of mountains, and the same is true of the other side, where now is the valley of Wood's Creek, for such ranges must have existed in order to form and wall in the valley in which the current of lava flowed. There has been, therefore, an amount of denudation, during the period since this volcanic mass took its present position, of not less than three or four thousand feet of perpendicular depth. And 
yet this was all done during the most recent geological epoch, as will be seen farther on, and it will also be shown that these surprising changes have not been peculiar to this region, but that the whole slope of the Sierra throughout the Gold Region has been the scene of similar volcanic overflows and subsequent remodelling of the surface into a new system of reliefs and depressions.

The fact that the lava flow of Table Mountain took place in a preexisting valley is not only capable of being demonstrated on general principles, but is confirmed by what has been shown, by numerous excavations beneath it, to be the character of the formation on which it rests. As the real nature of the deposits covered by the lava is not exhibited on the surface, a long time would probably have elapsed before their character would have been understood, if chance had not led to their being extensively laid open by mining operations. In 1854, a party of miners, in cleaning out an old shaft, near Shaw's Flat, struck a rich deposit of gravel, evidently of a different character from any which had been previously discovered in this region. It was a part of the old river-bed, now mostly covered to a depth of several hundred feet, but there near the surface, either because the overlying volcanic and detrital beds had been more thoroughly denuded at that point, or else on account of there never having been so heavy a deposit of them in that particular locality, a question which could not be decided without a more detailed survey and exploration than it was in our power to make. At all events, this discovery was followed up, and soon resulted in demonstrating that there was beneath the mountain a channel of auriferous gravel, portions of which were exceedingly rich, and which has been worked since that time, with a heavy expenditure of time and money, and often with large profits. The examination of several of these tunnels, as well as of the exterior of the mountain, shows the following facts in regard to the character of the formation.

The summit of Table Mountain is occupied by a heavy bed of basaltic lava, of a very dark color and dense texture. It is occasionally distinctly columnar, and it appears to have all been poured out in one flow, as there are no partings or divisions perceptible in the mass, which in the vicinity of Sonora is from 140 to 150 feet in thickness. Its width, at a point near the Buckeye Tunnel, was found to be about 
1700 feet. The surface of the basalt is very nearly level, with a gentle slope down the valley, and it is tolerably smooth and nearly free from the rounded, boulder-like masses of the same material which almost always cover the tops of these Table Mountains. As far as examined, this rock seems almost indestructible by time. Hardly a trace of soil has accumulated on it, and of course only a few bushes find a lodgment on its surface. Its bareness and smoothness give it the appearance of having been very recently erupted; and yet how long ago must this event have taken place, measuring time by anything except a geological scale! It would appear that the surface of this lava flow has hardly been worn away at all, while the slates on each side have been eroded to the depth of thousands of feet. The only evidences of erosion in the basalt are seen on its edges, which are nearly vertical, and which have evidently resulted from the breaking off of the volcanic material, as the underlying soft sedimentary strata were worn away, so as to leave the basaltic rock overhanging.

Underneath the lava is a heavy deposit of a detrital material, very distinctly stratified and lying nearly horizontal, or with a slight dip each way towards the centre of the mass. These sedimentary beds are of variable character, but are chiefly made up of a rather fine-grained sandstone, not very closely compacted, and which rapidly disintegrates on exposure. Interstratified with this sandstone, and especially near the bottom of the deposit, are fine argillaceous shales and clays, nearly white and often beautifully laminated. With these are beds of gravelly materials, strongly cohering together, and called "cement" by the miners, and at the bottom the "pay-gravel," or the "channel," a body of coarse gravel, exactly like that seen in the bed of an ordinary river. The entire thickness of the detrital beds, directly under the centre of the lava, is, in one locality at least, fully two hundred feet. But this thickness is much less at the edges of the deposit, owing to the rise of the auriferous slates on each side, forming what is known everywhere in California to the miners as the "rim-rock," the position and relations of which may be seen from the annexed section (Fig. 37), taken at the Maine Boys' 'Tunnèl, near Jeffersonville, where a good opportunity was afforded for measuring the thickness of the various rocks exposed, and for ascertaining the position of the top of the rim-rock. 
The lava is here 140 feet thick. The rin-rock rises fully 150 feet above the tumnel, which is carried in 1000 feet, with just sufficient rise to allow the water to flow off, and at that distance strikes the "channel ;"

Fig. 37.

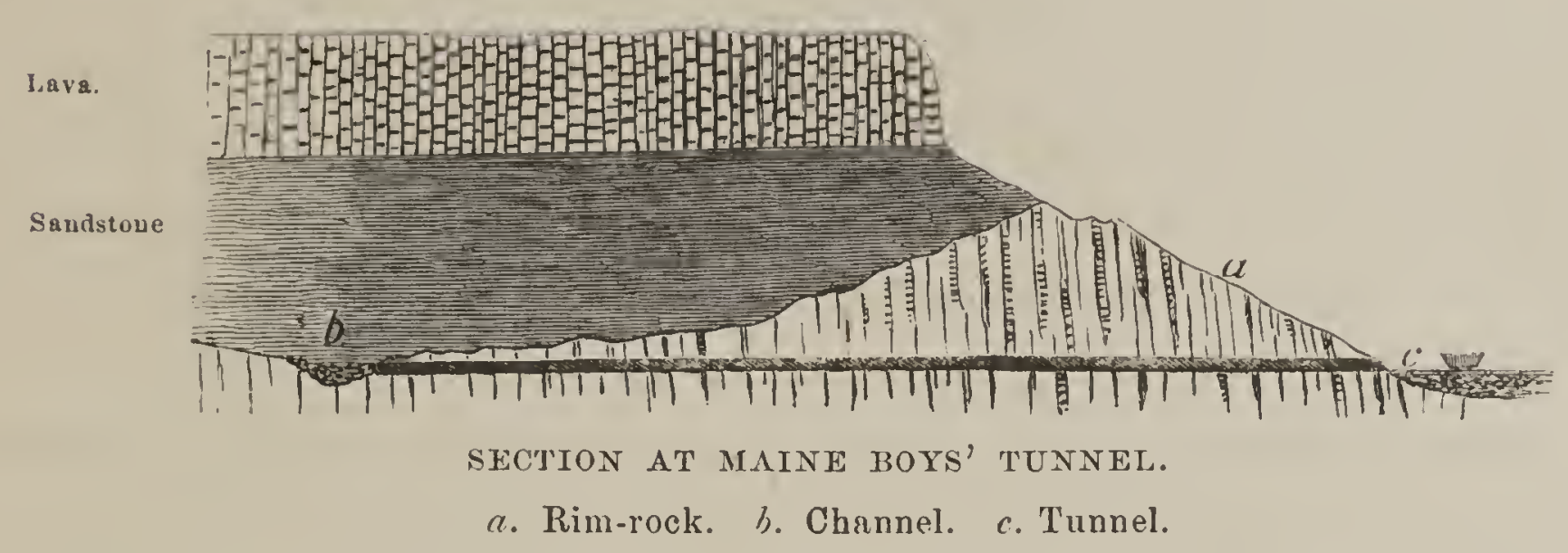

this is here 100 feet wide, and has a ledge of slate three feet high, standing up in the middle. The auriferous gravel in the channel is from four to five feet thick. It will give some idea of the cost and time required for opening a deposit of this kind, when it is stated that this tunnel was commenced in October, 1855, and that the pay-gravel was not struck until March, 1860, the cost of the work, up to that time, having been about $\$ 38,000$.

Another section was made at the Buckeye Tunnel, where the relative position of the different formations could be seen on both sides of the mountain, at points nearly opposite to each other. The section cannot be considered as absolutely correct; but a sufficient number of measurements were made to justify the statement that the facts are, in the main, about as accurately represented as the scale of the figure will allow. The details of any two tunnels will be found to vary somewhat, however near they may be to each other.

The basaltic lava forming the summit of the mountain has a maximum thickness of 140 feet, and is about 1700 feet wide. There are two channels, instead of one, and the first was reached by a tumnel going in on the north side, at a distance of 700 feet from the entrance. This channel was found to be 80 feet wide, and the miners extended their works upwards into it and took out some of the gravel; but, finding it not to pay as well as they had expected, they continued the tunnel forwards, in the expectation of striking another channel (see sec- 
tion, Fig. 38), of which the posi-

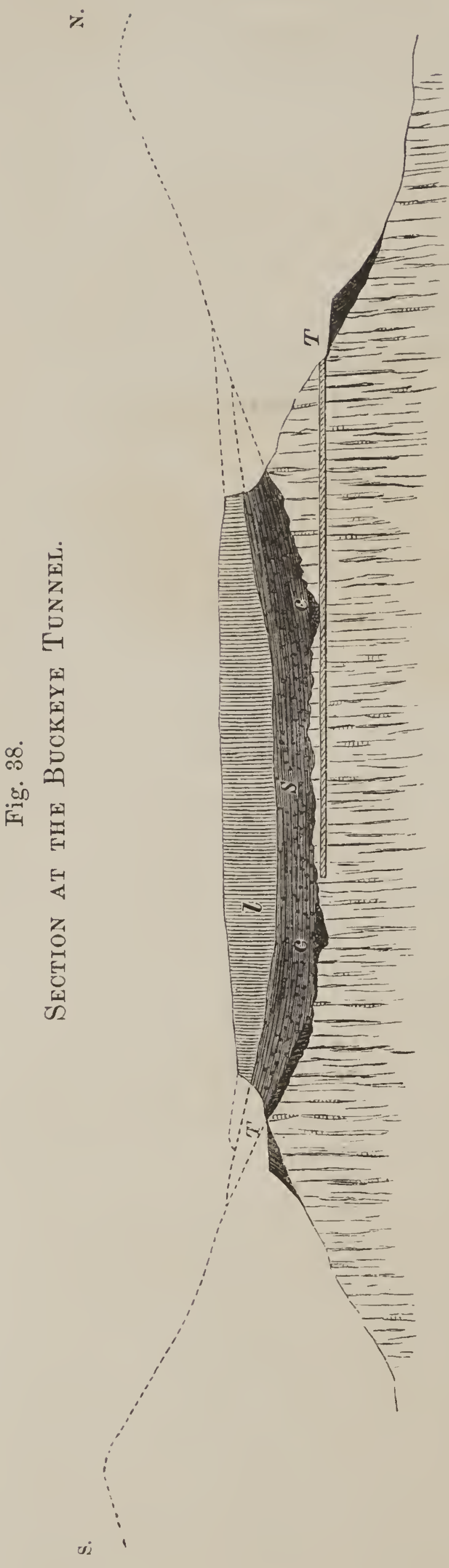
tion and character were known, or presumed to be known, from the results of other workings in the vicinity. At the time of our visit, the tumnel had been driven 700 feet beyond the first channel towards the second, which they were in constant expectation of reaching.

A tunnel had also been carried in, on the south side of the mountain, nearly opposite the one just described, without having reached the channel. This one was not driven through the rim-rock, but was carried down on its surface, in the "cement," with a slope of thirty-six feet in one hundred; it had reached a depth of three hundred feet when visited, in 1861.

The general appearance of Table Mountain, and of the sloping sides underneath the lava, with the tunnels driven in through them, may be seen in the annexed wood-cut (Fig. 39).

The tunnels under Table Mountain are usually run through the rim-rock, with just fall enough to drain the workings as they are carried forward. Sometimes, however, they go down on the inclined surface of the slates, or they are excavated 
in the soft sandstone themselves; in such cases, the water must be got rid of by pumping. When the channel is reached, it is drifted on,

Fig. 39.

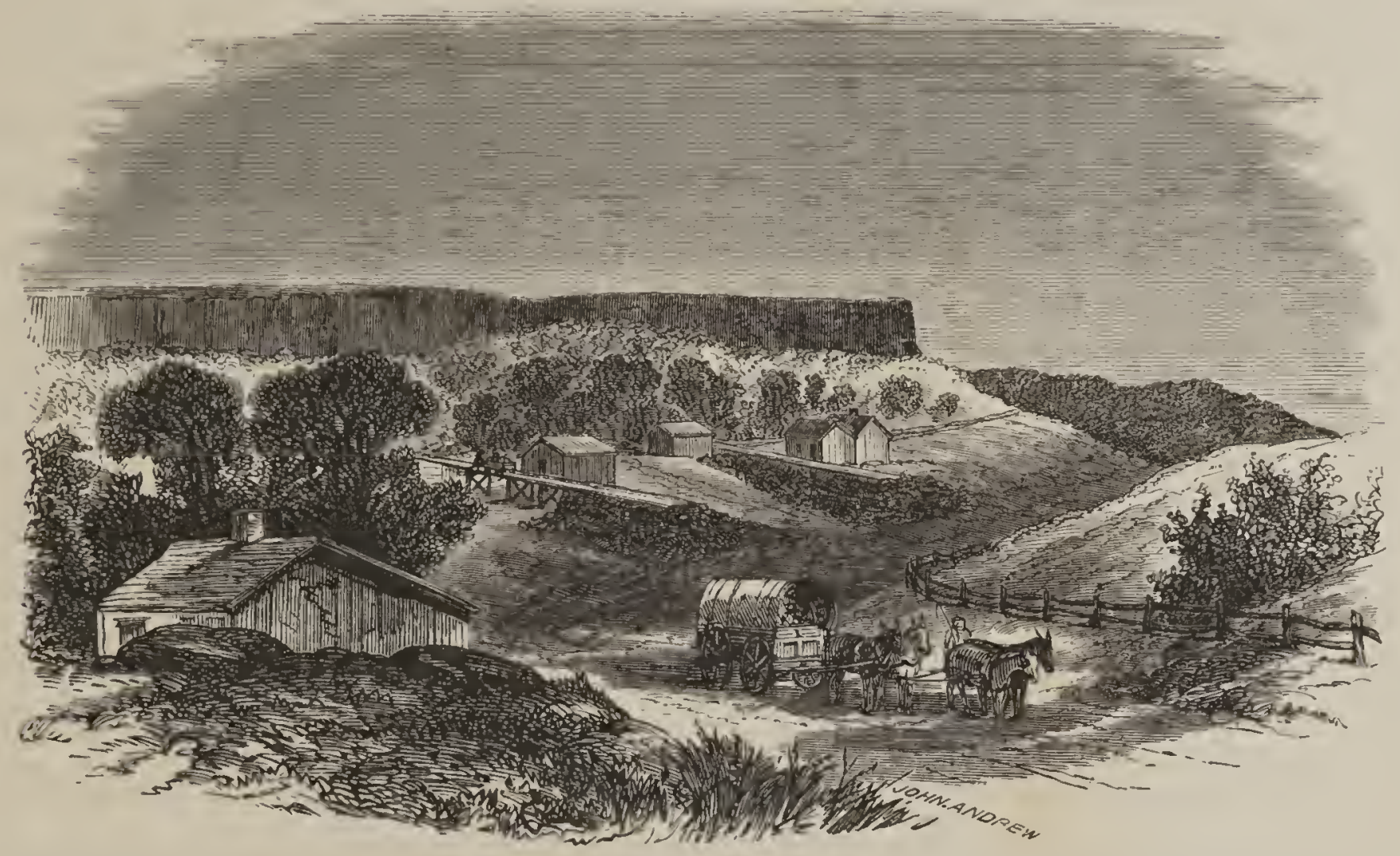

TUNNELS NEAR TABLE MOUNTAIN.

the miners following the paying streaks, or lines of auriferous gravel, up and down in the bed of the ancient water-course. The stuff is brought out to the month of the tunnel in cars, and there dumped into a long, hopper-shaped box, from which it is washed into the sluices, by playing on it with a stream of water through a hose, as in hydraulic mining, except that the operation is on a smaller scale.

The stratified materials under the lava are frequently found to contain masses of wood, and even entire trunks of trees. These are very commonly found under Table Mountain, although not as abundant here as in some of the hydraulic washings in other parts of the State. The wood is almost always silicified, being converted into semi-opal, or wood-opal, as it is frequently called. In this, the vascular structure is often perfectly preserved, and the specimens, especially such as have been partially carbonized before being fossilized, are often very beautiful. In the layers of finer sediment, called "pipe-clay" by the miners, which are very thinly and evenly bedded, and made up of the finest particles of clay, impressions of leaves are occasionally found. Neither the wood nor the leaves, from this and similar localities, have 
been, as yet, minutely examined; this will be done, however, if the Survey is continued, and the results, with figures of the different varieties, will be found in the second volume of the Palæontology.

A few specimens of the leaves from the Buckeye Tunnel were forwarded to Dr. Newberry, who has made a preliminary investigation of them, furnished us with some notes of his results, from which we are authorized to draw the conclusion that these stratified deposits underneath the lava of Table Mountain are of Tertiary age, and that, in all probability, they belong to the later Pliocene epoch. Dr. Newberry remarks, that the leaves submitted to him are quite different from those of any trees now growing in California, and that they are specifically distinct from those of the Miocene Tertiaries of Oregon, Nebraska, or any other part of the Continent. They include Tertiary and recent genera, such as Acer and Carpinus, and are, therefore, not older than the Miocene. They most resemble the species found in the later European Tertiaries.

These conclusions in regard to the age of the formation in question are also rendered more probable by the results of the examination of the bones and teeth of animals found, at quite a number of points, in the strata underlying the lava of Table Mountain and similar volcanic overflows.

Remains of land and aquatic animals are frequently found in the auriferous detritus of the State, and, not only in the beds which were deposited before the period of intense volcanic action, of which the crest and flanks of the Sierra in so many places exhibit the most striking proofs, but in the later accumulations of a similar kind, the formation and deposition of which has been going on uninterruptedly from the close of the Tertiary period up to the present time. A large number of specimens, of several different genera and species, have been obtained by the Survey in various localities, or have been examined in the collections made by others. These, remains consist of fragments of bones and teeth, of which much the larger portion are in a very poor condition for determination. Most of the bones, which are dug up or washed out by the miners, fall to pieces on exposure to the air; and there is rarely any one present, at the time of their discovery, who cares or understands how to collect and preserve them. Carelessness 
and idle curiosity lead to the destruction of most of the bones which are in a condition to resist the action of the elements; while it is also true that, in many cases, the fragments which are lucky enough to be preserved by the miners, are regarded by them as of immense value, and cannot be secured, at anything like a fair price, for the purposes of scientific description.

There is another difficulty in getting at the character of the Fauna of the auriferous gravels and other superficial formations. The localities of specimens obtained are frequently uncertain; and, even if the exact spot where the fossil was found happens to be known, it is often quite impossible to decide whether it originally belonged to the stratum in which it was found, or whether it may not have been washed out from an older bed. From what has been said in the previous pages, it will be seen what an immense amount of erosion of the surface has taken place since the volcanic outbreaks in the Sierra, and it will easily be recognized that many skeletons of animals, originally buried under the lava, must have been torn from their beds and distributed far and wide over the country.

In spite of these difficulties, we think we have clearly made ont that there are two distinct epochs represented by the animal remains found in the auriferous detritus. The beds which were deposited prior to the great volcanic disturbances and consequent overflows of lava, throughout the Sierra, inclose a peculiar Fauna, which we refer to the Pliocene epoch, and which appears to have some analogy with the group of the same age, occurring on the Niobrara and White River's, and in their vicinity, to the east of the Rocky Mountain chain, where such an immense profusion of vertebrate remains have been found by Dr. Mayden and other zealous explorers, and which have been investigated with such consummate skill by Dr. Leidy.

Among the animals of the Pliocene of California, or the group which preceded the epoch of volcanic activity, we recognize the rhinoceros, an animal allied to the hippopotamus, an extinct species of horse, and a species allied to the camel and resembling the Megalomeryx of Leidy; all these species, so far as we know, are peculiar to the deposits under the lava, and, as would be expected, they did not survive the grand 
catastrophe, by which the forests and streams in which they lived, and to which they resorted, were overwhelmed and annihilated.

After the close of the period of volcanic activity, a new Fauna made its appearance on the slopes and amid the foot-hills of the Sierra. This Fauna belongs to the Post-Pliocene epoch, and passes gradually into that of the present day, or the Recent. Prominent among the animals of that time were the mastodon and elephant, whose remains are found in the greatest abundance in the superficial detritus of the gold region; but never, so far as we have been able to ascertain, in the deposits under the lava. Associated with these proboscidians, were the tapir, the bison (buffalo), and the horse, the latter animal being very abundant and represented by two species, of which one is not to be distinguished from the present mustang, or Indian horse.*

In terminating this digression, it may be proper to add, that the works of man have been frequently found among the recent deposits of auriferous gravel, and in such close connection with the bones of the mastodon and elephant, that it is hardly possible to escape the inference that the human race existed before the disappearance of these animals from the region which was once so thickly inhabited by them. Other facts, long since collected by geologists in different parts of this country, have pointed most significantly in the direction of this conclusion, and the investigations of the last few years in Europe have made it certain that the same association of man with animals belonging to species now extinct formerly existed there. Thus the researches of scientific men, on both sides of the Atlantic, concur in giving to the human race a much greater antiquity than had been previously assigned to it, a conclusion which was so contrary to the popular belief, that it would not have been adopted had not the evidence in its favor been ample and conclusive.

* Our collection of vertebrate remains has been referred to Dr. Leidy, who has furnished a list of the same, and deseribed such as were new in the Procedings of the Philadelphia Academy of Natural Scienees for the year 1865. All our collections in this department will be worked up by him for the second volume of the Palæontology. The whole subject of the Fauna of the Tertiary and Post-Tertiary of the Pacific eoast will be thoroughly treated in a future volume of this Report; before which, we trust that considerable additions will have been made to our stock of materials. 
In the vicinity of Soulsbyville, six miles east of Sonora, is another series of volcanic deposits, which have not been traced to their origin in the High Sierra; but which very probably are the termination of one of the lava streams which originated in the great volcanic region towards the upper part of the Sonora road to Aurora, and where, over a wide area, lava caps nearly all the highest points. As exposed near Soulsbyville, the solid lava, which is about fifty feet thick, lies upon a heavy stratum of volcanic ashes and pumice-stone, which has evidently been washed down the Sierra, and deposited in a more or less perfectly stratified form. Under this, is a bed of fine clay, "pipe-clay" of the miners, from eight to ten feet thick. This again rests on the bed-rock, which is granite, very much decomposed. Here also bones and teeth have been found under the lava, including those of an' extinct species of horse, as noticed above.

\section{Section V.-Calaveras Country.}

The boundaries of Calaveras County are, the Stanislaus River on the southeast, and the Mokelumne on the northwest, the distance between the two, in the mining region, being from twenty-four to thirty miles. Quite an extensive range of mountains, called the Bear Mountains, runs from the Stanislaus nearly to the Calaveras River, and divides the district in question into two rather distinct portions, of which the lower or southwestern belongs to the foot-hills, the upper to the Sierra proper. The region of the foot-hills is pre-eminently the copper mining district of the State, while a belt about twelve miles wide on the other side of the Bear Mountains is one of the richest portions of the gold region. The foot-hills are very dry, there being $n$ streams which are permanent through the summer, excepting the Calaveras, of which the water is pretty much all used up for mining purposes, before it leaves the gold region. The numerous branches of this river drain the district between the Stanislaus and the Mokelumne during the rainy season, running mostly in deep cañons between spurs of the Sierrat, and their water is utilized for gold washing, as long as it lasts, by an elaborate systen of ditches. For a permanent source 
of supply during the whole summer, however, recourse has to be had to the canals, or ditches, as they are always called in California, which head in the very highest portions of the Sierra, as none of those do which are connected with the Calaveras.

The towns which have been built up by the gold mining business, and which still depend chiefly on that for their prospierity, are stretched along a belt running in a northwest and southeast direction through the county, and are ranged in two parallel lines six or eight miles apart. The southwestern series includes Angel's, Upper and Lower Calaveras Camps, and Mokelumne Hill; the other, Murphy's, Care City, and El Dorado. On the first-mentioned range there has been, and is still, a good deal of quartz mining, while along the other line the placer mines constitute almost the exclusive interest; but, as there has been a great falling off' in the yield of the surface diggings within the last few years, some of the camps appear to be entirely deserted.

In the central portion of Calaveras County, the belt of metamorphic rocks of the Sierra system, or the auriferous slate series, occupies a width, northeast and southwest, of about twenty-four miles. In its southwestern portion it is hardly covered at all by other formations, excepting that of the superficial detritus; but on the northwest, towards their junction with the granite, the auriferous slates are very extensively overlain by the volcanic beds which play so important a part in the geology of the Sierra Nevada. All the region between the Bear Mountain Range and the base of the foot-hills, from the Stanislaus to the Calaveras, is nearly of one character, consisting of low rolling hills, not very regular in direction or continuous, with many valleys, which would be most delightful if better supplied with water. The district to the north of the range is also deficient in this respect, but having the advantage of the artificial supply from the ditches, portions of it are well cultivated, and are especially productive in fruit.

The upper mining district, of which the town of Copperopolis is the headquarter's, extends across from the Stanislaus to the Calaveras; but the principal productive mines are at the eastern extremity of the range, not far from the head of Black Creek, an insignificant branch of the Stanislaus. Claims have been taken up in this region chiefly in two nearly parallel lines five or six miles apart, of which one runs along 
the base of the Bear Mountain Range, and the other follows a broken range of hills, called the Gopher Hills. The first of these ranges is on what is called, from its discoverer, the "Reed Lode," and claims have been taken up on it for a length of about twelve miles, in a remarkably regular sequence, the general direction of the productive part of this lode being $\mathrm{N} .30^{\circ} \mathrm{W}$. This line of claims curves very gently to the northward as it goes west. The other line is much more irregular, indicating great uncertainty in following the outcrop, and it does not appear that anything of importance has been discovered on it, except at its eastern end, although the length of the line along which claims have been made is fifteen miles or more.

The deposits of copper ore in this region, like nearly all the others in California, do not appear to be included in regular fissure veins, but rather to form independent masses lying in the direction of the strike of the inclosing rocks, and dipping with them. The metalliferous portion is not usually separated from the wall-rock by two regular selvages, nor is it accompanied by any considerable amount of veinstone of a peculiar character and clearly distinguishable from the formation in which it is inclosed. But, if not exhibiting all the character's of true veins, these metalliferous deposits are sometimes of enormous dimensions and of remarkable purity.

The Reed Lode was discovered by Mr. W. K. Reed, July 4th, 1861, and the first house built at what is now the thriving town of Copperopolis, September 5th. The outerop, along where are now the Union and Keystone Mines, was very marked, and considerable quantities of the oxidized ores of copper were obtained near the surface, as well as fine specimens of native copper in arborescent crystalline forms; some of the masses of malachite were very handsome, and there was a large quantity of impure black oxide (copper-smut) obtained, mixed with more or less of the red oxide. These oxidized combinations all give out at the depth of twenty or thirty feet, and the sulphuret (chalcopyrite, the yellow ore of the miners) takes their place. There is some iron pyrites mixed with the copper pyrites, even when the latter appears pure, as the percentage of the ore does not come quite up to that required by the formula, although no mechanical intermixture of foreign ingredients can be detected by the cye. 
The rocks inclosing the lode near Copperopolis are chiefly chlorite and clay-slates, passing in places into hornblende-slate and hornblenderock. Farther west there are very heavy beds of serpentine, in the line of strike of the vein, and with indications of copper disseminated through the mass of the rock.

The two principal mines at Copperopolis are the "Union" and the "Keystone;" both of these are opened on an extensive scale, and have been shipping large quantities of ore for a considerable time. It will not be possible to give a detailed description of these mines, as that belongs properly in the volume of Economical Geology, and they have not been examined by us with minuteness, since they attained their present development. A few items may, however, be given, to show the great value of this cupriferous region, and to give an idea of its importance to the State.

The Union Mine would appear to be opened on one of the largest deposits of ore ever struck in any part of the world, and the shipments from it have been, during the last year or two, on an immense scale. We regret not being able to give the exact figures for the whole time since the mine was opened; but it appear's that over 10,000 tons of first and second class ores were forwarded to San Francisco from March to July of the current year. In June, 1865, the shipments amounted to 3600 tons, and they were expected to be equally as large in July. The yield of the No. 1 ore, we suppose to be about twenty-four per cent. (at least, this was the percentage in 1862), and about an equal amount of the two grades has been shipped of late. When examined by us, in 1862, there was to be seen in this mine a mass of ore, apparently quite free from any intermixture of barren rock, and of which the dimensions were not less than three hundred feet in length and sixty feet high, while the average width could not have been less than five feet, and there were portions fully nine feet across, with only a thin seam of rock in the centre a few inches in width.

We learn that the principal shaft of this mine had, in July, 1865, reached a depth of 400 feet, the lowest level driven in the lode being at 300 feet from the surface. At the 200 -foot level, the lode is 21 feet wide; at the 250 -foot, 31 feet, and composed almost wholly of 
Nos. 1 and 2 ores.* There are now about 350 men employed at this mine.

The Keystone Mine is also in a prosperous condition, having a large amount of good stoping-ground opened, dressing works in successful operation, and bidding fair to be, at no distant day, not far behind the Union in the amount of its shipments.

The growing importance of the copper mining interests of the State may be inferred from the fact that the shipments of ore amounted, in 1863 , to 5933 tons, valued at $\$ 512,925$, and in 1864 to 14,315 tons, value $\$ 1,094,660$. Of these amounts very much the larger portion was derived from the mines at Copperopolis.

'There are several other mines at work in this vicinity, some of which may become paying concerns, if managed with skill and energy. Of the hundreds of claims located in this region, but few have had any serious work done on them; and it must be distinctly borne in mind that the occurrence of an unprecedentedly large mass of ore in the Union and Keystone Mines, does not necessitate the existence of others in the same mineral channel on either side; such bodies of rich metalliferous material must be looked on as quite exceptional. The establishment of smelting works on the Pacific coast will in time allow of the utilization of a lower grade of ore than can at present be shipped with profit to the Atlantic States or to England; and increased facilities of communication, especially the building of railroads from tide-water up into the mining districts of the Sierra, will enable many mines to be successfully worked, which at present must languish, on account of their distance from a port of shipment. There can be no doubt that California is destined to take a very high rank as a copperproducing State, in spite of the difficulties which scarcity of fuel and cost of transportation throw in the way of the development of the mining interests, in all cases where the bulk of the product is large in proportion to its value, as is the case with all but a few of the metals.

There is another group of copper mines in Calaveras County, between the Calaveras and Mokelumne Rivers, near Camp Seco. This range

* For the facts here given which have reference to the present condition of the Union and Keystone Mines, we are indebted to the kindness of H. H. Sheldon, Esq., the skillful superintendent of the latter.

GEOL. VOL. I. - 33 
seems to be almost exactly in the line of the trend of the Copperopolis mines. When examined, in 1863, there was considerable activity at several mines in this vicinity, the conditions being similar to those indicated above as common to most of the cupriferous deposits of the State. The ore seems a good deal mixed with iron pyrites, by which its percentage is considerably reduced; on assaying some of the samples, it was found that it was impossible to form a correct opinion of the yield of the ores from this district by simple inspection. The deposits of ore here are evidently quite large, and would be of high importance in a region where labor and fuel were not so scarce and high. At the Lancha Plana mine, when visited in August, 1863, a shaft had been sunk 150 feet, and, although little or nothing had been done in driving from it, 120 tons of ore had been shipped, and 200 more lay on the surface, the vein being about four feet in thickness. The ore appeared rich to the eye; but whether sufficiently so to pay, at present, the heavy cost of shipment to the Atlantic States, or England, had not then been ascertained. At the Copper Hill claim, a shaft had been sunk on the vein to the depth of 250 feet; the lode was two feet wide, and consisted of a mixture of iron and copper pyrites, but was not very rich in copper. Of the present condition of these mines nothing definite is known; that they will eventually become of importance can hardly be doubted, although the ore may be of too low a grade to be mined with profit under the present conditions.

Passing to the north of the Bear Mountain Range, we find essentially the same character of geological formations which has already been noticed as existing in Tuolumne County. The region from Angel's to Mokelumne Hill is almost a repetition of that between Big Oak Flat and Columbia. We have the auriferous slate series, with a wide and broken belt of limestone on the north, succeeded, in that direction, by the granitic masses of the High Sierra. As in Tuolumne, so here, the volcanic and sedimentary-volcanic formations play a great part, and cover very extensive areas of the gold-bearing slates, and are themselves worked in many places by the hydraulic method.

The average trend of the auriferous slates in Calaveras is more northerly than in Tuolumne; but there are many deflections from a straight line, and large bodies of strata run nearly due east and west. 
Judging from the position of the outcrops of the limestone belt between Abby's Ferry and Cave City, the mean trend of the formations through that part of the county is N. $20^{\circ} \mathrm{E}$., which direction appears to be continued on as far. as Volcano in Amador County, where the limestone crops out again.

The line of separation between the metamorphic slates and the granitic formations on the north has not been traced out; but, as noticed at various points, there appears to be a considerably greater width of metamorphic strata between the limestone and the granite than there is in Tuolumne. The belt of rock which occupies that position consists of coarse silicious slates, with some mica, and occasional bands of a gneissoidal rock. These strata do not appear to be auriferous, as there are hardly any mining camps of importance on the north of the limestone.

The limestone belt is first seen in coming into the county from Tuolumne, in the vicinity of Douglass Flat, a little east of Murphy's. The strike of the slates at Silver Knoll, three-fourths of a mile northwest of Douglass Flat, is nearly east and west, the rocks having evidently undergone great disturbances in this region, so that the continuity of the limestone-belt is broken in several places between here and Cave City; it now appears to consist of immense detached masses lying in an east and west direction, and entirely cut off from all connection with each other. At Murphy's, the limestone forms a lofty and picturesque outcrop of dark, bluish-gray color, nearly bare of vegetation; this elevation rises on the east and north of the town, which is also underlain by the same rock, worn into deep cavities filled with auriferous detritus, and resembling those described as occurring near Columbia; here, also, it is extensively and profitably worked. The belt of limestone at Murphy's is about a mile and a quarter wide; it has on its southern border slate, which contains numerous quartz veins and dips to the northeast at an angle of $70^{\circ}$. To the north, the limestone passes, through an intermediate stage of calcareous sandstone, into a silicious slate. Near the line of contact between the'limestone and slates, on this side, are quite extensive deposits of hematite iron ore, which have not been opened or worked at all, and whose exact extent cannot therefore be known. Were fuel abundant and labor cheap, this deposit 
might become of importance. Under present conditions, this is hardly possible.

The limestone belt in the vicinity of Murphy's is remarkable as containing quartz veins of sufficient size and richness to have been worked quite extensively at different times. At the Blue Wing Mill, threefourths of a mile north of Murphy's, a vein of quartz occurs in this position, and was mined quite extensively for some time. The vein is well-defined, is about two feet wide, and runs obliquely across the limestone, as nearly as could be made out; but the stratification is so disturbed that the relative position of the lode and the inclosing rock could not be satisfactorily determined. The rock from this vein paid handsomely near the surface, yielding as much as $\$ 80$ a ton. The strike of the limestone near the mill is N. $80^{\circ} \mathrm{E}$., and its dip is to the southeast at an angle of $65^{\circ}$ to $70^{\circ}$. It will thus be seen how entirely the dip and strike of this mass of rock separate it from other portions of the same formation north and south. The outcrop continues for some distance in the high hills between Murphy's Creek and the San Domingo, and is very conspicuous, at a distance, from the peculiar color of the rock. In this vicinity is an interesting vein in the limestone, called the Green Rock Ledge; this vein is inclosed in thinbedded calcareous slate, or slaty limestone, which runs almost exactly east and west, and dips to the north at an angle of $70^{\circ}$. The vein has a direction nearly at right-angles to this, and dips at an angle of $36^{\circ}$; its width is about two feet where opened. The veinstone, which assayed well for gold at the surface, also contained cinnabar in small quantity, together with traces of vitreous copper ore, and some blue and green carbonate of copper. This is one of the very few localities where an ore of mercury has been found in rocks belonging to the Sierra series.

Passing from the San Domingo Creek northwest of Murphy's, in the direction of Cave City, the limestone belt disappears altogether, so far as could be ascertained; and, although this last-mentioned place is about in the line of the average strike of the limestone through this part of the State, or N. $20^{\circ}$ W. from Murphy's, still, in travelling between the two places, no traces of its existence were discovered until we approached within about a mile of Cave City, where its outcrop is 
very conspicuous. Here the strata have their usual trend of about N. $25^{\circ}$ to $30^{\circ} \mathrm{W}$, and dip northeast at an angle of $60^{\circ}$. The masses of limestone rise in bare and precipitous ridges, which are picturesque in outline, and quite striking, on account of their light bluish-gray color, which contrasts in such a marked way with the reddish-browns of the auriferous slate-formation. From this point the outcrop of limestone may be traced northwest and southeast for a mile or more in each direction. Beyond this to the northwest, it has not been seen again by us anywhere to the southeast of Volcano.

Cave City, which is about twelve miles south-southeast of Mokelumne Hill, is noted for its extensive cave in the limestone rock; this is well worth seeing, and would be more frequently visited if decent accommodations could be had, which was not the case in 1863 . The cave has all the usual features of such places,-long winding passages opening into wide chambers, beautifully ornamented with stalactites, and it is said to have been traced more than half a mile in its windings. A visit may be made to it from Murphy's, there and back in one day, over a rough trail crossing three high ridges and passing through a picturesque and finely wooded region. Those who have never visited a large cave should see this one, when on their way to or from the Big Trees.

The great quartz vein of California appears to be continued across the county of Calaveras, entering it at Robinson's Ferry, making itself very conspicuous at Carson Hill, appearing again on Albany Hill, and then at Angel's. It is seen again between that place and San Andreas, and once more a little to the northwest of San Andreas. Beyond this it has not been recognized anywhere southeast of Jackson. It has been extensively worked at several points, especially on Carson Hill and near Angel's, quartz-mining having been at one time in this county a much more important business than it now is. Mr. Ashburner's notes, made in 1861, give the following information in regard to the condition of the quartz mills in that year.

Angel's Camp was formerly a very active quartz-mining centre, there having been thirteen mills in operation in its vicinity. In 1861, there were only three or four at work; and in 1863, only two. In 1861, the most important mill was the "Crystal Mill," built in $\mathbf{1 8 5 7}$, 
having twelve stamps, run by steam, and stamping dry. This is one of the few quartz mills in the State where the Freiberg barrels were in use in the amalgamating processes. It was running on custom-work in 1861, and was closed in 1863.

The "Cornish Mill," built in 1860, was running, in 1860, on quartz which paid only about \$4 a ton. The "Angels" Quartz-Mining Company's" Mill, built in 1857, had sixteen stamps, and was run by steam; as worked in 1861, the rock crushed yielded about $\$ 5$ a ton.

The mills at Angel's were all built to run on rock taken from a side vein about two hundred feet northeast of the great quartz vein, which is here very wide and prominent, forming a very conspicuous outcrop on the summit of the hill. The mines have been extensively worked in a series of open cuts, from six to twelve feet wide, and for a length of about a third of a mile. The masses of quartz lie parallel with each other and form belts in the talcose slate. The amount of material which can be obtained here is large; but its yield is low. At Foster \& Co.'s Mill, it was said, in 1863 , to be paying $\$ 6$ a ton. It is a question whether, by the introduction of improved machinery for saving the gold, these mines may not yet be made of great importance.

The vicinity of Carson Hill is classic ground in the history both of quartz and placer mining in this State. It would be hard to point out any spot in the Gold Region where richer placers or more astonishing masses of gold-bearing quartz have been found than in the immediate vicinity of Carson Hill; and yet, such is the apparent irregularity of the veins, that, thus far, all efforts to make gold-mining a permanent and profitable business at that place have failed.

The great quartz vein, in coming from Angel's, crops out a little before reaching the summit of Albany Hill, which it there crosses over, with a nearly southeast course, being a very conspicuous object, like the outcrop on the Peñon Blanco. It branches to the southeast and disappears as it descends the side of the hill, but rises again on the east side of Carson Creek and forms the crest of Carson Hill for a distance of about a third of a mile; here its strike is about N. $55^{\circ} \mathrm{W}$. Going down the southeast side of the hill, the vein seems again to be lost; the heavy outcrop of quartz reappears, however, in a line parallel with the outerop on Carson IIill, but a third of a mile to the southwest, as if the 
vein had been thrown in that direction by the movements of the strata. This outcrop is on the summit of the Santa Cruz Hill, which runs down to the Starislaus at Robinson's Ferry. There are also masses or irregular veins of quartz running north from near the southeastern end of the Santa Cruz Hill, several parallel north and south claims having been taken up here; one of these, the Stanislaus Mine, has been quite extensively worked, and has furnished some of the most striking specimens of rich gold-bearing rock ever found in the State. Associated with the gold are the tellurides of silver and gold, in much larger quantity than these rare substances have ever yet been found at any other locality in this country so far as known.* Quite extensive explorations have been made at this place by shafts and drifts, showing here and there rich bunches of gold-bearing quartz, but of which the connection is not easily to be made out. A most systematic and careful exploration is required here, to settle the question whether the vein is continuous and regular enough to be worked with profit.

A great many places have been opened on the summit of Carson Hill, and gold has been found disseminated very irregularly through the rocks. At one place, formerly called the Morgan Claim, now the Hope Mine, an immense amount of gold, between one and two millions, it is said, was taken out within a small space several years ago. The talcose slates in places along on the back of the great vein have proved very rich, paying as much as $\$ 80$ a ton. Our own examination demonstrated to us that portions of this rock still left standing contain a large amount of gold. The Enterprise Mine is located on the talcose slate belt, which lies between the main quartz mass and a very small vein parallel with it; these quartz veins sometimes approach each other very nearly; at others, they are widely separated. The belt of auriferous slates is from two to three feet in thickness; its yield of gold must be irregular, or it would be -worked with more persistence.

On Albany Hill, explorations and attempts at mining have been made, without much success. The north side of the hill consists of

* It is not certainly known which of the tellurium combinations are found at this mine, as they have not yet been subjected to any careful analysis, for want of sufficient material. There seems, however, to be two combinations present; Nagyagite, or telluride of lead, and Sylvanite, or Graphic Tellurium, a telluride of gold and silver. 
serpentine. A considerable amount of copper ore is seen in the various outcroppings around these hills.

Another interesting quartz-mining locality in Calaveras County is at and near West Point, about sixteen miles east of Mokelumne Hill. Here are a great number of quartz veins, all in granite, having a course of about N. $50^{\circ} \mathrm{W}$, and dipping to the west. Many of these veins have been worked by Mexicans, who treat the quartz with arrastras, and they have usually done a good business. Near the surface the rock is very soft, and requires no blasting to obtain the quartz; but at a depth varying from thirty to ninety feet, it becomes hard, so that the expense of mining is much increased. The miners have, therefore, usually abandoned their claims when water was reached, and betaken themselves to new discoveries; but there is reason to believe that in many of them the rich quartz is far from exhausted.

The Mill Vein, discovered in 1860, had yielded quartz during a year from its discovery, paying $\$ 133$ a ton. Its width was from three inches to one foot. The Myers \& Easton Vein, fourteen to twenty-four inches wide, is similar to the Mill Vein, and had yielded very well on the small quantity of quartz which had been raised when visited by $\mathrm{Mr}$. Ashburner, in 1861. The Rathgeber Vein is situated three miles east of West Point, runs north and south, and dips west at an angle of $25^{\circ}$. The ore from this vein, near the surface at least, was very rich; but the work had not been carried to a sufficient depth when visited to enable one to form an opinion of the permanence of the mine. There were three mills at work here, in 1861. These were: Jacobs \& Co.'s, with eight stamps; the Woodhouse Mill, with fifteen stamps; and Kerson's Mill, with eight stamps.

The placer and hydraulic mines in Calaveras County have been of great importance, but are now much fallen off. The ordinary river and gulch diggings being almost entirely exhausted, and not differing in any essential respect from those existing everywhere in the Gold Region, need not here be spoken of. The surface of the limestone at Murphy's is still worked to a considerable extent, a very long and expensive bed-rock sluice having been carried up, so as to afford fall enough to work many of the deeper cavities which could not before be reached. 
The principal hydraulic diggings now worked are in connection with the roleanic deposits, and these are very widely spread over this region. On the southeastern side of the county, parallel with the Stanislaus, 'Table Mountain comes down, crossing the river near Abby's Ferry, as before described. As exposed in the gap through which the road from the ferry to Murphy's passes, there appear's to be as much as 500 fect in thickness of volcanic and sedimentary material resting on the surface of the limestone, which is here about 2200 feet above the sea. 'The upper portion is basaltic lava about 150 feet thick, and this rests upon a series of beds, about 350 feet thick, made up of a mixture of sand and clay with roleanic ashes and pumice, containing many boulders of quartz and masses of silicified wood. These rest on the limestone, which has the same deeply eroded surface as at Sonora. There are many prospecting shafts sunk in the stratified beds which lie upon the limestone; but none of them seem to have been successful in striking at this point a channel of pay gravel. The view from the summit of the volcanic ridge above Abby's Ferry is rery striking, not only from its picturesqueness, but from the excellent opportunity which it aftords of sceing what immense changes have taken place in the topography of the country since this great current of lava flowed down from the high regions of the Sierra. The town of Columbia is observed to be almost exactly on the same level as the surface of the limestone on the north side of the river, and the dark mass of Table Mountain is seen stretching away to the south, evidently the continuation of the ridge on the north side, while between these two parts of what was once one continuous flow of solid lava 150 feet in thickness, lies the tremendous cañon of the Stanislaus fully 2000 feet below, with steep, bare walls, between which there is hardly more than room for the river to pass.

How large a portion of the county, in a northeasterly direction from Murphy's, is covered by volcanic overflows cannot be ascertained until a detailed survey is made of that region; but it is evident that several great lava currents swept down the flanks of the Sierra, during the period of volcanic activity, along the southeastern side of the county, as the deeply eroded outliers of erupted matter still bear witness.

Between Vallecito and Douglass Flat, on the south side of the roan GEOL. VOL. I. -34 
to Murphy's, is a high ridge of volcanic breccia, and to the north of this is an immense deposit of gravel extensively worked, but the exact position and relations of which, for want of an accurate map of the region, we were unable to determine. A decp adit, called the "Manmoth Tunnel," is being driven in, to drain this plateau of gravel. It passes through a fine-grained, granitoid rock, composed of black hornblende and feldspar. This is intersected by numerous quartz veins, which are very variable in size and direction, their width being from a few inches to four feet. The quartz has disseninated through it copper pyrites and crystals of brown-spar.

Another extensive region of volcanic rocks extends from the north side of the Big 'Trees west towards Railroad Flat, and to the north of Cave City; it is probably with this that the volcanic beds in the vicinity of Mokelumne Hill are connected, although the intermediate region has not been explored. Portions of this range are known by different names, "Table Mountain" being one of them. Railroad Flat is quite surrounded by these ridges, which rise from 600 to 800 feet above the level of the flat, and have a most picturesque effect. One, which from its fancied resemblance to a fortress has been called Fort Hill, is shown in the annexed wood-cut (Fig. 40). Its outline contrasts sharply with the rounded contour of the granitic rocks of Blue Mountain seen in the distance. There were no washings or mining going on in this vicinity when visited, in the autumn of 1863 .

The district of Mokelumne IIill and its vicinity has been noted for the extreme richness of its auriferous deposits under the volcanic beds. Those in the immediate neighborhood of the Hill are pretty much exhausted; but others about four miles south, at a place known as Chili Gulch, are still productive and actively worked. The bed-rock here is quite varied in character. Around French Hill, a little to the north of the town, silicious and micaceous slates are seen, overlain by beds of compact argillaceous sandstones; the dip of the metamorphic strata is to the northeast at an angle of $45^{\circ}$. Hornblende-rock also occurs in large masses, and seems to pass into a kind of granite.

The sedimentary and volcanic deposits near the town are about 250 feet thick and rest on the bed-rock, which has an elevation of about 1800 feet above the bed of the Mokelumne River, which is only a mile 
distant to the north. The upper part of the volcanic ridge is a mass of boulders or fragments of trachytic lava, not polished or smooth, but

Fig. 40.

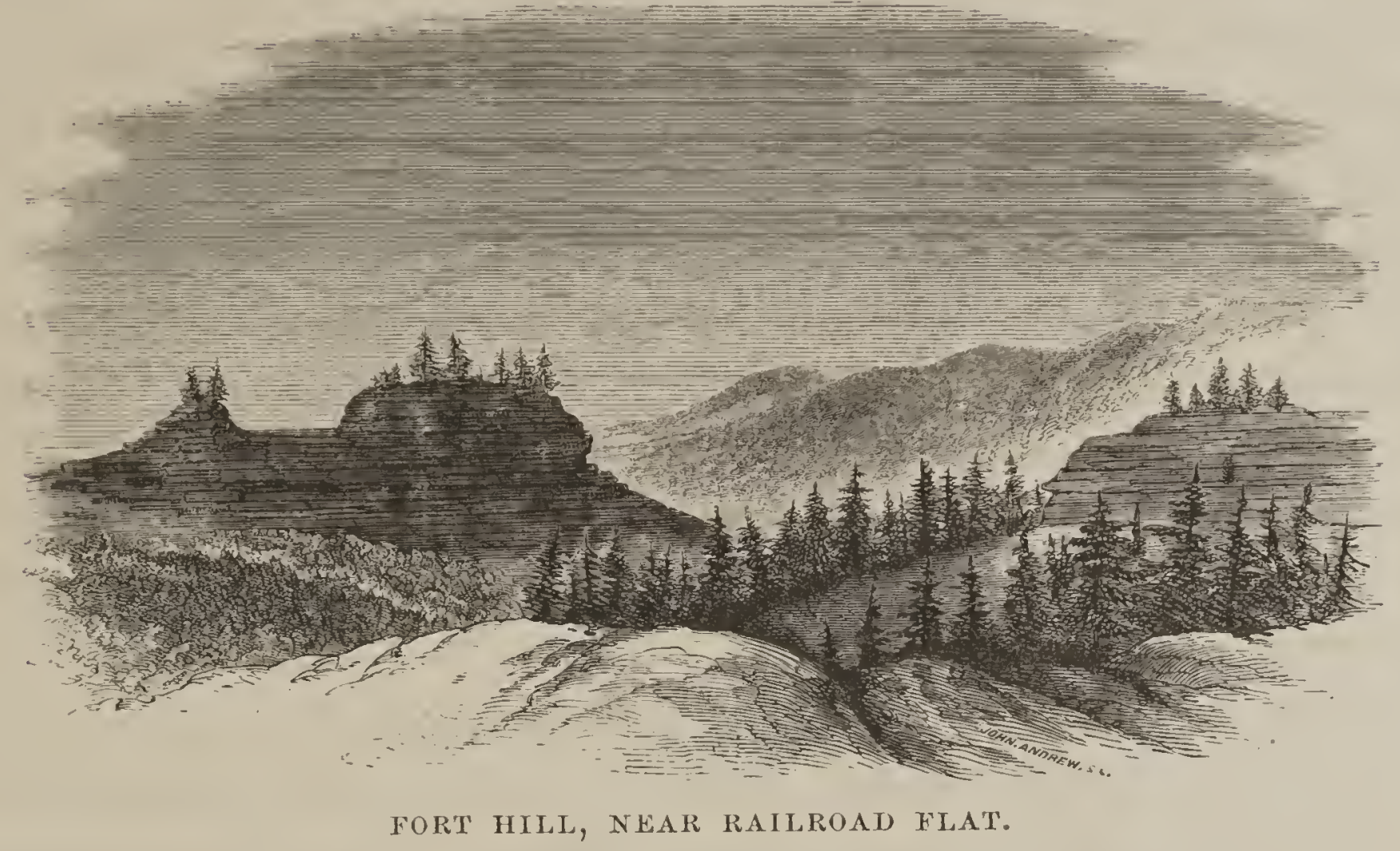

roughly rounded, as if by friction with each other, unaided by water. These boulders are largest at the top and grow quite small towards the bottom of the bed, which is here about fifty feet thick. There are no other kinds of rock than volcanic represented in this bed, and no stray pebbles, even of quartz or slate; this fact is not peculiar to the lava ridges of Mokelumne Hill, but has been observed in many other places in this region. To account for the formation of such deposits is not easy. It can hardly be the result of the disintegration of the lava by ordinary decomposition; nor is it possible to suppose that currents of water have brought the lava boulders together, as gravel is ordinarily accumulated; for how, in this case, could it be explained why the largest masses are on the top, and that no fragments of other rocks have become mixed with the trachytic materials? It would seem as if the mass of lava must have been broken up, while flowing and before it was entirely consolidated, and that the fragments were pushed over each other by the pressure of the mass from behind; under such circumstances, the lower portions, having to undergo the greatest amount of pressure and motion, would necessarily be broken up more completely than the upper, and the whole would thus present the appearance it now does, 
which is that of a mass of fragments of rock rounded by friction with each other, but not sorted by currents of water. Something of the same appearance has been observed by us in the beds of ancient volcanic materials, intercalated among the sandstones of Lake Superior.

Beneath this bed of lava boulders, is a mass of strata, in some places nearly two hundred feet thick, consisting chiefly of volcanic ashes, stratified and consolidated by water, resembling the beds seen under the lava, in so many localities in the Sicrra. These sedimentary volcanic strata are often fine-grained and homogencous, having a light pinkish-red color, and breaking with a conchoidal fracture. The upper beds lave much pumice mixed with them. Immediately on the bedrock lies the stratum of pay-gravel, which in some places has been of the most astonishing richness, but is now entirely worked out, having occupied only a very small area.

The Mokelumne Hill channel of auriferous gravel seems to be continued in that of Chili Gulch, which lies to the south, and where exploration was actively going on from 1860 to 1864 . The position of this channel is about 150 feet lower than that of Mokelumne Hill. There are several beds of gravel here in the lava; but the pay-dirt is at the bottom and forms a stratum about eight feet thick. Much of it is so compacted together that it has to be stamped before it can be washed. An interesting specimen of a part of the head of a rhinoceros was found here, and it is the first and only instance, so far as we know, of the discovery of this animal west of the Rocky Mountains. The species is considered by Dr. Leidy, to whom it was referred for examination, to be new, and it was called by him Rhinoceros hesperius, and will be found described in the Proceedings of the Academy of Natural Scicnces of Philadelphia, for the year 1865. The specimen consists of the right branch of the lower jaw, including the symphysial portion of both sides, with the left condyle. It is completely fossilized, and closely resembles in general appearance the fossils of the Mauvaises Terres, in Nebraska. 


\section{-Section VI.-Amador County.}

Amador County lies between the Cosumnes and the Mokelumne Rivers, and is considerably smaller than most of the mining counties north and south of it. The belt of auriferous rocks runs directly through its centre, the principal mining towns being .Jackson, Sutter, Amador, and Drytown, and it occupies a width of about twelve miles. The productive portion of this belt is, however, chiefly along its northeastern side. Ordinary gulch and river mining has been extensively carried on here; but is now almost entirely discontinued. The quartz mines, however, have been, and still are, of great importance. The belt of limestone, noticed as so conspicuous in Tuolumne and Calaveras, extends as far as Volcano; three or four miles beyond it, to the northeast, we strike the granite, which is continuous up into the High Sierra. The volcanic formations are principally developed along the southern side of the county, near the Mokelumne River, and especially in the vicinity of Jackson; the northwestern portion is occupied by the auriferous slates and has little of peculiar geological interest.

Coming into the county from the side of Sacramerito, Ione Valley was the first locality examined. Immediately north of Ione City, hard, blue metamorphic slates are seen, running $\mathrm{N} .20^{\circ}$ to $25^{\circ} \mathrm{W}$., and dipping east at an angle of $67^{\circ}$. Farther east the slates are seen, very little altered from their original condition; their color is light-gray at the surface, and dark bluish-black at a little distance beneath. The town is surrounded on the south, southeast, and southwest by low terrace-like hills, with flat tops, which are the remains of a late Tertiary formation with which this region was once extensively covered; but which is now very irregularly worn away, leaving outliers far out into the Sacramento plain. One of these outliers, four or five miles west of Ione, and called Pratt's Hill, was ascended by Mr. Rémond, who found it to be distinctly stratified and chiefly made up of alternating deposits of clay and gravel, with a bed of trachyte at the top. The gravel is composed exclusively of large pebbles of volcanic origin. The clays are of various colors, white, red, and purple; of the white, a good deal has been sold and used for paint. These strata are superior in position to the sandstones imme- 
diately about Ione, which latter are divided into two portions; the lower of these is made up of a series of white, pink, and red sandstones, while the upper is a highly ferruginous rock, and is about twenty feet thick. This member of the formation contains so much iron in places as to become a tolerable ore; in other localities it forms a quartzose breccia, cemented by brown oxide of iron. It is quarried to some extent for walls and fences. Where these rocks occupy the surface, they are covered thickly with chamisal, while the metamorphic slates of the vicinity support a scattered growth of fine oak trees, with a few pines on the slopes.

The lower division of the sandstones is of especial interest as containing a bed of lignite, or imperfect coal, which has been worked to some extent. The locality is about two miles south of Ione, near the Stockton road. This coal is associated with beds of white clay. A drift was run in, by Mr. Hall, the proprietor of the mine, for a distance of five hundred feet, in which a good section of the rocks connected with the coal was obtained; but it was not accessible at the time of our visit. From Mr. Hall we learned, however, that the upper stratum exposed was a white, somewhat argillaceous sandstone, containing a large number of fossil leaves, in a good state of preservation, one of which was eight inches long; unfortunately these had not been preserved. Below this, was a bed of white clay, with traces of vegetable matter; under this a seam of bituminous shale, one foot thick, succeeded by a bed of sandstone, with a thin layer of coal at the bottom, then a bed of clay, under which was the coal stratum, seven feet thick in its maximum development. Below the coal is a bed of sandstone, which has not been penetrated to the bottom.

The coal evidently occupies a small basin-like depression in the strata, and is made up of a mass of vegetable matter brought together and imperfectly carbonized. It is of the same age as the lignite seams of the auriferous gravels under the basaltic lava, namely, later Pliocene. It is of a brownish-black color, without lustre, and soon crumbles to pieces when exposed to the air. The upper part of the bed is something half way between peat and lignite; the lower, a denser material, brittle as resin, and burning with a hot and smoky flame. This material is used by Mr. Hall for running a steam flour-mill, and answers 
the purpose very well; some of it has been shipped to Sacramento for sale, but it is too crumbly to bear transportation. The whole region about Ione has been prospected for coal, but without success. At Buckeye Valley, about five miles northeast of Ione, on the road to Sacramento, coal, or lignite, has been found in several small independent basins; but these deposits were not accessible at the time of our - visit. They are undoubtedly of the same age as that at Ione, and probably of much the same character. Fragments of the Tertiary extend all along the foot-hills of the Sierra in this region, and wherever they occur coal is likely to be found; but these deposits cannot be expected to be of value except for local consumption, there being no reason to suppose that they occur in continuous and extensive beds. Besides, the material is not sufticiently consolidated to bear much transportation.

Between Jackson and Drytown, in a line about eight miles long, running nearly northwest from the first-named place, is a belt of quartz mines, which have been and still are worked with great activity, and are among the most important in the State. The outcrops of quartz on which these mines are situated, are in a line with the great quartz vein of Mariposa, Tuolumne, and Calaveras Counties, as alrearly noticed, and this seems to be the extreme northern point to which it can be traced, It is not, by any means, a continuous bed or vein of quartz; but, rather, a series of nearly parallel belts, or lenticular masses, with long barren intervals between them, but yet arranged pretty nearly in the same course, so that a straight line drawn in a direction of $\mathrm{N}$. $27^{\circ} \mathrm{W}$. from Jackson would either cut or pass very near the whole of them.

The mine as well as the mills on this belt were examined, pretty carrefully, by Mr. Ashburner, in 1861, and since that time have been occasionally visited by others of the Survey. The following statement of their condition refers to the year 1861, where a later date is not particularly specified.

The Oneida Mine and Mill are situated about two miles northwest of Jackson. The mill is one of sixteen stamps, run by steam, and capable of treating about 400 tons of rock per month. The vein is in slate, and dips to the east at an angle of $64^{\circ}$; its average width is eight 
feet, and the rock pays from $\$ 10$ to $\$ 11$ per ton. At the depth below the surface of 185 feet perpendicular, or 260 feet on the incline, the yield of the quartz was said to be as good as in any part of the mine.

The Eureka and Badger Mines are owned by Messis. Hayward \& Chamberlain, and have been worked for about ten years. Their daily production Twas, in 1861, about 100 tons. The vein is inclosed in at dark-colored, rather soft argillaceous slate; it has a strike of $\mathrm{N} .22^{\circ} \mathrm{W}$., and dips to the east at an angle of $70^{\circ}$. The foot-wall is soft and very friable, while the hanging-wall is harder and more decidedly metamorphic. The Eureka and the Badger were formerly two separate concerns; but are now worked together, the rock from the Eurekal being treated at the mill of the same name, while that from the other mine goes to the Upper and Lower Badger Mills. In the Eureka, the mass of veinstone is from eight to twenty feet wide; but in the Badger it widens out suddenly to forty feet. The length of ground worked, in both mines, is about 470 feet; to the south of the Badger Shaft, which is on the south end of the mine, there is hardly any quartz to be seen, and the lode, which is eight feet wide on the north side of the Eureka, pinches out very rapidly in that direction, so that the body of quartz worked is very short in proportion to its great width, being almost a column, or chimney, rather than a vein. At the junction of the two mines there is a large mass of slate and soft clay, mixed with a little quartz, which is often in a state of fine powder, owing to the pressure of the yielding foot-wall. This pressure is so great, that the timbers, which are sometimes two feet in diameter, are in a short time twisted and bent like reeds, and have to be replaced by new ones. The depth to which this mine had been worked, in 1861, was 500 feet on the incline, equal to 470 in a vertical descent; in 1863 the principal shaft was 650 feet deep, and the lowest level had then been extended on the vein for a distance of 560 feet.* The quartz is of a grayish-white color, and interlaminated with seams of soft slate, which have,a direction parallel to the walls of the vein. The gold is very regularly and uni-

* This shaft is stated in a newspaper of the vicinity (the Jackson Ledger) to be, in June, 1865, 920 feet deep. If so, it is, next to the Cliff Mine, on Lake Superior, the decpest shaft in the United States. 
formly diffused through the mass of veinstones, and is rarely in particles large enough to be visible to the eye. There is about two or three per cent. of pyrites in the veinstone, which was, in 1861, allowed to run to waste.

The Eureka Mill has forty stamps, and is run by water during the wet season, and by steam in the summer. About sixty tons of quart\% from the Eureka Mine were daily worked at this mill, in 1861, and yielded $\$ 10.25$ per ton; the expense of the treatment in the mill (stamping and amalgamating) being only $\$ 1.32$ per ton. The cost of the extraction of the quartz from the mine, at that time, was estimated at $\$ 2.50$ per ton, leaving, as wilk be seen, a handsome margin for profit. Indeed few, if any, mines in the State have been more uniformly and permanently successful, while the yield of gold to the ton of rock stamped is quite low.

The Upper Badger Mill has sixteen stamps and is run by water. As the quartz from the Badger Mine has a good deal of slate mixed with it, it is worked in this mill at the rate of two tons per day for each stamp, the whole cost of stamping and amalgamating at this mill is exceedingly low, namely, $\$ 0.66$ to $\$ 0.67$ per ton, when all the conditions are favorable, and water sufficient; this is a lower figure for the treatment of the quartz than any other mill in the State can show. The Lower Badger Mill has twelve stamps, and can run through twenty tons a day of the soft slaty quartz from the mine of the same name. As at the last-mentioned mill, the stamps are run at a very rapid rate, namely, eighty blows per minute. The yield of the quartz at these mills is about the same as at the Eurekit. The quartz at the Eureka and Badger Mines did not begin to pay well until a considerable depth had been reached (100 feet, it is said); but since that, its tenor in gold, at least up to 1863 , has been remarkably uniform.

The "Herbertville Quartz Mining Company," were, in 1861, working a mine near Amador, on another of those chimneys of quartz which characterize this region. The ground worked was only 200 feet long, and the depth reached in the western shaft was 640 feet on the incline, and 524 vertical. Its bearing is $\mathrm{N} .85^{\circ} \mathrm{W}$, and its dip to the soutl, at an angle of $55^{\circ}$. The rein was eighteen inches wide on the surface, and it expanded gradually, until a depth of 400 feet was GEOL. VOT. I. - B.j 
reached, where its width was four feet; below that, it became pinched and the quartz grew poorer, its yield of gold having been greatest at 200 feet from the surface.

The mill, which had thirty stamps, and was run by steam, was stamping dry, in 1861, and working over old tailings, which yielded $\$ 20$ per ton. The expense of the treatment was $\$ 4.59$ per ton.

The "Amador Quartz Mining Company" had, in 1861, a twentystamp mill, run by steam, and treating rock from a vein in the vicinity, which has a strike of $\mathrm{N} .40^{\circ} \mathrm{W}$., and dips to the east at an angle of $57^{\circ}$. The shaft was down 450 feet, on the incline, which is equal to a perpendicular depth of 377 feet. The vein varies in width from eight to twenty-four feet, averaging twelve probably. At the bottom of the shaft it was eight feet thick, and had been drifted on fifty feet to the north. The quartz was in many places exceedingly soft, and easily broken, having apparently been subjected to immense pressure, from the movements of the inclosing rock. The hanging-wall is of soft, black slate; the foot-wall of hard metamorphic rock. As is the case in most of the mines in this vicinity, the workings are chiefly in depth; the greatest amount drifted, to the north of the shaft, being 120 feet, at a depth of 302 feet, and to the south only fifty feet. The yield of the quartz was about $\$ 10$ a ton, and the mill could crush thirty tons per day, at an expense of $\$ 1.79$ per ton.

The Spring Hill Mills, on Amador Creek, are two in number, one with fifteen, the other with sixteen stamps; these were employed, in 1861, in working the quartz from a vein so near, that the rock could be dumped from the mouth of the shaft directly on to the spalling-ground. The direction of the vein is $\mathrm{N} .22^{\circ} \mathrm{W}$, and it dips to the east at an angle of $55^{\circ}$ to $60^{\circ}$. The shaft was sunk to the depth of 150 feet on the incline, or 126 feet perpendicular. The extreme length of the workings was about 900 feet, and the average width of the vein about eighteen inches. Near the bottom of the shaft, and a little to the south of it, there was a sudden expanding of the vein to a width of twenty feet, which it maintained for a length of 150 and a depth of 40 feet. In many places the lode entirely disappears and is replaced by a very soft, black shale, containing small quantities of quartz in fine powder. The yield of the quartz of this vein was about $\$ 10$ a ton, and the cost 
of treatment in the mill $\$ 1.63$ per ton; that of extraction from the mine was estimated at $\$ 2$ per ton.

The names of both the mills and the mines, and also the character and extent of the workings, have changed somewhat since 1861; but the facts given above are of interest, as showing the general character of the quartz-mining operations in this vicinity. Their present condition and future development, up to the time of publication of the volume more especially devoted to Economical Geology, will be found in that part of the Report.

There is quite an important mining district at Volcano, about sixteen miles east of Jackson. On the road between these two places, Mr. Rémond observed granitic and feldspathic rocks, which were first seen about five miles from Jackson. At Volcano, we are on the great limestone belt of the Sierra, which here has a north-northwest direction, and almost a vertical dip; as at other places, it is cut by heavy trapdykes. The formation at this place closely resembles that at Sonora, being a white saccharoidal marble, with shades and markings of blue, sometimes largely-crystalline, but, in places, quite fine-grained. Its surface had been extensively eroded previous to the deposition of the auriferous gravel upon it, presenting the same appearance which has been already noticed in describing the limestone belt of Tuolumne County, and, like that, having the deep and curiously eroded cavities filled with rich auriferous detritus. At Indian Gulch, near Volcano, there are small quartz veins in this formation. Near the contact of the slates with the limestone, the latter acquires a slaty character. There are also many layers of flint, or chert, which are most abundant along the line of division between the crystalline marble and the slaty beds of the same rock.

At the time of Mr. Ashburner's visit to this district, in 1861, there were three principal veins of auriferous quartz worked, and the prospects of this branch of the mining business were quite flattering. The Whitman Vein is about one mile east of Volcano, and occurs in a band of slate which lies between two masses of granite. It has been traced for more than two miles, and has a general trend of N. $25^{\circ} \mathrm{E}$., and dips to the west at an angle of $65^{\circ}$; this direction and dip are, as will be noticed, quite exceptional. The width of the vein varies from a few 
inches to ten feet, but averages about six feet. The Italian's Vein is in the same belt of slate as the Whitman; its direction is about $\mathrm{N}$. $40^{\circ} \mathrm{E}$., and it dips to the east at an angle of $45^{\circ}$. Its width is from four to fire feet. The Leviathan Vein is on the same range as the two others noticed above. It bears $\mathrm{N} .30^{\circ} \mathrm{E}$., and dips east at a varying angle; its width is from nine to twenty-five feet. The yield of gold, in this vein, was quite high near the surface, and, at the depth of seventy-five feet, when examined by Mr. Ashburner, it was still very good, although variable, running from $\$ 10$ to $\$ 70$ per ton. There was only one mill, that of Rouse \& Co., in operation in 1861. It was a small concern of only five stamps, run by steam, and doing custom-work exclusively, for which $\$ 5$ per ton was charged.

There was, in 1861, a quartz lode on the north fork of the Mokelumne River, about six miles east of Volcano, called the Mountain Quartz Vein, and a mill of the same name. The district is a continuation of that of West Point, and the vein is similar in character to those on the other side of the river. This lode is inclosed in granite, and runs about $\mathrm{N} .25^{\circ} \mathrm{W}$., dipping to the east; it was about three feet wide at a depth of 100 feet. The quartz contains a large amount of pyrites and a little galena. The mill had four stamps, with two arrastras, and the yield of gold was stated at $\$ 100$ per ton. Of the development of the Volcano quartz mines since 1861, we have no information.

In the vicinity of Volcano, the detrital formation resting on the auriferous slates is quite thick, and in many places has been extensively worked for gold. Two small diamonds were shown Mr. Rémond as having been obtained from the washings here, and the circumstances were such as to warrant the belief that the discovery was a bona fide one. The crystals were small, having the form of an icositetrahedron, and their faces were curved in the manner so peculiar to this gem. The auriferous gravel is overlain, as at Mokelumne Hill, by horizontal beds of white and pink volcanic materials, consisting chiefly of ashes and pumice cemented and stratified by water. Upon these is a mass of trachyte, broken into rounded fragments on the surface. A considerable number of bones and teeth of the mastodon and other animals have been found in the auriferous gravels near Volcano.

In one of the detrital beds in this vicinity, a distinctly marked quartz 
rein was observed, cutting through the gravel, and evidently formed since its deposition by the action of waters holding silica in solution. The mass of the vein was of agate and chalcedony; but portions were of a ferruginous character. This is not by any means an isolated case; other localities have been noticed, where all the conditions necessary to the formation of quartz veins, similar in their general features to those in the auriferous slates, must have existed during the most recent geological epoch.

These masses of volcanic materials which play so iniportant a part between Volcano, Jackson, and Mokelumne Hill, are connected with the great volcanic table, or lava flow, which extends up on the ridge between the Cosumnes and the Mokelumne Rivers; over this the road from Volcano across the Sierra passes for a distance of about thirty-five miles. The deep valley of the Cosumnes runs nearly parallel with this road for many miles, exhibiting a fine section of the sedimentary-volcanic and basaltic rocks. The same is the case with the Mokelumne River on the south, the channels of these rivers seeming to have both been entirely cut down in the volcanic masses since these were erupted.

The vicinity of Jackson affords an excellent opportunity for examining the lavas and the underlying beds of ashes and gravel. The town and the adjacent region are underlain by the auriferous slates; but ridges of volcanic materials have been formed by the unequal denudation of the great mass of eruptive matter which seems to have covered an extensive area in former times; but which has now disappeared, with the exception of these few outliers, which form plateaux or low table mountains, of no very regular forms, partly surrounding the town. We have here, as at Mokelumne Hill, a mass of rounded trachytic pebbles, or boulders, covering the tops of the ridges. This may be well seen on the edge of the plateau about three miles north of the town, where the stratum of rolled fragments of trachyte is not less than fifty feet thick, and cover's a deposit of sedimentary-volcanic beds at least 250 feet in thickness.

The Jackson Butte is a very conspicuous outlier of the volcanic formation so extensively dereloped in this region, and it is often ascended for the sake of the fine view of the surrounding country which can be 
had from its summit. It was not measured; but was estimated to be 1200 feet above the town of Jackson, and 800 feet above the ground at its base. The excavations made by prospecters around the Butte show that it rests on horizontal strata of the usual fine clays, stratified ashes, and pumice; but the upper 600 feet of the hill, which has an irregular, conical shape, is made up of beds of lava, of a reddish color, and very distinctly stratified. These beds are not horizontal, but inclined at an angle of from $50^{\circ}$ to $60^{\circ}$, the dip being in almost every direction, but chiefly either to the northeast or the southwest. It is possible, perhaps probable, that this was an independent volcanic vent, and that the inclined position of the beds of lava, of which it is made up, is due to their accumulation on the steep slopes of the crater. The instances are very few, however, in which an eruptive mass of lava can be seen to have made its way upwards through the slates; in such eases the form which is usually exhibited is that of a dyke, rather than that of matter coming from a crater-like orifice.

A very large amount of prospecting for copper has been done in Amador Connty, and many shafts sunk, from some of which a considerable quantity of ore was taken in 1862 and 1863. The principal field of these explorations was along a line which appeared to be the continuation of the great cupriferous belt of Calaveras County, already noticed as extending through from Copperopolis to Campo Seco. One of the principal mines is that of Dr. Newton, about four miles west of Ione City; from this a considerable amount of good ore is said to have been shipped. Of their present importance and probable permanent value we have, however, no accurate information, as no detailed surveys have been made by us in that region.

There is also another cupriferous belt, some miles to the northeast of the one already noticed, and in the vicinity of Fiddletown. Indications of copper ores are frequent through that region; but no large deposits had been developed at the time we passed through that district, in 1863. Here, as well as elsewhere in the State, the high price of labor and fuel, the scarcity of water and the distance from a market operate to retard the development of metalliferous deposits, which, under more favorable conditions, would be of great value. 


\section{Section VII.-Ei Dorado Countr.}

This county, which lies between Amador on the south and Placer on the north, comprises that portion of the Sierra which extends between the Cosumnes River and the middle fork of the American. Its western boundary is near the edge of the foot-hills. In the general features of its geology it differs very little from the counties to the south, which have already been noticed. The volcanic formations are less extensively developed than they are in Amador, although there are still the remains of at least one heavy flow of lava to be traced through the central part of the county.

The belt of auriferous rocks in El Dorado is quite broad, having an average width, at right angles to its direction, of perhaps thirty miles; the slates predominate in it, and in the cañons of the American and its branches they are eroded to an immense depth. With the slates occur many masses of sandstone, in various stages of metamorphism; occasionally limited patches of both these rocks are found, retaining almost entirely their original condition, as far as chemical composition and mechanical aggregation are concerned. They are always, howerer, turned up on edge, and dip invariably to the east, usually at an angle of from $70^{\circ}$, to $80^{\circ}$. The strike of the slates, through the principal mining districts, seems to vary from N. $20^{\circ} \mathrm{W}$. to N. $30^{\circ} \mathrm{W}$. In the vicinity of Placerville it is $\mathrm{N} .21^{\circ} \mathrm{W}$. Here the rock is of a dark color, very finely laminated, and containing occasional crystals of pyrites.

As far as the palæontological evidence which has been collected by the Survey can be relied on, a part at least of these slates is of Triassic age. No undoubted Jurassic fossils have been obtained in them, although Mr. Gabb discovered, about two miles west of Spanish Flat, some imperfect remains of Cephalopods, which could not be distinguished from the Belemnites found on the Mariposa Estate, in rocks known from the other fossils associated with them to be of Jurassic age.

Mr. Gorham Blake obtained at Spanish Flat, from the light-colored, fissile, and slightly metamorphic slates, a very distinct impression of what appears to be the same Goniatite (Goniatites lacidorsatus) found at Washoe and in the Humboldt Mining Region of Nevada. A similar 
specimen, from near Coloma, was given to Dr. Trask by Hon. John Conness, and Dr. Horn collected what appears to be the same thing from the mountains east of Owen's Valley. In the case of the California specimens, the condition of the fossils, which are impressions on the surface of the slate, is such as to preclude the possibility of accurate determination of the species; but, from the general resemblance of all of them to each other, it is highly probable that they are, if not the same, at least closely allied species. It is hardly possible to avoid the inference that a very considerable portion of the auriferous slates, in the heart of the Gold Region, is of Triassic age, especially as a large number of fossils, unquestionably of this period, have been obtained by the Survey, in the auriferous slate series farther north, in Plumas County. The evidence at the last-named locality is conclusive in favor of the exact equivalence in age of a part, at least, of the gold-bearing rocks of California to the formations of the Humboldt Mountains, which we know, from a great abundance of fossils collected, to belong to the Upper Trias, and to be the equivalent of the IFallstadt and St. Cassian beds of the Alps.*

The work of tracing out all the subdivisions of the auriferous slate series through the mining counties remains yet to be done, having been just commenced in the southern district. It will require a vast amount of time and labor fully to work out all these details and to trace the different members of the group, broken and obscured as they are by metamorphic agencies. It is reasonable to suppose that minute and thorough search will, in the course of years, furnish the necessary palæontological material by which these subdivisions can be distinguished from each other; but it is not to be denied that fossils are extremely rare in the auriferous rocks, and it should be remembered that, at the commencement of this Survey, there was not a particle of evidence in existence as to the age of the great metalliferous formations of the Pacific coast, nor a single locality of fossils known to exist in rocks which could be unequivocally connected with them.

The region in the southwestern and western portions of Placer County is occupied by obscure, highly metamorphic rocks, which have

* See Palieontology of California, vol. i, section 2, for a description of these Triassic fossils, by Mrr. Gabb. 
as yet been very little examined. A broad belt of granite makes its appearance on their western edge, and is well exposed in the bed of the American River at and near Folsom. Intrusions of granite are also frequent among the metamorphic rocks themselves; but they cannot be located until we have a map on which to lay them down.

The limestone formation of the Sierra occurs in detached masses through Placer County, appearing to form two distinct belts nearly parallel with each other and about ten miles apart. One of these belts is secn near Ringgold, where it forms an apparently disconnected mass, covering about a square mile of surface. The strata are evidently much broken here, as the strike of the beds of limestone is to the east of north; their dip is to the east, at an angle of $50^{\circ}$. This onterop is in a line with that at Indian Diggings, about eighteen miles southeast, taking the average strike of the rocks in this part of the Sierra as a guide; but it is not known that the limestone actually makes its appearance anywhere between these two localities. Following the same direction towards the north, the next outcrop known is at Cave Valley, on the middle fork of the American; still farther on, there is a large mass of limestone nearly in the same line, at Limekiln, on Wolf Creck, near Grass Valley. Between this last-mentioned locality and that of Pence's Ranch, already described, we have not yet been able to ascertain the existence of any evidence of the continuity of the belt in question, although all these localities are pretty nearly in the same position, with regard to each other, that they would have if they had all been originally parts of one continuous group of strata.

The other belt crops out in Marble Valley, a side-valley of Decr Crcek, near Clarksville, about eight miles cast-southeast from Folsom. This crosses the south fork of the American River near Salmon Falls, and has been traced no farther in that direction. After an accurate map of this portion of the State shall have been made, it will be extremely interesting to lay down upon it these detached outerops, and to trace their connection with each other. At present it can only be done in the most imperfect manner; but the results, like those already hinted at in noticing the great quartz vein or bed of the Sierra, give a clue to an immense edgervise or longitudinal thrust, which the mass of the Sierra Nevada must have undergone, by which vast bodies of GFOI. VOL. T. - 36 
strata, once continuous for hundreds of miles, have been torn asunder, portions of them engulfed, and the remainder twisted so as to lie at all angles with regard to the original line of direction of the mass, but not so far removed firom their former position as to leave any doubts of their having been once parts of the same continuous formation.

El Dorado does not, at present, occupy a very important position as a mining county, although it was here that the first discovery was made which led to the opening of the gold-fields of the Sierra. Most of the river and gulch mines are pretty nearly exhausted; but there is still considerable hydraulic mining going on at various points.

There were formerly a large number of quartz mills in operation in the county; but, in 1861, at the time of Mr. Ashburner's examination, there were few of them still rumning. Of late, however, attention has been again turned in this direction, and it would appear that there are many gold-bearing quartz veins, some of which may be worked with profit, under systematic and judicious management.

The following is a synopsis of all that was doing in the county, in 1861, in the way of quartz-mining. At Logtown, seven miles southwest of Placerville, there are several veins in the granite. Four of these, known as the Empire, Pocahontas, Excelsior, and El Dorado, have been worked, at intervals, since 1850. Their general direction is northwest and southeast, and their dip is to the east. The rock was said to yield $\$ 10$ per ton, and it was worked in a ten-stamp mill, run by steam, the cost of crushing and amalgamating being $\$ 1.49$ per ton.

A mill at Aurum City, one and a half miles east of Logtown, called the Union Mill, was run on a small but rich vein, which was said to yield $\$ 30$ a ton. The mill had ten stamps, and the cost of treatment of the quartz was $\$ 2.05$ per ton.

Another mill visited by Mr. Ashburner, was at Grizzly Flat, sixteen miles in a direct line east-southeast of Placerville, on Steely's Fork, a branch of the Cosumnes River. The vein is in the granite, and contains a large amount of the sulphurets of iron, lead, and zinc; it was said to have paid very well near the surface, where these combinations were in a decomposed condition. The mill had eleven stanps, and was run by water-power.

The volcanic formations, with the underlying auriferous detritus, do 
not occupy a very extensive area in El Dorado. Some patches, however, still remain and are worked by the hydraulic method. A good cxample of these may be seen in the hills about l'lacerville, and between that place and Diamond Springs. At Reservoir IIill, two miles north of the town, there is a stratum of auriferous gravel forty-fire feet thick, which contains gold through nearly its whole mass. It is surmounted by a bed of volcanic breccia, ten feet thick, and this, in turn, is corered by a thin stratum of rounded fragments of lara, the whole appearance indicating the thinning out, or the lower edge, of one of the great rolcanic masses coming down from the Sierra.

In the ridge south of Placerville, at a height of 375 feet above the town, similar voleanic beds may be seen, but much thicker, and covering heavy aceumulations of auriferous gravel, which have been and still are somewhat extensively worked. The principal features here are not materially different from those exhibited in the deposits of a similar character in the counties to the south. The rim-rock is very marked on the north side of the hill, and is at least seventy feet high above the bottom of the auriferous gravel, and perhaps considerably more. At one point enormous rounded boulders of quartz were observed resting directly on the bed-rock; one of these measured fifteen feet long by five feet wide and high. These deposits now occupy the summits of high ridges, the adjacent country having been worn down to a perpendicular depth of several hundred feet below the beds of detritus, which must originally have been deposited in a valley, but which now form the culminating points of the region.

\section{Section VIII.-Placer County.}

'This county has Bear River on the north, and the middle fork of the American on the south; it stretches east and west from the State line to the Sacramento River. It is very narrow from north to south through its central portion, so that the auriferous slate formation is not well exposed, the rolcanic deposits occupying a large area, and, through the lower part of the county, all of the elevated table between the north and middle forks of the American. Hence, hydraulic mining is the 
leading interest of the county; there are but few quartz-mines, and none of these have been in operation when visited by us.

Below the junction of the two forks of the American, the metamorphic rocks are well exposed, from Auburn to the northwest. In this vicinity the predominating formation is a dark-colored ferruginous, silicious slate, sometimes passing into hornblende-slate, often very compact and difficult to break. The dip is nearly vertical, and. the strike varies, in different localities at no great distance from each other, from $\mathrm{N} .20^{\circ} \mathrm{W}$. to $\mathrm{N} .45^{\circ} \mathrm{W}$. The slates extend to about three miles southwest of Auburn, where granite comes in and continues to the edge of the plain of the Sacramento. The surface underlain by this rock forms low, rounded hills, and the depressions between them are partly filled with granitic sand and detritus. The granite often weathers out in large, boulder-like masses, which are, in places, split up and used for building purposes. Quarries have been opened, along the line of the Pacific Railroad, for supplying stone for the State House at Sacramento, and the material seemed to be both durable and handsome, as far as could be judged from an examination of specimens taken near the surface.

Large masses of serpentine occur among the metamorphic rocks near the granite to the north of Auburn. Iron ore was also observed in this vicinity, of excellent quality, and in larger quantity than has as yet been discovered anywhere in the auriferous slate series. The locality is on the land of Lysander Utt, about one mile north of Wells's Ranch, which is on the Grass Valley road, six miles from Auburn. The ore crops out on a side-hill, and forms a mass more than thirty feet thick, of which the longitudinal extent is not known, although it is evidently considerable. It is a hematite, perhaps mixed with some limonite, and has not yet been analyzed; it appears, however, to be of excellent quality, and is remarkably pure and free from intermixture with rock. With the present prices of fuel and labor, it is not easy to say how soon California will be able to manufacture her own iron; but this locality is perhaps more favorably situated than any yet discovered in the State for trying the experiment,

The metamorphic rocks are finely exposed in the tremendous cañons of both the north and the sonth forks of the American River; these 
gorges or cañons (valleys they cannot properly be called) have been worn ont in the slates, since the epoch of voleanic activity in the Sierra, to the depth of from 1800 to 2500 feet. - Their sides have exceedingly steep slopes, sometimes areraging as much as $30^{\circ}$ for the entire distance, and are swept entirely clean, there being usually hardly a trace of detritus left along their sides. The bottoms of these cañons are rarely more than wide enough to allow of the passage of the river's which flow through them, and which at times of high water have their volume immensely increased. It is when a stream like the American rises twenty, thirty, or even as much as fifty fect above its ordinary stage, and tears down its highly inclined bed with incredible force and velocity, that one can understand how these cañons have been excavated; and if, as we have reason to believe, a much larger amount of rain fell on the Sierra in former times than now does, it is easy to see what the eroding power of these streams must have been, in those days when the great glaciers, which once covered so large a portion of the mountains above, were melting away.

Along the middle fork of the American, as far as "Forest Hill under" the Hill," the volcanic and detrital beds come down to the edge of the summit of the cañon. A little farther on, near Sarahsville, they recede to the north, and there are ample exposures of the auriferous slates. An immense ridge of serpentine occur's near the last-mentioned place, forming the largest mass of this rock seen in the State.

Quite a number of quartz veins have been worked here at various times; but they were all abandoned when examined by us in 1861. It is probable that some of these have been, or will be, taken up again, and new discoveries in this region have been reported, indicating that the quartz-mining business may be revived with success in Placer County.

An important chain of hydraulic diggings passes through Placer County, from north to south, on which the workings have been, and still are, quite extensive. The principal mining towns are Iowa Hill, Wisconsin Hill, Yankee Jim's, and Todd's Valley. The thickness of the detrital and volcanic formations on this line must be, in places, over 500 feet. Some of the washings exhibit a vertical section of over a hundred feet in thickness of "cement," or coarse gravel and boulders, often quite firmly compacted together. Over this are the usual 
beds of sedimentary-rolcanic materials, and above all the capping of hard basaltic lava, which forms the table of the divide between the north and middle forks of the American, and of which the thickness has not been measured, for want of a good exposure.

The lava tables seem to extend far to the east, and are seen finely exposed in the vicinity of Deadwood, Last Chance, and other mining camps high up on the divide. Here the cañons are very numerous, and have exceedingly steep sides. Near Deadwood the depth of one was measured and found to be a little over 1600 feet. El Dorado Cañon, a little farther down, was nearly 2000 feet deep; the steepness of the sides of these gorges may be inferred from the fact that the upper edges of the walls of the last-mentioned one were not over three-fourths of a mile apart, which would make the average slope of the walls but little less than $45^{\circ}$. In these cañons a very interesting fact was observed, which may be found to have an important bearing on the stratigraphy of the Sierra. It was noticed, namely, that where the auriferous slates were seen in an almost vertical section of over 1500 feet, the upper 1000 or 1200 only had the usual normal dip of the formation, or to the east, at a high angle; below this there was a gradual curve, and at the bottom the inclination was decidedly to the west, just as would be expected to be the case if the upper portion of the slates had been forced back by immense pressure from above, producing a condition of things similar to that so often observed in the Alps, which is known as the "fan-structure," and has so much perplexed geologists. Many facts of a similar kind to this have been noticed in the Sierra, although nowhere on so large a scale as in Placer County, which may perhaps be accounted for by the fact that there are hardly anywhere such good opportunities for observations of the dip at so great a depth from the surface:

Of the intricacy of the topography to which these numerous deep cañons give rise, one can hardly form any idea, who has not undertaken the task of laying them down upon a map. None of the mining camps in this part of the county have been located with any approach to accuracy, and the names of most of them will be sought for in vain upon any published map. After some approach to a correct delineation of the surface has been made by the Survey, it will be an exceedingly 
interesting work to connect together the various ancient river channels and lake-like expansions, which are now filled up with these vast accumulations of detritus, and thus to reconstruct the system of watercourses by which the Sierra was furrowed, at a time when the conditions were so different from what they now are. It may be allowable to direct attention to the practical value of such a work, as a means of guiding the miner in his explorations, and as giving a clue to the probable extent and duration of the hydraulic washings; but it seems almost useless, with our present paucity of data, to enter into any speculations on this subject.

At Todd's Valley, and at Yankee Jim's, the character of the detrital deposits and of the underlying slates may be very well studied, as extensive areas of the latter have been exposed by the washings. At Yankee Jim's, not less than 300 acres have had stripped from them a covering of "cemented gravel," which was rarely less than twenty-five, and in places as much as a hundred feet thick. The pebbles and boulders of this gravel are all thoroughly water-worn, and consist to a large extent of quartz; this was observed to be especially the case at Michigan Bluffs. The bed-rock, which is here a light-colored talcose, or silicious slate, decomposes very easily, and, in some places, can be excavated with a pick down to a depth of twenty feet from the surface. The occurrence of impressions of leaves and masses of wood, more or less completely silicified, in the detrital deposits, is frequently noticed, where the material is not too coarse.

\section{Section IX.-Nevada County.}

We pass to the next county north of Placer, that of Nevada, of which both the quartz-mines and the hydraulic washings are anong the most important in the State; and where, as the people were never so largely dependent on ordinary placer diggings for employment as they were in most other portions of the mining region, there has not been that falling oft in general prosperity of which some other counties have had to complain.

Nevada County includes the region between Bear River and the 
Middle Yuba; its western boundary is a north and south line, parallel with the course of Feather River, and about twenty miles east of it. It extends east to the State line. The absence of any tolerable map of the county renders it difficult to do more than to give some detached observations on the geology of this interesting region; but we propose to commence here, with one of our parties, our detailed work of the next season, connecting on the sonth with the topographical surveys of Mr. Wackenreuder, who has been engaged, during portions of two years, in mapping for the Survey the region between the Silver Momntain Road and Truckee Pass.

The auriferous belt in this county is very wide; but it has large areas of granite included within it, much larger than any in the counties to the south. The principal one of these granitic belts passes a little east of Grass Valley and extends by San Juan North, to Feather River. Between these belts, the slates are highly metamorphosed, and the sandstones sometimes pass into granitoid rocks, forming masses which can hardly be distinguished from true granite; as in the Sebastopol Claim, about a mile and a half west of San Juan, where the bed-rock is finely exposed by the removal of the overlying detritus, and shows a considerable number of parallel bands of slate and metamorphic gneissoid rock. The formation has a vertical dip at this point, and the strike of the beds is nearly north and south. Where the slates are highly altered, as in the vicinity of Grass Valley, it is very difficult to say what is their true position.

Farther to the east, where the metamorphism has not been so complete, the slates occupy a very extensive area, the limits of which have not yet been defined.

The limestone belt may be traced through the southwestern part of the county; and there are indications of another one much higher up in the mountains; but which cannot as yet be accurately located. The band of limestone, which is well exposed at the place known as "Limekiln," about ten miles south of Grass Valley, appears to be in the same line with that of Pence's Ranch, which is known by its fossils to be of Carboniferous age.

It is evident that, as we go north from Placer County, we find the slates and other rocks of the metamorphic series extending farther and 
farther to the east, encroaching upon the granitic, so to speak, or oceupying the place which that rock would have, if the trend of the great granitic mass of the Sierra remained the same which it is farther to the south. Thus, when we reach Sierra and Plumas Counties, we shall see that there are heavy belts of both slates and sandstones, fossiliferous in places, which occupy the crest of the Sierra, that is to say, the line along which are situated the highest peaks of the chain, although this is not here the real water-shed, which lies to the east of this, the Feather River breaking through the main ridge and heading far to the east, between a series of ridges which form great spurs of the Sierra and stretch off to the north into a region which, as yet, has been but little explored. The strike of the rocks also becomes more nearly north and south as we follow the Sierra northwards, everything indicating the gradual giving out of the system of northwest and southeast trends, which has impressed itself so strongly on the geography and geology of the State in the southern portion of the Sierra, and a preparation for the north and south axes of upheaval, by which the mountain ranges of Western Nevada, as well as of Northeastern California and Oregon, have been fashioned.

The same easterly dip which characterizes the rocks of the Central Sierra, seems, however, to prevail all through this northern region, at least on the western side of the crest, and it would appear that the inclination is generally higher along the lower edge of the belt, being nearly vertical in many places in the vicinity of San Juan. This high dip of the slates seems to be connected with the appearance of the granitic belts along the western edge of the Sierra, which rock becomes more and more predominant, as we proceed towards the northwest, and, crossing the Sacramento, enter the lofty and broken region of Trinity and Del Norte Counties.

Grass Valley has been, and is still, the headquarters of the quartzmining business; there are many mills here, and most of them have been successful. In 1861 the mills of this vicinity furnished about $\$ 1,500,000$ of gold, which was about one-fourth of the entire production of the California quartz-mines. Reserving all details in regard to this business for a future volume, some of the more important facts in regard to the mines and mills of Grass Valley, as they were in 1861,

GEOL. VกL. I. -37 
may be communicated from Mr. Ashburner's notes. The processes employed in these mills are different from those generally adopted in other parts of the State, amalgamating in the batteries not being in faror here. The richness of the veins in this vicinity, and their small size, rendering extraction expensive, have, more than elsewhere in the Gold Region, made it necessary for the proprietors of the mines and mills to use every possible means to improve their machinery, so as to save the largest possible amount of the precious metal at the least expense. Almost every new-fangled idea, in the way of crushers and amalgamators, has been, at one time or another, thoroughly tried here, and in most cases with more loss than gain. There seems to be a mania among inventors in this country for trying their skill on matters of which they know little or nothing, and in no department of the mechanical art has this been more conspicuous than in that which relates to the treatment of auriferous quartz. It would require volumes to describe all the ingenious but perfectly useless contrivances, each of which has, in its day, been considered as about to revolutionize the quartz business; these have nearly all either entirely disappeared, where there was luckily a foundry near enough to make the metal of which they were constructed available as old iron, or else lie as heaps of rubbish about the premises of the too confiding miners.

There will be hardly any way in which the Survey can be of more immediate pecuniary benefit to the State, than in making a thorough investigation of the principles which underlie the business of crushing and amalgamating gold ores, and thus settling some of the questions which are always coming up among the owners of mills and mines, as to what forms of machinery will be best adapted to working the class of ores with which they have to deal; if important improvements cannot be suggested, at least, a great saving may be effected by furnishing a basis of facts as a guide to inventors into the right direction for the employment of their talents. These matters do not properly come up for discussion in the geological volumes, nor have our means been sufficient to enable us to do more than make a beginning in this line of research. A few facts may, however, be stated in this connection in regard to the development of the Grass Valley mines and mills.

It may be premised, however, that the quartz lodes in this vicinity 
are not large; but that they more than make up for their slight development in width by their increased richness. They are irregular in their yield, as is evident, not only from the examination of the mines themselves, but from a consideration of their past history. The proverbial uncertainties of mining would be well illustrated by an exact history of all that has transpired in this region since the first quartz mill was erected. Fortunes have been lost by working mines which seemed to exhibit every indication of yielding large returns; and fortunes have been made by the purchase, at nominal sums, of lodes which had been abandoned as worked out or worthless. An idea of some of the peculiar characters of these veins may be gathered from what here follows: but of their relative position and mutual comnection it will not be possible to give any intelligible account, until a map of this district, on a large scale, shall have been prepared, and the results of a careful survey of the lodes laid down upon it.

The Allison Ranch Mine is perhaps as well known as any in California, and has the reputation of being fabulously rich. As no authorized statements of its yield have ever been published, and as it is known to have produced large sums, it is very. natural that the most exaggerated ideas should have been formed as to its importance. The direction of the lode is from $5^{\circ}$ to $15^{\circ}$ to the west of north, and it dips to the west at an angle of $40^{\circ}$ to $45^{\circ}$. Its average thickness is said to be about eighteen inches; when examined by us, in 1861, it was about twelve inches wide in the workings at the bottom of the shaft, which was then 214 feet deep on the incline. In 1863, this shaft had been sunk to the depth of 360 feet. The ground had been opened on, in 1861, to a distance of 500 feet north, and 400 feet south, of the shaft. The veinstone is almost exclusively quartz, with but a very small amount of the sulphuret of iron. The lode is regular and well-defined, having a distinct selvage of flucan on the hanging-wall, while the foot-wall is less distinctly separated from the "country," or inclosing rock. The yield of the quartz has been very variable, but is not known with aceuracy; it is believed by $\mathrm{Mr}$. Ashburner to have averaged about $\$ 50$ a ton on 14,858 tons stamped between March, 1857, and December, 1861; the lowest yield was estimated at $\$ 32$ and the highest at $\$ 144$ a ton. The rock near the surface, however, is known, from the returns of the cus- 
tom mill where it was worked, to have paid as much as $\$ 375$ per ton. The total amount of bullion deposited by the proprietors at the United States Mint, from March 25, 1857, to December 2, 1861, was 47,898.80 ounces, which is equal to $\$ 838,229$; estimating its value at $\$ 17.50$ per ounce. The mill has eight stamps, driven by steam, and the arrangements for saving the gold are similar to those of other mills in the vicinity. The sulphurets are saved and ground in large pans. A rich spot, or "bonanza," was struck in 1863, and the quartz was then said to be paying $\$ 150$ a ton; previous to that, for some time, the mine had hardly paid expenses.

Massachusetts IIill is one of the most interesting localities in California, and the mine of that name has had more than its share of ups and downs; but, of later years, has been exceedingly productive. The vein has a very flat dip, and seems to form a kind of basin, being quite different in this respect from any of the lodes seen in other districts of the State. Its maximum thickness appeared to be about two feet and a half, and where best developed, it was divided into three distinct floors or bands; with several inches of rock between each. It would be interesting to make a most thorough study of this lode, as it presents peculiarities, the exact knowledge of which could hardly fail to throw some light on the origin of quartz veins in general. The mill has sixteen stamps, working on the average 850 tons of quartz per month (in 1861). The proportion of pyrites in the Massachusetts Hill vein is large, averaging, it is said, as much as five or six per cent. The average yield of the quartz was stated at $\$ 70$ a ton, and the amount paid for the treatment at the mill was $\$ 5$, the mine and the mill not belonging (in 1861) to the same parties.

The Pacific Quartz Mining Company was at work, in 1863, on a vein east of Wolf Creek; and within the town of Grass Valley; it has a northeast and southwest strike, and dips to the east at an angle of $39^{\circ}$. This vein varies much in thickness, but averages about eighteen inches. The mine had been opened, in 1863, to the depth of 215 feet, and levels driven each way fifty and eighty feet. The rock was estimated to pay $\$ 40$ a ton.

The North Star Mining Company is located about two miles southwest of Grass Valley. The vein is, like all others in this region, of 
variable width, sometimes thimning down to a mere seam, and again widlening to six feet. The quartz was said to pay from \$15 to \$20 per ton, and, in 1863, the mine had been opened to a depth of 400 feet on the incline, and a length of 325 feet. The mill has nine stamps and is driven by steam.

There are several other mines in this vicinity which it is not worth while to describe in this place, and a number of mills which run on custom-work, among which the old Gold Hill Mill is one of the most venerable, having been built in 1853 .

There are also important mines and mills near Nevada City, and between there and Grass Valley, of which one or two will be noticed.

The mill of the Nevada Quartz Mining Company is on the right bank of Deer Creek, about one mile below the city of Nevada. The vein from which it is supplied is in the granite, and is situated on a steep hill-side directly above the mill; it runs northwest and southeast, and dips to the northeast at an angle of $45^{\circ}$. Its average width is about twelve feet, and it contains a considerable amount of pyrites and some galena. The mill has twelve stamps, driven by water-power. The average yield of the quartz for the two years $1862-3$, was about $\$ 15$ per ton, the net profits for the year ending March, 1863, being a little over $\$ 67,000$.

Sneath, Clay \& Co.'s mill, three-fourths of a mile southeast of Nevada City, was built in 1863, and was considered by many to be, at that time, the best arranged and most thoroughly built quartz-mill in California. It has twelve stamps, and is run by steam-power. The vein is near the mill, and has a dip of $30^{\circ}$, and a width of from eighteen inches to two feet. It yielded very finely, near the surface; but we have no data as to its present condition and prospects.

As the proprietors of this mill were generally considered to have adopted the most approved processes for saving the gold, it may be worth while to give a concise description of its machinery, as communicated to us by Mr. H. H. Sheldon.

The stamps are constructed on the revolving principle, and are arranged in three batteries, of four heads to each. Each stamp-head with its iron lifter weighs 900 pounds, and strikes sixty blows per minute, the mill being able to crush twenty-four tons of quartz in twenty-four 
hours. In front of each battery are placed two runs of blanket sluices, and at the end of the blankets is a labyrinth, of which the bottom is covered with copper plates. The washings of the blankets are caught in large wooden vats, and from thence passed through an "Attwood's amalgamator," and, after leaving that, through four Chilian mills. The muddy water that flows from the labyrinth is received into the same trough with that from the Chilian mills, and the whole is conducted to vats where the slimes have an opportunity to subside, and the water flows off. The material deposited in the vats is carried by at revolving screw to five Norton's pans, and what escapes from these goes on to four Bradford's vanning tables, by which the sulphurets are completely separated from the earthy particles, which are then allowed to run to waste. The sulphurets in the Grass Valley mines are usually sold, and treated by Plattner's chlorine process. If not rich enough to pay for working by that method, they are allowed to lie and become oxidized, when they are passed through the pans again.

There have been many discoveries of copper ores in Nevada County within the last two or three years, and mining has been commenced at several points, where there seemed to be very promising indications, and only capital and skill lacking to develop something of importance.

The district to which the most attention has been attracted is that near the "Zinc House," in the southwestern part of the county, where quite a number of mines were worked in 1863. The first discovery seems to have been in 1857, at what is now called the "Well Lode," by Mr. D. S. Tallman. Here is an immense body of pyrites, of a lenticular shape, having its longer axis in the direction of the metamorphic slates in which it is inclosed. When examined, in 1863, the width of the mass had not been ascertained, but a drift had been extended for a distance of forty-eight feet across the deposit, all the way in the solid sulphurets, and the western limit had not been reached. To the east, there was a well-marked wall, with a selvage of flucan between it and the country, five inches thick. The cupriferous portion of this mass seemed to be on its borders; the interior was almost barren of copper. There had been shipped, up to that time, 250 tons of ore, returns from sixty of which had been received, and the yield of copper was stated at nine and a half per ceut. 
The Eureka Consolidated Mining Company had, in 1863, a claim 5000 feet in length, in the Empire District, about two and a half miles north of the Zine House. The vein had a course of $\mathrm{N} .17^{\circ} \mathrm{W}$., and dipped to the east at a very high angle. At the depth of forty-six feet, the lode was four feet thick and well filled with bunches and strings of copper pyrites, giving the impression of a large and valuable deposit.

The Last Chance was another company, with a promising vein, supposed to be the continuation of the Eureka. It had been sunk on to the depth of sixty-one fect in October, 1863, and a considerable amount of good ore had been taken out. There were many other claims in this vicinity, where mining was going on two years ago, and which would have been considered, in the Atlantic States, as offering excellent inducements for the investment of capital. It remains to be seen how far the high rate of wages in California and the scarcity of fuel and water about these mines will operate to check their development.

Nevada County is not only celebrated for its rich quartz-mines, but it has some of the most extensive hydraulic washings of the State within its borders, being second only to Sierra County in this respect. Unluckily, there is no one of the mining counties of the State of which the published maps are so defective, so that any attempt to lay down the area occupied by the auriferous detritus in this region would be at present entirely futile, and it is quite impossible to estimate the amount of ground worked out, or that which still remains to be washed, when the positions of the places where the washings are carried on cannot be fixed within miles. Should the Survey be continued, this will be the region of our topographical labors during the next season, and, in time, we may hope to be able to give, what all would admit to be of the greatest interest, a connected view of the hydraulic washings, in regard to which the wildest and most absurd views have been put forth by those who have only had an opportunity of making a superficial examination of them.

Whether the "Blue Lead," or the great ancient river-bed of Sierra County, so well known throughout California, passes through Nevada also, it is not in our power to state. It undoubtedly enter's this county at Snow Point, and whether it continues its southerly course across it, connecting with the extensive detrital deposits near Red Dog, and then 
is continued across Placer County, finally running out at Todd's Valley, remains to be demonstrated. Judging from our present knowledge, such a course of this great river of the Pliocene Tertiary epoch seems not improbable. If this hypothesis be correct, then the lake-like expansions of the former river, like that near Red Dog, may have been caused by the coming down of side streams from the east, in the direction of the summit of the Sierra. But it is in vain to attempt to reconstruct the ancient topography of a country, of the present surface of which we have only the roughest outlines.

The hydraulic washings at Chalk Bluffs, near Red Dog, are especially interesting on account of the immense number of large trunks of trees which have been buried there, and which have been uncovered by the miner's work. There are also beds of fine sediments here, inclosing many impressions of leaves, of which a large collection has been made for future examination. The remains of animals seem to be much less abundant in the northern counties than they are farther south; but this is the only locality where we have seen the evidences of the overwhelming of a whole forest by the rush of the waters from the Sierra. The stems and branches are all silicified, and bear the marks of having been exposed to violent currents before they were imbedded in the detritus which now covers them.

The auriferous gravel underlying the volcanic formations has been extensively washed in the vicinity of Nevada City, and also, but on a smaller scale, near Grass Valley. The mines, at the first-mentioned place, are around the base of the Sugar Loaf, a conical knob at the end of a ridge of lava, which covers a mass of sedimentary-volcanic materials with deposits of gravel at the bottom. The Sugar Loaf itself is 603 feet above the level of Deer Creek, at Nevada City, and the upper hundred feet is a solid mass of lava. The bed-rock of the region is granite, which weathers in huge, rounded masses, like boulders, and shows this kind of surface wherever the superincumbent detritus has been washed off. The excavations around the base of the ridge expose a mass of strata from 70 to 100 feet high; of this, twenty feet at the bottom are chiefly made up of quartzose sand and pebbles, constituting the pay-gravel. Above this is an irregular bed of lignite, containing half carbonized trunks of trees, with much pyrites about them, showing 
the reducing power of the organic matter in its decay. Over this, again, is a heavy mass of fine gravels and sands, the latter occasionally consolidated into sandstone, the whole crowned with the usual beds of pumice and ash, with the solid lava at the summit. This range of washings extends for some distance to the east, and is still worked to some extent; but apparently not now so energetically as in former years.

The most important hydraulic washings in the county, at the present time, are those extending along its northwestern side, close by and parallel with the course of the Middle Yuba. There is a continuous line of claims from North San Juan to French Corral, a distance of about eight miles. As far as known at present, we are inclined to connect this deposit of gravel with the chain of detrital accumulations coming down, from the vicinity of Pilot Peak, through Sierra County, and occupying a line parallel with that of the "Blue Lead." But this remains to be demonstrated by a careful survey and map. All along the Middle Yuba, from San Juan west, the auriferous detritus occupies a belt somewhat less than 1000 feet wide, ås near as could be ascertained, the bottom of which lies at an elevation of about 1000 feet above the river at its east end, falling, however, very rapidly as it is followed down the valley. It seems evident that the present river cañon has been entirely excavated since the detritus was deposited. The materials of which this is composed are almost exclusively pebbles and boulders of granite and every variety of metamorphic rock found in the Sierra, together with many of quartz. There are occasional beds of finer gravels and sands, rudely stratified; but the general aspect of the mass is that of a body of detritus heaped together under the influence of violent and rapidly shifting currents. Near the surface the oxidation of the iron has given the gravel the usual brownish-yellow color imparted by decomposing ferruginous substances. Lower down, the mass has often a bluish color, and is firmly cemented together by pyrites, which consolidation has evidently been effected, since the deposition of the gravel, by the reducing agency of the organic matter buried in the deposit. This organic matter, through the region in question, seems to be exclusively of vegetable origin, as the remains of trees are found everywhere, while we examined and inquired in vain AROL. VOT. I. - 38 
for thiose of animals. The much greater frequency of the remains of animal life in the central mining districts of the State may be due to climatic causes; the conditions appear to have been unfavorable for the spreading of the mastodon and the elephant through this more northerly region.

All considerations and facts connected with the yield of the hydraulic washings and the cost of the process, as well as the description of the elaborate and costly system of "ditches," or canals, by which the water is supplied in sufficient quantity for these very extensive operations, must be deferred to another volume. Before anything satisfactory can be published, it will be necessary to make a careful instrumental survey of the ground, so as to determine approximately how many cubic yards have been removed at the localities which are to be described, this being the fundamental element in the calculation, and one in regard to which, so far as our experience goes, no reliable information can be obtained from the miners themselves.

\section{Section X.-Sierra Countr.}

Sierra County is an exceedingly rough and mountainous district, high up in the mountains and furrowed by immense cañons. It is of a very irregular shape, and small in size compared with many of the other counties in the State. Its southern boundary is the Middle Yuba, and its northern one follows the very irregularly curving watershed between the tributaries of the North Yuba and the Feather. The extreme eastern portion of the county, or that which lies beyond the crest of the Sierra, is drained by a branch of the Truckee. The North Fuba runs through its centre, and has several considerable tributaries coning in from the north, all running through very deep and narrow cañons, The western or principal mining portion of the county covers an area of about twenty-five miles square.

Sierra County has hardly been explored at all by the Survey. We have passed hastily over the western and southern portions of it, and Mr. Ashburner examined, in 1861, the principal quartz-mines then opened. Since that time the county has been highly prosperous; her 
quartz-mines have much increased in number, and some of them have been highly productive. The hydraulic washings are also of great extent, and there is still remaining a large amount of auriferous detritus to be worked over by this method. The county has suffered by its remoteness from the centre of the State and the source of supplies; but the improvements constantly making, especially the railroad to Marysville and Oroville, are gradually bringing. about a considerable change in this respect.

The western part of the county is chiefly occupied by the auriferous slates, where these have not been covered by the recent volcanic accumulations. These slates were seen near Camptonville, where they have the usual northwest strike and northeasterly dip. They are very soft and readily undergo decomposition. A dyke of granite, from ten to thirty feet wide, cuts through them at this place, and both it and the slates have been much softened and changed by chemical agencies; but this appears to have been effected since the deposition of the gravels and volcanic materials upon them, and not to be the result of the intrusion of the granitic mass.

The slates are seen again in the deep cañon of the north fork of the Yuba, near the mouth of Cherokee Creek; and also at Brandy City, a few miles farther on in the same direction. The North Yuba, where the west line of the county cuts it, is 2166 feet above the sea, and this is probably the lowest spot within the county, unless it be the bed of the Middle Yuba, for a small portion of its course along the south boundary. The rapid rise of the country and the generally great elevation of Sierra County may be inferred from the fact that Brandy City is 3592 feet and Eureka 5223 feet above the sea-level. All along this high plateau the surface is covered with lava; but the cañons which are cut in it everywhere reveal the presence of the underlying slates.

From Eureka to Poker Flat, a distance of nine miles, the road skirts along high volcanic "Buttes," which cap the slates. Some of these elevations are very sharp; but there is one which is a lofty table, probably over 6500 feet high, and very conspicuous through that region; it appears to be a bed of hard basaltic lava. This volcanic range lies along the crest of the Sierra, and the scenery in this part of the county is very grand. One peak was estimated at over 8000 feet in height, or 
500 feet higher than Pilot Peak. Most of the lava is basaltic; but there is a large amount of breccia, or volcanic conglomerate. At Deadwood, the trail followed by our party again descended on to the slates, and between them and Poker Flat large masses of serpentine were seen, together with talcose-slate. The last-mentioned place lies in the deep valley of Cañon Creek, which is one of the largest branches of the North Yuba. From here to Whiskey Diggings, close by the north line of the county, the slates predominate, with occasional masses of serpentine and talcose-slate. All through this region, however, the higher portions of the country are covered by lava: it is only in the valleys and cañons that the slates are seen. Where exposed, these rocks are found to have a strike more nearly approaching a north and south direction than is usual in the more southern portions of the mining region; but they are very much broken and twisted about. There are also many quartz-veins included in them, although none of these were worked at the time of our visit to this region.

There were, however, important quartz-mines above Downieville, and near the "Buttes," as they are called,* which were examined, in 1861, by Mr. Ashburner, from whose notes the following notice of them is condensed.

The mines in question are situated about fourteen miles above Downieville, and high up on the side of the Buttes, within 1500 feet of their summit, and at an estimated elevation of 7000 feet above the sea-level. In 1861 there was only a trail above Downieville, which was then much frequented by travellers to Washoe, and which has since been made into a road. To reach the mine and mill, it was necessary to leave this trail at the base of the mountain and climb up its sides to an elevation of some 2000 feet above the river. Here the outcrop of an immense vein is seen, which can be traced for a great distance, cutting across ravines and gulches.

On this vein, and working the quartz obtained from it, is situated the mill of the "Sierra Buttes Quartz Mining Company," as also that of the "Independence Company." The vein bears nearly east and

* These are sometimes designated as the Sierra Buttes, but, more frequently, the Downieville Buttes. 
west, and dips to the north, at an angle of $42^{\circ}$. It is inclosed in a hard metamorphic rock, and varies from six to thirty feet in width. Only the richer portions of the quartz are passed through the stamps, and this is obtained from near the foot-wall of the lode; this more productive streak varies in width from two to seventeen feet, and the average thickness of the portion worked out is twelve feet.

The mills of the Sierra Buttes Company are two in number, each having twelve stamps; they are worked by water-power, the water being obtained from the numerous springs which issue from the mountains. One of them was built in 1853 and the other in 1856; but quartz was worked here as early as 1851 by means of arrastras. These mills crushed, at the time of Mr. Ashburner's visit, an average of 900 tons of quartz per month, at a cost per ton of $\$ 1.35$; the yield was, on the average of the two years $1860-1, \$ 14.82$ per ton, making $\$ 20,000$ for each run of six weeks between the cleanings. The cost of extracting the quartz and delivering it at the mill being reckoned at $\$ 5.87$ per ton, it will not be difficult to perceive that this mine is one of the most valuable pieces of property in the State, especially as the moderate percentage of gold in the quartz indicates a permanently productive mine.

The Independence Mine is on the same vein as the one just described. The portion of the lode which is worked is from three to nine feet in thickness. The average yield of the quartz was, in 1861, $\$ 15$ a ton, and the expense of extraction $\$ 5$; that of treating the quartz at the mill was $\$ 2.89$. The mill had twelve stamps; but another of the same size was erecting at that time.

- Mr. Ashburner, in his notes, under date of 1861, speaks very highly of Sierra County as a quartz-mining region, and it would appear that events have proved the justice of his remarks. Quite a number of important lodes have been opened in that region and have been successfully worked, as is reported on good authority; but we have no details of their location or of the capacity of the mills which have been erected.

Few counties in the State are so thoroughly covered by beds of volcanic origin as is Sierra. The whole region west of the crest of the mountains seems to be everywhere overlain by these deposits, excepting in and near the river valleys and cañons, which, as before remarked, 
are cut down to an immense depth in the underlying slates. The volcanic formations seem, wherever examined, to cover vast accumulations of auriferous detritus, which are extensively worked at a great number of points. It must not be inferred, however, that these beds of gravel are scattered uniformly over the surface, or deposited in one great sheet, as would be the case if they had been formed along an ocean shore, or had assumed their present position under the influence of marine currents. On the contrary, nothing can be clearer than that these accumulations of detritus have been formed by torrents of fresh water tearing down the sides of the mountains, and sometimes giving rise to extensive rivers, of which the former courses may now be traced across cañons thousands of feet deep; while in other cases the torrential flows have been of limited extent, and have not borne the detritus with which they were charged to any great extent from its source.

We could, at the present time, give some idea of the physical conditions which must have prevailed in the Sierra, at the time these remarkable phenomena were exhibiting themselves; but there are many points on which more light must be thrown by a minute examination of the region, and what we especially need is a map of the Gold Region, with sections across the formations from actual surveys, without which it will be impossible to give any intelligible view of the geological order of events, and of the gigantic scale on which causes, not very different in their nature from those now operating in the Sierra, were, in former times, moulding the country into its present condition, and storing away those vast deposits of auriferous material which can be drawn upon for so long a time without fear of their being exhausted.

The famous "Blue Lead" of Sierra County, although only examined by us at one or two points, so that we are unable to give any connected description of it from our own knowledge, should not be omitted in this imperfect sketch of the geology of this part of the State. It has been well described by Mr. C. S. Capp in the "Evening Bulletin" of San Francisco,* and the facts will there be found clearly set forth which have long since led the intelligent miners of California to a clear under-

* Quoted in Hittell's "Handbook of Mining for the Pacific States ;" see page 72. 
standing of the origin of this, as well as of the many other ancient river channels in the mining region.

The course of this channel of detritus, as appears from a sketch kindly furnished the Survey by Mr. George Black, of San Francisco, who has superintended the construction of some of the most important ditches in this region, was nearly north and south, and it has been distinctly traced from Sebastopol, in the northern part of Sierra, quite across into Nevada County, to Snow Point, on the south side of the Middle Yuba, a distance of between twenty and twenty-five miles. The principal points where it is worked, between these two places, are Monte Cristo, City of Six, Rock Creek, Forest City, Wet Ravine, Smith's Flat, Chip's Flat, and Minnesota. The phenomena of the "Blue Lead" do not differ materially from those exhibited by the auriferous deposits under the Table Mountain of Tuolumne County, which have already been noticed. All the most striking facts of the one are repeated in the other; but the course of the ancient river of Tuolumne was nearly coincident with that of the present ones, so that it has only been cut through in one place by a very deep cañon, while the "Blue Lead" ran nearly at right-angles to the river's now existing in Sierra County, and consequently its continuity has been repeatedly broken. Moreover, while the valley of Table Mountain River is clearly seen to have been filled up with one flow of lava from the High Sierra, so numerous and complicated were the volcanic phenomena in the northern portion of the Sierra, that it would not be easy to say, without a careful examination of the region, that the obliteration of the "Blue Lead" may not have been the result of several successive eruptions, or even a long-continued series of volcanic outbreaks.

From what has been seen of the geology of the region east of the crest of the Sierra, the predominance of volcanic formations in that region is inferred. Large deposits of a sedimentary material of freshwater origin and a later Tertiary age are believed to occur in some of the valleys, and these have been often reported in the newspapers as containing beds of coal. This may very possibly be the case, although it is not likely that they will be found to be very extensive. Of the many seams of lignite and half-formed coal which have been noticed 
by us in these fresh-water Tertiary beds, on the east slope of the Sierra, none have yet been observed of any considerable magnitude.

\section{Section XI.-Plumas County.}

The few observations which our time and means have allowed us to make in the counties of Yuba and Butte have already been given in Chapter VIII, and we pass on, therefore, to the next county north of Sierra, namely, Plumas.

This county is very much larger than those to the south along the auriferous belt; it is fully fifty miles across it from north to south, and about seventy-five in the opposite direction. It comprises the whole region drained by the Upper Feather River and its affluents. This river has two principal forks, the north and middle; the south fork being of very insignificant size compared with the others. The middle fork rises on the east side of the crest of the Sierra, and has cut its way through it, flowing down one of the deepest and grandest cañons in the State. Its course is in a series of zigzags, alternately flowing in directions parallel with, and at right-angles to, the trend of the mountain ranges which make up the great chain of the Sierra in this region. The main branch of the north fork of the Feather rises on the south slope of Lassen's Peak, and its chief tributary, Spanish Creek, heads on the southwest side of a lofty range of mountains which lies parallel with the main ridge of the Sierra, and extends along the west side of Honey Lake Valley. This lake is an independent basin, like so many others on that side of the Sierra, and it receives two principal streams, one coming in from the south and heading near Beckworth's Pass; the other from the north and having its source in the vicinity of Noble's Pass.

The above-named two passes are the principal ones crossing the mountains and leading to the eastern side of Plumas County, and much discussion has been carried on, in the newspapers, as to their comparative feasibility for railroad purposes, it having been claimed by the residents in this part of the State that the route following up the cañon of the Middle Feather, and crossing by Beckworth's Pass, was 
lower than any other north of Walker's Pass, and that it presented great advantages on account of the small body of snow which lies here during the winter. For an account of the exploration of the region around Noble's Pass, and the northern portion of Plumas County in general, reference may be made to Lieutenant Beckwith's examinations, in Volume II of the Pacitic Railroad Reports. It does not appear that the Beckworth route has ever been instrumentally explored, and we are unable to state the height of the pass; that of Beckworth's house, at the junction of the branch of that name with the main stream is given by Goddard at 4570 feet. The altitude of Noble's Pass is given by Lieutenant Beckwith at 6074 feet.

The main crest of the Sicrra, or that on which the highest peaks are situated, is near the western side of the county, the most prominent elevations being Pilot Peak, Spanish Peak, and Lassen's Peak, which latter is the most northwestern point of Plumas, and is where that county corners with Tehama and Shasta.

The valleys between the mountain ranges, in the western part of the State, are very narrow, and occupy but an insignificant proportion of the surface, as compared with the mighty masses of the mountains themselves. Honey Lake Valley, however, comprises quite an extensive area, being about sixty miles long from east to west, and from fifteen to twenty miles across in the opposite direction. According to Mr. J. F. Kidder, engineer in charge of the Boundary Survey from Lake Bigler north, this valley, from the head of the lake eastward, is dry and barren and destitute of vegetation, excepting sage-brush and grease-wood. But, near the Sierra, on the west and southwest of the lake, and also on Susan River, which empties into it from the north, are excellent farming lands, under cultivation, while the mountains around are well supplied with good timber. Considerable business is done here in raising supplies and sawing lumber for the mines in the adjoining State of Nevada.

Some explorations were made in Plumas County, in 1861, by Mr. Ashburner, and Messrs. Brewer and King passed through the central and northwestern portion of it in 1863, while engaged in a reconnaissance of the northern part of the State; from their notes most of what follows in regard to the geology of the eounty is taken. 
The party entered Plumas from the south, passing over the trail from Poker Flat, in Sierra County, to Quincy, the county-seat. All through the region between Poker Flat and Whiskey Diggings the rocks exposed in the cañons are slates, with some heavy masses of serpentine included among them; all the higher parts of the country are covered with immense accumulations of lava.

Pilot Peak, which is near the southern line of the county, is an isolated, volcanic knob of hard, ash-gray, crystalline basaltic rock, which is most beautifully columnar on its northern slope. The view from the summit is peculiarly fine, Lassen's Peak being visible in the northwest, and the Coast Ranges in the southwest. Fifteen or twenty miles to the northeast, mountains are seen which are of about the same height as Pilot Peak, and very deeply eroded on all sides; indeed, the whole region to the east and northeast is furrowed by tremendous cañons, many of them being over 2000 feet deep. In the southeast the Downieville Buttes were seen, with a very rugged outline. The most elevated points in the range lie to the east of the line connecting Pilot Peak and the Downieville Buttes; the highest of these is perhaps 500 feet higher than Pilot Peak itself; Table Mountain, already mentioned, lies to the west, and is nearly as high. The whole region to the south of the summit is extremely rough, and its sky outline very serrated. On the peak, the magnetic needle is very irregular, and was observed to be directed towards nearly every point within the space of a few square rods. The elevation of Pilot Peak above the sea is 7605 feet, and of this the upper portion is exclusively volcanic; the lava forming a mass about 650 feet thick, as estimated from observations taken at Onion Valley, 1216 feet below the summit of the peak.

The auriferous slates are very finely exposed on the north side of the mountain, having a north and south strike, and a dip to the east of about $80^{\circ}$; they are cut squarely off at the top and covered with lava. The strike of the slates, however, is not uniform in this region. One mile northeast of Onion Valley, large masses were observed with a trend of $\mathrm{N} .35^{\circ} \mathrm{W}$., and a southwesterly dip; and again, on descending into the cañon of the Middle Yuba, they were seen running N. $15^{\circ} \mathrm{W}$., and from that to $\mathrm{N} .35^{\circ} \mathrm{W}$., and standing nearly vertical. Great masses of serpentine oecur along the trail between Pilot Peak and Onion 
Valley, and between this and Nelson's Point a variety of magnesian rocks were noticed.

The cañon of the Middle Yuba is exceedingly deep, the difference of level between the river at Nelson's Point and the summit of Pilot Peak being fully 3650 feet. From the bottom of the cañon to the top of the slates, the vertical height is not less than 3000 feet, all of which has been removed, by the agency of water, since the time of the eruption of the overlying volcanic materials. Nowhere in the Sierras do we find more stupendous examples of denudation than occur in the region north and northeast of Pilot Peak, in the cañons of the Middle Yuba and its branches. At Nelson's Point, the slates stand nearly vertical, and crop out in grand masses along the sides of the cañon. But on the steep slopes, on both sides, the surface strata often curve, as if bent by sliding down the hill, so as to give the impression of a dip to the east, when in fact they stand perfectly vertical below. The elevation of Nelson's Point above the sea is 3858 feet.

The basin, called the American Valley, in which the town of Quincy is situated, is about eleven miles long and from two to three wide; it has an elevation of 3500 feet above the sea. In the range of mountains which was crossed in going from Quincy to Elizabethtown, and which is about eight miles wide, slates and sandstones were observed, sometimes but little metamorphosed. They had the usual northwest strike, but dipped towards the southwest. These slates are capped, at the summit of the range, by hard lava, which occupies only a narrow belt, the flanks of the mountain on the north side being of metamorphic rocks, similar to those seen on the south. Some granitic masses occur in this region. A bold and elevated ridge of this rock was seen a few miles west of Quincy, and again, about two miles before reaching Elizabcthtown, where it occupies a belt about a mile in width. The slates, however, are the predominating formation. This part of the county is principally occupied by the metamorphic rocks over an area of about thirty miles in diameter; but this is almost entirely surrounded by volcanic materials, the great lava streams which have come down from Lassen's Peak on the north, and Pilot Peak on the south, uniting with the volcanic crest of the Sierra, so as to cover the slates around threequarters of the circumference of the circle. 
From Indian Valley the route followed led up to Genesee Valley, following Genesee Creek, a branch of Spanish Creek. This stream runs nearly west, through a cañon, which a few miles higher up opens out into a valley about four miles long and three-fourths of a mile broad; the upper part of this is occupied by granitic rocks, the lower by slates. In the cañon, about a mile and a half from its mouth, Messirs. Brewer and King discovered a locality of fossils, where a considerable number of specimens of various genera and species were obtained. They were found principally on the spurs of rock coming down from the north and in the cañons between them. The rock is a metamorphic sandstone, rather fine-grained, and portions of it are of a deep-red color, resembling in appearance much of the Old Red, or Devonian sandstone in England and on the Continent. In places it is so much changed that the fossils have become nearly or even quite obliterated; but a number of species were obtained in a sufficiently good state of preservation to be determined. The specimens collected here were referred to Mr. Meek for examination, and were considered by him to be almost certainly of Jurassic age; they have been described by him in Section III of the first volume of the Palæontology of this Report, and are figured in plates 7 and 8 of that volume.* The strata in which the fossils were found have a trend varying from east and west to northeast and southwest, and they dip to the south at all angles between $30^{\circ}$ and $80^{\circ}$. This locality is about four miles below Gifford's Ranch, and near a small grassy flat into which the cañon opens, and which is called Mormon Station.

Above this the valley contracts again into a narrow cañon; but two miles farther up it opens into another and larger basin, called Genesee Valley. Along the ravine, the rocks are highly metamorphosed, and their stratification is much disturbed. It is in this valley that Gifford's Ranch is situated, and near it is the junction of the granitic and metamorphic rocks. Near the line of contact of the two formations, is a belt of limestone which is highly crystalline, but contains a few obscure fossils, apparently the fragments of stems of crinoids, and which are

* For some notes by Mr. Meek on the relations and affinities of the fossils found at this locality, see the Appendix to this volume. 
probably of Carboniferous age, although this question could not be definitely settled.

At one locality between the main belt of limestone and the granite, where there is a curve in the strata, there is a limited patch of calcareous slates containing quite a number of fossils, some of them in very good preservation. These fossils belong to the Triassic series, and prove clearly the existence at this point of the same formation which is so well developed in the Humboldt mining region in Nevada, and also at Washoe, and which, as we have abundant evidence to prove, extends over a vast area on the Pacific coast. Among the species recognized by Mr. Gabb as occurring here, are Ammonites Ramsaueri?, Avicula mucronata, Halobia dubia, Monotis subcircularis, Myophoria alta?, and Pecten deformis.*

We have strong reasons for believing that a large portion of the auriferous slates belong to the same formation with these of Genesee Valley, which are themselves worked for gold, there being placers all along the range on the south side of the creek quite up to the locality in question.

The stratification is so broken in this region, and the rock so much disturbed and metamorphosed, that it would require a much longer time than our party were able to give to it, before the relative position of the different bodies of strata could be made out; the district, however, demands a most thorough examination.

Some localities of rich copper ores have been discovered about Genesee Valley, and very fine specimens of vitreous copper, containing $\$ 200$ of silver to the ton, were obtained from a mine in that neighborhood, the exact position of which we are unable to give. Our party visited two localities where mining was going on. One was the Cosmopolitan Mine, three-fourths of a mile from Gifford's Ranch. The vein at this place lies between the limestone and the granite, having a direction of about N. $25^{\circ} \mathrm{W}$. The width of the lode, as exposed in a shaft a few fect deep, was about twelve feet. The ore is a mixture of copper pyrites and iron pyrites.

\footnotetext{
* For descriptions of these fossils, see Section II of Palwontology of California, Vol. I ; they are figured on plates 3 to 6 .
} 
It is evident that, for the present, copper-mining labors under great disadvantages in this region, from its remoteness, and the consequent cost of getting supplies and of conveying the ore or metal to a market.

From Genesee Valley, our party returned to Indian Valley, and thence made their way in a westerly direction to the Big Meadows, in order to explore the vicinity of Lassen's Peak,* and to seek out a route to its summit. Indian Valley is from ten to twelve miles long and is a fertile and pleasant spot, although its elevation is considerable. It is quite surrounded by high mountains, those on the east having an elevation of about 6000 feet. In passing down the valley, the slates which are seen on the east side were observed to contain more jasper than is usual in the Sierra.

Between Indian Valley and the Big Meadows, the edge of the great volcanic region is struck; from here the mass of lava extends almost uninterruptedly to the Oregon line and far beyond. The Big Meadows are on the north fork of the Feather River, and form a delightful valley about fifteen miles long and from two to three wide; it is quite surrounded by volcanic tables and ridges, those on the east side having an elevation of about 500 feet above the valley, which is itself 4564 feet above the sea. This elevation was taken at the lower end of the valley, near Bidwell's store, and where the Chico road crosses.

All the pebbles seen about here were of volcanic rock; but the metamorphic slates are reported to occur at Mountain Meadows, which is a basin similar to the Big Meadows, and about fifteen miles farther to the northeast. The soil of this valley is rather sandy, especially towards its upper end, and the elevation is too great for any other agricultural occupation than that of pasturing cattle. The views of Lassen's Peak rising above the upper end of the Big Meadows, are peculiarly grand. The mountain does not show so distinct a conical shape

* This is the voleanie mass designated as Mount St. Joseph on the Paeifie Railroad Maps; but it is universally known, in California, as Lassen's Butte, or Peak; we prefer the English word, especially as the French one is not properly used, when applied to a higl mountain. A "butte," aeeording to the dietionary of the French Aeademy, is a "petite elevation de terre," or a "petit tertre ;" "knoll" would be the exaet translation of it. 
when seen from this direction, as it does from others; but its slopes are very steep, especially the eastern one.

From the head of the Big Meadows, Lassen's Peak is not over fifteen miles distant in a direct line; but by any practicable route it is fully twenty-five. Our party followed up the Red Bluff road to Loveless's Ranch, and then struck through the forests without a trail, ascending gradually over a volcanic table, the surface of which had some large rounded boulders of lava scattered over it; but which was, in general, covered by a deep soil of a dark-red color, formed from the decomposing basaltic rock, and supporting a heavy growth of timber, Pinus contorta being the most abundant tree. In this lava table the branches of the north fork of the Feather have cut many deep cañons.

A few miles southeast of the peak, there are several hot springs, and indications of the existence of others, from which cold water is now issuing. One of these is called "Steamboat Spring," and from this there is a copious flow of boiling water, while steam escapes from a great number of vents, scattered over an area of two or three acres. The lava has been very extensively decomposed by the action of the hot water, which dissolves out a portion of the silica, and leaves a mass of clay, either white or colored, according to the amount of iron in the rock. Portions, which are now quite soft, still retain perfectly the original structure of the mass. In one place, a large amount of steam issues in a pool of hot water, throwing it up in jets to the height of several feet, with considerable noise. Hunters say that they have seen the water raised as high as twenty-five feet, but at the time of the visit of our party the jets did not exceed eight fect in elevation.

Northwest of the locality just noticed, about two miles from it, and eight miles from the summit of the peak, in a direction N. $70^{\circ} \mathrm{E}$, magnetic, is the so-called "Boiling Lake." This is a pool of hot water, about 600 feet long and 300 wide; it lies in a depression between two streams of lava, the banks rising to the height of a hundred feet around it, except on the side of the mountain, where it has an outlet of a foot or two in width. The same decomposition of the lava has gone on around this lake which was noticed above as having taken place at the Steamboat Spring. The water is whitened with the clayey material, and, in some places, is thickened to the consistency of cream. Steam 
jets issue from this viscous material, and along the banks and around them the clay accumulates, so as to form tubes, or miniature mud-rolcanoes, from a few inches to four feet in height. At the upper end of the pool, clouds of steam and sulphurous gases rise from crevices in the lava, which is slowly slaking and wasting away under their influence, the rocks being covered with deliquescent salts, especially the sulphate of iron, which by its decomposition gives to the clays a variety of shades of red, pink, purple, and brown. The elevation of this place is 5976 feet above the sea.

About four miles northwest of the Boiling Lake are other hot springs, which are much more copious than at either of the localities already described, and where the decomposition of the rocks has taken place on a most extensive scale. These springs are scattered along a cañon for half a mile, and they are copious enough to form quite a stream, which, in its downward course, bears away the decomposed materials constantly falling into it from the sides of the adjacent clifts. Sulphur is sublimed from many of the cavities, forming the most delicate and beautiful crystallizations on the surrounding rocks. The same highlycolored clays and saline incrustations occur here which were described as existing at the other localities. In all of these hot springs the Panicum thermale and a low form of vegetation, supposed to be Nostoc, are found growing in and about the hotwater and in places exposed to the jets of steam, exactly as at the Geysers, which have been already described.

From the last-mentioned hot spring, the land rises rapidly towards the north, and a greater variety of rocks begins to be noticed. About four miles south of the summit, beds of volcanic material, having a decidedly slaty structure (rhyolite?) were observed. Ascending to a height of about 1000 feet above the hot springs, at about 7000 feet above the sea, the vegetation changed and assumed the peculiar character which it has in the High Sierra; Abies Williamsoni, Pinus Balfouriana, with here and there a Picea, were the principal trees in the neighborhood of the camp, which was established for several days, at an altitude of 7596 feet, while the party was engaged in examining the summit of the mountain.

From this camp (No. 149) two ascents of the peak were made by 
Messrs. Brewer and King; one September 26, 1863, the other on the night of the 29th. 'That on the first day was not satisfactory, as a dense cloud of dust and smoke hung over the Sacramento Valley, and obscured the neighboring mountains. At the time of the second ascent, the weather was perfectly clear, a light rain having fallen in the valleys, and snow on the mountain tops. The camp was left at 2 A.M., and the summit reached before sunrise. The view is described as one of unsurpassed grandeur, the field embraced within the scope of vision extending from Mount Hamilton on the south to Mount Pitt on the north, a distance of about 340 miles in a straight line. Along the line of the Sierra to the south, the whole chain could be distinctly seen, as far as Pyramid Peak. East and west the field was more contracted, extending from the Coast Ranges, west of the Sacramento River, to the mountains near Pyramid Lake.

There are four distinct summits to the peak, the highest of which is 10,577 feet above the sea. Three of these points are quite conspicuous; the other is less so. These rise to the height of from 250 to 350 feet above the depression or cavity, which was undoubtedly once the crater of the volcano, the rim of which has gradually been denuded so as to leave only these fragmentary evidences of its former existence. The western point shows, in a very marked manner, the action of steam and sulphurous gases upon it, as it is much whitened and decomposed, everything indicating a long-continued solfatara action within the crater, which has now entirely died away.

The upper portion of Lassen's Peak is an imperfect flattened cone, with an elliptical base, having its longer axis at right-angles to that of the Sierra, so that, when seen from the plain, it has the appearance of a very steep cone, while from the mountains north or south it looks broad and dome-shaped. The cone rises about 2000 feet above the wide, gently sloping plateau of gray lava at its base. It is principally made up of ashes and the debris of trachytic rocks, from which project four precipitous ridges of trachyte, radiating from the crater in various directions. The highest point of the crest is about a hundred feet above any other of the remains of the rim of the former crater, and although quite a sharp peak, it can be ascended to the very summit. An idea of the shape of the upper portion of the mountain, as seen GEOT. VOL, I.-41) 
from the southeast, may be oltained from the annexed wood-cut (Fig. 41), drawn from a sketch by Mr. King. The point of view was at a distance of about three miles from the summit, and about 2000 feet of vertical height is represented in the figure.

Fig. 41.

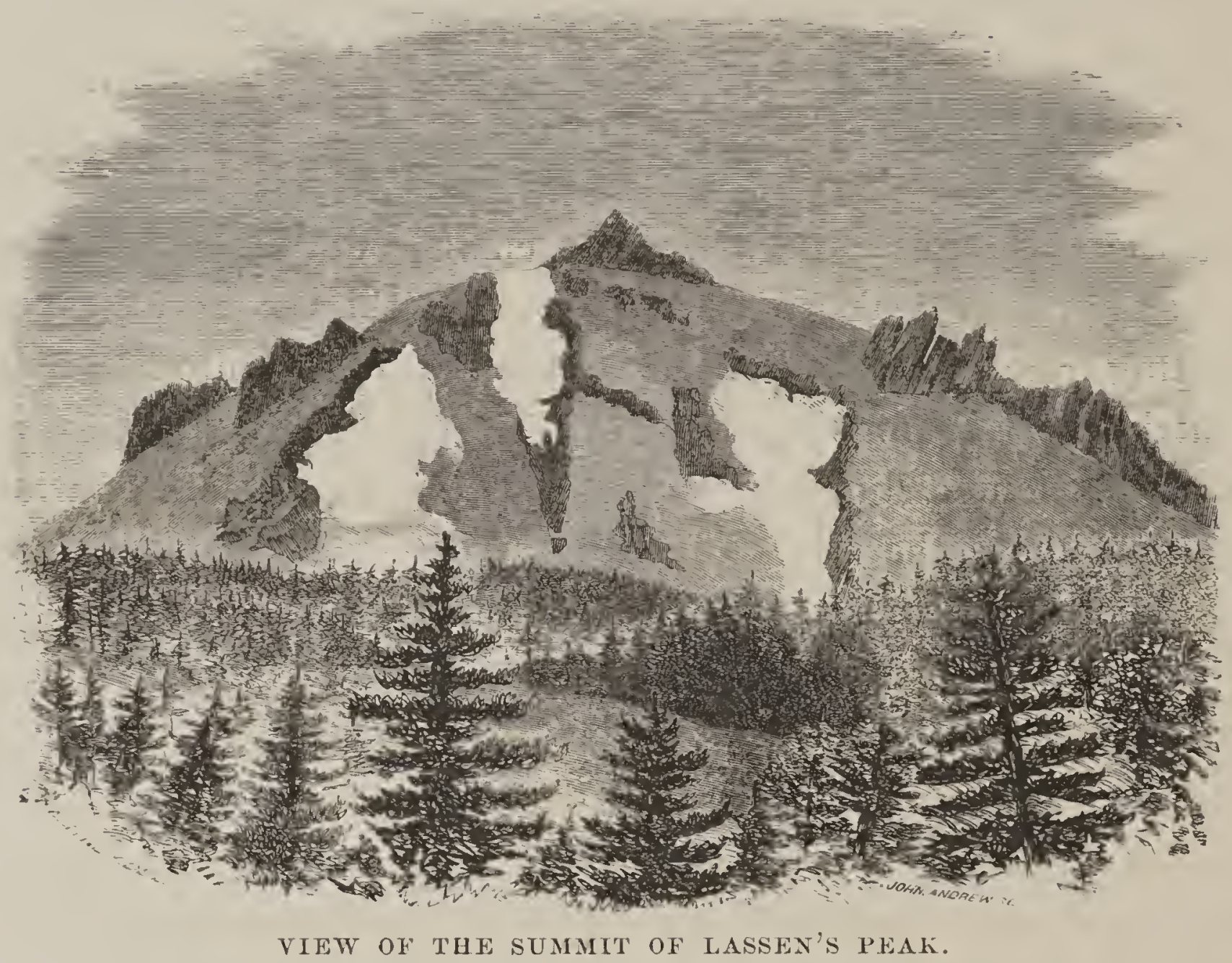

From the volcanic tables which cover the region in the vicinity of Lassen's Peak, rise a great number of cones of all heights, several of them being nearly as elevated as the peak itself. Some of these are sharp, pointed ridges, while others have well-defined circular craters at their summits. A line of these cones runs in a nearly northerly direction to beyond Pitt River; some of them are nearly 9000 feet high, and Black Butte, about fifteen miles east-northeast from Lassen's, is probably over 9500 feet above the sea. Around the base of this are several lower cones, some with finely-formed craters, now covered with forests.

On the northeastern slope of the peak, at about 2000 feet below the summit, is a crater surrounded with vertical walls, except at one point; the exterior slopes are covered with ashes and pumice.

Four or five miles north of the summit of Lassen's Peak, is a cluster 
of irregular truncated cones, having all the appearance of a very recent origin. Several persons gave their independent testimony that, from 1854 to 1857 , these cones were constantly emitting large quantities of steam and gases. Their sides were found to be of loose ashes, and their broad summits were covered with loose angular fragments of lava, as if they had been raised up and broken by a force acting from beneath. The rocks of which these cones are made up is that peculiar variety of rhyolite for which Richthofen has proposed the name of "Nevadite." It has a resemblance to granite, so that, at a distance and without close examination, it would be taken for that rock. The minerals which make up this curious variety of lava are chiefly quartz and feldspar (both sanidin and glassy oligoclase, according to Richthofen), with long slender prisms of hormblende and hexagonal crystals of mica sparsely disseminated through the mass. The feldspathic material is drawn out into an imperfectly fibrous form, which is half way between pumice and the "Pele's hail" of the Sandwich Island volcanoes. This condition has evidently been the result of the flowing of the mass of lava after the consolidation of the quartz, and while the feldspathic ingredient was still in a plastic condition. This is shown by the fact that the threads or fibres are all directed in one way, which was evidently that of the movement of the mass. The quartz is present in very large quantity in this rock; it is transparent, but full of fine flaws and cracks.

The annexed wood-cut (Fig. 42) will serve to give an idea of the outline of that part of the volcanic chain to which Lassen's Peak belongs. It was carefully sketched by Professor Brewer, from the cone ten miles east of Fort Reading, noticed on page 205, and from which Lassen's Peak bore N. $69^{\circ}$ E. (magnetic). In this diagram $a$ is Crater Mountain, $b$ Lassen's Peak, twelve miles south, while $c$ and $d$ are apparently the two sides of an enormous crater, of which the northern one $(c)$ had a distinctly stratified appearance, as indicated in the figure. This crater was very conspicuous from the peak, the rock appearing to be black basalt; it was not ascended or examined except from a distance. $S S$ represents the snow line, in the position it had when the sketch was made (October, 1862). From $d$ the lava slopes gradually down to the Sacramento River. 


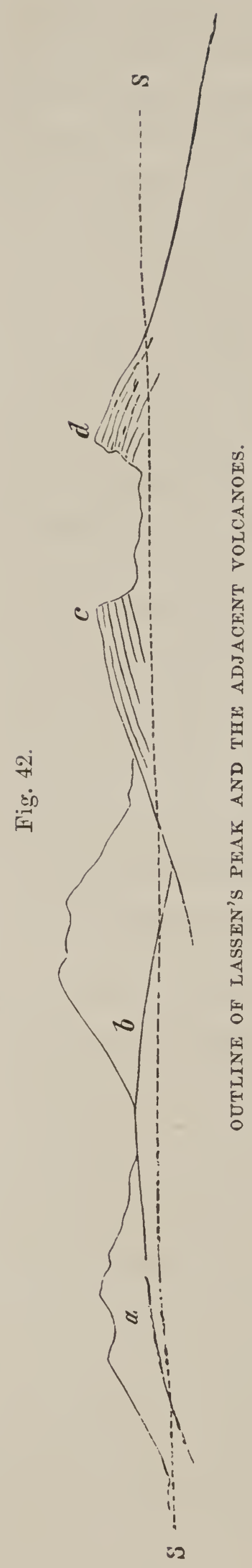

On all sides of Lassen's Peak, evidences of the existence of former glaciers were observed. The traces of them were most numerous and best preserved at an altitude of from 7500 to 8000 feet; but they occurred in abundance between 6000 and 9000 feet. An immense glacier formed on the south slope, just below the farthest cone, and flowed south, covering a table several miles in extent and descending to the cañons of the Feather River. Another one originated along the divide east of the peak, and descended into the valley of Hat Creek.

Section XII.-The Northern Counties:-Shasta, Tehama, Siskiyou, Del Norte, and Trinity.

The geology of Lassen's Peak has been described under the head of Plumas County, as that interesting volcanic mass marks the corner of Plumas, Shasta, and Siskiyou. North of this is an immense area, not less than 200 miles long from east to west, and 100 in the opposite direction, comprised within the counties of Shasta, Tehama, Del Norte, Siskiyou, and Trinity. This region, which is equal in size to the two States of Vermont and New Hampshire, has been but little explored by the Survey, a large portion of it being quite inaccessible to a small party, on account of the hostile character of the Indians who are sparsely scattered over it. Some parts of it were examined, however, and the results may conveniently be placed together in one section.

The explorations in the northern counties were made during parts of two different years. In 1862, the whole party started from Shasta City and went up the Upper Sacramento Valley to Mount Shasta, making the ascent of that great volcanic cone, and then returned by the same route, in order to con- 
tinue the reconnaissance down the foot-hills of the Sierra Nevada. Previous to starting back from Shasta, however, Messrs. Brewer and Rémond made a hasty excursion into Trinity County, as far as Weaverville. In 1863, Messrs. Brewer and King continued their observations from Lassen's Peak, as noticed in the preceding section, north through Shasta County by the Hat Creek road to Fort Crook. From this point, they passed around on the east and north sides of Mount Shasta to Yreka, and thence to Crescent City. After examining the copper mines in that region, Professor Brewer returned to San Francisco by steamer, and Mr. King by stage. The scattered observations made as above will be given nearly in the same order in which they were taken, as our information is by no means complete enough in regard to this region, to make it worth while to endeavor to present it in a systematic form.

For the same reason we shall not undertake to go into any extended generalizations in regard to the stratigraphical geology of the northern portion of the State; but will leave that for a future volume. We may, however, make a few observations, in order to throw some light on the condition of things in this complicated region.

As, in following up the Sierra, we pass into Plumas County from the south, we find the grand simplicity of that chain to become less and less conspicuous. This is evident from the fact that many persons consider the Sierra Nevada to terminate in this region, and do not reckon Mount Shasta as one of the elevations which belong to it. Indeed, all will admit that the topography of the northern part of the State is not easily to be brought into harmony with that of the Central Sierra. Nor can any entirely satisfactory results be arrived at, in endeavoring to make the connection between the Sierra and the Cascade Range intelligible, until we know more of the position and age of the great mass of mountains which occupies the extreme northeastern corner of California.

We know, however, that the vast overflow of volcanic material, which extends from Mount Shasta to Lassen's Peak, lies upon the same geological formations which form the flanks of the Sierra farther south through the gold-mining districts. We know that these appear again to the west and northwest of the volcanic formation, having, in 
many respects, the same lithological and metalliferous character which they had to the south, and being evidently a continuation of the same series of formations. We see also that Mount Shasta, itself an exclusively volcanic mass like so many of the loftiest summits of the Sierra, is exactly in the line of the axis of that range. Hence, for the present, we consider all the region lying to the northeast of a line drawn parallel with the axis of the Sierra (N. $31^{\circ}$ W.) from the mouth of the Klamath River, as belonging to the system of the Sierra Nevada.

It is true, however, that portions of this area have been disturbed since the deposition of the Cretaceous series, and that a part or the whole of the mountain ranges embraced within it owe a portion of their present elevation to changes which have taken place while the Coast Ranges were being uplifted. The Cretaceous strata, which everywhere along the flanks of the Sierra to the south of Shasta City are horizontal in position, to the west and north of that place are upturned, but not metamorphosed. And as these Cretaceous beds occupy only very limited areas in the region in question, so far as yet known, we are unable to say whether their disturbance is due to a general upheaval or only to a local one; nor can we yet trace the connection of these newer deposits with each other, or the direction of the system of elevations by which they have been disturbed. A much more thorough exploration of the northwestern corner of the State will be required, before we can solve the difficult but interesting problems which are presented in this region, where the systems of the Sierra and the Coast Kanges are brought into direct contact with each other.

With these few preliminary remarks, we will proceed to give the results of our reconnaissance of the region in question, commencing with the vicinity of Shasta City, and giving our observations between there and Weaverville, in Trinity County. We will then take up the country north and northeast of Shasta City, sketching first the geological structure of the Upper Sacramento Valley and the vicinity of Mount Shasta, ending the chapter with a description of the route of our party around from Lassen's Peak to Yreka and Crescent City. The order here followed is almost entirely a geographical one; but the limited number of observations renders any systematic description of the country quite impossible. 
The Sacramento Valley, which was expanded into a wide plain below Red Bluff, is contracted in width at that point by an elevated slope of volcanic materials which extends from the base of Lassen's Peak on the east quite to the river, while on the west side there is a heary deposit of gravel, clay, and volcanic tufas, forming tables and low hills from the river to the Coast Ranges. At Red Bluff these deposits are at an eleration of from 80 to 100 feet, and are deeply eroded with ravines separating rounder liills; these have a dry soil and are covered with scattered oaks and pines (Quercus Garrycusa and Pinus Sabiniana), and with a shrubby growth of Ceanothus and Manzanita.

About four miles north of Red Bluff a lower plain occurs, which appears to have been once the broad bed of the Sacramento, when it flowed in a more direct course and at a higher level; but the present channel of the river is in a deep cañon, which it has cut through the mass of materials forming the edge of the great volcanic plateau coming down into the valley from the east. The surface of the plain is of indurated rolcanic tufa, of a light ash-gray color, and containing many small fragments of pumice. The gravel deposits, before alluded to, lie upon this ash bed and contain numerous pebbles of red and green jasper, being apparently derived from the metamorphic Cretaceous rocks of the Coast Ranges west. All of these deposits lie nearly horizontal. The valley of Cottonwood Creek forms a wide sandy plain at a somewhat,lower level, and on the north the whole valley rises into a table-land which expands out, in the latitude of Fort Reading, to nearly fifty miles in width, and is from 800 to 1000 feet high. It is deeply eroded by the various streams which flow down from the mountains on both sides. This plateau is limited on the north by the mountain ranges which occupy the whole area beyond Shasta City. These do not cross the State transversely, as represented on some of the maps, but have a general northwest and southeast trend, their southern extremities terminating rather abruptly at the head of the Sacramento Valley.

On the north side of the Cottonwood, beginning at Horsetown, and extending west to the Coast Ranges, Cretaceous strata lie at the base of the mountains. These strata were examined most fully at Horsetown, Eagle Creek, Bee Creek, along the north fork of the Cotton- 
wood, and in the Bald Hills; but there are numerous other localities where Cretaceous fossils are reported to have been found.

From Horsetown, eight miles southwest of Shasta, to the base of the Coast Ranges, the Cretaceous strata form a table-land, about 1200 feet high, and have generally a southeasterly dip. They have evidently been denuded by the action of the waves and worn down to a level surface, which has since been eroded by streams of water and is now intersected by numerous cañons and gulches. In the localities examined about the north fork of the Cottouwood, shales greatly predominate, having at least fifteen or twenty times the thickness of the interstratified sandstones; there are also some beds of conglomerate, and limestone occurs, but chiefly in the form of nodules, and very often having an Ammonite as a nucleus. The strata in this region have a northeasterly direction, and dip to the southeast at an angle varying from $20^{\circ}$ to $36^{\circ}$, and generally averaging about $23^{\circ}$. Some of the beds are highly fossiliferous and have furnished many of the largest and finest Cretaceous fossils in our collections, especially Ammonites, the best of these being inclosed in the limestone nodules.

In some of the strata very large quantities of fossil wood are found, and the pieces generally bear marks of having floated long in the water, being worn on the edges and partially decayed; they are frequently bored by teredoes, some specimens having been perfectly honeycombed by them before sinking and becoming silicified.

Thin beds of coal are not unfrequent in these shales, and near the mouth of Huling Creek this material has been found in sufficient quantities to create some excitement, and to lead to explorations for workable beds, which, however, have not yet been found.

The "Bald Hills" are numerous rounded elevations, lying between the north and middle forks of the Cottonwood, and rising from 1200 to 1300 feet in height. They are entirely destitute of trees or shrubs, and present a very peculiar appearance. These hills are mostly made up of the Cretaceous shales, and they owe their remarkable form to denudation. With the exception of the Bald Hills, the region is covered with a scattered growth of trees, chiefly the Quercus Garryana and Pinus Sabiniana, with Ceanothus and Manzanita. The soil is partially derived from the decomposition of the rock beneath, but there are 
many heavy beds of detrital materials which have come from the auriferous slate formation in the higher mountains to the northwest, and a large portion of the surface has been washed over for gold, some of the placers being quite rich. At Piety Hill this formation is, in some places, orer 100 feet thick, and has been found auriferous from the bed-rock to the surface.

The Cretaceous strata of this region, although not metamorphosed, and having generally a dip of less than $30^{\circ}$, have evidently been disturbed since their deposition, while the beds of the same age on the other side of the Sacramento River, twenty-five or thirty miles distant, remain in their original position. The local character of this disturbance is made evident by the varying direction and amount of the dip and the irregularity of the strike. The inclination, which is usually from $22^{\circ}$ to $25^{\circ}$, becomes in some places as much as $36^{\circ}$, and the strike of the beds, which is, in the main, about northeast and southwest, varies as much as $50^{\circ}$, even in short distances. On Alderson's Gulch and Bee Creek, the shales are found broken and bent, and fissures in them are seen to have become filled up with sand, forming the same kind of dykes as were observed in the Monte Diablo Range.

Between the Cretaceous strata just noticed and the high granitic mountains to the northwest, is a large body of the metamorphic auriferous slates. These are scarcely seen at Eagle Creek; but at Piety IIill, Horsetown, and south of Shasta, they are well exposed. Between Shasta and Horsetown they form an elevated table, about 1200 feet high, much intersected by ravines, and in many places covered by auriferous detritus. The strata are quite contorted, and have a general eastern dip, being usually very highly altered, although in places they are very little changed from their original character, and in such cases they resemble the rocks of the Cretaceous series.

At Horsetown, the unaltered Cretaceons shales are seen resting directly on the granite, and dipping to the east and southeast at a low angle, about $15^{\circ}$; they are of a dark-blue color, not in the least metamorphic, and well filled with fossils. Very near this, in fact not more than fifty yards distant, the auriferous slates are seen, highly altered and having a strike north and south and a high dip to the east. It was not possible, however, to find any locality where these metamorphic คr.กT. VOI. I. -41 
rocks and the unaltered Cretaceous could be seen in contact, and some difficulty was met with in clearly making out whether the metamorphic beds might not themselves be of Cretaceous age. The weight of evidence, however, seemed to be decidedly in favor of the auriferous rocks being older than the Cretaceous. The older rocks seem to have been very irregularly denuded, and a patch of the underlying granite being left bare, it was covered by a deposition of sediment from the Cretaceous ocean.

The region about Shasta City is entirely of metamorphic rocks, chiefly the auriferous slates. On the south of the town, for six or eight miles, these form a plateau from 1000 to 1100 feet high, but intersected by numerous and deep ravines, in which are many placer-mining claims, although these are to a large extent worked out. The slates have a general easterly dip, but are much contorted. Extensive belts of a light-colored rock, chiefly made up of quartz and feldspar, occur on both sides of the town; this occasionally contains a little mica, and becomes granitic in character. These belts run northeast and southwest, or nearly at right-angles to the strike of the auriferous slates. From their position and lithological character, they would seem to be large veins or dykes of eruptive origin; but their real nature was not clearly made out.

On the southwest of Shasta City, near Middletown, the metamorwhic rocks rise in ridges over 2000 feet high, and on the north there are still higher elevations, some probably exceeding 3000 feet. Five or six miles north of the city, after crossing the belt of quartz and feldspar rock, high ridges of metamorphic slate are met with, much fractured and broken both in strike and dip. Near the head of Spring Creek large bodies of hematite iron ore occur, pure and of good quality, of which numerous boulders have been washed down the cañon. Under favorable circumstances as to fuel and labor, these deposits would be very valuable. The quantity and quality of the ore seem to be all that could be desired.

In passing northwest from Shasta, on the Weaverville road, a ridge of quartz and feldspar rock is crossed before passing Whiskeytown, and this is succeeded by the auriferous slates, which occupy the surface mil the granite of the Trinity Mountains is reacher. These slates 
THE WESTER SLOPE—THE NORTHEN COUNTIES, 329

are well exposed in many places along Clear Creek, having a general northrest and southeast direction, and dipping to the northeast. The exposures are particularly fine between Oak Bottom and 'Towers's, where the slates are often nearly unaltered, and closely resemble in appearance the least metamorphosed portion of the auriferous rocks in the Central Sicra.

The Trinity Mountains extend along on the west side of Shasta County, stretching off towards Mount Shasta, and sceming to be the northerly continuation of the main ridge of the Coast Ranges, of which Mount Linn and Mount St. John are two of the eulminating points. Along the line of Shasta County, these mountains arerage about 4000 feet in elevation; the pass where the Weaverville road crosses is 3364 fect high, and Mount Balley, the culminating point, 6357. The centre of the chain is of granite, which occupies a belt about four miles wide where the pass crosses. This rock is generally very soft and decomposable, and has bands of syenite in it and patches of crystallized hornblende. Trees grow more abundantly on the decomposing granite than they do on the slates, so that the limits of the two formations may casily be traced, when the country is examined from a high point. Mount Balley is on a spur running off to the east from the Trinity Mountains, and Bullet Chup is another high point in the main ridge, about fifteen miles west of Mount Balley. As seen from the summit of the last-named elevation, the granitic mass of Trinity Mountains appears to become much broader towards its southeastern end and narrows to the northeast, disappearing entirely before crossing the 'Trinity River, on the other side of which the same range appears to be continued in the Salmon Mountains.

To the west of this granitic belt the auriferous slates reappear and probably form the predominating formation of Trinity County. Wherever seen between 'Trinity Mountains and Weaverville, this formation was found to be much metamorphosed and to have a very variable dip and strike, although usually inclining to the northeast; often, however, the stratification is entirely obliterated. The slates appear everywhere to be auriferous. Near the bend of Trinity River are rery rich placer and hydraulic washings. From the bank or plateau at Douglas City, over $\$ 1,000,000$ is said to have been taken by the 
hydraulic method, and a very large amount of gravel still remains to be worked.

A single specimen of a fossil, Crioceras latus, Gabb, was found several years ago in a boulder in Trinity River, near the mouth of Reading Creek. It is a very interesting cephalopod, belonging to the Cretaceous series; but its original locality is a matter of question, as it was not found in place, and is the only fossil which has yet been discovered in the county. It is to be presumed that it may have originated in the mountains southwest of Weaverville, where we may suppose the Cretaceous formation to be largely developed.

High mountains rise immediately north of Weaverville, the nearest considerable elevation being known as Mount Balley. "Balley" appears to be the Indian term for a bare mountain, and the "Shasta Balley" is to be distinguished from the "Trinity Balley," or the one near Weaverville; the orthography of the word is very doubtful. This mountain is 7647 feet high, and another high summit near the head of Stewart's Fork was estimated at 8250 . These belong to a range forming the southern portion of the Salmon Mountains, and have a central mass of granite of varying hardness, their crests weathering into rugged and fantastic pinnacles:

Trinity Balley is partly of granite, intersected by dykes of the same rock, but having a finer grain. On the west side hornblende-slate occurs, which is often nearly black, and has veins of granite and syenite running through it. This region is worn into deep and very abrupt cañons, and in these the detritus is auriferous wherever the slates have been eroded. The flanks of this mountain, from a height of 4000 to 7000 feet, are covered with a heavy growth of forest trees, anong which Picea grandis, P. nobilis, Abies Douglasit, Pinus ponderosa, and P. Lambertiana are the predominant species. The Douglas fir in this region often attains an immense size. The direction of the ridge each way from the culminating point is $\mathrm{S} .25^{\circ} \mathrm{W}$. and N. $33^{\circ} \mathrm{E}$.

The region as seen from the summit of these two Balleys is exclusively a mountainous one. No valley or plain of any size is in sight, and no indication of a break, or of a physical disconnection between the Coast Ranges and the Sierra Nevada, can be perceived.

On the southwest of the Bald Hill region, at the headwaters of the 
Cottonwood, there are lofty mountains, on which snow remains all the year, and the highest peaks of which are probably fully 8000 feet in altitude. The highest point of this region is known locally as the "Yalloballey," an Indian name of which the orthography and meaning are cloubtful. It is not unlikely that the Yalloballey is the same mountain that is indicated on the maps as "Mount Linn," a name which, so far as we have been able to ascertain, is not known to any one in this part of the State. The position of this point is uncertain and the geology of the region entirely unexplored, a large part of Klamath, Trinity, and Humboldt Counties being a very unsafe country to travel in, owing to the hostile and warlike character of the Indians, who have almost unrestrained possession of this part of the State. The natural difficulties in the way of the exploration of this region are very great, as the mountains are very high and very rough; besides, the heat of the summer is intense, water scarce, and the undergrowth tormenting.

Of the two roads from Shasta City to Yreka, that which crosses the Trinity Mountains by a skilfully constructed grade is the one travelled by the stage; the other, which passes up the valley of the Upper Sacramento River, is well laid out, but not worked to a sufficient width to admit of passing with teams, except at intervals. It is used, however, to a considerable extent, and was, in 1863, travelled over twice a week by an accommodation stage from Red Bluff to Yreka. Were the beauties of this route better known, there would be a large amount of pleasure travel over it in the summer, for it is hardly possible to find in the State a series of grander views than is presented by the gorge of the river, the rocky and forest-clad sides of the valley, and the stupendous mass of Mount Shasta in the background, so imposing in its outline that the most striking views of it are those which are presented at a distance of not less than from twenty to forty miles. Every traveller through the northern part of California should pass over the Sacramento Valley road, by the base of Mount Shasta, either in going or returning; preferably the former, as, in that case, he has the mountain facing him.

This road crosses the Sacramento River at Waugh's Ferry, near Shasta City, and runs northeast about fifteen miles, to Bass's Ranch. Pitt River is crossed at Stone's Ferry, a little below the mouth of 
the MeCloud Fork, and from there runs in a direction a little west of north to the Sacramento River, crossing it at a point called fifteen miles from Stone's Ferry. At this point, it unites with the old trail, which follows up the river from Shasta, most of the way on the west side, but which has not been worked into a wagon-road. The Upper Sacramento is the stream called "Destruction River" by the United States Exploring Expedition, and it was down this old trail that one of their parties travelled, on their way from the Willamet Valley to Sacramento.

The rocks at Waugh's Ferry are metamorphic slates of a bluish-gray color; they dip to the east and southeast, but not at a high angle. The river at the ferry is about 125 feet wide, and is both deep and rapid. Between this ferry and Bass's Ranch, there are numerous gold washings around the head of Churn Creek, at Buckeye and Churntown.

Near Bass's Ranch is a locality which is very interesting to the geologist as being the only one in the State where any considerable number of fossils have been found in the limestone formation of the Sierra Nevada. The outcrop of this rock is a very conspicuous ridge or chain of hills, extending in a nearly north and south direction, and forming several elevations, which are very marked on account of their peculiar grayish-blue color, which is so different from that of the other rocks of the auriferous series. These hills, which rise to the height of about 2000 feet above the plain at Bass's, are called on the official map of Shasta County, the Gray Mountains; they are also known as the Marble Mountains. This limestone belt stretches far to the north, along the east side of McCloud's River, forming a range known by the same name as the river; but its extension in this direction was not traced out by us, for want of time. Some of the points in the McCloud Range appear to be fully 3000 feet high above the river.

The limestone formation, as seen in the Gray Mountains, is estimated at nearly 1000 feet in thickness, and it is inclosed in the metamorphic slates, with which it is conformable both in dip and strike. As farther south, so here, this rock is cut by heavy dykes of trap, usually in a direction at right-angles to its strike. These, being here of a more easily decomposable material than the inclosing rock, have weathered so as to leave large cavities or troughs in the ridges. The limestone 
differs from that seen in any other portion of the State in containing very large masses of pyrites seattered through it, sometimes of several cubic feet in size. This mineral is in radiated forms, and has undergone a more or less complete decomposition, having become converted into brown oxide of iron. Large erystalline masses of garnet also occur in great abundance in this rock.

Fossils were first noticed in this range by Dr. Trask, who in his Report of 1855 mentions the locality, and correctly refers the formation to the age of the Carboniferous group. A large supply of material for investigation was collected by us at several different localities along the range, and the whole was placed in the hands of Mr. Meek for examination. His description of these fossils will be found in the first section of the first volume of the Palæontology of California, and the figures of the different species are included in plates 1 and 2 of that volume.

Our collections at this locality embraced about fourteen species, belonging to eleven different genera, viz.: Lithostrotion, Clisiophyllum, Chatetes or Alveolites, Fusulina, Orthis, Rhynchonella, Productus, Retzia, Spirifer, Spiriferina, and Eumphalus. Of these fourteen species, six are described as new, and four or five are regarded as probably identical with known forms; while the remainder cannot be satisfactorily determined, on account of the imperfect character of the specimens collected. Mr. Meek makes the following remarks in regard to these fossils:

"Although generally in a bad state of preservation, and imbedded in a very hard limestone matrix, they retain enough of their original characters to establish, beyond a doubt, their Carboniferous age. They are scarcely, however, sufficient, in the present state of our knowledge, to warrant a positive opinion in regard to their exact stratigraphical position in the Carboniferous system, though I am much inclined to think that they belong below the horizon of the Coal Measures. The strongest evidence, to my mind, in favor of this conclusion, is the presence among them of a coral which I cannot distinguish froni Lithostrotion mamillare, a common and widely-distributed species in the Subcarboniferous rocks of the Mississippi Valley. So far as my knowledge extends, this coral has never been found in the Coal Measures, nor fur 
abore the position of the St. Louis limestone of the Western Subcarboniferous series.

"To a European geologist, unacquainted with the range of the various types of fossils in our Carboniferous rocks, the occurrence, in this collection, of species either identical with, or closely allied to, such forms as Fusulina cylindrica, Spirifer lineatus, and Productus semireticulatus, would also be regarded as additional evidence of the Subcarboniferous age of the rock in which they occur. I do not, however, allow so much weight to the presence of these fossils, because we find, often in considerable abundance and widely distributed in our Coal Measures, forms that have been pronounced identical with these, even after a direct comparison of American and foreign specimens, by European palrontologists. It is also well-known to those familiar with the Carboniferous Fauna of the Mississippi Valley, that great numbers of brachiopods, gasteropods, corals, and other marine remains occur in our Western Coal Measures often closely allied to forms rarely, if ever, found above the horizon of the Subcarboniferous rocks in Europe. So strikingly is this fact exemplified, that we should be almost tempted to adopt the conclusion that the Coal Measures of the West rather represent some upper member of the Subcarboniferous series of the Old World, than the Coal Measures proper, as developed there, were it not for the fact that the Flora of these strata is known to be remarkably like that of the European Coal Measures; so much so, indeed, that competent authorities pronounce a very large proportion of the species in all respects identical. The testimony of these plants is also corroborated by the physical structure of our entire Carboniferous system, as developed in the States lying within the Valley of the Mississippi."

The limestone belt of the Sierra has been proved to be of Carboniferous age at Bass's Ranch, and also at Pence's, about eighty miles southeast of Bass's. The same rock in Genesee Valley contained traces of fossils, which were considered by $\mathrm{Mr}$. Gabb as probably belonging to the same epoch. In no other of the numerous outcrops of crystalline limestone in the Sierra have any recognizable fossils been obtained; but, from their general lithological resemblance to each other, and their position in relation to the auriferous slate series, it is thought probable that all these are of one and the same age. It is almost certain that 
the different masses which make up the most western of the belts of limestone which can be traced through the Sierra are all Carboniferous; but whether the other outerops, which oceur much higher up in the mountains, and which appear to form one or more distinct belts, are of the same age remains to be demonstrated. Our researches in the Sierla Nevada have not yet been sufficiently extensive to justify an attempt to settle this question on purely stratigraphical evirlence.

Near Stone's Ferry, on the north side of Pitt River, there is a high ridge of granitic rock, in places resembling the quartz and feldspar rock of the vicinity of Shasta City; but its extent to the north was not traced out. It is probably an isolated mass included in the auriferous series. Crossing this, we come upon the regular slate formation, which occupies most of the region along the road, between McCloud's Fork and the Upper Sacramento. Near to the granite, and for some distance farther north, the slates are a good deal altered and broken up by intrusions of trappean rock and granite. Beyond this we meet with slates which are very little metamorphosed, and which have everywhere an eastern or northeastern dip, at an angle varying from $20^{\circ}$ to $50^{\circ}$. The country is a wilderness of high rolling hills, rather dry, and covered with scattered oaks and pines, and with an undergrowth of oak chaparral.

At the crossing of the Sacramento, the rocks are hard metamorphic slates, which soon pass into almost entirely unaltered shales; indeed, hardly any portion of the Sierra Nevada shows so large an extent of sedimentary rock, in a condition so nearly approaching that in which it was originally when deposited, as this along the western side of the Upper Sacramento. The dip of these rocks is everywhere to the east, and usually at an angle of about $30^{\circ}$; their strike becomes more nearly north and south as we go northward. The rocks come close down to the river, forming steep slopes, along the sides of which the road is notched out, being often, for long distances, not wide enough for two wagons to pass. These hills rise in places to 3000 feet above the river. In these unaltered focks careful search was made for fossils, at many points, but without success. At a locality a mile and a half south of Dog Creek, the strike of the slates is about N. $20^{\circ} \mathrm{E}$, and their dip from $45^{\circ}$ to $50^{\circ}$ to the east. At Slate Creek also, the schistose rocks GEOL. VOI. I. -42 
are beantifully exposed, and they pass into a kind of flagetones; the dip continuing to be in an easterly direction.

From Portuguese Flat, a little above slate Creek, going north, the states are more nnetamorphic and begin to contain quart\% veins. In this region there has been wonsiderable prosprecting for placer and quartz-mines, and there are gold washings in the bed of the river, which are sald to pay well. Between Slate and Castle Creeks there is a large amount of coarsely crystallized hornblende-rock, with many trappean and metanorphic varieties, the formation growing more and more erystalline as we approach the granitic range of which Castle Rock forms the termination on the river.

These metamorphic rocks are almost everywhere covered by a heavy mass of volcanic materials, which first begin to be seen three miles after crossing the Sacramento; and, as we go north, we find this formation occupying more and more of the surface. As the road rises in elevation, following up the river, which has a very rapid fall, the lava appears lower and lower down; until finally, before reaching Castle Rock, the slates are seen only in the gulches near the water. Beyond this granitic range, they sink altogether out of sight, and the road keeps entirely on the volcanic formation.

Between Sweetbrier Ranch and Castle Rock, all the streams contain boulders of granite, syenite, and hormblende-rock. In crossing one of the spurs of the Castle Range, two and a half miles from Sweetbrier, large veins of granite were observed in the highly altered and much contorted slates; over these the lava occurs in places and, in close proximity, the granite rises through the whole, it being apparent, from the pusition of the different formations, that the granite has been forced up firom below through the slates, in consequence of which, or after which, an extensive metamorphism of the latter took place, followed by longcontinued denudation, leaving an irregular surface, over which the lava streams flowed, probably from Mount Shasta or some of the smaller cones adjacent to it. No changes have occurred since, except the continued denudation and erosion of the surface, of which the eruptive materials, as well. as the underlying slates, show abundant evidence.

The Castle Range, which terminates on the river in a conspicuous 
peak called Castle Rock, is a spur of the Trinity Mountains, running nearly east from the main range. It is a ridge of granite, rising about 2500 feet above the valley, and having an extremely sharp and serrated outline. The upper part of the mountain is a ragged crest of pinnacles and spires of a light-gray color, presenting a most imposing appearance from the south side, as is faintly indicated in the annexed wood-cut (Fig. 43): In the valley on the north side of this range, beautiful

Fig. 43.

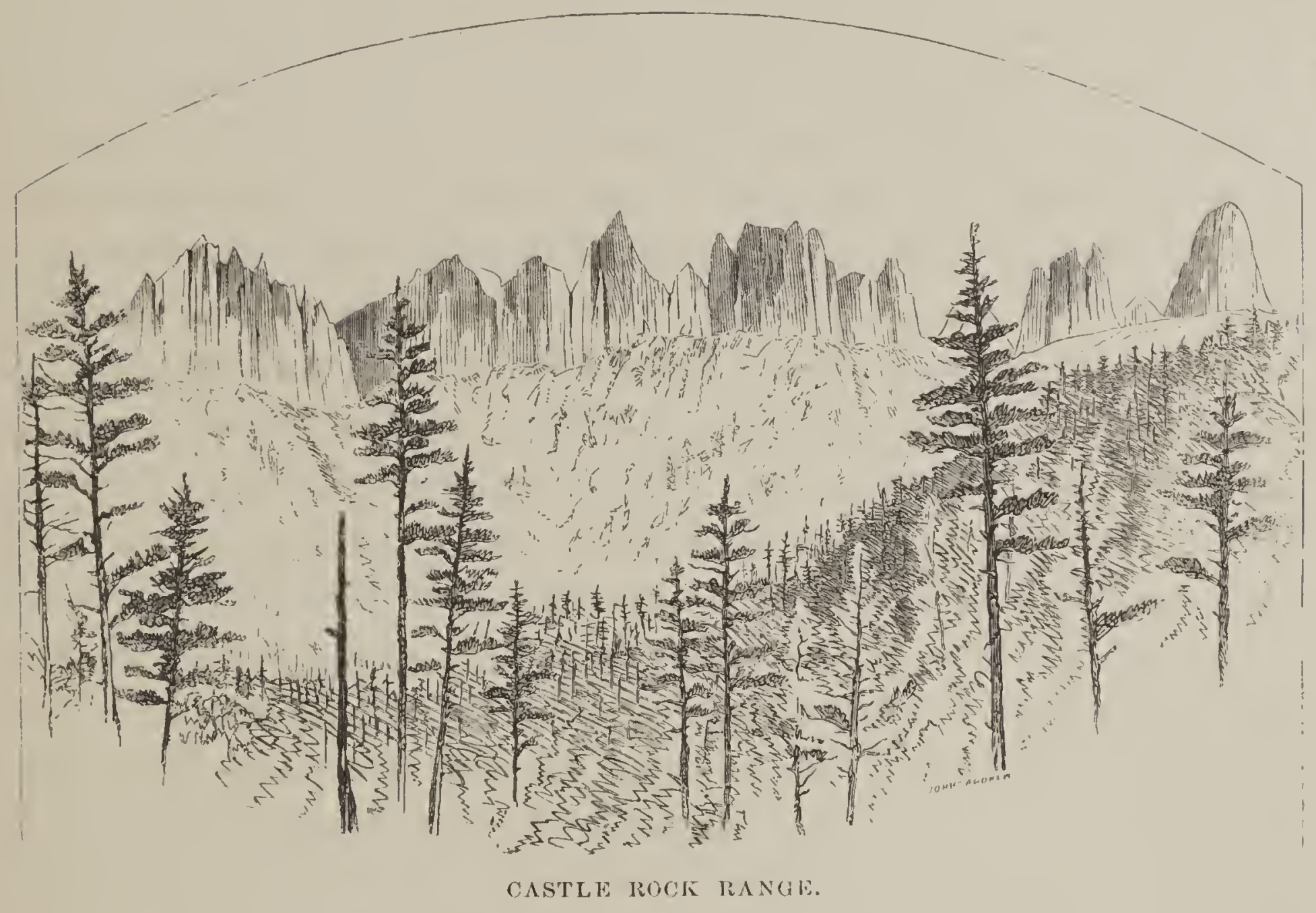

specimens of rose-colored foldspar were collected, in large crystals. Hypersthene-rock and a variety of coarsely-erystallized hormblenterock occur also in the ravines on this side of the granite. The portion of the Trinity Mountains with which Castle Range connects appears to be entirely unexplored; it is a wild and forhidling region.

There are two groups of mineral springs in this vicinity, one of which is on the east side of the Sacramento, nearly opposite the mouth of Castle Creek; the other is three and a half miles firther up and eight miles from Strawberry Flat, at the base of Momt shasta. The first is called "Lower Sola," the other "Soda springs." The latter" 
are in the cañon of the Sacramento, at an elevation of 2363 feet, and they are considerably resorted to, the water having a high reputation for its tonic effect, and being reported to have a specific action on the kidneys. The water is a chalybeate, there being an extensive ferruginous deposit around the spring; it is also highly impregnated with carbonic acid, sparkling like soda-water, whence the name, which is one usually given in California to springs giving off carbonic acid, and not to those containing carbonate of soda. The temperature of the water was $52^{\circ}$, in September, 1862.

From Soda Springs to Strawberry Flat, a distance of eight miles, lava covers the surface, forming a gradual slope, heavily covered with a magnificent forest vegetation, chiefly of pines and firs. From a hill a little to the east of the road, about two miles south of the Lower Soda Springs, one of the finest possible views of Mount Shasta may be obtained, the distance being just about sufficient to give full effect to the mountain mass, and the ragged cliffs in front furnishing such a foreground as any artist with a feeling for rocks would delight in painting; these, and the noble forests by which they are crowned, form a worthy frame for the stupendons snowy mass in the background.

Mount Shasta has always been ascended from the west side, Strawberry Flat being the most convenient and suitable point for making the necessary preparations for the trip. The route followed to the summit of the mountain is an easy and natural one, and it is hardly possible that any other can be found which will be as desirable; indeed, so far as our observations go, we are unable to say where any other practicable one could be laid ont.

The mountain has been ascended quite a number of times; in fact, hardly a summer passes, that one or more parties from Yreka does not reach, or attempt to reach, the summit. To one possessed of sound lungs and accustomed to mountain-travelling, there is no difficulty in the ascent, except such as arises from the system having to alapt itself so suddenly to the rarefied condition of the air at an elevation of over 14,000 feet.

There is no regular guide to conduct parties up the mountain; but Mr. J. H. Sisson, the attentive landlord of the hotel at Strawberry Flat, has accompanied travellers to the summit, and will undoubtedly 
aid and advise all who desire to make the ascent. The time will undoubtedly come, when the travel to this beautiful spot will be sufficient to justify more ample preparations than have yet been made to accommodate those who seek to climb Mount Shasta. It is hardly possible to exaggerate the beauty and grandeur of the views from this point, so that those who do not feel equal to the task of ascending to the summit will find themselves amply repaid for visiting Strawberry Flat, by the nearer view of the mountain itself from that place, as well as the clear water, cool air, and magnificent forest vegetation, which are so grateful to the traveller who comes, during the summer months, from the burning plains of the Sacramento Valley, or the alkaline deserts of Nevada.

The best season of the year for the ascent of Mount Shasta is in the months of July and August. Before July the snow is hardly gone from the camping-ground, from which the ascent to the summit and the return is to be made in one day; and, after that month, the incessant fires in the surrounding forests fill the air with smoke and take away all distinctness from the distant view. The plan adopted by those ascending the mountain is, to pass the first night at Camp Ross, near the line of perpetual snow, and from that point to start the next morning sufficiently early to keep always on the hard frozen snow, the heat of the sun by mid-day softening it nearly to the summit, so as to make climbing almost if not quite impossible, while the ascent on the frozen surface is very easy, especially if one has the soles of his boots well provided with nails. Our party started at $3 \frac{1}{2}$ A.M., and reached the summit at $11 \frac{1}{2}$; but others not encumbered, as we were, by barometers and instruments of various kinds, would be able to make the ascent in considerably less time, if in other respects on an equality with us as regards their climbing powers. Of course, a night near the full of the moon is preferable for this expedition, although the usual bright starlight of the summer in this regign will answer, to cnable one to pick his way orer the snow.

It is adrisable to leave Strawberry Flat in season to camp early and comfortably at the base of the snow, and to have plenty of warm clothing, as the temperature, at an altitude of 7629 feet, will probably be pretty near the freezing-point before morning. There is an abundance 
of wood and water at Camp Ross, as the station half way up the mountain is called, and the trail from Strawberry is sufficiently good to allow those wishing to save their strength to ride nearly the whole way. 'The trail passes through one continuous forest of magnificent coniferons trees. In the lower regions the sugar and pitch pines predominate; but cedars and firs gradually take their place, the former becoming less abundant as we rise. As the forest vegetation of Mount Shasta adds much to the grandeur and beanty of the scenery, and as this is a convenient opportunity, we introduce a few remarks on the subject of the distribution of the trees in this region, which are chiefly drawn from the notes of Professor Brewer.

The base of Mount Shasta is clothed with forests everywhere except on its north side. In this direction a valley stretches northward to the Klamath River, and the side of the mountain which leads down to it is covered with too scanty a soil to support any more vigorous growth than that of scattered cedars and oaks, which seldom rise to over thirty feet in height; there is, however, a pretty dense undergrowth, among which the manzanita is the predominating shrub. The valley itself, into which the north slope of the mountain descends, is quite destitute of trees, and lies at an elevation of from 2500 . to 3000 feet above the sea. This valley is not a level plain, but has a great number of gently rolling hills scattered over it. These are a few hundred feet high, and are also treeless, but covered for the most part with a low herbaceous vegetation, which ripens and dries up in the early summer. Limited areas have a thick growth of chaparral over them, consisting of manzanita, sage, chamiso, and greasewood.

The finest forests are fonnd on the southern and western slopes of the mountain, and the route usnally taken to the summit aftords as good an exhibition of all the varieties of trees and their distribution at different altitudes as could be desired. At Strawberry Flat, at an elevation of about 3600 feet, the forests are of the character observed everywhere in the northern part of the State at that height. The largest trees are the pitch pines (Pinus ponderosa), which not uncommonly attain a diameter of ten or twelve feet and an elevation of two hundred and fifty. This is a stately tree, symmetrical in outline, as well as gigantic in size. Its most striking feature, next to its height, is the 
size of the plates of the bark. These are smooth, of a bright cinuamon color, and often as much as twenty inches wide and three fect long. The crevices between these plates are often blackened by tire, making their smooth surface and bright color more conspicuons.

At this altitude and lower, down to the Sacranento River, the forests are chiefly made up of the following species: sugal pine ( $P$. L trembertiana), spruce (Abics Douglasii), bastand cedar (Librocedrus decurens), Oregon cedar (Cupressus Lansonianu=C! fiargrans of Kellogg), black oak (Q. Sonomensis), live oak ( $Q$. crussipocula), and, along the streams, an occasional yew (Taxus brevifolia). The undergrowth is formed of a variety of shrubs, among which several species of Ceanothus are abundant. The California chinquapin (Castanopsis chrysophylla) covers large areas, occurring in dense masses. 'This species grows, in Oregon, to the size of a tree, but here is a bush not often more than six feet high, and occasionally forming a dense chaparral. It is an evergreen, and the dark glossy upper surface of its leaves contrasts beautifully with the bright golden-yellow of the lower. The flower, which resembles that of the chestnut, remains on the stem for some months and adds to the picturesque effect of the species. A cornus (C. Nuttalii) is common in this region, and is a small tree with very conspicuous flowers, reminding one of the dogwood of the Eastern forests. A species of maple (Acer macrophyllum) grows to the size of a tree along the streams, but is not abundant; another species ( $A$. circinatum) is common, forming in places a tangled undergrowth. Manzanita is not rare, and other shrubs occur. Herbaceous plants are numerous, and some hundreds of species might be collected by the botanist in this vicinity.

The above-mentioned trees and shrubs form together the vegetation of the valleys and lower elevations around the base of Mount Shasta. Some of the species descend to the lcvel of the sea, while others extend up into much higher altitudes.

The great forest belt of the mountain, however, lies higher, at an elevation of from 4000 to 7000 feet above the sea. Of this belt all the most conspicuous trees belong to the family of the Coniferce, and the forests of this region, as well as their continuation along the coast farther north, are unsurpassed, and probably unequalled, in grandeur, by those of any other part of the world. Ten or twelve species occur, but 
the principal effect is produced by eight of them, all of which attain at times a diameter of over six feet, and a height of over 200 , while several are often over 250, and some as much as 300 feet high. These species are:

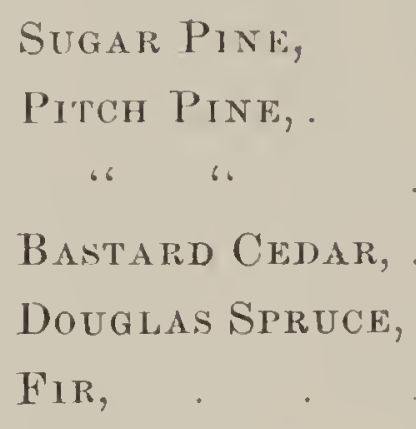

\author{
Pinus Lambertiana. \\ P. ponderosa. \\ P. Jeffreyi. \\ Libracedrus decurrens. \\ Abies Donglasii. \\ Picea grandis. \\ P. amabilis. \\ P. nobilis.
}

Pinus contorta, $P$. Balfouriana, $P$. tuberculata, and two or three species of fir and spruce, besides those named above, also occur; but are not among the common and conspicuous trees.

Of these species the sugar pine is the grandest tree. It occurs at all altitudes between 3000 and 6000 feet; but attains its greatest dimensions between 4000 and 5000 feet, where it is frequently 300 feet high. Its trunk is perfectly straight, its head symmetrical, and from the slightly drooping ends of the horizontal branches, the enormous cones hang down in bunches of two or three, like tassels. One tree, measured by us, was found to be 300 feet high, without a flaw or curve in its trunk, and only seven feet in diameter at the base. These forests are rather open, the trees being seldom densely aggregated; and, owing to the dryness of the air; their trunks are very free from mosses and lichens.

As we go higher on the sides of the mountain; among the forests, we find the pines decreasing in number, while firs are constantly becoming more abundant. Picea nobilis is the predominating species at 7000 to 7500 feet. All the species of firs which are found here are very beautiful. They all attain a large size, are very symmetrical in their growth, and have a very dark-green and brilliant foliage, which is very fragrant. The branches are often very regularly and pinnately divided, producing a most brilliant effect. The color of the sky is perceptibly darker, as seen through this peculiar foliage raised in a canopy so high above the observer. Taken together, the grandeur of the forests, the clear and 
(ieep blue of the sky, and, towering in the background, the mighty snow-corered mass of Mount Shasta itself-these all form a picture of the effect of which no language can convey an idea.

Here and there, the forests are interrupted by large patches of chaparral, locally known as "Devils' Acres." These are sometimes of a square mile or more in areal, and, as seen from a distance, look as smooth and green as the most carefully kept lawn; but the mhappy mortal who should attempt to penetrate one of them, would soon make a personal experience of the propriety of the name, in both its parts. These patches of chaparral are made up of a single species of Ceanothus (C. velutinus?) which forms the densest possible undergrowth, and also occurs seattered through the forests. Generally, however, the woods are quite open, the undergrowth being only sparsely distributed orer the surface.

The forests cease very suddenly at the elevation of about 8000 feet, the trees maintaining their usual dimensions nearly up to this altitude, and then disappearing at once. A Picea nobilis was measured near Camp Ross, at a height of 7600 feet, which was six feet in diameter, although the snow lay quite near in the forests and ravines, at this season, September, 1862, when its quantity was at a minimum. About 500 feet higher, the trees were found to have ceased altogether.

Above this limit of the tree-vegetation on Mount Shasta, a few species still exist as shrubs, and struggle for an existence up to a height of about 9000 fect, or possibly a little more in some sheltered nooks. Of these, a pine ( $P$. allicaulis, or P. flexilis, of the English botanists) is the most important. This species grows, as a shrub, in favorable places, up to 9000 feet, and small trees were seen so compacted by the pressure of the snow on them in the winter, that a man could easily walk orer the flat surface formed by their foliage. The upper part of the mountain is extraordinarily bare of regetation, neither shrub, nor flower, nor even moss or lichen occurring anywhere within a range of 3000 to 4000 feet below the summit. This is perhaps the most marked difference which the botany of this mountain shows, as compared with that of the Alps, or other lofty chains in Europe. The long, rainless summer of California is peculiarly unfarorable to the development of a rich herbaceous vegetation; only the forest trees, with their deep- 
reaching roots, can live through it. Here, on Mount Shasta, we see true forests extending up to where the snow lies, in sheltered patches, through the whole of an ordinary summer; while trees attain a large size in a climate which, taking temperature alone into consideration, would only produce shrubs in Europe. Several species of trees on this momntain, as well as elsewhere in the Sierra Nevada, attain a diameter of four feet in localities where it freezes during nearly every night in the year. The upland pastures, which, in Europe, intervene between the forests and the snow, have no representation in California, nor are any of the Alpine species sufficiently abundant here to form a noticeable element in the scenery. So far as our botanical collections have been examined, the Flora of these upper regions is found to be much more nearly allied to that of the Arctic zone than of the Alps.

The only signs of life on the upper part of the mountain was the "red snow," which was seen over a very considerable area, and chiefly at an elevation of from 8000 to 12,000 feet. In our descent, when the snow was softened by the warmth of the sun, our footprints were of a blood-red color', owing to that low form of vegetable life, called "Protococcus nivalis," and which is so characteristic of the high Alpine regions in other parts of the world.

It was a bright moonlight night when our party made the ascent, the moon being about three days past the full, and we were able to pick our way over the snow without any difficulty; it was quite hard and rough, so that we did not slip on it much, especially as our boots were well provided with nails, which are decidedly better than "creepers." Those who had barometers to carry, of which two were taken up, found a sort of long walking-stick, or roughly improvised "Alpenstöcke," almost indispensable. We also took with us a small supply of eatables, and, what was more important, a large canteen of water, as the quenching of thirst by melting snow in the mouth is highly injurious. It may here be added, as a hint to mountain climber's, that the use of either wine or alcoholic beverages of any kind, when hard work is to be done, is not to be recommended, if our experience can be trusted. We wore thick clothing, and found it necessary at the summit, and not at all inconvenient in going up.

The first part of the climb, until we reached the height of 11,000 
or 12,000 teet, wals very easy, as we did not feel the effects of the rarefied air, and the temperature was low enough to enable one to use his museles actively without sensible perspiration. The ail was still and the moon shone brilliantly on the snow in the gorge up which we were climbing, while the dark clifts on either laand frowned majestically upon us. The most profound stillness prevailed. Our way led up a sort of rarine or gorge between two great buttresses of the mountain, one of which comes down from near the summit in a southerly direction, the other a little west of south. The bottom of this ravine was filled with snow to a great depth; the sides were formed by bare and precipitous masses of black lava, rising in lofty clifts, topped by fantastic pinnacles of the same, hemming us in by a wall from 500 to 1000 feet in height.

The ravine rose at first with a moderate grade, but soon became exceedingly steep, the slope varying from $30^{\circ}$ to $45^{\circ}$. The surface of the snow formed longitudinal furrows, three or four feet in depth, with ridges between, on which we walked, crossing from one to the other, or occasionally picking our way along the edge of the snow, on the fragments of lava which had fallen from above and which the snow did not rise high enough to cover. At daybreak we found ourselves pretty well up the mountain, and the "Red Bluff's," the highest point of the road which was in sight, and which is about 1200 feet below the suminit, appearing to be close at hand, and almost to overhang our path; but hours of hard climbing were required before we should reach it. The angle of elevation of the ravine grew steeper and steeper as we mounted upwards, and the surface of the snow rougher and rougher, so that we were continually edging oft on to the talus of rocks in the hope of fincling relief; but scrambling over the loose blocks of rough lava was found even more fatiguing than slipping about on the snow.

At length, with frequent stoppages for breath, of which the supply scemed to grow very scanty after we passed the altitude of 10,000 feet or thereabouts, we reached, at about 10 o'clock, the "Red Bluffs," a low wall formed by the edge of a mass of rudely stratified volcanic breccia, having a reddish tinge which contrasts strongly with the dark gray, almost black color, of the mass of the mountain, this dark shade being intensified by contrast with the dazzling whiteness of the snow. 
Climbing this wall of rock, which was effected without difficulty, our course was now nearly at right-angles to our former one, and orer a much less steep slope, for a distance of about two miles, which brought us to a rudely circular and nearly level area, evidently the bottom of the ancient crater, along the eastern edge of which rises a broken ridge with very abrupt sides forming the summit of the mountain, and apparently the remains of the edge or lip of the crater. In passing orer the snow-covered slope before reaching the level area, considerable difficulty was experienced in crossing with the barometers orer a wide space on which the snow, here almost icy in its texture, was laid in sharp ridges, running in the direction of the prevailing winds and inclining towards the sun, forming a series of knife-edges, with crevices between deep enough to let one down to the depth of from one to three feet. Across these we had to step as best we could, knowing that a single fall would bring sure destruction to our instruments. The dogs, which accompanied us to the summit, gave most unmistakable signs of entire disgust along this part of the route. However, this difficult, but not dangerous, ground was passed, and the level area noticer above was reached at $11 \frac{1}{2}$ o'clock.

On one side of this flat space, just at the edge of the high wall, the remains of the edge of the crater, there are several orifices from which steam and sulphurous gases are constantly escaping, and around which is a considerable deposit of sulphur, some of it being handsomely crystallized. It is in fact a small solfatara, and the last remains of the once mighty volcanic agencies which have piled up this now extinct volcano to a height nearly 4000 feet greater than that of Etna, the monarch of the Mediterranean.

The summit of the mountain, which is about 400 feet above the hot springs, was reached by all the party before 12 o'clock, and both barometers hung up in safety in a sheltered nook about eighteen feet below the highest point. The cold was not intense, nor was the wind severe. The barometers, after attaining the temperature of the air, remained nearly stationary at 17.658 inches, and the corresponding observations, taken 6800 feet lower down, indicated the same condition at that station. The thermometer freely exposed to the air stood at $27^{\circ}$, and the wet bulb had the same temperature as the dry, a thin 
cloud forming all the time around us and disappearing as it was carried away by the breeze.

The effects of the great elevation were very perceptibly felt by some of the party, resembling in many respects those produced by sea-sickness, and arising certainly in part from nervous exhaustion interfering with the process of digestion. A disinclination to farther exertion after reaching. the summit was decidedly pereeptible in all the party, and one or two exhibited, in their very much darkened complexions and bloodshot eyes, the unmistakable symptoms of congestion. That this condition was due to the system not having had time to accommodate itself to the diminished pressure of the atmosphere was afterwards made evident enough by the fact that, after camping for some weeks at an altitude of from 8000 to 10,000 feet, none of the party experienced any unpleasant sensations in climbing to the height of 13,000 feet, except, of course, that muscular exertion was not so easy with the diminished pressure at that eleration.

The riew from the summit of Mount Shasta is surpassingly grand; but we were not favored with it in its greatest beauty. To have the full effect of the panorama, one should make the ascent in the night, so as to stand upon the summit at sunrise, that being the time when the air is clearest and the effect of light and shade most magical, as was clearly seen by the party which enjoyed the sunrise from Lassen's Peak. Besides this, it was too late in the season when we ascended, and a heavy bank of smoke hung over all the valleys at the base of the mountain. From out of this obscuring veil of mingled smoke and dust, which took off the sharpuess of all objects below 5000 or 6000 feet in altitude, the summit of Lassen's Peak appeared, distant about seventy miles, but seeming to be close at hand and to float on the cloudbank like an inmense iceberg on the ocean. From the summit of Lassen's Peak itself, the same thing was observed with regard to Mount Shasta, except that the mass of the latter being vastly greater, the effect was of course proportionately increased. Next to the view of Lassen's Peak, the most impressive part of the panorama was that presented by the slopes of Mount Slanstal itself, especially those of the east and southeast sides, down which we could see for thousands of feet of almost sheer perpendicular deseent, and over which vast fields 
of snow alternated with jagged, dark ridges and pimnacles of black volcanic rock.

But we were not permitted to enjoy any part of the sublime panorama for a long time, as the clouds began to thicken about us, and soon shut out our view entirely. In the course of the afternoon a light fall of snow took place, which hastened our descent, as we were not sufficiently at home at that altitude to consider ourselves justified in remaining on the summit until it was too late to reach our camp before dark, especially as it was highly desirable for the progress of our work in the vicinity that the barometers should not be broken in the descent.

Learing the summit at about two o'clock, Camp Ross was reached at six without difficulty or accident either to ourselves or our instruments. The snow being considerably softened, the steep slope was descended by a process half way between sliding and floundering, an agreeable amusement for those who had no barometers to take care of, and who were soon far in adrance of those who were thus encumbered. During the night, at camp, a strong wind prevailed, and a snow squall passed over, during which about an inch of snow fell. The next day was much clearer than the one before, a slight fall of rain, the first token of the approach of winter, having in a measure washed away the smoke, and we were strongly tempted to repeat the ascent; but want of time forbade it, and we descended to Strawberry Flat the next day, leaving one of the party at Camp Ross to continue the barometrical observations, in order to fix as accurately as possible the elevation of that station.

We have thus given a more minute description of our ascent of Mount Shasta than we could afford space to do for any other mountain of the many which have been climbed by our parties, in order to show how easy a matter it is, and with the hope of increasing the number of those who may be inclined to attempt this excursion, which even the moderately practised mountain-climber may undertake with success, and which no one who visits California with the idea of becoming acquainted with the noblest features of her mountain scenery should omit.

Some general observations on the form and geological structure of the mountain and its vicinity may be here appended. 
Mount Shasta has been seen by our parties from all sides, and the surprising regularity of its outline and its beautiful conical form have again and again excited our admiration, as they have that of other travellers in this region. As seen from the southwest, however, this symmetry is somewhat broken by the side-cone which rises on the flanks of the main mountain, and almost rivals it in its dimensions. This has never yet been ascended, and is believed by many to be quite inaccessible. Its sides appear to be covered with loose volcanic materials, probably ashes, lying at the highest angle possible without sliding down. As seen in the sky-outline, this angle is from $34^{\circ}$ to $35^{\circ}$. The height of this appendage of Mount Shasta was estimated by us at between 12,500 and 13,000 feet.

The annexed wood-cut (Fig. 44) will show the relation of the sidecone to the main mass of the mountain, and will also exhibit the steep-

Fig. 44.

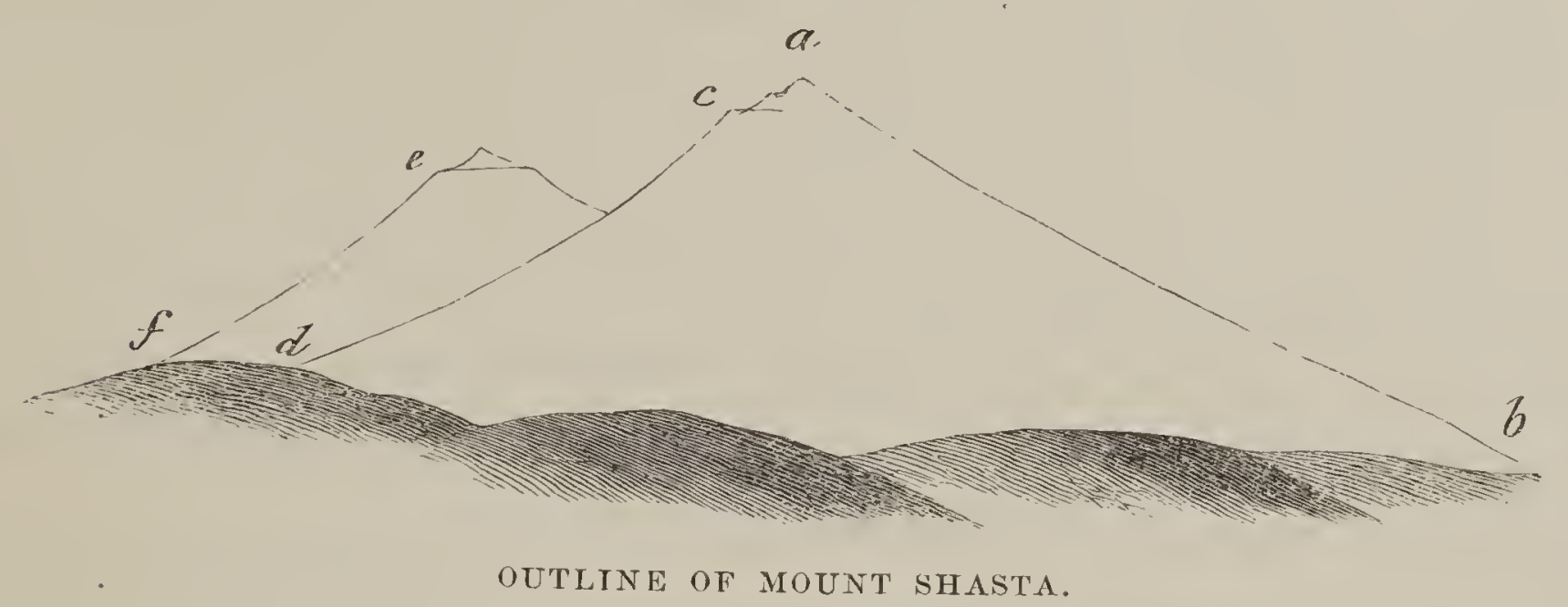

Inclination of $a b, 27^{\circ}$ to $28^{\circ}$; of $c d, 30^{\circ}$ to $31^{\circ}$; of ef, about $36^{\circ}$.

ness of its slopes, as the diagram was constructed from measurements of the sky-outlines with the clinometer. It represents Mount Shasta as seen from Marble Mountain, near Bass's Ranch, fifty-three miles distant, and looking in a direction of $\mathrm{N} .10^{\circ} \mathrm{W}$., magnetic. Although the upper part of the cone is not entirely covered with snow, there being large patches of bare rock on it; yet, as seen from a great distance, these all disappear, and the whole seems to be one continuous sheet of white above the snow-line, which is very distinctly marked. In this diagram, however, the lower edge of the snow is not seen, the intervening hills rising so as to conceal it. The very great steepness of the side-cone is apparent. 
To judge from the views of Mount Hood, Mount Rainier, Mount Baker, and the other rolcanic cones of the Cascade Range, given in the Pacific Railroad Reports, one would conclude that these were all very much steeper than Mount Shasta; but it must be remembered that these were sketched by the eye, and that the tendency to greatly exaggerate slopes of this kind can hardly be overcome by an artist, or by any one not correcting his conceptions by actual measurements. This has been well illustrated by a comparison of the sketch of the volcano of Cotopaxi, as given by Humboldt, and which has figured in all our school geographies and geologies as having a slope of $48^{\circ}$; whon, in reality, as measured on the photographs now easily to be had of this cone, the arerage inclination of its sides is found not as great as that of Mount Shasta in the diagram given above, being in fact between $28^{\circ}$ and $29^{\circ}$, while the greatest angle, near the summit, is only $32^{\circ}$ (see J. D. Dana, in Journal of Science (2), xxxriii, 427). As seen from Lassen's Peak, seventy miles distant, from which Mount Shasta bears $\mathrm{N} .48^{\circ} 30^{\prime} \mathrm{W}$., magnetic, the angle of the east side of this nountain is not less than $35^{\circ}$, and that of the west slope $26^{\circ}$.

Our stay in the vicinity of the mountain was so short, and the difficulty of getting about the more elevated portion of it so great, that only a general idea could be obtained of its geological character and structure. No other rocks than those of volcanic origin were seen, anywhere from the base to the summit of this great mass. In the lower region about the mountain the lava was of a trachytic character, having a fine-grained base, with slender needles of hormblende disseminated through it. Higher up, much basaltic rock occurs, and the orerflows of this material must have been of immense thickness, as the masses have a homogeneous character through a very great vertical range. It was surprising to notice how little of scorix, ashes, or pumice-like materials could be found about the mountain. There is a heary bed of volcanic breccia near the summit, and around the ancient crater; but, with this exception, nothing else than dense and heavybedded lava was seen. Nothing was observed, howerer, which would indicate that this vast pile of igneous material had been formed in any other way than by eruption from a crater-like orifice, while the nearest sedimentary rocks do not show any indications of disturbance, as con- 
nected with an elevation over an area having Mount Shasta for its centre. The subjects of the composition and arrangement of the volcanic materials of this, as well as of other regions in California, must be reserved for another volume, after a thorough examination shall have been made of the many varieties which we have collected.

There are a great number of volcanic cones, more or less regular in outline, seattered over the plain to the northwest of Mount Shasta. These give a very peculiar aspect to the region, and add no little to the impressiveness of the views one obtains of the mountain from the neighborhood of Yreki. One of these conical mountains, which was much higher than any of the others, and which lay close at the western base of Mount Shasta, was so beantifully regular in its outline that we gave it the name of Cone Mountain. It is a conspicuous object from Strawberry Flat, and is no insignificant hill itself, being fully 3000 feet above the level of the surrounding plain, although utterly dwarfed by its proximity to the higher mountain. This conical eminence shows no signs of a crater at the summit, but is covered on the side from which we ascended it (the north) with loose fragments of trachyte, which grow larger as we approach the summit, while at the same time the angle of the slope increases, so that the ascent was very difficult and not a little hazardous. By mistake, the summit was not reached, but the point next west of it (that next to the left hand of the highest peak, in the sketch); it was 2566 feet above the camp at Strawberry Flat, and the highest point was estimated at about 450 feet above this. The annexed wood-cut (Fig. 45) shows the outline of Cone Mountain, without any exaggeration of its slopes, as it is a reproduction of a cameralucida sketch. It is a singularly graceful and beantiful object. 'T'he rock of which this cluster of peaks is composed is a light-gray, rather fine-grained, trachytic material, with occasional small prismatic erystals of hornblende disseminated through it.

For the determination of the height of Mount Shasta, the barometer was exclusively relied on, and the following system of observations was adopted. As in our other measurements of the highest points of the Sierra, it was our object to have some station selected as high up as possible, where a longer series of observations could be had than it would be convenient to make on the very summit of the mountain; of GHOL. VOI. I. -44 
course it would have been desirable to remain there over night; but, with our limited time and means, only a few hours during the middle of the day conld be spent in so elevated a position. But, by having a

Fig. 45 .

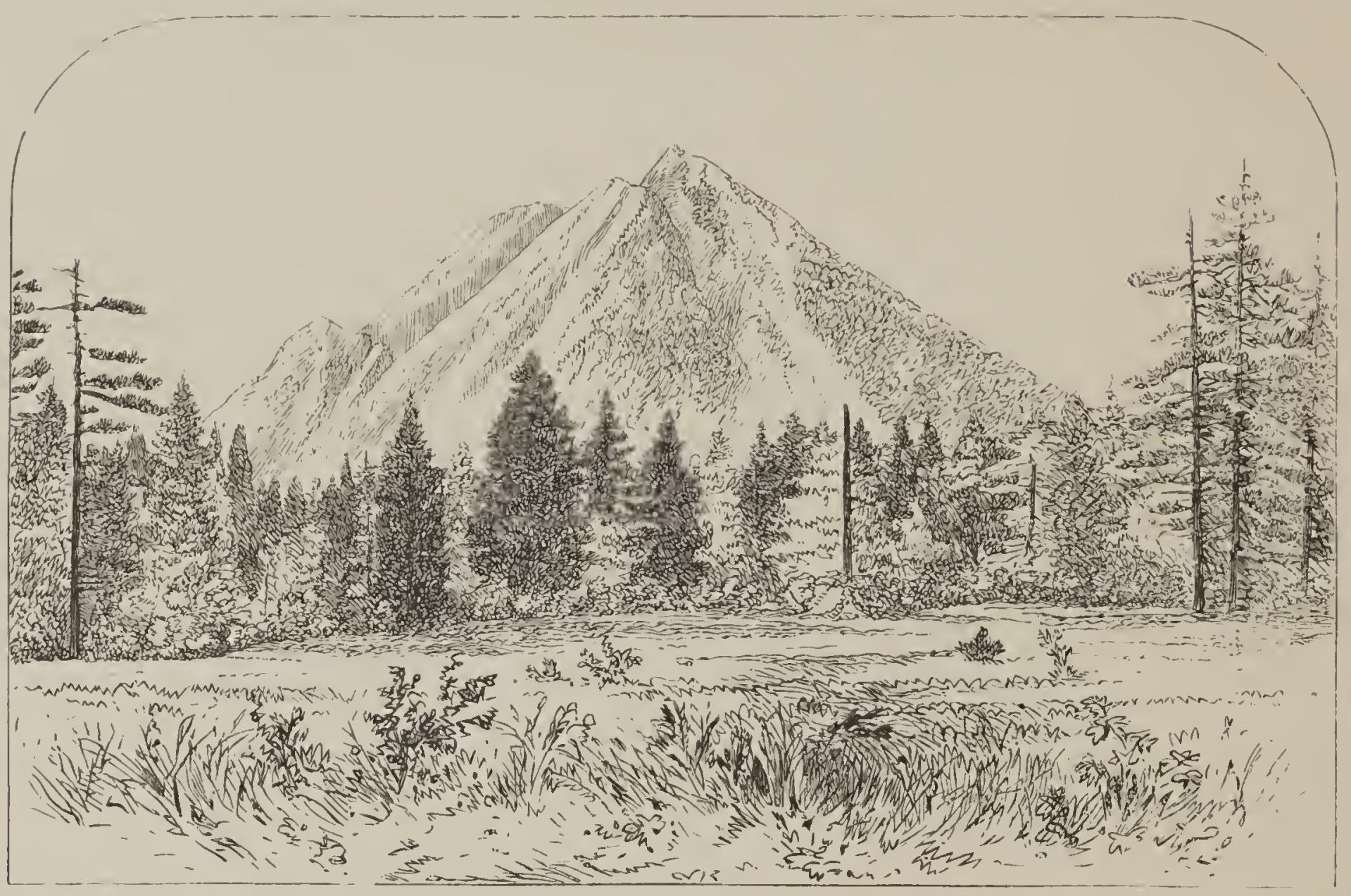

CONE MOUNTAIN.

station as high up on the mountain as possible, of which the height could be pretty accurately fixed from the mean of several days' observations, and by having a barometer stationed there at the same time that one was observed on the summit, the horizontal distance being very small, it is evident that a considerably greater degree of precision would be likely to be attained than if this precantion had not been taken.

During the whole of our stay in the vicinity of Mount Shasta, which was abont ten days, a station-barometer was observed at Shasta City, by Mr. Rémond, at every hour from 7 a.m. to 10 P.m. The next station was at Strawberly Valley, at the base of the mountain, about ten miles firom the summit, in a direct line, and the third one was at Camp Ross, at the base of the snow-line, the elevations of each of these stations being respectively about 1160,3570 , and 7630 feet. The heights of these points were determined by a series of simultaneous hourly 
observations extending over three days at each station. To fix the elevation of Shasta City, stations were selected at two intermediate points between that place and Sackanchto, mamely, Red Bluff and Marysville, the elevation of 1)r. Logan's barometer at Sacrancuto being taken tron Majol Williamson's computations of a long series of observations marle at that eity. The following table gives the results obtained :

\begin{tabular}{|c|c|c|}
\hline Sacramento, & $\begin{array}{l}\text { He-ight abowe next } \\
\text { lower station. }\end{array}$ & $\begin{array}{l}\text { Height above } \\
\text { low tide. } \\
65 .\end{array}$ \\
\hline Marysville, & 78.3 & 143.7 \\
\hline Red Bluff; & 237.6 & 381.3 \\
\hline Shasta City, & 778.3 & 1159.6 \\
\hline Strawberry Flat, . & 2407.8 & 3567.4 \\
\hline Camp Ross, & 4061.6 & 7629.0 \\
\hline Summit Station, & 6795.3 & $14,424.3$ \\
\hline Highest point of Mount Shasta, & 18.0 & $14,442.3$ \\
\hline
\end{tabular}

Or, in round numbers, 14,440 feet above mean-tide.

The direct calculation of the observations at the summit, as compared with the corresponding one at the same hour at Sacranento by Dr. Logan, gave as the height of Mount Shasta 14,401.3 feet, which is a closer approximation than should be expected from observations taken so far apart. In the volume of Physical Geography, forming a portion of the Final Report, the figures given above may undergo some slight modification, after a more complete elaboration of all our barometrical observations shall have been made. Indeed, it is not unlikely that the mountain may be again ascended during the progress of the Survey, in which case Yreka will be made one of the stations, the eleration of this place having been determined by a long series of observations, made by Mr. W. S. Moses, and worked out by Major Willianuson.

At the time that Mount Shasta was visited and ascended by our party, itwas supposed that it was the most elevated point in California, there being nothing then known of the high region of the Sierra Nevada at the head of King's and Kaweah River's, between latitudes $36^{\circ}$ and $37^{\circ}$. It was attempted to be shown, in a paper read before the 
California Acadeny, and published in the second rolume of their Proceedings, that, if Mount Shasta was the highest mountain of the Sierra Nevada and Cascarle Ranges, it was very probably the highest point in the United States. It was pretty satisfactorily made out that Mount Shasta is higher than any of the lofty volcanic cones to the north, namely, Monnts Pitt, Hood, St. Helens, Adams, Rainier, and Baker, although it is the almost universal opinion of the people of Oregon and Washington 'Territory that Mount Hood is much higher than any other peak on the coast. An easy explanation will be found for the exaggerated opinion of the height of Hood as compared with Shasta, in the cireumstance that persons do not ordinarily take into account the higher latitude of the volcanic peaks of Oregon, the greater precipitation of moisture in that region, and the consequently much lower descent of the snow line, which would have a very great effect in biasing the opinion of an unskilled observer, and leading to an overestimate of the more northern summits. The converse of this has happened in the more southern portion of California, where the comparatively small quantity of snow on the Sierra has entirely diverted attention from the great elevation of the range in that region. We may still maintain, as being probably true, and certainly so, as far as actual measurements made up to the present time show, that Mount Shasta is higher than any of the volcanic peaks to the north, in the Cascade Range, although inferior in elevation to one or more of the great granitic masses of the Sierra Nevada in the central part of the State.

In regard to the height of Mount Shasta as compared with that of the loftiest peaks of the Rocky Mountain Ranges, some additional light has been given by the valuable series of observations made by Dr. Parry, in 1862, elaborated by Dr. Engelmann, but not published until May, 1863 (see 'Trans. Acad. of Science of St. Louis, Vol. II, page 120). From this paper it appears that Pike's Peak has an elevation of 14,216 feet above the sea, and that Gray's Peak, southwest of Empire City, is 14,245 feet. 'This last is the highest point yet measured in the Rocky Mountains, so that Mount Shasta, as yet, maintains its supremacy over the peaks of that region. But Dr. Parry states that he is confident that there are summits in the Rocky Mountain chain still higher than those measured by him, and which may reach 
15,000 feet or more. Te does not, however, specify where these lofty peaks are situated, or give the reasons for supposing them to be 15,000 feet or more in elevation. No doubt, since Colorado is so rapidly increasing in population, we shall have before long a more extended series of observations, and possibly the lofty summits of the Sierra may have to yield the palm to the more eastern peaks. It should be remembered, however, as Dr. Engehnamn himself does not fail to notice, that a considerable element of uncertainty enters into the results obtained by observations with a single barometer, calculated with reference to a station separated from it by fifteen degrees of longitude. It is to be hoped that, if not already done, one or more permanent barometrical stations will soon be established at the base of the Rocky Mountains, furnished with carefully compared instruments and good observers, so that it may be possible for future parties seeking for Dr. Parry's 15,000-foot peaks, to refer their observations to a base near at hand, of which the elevation may have been fixed by at least a series of a year's duration.

Previous to the measurements of the Geological Survey, there had been great uncertainty in regard to the height of Mount Shasta. It had been variously estimated at from 14,000 to 18,000 feet. Lieutenant Wilkes, of the Exploring Expedition, says "it is said to be 14,350 feet; but Lieutenant Emmons thinks it is not so high." Where these figures and those given by other authorities, especially the editor of "Colton's Atlas" and the author of the article "California," in the "New American Cyclopæedia," came from, namely, 14,390 feet, we have been entirely unable to ascertain. It is certainly a very close approximation, but whether a lucky guess, or the result of some measurement of which the record cannot be traced, we are unable, at present, to state. Naturally enough, the general opinion in California was, that the mountain was much higher than our measurements have made it; just as now Mount Iood is firmly believed, by many, to be from 17,000 to 18,000 feet high, although the only actual measurement made of it, a rough one, no doubt, puts it at 11,934 feet.*

Having devoted as much space as seems proper to Mount Shasta

* See Proceedings of the California Academy of Natural Sciences, vol. ii, page 221. 
and its vicinity, we will next take up the region on the north side of it, following the route of Messrs. Brewer and King to Treka.

About four miles north of Fort Crook, Fall River has its souree in a few very copious springs, the main river issuing from a single one. This is a characteristie feature of the region near the high lava cones, and was noticed in an eminent degree abont Lassen's Peak. The water sinks about the summits, and issues at a lower altitude from between the lava flows. On both the northern and southern slopes of Lassen's Peak, especially the former, there are numerous very copions springs of this character, between the altitudes of 6000 and 7500 feet; but neither springs nor streams were observed above the last-mentioned height. They occur also both north and south of Mount Shasta, the source of Fall River on the southeast of the mountain being the most marked. On the north side, near Hurd's Ranch, in Big Shasta Valley, the Shasta River issures in the same way from the rocks, as a large stream.

In going northwest from Fort Crook to Yreka the road passes over a plain to the New York Ranch, twelve miles from the mouth of Fall River, and there begins the gentle ascent of the great lava tables which lie along the southeastern flank of the mountain. The rock is generally basaltic, that near the surface of each flow or lava stream being often porous. It decomposes and forms a loamy soil, which supports a growth of rather heavy timber; but in places where the soil is thinner and consequently drier, the trees are replaced by chaparral. But few streams flow over these lava slopes; most of the water sinks, and issues in large springs below; in consequence, grass and forage are not abundant over this region, except on occasional moist grassy flats.

Elk Valley is barren, the soil being a volcanic sand, supporting a scattered growth of low shrubs, chiefly Linosyris. It has an altitude of 3751 feet, and may be considered as the base of the cone of Mount Shasta. The views of that mountain from this valley are among the grandest, if not the very finest, which can be had. It bears from here N. $58^{\circ} \mathrm{W}$, and has the form of a perfect cone, both slopes being very steep, as seen in the sky-outline, and the line of vegetation very distinctly marked, extending above the lowest of the snow-banks, even on this side. 
A resident hunter states that there are extensive caves under the lava near Elk Valley. He had never explored them fully, but describes them as similar to those of Hat Creek. He also stated that glacial markings occur on Mount Shasta, along its eastern and southeastern slopes, at the upper edge of the timber, where he describes the scratches and polished surface as existing on an extensive scale. He also mentioned that similar phenomena were to be seen on the high peak east of Mount Shasta.

From Pilgrim Camp to the summit of the pass is about twelve miles, the ascent being a gentle one up the lava slopes, and the summit broad, the road passing for about two miles over a nearly level plateau. The highest point is about N. $53^{\circ} \mathrm{E}$. of the summit of Mount Shasta. From this plateau the views of the mountain are grand in the extreme, the slopes appearing very steep and the apex exceedingly sharp. Large fields of snow extend downwards for 6000 feet below the summit, broken by enormous fissures, like the "crevasses" of the glacier's; there are extensive slopes lying at an angle of from $30^{\circ}$ to $40^{\circ}$, too high an angle for the snow to remain without becoming extensively fissured, although no real glaciers are formed, as there would be, undoubtedly, if rain and snow fell during the summer.

At the elevation of the summit of the pass, which is about 6300 feet, the sky was of the most intense blue, and a few light clouds were observed clinging to the summit of the mountain. From the pass, the descent to Shasta Valley is more abrupt than it was on the south; the rocks, however, are of the same character' on both sides.

Under one of the tables of the north slope of the pass there is a cavern known as "Pluto's Cave;" it is about four miles north of Hurd's Ranch. The surface of the lava table in the vicinity of the cave has a gentle slope to the north, is very rough, and is raised into numerous domes or "blisters;" the soil upon it is thin and dry. The cavern is a long gallery extending under this table, now open for about a mile in a north-northwest direction. Near the entrance the roof has fallen in several places; but, otherwise, the gallery is continuous, and it has a width varying from twenty to fifty feet, the height being in some places as much as sixty feet. Throughout most of its extent the cavity is beautifully arched, having a section resembling that of an egg 
set up on its smaller end. The rock at the top and sides often has a concentric structure parallel with the sides of the arch. In places there are considerable quantities of spongy lava, which seems to have oozed from the sides in a frothy state. The whole appearance of the place is that of a cavity produced by the flowing out of the liquid lava after the sides and top had become consolidated. The gallery doubtless extends much farther, but the north end has become blocked up by fallen rock.

Shasta Valley, on the north side of Mount Shasta, like the Pitt Valley, is a lava plain, and most of it rather barren, although there are some fertile spots on it. It has an altitude of 3087 feet above the sealevel. Rising from this plain are an immense number of conical hills of volcanic materials, most of them but a few hundred feet high; they give the region a very peculiar and striking appearance.

In the vicinity of Yreka, on the western edge of the Shasta Valley, are low hills of sandstone, of which the strata are horizontal, or have a low dip east towards the plain. These sandstones rest on the edges of the auriferous slates which lie west of the valley; they are very coarse, and have beds of conglomerate interstratified with them. These rocks are probably of Cretaceous age, although no fossils were found in this immediate vicinity.

On passing to the northeast of Yreka, the sandstones interstratified with shales again occur, about six miles from town, and they extend from here nearly to the Klamath River. They are probably continuous to Cottonwood Creek, but they are covered for a part of the distance with an overflow of lava. Cretaceous fossils are abundant six to ten miles northeast of Yreka, where the strata have a low dip under the plain, and appear to be covered with the rolcanic rocks farther east. In two places well-defined dykes of basaltic lava were observed cutting these strata; they were but a few feet thick, and the shales were scarcely altered along the line of junction, although the stratification was somewhat disturbed. Before reaching the Klamath River, the road from Yreka passes among hills of basaltic lava, which cuts through the sandstones, and rises in considerable elevations, having in places a columnar structure. At the river, near the ferry, the lava is 
seen in places to have had a decided metamorphic action on the arjacent stratified rocks.

Cottonwood Creek runs nearly south from the summit of the Siskiyou Mountains to the Klamath River, a distance of about thirteen miles. The valley, which is about ten miles long, is excavated in the softer and unaltered Cretaceous strata, having on either side harder rocks, namely, the auriferous slates on the west, and the modern volcanic on the east. About a mile from the mouth of the valley is the town of Cottonwood (officially known as Henley), and a section was examined across it at this point.

On the west of the town, the mountains of auriferous slate rise to the height of 3000 feet above the valley, or about 5000 above the sea. Resting on these unconformably, are fossiliferous Cretaceous strata, which extend up as high as 1800 feet above the valley; the relative position of these rocks may be seen in the ravines called Rancherie Creek and Rocky Gulch.

The auriferous slates are much contorted, but generally stand nearly vertical, and contain a narrow belt of limestone, which is well seen in the cañons. Resting on the edges of these slates, are coarse conglomerates in thick beds, then follow sandstones, some beds of which are highly fossiliferous, the fossils not being, however, in a very good state of preservation. Ascending in the series the conglomerates almost cease, the sandstones become less abundant and shales take their places. It is in these shaly strata that the most of the Cottonwood Valley is excavated; they are occasionally cut by a few dykes of lava. On the east side of the valley, as we rise in the series, we observe a great thickness of shales and sandstones interstratified with each other. These rocks contain but few fossils, except silicitied wood, which is abundant in certain strata. The shales sometimes contain concretions, or imperfectly formed beds of argillaceous limestone, resembling the hydraulic cement-rock of the Cretaceous series in the region farther south. As we ascend the hills to the east of the valley, and at the same time rise to higher beds in the geological order of succession, we find the latter more and more disturbed and cut by injections of lava and finally covered by it. Near the junction, and along the hills where the metamorphism commences, the shales contain much silicified wood, GEOL. VOL. I. - 45 
of which many specimens are most beautifully preserved. No detailed examination has yet been made of these fossil woods, but the Coniferce and the Plantanacere appear to be best represented among them. Some

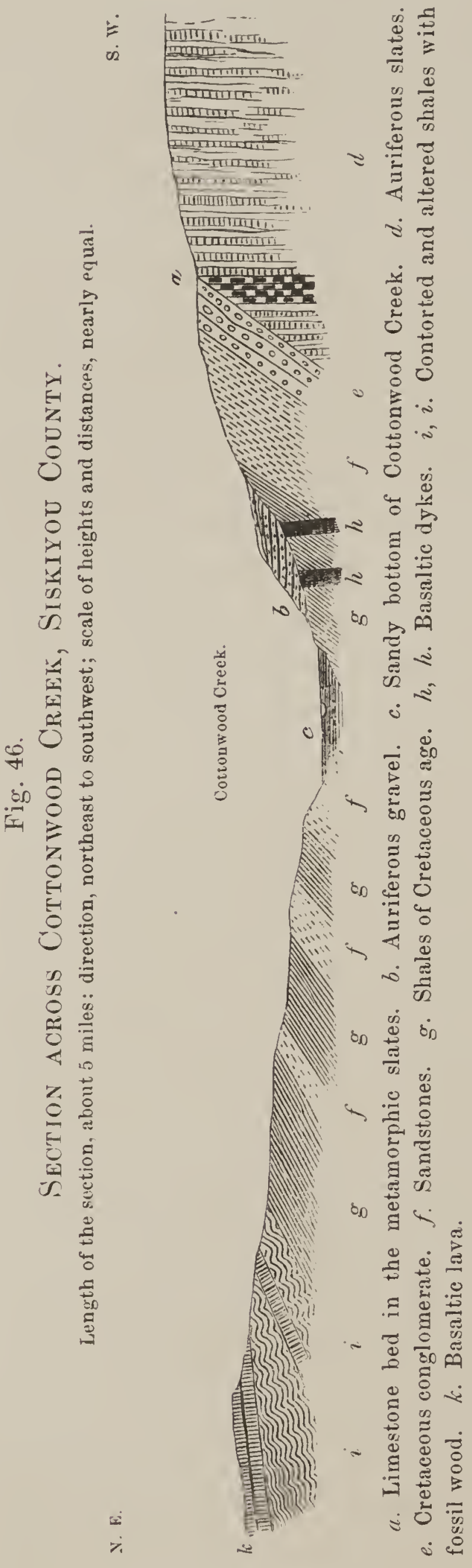
of the strata containing the fossil wood are so much altered that it is difficult to see how the organic structure of the regetable matter can have been preserved. These are succeeded by beds in regard to which it is difficult to say whether they are of eruptive or sedimentary origin; some of the strata appear to be made up of a volcanic breccia, and yet contain fossil wood. Above the whole of this assemblage of beds is a covering of basaltic lava, extending east for a great but unknown distance. It connects on the southeast with the great volcanic belt of Mount Shasta.

The annexed wood-cut (Fig. 46) will give an idea of the section which has just been described. The dip of the fossiliferous rocks is to the northeast at an angle of from $15^{\circ}$ to $35^{\circ}$.

In passing up the valley of the Cottonwood, the Cretaceous rocks are found to be everywhere disturbed, the strata being much broken and sometimes cut by volcanic dykes; the dip is generally to the northeast. On ascending in the series, and at the same time rising on to the Siskiyou Range, the sandstones become softer, and have a smaller dip to the east, generally less than $20^{\circ}$. Near the summit of the pass, we cross two belts of metamorphic rock cutting the sandstones having the appearance as if the strata 
had been fissured and had then undergone alteration along the lines of the fissures, in the mamner indicated in the accompanying wood-cut (Fig. 47). These belts of altered rock $(b, b)$ run northwest and southeast, nearly parallel with the strike of the strata $(a, a)$; they are interesting as illustrating the manner in which metalliferous veins begin to be formed in sedimentary rocks. Had the thermal

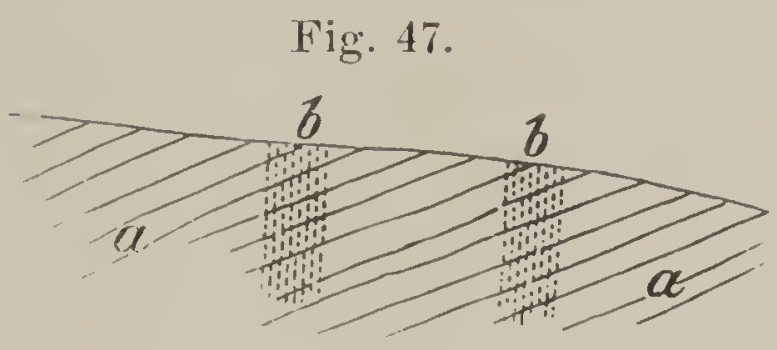
waters by which these changes were effected been impregnated with metallic salts, we should have had here a metalliferous deposit of more or less extent and value, according to the character of the solution and the length of time the operation was permitted to go on without permanent interruption.

At the head of Cottonwood Creek, the Siskiyou Mountains rise to the height of from 5000 to 6000 feet, and a few miles farther west there is a peak which is probably over 7000 feet high, as it has patches of snow on it during the whole summer. A point was ascended in this range, which bore S. $28 \frac{1}{2}^{\circ} \mathrm{W}$. from Mount Pitt, and N. $26^{\circ}$ W. from Mount Shasta. This commanded a wide view. The Cretaceous sandstones appeared to pass through the chain, a short distance east of the pass, and then to extend far northwest into Oregon, forming a table west of Mount Pitt, deeply cut by cañons, and mostly destitute of forests. It is not impossible, however, that this is a volcanic belt. Rising above and beyond it is Mount Pitt, a more regular cone than any seen in California, among the highest mountains; its sides are very steep and apparently covered by loose detrital materials, such as ashes or cinders. The upper limit of trees is most beantifully marked upon it. It appears to be about 10,000 fect in height. The annexed wood-cut (Fig. 48) shows the outline of this cone, with the exact angles of the sides, as measured by the clinometer. The eastern slope makes an angle of $23^{\circ}$ with the horizon; the western of $26^{\circ}$.

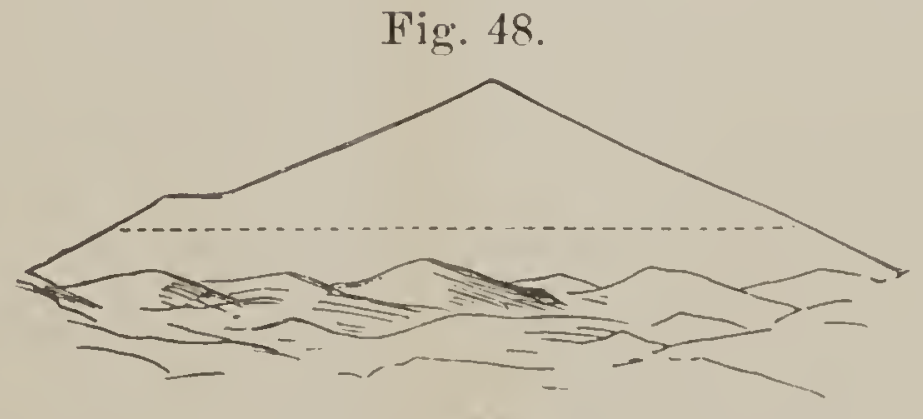

OUTLINE OF MOUNT PITT.

The crest of the Siskiyou Mountains is of fine-grained granite, with some hornblende disseminated through a portion of it. In some places 
it is quite destitute of mica, being entirely made up of quartz and teldspar.

A rapid reconnaissance was made of the region between Yreka and the Pacitic coast, Messis. Brewer and King passing over the principal roads or trails, by way of Deadwood, Fort Jones, Scott's Bar, Happy Camp, Waldo, Rockland, and Altaville, to Crescent City.

Directly west of Yreka the mountains rise rather abruptly and are much furrowed by deep cañons. They consist chiefly of the auriferous slates, evidently a continuation of those of the Sierra Nevada proper. Near the town the slates contain two beds of metamorphic limestone, much contorted and of a slaty character. The slates and limestones have a general strike nearly north and south, and a high dip to the east, and both rocks contain quartz veins. Placer-mining is carried on extensively in all the cañons and gulches. The same kind of rocks, with the same dip and strike, are seen in passing up Greenhorn Creek, and quartz veins are numerous. Until lately, these have had but little attention paid to them; but they will, very probably, repay a careful prospecting.

From Greenhorn Creek, the road crosses a low pass to Cherry Creek, in travelling down which, in a southwest direction, the Samon Mountains were seen in front; these are very high and rough, and have patches of snow on their sides. The rock was everywhere of the auriferous slate formation, large masses of which dipped to the west, however. Below Deadwood, where the cañon widens, the gravels are deeper, and in places are worked by tumnelling.

From Fort Jones the party travelled north, down Scott Valley, for a distance of five or six miles. This is a pretty and fertile valley, surrounded by high mountains; those on the west side are grandly furrowed, and retain large patches of snow through the summer. The trail then crosses a high ridge, at least 2000 feet above the river, which finds its way through a very deep and steep cañon, impassable for a road. The crest of the mountain is of granite, which is flanked by mica-slate and other metamor'phic rocks. Scott's Bar was formerly a locality of very important placer-mines; but they are now mostly worked out, although considerable mining is still carried on at intervals. The slates are very much contorted, and are traversed by quartz veins; the dip of the rock 
at the crossing of the river is to the southwest. The bar is three miles above the mouth of Scott's Creek, and the intermediate space between this place and the Klamath is occupied by granitic and metamorphic rocks. At one-fourth of a mile north from the town the granite begins, and extends one mile; mica-slates then occupy the space to the river, while the high mountain on the west is of granite. The micaslates continue down the Klamath for some miles; at the mouth of Scott's River they have a strike of N. $20^{\circ} \mathrm{E}$., and dip to the west; three miles further on they run N. $35^{\circ} \mathrm{E}$., but have the same westerly inclination. Below this they become irregular, and in some places have a gneissoid character. All the streams which issue from the mountains to the north bring down almost exclusively granite boulders, and the ridges which lie between Scott's River and the Klamath, and west of the former, are very steep and high and have some patches of snow on them. The bottom of the cañon of the river is at least 5000 feet below the summit of this range, and the slopes exceedingly steep. Rich placers were formerly worked along this portion of the Klamath, but they are now nearly exhausted, and the town of Hamburg, which a few years ago was an active mining-camp, is now deserted by white men and its site occupied by the huts of the Indians.

About nine miles below the mouth of Scott's River, the Klamath strikes the granite, and flows over this rock for four miles. This belt of granite stretches across the river and appears to connect with the granitic centre of the Siskiyou Mountains on the north and with that of Scott's Mountain on the south. The cañon of the Klamath is narrow and without any bottom-land, except at Reeves's Ranch in the Sciad Valley. Here, at an angle in the river, the Sciad Creek comes in and there is a fertile patch of about 150 acres, this being the most valuable ranch along the river for more than a hundred miles.

Just north of this place are three prominent peaks of the Siskiyou Range, known as the "Three Devils," one of which was ascended and ascertained to be 3746 feet above the ranch, and about 5000 feet above the sea. It was examined on the south side and found to be made up almost entirely of mica-slate, with a northwest and southeast strike. Other peaks were seen from the summit, some of which are still more elevated than the one ascended. One in the immediate vicinity 
was estimated at 6000 feet above the sea, and there are still higher ones to the southwest of the Indian Valley Pass. The summit of the Three Devils is entirely of granite, cut by enormous veins of the same rock, but of a lighter color; this granitic mass appears to extend to the northeast as far as the pass at Cottonwood Creek, on the Jacksonville road. Along this line there is a wilderuess of peaks, many of which are higher than the Three Devils, a great number being from 6000 to 7000 feet high, and some between 7000 and 8000 . There is no appearance of volcanic rocks in this chain. To the southeast, between the Three Devils and Yreka, sharp ridges are seen, which appear to be from 5000 to 6000 feet high and are chiefly made up of slates. Scott Mountains, between Scott's and Klamath Rivers, and west of the former, are supposed to be from 6000 to 7000 feet high; they have patches of snow on them through the summer.

The Sciad Creek has a valley or cañon; which may be traced some fifteen or twenty miles in the direction of $\mathrm{N}$. $56^{\circ} \mathrm{E}$, and another creek comes in from an exactly opposite direction; heading far back in the mountains south of the Klamath.

There is a group of very high and rugged mountains northwest of Happy Camp, belonging to the Siskiyou Range. The culminating points of these are probably nearly 8000 feet high, as extensive patches of snow remain on them during the whole summer. One double peak is especially conspicuous, and is plainly visible from the sea-coast near Crescent City. At the head of Indian Creek, between that and Sailor Diggings, or Waldo, there is a very considerable depression in the chain of the Siskiyou Mountains.

The whole of the region about the junction of Del Norte, Siskiyou, and Klamath Counties is highly impressive in character, from the evidence it exhibits of having undergone an immense denudation. The great body of the mountains has been lifted up to a height of from 6000 to 8000 feet, not in one continuous chain, as in the Sierra Nevada, but in a number of irregular and independent masses, and these have been so cut up and furrowed by the action of denuding forces, as to leave a labyrinth of sharp ridges and peaks, separated by deep cañons, cut down to a depth often as great as 5000 or 6000 feet, a large part of which can only have been formed by the gradual wearing away of the 
rock, which once occupied the space between the walls of these stupendous ravines.

The slates of these mountains are universally auriferous, and placers exist in very many of the cañons. Quartz-mining has been but little attended to here as yet, owing probably to the roughness and inaccessibility of the region. In passing down the Klamath, from Reeves's Ranch to Happy Camp, after leaving the granite we strike mica-slates, which soon pass into the ordinary silicious and clay slates of the Sicrra. They have a strike of about northwest and southeast, and dip sometimes to the northeast, and sometimes in the opposite direction. The distance from Reeves's Ranch to Happy Camp is called eighteen miles, and the slates are seen along nearly the whole route.

From Happy Camp, the road strikes north to Waldo or Sailor Diggings, thirty-one miles distant; it is about twenty-one miles to the summit from the Klamath, by the trail. The road follows up Indian * Creek for fifteen miles, the rock being all metamorphic slate, often very hard and finely laminated. These slates are traversed by quartz veins, and placer-mining is carried on all along the creek. The mountains on either hand are well timbered, more so than the foot-hills of the Sierra, there being a large proportion of oaks and other trees not belonging to the Coniferæ; there is, however, much pine, fir, and cedar. The chestnut, or chinquapin (Castanopsis chrysophylla), abundant on the Sierra as a bush, becomes, on the Siskiyou Mountains, a tree one and a half feet in diameter and from forty to sixty feet high.

Towards the highest point of the road, the metamorphic slates begin to give way to altered sandstones, and some serpentine and talcose rocks occur. These are all so irregularly disturbed and upheaved, that no satisfactory idea of their general position could be obtained. The summit of the pass is 5434 feet above the sea. The rocks here are metamorphic, but granitic peaks rise much higher on both sides; those southwest of the pass are very high and rugged. Two peaks, bearing S. $20^{\circ} \mathrm{W}$. and S. $24^{\circ} \mathrm{W}$., appear to be fully 8000 feet high, and have large fields of snow upon them through the year.

The descent from the summit of the pass to the head-Ivaters of the Illinois River is quite steep, and over metamorphic rocks with much serpentine, granite boulders occurring in the stream. Placer-mining 
begins from 1000 to 1500 feet below the summit. About Sailor Diggings were formerly very rich placers, and they are not yet exhausted. It is stated that a nugget worth $\$ 3100$ was obtained a few years ago on Althouse Creek. A quartz-mine, known as the Enterprise, is worked about eight miles east of Sailor Diggings. The vein is welldefined, with smooth walls, from eight to eighteen inches thick, and runs N. $10^{\circ} \mathrm{E}$., dipping to the east at an angle of $50^{\circ}$. It is included in the metamorphic sandstone. The quartz is said to yield $\$ 26$ a ton as worked by arrastras; but it is reported as having been shown by assay to be much richer.

In this vicinity are enormous masses of serpentine, in places stained with copper, and we were told that a heavy vein of copper pyrites occurs four miles southeast of Waldo, Specimens of the ore were seen, in massive pieces, but apparently not of a high percentage. The cost of getting the ore to market from this region will operate as a serious drawback to the development of these mines. Between Waldo and the Enterprise Mine there is a plain or basin, which is excavated in the slates, and is six or eight miles across; it is covered with gravel, some of which has paid well when washed for gold, although the richest deposits are in the gulches and smaller basins that surround this. These mines are in Josephine County, Oregon, the State line crossing between the summit of the pass and Waldo.

From Waldo there is a road to Crescent City, where the business of this region is transacted, the distance in a direct line being about thirty-five miles, but called sixty by the road. In passing across the valley of the Illinois River, which is five or six miles wide, a dyke of eruptive basaltic rock was observed cutting the slates; this was the only rock of the kind seen in this region.

Between the valley of the Illinois River and the coast, there is a great table or plateau, between 3000 and 4000 feet high, with a gentle slope to the west, but cut up by innumerable cañons, so that only sharp ridges remain to indicate its original level; this, of course, is a very rough and difficult country to travel over. The rock is almost exclusively of a magnesian character, serpentine predominating. Where the road crosses this table, between the Illinois and Smith's Rivers, it has an altitude of about 3800 feet, and from the summit there is a wide 
view in all directions, extending east and west from Mount Pitt to the ocean. From this point the Siskiyou Mountain ranges present a very rugged appearance; these are almost entirely unknown, both geographically and geologically. It is stated by explorers that the higher summits are of granite, but that mica-slate and other metamorphic rocks occur high up on their sides.

The elevated plateau-like region of serpentine and other magnesian rocks appears to have been formed from the metamorphism of the sandstones. The rock supports a shrubby vegetation, with scattered trees, the soil being very red and ferruginous. In some places the stratification of the mass is preserved, and the general strike appears to be northwest and southeast. Small patches of soft granite were noticed about twenty miles from Waldo, and a volcanic dyke was seen near the Rockland copper mines. The cañons by which this mass of metamorphic rock is cut up are very deep and have steep sides, many of them being over 2000 feet, and that of the north fork of Smith's River, at Rockland, over 3000 feet below the general level of the region. These tremendous gorges seem here, as elsewhere in the State, to have been formed exclusively by aqueous erosion. After passing this, the same character of country continues, the rocks being almost entirely magnesian, and containing a great deal of chromic iron, which weathers out on the surface like grains of shot, and is called by the people in the vicinity "iron shot." Before reaching "Low Divide," which lies between Hard Scrabble Creek and Rowdy Creek, a belt of slates, shales, and sandstones, is passed; these rocks cover a width of three or four miles. They are but little metamorphosed. All the cañons and gulches in this vicinity are reported to contain gold, and, in many cases, they are, or have been, worked with profit. This belt of auriferous rocks stretches away to the northwest, and forms a chain of peaks with a very ragged outline, rising rapidly in that direction; but to the south it appears to lose itself in the magnesian belt. Near Low Divide, the serpentines commence again and continue for several miles to the west. Along in a line north and south from the Low Divide there are quite a number of copper claims and places where mines have been opened and worked for this metal. There is also a GEOL. VOL. I. -46 
cupriferous district tour or tive miles farther east, near the north fork of Smith's River, called the Rockland District.

The Rockland District is about twenty-four miles in a direct line from Crescent City, and thirty-five by the road, this being as direct a course as the topography of the country will allow. These mines were discorered in 1863, and a great many claims were taken up at that time, over a belt several miles long and running in a direction of X. $28^{\circ} \mathrm{W}$. In this line of outerop, and for a distance of over nine miles, masses of vitreons copper ore have been found at short intervals. The "Diamond Mine" had done the most work in 1863, having shipped nine tons and taken out as much more of very rich ore, chiefly vitreous copper and red oxide, although native copper and the carbonates are also found. One piece of native copper found here is said to have weighed over 100 pounds. At the "Cruikshank Mine" the same ores occur as at the Diamond, with more magnetic oxide of iron and also large masses of native copper; one of 235 pounds was found during the time of the visit of Professor Brewer, and another of 300 to 400 pounds was reported.

Nearly parallel with these outcrops, on the east side, a volcanic dyke runs, and is very conspicuous a short distance east of the Ruby Claim. It approaches the copper lode nearest at the Cruikshank Mine, and diverges from it in both directions from this point. At the Diamond Mine, it lies about one-third of a mile east, and is several hundred feet thick. It contains large crystals of hornblende and feldspar, and is generally very hard.

The Alta mining district, of which the mining camp of Altaville, at the Low Divide, is the centre, is about fifteen miles northeast of Crescent City, in a direct line and twenty by the road. A considerable district here is covered with claims; but, owing to a variety of opinions as to the direction of the lode, there is much confusion in their location. Some twenty-five different companies were at work in this district in the autumn of 1863 , either mining or prospecting. The mineral channel or lode appears to run nearly north and south, and there would seem to be two or more parallel veins. The Alta Mine was, in 1863, the most important, having been the first one worked, and having furnished over three-fourths of the ore shipped from the county up to that 
time. The workings were then about 240 feet deep, and more or less nre had been taken out all the way down, the lode varying in width from an inch to seren feet. The wall-rock is serpentine, and white talc accompanies the best deposits or bunches of ore. Near the surface, large quantities of the carbonates were found, and lower down, a darkcolored ore, which seems to be a mixture of various sulphurets and red oxide, yielding quite a high percentage of the metal, as is evident from the returns of the shipments, which had, in 1863, amounted to about 400 tons, yielding from 18.4 to 57.8 per cent. of copper.

In 1863, seven companies had made shipments from this region, amounting in all to somewhat over 600 tons, as nearly as could be ascertained. How far these mines can be relied on for permanent working, at considerable depth, remains to be seen from future developments. There can be no doubt that the surface indications are of an important character, and such as would justify and require careful explorations. The quantities of ore obtained in this region are certainly such as would indicate the existence of an important copperproducing district in Del Norte County.

From Altaville to Meyer's, about three miles west, serpentine continues to be the prevailing rock; but west of Meyer's, to Crescent City, other metamorphic rocks are met with, of which the exposures are few, the soil becoming deeper and supporting a heavy growth of timber. Near the base of the hills slates are seen, much contorted and dipping northeast, and along Smith's River they resemble the auriferous rocks of the Sierra.

At and north of Crescent City, a plain stretches along the ocean for about twenty miles, having a width of six or seven miles in places. The metamorphic slates make their appearance along the beach, as is well seen about four miles to the east of the town, where the sea washes the base of the hills. These slates continue south to the mouth of the Klamath River, where, as we are told, there is an entire change in the character of the formation, the metamorphic rocks of the Coast Ranges coming down to the sea at this point and extending along the shore far to the south. The auriferous slates crop out in reefs and on the main land near Crescent City, forming the promontory near which the town is built, and they extend north for a mile or more, where they disappear under a covering of Tertiary sandstone. 


\section{CHAPTER X.}

THE HIGH SIERRA.

\section{Section I.-Preliminary Remarks.}

Having, in the preceding chapter, taken a rapid view of the geology of the mining region of the western slope of the Sierra Nevada, we pass now to a description of the general features of the High Sierra, by which term we understand that portion of this great chain which lies above the metalliferous belt just described, forming the crest of the range, and the water-shed between the streams flowing west to the Pacific Ocean and those which find their way eastward into the Great Basin, or some subordinate one, where they are lost by evaporation. It is, however, the central portion of the Sierra to which this chapter will be especially devoted, for although the range extends along the entire length of the State, yet the most elevated and important part of it is that which lies above and to the east of the principal mining counties, or between the parallels of $36^{\circ}$ and $39^{\circ}$.

It is in the central region of the State that this chain of mountains exhibits the greatest simplicity of structure, both topographical and geological, and it is here that it rises to its highest elevation, forming, so far as we know, the grandest mountain mass of the North American continent. The culminating points of this range lie between the parallels of $36^{\circ}$ and $37^{\circ}$, and towards its southern end farther south the chain sinks down very rapidly, while it also declines in elevation, although much more gradually, as we pass north from the 37 th parallel.

Our researches have not yet been sufficiently extensive to justify the attempt to give a systematic description of the Higher Sierra: but we can present the results of a rapid reconnaissance of this chain, in the course of which we have crossed over nearly all the passes of importance, and have climbed to the summits of a great number of the most prominent peaks. Thoroughly to study out and lay down on a map the details of this vast mass of mountains will require many years of the severest labor. 
For convenience in the present chapter a geographical order will be followed in the description of the High Sierra, beginning at the southern end of the range, and proceeding towards the north. Should the proposed volume of Physical Geography ever appear, many things which are here only briefly mentioned will be more thoroughly elaborated, after a sufficient store of observations shall have been accumulated to make this possible. The candid reader of this volume will not fail to bear in mind that we have in the Sierra Nevada a chain of mountains nearly as extensive as the Alps, forming a portion only of the region confided to us for examination; and, when we consider that the number of Alpine explorers and of the published volumes of their results may be counted by the hundreds, their researches extending over nearly a century, we feel that we need not apologize for the imperfections of our work, believing, as we do, that we have done the best which our time and means have permitted.

\section{Section II.-The Region about the Head of Kern and King's Rivers.}

During the summer of 1864 an expedition was planned for a reconnaissance of an entirely unknown region of the Sierra Nevada, namely, the higher portions of this great range lying between the Yosemite trail to Mono Lake, on the north, and Walker's Pass on the south. The glimpses of the high peaks of this portion of the Sierra, obtained during the clear winter weather, from Mount Bullion, on the Mariposa Estate, by Mr. King, had led him to the belief that here were the most elevated summits of the range; and this fact, coupled with the circumstance that, unless explored during this season by the Geological Survey, this region might long remain a blank on the map of California, led to the organization of a small party, whose object should be to make as complete a recomnaissance of this portion of the Sierra as their limited time and means would permit.

The party organized for this purpose consisted of Professor Brewer, who had charge of the expedition, Mr. Hoffmann, topographer, Messrs. King and Gardner, volunteer assistants in the geological and topo- 
graphical departments, and Richard Cotter, an indomitable mountain-climber, whose services were of great value in more than one branch of the work. As there were many reports of the presence of hostile Indians in portions of the country to be traversed, an escort of soldiers was considered necessary, and was supplied from the United States Military Station at Camp Babbitt, near Visalia, through the intervention of Gorernor Low, and the kindness of General Wright, at that time in command at San Francisco.

The party left Oakland on the 24th of May, and reached Clark's Ranch, on the Yosemite trail from Mariposa, where their labors ended, August 23d, having been engaged in the work for just three months. The following sketch of the explorations made during this time is compiled chiefly from Professor Brewer's notes, with additions from those furnished by Messrs. King and Gardner. The geographical information obtained by the party will be incorporated by $\mathrm{Mr}$. Hoffmann in the "Map of Central California," now in process of construction, and which will contain the results of all our work in the Sierra, from Owen's Lake to Lassen's Peak.

The route taken led first through Pacheco's Pass, across the plain of the San Joaquin, to Visalia, from which point the Sierra was to be entered. The season was the summer following the extraordinarily dry winter of 1863-4, a time when there was probably less snow on the mountains than will be found again for many years to come.

The dry and burnt up. plain of the San Joaquin was passed over between May 30 and June 6th. It was almost destitute of forage, and entirely so for long stretches, thousands of dead cattle being seen by the way. The only green spot met with was at Fresno City, with the exception of those produced by artificial irrigation near Visalia. While passing over this plain, many whirlwinds were seen; often ten or fifteen, and sometimes as many as twenty-five or thirty, were in sight at once. The dust of the plain was raised by them into columns several hundred feet high, and occasionally more than a thousand feet. These pillows of dust sometimes assumed the form of slender columns, which swayed backwards and forwards like gigantic ropes. At other times, they rose in hollow, inverted cones; or a column would expand into a cone at some distance from the ground. At the junction of the column 
and the cone a fringe or horizontal cloud of dust would occasionally be seen, with many fantastic forms, in which column and cone were variously combined with each other. 'These phenomena were observed chiefly between the hours of 10 A.M. and 2 P.M.

As seen from the plain of the San Joaquin, the high mass of mountains near Owen's Lake (now known to be eonsiderably the highest part of the Sierra) appeared to have much less snow on it than the peaks about Mount Lyell and the region east of the Yosemite; the much greater distance of this high mass rendered it difficult to realize its great altitude. The view of the Coast Ranges from the plain was also an interesting one. The Panoche Grande, a short distance south of New Idria, with its broad summit, is the dominating elevation, being a little higher than the sharp peak of San Carlos. The metamorphic core of the chain, dark with scattered trees, exhibited a marked contrast with the lighter-colored and bare hills of unaltered strata in front. These Tertiary foot-hills of the Coast Ranges, at this season, presented a striking picture of desolation and aridity. They are deeply furrowed by denudation, and appear to run out into the plain in a narrow point at Cantua Creek, as has already been noticed in a preceding part of this volume.

The trees on the plain at King's River form a belt about four miles wide, and this is succeeded by a barren, alkaline region, which continues to the Four Creeks. The soil in places is as crisp with alkali and salt, as if it had been frozen while saturated with water. Near Visalia is another grove of beautiful oaks, but of limited extent. It was soon traversed, in going in a northeasterly direction towards Thomas's Mill, and was succeeded by a hard, clayey soil, thrown up into alternate hillocks and hollows, popularly known as "hog-wallows," the origin of which it is not easy to explain. They resemble the hillocks left by the gradual decay of trees uprooted by the wind in our Eastern forests, and the depressions between them contain water in the rainy season.

At a distance of from five to eight miles from the apparent base of the Sierra is a range of low, isolated, rocky hills, which forms an irregular belt of elevations, separated from the main chain by an intervening plain. These hills are made up of metamorphie rocks, such as 
silicious slates, altered sandstones, and serpentine, and appear to be the feeble representative of the great metamorphic belt of the Sierra farther north. A line drawn through the centre of the slates, from Sierra Comnty to the Fresno River, if continued to the south, would pass out into the valley of the San Joaquin. It is certain that the belt of metamorphic rocks which constitutes the main body of the productive Gold Region of the State narrows down almost to a point south of the Fresno, the area occupied by the foot-hills becoming narrower, while the edge of the mountains retreats to the east, apparently owing to the great diminution in thickness of the metamorphic rocks which form the lower portion of the Sierra farther north.

At the base of the Sierra, on the route from Visalia to Thomas's Mill, granite is met with, and a scattered forest vegetation commences at the same time, with some shrubby undergrowth. The oak ( $Q$. Garryana) is the most abundant tree; but the pine so commonly seen farther north in this position ( $P$. Sabiniana) is here of rare occurrence. For a distance of ten miles on the road, equal to eight miles in a straight line, from the edge of the foot-hills, thin belts of massive black hornblende-rock, with some mica-slate, were observed, intercalated in the granite; these occupy, however, but a very small portion of the surface as compared with the other rock.

The belt of pines is entered quite suddenly at an elevation of from 3200 to 3500 feet, and at 5000 feet the forests are already made up of large trees. 'Thomas's Saw-mill (Camp 164), at an elevation of 5484 feet above the sea, and about forty miles northeast of Visalia, was fixed on as the base of supplies for this expedition. The mill stands on the edge of a beautiful meadow, the water from which runs into King's River. It is surrounded by a magnificent forest of the usual coniferous trees found in the Sierra at this altitude, and a little higher up the Big T'rees (Sequoia gigantea) are abundant. They do not occur in separate groves, as is the case farther north, but are scattered through the forests at an elevation of from 6000 to 7000 feet. They extend all the way from King's to Kaweah Rivers, and perhaps farther. The largest tree seen was 106 feet in circumference at the base, and 276 feet high. It had, however, been burned on one side, and, when entire, must have had a girth of from 115 to 120 feet. It expands very much at the 
base, and at twelve feet from the ground was only seventy-six feet in circumference. Another noted tree in this region is prostrate and hollow; it is burned out so that one can ride in on horseback for a distance of serenty-six feet, and then have room enough to turn round. At 120 feet from the base this tree is thirteen feet in diameter, inside the bark. There are an immense number of the Big Trees in this vicinity which are from ten to fifteen feet in diameter, and smaller ones in abundance, the latter being cut up into lumber at the saw-mill, in a manner entirely at variance with the often-repeated story of the exceptional character of this species. The Indians in this region report the existence of a tree much larger than either of those noticed above, but our party was too much pressed for time to go in search of it.

About six miles east of Thomas's Mill, a rocky summit, called Bald Mountain, was ascended for the purpose of getting the first idea of the topography of the unknown region about to be visited. It was . easy of access, although 7936 feet high, and offered a fine view of the neighboring country and the extended crest of the Sierra. Its position was at once seen to be on the great elevated divide between the waters of King's River on the north, and the Kaweah on the south. This divide runs up to the snowy mountains at the summit of the shain, and appeared to terminate in the highest group of peaks, some twenty-five or thirty miles distant. The ridge of the divide rose at intervals into peaks, each one commanding the country on either side and behind it, as well as forward to the east as far as the next high point in that direction. About eight or nine miles to the north, and several thousand feet below, was the cañon of King's River, which seemed precipitous and impassable. Some twenty miles to the northeast, this river divides into two branches, and the course of the northern of these is such that the observer on the summit of Bald Mountain can look directly into it. The view is most impressive. Granite walls with buttresses, pinnacles and domes rise perpendicularly from three to five thousand feet above the river, and above these the bare rocky slopes tower up, high above all vegetation, into regions of perpetual snow. Dark lines of trees wind up the ravines on the mountain sides, becoming thinner and more scattered, until they disappear altoGEOI. VOI. 1. - 47 
gether, the summits of the mountains rising far above all vegetation, barren, and desolate.

Such is the character of the divide between the main forks of the King's River, although the southern side is not as steep as the northern. Its lofty summit, everywhere crested with precipices, presented an insurmountable barrier, over which our party never succeeded in taking their animals. Just at the junction of the forks, the end of the divide is crossed by a broad red stripe, bearing about northwest, and which could be seen appearing again on the north side of the cañon. This, which seemed to be a great dyke of volcanic rock, but which was afterwards found to be a vein of granite, led to giving this divide the name of "Dyke Ridge."

An attempt was first made to reach the summit of the Sierra by travelling up this divide, an old Indian trail being discovered which was followed for about fifteen miles. This trail led to a point where the ridge widened out into a plateau occupied by a large meadow; a number of cattle had been driven here, and the place was known to hunters as the "Big Meadows." Camp 165 was intermediate between Thomas's and the Big Meadows, and was 7480 feet above the sea. The rock along the whole route is granite, which has a tendency to weather into grand, rounded, boulder-like masses. Near Camp 165, it was very light-colored, inclosing an immense number of bands of darkercolored and finer materials, which were generally lenticular in shape, and from a few inches to several feet in width, with their longer axes parallel. In places the rock assumes a gneissoid structure; but passes gradually into the homogeneous granite on all sides.

Canp 166, about two miles below the Big Meadows, but nearly at the same altitude, was at an eleration of 7827 feet. Here the granite is of more uniform texture over large areas, and is made up of quartz, feldspar, mica, and hornblende, the last-named mineral predominating over the mica. The massive granite is traversed by occasional dykes of a fine-grained variety of the same rock, and with veins of milky quartz. Large areas of nearly level or gently sloping ground occur here, covered with meadows or forests of Pinus contorta, and there are also extensive patches of bare rock, or of granitic sand derived from its decomposition. As the granite decomposes very irregularly, the 
larder portions rise in rocky, rounded hills, and the softer are occupied ly small valleys. A series of these grassy plats, five or six miles in length, makes up the Big Meadows, and they are diained in both directions, namely, into the King's and Kaweah Rivers. At this altitude the sugar and pitch pines, as well as the Big Trees, are left behind, and the forests are made up of the dark and sombre fir and Pinus contorta. Although it was the month of June, the thermometer sank as low as $16^{\circ}$ at night, and a snow storm, of three or four hours' duration, occurred.

Just east of the Big Meadows, and on the summit of the divide, are two elevations, to which the name of "Dome Mountains" was given, from the finely rounded, dome-like sweep of their outlines, which contrast in a striking manner with the sharpness of the summit peaks behind them. On their southern sides the forests rise in an unbroken curve to their summits; but on the north side there is a precipice for 200 to 300 feet below the crest, then a short concave curve, and then the rounded and wooded slope descending to the King's River Valley. In this part of the mountains, as at the Yosemite, the granite exhibits a tendency to form dome-shaped masses on a grand scale; but on the very crest or summit range, it rises in pinnacles, giving a very different character to the scenery, as will be noticed farther on. That one of these Dome Mountains which was ascended was found to be 9825 feet high. Its summit was made up of concentric layers or beds of granite from one to five feet thick, having no trace of gneissoidal structure, but breaking into large rectangular masses, sufficiently smooth and regular in form to be used for masonry, without dressing. The north slope of the mountain is covered by immense masses of this angular debris.

The peculiar concentric or dome structure of the granite in this and other portions of the Sierra may be illustrated by the annexed wood-cut (Fig. 49), which represents the summit of one of these great rounded

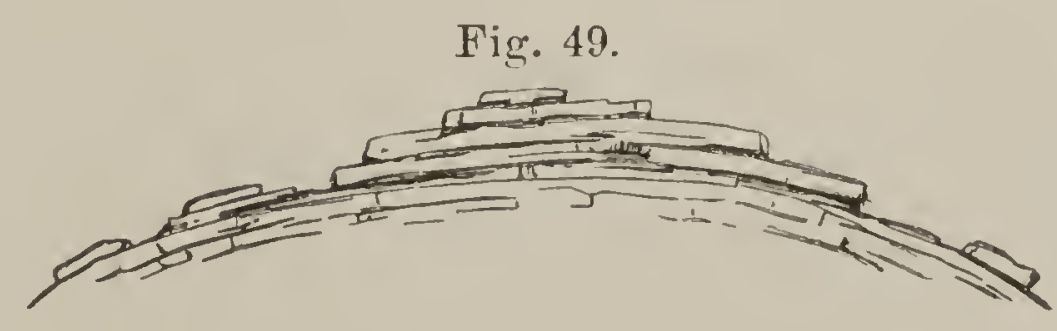
masses. These give a very peculiar aspect to the scenery, and they are also of no little interest in a geological point of view. That this 
structure is not the result of the original stratification of the rock is evident from a study of the phenomena, which do not indicate anything like anticlinal or synclinal axes, or any irregular folding. The curves are arranged strictly with reference to the surface of the masses of rock, showing elearly that they must have been produced by the contraction of the material while cooling or solidifying, and also giving rery strongly the impression that, in many places, we see something of the original shape of the surface, as it was when the granitic mass assumed its present position. In the cañons between these domes, we sometimes have large surfaces exposed by denudation, and, as a result of the original concentric structure of the rocks on each side, we see the great plates of granite overlapping each other in the manner represented in the annexed wood-cut (Fig. 50).

Fig. 50.

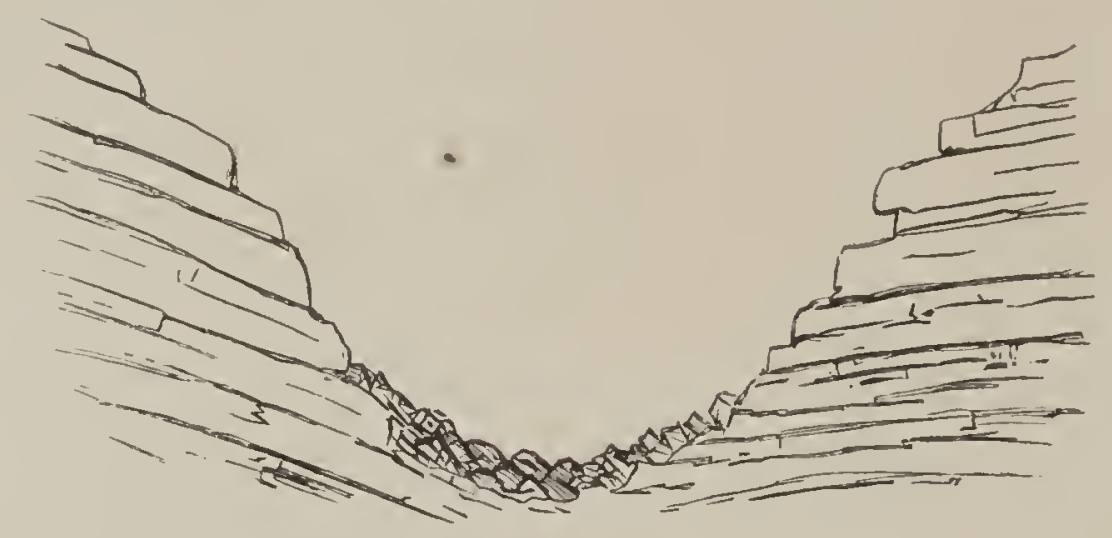

Where considerable weathering and denudation has taken place, we have picturesque and curious forms as the result; pyramids and pinnacles are left standing on the prominent points, and their bedded structure adds to the peculiar impression which they give of their being works of art rather than of nature. A sketch by Mr. Hoffimann, taken above Camp 169 (Fig. 51), will serve to illustrate the kind of scenery, which is common in the region of this concentrically-bedded granite.

Abundant traces of glacier action were observed on and about these mountains; but it will be more convenient to group together in another place what there is to be said in regard to the former"existence of glaciers, on an immense scale, in this part of the Sierra.

The route followed by the party, in their attempt to reach the summit, led around the north side of the Domes, over the huge piles of 
angulal fragments, and was on this account tedious and difticult. Camp 167 was made at a point two miles northeast of the Dome, and at an altitude of 8890 feet above the sea. Camp 168 was fonl or five

Fin. 51.

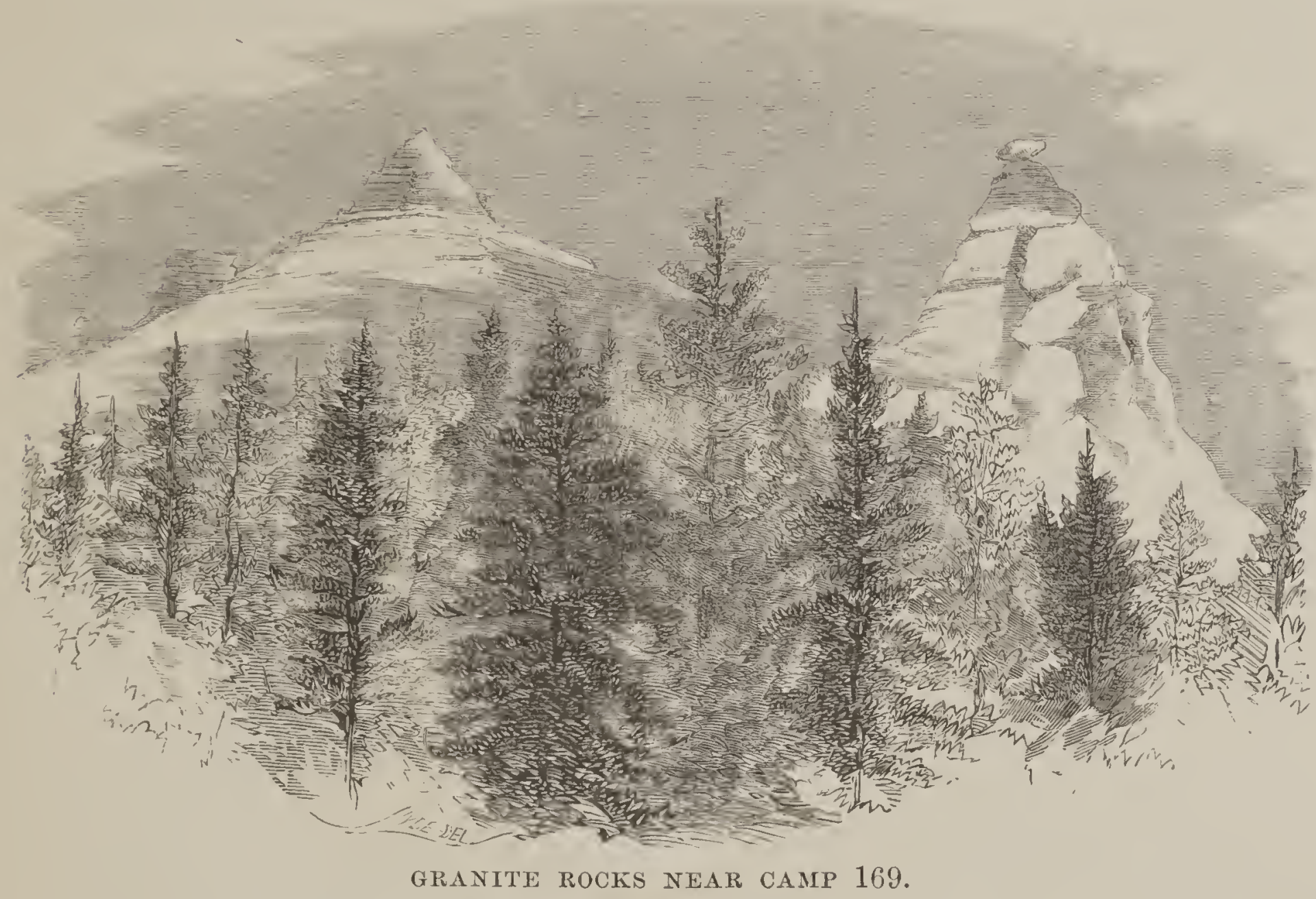

miles southeast of the Dome, at a small meadow on the divide, and at an elevation of 9569 feet. Progress was necessarily very slow, owing to the heavy load of provisious and instruments with which the small train of animals was packed, and the extreme roughness of the region travelled over. Beyond the Domes the divide contracts to a mere ridge; the slope to the south, although steep, is comparatively smooth, and spreads out, towards its base, into rolling wooded spurs, between which small brooks run down into the Kaweah. Nearly all these streams head in little sedgy meadows, whose bright green contrasts beautifully with the deep shade of the surrounding forests. To the north, the aspect of things was different; instead of a smooth slope, there was a fractured granite precipice, descending 200 feet, then a slope of debris, and at its foot two small lakes, forming the headwaters of a stream which unites with the south fork of King's 
River a few miles above the dyke. This stream was called Glacier Brook, from the abundant traces of former glacial action in its vicinity. From Camp 168 to the Big. Neadows is only sixteen miles; but so difficult was the way, that it required two days for the party to accomplish that distance. From this camp, and the next (No. 169) two miles farther up the divide, an examination was made of an interesting and characteristic feature in the topography of this granitic region, and to which the name of "The Kettle" was given.

This is a rocky amphitheatre at the head of a stream which flows back directly northeast from its source towards the axis of the chain, for a distance of twelve miles, and then curves and enters King's River, a peculiar and almost unique course for a stream in the Sierra Nevada. The kettle-like form of the head of this valley may be seen from the annexed section across it transversely, at a distance of about a mile from its head (Fig. 52); it is plotted on an equal scale of horizontal and vertical distances.

Fig. 52.

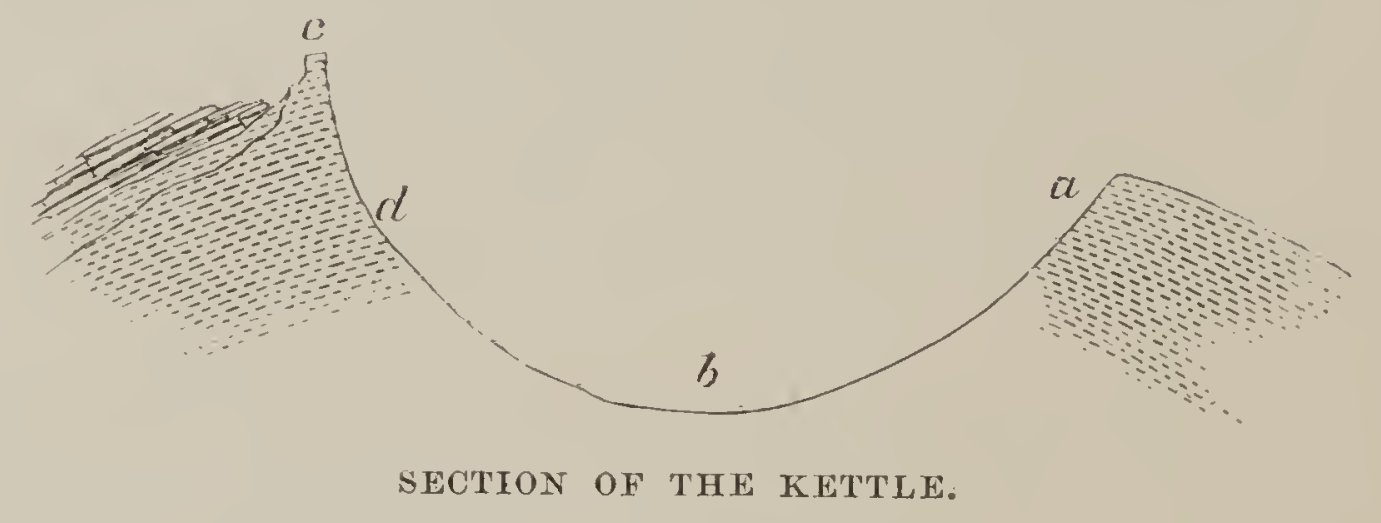

The northern rim $(a)$ is about 1100 feet above the bottom $(b)$; the southern one $(c)$ rises in a sharp ridge 1606 feet above $b$; in some places $c d$ is a vertical wall, in others a steep slope. The distance from $a$ to $c$ is a little less than a mile. The Kettle is open at the north-northeast eud, and extends as a green valley some six miles, to the south fork of King's River. There are several small domes and pinnacles on the east side, and in some places the granite along the rim, forms a parapet, which has a striking resemblance to an artificial structure, as the rock is most beautifully and regularly bedded, so that the wall seems to vie with the most finished mason-work in execution. The annexed wood-cut (Fig. 53) will show the exact appearance of a por- 
tion of this wall, which is in some places so thin that the light can be seen shining through between the cracks. It is from eight to twenty feet high.

Fig. 53.

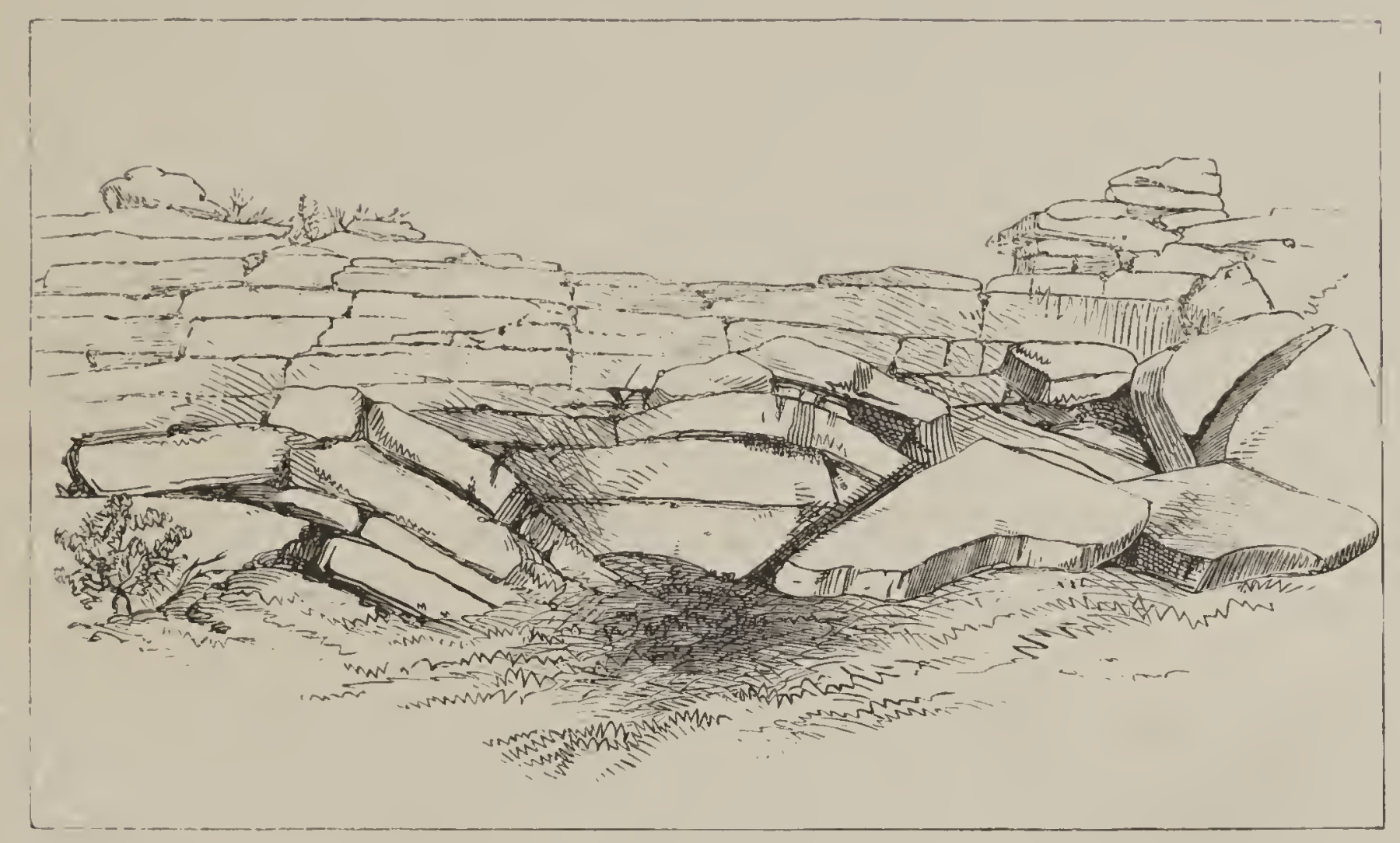

RIM OF THE KETTLE.

This rim of the Kettle is a beautiful illustration of the concentric or "dome-structure" of the granite of this region. The dotted lines in figure 52 show the bedding or lamination of the rock, in the cross section of the whole, and figure 54 explains how the parapet has been formed by the wearing away of a part of the concentrically-laminated granFig. 54 . ite near the summit. This peculiar crater-like cavity in the granite is typical of many others seen afterwards in this region, the origin of which it seems impossible to refer to any ordinary denudation, or to the action of glaciers. These cavities were all occupied by masses of ice, as is evident from the polish of the interior walls and bottom of each of them; but it hardly needs to be added that no glacial action could have originally formed one of these kettles; the most that it could 
do would be to scour out and polish up the interior. This subject will be discussed in full at some future time.

Beyond the Kettle, the divide becomes quite impassable for animals, and nearly so for men. Sereral unsuccessful trials were made to pass the barrier of nearly perpendicular rocks; but, at last, a chink in the granite was found, through which the party crawled, and proceeded to ascend Mount Silliman, which is the next high peak on the divide and about six miles southeast of Camp 169. As seen from the north or northwest, Mount Silliman appears like a great lava or volcanic table mountain, with mural sides. A drawing from a sketch by Mr. Hoffmann (Fig. 55), will serve to give an idea of this prominent point; it

Fig. 55.

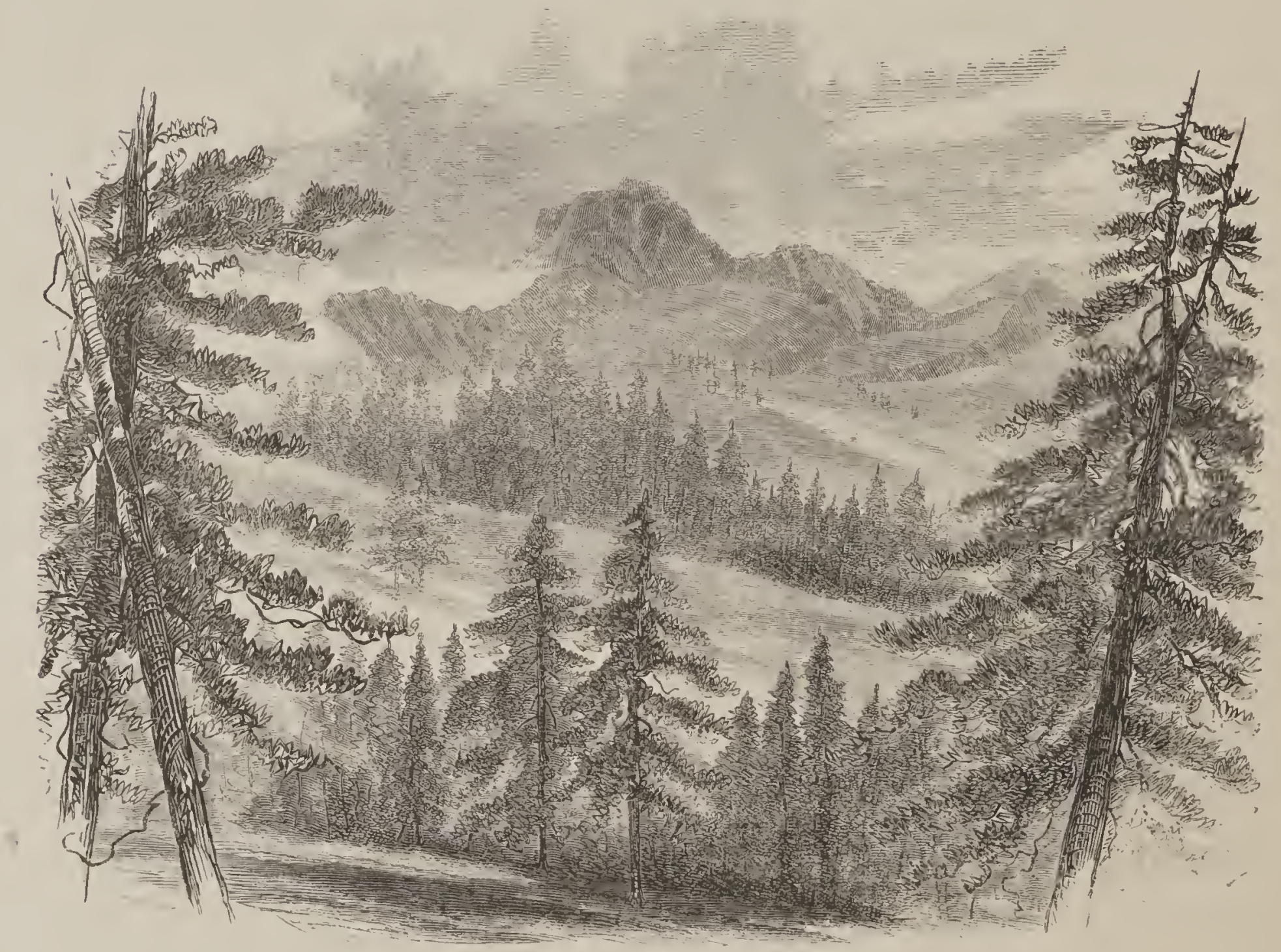

MOUNT SILI.IMAN.

was taken near Camp 168. This mountain is of granite, but of a darker color than the rock of the surrounding country; it is much intersected with reins of granite of a still deeper tinge than the main body of the rock, and portions of it are reddened and discolored by 
the oxidation of the iron it contains. Tts elevation was found to be 11,623 feet above the sea. 'This mountain is formed by the meeting of' two knife-edges of the main divide, forming the western and northeastern taces of the peak, and inclosing between them a crater-like cavity, at least a thousand feet deep, the walls of which present a mural face to the north and slope ofl gradually to the south.

From the summit of this peak a mangificent view was obtained of the erest of the Sierra, as well as of the divide whieh hat been traversed by the party. The region to the east presented a complicated system of very sharp ridges, rising here and there into pinnacles, apparently all of granite, with numerous immense circular amphitheatral cavities, forned by sharp ridges surrounding basins, of which one side is always broken away, and which have exactly the appearance of ancient craters both in form and outline. To the west the predominance of rounded or dome-shaped mountain summits was most striking, the whole country having the appearance as if it had suddenly been cooled or congealed while violently boiling.

Camp 170 was about seven miles north-northeast of No. 169, in the valley of the stream which flows from the Kettle, and at an altitude of 7408 feet, which was a lower point than was afterwards reached by the party for a long time. The way to this camp led around the west and north sides of the Kettle over a region exceedingly difficult to traverse, with alternating steep, naked slopes of granite, and thick, low forests. Some of the ancient moraines, piles of angular fragnents of granite, were almost insurmountable obstacles to the passage of the animals. This camp was situated behind a sharp granite knob which rises from the valley like a sugar-loaf, as seen from below; but which, in reality, is the end of a ridge a mile or two in length. This is several hundred feet high and its summit is quite inaccessible. Its sides show undoubted evidence that it was once surrounded by a great glacier flowing down the valley. The slopes directed towards the moving ice are worn and polished, and huge boulders have been pushed up on them, and left all along, wherever the angle was not too steep for fragments of rock to lie. The meadow occupies a basin behind this knob, which appears to have been scooped out by a glacier.

From the Sugar Loaf Rock there is a magnificent view up the valley GEOL. VOL. I. -48 
to the group of mountains forming the vestern erest of the Sierra, the culninating point of which was named Mount Brewer. This was directly east, and about ten miles distant. A grand view was also had of the great moraine on the eastern side of the extreme south fork of King's River; this moraine stretches along for six or eight miles in an unbroken line, resembling an immense artificial embankment, as will be noticed farther on.

In moving from Camp 170 to 171, the party crossed King's River, a stream twenty feet broad, and travelled up the valley of the south branch of the south fork of that river, camping at the western base of Mount Brewer, seven miles east-southeast of Camp 170, and at an elevation of 9969 feet above the sea. From this point farther progress with animals was entirely out of the question. The fork on which Camp 171 was situated runs from Kaweah Peak, nearly straight northnorthwest, about twenty miles in distance, to the main King's River. A ridge which rums from Mount Brewer to Kaweah Peak forms the eastern edge of this valley, and rises generally to an altitude of 12,000 feet and in places to about 14,000. On the west, the ridge which bounds the valley, extending from Mount Silliman to Kaweah Peak, is also about 12,000 feet high; while Camp 175, in the valley, nine miles west of Mount Brewer, was found to be 6300 feet below the summit of that peak. These figures will give an idea of the tremendously rough character of the country, especially if considered in connection with the circumstance that these slopes, a mile high, are cut by numerous sidecañons, with almost vertical walls.

At the head of this valley a great glacier formerly originated, and extended down between its walls, far towards the great plain of California. On the eastern side of the valley a medial moraine still exists in all its perfection of form, as if just left by the glacier, and it is the most extensive and striking one which has been observed by us in the State. It was formed between the main glacier and a smaller side one which originated just north of Mount Brewer. Its appearance is that of a vast embankment of loose boulders and angular fragments of rock, piled up with the steepest slope on which such materials will lie without sliding, the upper edge of the western side being elevated from 1400 to 1500 feet above the bottom of the valley. On the side nearest 
to the mountain the depression is much less marked, as may be seen from the annexed wood-cut (Fig. 56).

Fig. 56. W.

Section of Moraines on the South Fork of King's River.

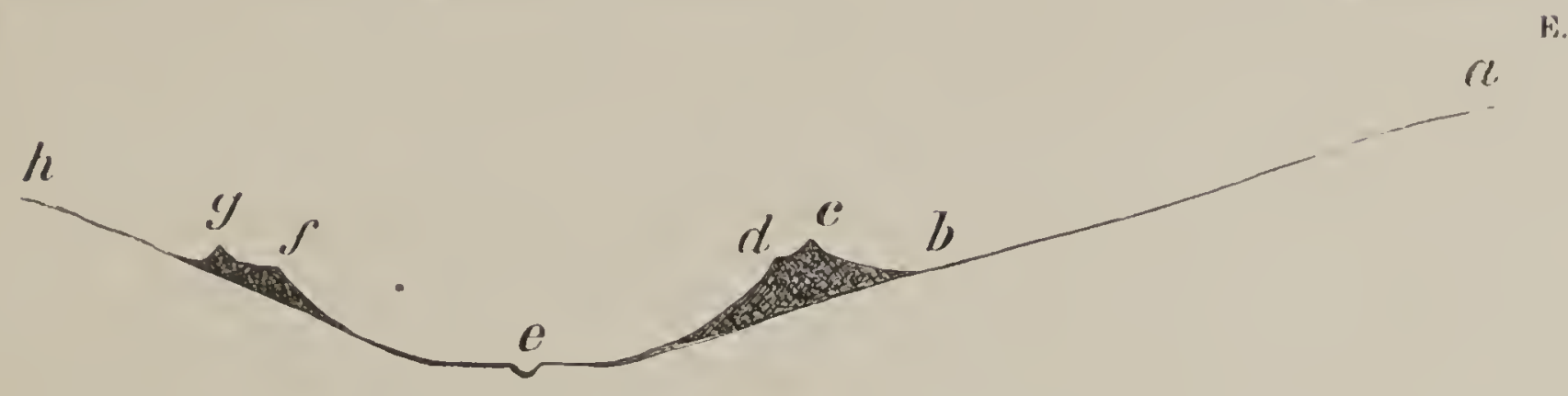

a. Slope of eastern ridge, which rises to 13,000 feet above the sea. b. Valley, 500 feet below $c$. $c$. Crest of principal moraine. $d$. Shelf or bench. $e$. Bottom of the valley. $f, g$. Moraine on west side of valley. $h$. Western slope, rising to about 11,000 feet above the sea.

The two moraines on the opposite sides of the valley are both very distinct, but the eastern one is much the largest. The horizontal distance across from one to the other is about a mile and a half. At a distance, these moraines, especially the eastern one, appear as regular as railroad embankments, their crests being quite smooth, and having a uniform and gradual inclination up the valley. To ascend or descend their sides with animals was a task of the greatest difficulty; but once on the top, travelling was quite easy. In the bottom of the valley the granite is everywhere grooved and beautifully polished.

The view of the cañon, towards its head, as seen from this moraine, near Camp 175, was sublime, strongly resembling the valley of the Yosenite in some of its grandest features. It curves but little, so that the view is unobstructed. Great surfaces and precipices of naked granite are seen, often over 1000 feet high, but seldom vertical, although sloping at a very high angle; these surfaces are everywhere in the valley rounded and polished. Side cañons of the sane character, but still more precipitous, open into the main one.

From Camp 171, Mount Brewer was twice ascended, on the 2d and 4th of July, by passing up the valley in which the camp was situated, and which divides at the base of the mountain, extending up to the crest of the ridge. Its sides were found to be very steep up to abore 12,000 feet, the southern one being an almost vertical wall of 1000 feet in height. The granite of this region is hard, not very coarse, and of 
a light ash-gray color, with a pearly lustre when seen in great masses. It is intersected with veins of quartz and also of feldspar, and with some made up of a mixture of both these minerals; these veins were

Fig. 57.

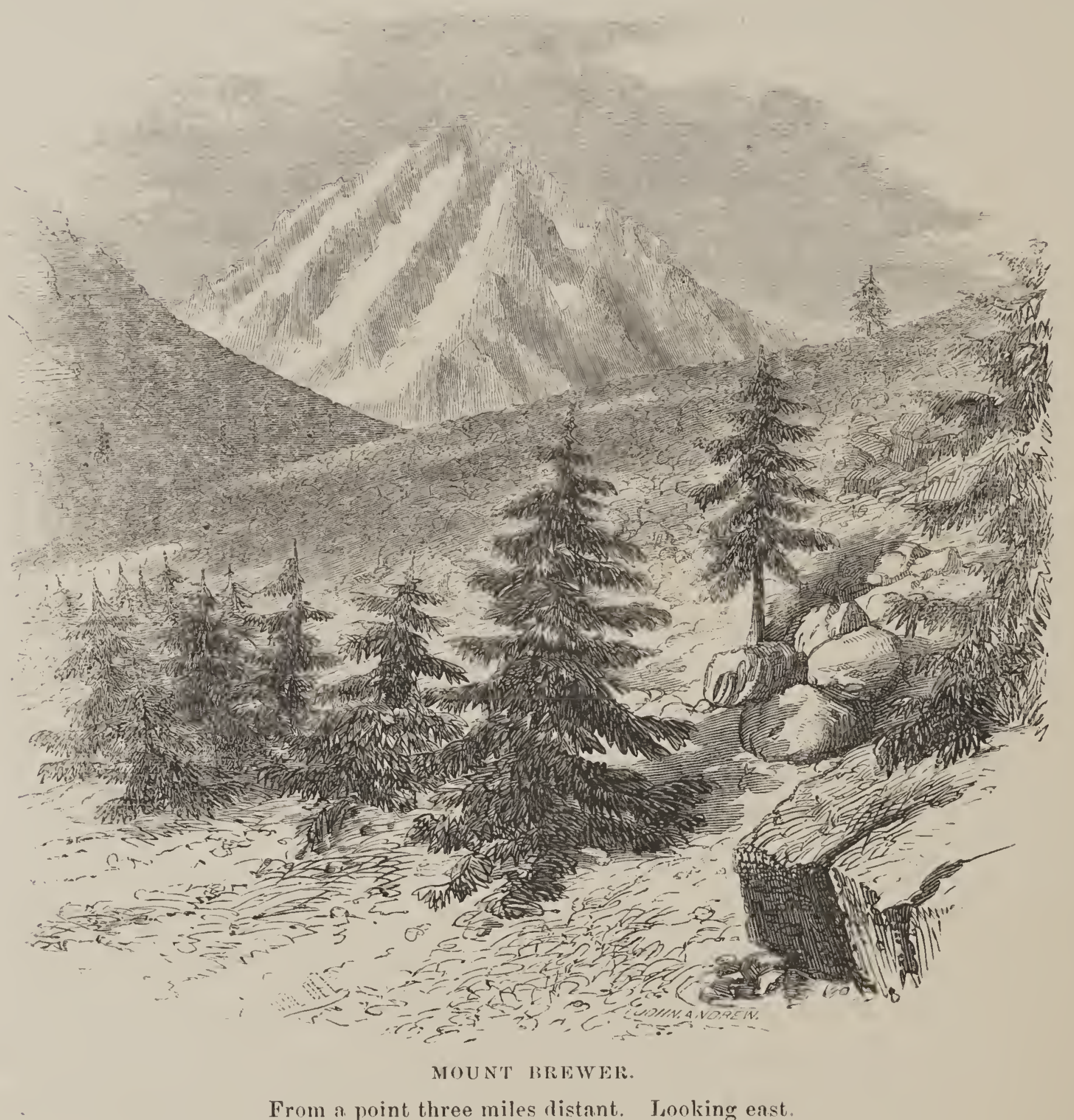

rarely more than two or three feet in thickness. In general, however, the rock is remarkably homogencous and almost destitute of accidental minerals, a little epidote being the only one observed in this region.

The view from the summit of Mount Brewer is one of the most sublime which it is possible to obtain, even in this sublimest portion of the Sierra. The snowy peaks, rising to over 11,000 feet in elevation, 
cover a breadth of more than twenty-five miles, and the point of view on the summit of this mountain is such, that the observer is placed in

Fig. 58.

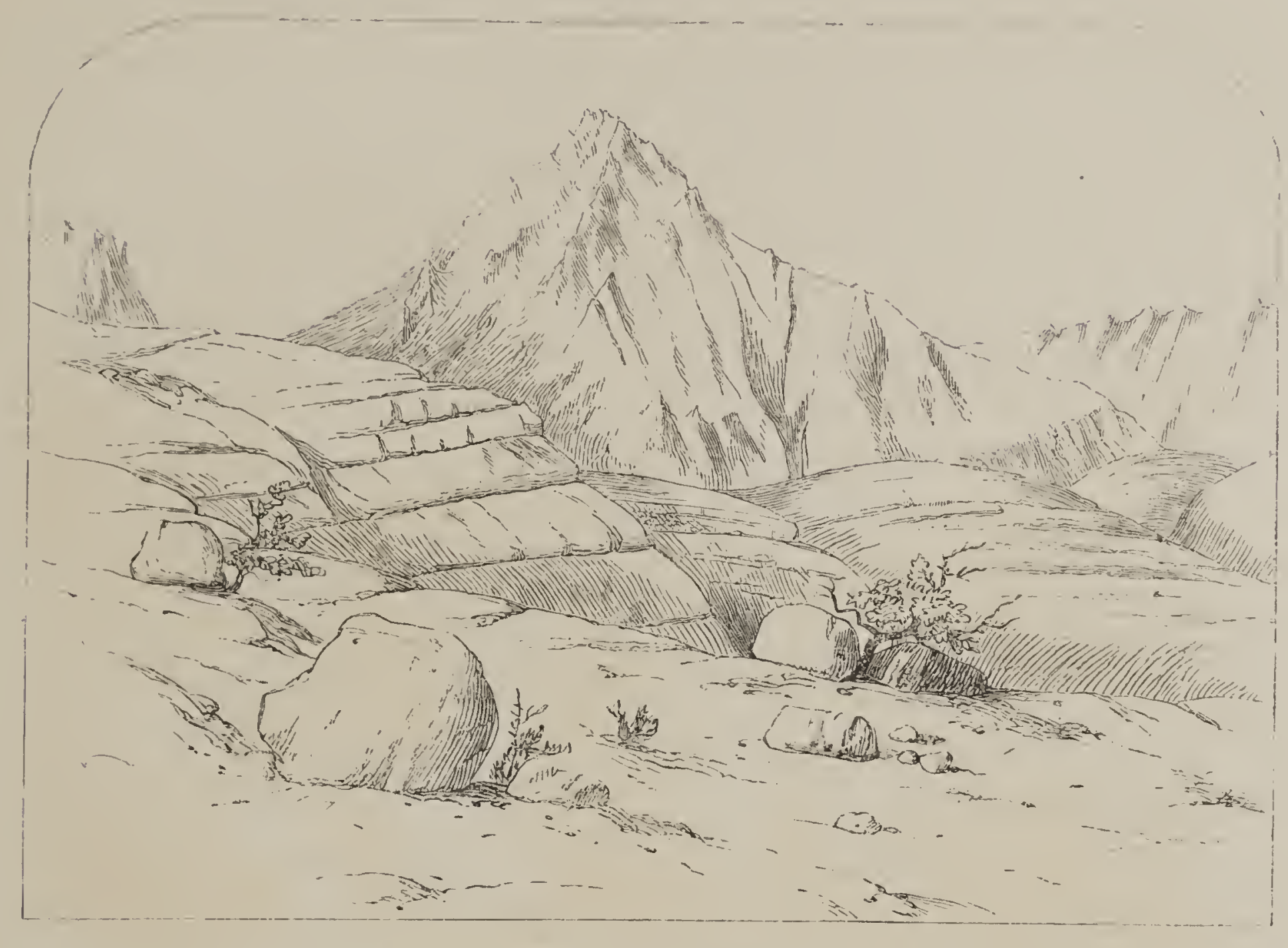

MOUNT HREWER.

From the southwest, at an elevation of 10,800 feet.

the very midst of this grand asscmblage. High peaks, sharp ridges bristling with pinnacles, rocky amphitheatres, and deep cañons constitute the main features of the scenc. The summit is a loose and shattered mass of angular pieces of granite, forming a ridge some thirty feet long by five broad, which from the west appears as a sharp cone. The castern side of the mountain is a precipice buttressed by a thin rirlge, running out between two great vertically-walled basins, white with snow, which contrasts beantifully with the vivid blue of the frozen lakes 3000 feet below.

Two views of Mount Brewer are here given (Figs. 57 and 58), the first of which is from a sketeh by Mr. Garduer, the other an ontline by Mr. Hoftimann. The one shows better the form of the mountain itself; 
the other, the peculiar surface and bedded structure of the bare granite slopes in its vicinity.

'The barometrical measurements make the height of Mount Brewer 13,886 feet; it is not, however, the culminating point of the Sierra, but is on a spur embraced by two branches of King's River. 'Ten miles farther east another ridge stretches in an unbroken line north and south, and through its depressions the blue ranges of the desert are plainly seen. On this ridge there are fourteen peaks visible, ten of which are as high as Mount Brewer, and four higher. One of these, directly opposite, and which appeared to be the highest point but one, was called Mount Tyndall, in honor of this distinguished physicist and Alpine explorer. The other high point, eight miles south of Mount 'Tyndall, and, so far as known, the culminating peak of the Sierra, was named by the party Mount Whitney, Farther observatious, by Mr. King, showed that a point about two miles northeast of Mount Tyndall was a little higher than this mountain; it was named in honor of Major R. S. Williamson, of the United States Engineers, so well known by his topographical labor's on the Pacific coast, especially in connection with the United States railroad surveys. Thirty-two miles northnorthwest is a very high mountain, called Mount Goddard, in honor of a Civil Engineer who has done much to advance our knowledge of the geography of California, and who is the author of "Britton \& Rey's Map." A transverse ridge running obliquely across from Mount Brewer to Mount Tyndall forms the divide between the headwaters of the Kern and those of King's River. South of this, the division of the summit of the Sierra into two parallel ridges is very marked, the Kern flowing in the tremendous gorge between them. The eastern ridge forms an almost unbroken wall for a great distance to the north, while the western one is less distinctly marked, being broken through to allow of the passage of the headwaters of the King's and San Joaquin Rivers. The highest portion of the western ridge is that extending between Mount Brewer and Kaweah Peak, twelre miles to the south. This last-named peak was not reached by our party, but its height was estimated to be orer 14,000 feet. From its great elevation and peculiar position, opposite to the highest point of the Sierra, and the immense depth of the cañon of the Kern between it and Mount Whit- 
ney, it would probably command the grandest view which could be obtained in the whole range of the Sierra. Kaweale Peak is distinctly visible from Visalia, to one looking up the valley of the Kaweah River.

Of the terrible grandenr of the region embraced in this portion of the Sierra, it is hardly possible to convey any idea. Mr. Gardner, in his notes of the view from Mount Brewer, thus enumerates some of the most striking features of the scene: "Cañons from two to five thousand feet deep, between thin ridges topped with pinnacles sharp as needles; successions of great, crater-like amphitheatres, with crowning precipices over sweeping snow-fields and frozen lakes; everywhere naked and shattered granite without a sign of vegetation, except where a few gnarled and stormbeaten pines (Pinus contorta, $P$ : albicaulis, and P. Breweri*) cling to the rocks in the deeper cañons; such were the elements of the scene we looked down upon, while cold gray clouds were drifting overhead." Mount Brewer was ascended July 4th, 1864, by Messrs. Brewer, Hoffmann, and Gardner, and the American flag was duly planted on its summit, in honor of the day.

The upper part of the mountain slopes rapidly on all sides for 2000 feet from the summit, then falls oft more gradually on the west towards the cañon of the south fork of King's River. On the east, it breaks off suddenly into a great amphitheatre, the head of a cañon between 4000 and 5000 feet deep below the erest, surrounded by sheer vertical walls, and with glacier-polished slopes at the bottom, over which are scattered several small and beautiful lakes. These cañons and precipices, which lie between the two principal ridges, constitute the main difficulty in reaching and exploring the eastern summit peaks. The region is desolate and cold; but these hindrances, incidental to all high mountain climbing; could be overcome, were it not for the impassable precipices which continually block the way, necessitating long detours, and rendering it impossible to reach any high peak without a long series of perilous and extremely fatiguing ascents and descents.

As want of provisions and the absolute impossibility of proceeding any farther with the animals were sufticient reasons to prevent the

* The provisional name of a new species of pine, first noticed by Mr. King on Mount silliman, and which will be described in the volume of Botany. 
whole party from making any attempt to climb the summit of the eastern ridge, Mr. King volunteered to undertake this task, although it seemed to most of the party that it was quite impossible to reach either of the highest peaks from the western side. Packing provisions for six days and one blanket, he started, aceompanied by Richard Cotter, from the camp at the base of Mount Brewer, July 4th, and the following account of the trip, in which the summit of Mount 'Tyndall was reached, is given nearly in Mr. King's own words:

"To follow down the ridge which forms the divide between King's and Kern Rivers, and which runs obliquely across from Mount Brewer to Mount Tyndall, was impossible, for it rose in sharp crags above us, and had we been able to pass around these, we should have been stopped by vertical clefts over a thousand feet deep. We began therefore to climb down the eastern slope of the ridge, instead of trying to keep on its crest. The only way down was along a sloping shelf, on which we were obliged to proceed with the greatest caution, as our packs had a constant tendency to overbalance us, and a single misstep would have been fatal. At last we reached the base of the cliff safely, and made our way rapidly down a long snow-slope and over huge angular masses of debris to the margin of a frozen lake.

"We were now in the amphitheatre; the crags towering around us were all inaccessible, and we were obliged to spend six hours in climbing down from the outlet of the lake, over a slope of smooth granite, polished by glaciers and kept constantly wet by a shallow current of water, into King's River cañon, and then up again over a long, difficult debris-slope and across several fields of snow, into another amphitheatre. Of this the southern wall is the divide between King's and Kern Rivers. The sky, by this time, had become quite overcast, and we were obliged to take refuge under some overhanging rocks, while a severe hail-storm went by. We started on again, hoping to cross over to Kern Cañon; but the ascent proved very difficult, and night overtook us at the foot of a cliff 2000 feet high. There was no wood, so we burned paper and dead carices enough to make some luke-warm tea, and finding a crevice among the ice and granite blocks, somewhat sheltered from the biting winds, we retired. The elevation was over 12,000 feet, and the air stinging cold; but the sunset view was glori- 
ous. The east wall of the basin was brilliantly lighted up, its hundred pinnacles were of pure yellow, relieved by the dark blue of the sky, which is so noticcable when one looks up from a deep cañon in the Sierra. A long slope of snow opposite us warmed with a soft rosy tinge (the Alpine glow), and the rugged ridge behind us cast a serrated gray shadow across it, which slowly crept up and scaled the granite wall, until only the very topmost spires were in the light. All night long, large masses of granite came crashing down from the crags overhead, striking at times too near for comfort.

"The next morning we ate our frozen venison by starlight, and started at sunrise to ascend the snow slope before it should become softened. We had to cut steps, and after working up a while it became quite difficult, so that we were three hours in reaching the rocks, after which we climbed two hours more, until we came to a very bad ravine where it was impossible to proceed with our packs. It was now that our reata came into play, and we took turns in climbing the length of it, and pulling packs and blankets after us, reaching the top about noon, by which time the novelty of this method of ascent had quite worn off. What was our consternation to find ourselves, as we scaled the summit, on the brink of an almost Yosemite cliff! We walked along the edge, however, for some distance, until at last we discovered three shelves, each about fifty feet below the other, from the lowest of which we might, by good luck and hard climbing, work along the face of the cliff to a sort of ravine, down which we might probably reach the debris. I tied the reata firmly about my body, and Cotter lowered me down to the first shelf; he then carefully sent down the precious barometer and our packs. Next, he made a fast loop in the lasso, hooked it over a point of rock and came down hand-over-hand, whipping the rope off the rock to which it had been fastened, thus severing our communication with the top of the eliff. 'This operation was repeated, not without considerable danger, from the impossibility of finding a firm rock around which to secure the rope, until the bottom was at last safely reached. At the foot of the debris was a beautiful lake, half a mile long, the Kern River being visible below as a little brook, which was once the bottom of the bed of a great glacier.

"There were a few Pinus contortu, visible down the course of the GEOL.VOL. I. -49 
Kern, and quite a grove of P. Breweri; these, with a few willows and an Alpine Ribes, were all the regetation we could see, excepting a few carices. Camp was marle at the base of the peak, after climbing up a difficult ridge, near a little cluster of the Pims contorta; this was about 11,000 feet above the sea.

"The next day the summit was reached, without serious difficulty, after some risky climbing of smooth dome-shaped masses of granite, where the only support and aid in climbing was an oceasional crack. The barometer stood, at 12 M., at 18,104, the temperature of the air being $44^{\circ}$. On setting the level, it was seen at once that there were two peaks equally high in sight, and two still more elevated, all within a distance of seven miles. Of the two highest, one rose close by, hardly a mile arvay; it is an inaccessible bunch of needles, and we gave it the name of Mount Williamson. The other, which we called Mount Whitney, appeared equally inaccessible from any point on the north or west side; it is between seven and eight miles distant, in a south-southeast direction, and I should think fully 350 feet higher than our peak. (Farther examination showed that it was really 600 or 700 feet higher than Mount Tyndall.). Within our field of view were five mountains over 14,000 feet, and about fifty peaks over 13,000 .

"The five highest peaks are all on the eastern ridge. Owen's Valley, a brown sage plain, lies 10,000 feet below on the one side, and Keru Cañon, once the rocky bed of a grand old glacier, 4000 feet down on the other. About fifteen miles north of here, King's River euts through the western ridge and turns at a right angle towards the plain. North of this point, again, the two great ridges unite in a grand pile of granite monntains, whose ontlines are all of the most rugged and fantastie character. Twenty-five miles south, the high group ends, there (eertainly for a breadth of sixty miles) forming one broad, rolling, forestcovered platean, 8000 to 9000 feet in elevation.

"From Mount Brewer to Kaweah Peak, tho two culminating points of the western ridge, for a distance of fifteen miles there is nothing that can be called a separate mountain; it is, rather, a great numal ridge, capped by small sharp cones and low ragoed domes, all covered with little minarets. At one place the ridge forms a level table; upon this lies an unbroken cover of snow. To the eastward, all this range. 
from King's Rirer gateway to Kaweah l'eak, presents a series of blank, almost perpendicular precipices, broken every mile or so by a bold samite buttress. Between these are vast snow-ficlds, and also numberless deep lakes, of which the most elevated are frozen.

"T'he few Pines contorta, and the groves of our new pine have a peculiar black color, or, rather, dark bluish-green, which rather angunents than relieves the desolate, naked aspect of things. The only bits of hright color to break the solemm monotony of granite and snow are the bhe lakes, which lie everywhere in the ancient glacier-beds.

" H'ar away in the north there is a broad red band in the granite; other than that, all is gray. Beyond Owen's Valley is a low desert range. The Coso and Inyo Mountains are in plain sight.

"To the eastward, parallel ridges, one beyoud another, lie stretehed before us, rigid and stony. They have the same aspect as the mountains near Washoe, the same brown color, with red and yellow shadings.

"Nearly due north, fifty or sixty miles distant, rises a lofty group of mountains which culminates in a white cone. This must be very high, for unbroken snow coveris fully 2000 feet on the south side of the peak, while even the highest mountains in our group have no snow except on the north flank. These are probably the White Mountains. I venture 14,600 feet as a guess at the probable elevation of the highest point in the group.

"We were six hours in returuing to the camp at the base, and early the next morning we began our return march. We were obliged to take a new route home, but made the whole successfully, reaching the canp near Mount Brewer with our bones and the barometer whole, aithongh twice on the way back Cotter cane within a hair's breadth of losing his life, and once I alnost gave myself up:"

The elevation of Mount 'Tyndall, as calculated from Mr. King's observations, compared with those of the other party, and with the station barometer at Camp Babbitt, was fixed at 14,386 feet; this is only tifty-four feet less than the altitude of Mount Shasta.

The White Mountains, of which Mr. King speaks, in the extract cited above, lie just on the borders of California and Nevada, in about longitude $118^{\circ}$, latitude $37^{\circ} 30^{\prime}$; they were distinctly visible to us from 
Mount 1)ana and the other high peaks noal Mono Jake. It is doubtful whether the highest points are within the State of California; but they are probably very near the line on one side or the other. As it is by no means impossible, although we do not consider it probable, that some points of this range of mountains are higher than any yet measured or ascended by our parties, we still have to remain for some time in uncertainty as to whether California can claim the highest elevations in the country as within her borders; we can, at least, say that the highest measured ones are.

After Mr. King's return to ('amp 171, at the eastern base of Mount Brewer, the whole party went back to Big Meadows, having been out of provisions for several days, with the exception of a few strips of jerked bear meat. Here, also, they were to meet the escort which was considered indispensable for safely exploring the region to the north. Mr. King, however, not being satisfied with his first attempt to reach the culminating point of the Sierra, made another start from Visalia July 14th, with no other company than an escort of two soldiers. His intention was to follow the Owen's Lake and Visalia trail, which leads up the Kaweah River, keeping the south fork from its junction with the main river. It was supposed that it might be possible to reach the summit of Mount Whitney from this side, previous explorations having shown that this could not be accomplished from the northwest or west.

'The first range of foot-hills on the line of the Kaweah is of a highly metamorphic rock cut by east and west quartz veins. This formation continues only two or three miles, and is succeeded by granite, which continues through the whole range. The Kaweah emerges from the mountains through a narrow cut or gateway, and above this it occupies for some distance a winding valley with considerable bottom-land, sometimes as much as a mile wide on both sides. The stream meanders between chaparral-covered ridges which are deeply furrowed by precipitous cañons. About twenty miles from the plain a narrow belt of limestone was traversed; it was highly metamorphosed, of a gray color, and destitute of fossils. It was remarkable as being entirely included in the granite.

The first camp was at forty miles distance from the edge of the foot- 
hills, the road up the valley being intensely hot, dry, and dusty. From this camp the trail led over a rolling plateau of high altitude (probably between 8000 and 9000 feet), partly covered by forests of Pinus contorta, and partly by chains of meadows. North of the road was a range of bald, granite hills, with groves of pine scattered about their bases, an occasional patch of snow appearing on the higher points. This chain of peaks seems to be the continuation of the divide between the south and main Kaweah Rivers, and it continues eastward to the summit of the Sierra, being the southern termination of the high rauges to the north; south of it the country falls off' gradually to Walker's Pass, forming numerous broad, flat-topped lidges, which give the region the general aspect of a table-land, scored down from north to south by parallel cañons, of which the Kern occupies the deepest. The main and north forks of this river rise far to the north of this tableland, and cut their way through it, while the south fork heads on its southern slope, and joins the main river, about eight miles below where the trail crosses. This plateau is entirely of granite, and the vegetation varies according to the altitude. West of the cañon of the south fork, the forests are chiefly of the Pinus contorta; between this and the main Kern are fine groves of P. Jeffreyi, and occasional oaks. The mountains of the ridge between the main and south forks of the Kaweah are all of granite; those at the western end are of very lightcolored rock; but near the head of the south fork the granite becomes quite red, and the points near the main summit vary from dark-brown to yellowish-red. The same change of color in the rock is observed in going from the Yosemite to Mount Lyell. In the valley of the South Kern, the granite is much altered, probably from the decomposition of pyrites, as a good deal of oxide of iron was seen around the springs issuing from it. In the region between this and the main Kern, there are large accumulations of granitic detritus on the surface. Where the trail crosses the main Kern, the river is twenty-five or thirty yards wide; the water is clear and cold, and abundantly supplied with trout.

From this point the old trail bent southward, crossing the mountains some distance below Little Owen's Lake; the new one was built no farther, and from here it was necessary to continue the exploration, without any other guides than the eye and the compass. Striking the 
worth fork of the Kern, at that point only a brook four or tive yalds wirle, Mr. King followed it 11) for several miles, to where it breaks thromgh an east and west range of craggy peaks, which comes down like an inmense spur, at right-angles to the general course of the Niera, and is continued as an clevated ridge far down the north side of the Kaweali. 'This lange heads in a very high and batre goranitic rak, caller sheep Rock, from the great number of momntain sheep found in this vicinity. It is about eight miles south of Mount Whitney, and is the termination of this high portion of the Sierra.

North of this spur, or lateral l'ange, through which the north and main forks of the Kern both make their way, there is a quadrilateral area, comprised between the two great divisions of the Sierra on the east and west sides, and having on the north the transverse ridge which connects Mount Tyndall with Mount Whitney. In this the main Kern heads with many branches, and to the east of it, in the midst of every difficulty, Mr. King worked for three days before he could reach the base of the mountain, whose summit he was cndeavoring to attain. All his eftorts, however, proved unsuccessful, as far as this particular object was concerned; but he was enabled to determine the main features of the topography of a considerable area, which otherwise would necessarily have been left an entire blank upon our map.

The highest point reached by Mr. King in his eftorts to scale the sumnit of Mount Whitney was, according to the most reliable calculations, 14,740 feet above the sea-level. At the place where this observation was taken, he was, as near as he was able to estimate, between 300 and 400 feet lower than the culminating point of the mountain, which must therefore somewhat exceed 15,000 feet in height. So far as known it is the highest point in the United States, and the elevation attained by Mr. King was greater than any other person has reached, within our territories, or anywhere on the continent north of Popocatapetl.

Mount Whitney is a ridge having somewhat the outline of a helmet, the perpendicular face being turned towards the east. There is snow on its sumnit, which indicates that there must be a flat surface there. The mountain is the culminating point of an immense pile of granite, which is cut almost to the centre by numerous steep and often almost 
rertical cañons, ending in high walled amphitheatres. Southward of the main peak, there is a range of sharp needles, four of which are over 14,000 feet high. 'The general aspect of the group is much like that of Mount Tyndall. This mountain has been approached on all sides, except from the east, and found to be utterly inaccessible. Mr. King thinks it possible, however, that some route may yet be found by which the summit can be reached.

\section{Section III.-The llead of the San Joaquin River.}

During the time while Mr. King was exploring about the sourees of Kern River, Professor Brewer and party continued their route northward, in the hope of being able to cross over the higher ridges of the Sicrra to the head of the San Joaquin. They left the Big Meadows July 17 th, and made their way into the great cañon of the south fork of King's River by a terribly steep road, the deseent being between 4500 and 5000 fect. The cañon here is very much like the Yosemite. It is a valley, from half a mile to a mile wide at the bottom, about eleven miles long and closed at the lower end by a deep and inacessible ravine like that below the Yosemite, but deeper and more precipitous. It expands above and branches at its head, and is everywhere surrounded and walled in by grand precipices, broken here and there by side cañons, resembling the Yosemite in its main features. The walls of the King's River cañon, however, are nowhere vertical to so great a height as Tutucantila; but rather resemble the Sentinel and Cathedral Rocks, or the Three Brothers, of the Yosemite Valley. They rise at various points to heights estimated to be from 3500 to 6000 feet above their base, and there is but little debris at the foot of the walls. The height of the lower end of the valley (Camp 178) above the sea was found to be approximately 4737 feet; that of the upper end (Camp 179) 5218 feet. At the hearl of the valley, oceupying a position analogous to that of the Half Dome at the Yosenite, is the inost elevated part of the wall; it is nearly vertical, and between 6500 and 7000 feet high.

'The King's River cañon rivals and even surpasses the Yosennite in 
the altitude of its surrounding clifts ; but it has no features so striking: as the Half Dome, or Tutucanula, nor has it the stupendous waterfalls which make that valley quite unrivalled in beauty; its streams descend by a series of what may be called (in California) cascades, of from 150 to 200 feet high.

The bottom of the valley is covered with granitic sand, forming a soil which supports a fine growth of timber, with here and there a meadow. The river abounds in trout.

The party came into the valley by an old Indian foot-trail, which passed out by the north fork, over an exceedingly rough country, and must cross the Sierra at an elevation of at least 13,000 feet. This trail was entirely impracticable for animals. As it was quite impossible to get north at the head of the valley, the party returned a distance of two or three miles, and made their way out on the north side, by an exceedingly steep and difficult route, camping four or five miles from the edge of the cañon, and at an elevation of more than 4000 feet above it, or 9308 feet above the sea. This camp (No. 180) was situated between the two main forks of King's River, and from it a series of fruitless attempts were made to reach Mount Goddard, about twenty-four miles distant, in a north-northwesterly direction. The ridge between the forks of the King's rises up in a crest, which, three miles southwest of Camp 180, is 12,400 feet above the sea. From the summit of this ridge there is a precipitous descent to the north, into the cañon of the middle fork, which is perhaps even deeper than the one just described.

The erest presents a very serrated outline. Two peaks lying just in front of it are especially fine; they are between five and six miles east of Camp 180; both are probably orer 14,000 feet high, the norther'n being a little the highest. This we named Mount King, and the southem one Mount Gardner. Mount King breaks off in grand precipices on the northwest side, like the Half Dome; these are several thousand feet in height, and almost vertical, producing the effect of an immense obelisk. The annexed wood-cut (Fig. 59) from a sketch by Mr. Hoftmann, gives an idea of the form of this grand peak; the point of view was at Camp 180, about six miles west of the summit.

The region around the crest of the ridge between the forks of the 
King's consists of granite masses, with spurs projecting out from them, and embracing basins of bare rock, each having a small lake at the bottom. The only living things visible in these valleys are the grasses

Fig. 59.

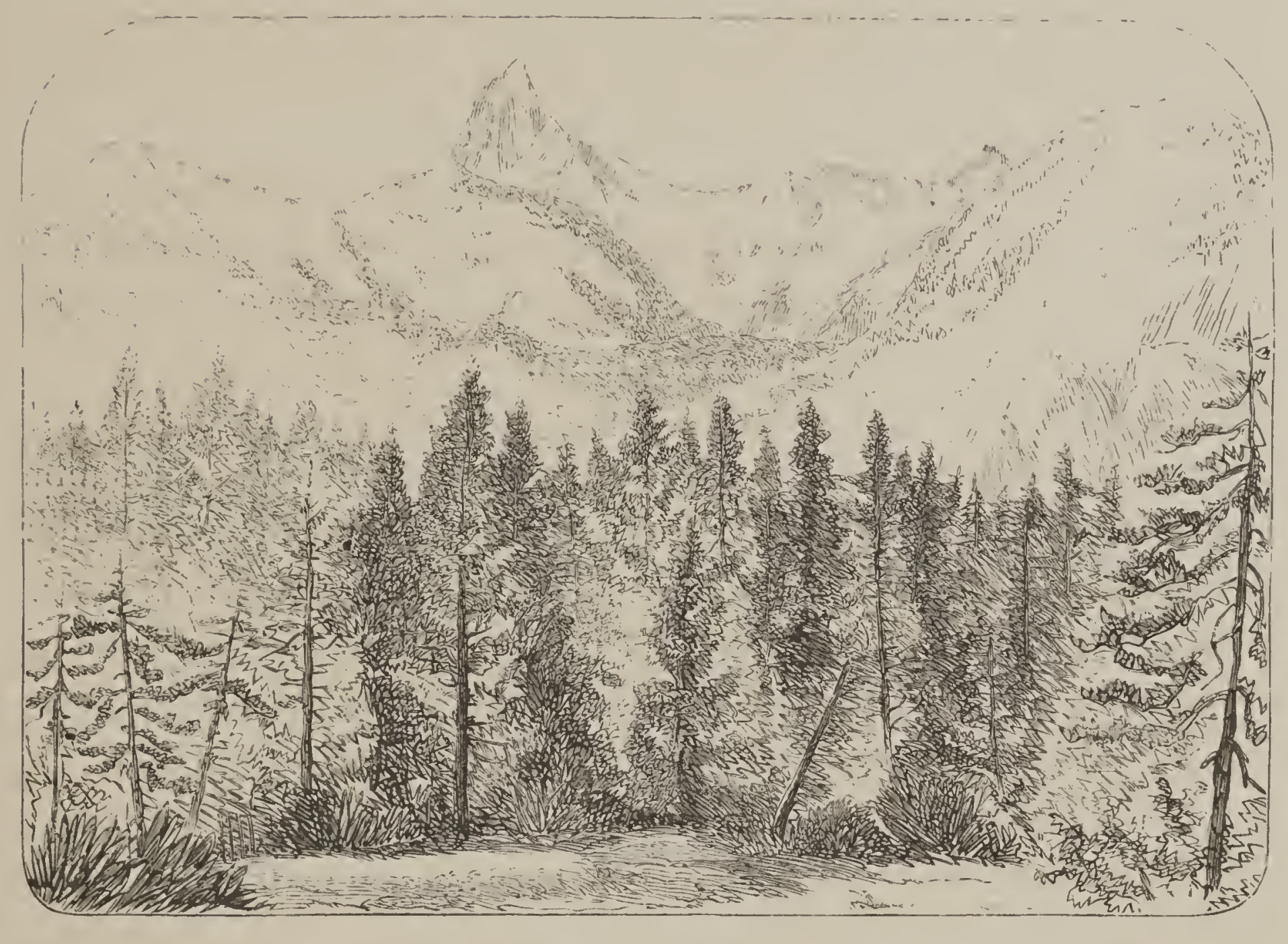

MOUNT KING.

Looking east, from Camp 180.

in the small meadows which border the lakes. Everywhere else are to be seen only smooth, bare rocks, or granitic debris in steeply-sloping piles at the base of the precipices. The crests of the ridges are thin and shattered-so thin that, in some cases, they could only be traversed by hitching the body over while sitting astride of them.

At the head of the north fork, along the main crest of the Sierra, is a range of peaks, from 13,500 to 14,000 feet high, which we called "the Palisades." These were unlike the rest of the crest in outline and color, and were doubtless volcanic; they were very grand and fantastic in shape, like the rocks seen on the Silver Mountain trail near Ebbett's Pass. All doubts as to the nature of these peaks were removed after observing on the east side of the crest, in Owen's Valley,

GEOL. VOI. I. -50 
that vast streams of lava had flowed down the slope of the Sierra, just below the Palisades.

Three days were spent by the party in trying to find some place where the ridge between the forks of the King's could be crossed with animals, so that the party could reach the middle fork and thence make their way to Mount Goddard. This was ascertained to be impossible, and it was found necessary to return to the cañon of the south fork. From here it was, after some hesitation, decided to cross the mountains into Owen's Valley, and after following it up for forty or fifty miles to turn west and cross the Sierra again, so as thus to reach the headwaters of the San Joaquin, over a trail which was made, in 1863, by a party of soldiers in pursuit of Indians.

A day and a half was requived to make the distance of twelve miles which lay between Camp 179, in the south fork cañon, and the summit of the Sierra; although the labor of crossing was much facilitated by the fact that a party of prospecters had crossed here not long before, and had done a good deal towards making a passable trail. Camp 181, midway between the valley and the summit, was found to be 9627 feet high. To the north of this camp, and nearly east of Mount King, but on the main crest of the Sierra, was a high, naked rock, rising fully 3000 feet above the trail at its base, and one of the grandest objects seen among these mountains. The sketch (Fig. 60) will serve to convey a faint idea of its majestic form.

The distance from Camp 181 to the summit was found to be about eight miles. The crest, on the pass, is double, the first summit being 11,031 feet high, and the eastern one 12,057 feet. The latter is a very sharp ridge, with both sides inclined at as steep an angle as the loose materials conld maintain without sliding; the actual crest is a sharp comb of rock. The peaks on each side are very steep, and were estimated to be 2500 feet above the pass, or fully 14,500 feet above the sea. At this time (July 27) there was no snow on the line our party traversed, although large patches were seen much lower down in shaded localities.

The granite along the crest is reddened by oxide of iron, and showed considerable tendency to decomposition, a condition of things which 
seems to be peculiar to the main ridge along the whole range from Mount Whitney north, but not noticed as extending far to the west.

Fig. 60.

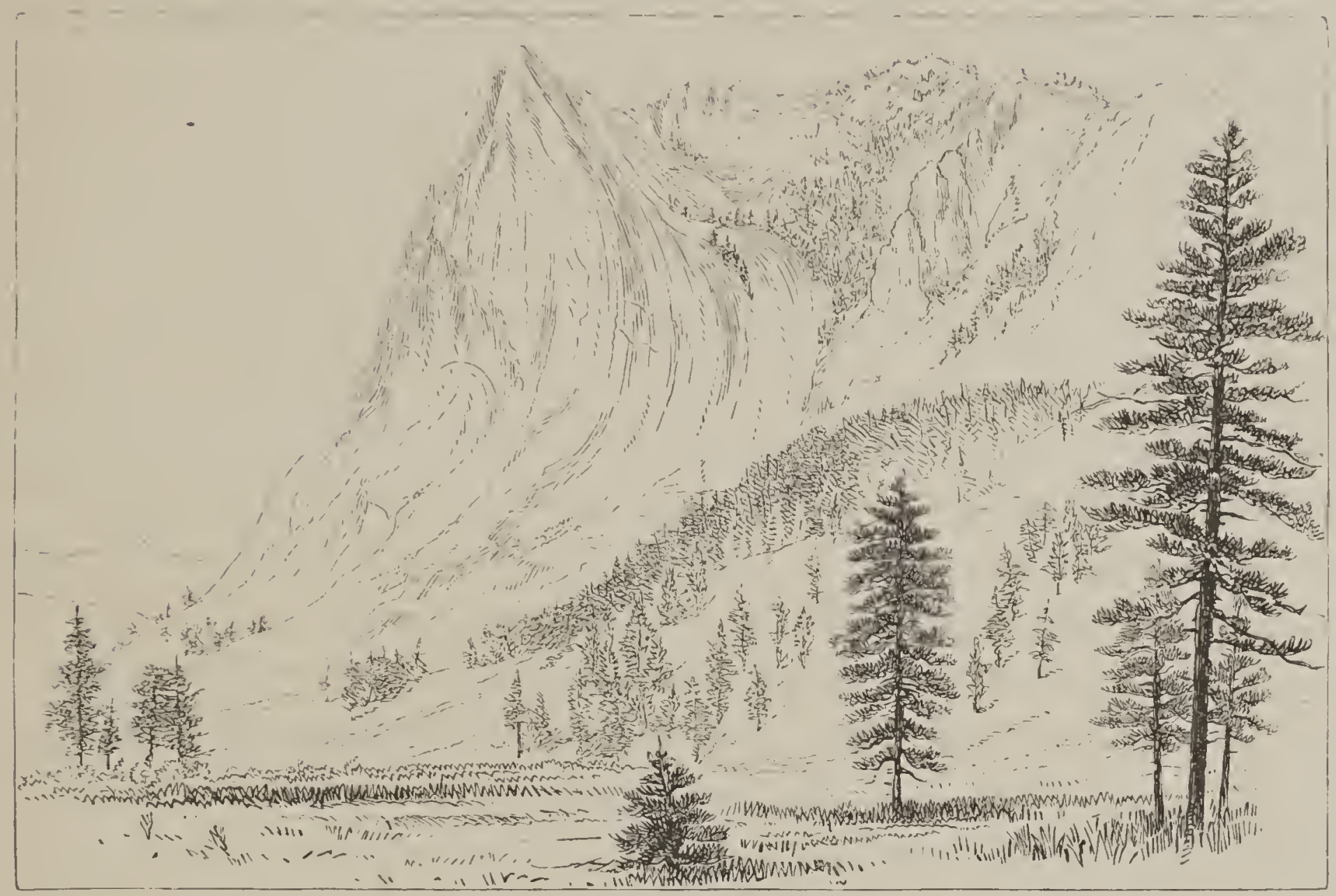

PEAK NEAR CAMP 181.

From the crest of the Sierra to its base in Owen's Valley is about eight miles in a direct line, and the average descent is just 1000 feet per mile for that distance. From the foot of the mountains, a gradual and uniform slope extends into the valley, forming an inclined plane, strewn with boulders resting upon a sandy soil. This plain is dry and barren, and covered with the usual desert shrubs, Artemisia, Purshia, Linosyris, and others. The highest peaks of the main crest are not more than ten or eleven miles from the valley, and fully 10,500 feet above it. For a description of Owen's Valley and the route of the party through it, the reader is referred to the chapter devoted to the eastern slope of the Sierra.

The mountains were entered again at the head of the west branch of Owen's River, on which Camp 187 was situated, at an elevation of 9298 feet above the sea. To the north of this is an extremely barren table of lava, and on the south granite. The valley of the stream is 
half a mile wide and flanked on both sides by beautifully regular moraines, from 1000 to 1200 feet above the bottom.

The summit of the Sierra was crossed at an altitude of 12,400 feet, and although the crest rose up in front, appearing as one continuous wall and scemingly not to be scaled, yet the ascent was found to be on a comparatively easy grade, with the exception of one rocky place near the summit. There is an obscure Indian foot-trail which crosses here, and a body of seventy cavalry, with their pack-train, crossed by it in June, 1863. At that time there were patches of snow half a mile long upon the road. A wagon-road could be made over this pass, withont much difficulty; but its great height, and the immense body of snow which must lie here during nearly or quite all the year, forbid the idea of any such undertaking. The crest here is very rugged, rising in precipitous ridges about 1000 feet above the pass in its immediate vicinity, and perhaps 2000 feet at a little distance north and south.

The views from the high points above the trail at the summit were of the grandest description. Eight miles to the north was a group of dark, crimson-colored peaks, and twenty-five miles farther in that direction were the snow-clad ranges near Mono Lake. In a southerly direction rose a vast mass of granite peaks and ridges, with the same sharp scattered crests, vertical clifts overhanging snow-fields and amphitheatres with frozen lakes, which were the main features of the views in the region about the head of King's River.

On the west side of the pass, there was one mile of rocky and steep descent; but otherwise no difficulty was experienced. Great slopes were traversed, which were worn and polished by glaciers, and, as everywhere else in the Sierra, these exhibitions of ancient glacial phenomena were exhibited on a much grander scale on the west slope of the Sierra than they had been observed to be on the eastern side.

Camp 188, a little below the summit, was at an elevation of 9940 feet, and from this high peaks on both sides were ascended and examined. Mr. Gardner visited the crimson-colored group noticed above, and which was about five miles north of the camp. The rocks were found to be of metamorphic slate, having a strike of $\mathrm{N} .50^{\circ} \mathrm{W}$. (magnetic), and dipping to the northeast, at an angle of $74^{\circ}$. This slate does not continue for more than eight miles to the north, and is there 
lost under the granite. Inclosed in the slate, and having the same dip and strike, is a vein sixty to seventy feet wide, of white quartz-rock. The "Slate Peaks," as they were callerl, were found to be about 13,400 feet in elevation. This group forms the northern termination of the great elevated lange of the Sicra, which stretches to the south, for a distance of over ninety miles, without any depression below 12,000 feet, in all probability the highest continuous mass of mountains in North America. To the north, between the Slate Peaks and the Mono Group, a considerable depression exists, over which is a pass, of the height of which we have no positive knowledge.

The point three miles south of Camp 188, which was ascended by Professor Brewer, was found to be 12,740 feet high, and another one, three miles farther southeast, was about 800 feet higher than this. These summits are of granite. Another patch of slate was seen, however, in passing down the San Joaquin River from Camp 188 to Camp 189; these form rather prominent knobs, one of which was called Mount Gabb. Whether the slate extends south, so as to connect with the mass of Mount Goddard, was not ascertained. Several dykes of rolcanic rock were observed cutting the granite, in this vicinity.

There is a great depression where the three largest branches of the King's come together. In this Camp 189 was made, at a distance of twenty-two miles from the summit of the Sierra, and 6930 feet above the sea. Grassy meadows occur here, and rising above them are many rocky knolls rounded by former glaciers. Here and there are patehes of lava, one of which, near the camp, was about a mile long; it rests ou the granite, and is entirely surrounded by that rock. This locality has long been a favorite resort of the Indians, on account of its remoteness from the settled part of California, and its consequent security. The abundance of game and the great number of pine trees in this valley also added to its charms. Thousands of trees were seen which had trenches dug around them, to eatch the worms which live in the bark, as is said; these, as well as the nuts of the pine, are staple articles of food among the "Diggers." All the movements of our party were watched by the Indians from a distance and signalled by smokes, but no attack was made, as there probably would have been had they not been provided with an escort. 
From Camp 189, the country to the south was explored, in the direetion of Mount Goddard, an important topographical station for connecting with the work on the other side of the King's. In going from Camp 189 to 190 , the middle and south forks of the San Joaquin were crossed, and a due south coulse was kept towards a high point on the ridge, eight miles distant. The valley widens out here, and includes a broad belt of rolling country, with numerous low hills of granite, whose tops and sides are all smoothly rounded by glacial action. The predominant trees here are Pinus. Jeffreyi and $P$. contorta. As we rise out of the valley, immense moraines are seen at the height of from 1500 to 2000 feet above the valley. A glacier, at least 1500 feet deep, eight or nine miles wide, and probably thirty miles long, perhaps much more, once flowed down this valley, and has left its traces everywhere along its sides.

A peak a little south of Camp 190, and 10,711 feet above the sea, was climbed; from this a grand view of the Sierra between the Obelisk range and the Mount Brewer group was obtained. The snow lay on this ridge several hundred feet below the summit; but the Pinus albicaulis grows to the very top. This forms one of a series of high points which extend in a line nearly parallel with the crest of the Sierra, and from sixteen to twenty miles distant from it, thus preserving all through this region the same double-crested character which the range has farther south around the head of King's River.

About nine miles south was a prominent point of a dark color, which was presumed to be volcanic, and it was thought probable that it might be connected with the lava stream which is seen at Fort Miller. Some of the party, however, who passed over the line of this supposed connection, on their way to Fort Miller, saw nothing but granite until they were near the fort.

The next move took the party about twelve miles in a southeasterly direction, and to a point only eighteen miles from Mount Goddard. This camp (No. 191) was at an elevation of 10,268 feet. The route followed lay along and over a ridge, with a very sharp crest breaking off in grand precipices on each side. It has also a parapet along the south edge similar to that described as forming the rim of the Kettle; this is in places thirty feet high, and rises like a grand wall, with a 
narrow shelf on the north; from this there is a very steep slope down for a thousand feet or more.

From Camp 191 an unsuccessful attempt was made to reach Mount Goddard, without the animals, as they could be taken no farther. The only possible way led along the divide between King's and San Joaquin River's, over a series of ridges, high and sharp, with valleys between, a thousand feet deep or more, so that progress was excessively slow and tiresome. Cotter and one of the soldiers succeded, after a day's climbing, in getting within 300 feet of the summit, and hung up the barometer just before it was too dark to see to read it. They were then at an elevation of 13,648 feet, making the height of the mountain about 14,000 feet. The return to an impromptu camp, at an elevation of about 12,000 feet and without provisions or fire, made by the remainder of the party at the base of the mountain, required the whole night and was hazardous in the extreme. This was Camp No. 192, or "Cold Camp."

The geological structure of the mountain and the arljacent ridges is peculiarly interesting and would repay a careful study; but the party, being entircly out of provisions, was obliged to beat a hasty retreat. There is much metamorphic rock here, especially mica-slate, forming vein-like masses inclosed in the granite. Cotter described the summit of Mount Goddard as made up of alternate veins or beds of slate and granite. Visible for miles across a cañon from Camp 192 was a cliff several hundred fect high, in which the veined or bedded structure of the granite was very conspicuous, the dark masses of the slate contrasting finely with the lighter-colored granite. Where the slates were seen in large bodies they were generally dipping at a high angle to the northeast, but sometimes vertical and often much contorted.

Mount Goddard seems to be the southern end of the belt of slates which forms Castle Peak, Mount Dana, and the high mountains near Camp 188, as already noticed. No slate was seen to the south of Mount Goddard in this direction, for nearly a hundred miles, which is the distance from this metamorphic region to that on Kern River, near Keysville, It is possible, however, that farther explorations might show a connection of the metamorphic masses through on this line.

From Camp 191 the party returned to 189, and from there worked 
to the northwest in the cañon of the north fork of the San Joaquin. For three-fourths of the way, the route followed led down the depression at the junction of the three forks before noticed. This depression has the appearance of a valley, only when seen from the heigh around it. There are numerous flats lying between rounded hills of bare granite; these flats are sometimes covered by forests, but many of them form beautiful open meadows in which many thousand cattle might be pastured.

Several small patches of rolcanic rock were noticed in this region, usually a hard, dark-colored, basaltic material. Occasionally, however, the lava was red and porous, and a piece of pumice was seen floating on the river.

Fig. 61.

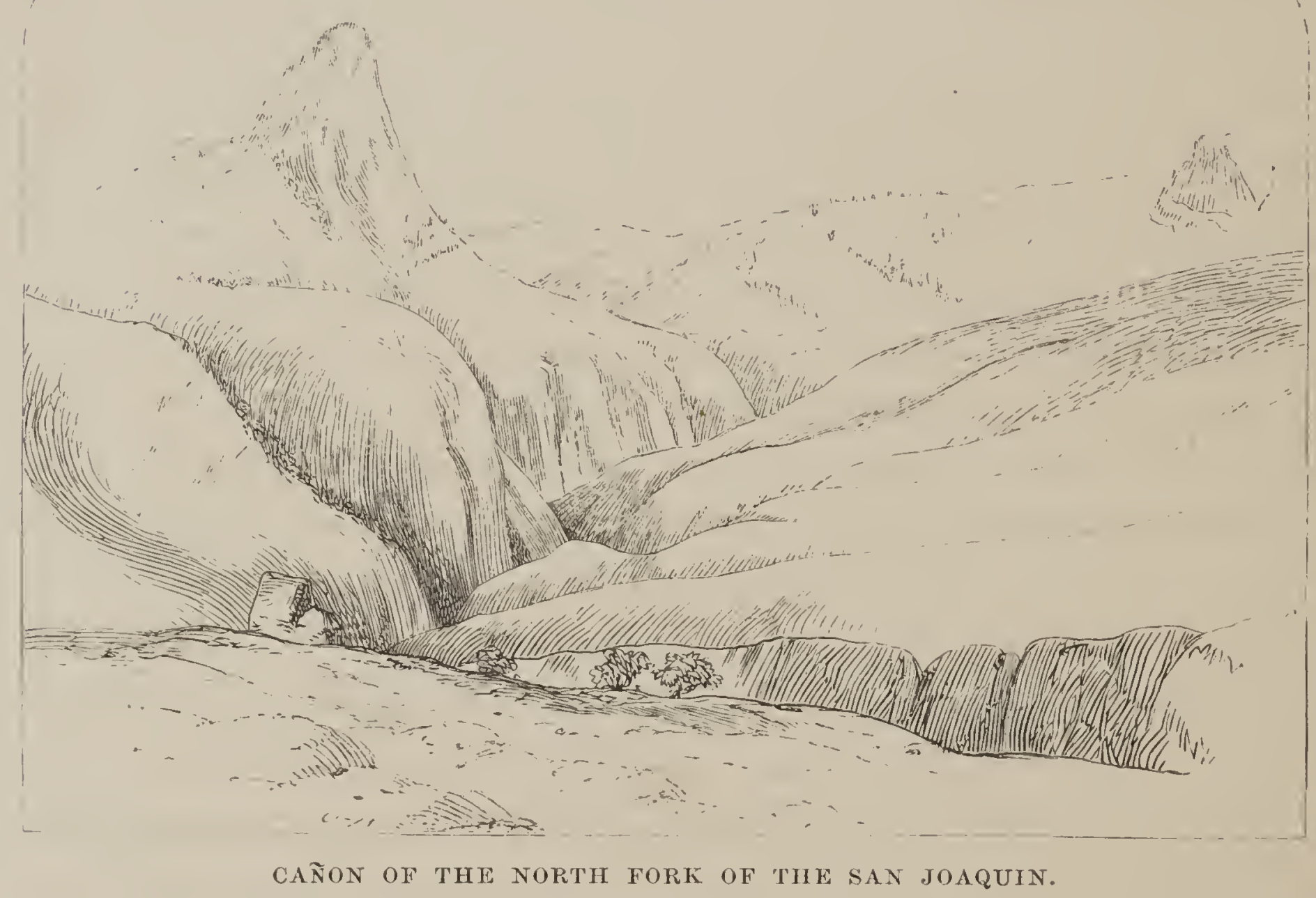

The north fork of the San. Joaquin comes down through a very deep cañon, and the wide, open, valley-like depression terminates here. This cañon is from 3000 to 4000 feet deep, and proved to be a serious obstacle to the advance of the party. Near the junction of the north and main forks, it is a mere notch, and its walls exhibit some grandly picturesque features. The above wood-cut (Fig. 61) represents one 
of bare and rugged masses of rock, rising 1500 feet above the inaccessible gorge at its base, through which flows the north fork.

Two or three miles southeast of this is a most remarkable dome, more perfect in its form than any before seen in the State. It rises to the height of 1800 feet above the river, and presents exactly the appearance of the upper part of a sphere; or, as Professor Brewer says, "of the top of a gigantic balloon struggling to get up through the rock."

Camp 194, in the cañon, was at an altitude of about 4750 feet, while the ranges to the east and northeast rose from 4000 to 5000 feet above this, and those on the west about 3000 feet. The sides of the cañon are very abrupt, and present immense surfaces of naked granite, resembling the valley of the Yosemite. There are everywhere in this valley the traces of former glaciers, on an immense scale, and as the party rose above the cañon on the north, in leaving the river, the moraine on the opposite side was seen very distinctly, and appeared to be at an elevation of not less than 3000 feet above the bottom of the valley. It was evident that the glaciers which came down the various branches of the San Joaquin all united here to form one immense "sea of ice," which filled the whole of the wide depression spoken of above, and left its moraines at this high elevation above the present river-bed.

The party passed out of the cañon to the northwest, first ascending a steep ridge, over 3000 feet high, and then entering a wide elevated valley, where Camp 195 was made, at an elevation of about 7250 feet. On the high ridge, traversed in getting to this camp, were many boulders of lava, which must have been brought from some more northerly point and dropped in their present position by ancient glaciers. The source of these boulder's seems to have been near Mount Clark, in the Obelisk Range. The view from the summit of the ridge was a grand one, commanding the whole of the Mount Lyell and Obelisk groups, as well as the main range of the Sierra to the east, where are many darkcolored peaks, apparently volcanic. A very high and massive peak wals seen to the east of Mount Lyell, which it nearly equalled in altitude; it was called Mammoth Mountain, and was estimated to be 13,000 feet in height.

In the depression to the west of the ridge noticed above are heavy forests and fine meadows scattered over the country, into which many

GEOL. YUL. I. -51 
cattle had been driven from Fresuo County, to escape the extreme drouth of the season. The meadows occupy the flats or level intervals between the domes of granite; grassy-flats, as they are called, occur everywhere along the Sierra at about this altitude, on the high lands between the large streams.

In the region about Camp 195 a few narrow belts of mica-slate were noticed in the granite; some patches of lava were also observed.

Camp 196, a few miles north of 195 , was at the base of a prominent peak, which was supposed to belong to the Obelisk group, for which the party was aiming. On ascending it, however, it was found to be about eight miles due south of the Obelisk. It was found to be 10,950 feet high and commanded a fine view. The base is of granite, and it is capped with lava; from this point it was noticed that some of the peaks of the Obelisk group are covered with the voleanic rock in the - same way.

Eighteen miles northeast of this is the lowest gap or pass over the Sierra which occurs between Carson's and Walker's Passes, a distance of about 250 miles. An approximation to its height was obtained by an observation of the barometer on the peak ascended near Camp 195, at a point which was ascertained by levelling to be at about the same altitude as the pass itself. The result of the calculation gave 9200 feet as the height of the summit of the pass, which is considerably lower than the Mono Pass. Cattle have been driven across to Owen's Valley over this route, the north fork of the San Joaquin being crossed at a point much farther up than where our party traversed it, and where the cañon is not nearly so deep.

From Camp 196 the party made their way, as rapidly as the wornout condition of the men and horses permitted, to Clark's ranch, on the trail from Mariposa to the Yosemite: They first travelled in a southwesterly direction, over a region of dome-shaped granite hills, for a distance of twenty-three miles, and camped at the head of the Chiquito Sam Joaquin, and at the altitude of 7463 feet. Many meadows were passed, into which large numbers of eattle had been driven. One of these is known as Neal's ranch, or Jackass Meadows. From this point there were trails which could be followed, and this was the first sign of a return to the regions of civilization. 
Gold had been found during the summer in the bed of the Chiquito Joaquin, and also on the Lower King's River, and quite a number of miners had flocked to this region. Of the productiveness of the diggings our party had no means of judging, nor was the precise locality known; as near as could be ascertained, it was about ten miles from Camp 197.

Canip 198 was at the head of the Fresno River, and at an elevation of 3217 feet. Along this part of the route the rock was chiefly metamorphic, but highly crystalline, and exceedingly obscure in its lithological characters. It forms a red soil in decomposing, and is probably the source of the gold found in this vicinity. The trail descended sufficiently to strike the true foot-hill vegetation; but afterwards rose again into the High Sierra, and on the 23d of August, Camp 199 was made at Clark's Ranch, at an elevation of 4270 feet, by the party, who were, by this time, pretty nearly at the end of their resources, as well as their strength. One of them, indeed, remained in a precarious condition for some weeks, and did not entirely recover until after the lapse of several months.

\section{Section IV.-The Region about the Heads of the Merced and} Tuolumne Rivers.

That portion of the High Sierra in which head the numerous branches of the Merced and Tuolumne Rivers is, on many accounts, one of the most attractive regions of the State to the lovers of the picturesque. Although its scenery may not exhibit that awful sublimity of desolation which marks the Sierra at the heads of King's and Kern Rivers, yet it has some peculiar features which are to be found nowhere else in the State. It has by far the greatest water-falls, not only of the Sicrra Nevada, but, as may fairly be claimed, of the world, for we know of nothing of this kind which will compare with the falls of the Merced or of the Yosemite Creek in height or sublimity, or in the general effect of their surroundings. The region of this grand scenery in Mariposa County is comparatively accessible, so much more so indeed than that described in the two preceding sections, that thousands will visit the Yosemite to one who scales the summit of Mount Brewer 
or Kaweah Peak. But the traveller, desirous of learning something of the grandeur of the mountain scenery of the Pacific side of our continent, should not be contented with seeing the Yosemite only; he should push on still farther into the heart of the Sierra, visit the sources of the Tuolumne River, and climb Mount Dana; all of which may be done, even by ladies, without danger and almost without difficulty. It is true that, at present, there are no accommodations for pleasure-travellers in this region, and they must, therefore, provide themselves with camp-equipage and provisions; but, as the tide of travel turns more strongly every year in this direction, the time must soon come when a public house at Soda Springs, in the Tuolumne Valley, will afford the necessary facilities for visitors to this region, and the ascent of Mount Dana, or other yet undescribed peaks, will be as common as a visit to the White Mountains and the summit of Mount Washington was a few years ago.

In the hope of directing the attention of travellers and tourists to this grand and yet easily accessible portion of the Sierra Nevada, we shall, in this section, dwell rather more on the scenery and topography of the region than we should otherwise feel authorized to do in a volume devoted to geology. In that part of the final report which will be devoted to Physical Geography, we hope to be able to go much more at length into all the subjects which will especially interest the intelligent traveller in the Sierra, and the consideration of which will, as we hope, induce others to continue the observation of the physical phenomena of this great chain of mountains-a task which we can only begin, and must then leave for others to work upon, knowing that the material is ample and interesting enough to give full scope to the powers of many a lover of science, nature, or art, who may come after us, and perhaps owe his happiest and best inspirations to the study of these glorious objects.

The exploration of the region about the heads of the Merced and Tuolumne Rivers was chiefly done by our whole party in the months of June and $J u l y, 1863$, about three weeks having been then devoted to the survey of the route between Big Oak Flat and Mono Lake, one of which was spent in and about the Yosemite Valley. The next year' after, however, Professor Brewer, at the close of the reconnaissance de- 
scriber in the precerling section, made a short visit to the Yosemite. Still later in that season, during the months of October and November, Messrs. King and Gardner spent several weeks there, engaged in making a survey of the valley, for the use of the Commissioners appointed by the Governor to have the care and oversight of the tract granted by the United States to the State of California, embracing the Yosemite Valley and the Mariposa grore of Big Trees. After completing the survey of the grant, Mr. King wrote out his notes of the geological observations made by him while thus engaged, and has kindly placed them at the disposition of the Survey. An accident having occurred which prevented the immediate comparison of the barometer's at the time of the completion of the work, and the record of a subsequent one not having been received, the results of Messi's. King: and Gardner's observations of heights may hereafter require a slight correction; but a sufficient number were made by our party, in 1863 , to give a general idea of the elevations around the valley. To go in to the minute details of the topography of this region would almost require a volume by itself. The map drawn by Mr. Gardner is now nearly completed, and it is supposed that it will be published, either by the Commissioner's or by the Geological Survey, according as the Legislature may determine. A rough survey and map of the valley was, however, made in 1863 by Mr. Hoftimann, which was intended to be used in a future volume of our Report, in case we should not have the means of preparing a more detailed and accurate one.

After our hasty survey of the Yosemite Valley, in 1863, we followed the trail from there to Mono Lake, camping for about two weeks near the head of the Tuolumne River, and securing the first outline of the geography of that extensive region, which had never been laid down with even approximate accuracy on any published map; indeed, so far as we can learn, the higher elevations of this part of the Sierra had never been ascended, certainly not measured or located, previous to our visit. Since that time, howerer, we lear'n that Mount Dana has been visited repeatedly, and that our pioneer work in this region has already had the effect to attract quite a number of visitors in its direction.

In a previous chapter we briefly noticed the geology of the route to 
the Yosemite, as far as the Bower Cave (see page 235), the point where the trails from Big Oak Flat and Coulterville unite. That by the lastnamed place is the one usually followed, and the distance to the valley is called fifty miles; this portion of the route must be done on horse or mule-back. Two days are required to make the distance comforta$\mathrm{bly}$, and the journey cannot fail to be a delightful one to those who are accustomed to riding, and not alarmed at mountain trails, where with a reasonable amount of care there is no danger whatever. The trail passes, for the entire distance, through the magnificent and unrivalled forests of the Sierra, and the sight of these alone would well repay the cost of the excursion.

From Bower Cave, we cross obliquely over the great limestone belt, already described, in a southeasterly direction, to Bull Creek, the distance being called six miles; here we have attained an altitude of 2793 feet. Beyond this, the auriferous slates are struck again, and there are some washings in Bull Creek, and along a branch of it which the trail follows for some distance in a northerly direction. A little beyond this the granite is met with, and this is the only rock seen along the road, until we have passed far beyond the Yosemite and reached the very summit of the Sierra. Along the edge of the granite, however, there are limited patches of highly metamorphosed strata, apparently masses of the slates which have been caught up in the intrusive rock, and have had their original structure so nearly obliterated that it is quite difficult to make out their real nature. A few miles after passing the western edge of the granitic formation, the rock becomes very homogeneous, and appears to contain exceedingly few accidental minerals, although there are, in places, a considerable number of quartz veins; these, however, become less and less frequent as we ascend towards the crest of the mountains.

From Bull Creek to Black's Ranch is called six miles, and parties often spend the night here on their way to or from the valley. Six miles farther on is Deer Flat, where was, in 1863, the last house on the road before reaching the Yosemite. From here to Crane Flat is twelve miles, and the trail between the two places passes over and along a high granitic spur of the Sierra, rising at the summit to the elevation of 6669 feet. Along this part of the route many quartz veins were 
noticed. At Crane Flat, 6130 feet above the sea, there was, in 1863, a deserted shanty, and abundant forage for animals. The forests in the vicinity are superb, consisting of pine, spruce, and fir, with a small group of the Big Trees not far from the Flat. This "Flat," as these small level areas of grassy land in the high mountains are usually called, is but a few acres in extent, and is almost wet enough to be called a marsh.

From here on to the Yosemite, the character of the scenery begins to undergo a change, and to show indications of an approach to the higher regions of the Sierra. The larger outcrops of granite assume more and more of the dome form, and are almost bare of vegetation. The forests become less dense; the sugar pine, that most striking of all the trees of California (the Big Trees themselves hardly excepted), grows less frequent, and the firs and spruce begin to predominate over the pines.

From Crane Flat to the edge of the valley, where it is met by the trail on the north side, is called ten miles, making fifty-two miles from Coulterville. At a little distance from the trail on the southern or right-hand side, is a place from which a partial view of the Yosemite Valley may be obtained. It is not a satisfactory one, however, on account of the number of trees in the way and the bend in the valley itself, which cuts off the view of all the upper part. In this respect it is inferior to the bird's-eye view of the Yosemite and all its surroundings which is had from "Inspiration Point," on the Mariposa trail into the valley, and approaching it from the south. Those who desire to have the finest and most comprehensive view of the whole scene at the first, should enter the valley by the Mariposa and return by the Coulterville trail; those, on the other hand, who would reserve to the last the grandest effect of all, and who would wait until they have become familiar with the details, before having the whole scene spread out before them, will do well to reverse the order of their coming and going.

The Yosemite Valley is situated on the Merced River. It is about 140 miles in a direction a little south of east from San Francisco. It is nearly in the centre of the State, north and south, and exactly mid- 
way between the east and west bases of the Sierra, here about seventy miles wide.

The valley is a nearly level area, about eight miles in length and varying from half a mile to a mile in width. For the lower six miles its course is from northeast to southwest; the upper two miles are nearly at right-angles to this, the angle of the bend being at the spot where the Yosemite Fall comes over the precipice on the north side. Below the expanded portion of the valley, the Merced enters a terribly deep and narrow cañon, which is said to be inaccessible, and which we had no time to explore.

To make the peculiar features of the Yosemite more intelligible to those who have not seen it, or who have not enjoyed, what is next best to the thing itself, the admirable photographs of Mr. C. E. Watkins,* we give a wood-cut (Fig. 62), representing a portion of both sides of the valley, and which is one of the first near views which the traveller gets of the grander masses, whether he descends by the Coulterville or the Mariposa trail. On the right-hand or south side (the view being taken looking up, or to the northeast), we have the cliffs on the face of which the Bridal Veil Fall is seen. Behind this is a much higher mass, which forms a portion of the Cathedral Rock. On the other side is Tutucanula, or El Capitan, the first of these names being the original Indian appellation for this mighty clift, and supposed to be either the name of some great chief, or else the word by which their "Great Spirit" or Deity was called, while "El Capitan" is the term by which the first visitors to the valley undertook to translate the aboriginal idea into the Spanish.

As the idea of the dimensions and verticality of the walls of the Yosemite may be somewhat less easily taken from the shaded woodcut, a section (Fig. 63) is appended of the valley at this point, on an

* 'These photographs, thirty in number, and twenty-one inches by sixteen in size, are pronounced by all artists to be as near perfection as possible. They are already well known and widely distributed through the Eastern States, and will be more so. The glass stereographs taken in the valley, by Mr. Watkins, are in some respects even more effective than the photographs. All the views of the Yosemite given in this volume are taken from these photographs, by permission. 
THE UEAD OF THE UERCED A ND TUOLUMNE RIVERS. H(19)

equal scale of rertical and horizontal distances, from careful measurements by Mr. King. The distance across from the inside edge of the

Fig. rie.

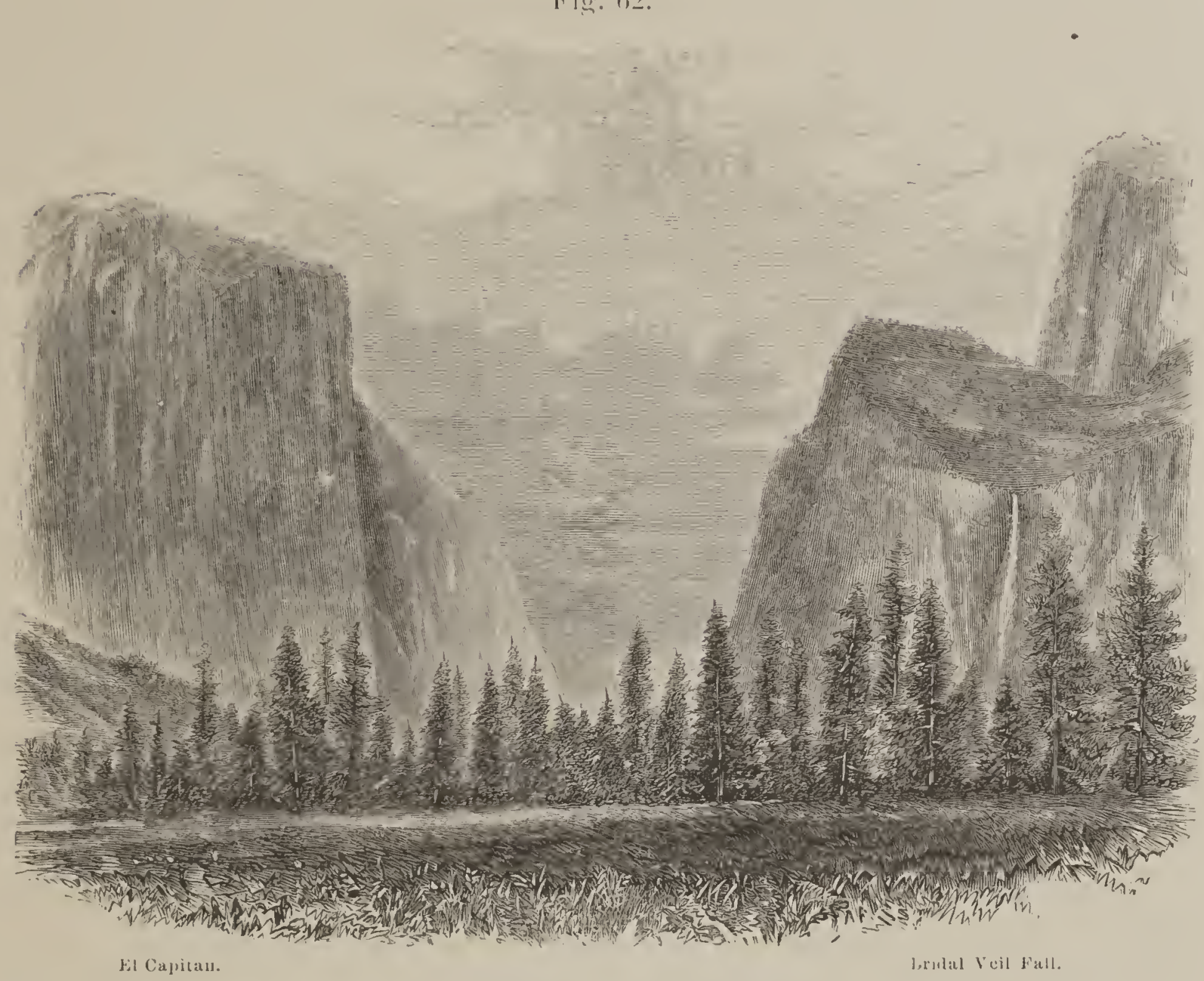

IOSEMITE VALLET.

talus on one side to that on the other (represented in the section by the (ark shading) is a little less than half a mile.

Fig. 68.

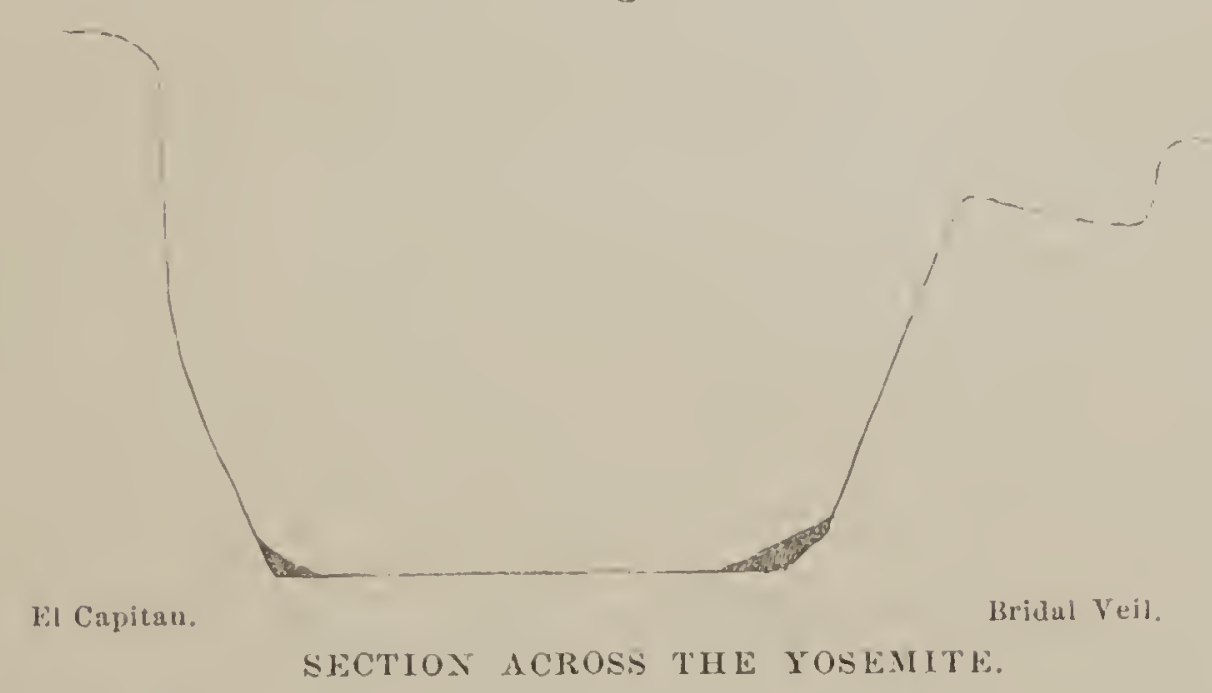

GEOL. VOL. I. - $5:$ ' 
From these two wood-cuts it will be evident to all that the peculiar features of the Yosemite are; first, the near approach to verticality of its walls; next, their great height, not only absolutely, but as compared with the width of the valley itself; and, finally, the very small amount of debris, or talus, at the bottom of these gigantic cliffs. These are the great characteristics of the valley throughout its whole length; but besides these, there are many other striking peculiarities, and features both of sublimity and beauty which can hardly be surpassed, if equalled, by those of any mountain scenery in the world.

Tutucanula is an almost vertical cliff of naked, smooth granite. From its edge down to the valley below is about 3300 feet, according to Mr. King's measurement; it is usually called 3600 fect, which may be the extreme height of its slightly rounded summit. It is undoubtedly one of the grandest objects in the Yosemite, and it would be difficult to find anywhere in the world a mass of rock presenting a perpendienlar face so imposing and elevated. The pile of debris at its base (represented by the dark shade in the section) is so insignificant in dimensions, compared with the cliff itself, that it is hardly noticed at all from some points, in a general riew of the valley, and this is one of the most striking and unique features of the scene, for it is a condition of things of the rarest possible occurrence. We know of nothing like it in any other part of the world.

The Bridal Veil Fall, of which the Indian name is "Pohono," is about 1000 feet in height, and, during the season when the stream is fed by the melting snow on the mountains above, it is a wonderfully beautiful object. The body of water is not large, but is sufficient to produce the most picturesque effect. As it is swayed backwards and forwards by the varying force of the wind, it is continually altering its form, so that it seems, especially as seen from a distance, to flutter like a white veil; hence the name, which is both appropriate and poetical.

Proceeding up the valley, we find, a little above the Bridal Veil Fall, and on the same side, the prominent and massively sculptured pile to which the name of Cathedral Rock is given (Fig. 64). It was not measured by us, but it appears to be about 3000 feet in height. Its massive, and yet nobly proportioned, form can be perhaps faintly conceived of from the wood-cut, which reproduces with accuracy the ont- 
line, and some of the artistic effect, of the photograph. Behind this are the "Cathedral Spires," two slender and beantiful columns of

Fig. 64 .

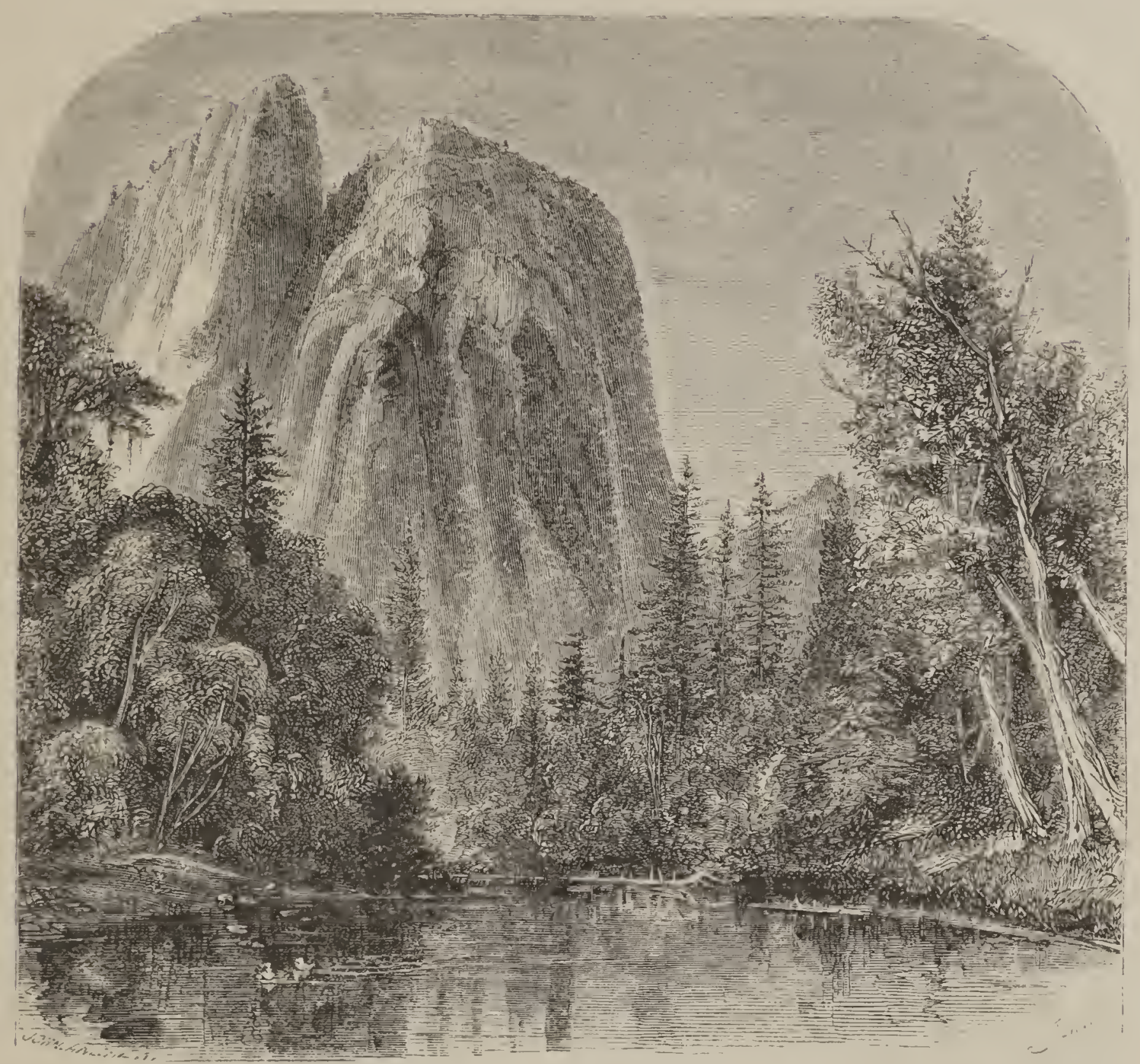

CATHEDRAL ROCK.

granite, on the same gigantic scale as everything else in this region, and which here are passed almost unnoticed, although, by themselves, in other parts of the world, they would be considered objects of the greatest interest.

A couple of miles farther up the valley, and on the other side, is the next cluster of peaks, a triple row of summits rising in steps one above the other" these are called the "Three Brother's." From the highest of these, nearly 4000 feet above the valley, there is, as Mr. King thinks, the finest view which can be had of the Yosemite itself and the whole surrounding region up to the crest of the Sierra. 
Opposite the Three Brothers is a prominent point, which stands ont near the angle where the valley makes its most distinct turn, and which, from its fancied likeness to a gigantic watch-tower, is called "Sentinel Rock." As seen from the sonthwest, it is a group of cliffs, of which the outside one has quite the form of an obelisk, very regular and beantiful, for at least a thousand feet down (see Fig. 65). The entire height of the Sentinel above its base is a little over 3000 feet.

Fig. 65)

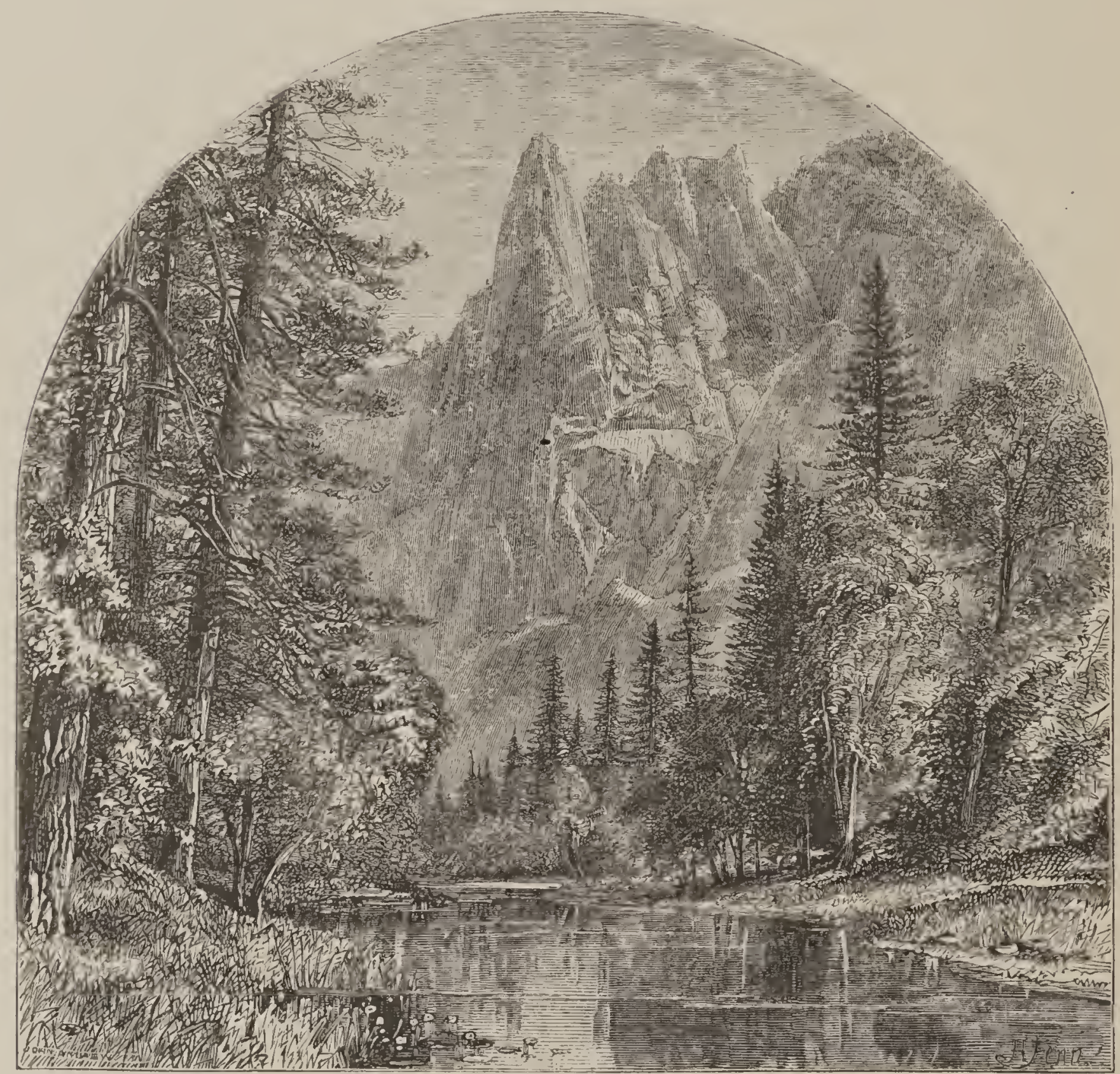

SENTINEL ROCK.

Three-quarters of a mile southeast of the Sentinel is the Dome of the same name, 4150 feet high, and one of the most perfect of the domeshaped masses of granite so peculiar to the Sierra Nevada. Its horizontal section is nearly circular, and its slope very regular and uniform on all sides. From its summit the view is, of course, extremely grand; 


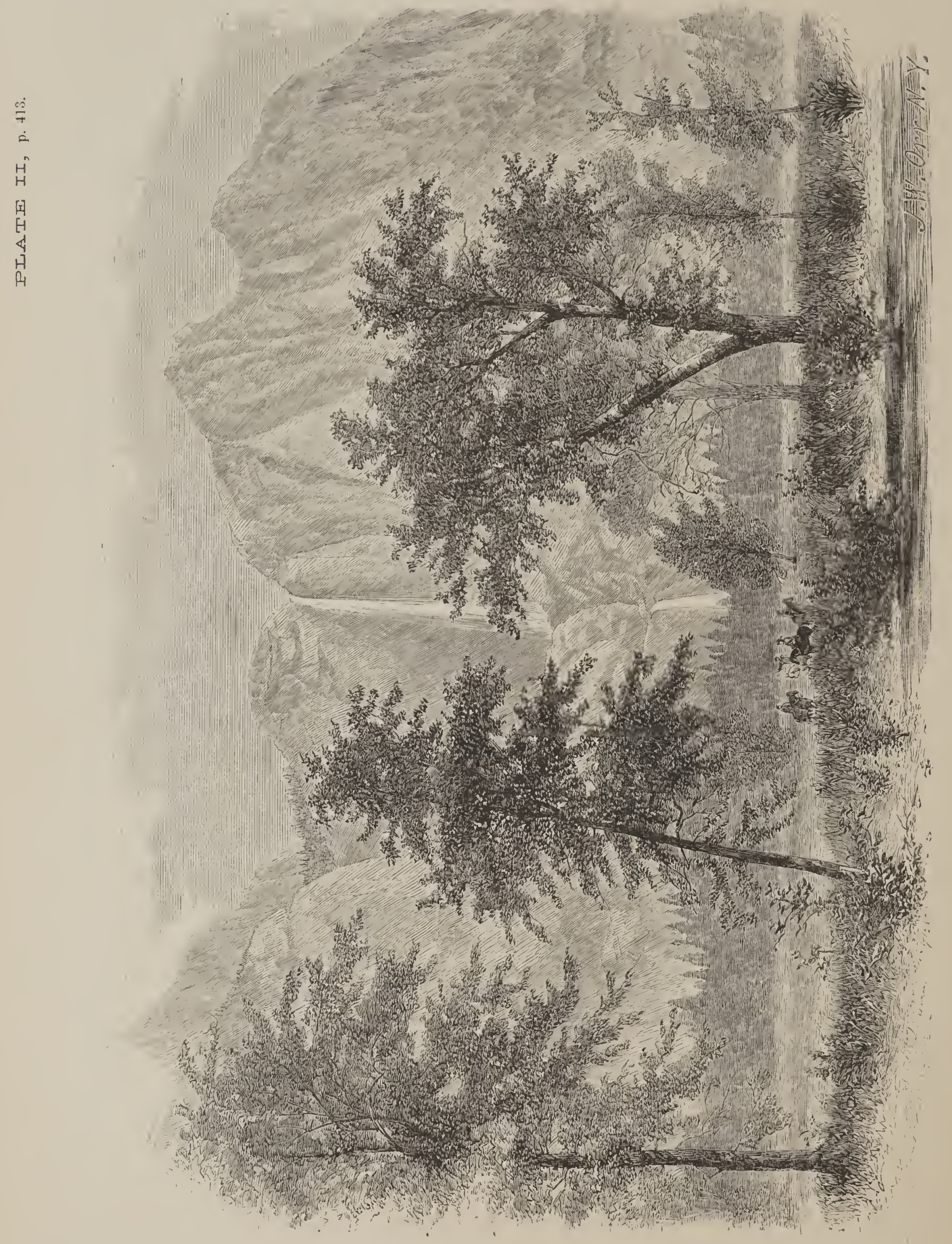


it is especially fine in the direction of the Obelisk Group of mountains, and it commands the cañon of the south fork of the Merced"Illilonette," as it is called by the Indians. From this point the glacial phenomena, and especially the regular and extensive moraines, of that valley are finely displayed. The profile of the Half I)ome, of which more filrther on, is best seen from the Sentinel Dome.

From near the foot of Sentinel Rock, looking directly across the valley, we have before us, if not the most stupendous feature of the Josemite, at least the most attractive one, namely the Yosemite Fall. We have endeavored to convey some idea of the grandeur and beanty of this fall, by reproducing (in Plate 2) as well as can be done on the small scale allowable in this volume and on wood, one of Mr. Watkins' photographs; but it is in vain that we attempt, by any work of art, to do more than give the faintest echo of the impression which this glorious exhibition of nature produces on all who are so fortunate as to see it under favorable circumstances. About the time of full moon, and in the month of May, June, or July, according to the dryness and forwardness of the season, is the time to visit the Yosemite, and to enjoy in their perfection the glories of its numerous water-falls. Those who go later, after the snow has nearly gone from the mountains, see the streams diminished to mere rivulets and threads of water; they feel satisfied with the other attractions of the valley, its stupendous clifts, domes and cañons, and think that the water-falls are of secondary importance, and that they have lost little by delaying the time of their visit. This is not so; the traveller who has not seen the Yosemite when its streams are full of water has lost, if not the greater part, at least a. large portion, of the attractions of the region, for so great a variety of cascades and falls as those which leap into this valley from all sides has, as we may confidently assert, never been seen elsewhere -both the Bridal Veil and the Nevada Fall being unsurpassed in some respects, while the Yosemite Fall is beyond anything known to exist, whether we consider its height or the stupendous character of the surrounding scenery.

The Yosemite Fall is formed by a creek of the same name, which heads on the west side of the Mount Hoftmann Group, about twenty miles north of the valley. The volume of water varies, of course, with 
the scason; at the ordinary stage of summer, through the months of June and July, it is about twenty feet wide and two feet deep, on the average. From the edge of the clift over which it is precipitated to the bottom of the valley, the perpendicular distance is, in round numbers, 2550 feet. Professor Brewer's measurement gave 2641, and that of Mr. King 2537, the difference being due to the circumstance that the lip or edge is a gradual curve, and so highly polished that a near approach to, or a precise definition of, the place where the perpendicular portion of the fall commences is impossible. As the quantity of water was at a minimum at the time of Mr. King's visit, so that lie could approach with safety more nearly to the edge, it is probable that his result is the nearest to the truth.

The fall is not in one perpendicular sheet. There is first a vertical descent of 1500 feet, where the water strikes on what seems to be a projecting ledge; but which in reality is a shelf or recess, almost it third of a mile back from the front of the lower portion of the clift: From here the stream finds its way in a series of cascades down it descent equal to 626 feet perpendicular, and then gives one final plunge of about 400 feet on to a low talus of rocks at the base of the precipice. As these various falls are in one vertical plane, the effect of the whole from the other side of the valley is nearly as grand, and perhaps even more picturesque, than it would be if the descent was made in one sheet from the top of the cliff to the bottom. The mass of water in the 1500 foot fall is too great to allow of its being entirely broken up into spray, but it widens very much as it descends, and as the sheet vibrates backwards and forwards with the varying pressure of the wind, which acts with immense force on this long column of water, the effect is indescribably grand, especially under the magical illumination of the full moon. The cliff a little east of the edge of the Yosemite Fall rises in a bold peak to the height of 3030 feet above the valley; it can be reached through Indian Cañon, a little farther east, and from here a magnificent view of the whole region may be obtained. The ascent to the summit of the upper fall and the return to the valley may be made in one day, but only by good mountain-climbers.

About two miles farther" up from the falls just noticed, the main valley of the Yosemite comes to an end, and runs out into three dis- 
. 


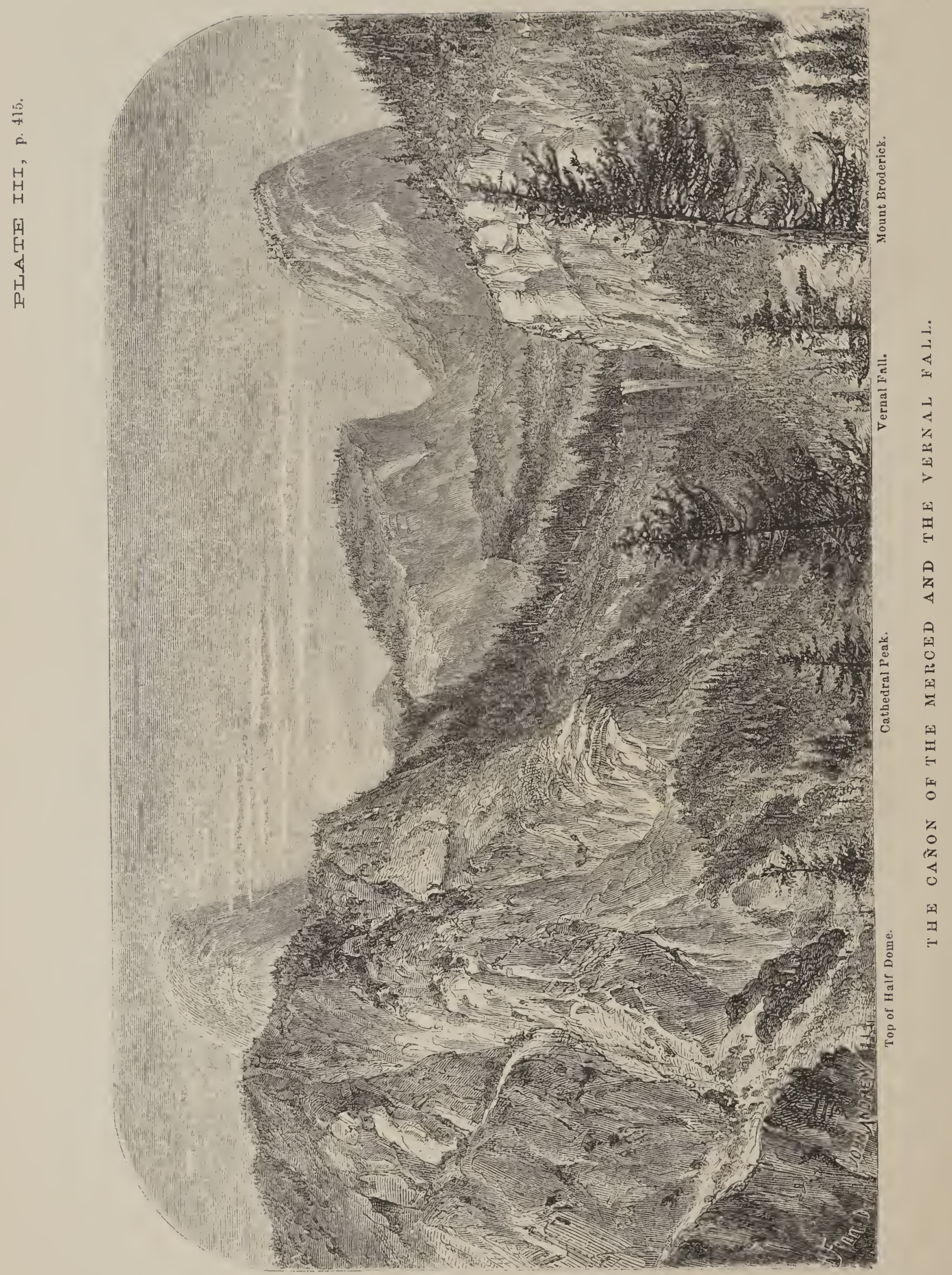


tinct cañons, each of which, however, has new wonders to disclose. The Merced River keeps the middle one of these, and its course here is about the same that it was below, or nearly west. It holds this direction nearly up to the base of the Monnt Lyell Group, where it heads. In the left-hand, or northwesterly cañon, the Tenaya Fork comes down; in the right-hand one, the south fork or the Illilouette.

Fig. 66.

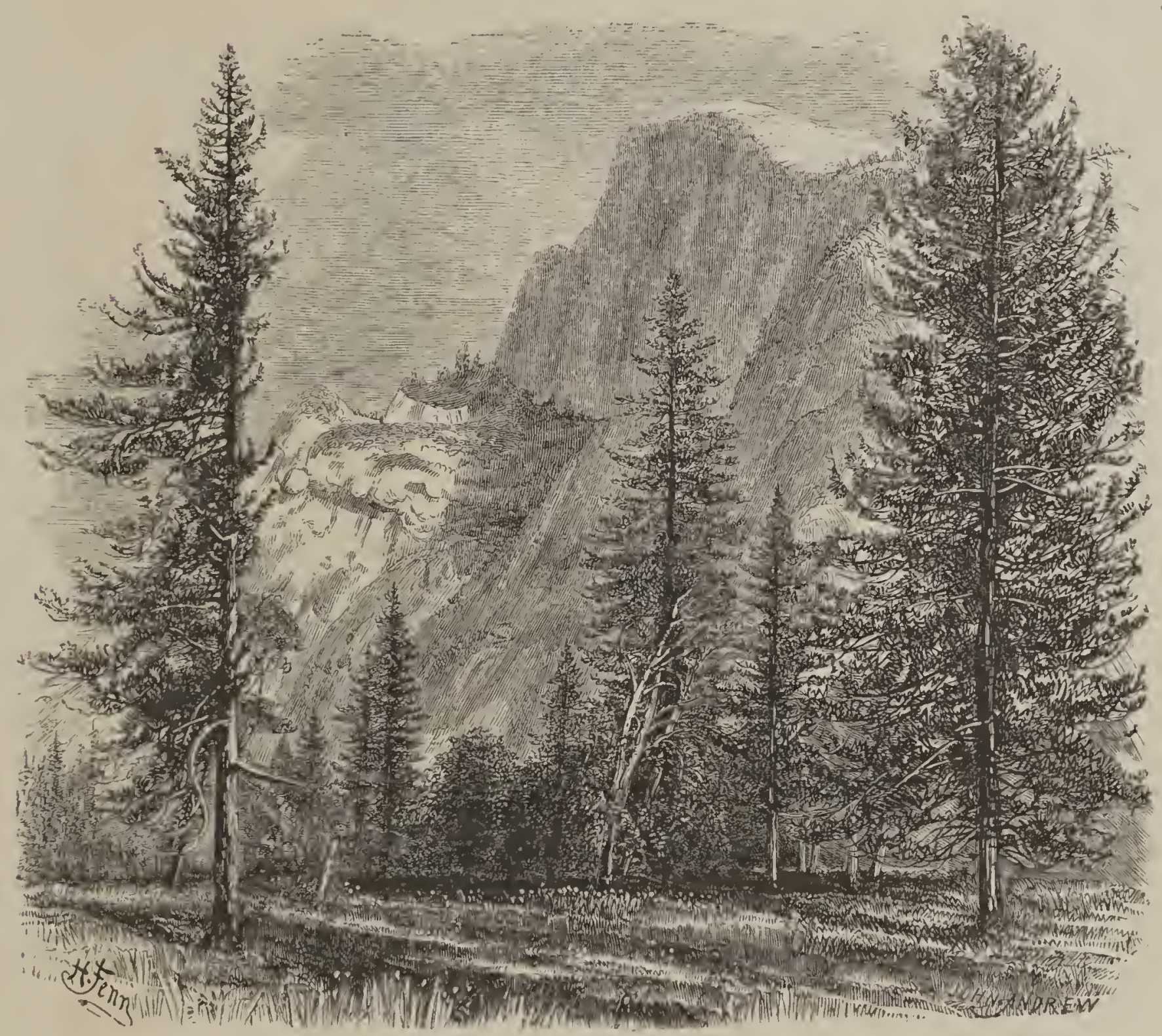

THE UALF DOME. YOSEMITE YALLEY.

Following up the 'Tenaya Fork, which rises on the east side of Mount Hoffimann, we have on the right hand, just at the entrance of the cañon, that grandest and loftiest mass of the Yosemite Valley, called the Iralf Dome. This has been in sight, however, through all the upper part of the valley, above the Yosemite Falls, and is a conspicuous point from all the region aromnd. Its form, as seen from near the entrance of the cañon, may be understood from the woodcuts (Fig. 66 and Plate 3). Tn one it is seen flatwise; in the other, 
edgewise. It is an inaccessible erest of granite, rising to the height of 4737 feet above the valley, the face fronting towards Tenaya Creek being absolutely vertical for 2000 feet down from the summit. The outline of this wonderfully formed mass of rock may be seen in the annexed section (Fig. 67) through the Half Dome, Lake Tisayac

Fig, 67.

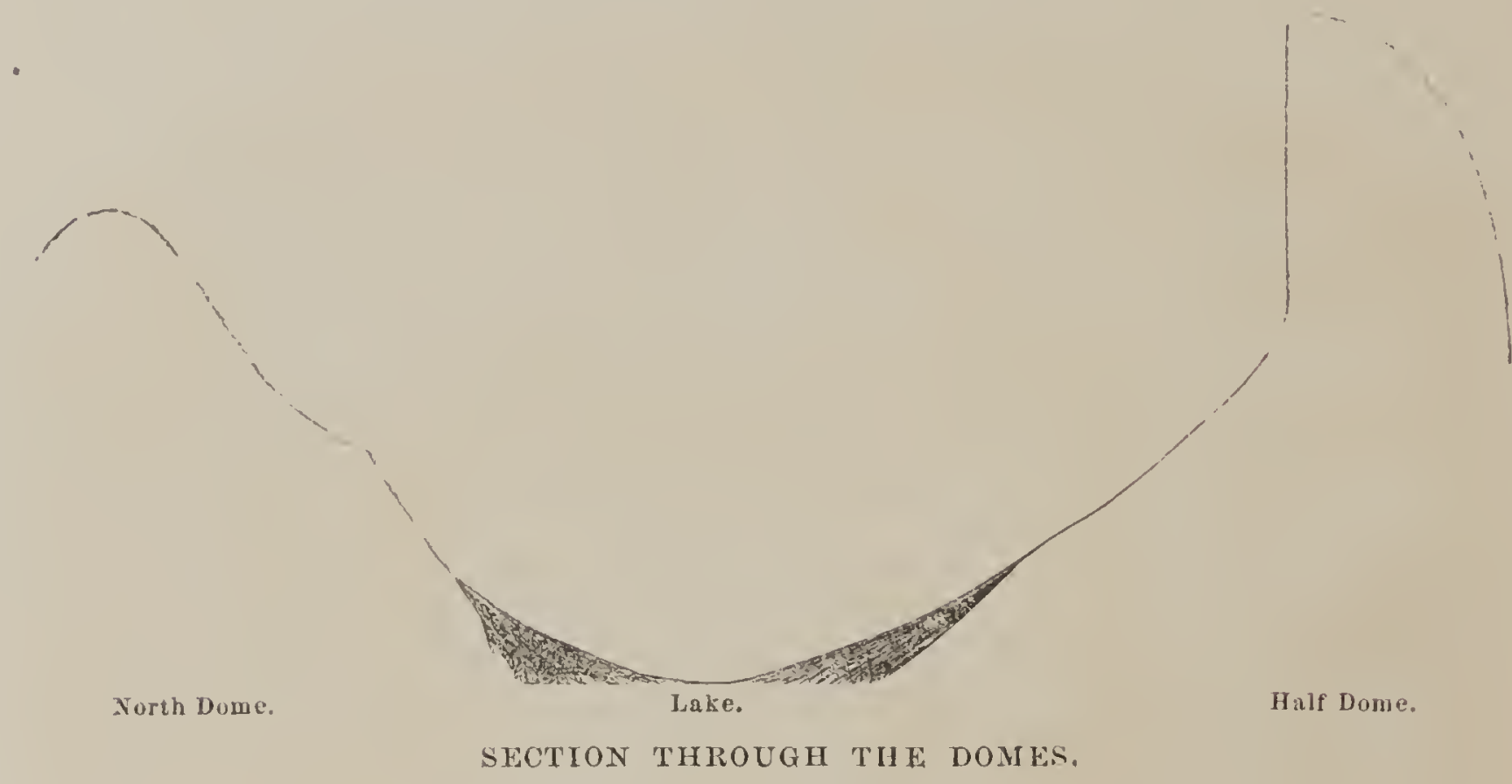

and the North Dome, on an equal vertical and horizontal scale, the distance across from the summit of one dome to the other being about a mile and three-quarters. Such a representation of a mountain or cliff seems to be something imaginary, rather than the plotting of measured angles and distances, which it really is. By turning to Plate 3, which is accurately copied from a photograph, it will be seen that there is no exaggeration in this outline. The whole appearance of the mass is that of an originally dome-shaped elevation, with an exceedingly steep curve, of which the western half has been split oft and has become engulfed. Hence the name, which is one that scems to suggest itself at first sight of this truly marvellous crest of rock. From all the upper part of the ralley, and from the heights about it, the Half Dome presents an aspect of the most imposing grandeur; it strikes even the most casual observer as a new revelation in mountain forms; its existence would be considered an impossibility if it were not there before us in all its reality; it is an unique thing in mountain scenery, and nothing even approaching it can be found except in the Sierra Nevada itself: 
'The North Dome, on the opposite side of the valley of 'Tenaya Creck, is another of these rounded masses of granite, of which the concentric structure, already frequently alluded to in this chapter, is very marked. The annexed wood-cut (Fig. 68), engraved by Mr.

Fin. 68.



Andrews from one of TVatkins's photographs, will illustrate both the form of the dome and its structure. It is 3568 fect in elevation above the valley, and is very easy of aseent from the north side. At the angle of the cañon, appearing as a buttress of the North Dome, is the Washington Column, a grand, perpendicular mass of granite, and by its side the Royal Arches, an immense arched carity formed in the clifts by the giving way and sliding down of portions of the rock, the vaulted appearance of the upper part of it producing a very fine effect.

Farther up the añon of 'Tenaya Creek is a little lake, called TisalGEOL. VOL. I, - , i: 
rac; it is surrounded by the most picturesque cliffs, having the giant Half Dome orerhanging its eastern side.

The cañon of the Mereed, above the Yosemite Valley proper, rises very rapidly for the distance of about two miles, when it attains the level of the surrounding platean. In this two miles the river descends 1980 fect, making, besides innumerable cascades, two grand falls, which are among the greater attractions of the Yosemite, not only on account of their height and the large body of water in the river during the early part of the season, but also beeause of the stupendous peaks and (liff's by which they are surrounded.

The first fall reached in ascending the cañon is the Vernal, or Piwyac. It is a simple perpendicular sheet, 475 feet in height, as nearly as we could determine, the blinding spray at the bottom rendering exact measurements impossible. A distant view of this fall, with a portion of the cañon and the top of the Half Dome in the distance on the left hand, and Mount Broderick on the right, is given in Plate 3. The rock behind the Vernal Fall is a perfectly square cut mass of granite, and it is wonderful to see how little any eroding effect of water can be traced in its outline. It would seem as if causes now in action had nothing to do with the formation of this step in the descent of the Mereed down to the valley below.

Ascending to the summit of the Vernal Fall by a series of ladders, and proceceding a mile farther up the river, passing a series of rapids and cascades of great beauty, we come to the last great fall of the Merced, namely, the Nevada, or the "Yowiye," of the Indians. The total descent, from the edge of the Nevada Fall to that of the Vernal, is 894 feet; of which 639, as near as we could determine, is in one perpendicular sheet. The Nevada Fall, however, has a peculiar twist in it, near the summit, caused by the mass of water falling on a projecting ledge, which throws it off to one side, adding greatly to the picturesque effect. This may be seen in the wood-cut (Fig. 69), which also gives a view of the stupendous mass of Mount Broderick, an inaccessible peak, rising, as near as we could estimate, 2000 feet above its base, and little inferior to the Half Dome in grandeur. (Sce also Plate 3.) The Nevada Fall is certainly to be ranked as one of the very finest cataracts in the world, taking into consideration its beight, the 
volume and purity of the water, and the whole character of the scenery which surrounds it, Mount Broderick alone being an object of which

Fiщ. (i?).

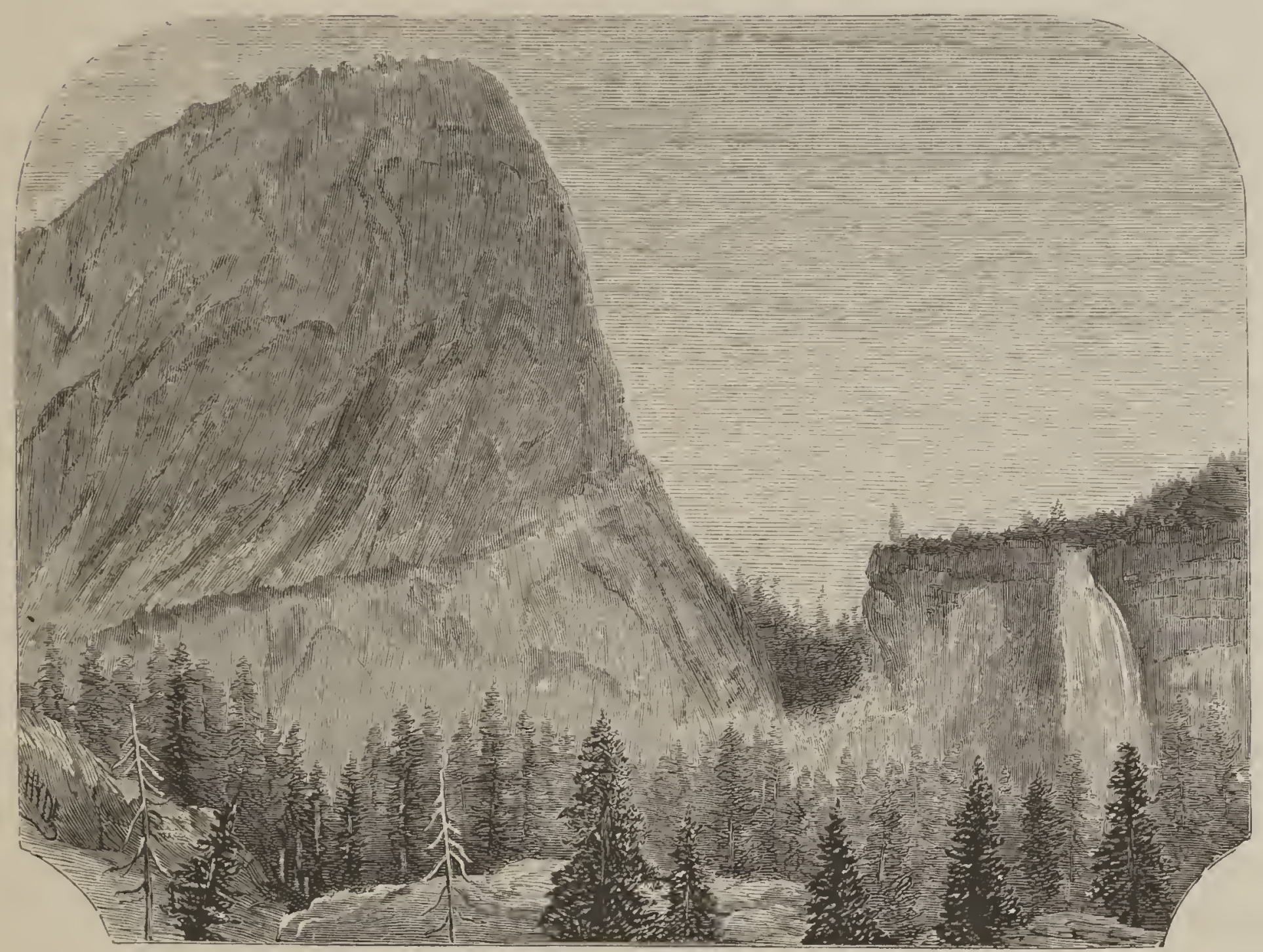

MOUNT BRODERICK AND THE NEVADA FALL.

the fame would be spread world-wide, if it were not placed as it is, in the midst of so many other wonders of nature.

There are also grand cascades in the South Fork Cañon, the scenery through the whole of which is little inferior to that of the other portions of the Yosemite; but, amid so many objects of attraction, few visitors find time to examine this cañon, especially as the trail by which it is reached is a rough and difficult one. Judging from Mr. Watkins's photographs, the view's from points along the slopes of the South Fork Cañon must be equal to almost any which can be had in the whole region.

In the angle formed by the Merced and the South Fork Canon, and about two miles south-southeast of Mount Broderick, is the high point, called the "South Dome," and also, of later years, "Mount Starr King." 
This is the most symmetrical and beautiful of all the dome-shaped masses around the Yosenite; but it is not visible from the valley itself: It exhibits the concentric structure of the granite on a grand scale; although its surface is generally smooth and unbroken. Its summit is absolutely inaccessible.

Having thus briefly noticed some of the more prominent objects of interest about the Yosemite, we may add a few words in regard to the valley itself. This is an almost level area, the fall from one end to the other of the valley proper being only about fifty feet. The width of the bottom-land, between the slopes of debris at the base of the clifts, is only about half a mile; below El Capitan, howerer, it is nearly twice as much. Its smooth surfice and brilliant color, diversified as it is with groves of trees and carpeted with showy flowers, offer the most wonderful contrast to the towering masses of neutral and light purpletinted rocks by which it is surrounded. Its elevation above the sea is, according to our measurements, 4060 feet. A much longer series of observations than ours was taken by Miss Sproat, at the request of Messrs. Gardner and King, while they were engaged in their survey; the result has not yet been calculated. It will be safe, however, to call the height of the valley 4000 feet, in round number's; the clift's and domes about it are from 7000 to 9000 in altitude above the sca-level.

The trees are thickly enough scattered over the valley to produce a fine picturesque effect. They are not as lofty as those of the forests of the Sierrat at that altitude usually are. The predominating species is the pitch pine ( $P$. ponderosa), which grows here from 125 to 150 feet high. Besides this, there are a number of $P$. Jeffreyi and a few sugar pines. The white oak ( $Q$. lobata) and the evergreen oak ( $Q$. crussipocula) are also common, and there are numerous willows, and a poplar, called "cottonwood," but really allied to the "Bam of Gilead," of the Eastern States. On the cliff's there are some cedars. In the high region about the Yosemite, at an elevation of from 3500 to 7000 feet, there is precisely the same vegetation which has already been described as existing around Mount Shasta, except that the trees are not quite as high, and there are more black oaks (Q. Sonomensis) in the lower forests.

All will recognize in the Yosemite Valley a peculiar and almost 
unique type of scenery. Cliff's alsolutely vertical, like the upher portions of the Ifalf Dome and El Capitan, and of such immense heights as these, are, so far as we know, to be seen nowhere else. The dome form of mountains is exhibited on a grand scale in other parts of the Sierra Nevada; but there is no Half I)ome, even among the stupendous precipices at the head of King's River. It is natural to ask, then, how these vertical clift's have been formed, and to what geological canses does the Yosemite Valley owe its existence?

Most of the great canons and valleys of California have resulted from denudation, as has been already repeatedly stated in the course of this volume. The long-continued action of the tremendous torrents of water, rushing with impetuons velocity down the slopes of the Sierra, has excarated those prodigious gorges, by which the chain is furrowed to the depth of thousands of feet. But these eroded cañons, steep as they may be, have not vertical walls; neither have their sides the peculiar angular forms which the mass of El Capitan, for instance, has, where there are two perpendicular surfaces of smooth granite meeting at right-angles, and each over 3000 feet high.

When Messr's. Gardner and King's map of the Yosemite is published, and farther investigations made to clear up some doubtful points, the theory of the formation of this valley may be discussed more intelligibly than it can be at present. It may, however, be stated, that it appears to us probable that this mighty chasm has been roughly hewn into its present form by the same kind of forces which have raised the crest of the Sierra and moulded the surface of the mountains into something like their present shape. The domes, and such masses as that of Mount Broderick, we conceive to have been formed by the process of upheaval itself, for we can discover nothing about them which looks like the result of ordinary denudation. The Half Dome seems, beyond a doubt, to have been split asunder in the middle, the lost half having gone down in what may truly be said to have been "the wreck of matter and the crush of worlds." It has been objected to this view, by some of the corps, that the bottom of the valley, in places where an engulfinent must, according to this theory, have taken place, seems to be of solid granite, when there should be an unfathomable chasm, filled now, of course, with fragments, and not 
occupied by a solid bed of rock. T'o this it may be replied, in the first place, that the masses which have been engulfed may have been of such enormous size as to give the impression, where they are only imperfectly exposed, of perfect continuity and connection with the adjacent cliffs. But, again, this grand cataclysm may have taken place at a time when the granitic mass was still in a semi-plastic condition below, although, perhaps, quite consolidated at the surface and for some distance down. In this case it is not impossible, certainly, that the pressure from above may have united the yielding material together, so that all traces of the fracture would be lost, except in that portion of it which affected the upper crust. If the bottom of the Yosemite did "drop out," to use a homely but expressive phrase, it was not all done in one piece, or with one movement; there are evidences in the valley of fractures and cross-fractures at right-angles to these, and the different segments of the mass must have been of quite different sizes, and may have descended to unequal depths.

In the course of the explorations of Messis. King and Gardner, they obtained ample evidence of the former existence of a glacier in the Yosemite Valley, and the cañons of all the streams entering it are also beautifully polished and grooved by glacial action. It does not appear, however, that the mass of ice ever filled the Yosemite to the upper edge of the cliffs; but $\mathrm{Mr}$. King thinks it must have been at least a thousand feet thick. He also traced out four ridges in the valley which he considers to be, withont a doubt, ancient moraines. One of these ridges is a low and narrow band of fragments of rock and rounded boulders, extending from the base of the IIalf Dome in a curve down the valley, and up again to the debris under the Washington Colunn. This seems to be the terminal moraine of the Tenaya Creek glacier.

A well-defined medial moraine extends from the foot of the western end of the Half Dome out into the valley, in a slight curve. Another one was formed between the glaciers descending from the cañon of the Merced and the south fork, and remains now as a large pile of debris extending down the valley.

A terminal moraine, according to Mr. King, extends across the Yosemite Valley from the clifts just below the Bridal Veil Fall, curv- 
ing down the river on the sonth side and up again on the north until it meets the talus about a quarter of a mile below El Capitan, thus forming a complete barrier across the ralley. It is not rery conspicuous, rising only about twenty feet above the general level, ret it scems to mark an important change in the character of the talus at the font of the cliff:s of the Yosemite. Above it the quantity of debris aceumulated in this position is exceedingly small; indeed, there is in some places actually none at all, the lower edge of the cliff meeting the floor of the valley, with hardly a fragment of rock lodged in the angle; below the moraine, on the other hand, the debris piles are extensive, uniting at the river, and extending high up the cliff's on each side.

It seems not unlikely that this moraine may have acted as a dam to retain the water within the valley, after the glacier had retreated to its upper end, and that it was while thus occupied by a lake that it was filled up with the comminuted materials arising from the grinding of the glaciers above, thus giving it its present nearly level surface.

It is evident, from the fresh appearance of large masses of debris along the sides of the valley that these materials are now accumulating with considerable rapidity; and when we consider how small the whole quantity of talus is, as compared with the height and extent of the cliffs, we are forced to the conclusion that the time which has elapsed since the Tosemite was occupied by a glacier cannot have been very long. It would seem that there are strong reasons for beliering that a great change in the climate of California may have taken place within the historical period. We know that such a change has occurred, as there is abundant evidence to prove that the precipitation of moisture in the Sierra Nevada was once vastly greater than it now is; but to the cause of this change we have as yet no clue. This subject, however, will come up for a much fuller, and, it is hoped, a more satisfactory discussion than we have either the space or the data for at the present time.

Having given the above brief account of some of the more interesting features of the Yosemite, we leave this wonderful valley, and proceed to sketch the geography and geology of the higher mountain region above, at the head of the Merced and Tuolumne Rivers.

We followed the Coulterville trail out of the valley, but turned east 
on arriving at the summit of the eliff, taking the usual route followed by mule trains to the Mono Pass. This trail is considerably used in the summer, as there is sufficient forage for animals at a number of points, and the meadows not having been claimed or fenced in, they are, as yet, free to all. On the more travelled rontes north of the Mono Pass, there are public houses, the pasture-land is inclosed, and feed must be purchased. In 1863, there was not a house or a settler anywhere between Deer Flat, twenty-two miles below the Yosemite, and the eastern base of the Sierra.

After leaving the valley, we crossed over high granite ridges running north and south between the Yosemite and Indian Creeks. From the summits of these, fine views were obtained of the IIalf Dome and the other great precipices about the head of the Merced River. IIigher up in the Sierra the mountains no longer appear in the form of domes, but rise in sharp ridges and needles, giving more of an Alpine character to the scenery.

Our first camp, after leaving the Yosemite, was at Porcupine Flat, a little meadow of carices, 8173 feet above the sea. From here we made some explorations of the north and south range, which stretches from the North Dome to the 'Tuolumne River, a distance of abont eighteen miles; it is the group of mountains in which head the Yosemite, Indian and Tenaya Creeks. The highest point of this range, which we called Mount Iloffimann, was found to be 10,872 feet in elevation. It is entirely of granite, having a gentle slope on the southern side, but breaking off in grand precipices to the north. From its summit the view of the Sierra, in all directions, is one of the finest which can be obtained, and its ascent may be strongly recommended to those who have not time to visit the still higher peaks of the main ridge of the Sierra. The excursion from the Yosemite to the summit of Mount IToffmann and the return may be easily made in three days, and the tourist who derotes this amount of time to getting a much better idea of the gralidenr of the Sierra Nevala than is usually obtained by visitors to the Tosemite will find himself amply rewarded. The highest point of the Mount IIoffmann Range is about four miles northeast of Porenpine Flat, and there are no difficulties of any kind to be encomintered in reaching it. 
LIBRARY
OF THE
UNIVERSITY OF ILLINOIS 


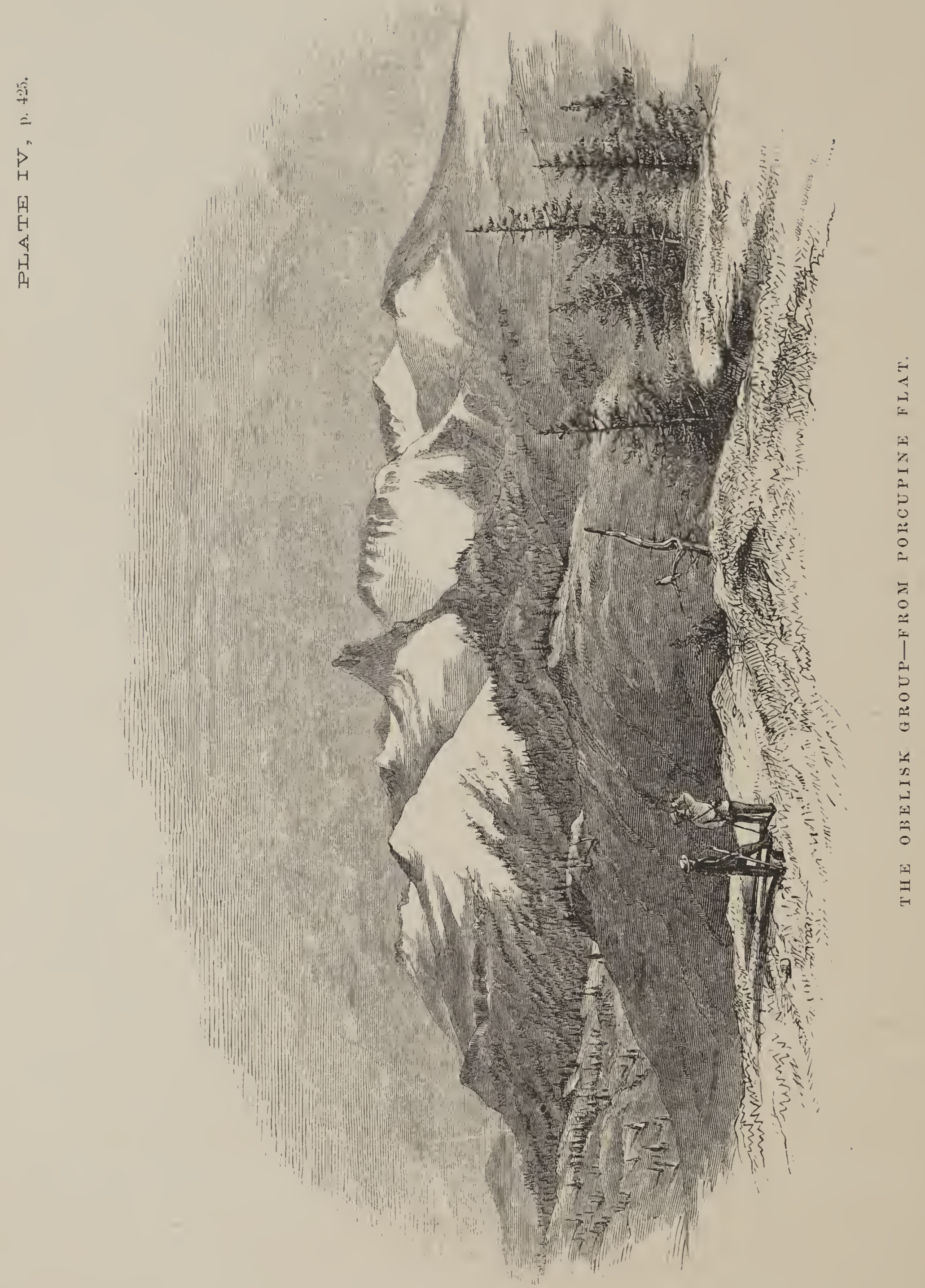


From Porenpine Flat we also enjoyed a masniticent view of the great spur of the Sierra which lies to the southeast of the Yosemite, and which we called the Obelisk Group, from a high and very conspicuous peak, which rises in the centre of the group, as may be seen in the sketch (Plate 4 ). This is an extremely picturesque range of mountains; but it has not been explored by us. Mr. King, accompanied by Cotter, started to make an examination of the group, during the latter part of October, 1864; but they were driven back by a severe snowstorm of several days' duration, having had a very hard and dangerous trip.

From Porcupine Flat we followed the trail to Lake Tenaya, six miles east-northeast in a direct line. This is a beautiful sheet of water, a mile long and half a mile wide. From a high ridge, crossed just before reaching this lake, we had a fine view of a very prominent and exceedingly grand landmark through all the region, and to which the name of Cathedral Peak has been given. As seen from the west and southwest it presents the appearance of a lofty ridge of rock, cut squarely down for more than a thousand feet on all sides, and with a cluster of pimnacles at one end, rising several hundred feet above the rest of the mass. It requires no effort of the imagination to see the resemblance of the whole to a cathedral; but the majesty of its form and its vast dimensions are such, that any work of human hands would sink into insignificance if placed beside it. It is at least 2500 feet above the surrounding plateau, and its summit is 11,000 feet above the sealevel. The wood-cut (Fig. 70) gives but the faintest idea of this wonderfully grand mass of rock.*

At the head of Lake 'Tenaya is a very conspicuons conical knob of bare granite, about 800 feet high, the sides of which are everywhere finely polished and grooved by former glaciers. The traces of the existence of an immense flow of ice down the slopes of the valley, from this part of the trail onwards for many miles, are exceedingly conspicuous. The ridges on both sides of the lake are worn and grooved by glacier's nearly up to their summits, and travelling over the

* By accident, this view was not reversed on the wood, so that its reflection in a mirror must be examined, to gret a correct idea of the real position of the peak.

GEOL. VOI. I. - 54 
pass, from the valley of the 'Tenaya into that of the 'Tuolumne, became very difficult for the animals, so highly polished and slippery were the

Fig. 70.

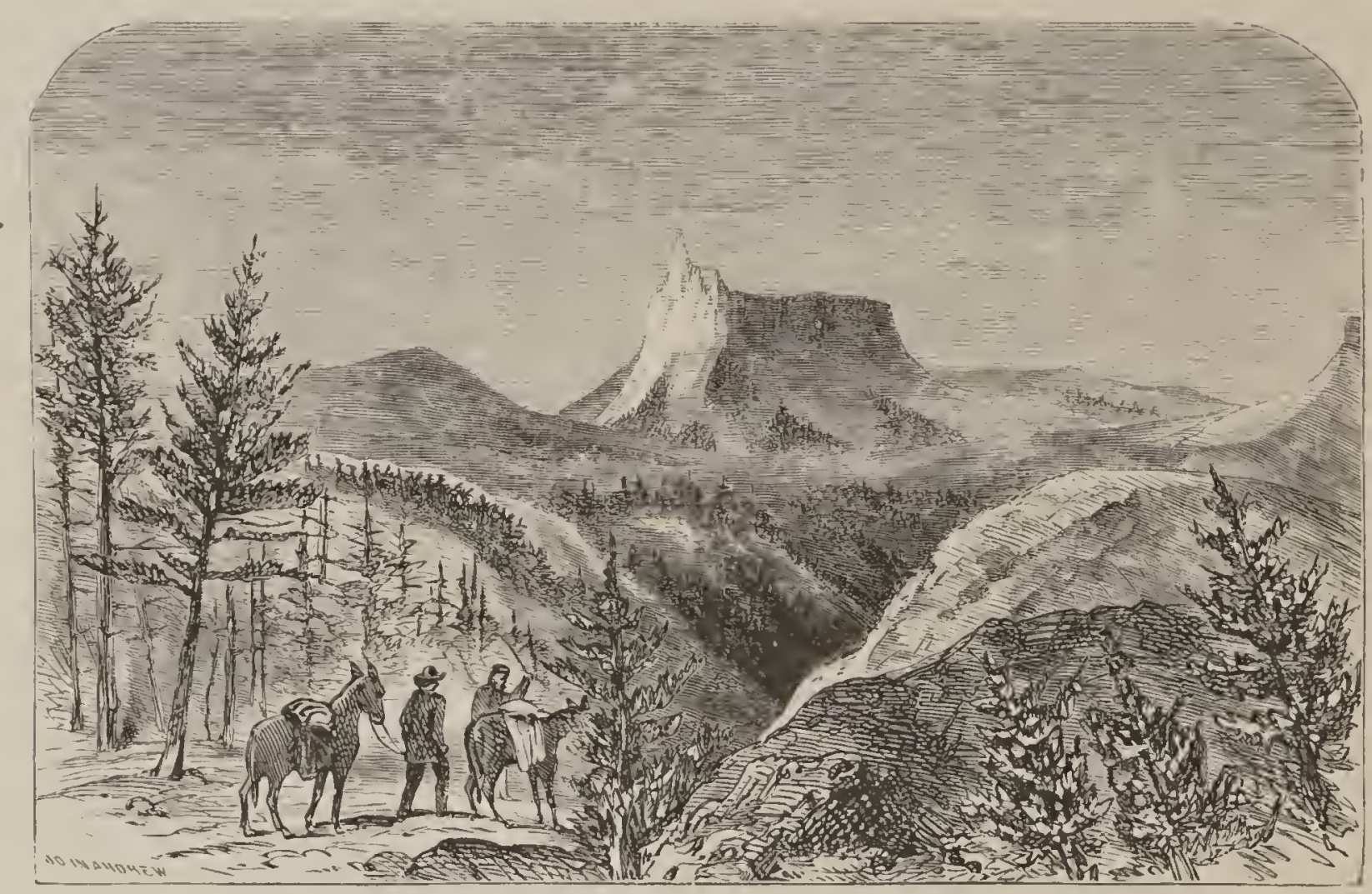

CATHEDRAL PEAK. FROM THE WEST.

broad areas of granite over which they were obliged to cautiously pick their way. The granite here has a very coarse texture, the crystals of feldspar being often three or four inches long. Above the sphere of glacial action, these crystals project from the weathered surface of the rock; but, below that, they are planed down to a level with it, and most beautifully polished.

The summit of the pass over into the Tuolumne Valley is 9070 feet above the sea, and the descent to the river is only about 500 feet. The trail winds along under the brow of the Cathedral Peak Group, and finally comes down to the river near Soda Springs, a point which for several days we made our head-quarters while engaged in exploring the vicinity.

The Tuolumne River, contrary to what is represented on any published map of the State,* drains a considerably larger portion of the

* The United States linear surveyors, in running a line over the Sierra to eommence their work in MLono Valley, erossed the Tuolumne River and its branches; but they supposed it to be the San Joaquin, and this mistake has been perpetuated on all the maps up 
LIBRARY

OF THE

UNIVERSITY OF ILLINOIS 
Sierra than the Merced, its branches heading quite around and to the east of that river. 'Three miles above Soda Springs the T'uolumne forks, a large branch coming in from the east and another one from the sontheast. The first of these heads in the Mono Pass and at the foot of Mount Dana, the culminating point of the Sierra in this region; the other rises on the north slope of the Mount Lyell Group, abont twenty miles farther south.

The Upper Tuolumne flows through a beautiful valley, from half a mile to a mile wide and about fifteen long. It is covered with a verdant carpet of carices, forming a turf, and has a scattered growth of pines (P. contorte and P. Balfouriana), and spruce (Abies Williamsonii). Soda Springs is about nine miles from the head of the valley, and six above the point where the river enters a deep and almost inaccessible cañon. At the springs, which are thirty or forty feet above the level of the river, the elevation of the valley above the sea-level is 8680 feet, and our camp nine miles farther up, at the head of the valley and the foot of the Mono Pass, was 9805 feet in elevation.

From our camp at Soda Springs the view was a magnificent one. The Catherlral Peak Group, on the south side of the valley, was the most conspicuous feature in the scene (see Plate 5); but from this point of view the resemblance to a cathedral is not by any means as striking as it was on the west side. The spires now become the most prominent objects, and they are seen to be two bare pyramidal peaks rising precipitously from the forest-clothed sides of the ridge, to the height of about 2300 feet above the valley. Farther east the range is continued in a line of jagged peaks, too steep to allow the snow to remain upon them, and rising above great slopes of bare granite, over which, through the whole summer, in sheltered places, large fields of snow are distributed. A very prominent peak, with à peculiar horn-shaped outline, was called "Unicorn Peak."* A view of Cathedral Peak, from

to this date, the whole course of all the upper portion of the San Joaquin, the Mereed, and the Tuolumne being laid down entirely wrong.

* Names are frequently given to prominent oljects, by parties like ours, for convenience; as where peaks are used for topographical stations. If not named, they would lave to be numbered. which would be both awk ward and inconvenient. 
this side, but a little higher up in the valley, is given in the annexerl wood-cut (Fig. 71). It is, from all sides, a singularly attractive object.

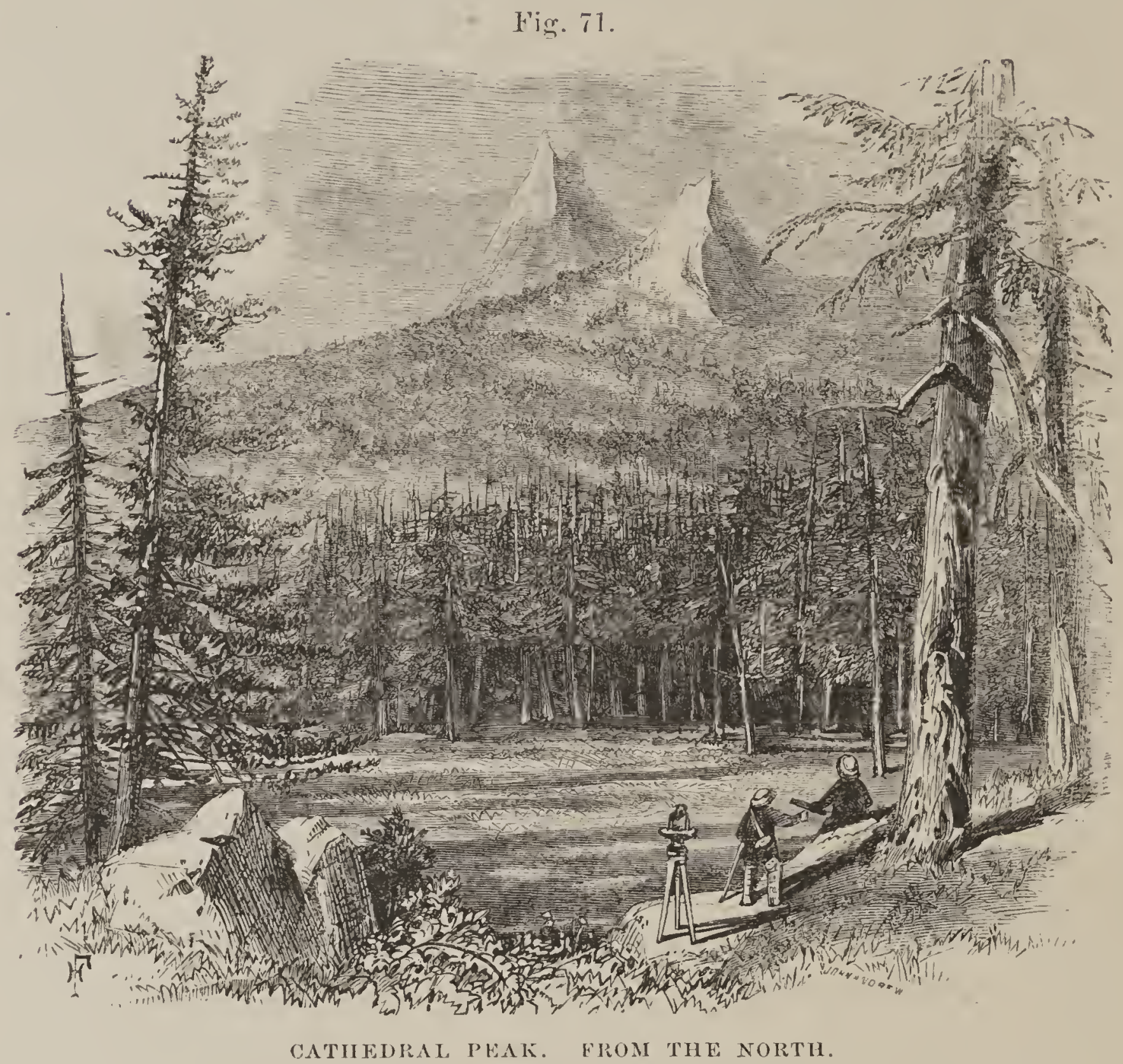

The Soda Sfrings cover quite an extensive area, and have a copious flow of water, which, at the time of our visit, July, 1863, had a temperature of $46^{\circ}$ to $47^{\circ}$. There is a continual escape of carbonic acid gas over the surface, the water resembling in taste that of the "Congress Spring," at Saratoga: It is a mild aperient, and might become of importance, were it not situated in rather too high a region to be visited by invalids.

The vicinity of Soda Springs and, indeed, the whole region about the head of the Upper Tuolumne is one of the finest in the State for studying the traces of the ancient glacier system of the Sierra Nevada. The valleys of both the forks-that heading in the Mono Pass and the one coming down from the noith slope of Monnt Lyell-exhibit abun- 
LIERARY

OF THE

UNIVERSITY OF ILLINOIS 


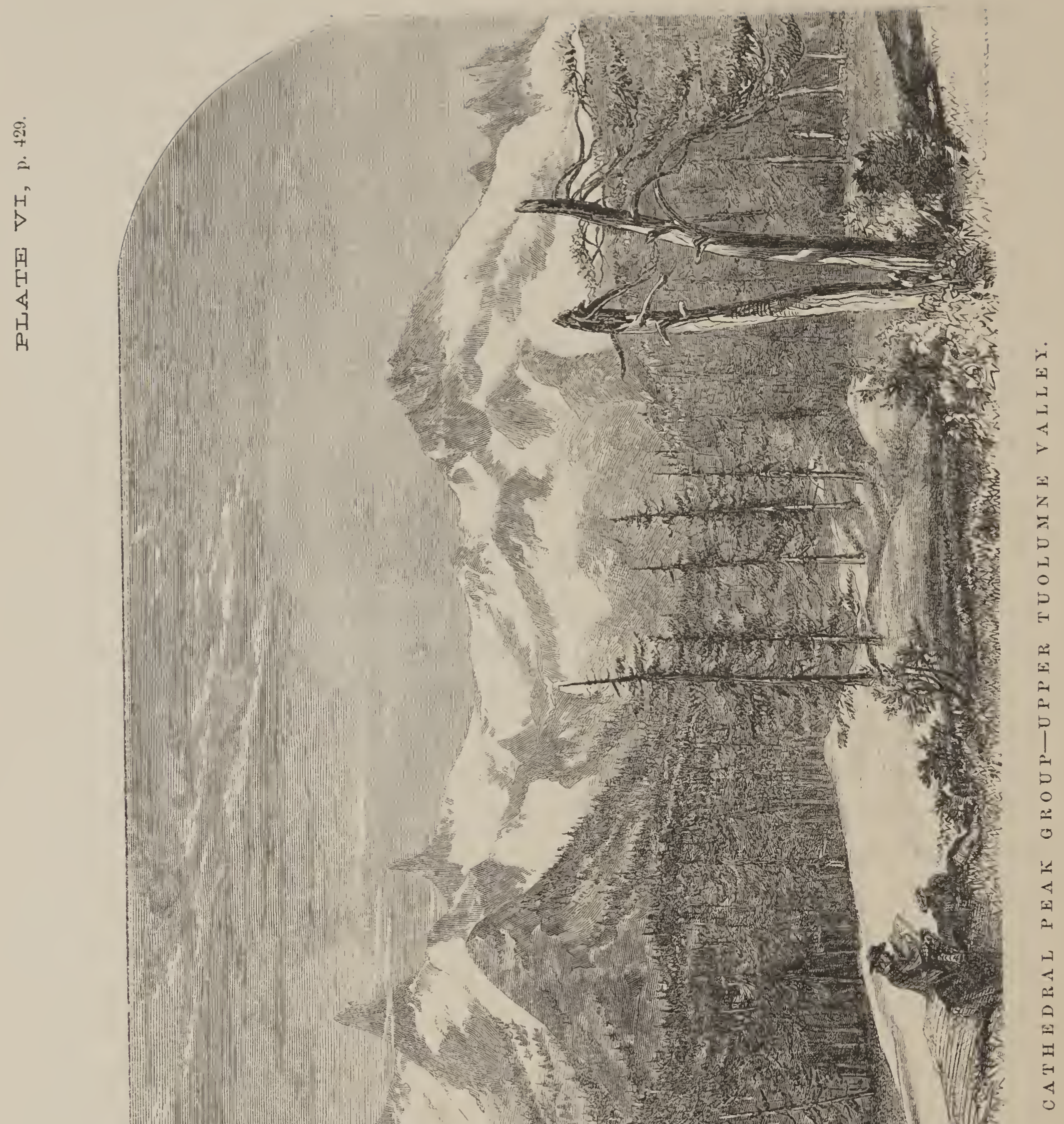


dant evidences of having, at no very remote period, been filled with an immense body of moving ice, which has everywhere rounded and polished the surface of the rocks up to the height of at least a thousand feet above the present level of the river at Soda Springs.* This polish extends over a vast area, and is so perfect that the surface is often seen from a distance to glitter with the light reflected from it as from a mirror. Not only have we these evidences of the former existence of glaciers, but all the phenomena of the moraines-lateral, medial, and terminal-are here displayed on the grandest scale.

To the north of Soda Springs, a plateau stretches along the sonthwestern side of the crest of the Sierra, with a gentle inclination towards the river. It is about four miles wide from northeast to sonthwest, and six or seven miles long" parallel with the range. This plateau lies at an elevation of between 9000 and 10,000 feet. It has clumps of Pinus contorta scattered over it, and is furrowed by water-courses, which are generally less than fifty feet deep. The whole surface of this is most beautifully polished and furrowed, except where covered with piles of debris, which stretch across it in long parallel lines, and which are the medial moraines of the several side-glacier's which formerly came in to the main one of the valley, from the numerous gorges and amphitheatres of the great mass of the Sierra behind. Plate 6 also shows one of these broad surfaces of polished granite, over and around which the glacier once extended, while above and in the distance is the range of Cathedral and Unicorn Peaks, which from this point of view exhibits in the most striking manner the peculiar pinna.cled form of the culminating granitic summits. There is a greater amount of snow represented in the drawing than was to be seen at the time of our visit, but not more than may usually be found during the earlier summer months.

About a mile below Soda Springs are the remains of a terminal moraine, stretching across the valley. It is not very conspicnous, except from the fact that it bears a scattered growth of pines, contrast-

* These glacial markings wele first noticed by M[r. T. E. Clayton, and the fact of their existence was communisated by him to the California Academy of Natural scinuces, sevwral years ago. 
ing beantifully with the grassy and level area above and below. A mile and a half lower down, a belt of granite, a mile or more wide, stretches across the valley; orer this the river falls in a series of rapids, having a perpendicular descent of above a hundred feet in all. Below this is another grassy flat, which extends down to the entrance of the cañon. This granite belt is worn into many knobs, some of which are a hundred feet high and orer; between these there are great grooves and channels, and their whole surface, to the rery summit, is groover and polished, the markings being parallel with the present course of the river.

The annexed woorl-cut (Fig. 72) is a not very successful attempt to whibit the appearance of this glacier-polished ridge. Beyond it, and

Fig. 72.

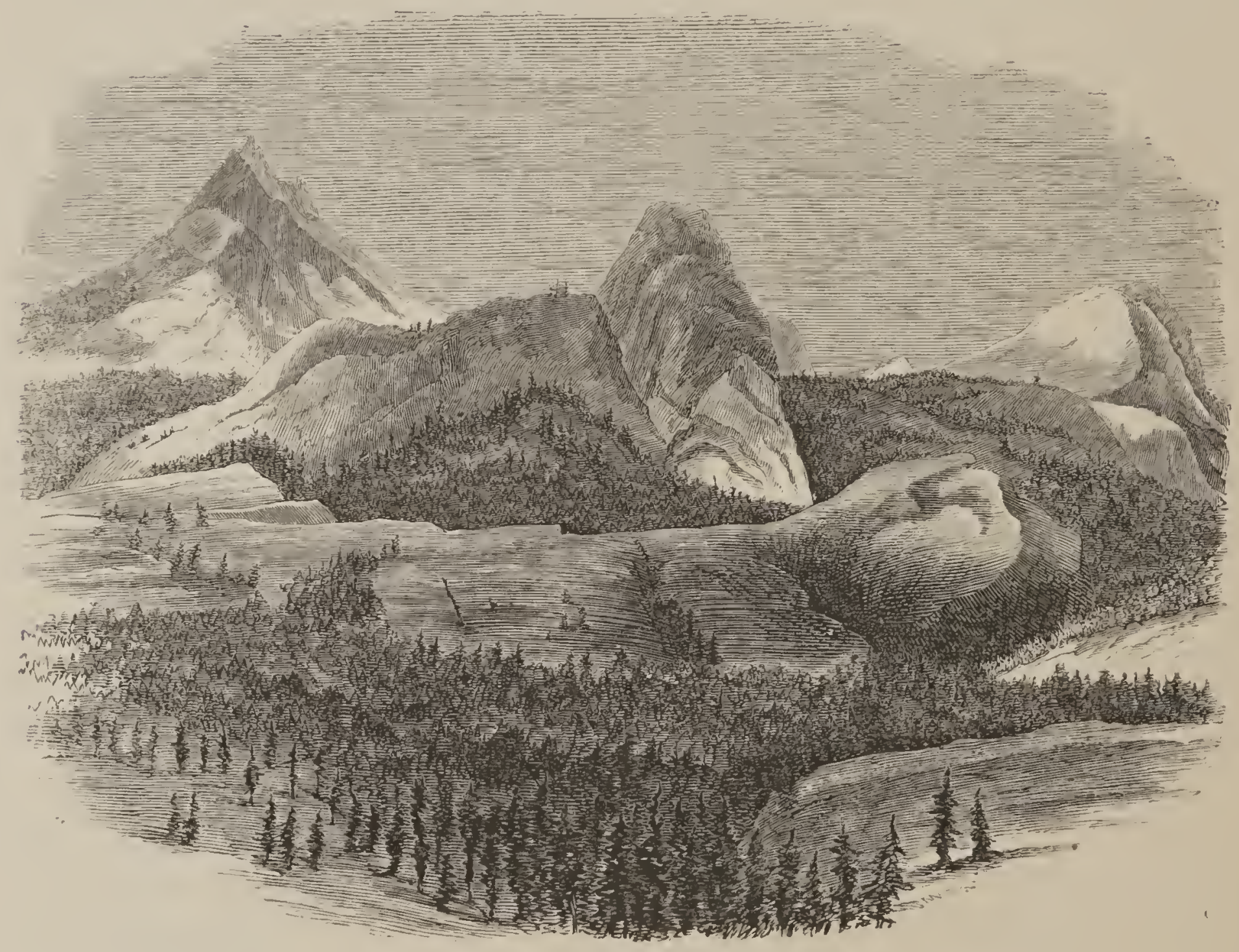

Cathedral Peak.

GLACIER-IOLISHED SURFACE IN TIOLUMNE VALJAY,

in the background, is the range of Cathedral Peak, and the peak itself, of which the double summit is no longer recognizable from this direction. 
Just below this is an isolated granite knob, rising to a height of about soo teet above the river, and heautifully polished to its very smmmit. At this point, the great glaciel' of the 'T'uolumme must have been at least a mile and a half wide, and over 1000 teet thick. From this knob the view of the valley and the surounding nountains is one of hardly surpassed interest and gramdeur. In the lower part of the valley are the smooth and glittering surfaces of granite indicating the former existence of the glacier" above this, on either hand, the steep slopes of the mountains, elad with a sombre growth of pines (Pinus contorta); and beyond, and still higher up, the great snow-fields, above which rise the Unicorn and many nameless pinnacles and peaks, in grand contrast with the dome-shaped masses seen, in the farthest distance, in the direction of Lake Tenaya.

At the head of the south branch of the Tuolumne, which unites with the other three miles above Soda Springs, is a grand mass of mountains, to which we gave the name of the Mount Lyell Group, calling the highest peak after that eminent geologist. In this group, and within a circle only three or four miles in diameter, four of the principal rivers of California have their sources; these are the Merced, Tuolumne, San Joaquin, and Owen's Rivers.

The fine wood-cut (Plate 7, the frontispiece to this volume), drawn by H. Fenn, from a sketch by Mr. Hoftmann, will give a good idea of the grand appearance of this truly Alpine range.

The culminating point of the Mount Lyell Group was ascended by Messis. Brewer and Hoftmann; but they were unable to reach the very summit, which was found to be a sharp pinuacle of granite rising up above the snow. By the observations taken at a point estimated to be 150 feet below the top of this pinuacle, Mount Lyell is calculated to be 13,217 feet high, or only ten feet less than Mount Dana. As we had no station barometer nearer than Stockton on the day of the ascent, the result is only to be considered an approximation. As near as could be made out with the pocket-level from Mount Dana, Mount Lyell was a little the lower of the two. The annexed sketch (Fig. 73) will give an idea of the form of the summit of this grand mountain.

The culminating peaks of Mount Lyell have a gradual slope to the northeast; but, to the south and southwest, they break off in precipices 
a thousand or mole feet in height. Between these cliffis, on that side, a vast amphitheatre is included, once the birthplace of a grand gla-

\section{Fig. 73.}

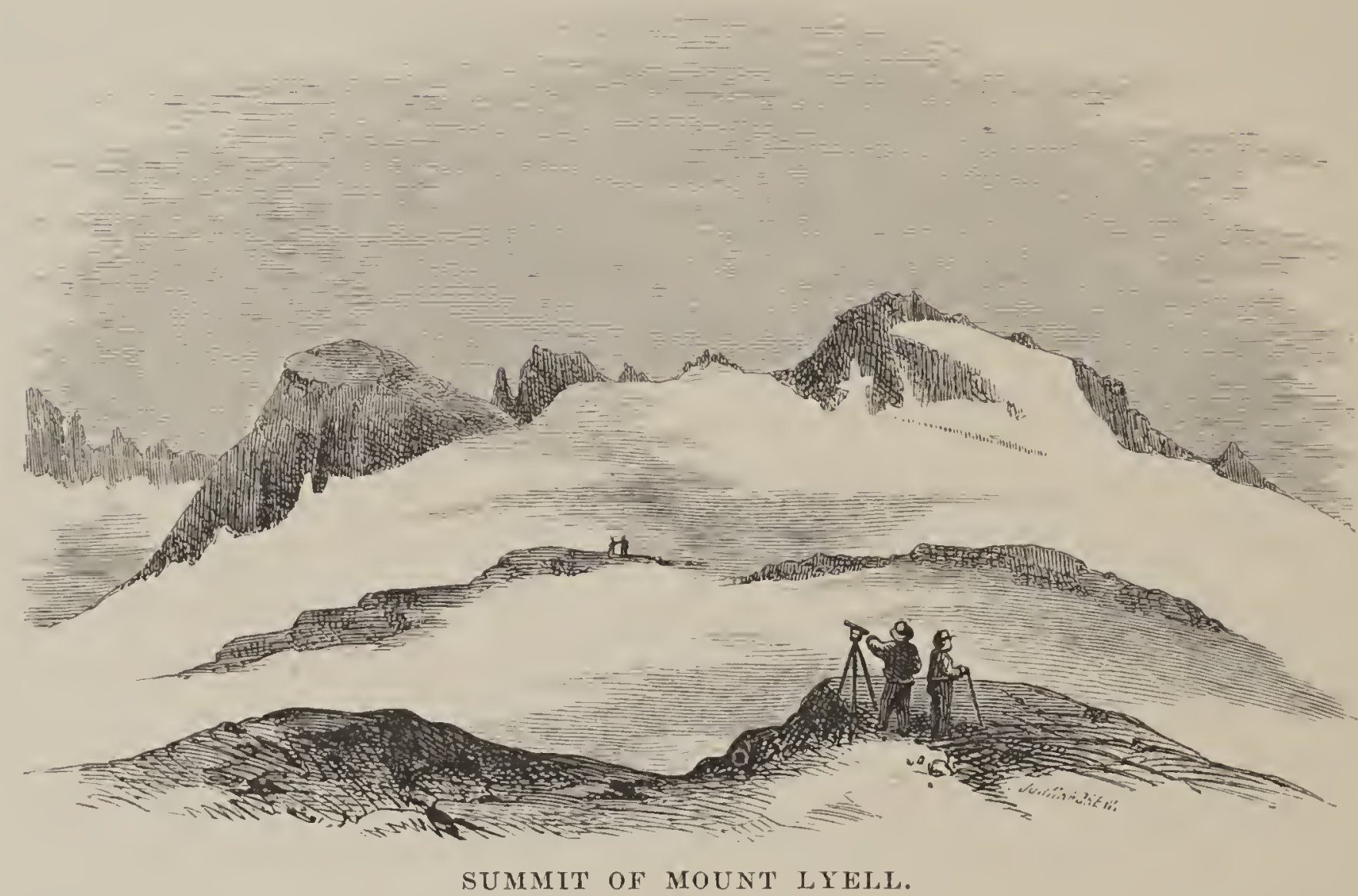

cier, which flowed down into the cañon of the Merced. Several other former heads of glaciers were seen in various directions, and traces of their action were observed up to within a thousand feet of the crest.

On the north slope of Mount Lyell, and among the peaks one or two miles northwest of the summit, there are outcrops of a highly metamorphic slate, the continuation of the belt which is so conspicuous on Mount Dana. Want of time rendered it impossible for the party to make any detailed examination of the rocks in this group.

From the high points around Mount Lyell, a fine view was obtained of the extension of the range of the Sierra to the southeast. There are hundreds of peaks, in that direction, which rise to an elevation of over 12,000 feet. Most of these are sharp pinnacles of granite, towering above extensive snow-fields, with small plateaus between them. Fifteen or twenty miles south, the chain appear's to sink considerably, the average height of the dominating peaks being from one to two thousand feet less than it is about Mount Lyell. 'This region is, as yet, entirely unexplored. Traces of an old Indian trail were discovered, 
however, leading from the ridge at the head of the Tuolumne over into the valley of Owen's River.

Avalanches of snow are frequent on the steep mountain sides in this region. They start on the slopes, above the limits of the forests, and sweep down with irresistible force, crushing the trees which lie in their paths, and carrying large masses of rocks and soil with them. The amount of snow brought down by one of these slides is so great sometimes, that years are required for the mass accumulated at the bottom to melt away.

The Mono Pass is at the head of the more northerly of the two forks of the Tuolumne which unite a little above Soda Springs. From the springs to the summit of the pass is twelve miles in a direct line, and about fourteen by the trail, which follows the river all the way. For exploring the region in this vicinity, our camp was fixed for several days at a point about three miles from the summit, on the left bank of the stream, and near the junction of a small branch coming in from the slopes of Mount Dana to unite with the main fork, which heads in the pass itself and along the ridge to the southeast of it. This camp was 9805 feet above the sea, and about a thousand feet below the summit, which is 10,765 feet in height, this being the most elevated pass in actual use within our territory, and, so far as we know, in North America. There are higher passes in the more southern portion of the Sierra; but these are very rarely crossed by travellers, and can hardly be said to be in use.

The highest crest of the Sicrra, in the region of the Mono Pass, is along the extreme eastern edge of the range, the distance from Mount Dana to Mono Lake being but little over six miles, and the descent no less than 6773 feet, or over a thousand feet to the mile. The culminating ridge, to the north of the pass, is crowned by a series of elevations, which have rounded summits and rather gently sloping sides, contrasting in the most marked way with the pinnacles and obelisks of the central portion of the range. The geological cause of this condition of things is to be found in the fact that the very highest part of the Sierra, through a considerable distance to the north of the Mono Pass, is not granitic, but made up of metamorphic slates, which, as they decompose, give a very different aspect to the scenery from that proGKOL. VOL. I. - 55 
duced by the weathering of the granites and lavas which usually form the crest of the chain.

This belt of metamorphic rock is three or four miles wide at the pass, and its junction with the granite is very distinct and well-defined wherever the two formations are exposed in contact with each other. The relative position of the granite and the slates was carefully examined for several miles along the ridge south of our camp in the pass, and about 1200 feet above it. The metamorphic rock here is chiefly a mica-slate, passing into a silicious variety of the same. It is quite evenly and thinly bedded in some places; other portions are apparently more metamorphosed and less distinctly stratified. The dip of the slates was found, all along this ridge, to be at a very high angle, and always to the east and northeast, or away from the axis of the chain. The granite was observed, in many places, to have penetrated the slates in ramifying veins; but there was nothing seen indicating a passage of one rock into the other. The direction of the strata is nearly that of the chain itself, or about $\mathrm{N} .30^{\circ} \mathrm{W}$.

In the pass itself the slates also dip to the northeast, the strata being in places much contorted; but the junction of the two formations is perfectly well-defined. A little east of the summit there is a belt of a red, scoriaceous rock; this, however, does not appear to be of volcanic origin, but, rather, a mass of ferruginous slate which has become considerably decomposed, after having been imperfectly metamorphosed.

Directly north of the pass, a rounded summit rises to the height of about 12,000 feet; it is probably metamorphic. Between this and Mount Dana is another gap, somewhat lower than the Mono Pass, but which is not used for a trail or road, because the descent on the east side is too precipitous to allow it to be traversed with animals without extensive excavation. There is also another gap on the north side of Mount Dana, which is called MacLane's Pass; it is about 600 feet lower than the Mono Pass, and has been examined, in behalf of the county, by a committee appointed to search out a better route than the present one across the mountains, in this vicinity; what conclusion was arrived at we have not ascertained.

Plate 8 will serve to give an idea of the appearance of the crest of the Sierra to the north of Mono Pass; it was taken from a point a little 


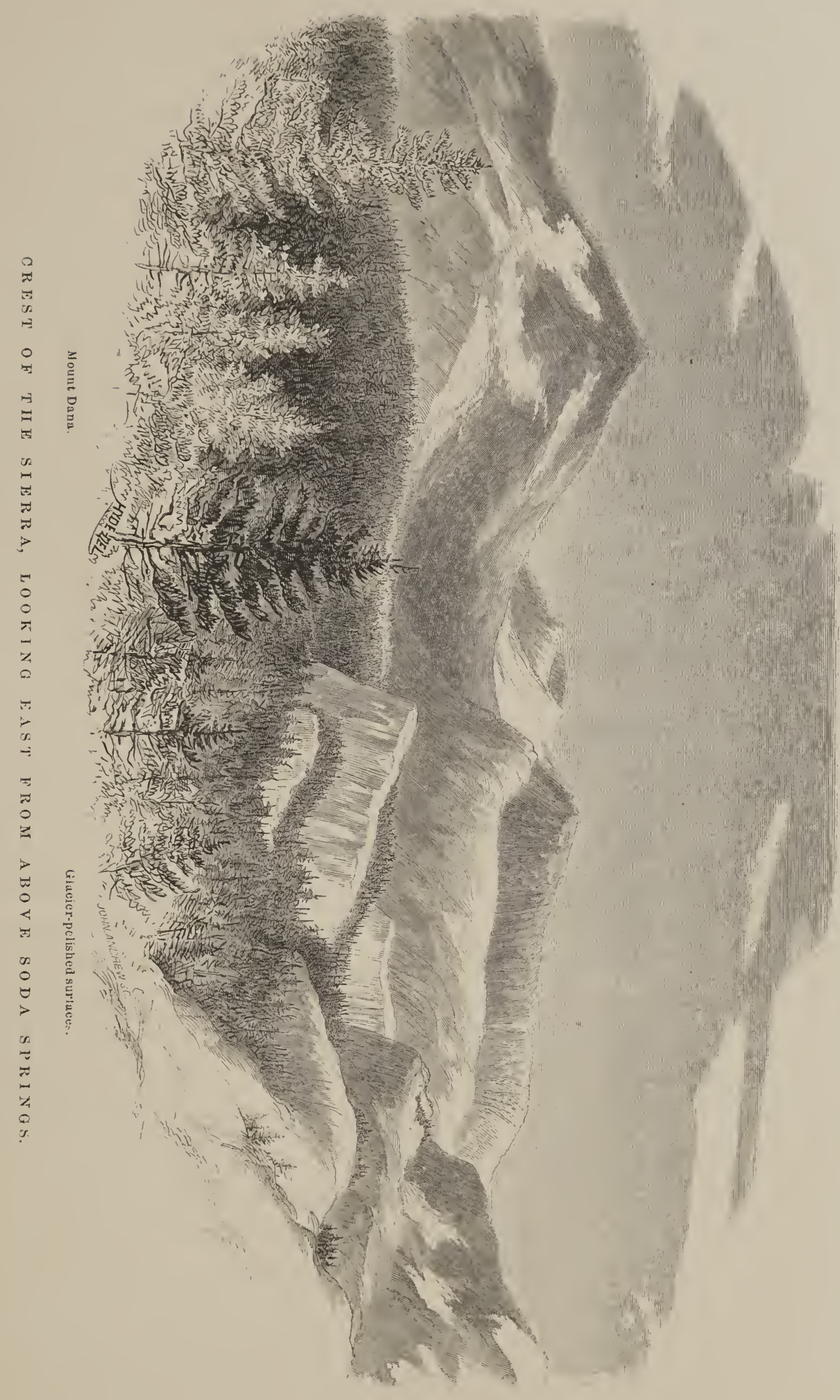




\section{LIBRARY}

OF THE

UNIVERSITY OF ILLINOIS 
above Soda Springs. The mountain on the left is Mount Dana. 'The first depression on the right, or south, is the gap noticed above as having too precipitous a descent on the east side to be used as a pass. The present trail, or the Mono Pass, winds around and behind the rocks in the middle ground of the sketch, and crosses the mountains at its extreme right. The lower clifts, in the centre, are of granite, and are most beautifully polished by glaciers.

Mount Dana, as already remarked, is the culminating point of the Sierra in this region, and there is no higher one north as far as Mount Shasta, or south until we reach the high peak to which we gave the name of Mount Goddard. The mass of this mountain is of metamorphic slate, extremely contorted, but having a general dip to the northeast. The rock, especially on the south side, is made up of alternating bands of a bright green (sandstone passing into epidote-rock) and deep reddish-brown. The effect of this contrast of colors is very pleasing, especially where the surface is wet, so as to bring out the different shades.

The view from the summit of Mount Dana is a very extensive one; and, as the ascent can be made without difficulty, all tourists who have any desire to learn something of the grandeur of California scenery should not fail to climb at least this one high point. The innumerable ranges and peaks of the Sierra itself, stretching off to the north and south, form, of course, the great feature of the view. To the east, Mono Lake lies spread out, as on a map, at a depth of nearly 7000 feet below, while beyond it rise the lofty, and here and there snow-clad, ranges of the Great Basin, a region of stupendous mountains, possessing all the attractions of the unknown.

From the summit, the belt of metamorphic slates is seen to extend off for a great distance to the northwest, forming a line of high peaks with rounded outlines. Of these Castle Peais is the next prominent one north of Mount Dana, from which it is twelve miles distant. This peak is 13,000 feet high, as nearly as we could estimate by levelling across to it.

Along the western and southern slope of Mount Dana the traces of former glaciers are exceedingly distinct, up to an altitude of 12,000 feet. In the gap directly south of the summit a mass of ice must once 
have existed, having a thickness of at least 800 feet, at as high an elevation as 10,500 feet. From all the gaps and valleys of this side of the range, in both directions from Mono Pass, tributary glaciers came down, and these all mited into one grand mass lower in the valley, where the medial moraines which accumulated between them are perfectly distinguishable, and in places as regularly formed as any to be seen in the Alps at the present day.

The trail down the eastern side of the Mono Pass descends in what is called "Bloody Cañon;" and this is, at present, the only practicable route from the head of the Tuolumne over into Owen's Valley. It is very steep and rough; the name is suggestive of the disagreeable effects of the sharp edges of the slates on the legs of the unfortunate animals driven over it. The perpendicular descent is not less than 4000 feet in a distance of three miles.

In descending this cañon, considerable bodies of slate were observed, with a dip towards the axis of the chain. About a mile from the summit they become more highly altered, and the stratification is nearly obliterated, the rock becoming porphyritic occasionally. Two miles east of the summit of the pass, granite is again met with and continues to the foot of the cañon. It is a finer-grained variety than that seen on the western side of the mountain, and is of a light rose color, and largely made up of quartz.

Traces of ancient glaciers are very abundant from near the summit to the very foot of the cañon. The rocks are rounded, polished, and grooved; and there are evidences of immense pressure of the mass of ice against the walls, where the cañon is narrow and shut in by high precipices on each side. In such places, and in other localities where there has been a very thick mass of ice resting upon the granite, the structure of this rock is changed, near the surface, as if by the crushing and closely compacting together of the different minerals of which it is made up, so that a crust is formed, sometimes as much as half an inch thick. This crust seems to be more durable than the body of the rock, and as the granite weathers it scales off, sometimes in large flakes, with a highly polished surface on one side, seemingly as fresh as if made only yesterday; while other portions of the granite, which have 
not been subjected to this pressure, are corroded to a considerable depth, as is easily seen where large areas of uneven rock are exposed.

There are several small lakes in the cañon, the lowest of which is about 7000 feet above the sea-lerel, and about a mile long. These lakes have been produced by the damming of the gorge by the terminal moraines left by the glacier in its retreat. At the lowest lake, the moraine rises about fifty feet above the level of the water, and extends entirely across the cañon. At the eastern base of the mountains, each gorge or valley coming down has long ridges of gravel and loose materials extending out into the plain for a considerable distance, indicating the position of the glaciers which once found their way down on this side, as well as on the western slope. These old moraines were very conspicuous, at a distance of several miles, from the summits of the volcanic cones near Mono Lake.

Having devoted all the space to the interesting district about the head of the Tuolumne which our limits will allow, we will take up next the region at the head of the Stanislaus River, and along the road over the Sonora Pass, which is the first travelled route across the Sierra north of the Mono Pass, and the most southern of the wagon-roads which have yet been completed, to connect California with the great mineral region to the east.

\section{Section V.-The Sohora Pass.}

The following notes of the region between Aurora and Sonora, as seen on the Sonora trail, were furnished by Professor Brewer, and will throw some light on this portion of the High Sierra. At the time our party crossed by this route a wagon-road was in process of construction, a large force of men being engaged upon it; it is now probably opened through, but how much it is used by wheeled vehicles at present we are not informed. Its value depends, in a great degree, on the future importance of the Esmeralda mining region, as its great elevation renders it unlikely that it will be able to compete with other routes farther north, in the trade with Washoe.

On leaving Aurora by this route, at about ten or twelve miles from 
the town, there are several places where, at a recent date, there have been extensive hot springs, which have had a powerful action on the surrounding rocks, but which are now extinct. The "Meadows" on Walker's River, through which the road passes, is a basin, quite level and surrounded by mountains; it is from six to eight miles long and three or four wide, but has little good forage upon it. A large branch of Walker's River passes through it, and several smaller streams come in from the mountains on the west. The distance from the Meadows to the summit of the pass is estimated at twenty-six miles, and two considerable branches of Walker's River are crossed on the road. Between these two there is a copious thermal spring, the water of which is nearly at a boiling temperature, and slightly saline; it evolves a large amount of carbonic acid gas. A large quantity of calcareous tufa is deposited about it, and still more exists on the sides of the hill, higher up, showing where formerly other and more copious springs once discharged themselves. Granite and lava form the predominating rocks in this vicinity; but the exact boundaries of the two could hardly be defined without more accurate maps than we have yet at our command. The altitude of the Meadow is about 6500 feet above the sea, and of the hot springs, 7334 feet.

The second fork of Walker's River is thirty-six miles from Aurora; and where the road crosses it there is a basin which has evidently once been a lake. Two large branches unite a short distance north of the trail, and together flow through a deep cañon, while the region above, extending for several miles up both streams, was evidently a lake, which became partially filled up with the detritus washed in from the surrounding mountains; afterwards, the removal or cutting through of the barrier by which the lake was dammed up being effected, the accumulated materials in its bottom were gradually denuded into their present form. Deep arroyos are cut into this deposit, and these are most beautifully terraced, especially on the western branch, where in places as many as eight or ten benches may be traced. Of these two are more conspicuous than the others, and the highest one was estimated at about 1000 feet above the river.

The party encamped (Camp 125) at a small lake about forty-two miles from Aurora, near the western branch of the river, and from here 
ascended a high point to the north, from which a fine view was obtained. The elevation of the camp was 7282 feet above the sea, that of the point ascended, 9739. From its summit, peaks are seen to the north-northwest, much higher, and apparently of rolcanic materials. Another high volcanic mass, with some snow upon it, was seen in a direction $\mathrm{N} .49^{\circ} \mathrm{E}$; the upper part of this was bare of vegetation, and covered with ashes, lying upon very steep slopes, like the volcanic materials on the cones south of Mono Lake.

All the rock seen in this vicinity was volcanic, and the same was the case as far as the west fork of the Walker, two miles beyond Camp 125 , where the stream was crossed at an elevation of about 7000 feet above the sea. Near the crossing on the east side, and north of the trail, are several hills or knobs of basaltic lava, distinctly bedded and most beautifully columnar, the columns always at right-angles to the bedding; although the beds themselves lie at all angles, from horizontal to perpendicular. Soon after crossing this branch, mica-slate is met with, forming a narrow belt, dipping northeast, and traversed by veins of granite. Beyond this, granite makes its appearance and continues to be the only rock seen on the pass nearly to the town of Sonora, far down on the western slope, except that in places it is covered by volcanic accumulations. In the valley up which the trail passes few glacier markings were seen, until within two miles of the summit, when they became very conspicuous.

The Sonora Pass has two summits, the eastern forming the watershed and being 9607 feet above the sea; the western one is higher, its altitude being 10,115 feet, according to our measurements. All about the eastern summit the granitic rocks, which form the mass of the mountains, are covered with beds of lava, which has flowed out in sheets over the uneven and irregularly denuded surface of the granite, and both lava and granite have undergone considerable erosion since the former was erupted, so that the volcanic materials lie in irregular and uneven masses. No craters were observed here, and it appear's that the lava has issued from fissures in the granite, forming dykes, of which many examples were seen near the pass. One about a mile east of the western summit, and near the trail, shows the relation of the two formations very well. The granite is reddened and softened near 
its junction with the lava, as is seen in a great many places in the Sierra.

North of the pass are high and sharp peaks of bedded lava, which were not ascended; others to the south were examined, and one was measured and found to be 11,643 feet above the sea; one or two other points about a mile farther to the south were about 150 feet higher than this. Glacial scratches were seen nearly to the summit of the most elevated ridges. To the west and northwest of the pass, masses of granite and lava alternate with each other, as far as the eye can reach, and very lofty and rugged peaks of granite were noticed to the west of Castle Peak, which is seven miles southeast of the eastern summit; this for a long time was considered the highest peak of the Sierra and the loftiest mountain in the State, except Mount Shasta.

The two summits of the pass are about three miles apart, and the Stanislaus River heads at the eastern; but, in descending from the valley between the summits, it runs through a deep cañon, as yet impassable for animals. Through this it was, in 1863 , proposed to construct a road, thus avoiding the western and higher summit altogether.

In going west, the trail follows the Stanislaus River for nineteen miles from the western summit. The valley keeps in the granite all the way, but lava caps the hills on both sides, the cañon being cut down deep into the underlying rock. Several dykes of basaltic lava were seen, showing how the volcanic material had found its way to the surface. The region is covered with open forests, and there is but little forage, only one grassy flat, called Onion Valley, being seen; this is about ten miles west of the summit.

Camp 127 was made at the lower crossing of the Stanislaus, about eighteen miles from the pass, and at an elevation of 5454 feet, the river at the bridge being 5405 feet above the sea. From this camp some examination was made of the mountains to the south. The sides of the cañon rise abruptly to the height of from 2500 to 3000 feet, granite forming the mass and extending up to within 700 feet of the summit; above that point it was covered with rudely columnar basaltic lava. Higher mountains were seen on every side, all of granite capped with lava. On the ridges lying between the forks of the Stanislans, to the north, these were exceedingly grand, rising to about 3500 feet above 
the river, and having their summits worn into fantastic forms; one, of which a wood-cut is given (Fig. 74), resembled an immense castle crowning the bald mountain of granite.

Fig. 74 .

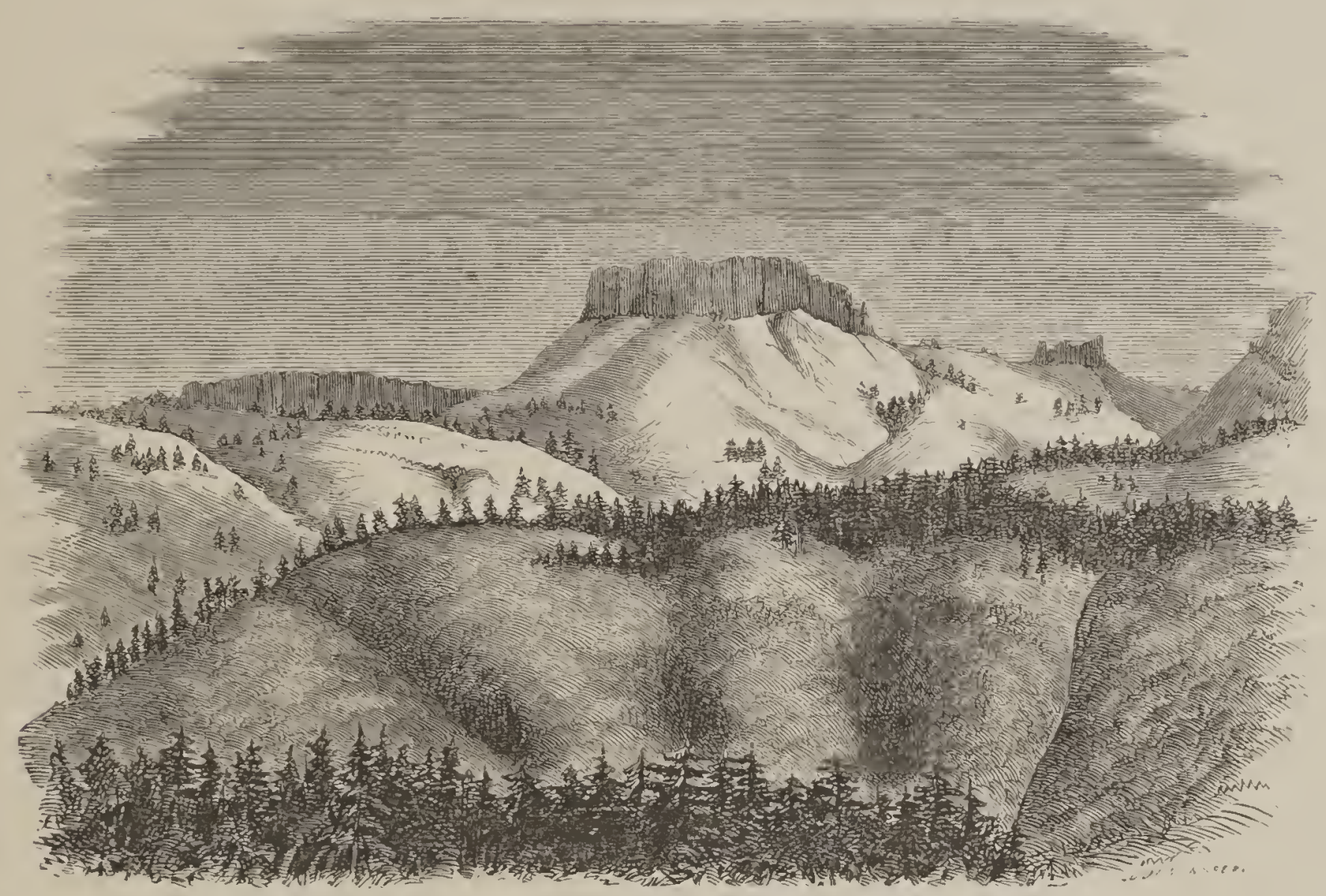

SUMMTS CAPPED WITH LAVA, ON THE SONORA ROAD.

Another sketch (Fig. 75) gives a view of a ridge of similar character in the same vicinity, showing, however, only the volcanic capping,

Fig. 75.

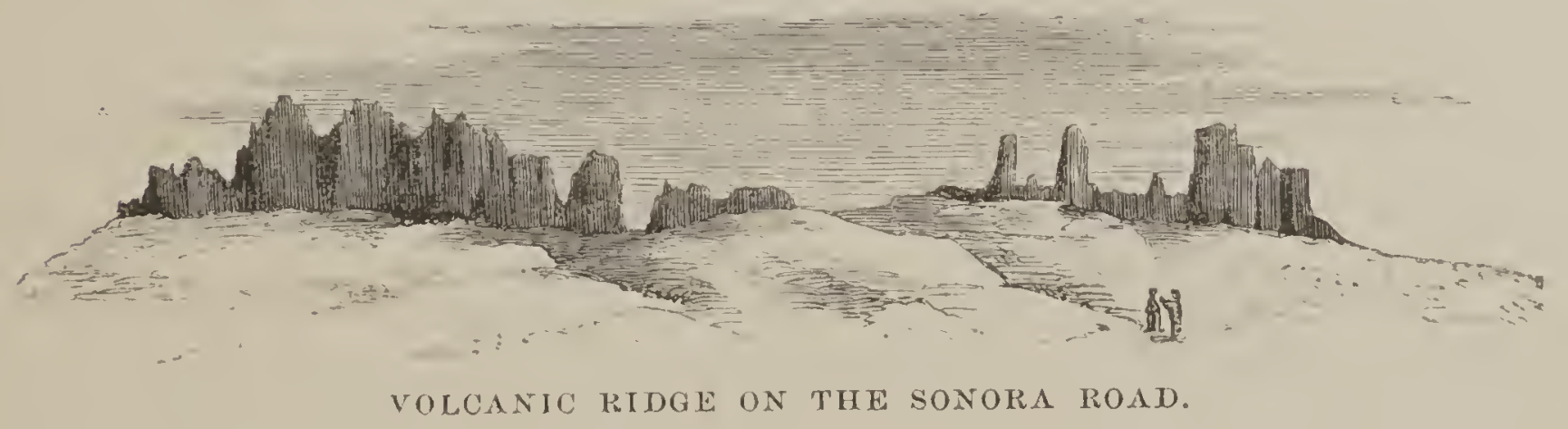

which appears like the ruins of a gigantic wall. There is an almost endless variety of these very picturesque masses, of which the dark and sombre color contrasts admirably with the lighter tint of the underlying granite.

(AEOL. VOL. I. -56 
The ridge of lava which was ascended was found to have on its summit ten or twelve boulders of granite, of coarse texture, containing large crystals of feldspar; some of these were angular, others worn and rounded. One of them, which was perched on a sharp ridge of lava, was found to be seventeen feet long, fourteen wide, and twelve high; the others were smaller. Another lava spur, a quarter of a mile east of this, had its summit strewn with similar masses of granite. They must have come from the main ridge of the Sierra to the east, in which direction, at a distance of three or four miles, there is granite at a higher elevation than that of the boulders observed, and it seems clear that these must have been transported by glaciers to their present position, as no other cause can be conceived of as possible. This would indicate an immense thickness for the glacial mass capping the Sierra during the "ice-period;" but the former existence of glaciers firom 1000 to 2000 feet thick, in other parts of the range, has been proved by the clearest evidence.

From the Stanislaus River to Sonora, the distance is called forty-six miles. At the lower crossing there are well-defined terraces, one on the northern and two on the southern side of the river; the highest of these is about 100 feet above the water.

From the river the trail ascends the ridge on the south side, and follows down the divide between the Stanislaus and the Tuolumne Rivers, on a volcanic table, for some twenty miles or more, the lava covering the surface everywhere except when cut into by erosion, so as to expose the underlying granite. A correct topographical map on a very large scale would be required to show the exact position of all the lava masses on this route. Much of the material is a hard basaltic lava, but there is also a large amount of volcanic breccia, or fragments of volcanic rock thrown promiscuously together and cemented by finer materials of the same kind. Before reaching Strawberry Flat the granite is seen weathered out into immense rounded, boulder-like masses. About fourteen miles from Sonora is the "Sugar Pine District," where are valuable and important mines of auriferous quartz in the granite, as has been already noticed. The rock along the lower part of the trail towards Sonora becomes softer, and by its decomposition furnishes 
a redder soil than that derived from the harder granite farther up in the mountains. It bears gold, and placer diggings are extensively distributed over it.

Section VI. - The Head of the Mokelume River. The Road from the Calaveras Big Trees to Siluer Mountala.

In continuing the aceount of our rapid recomnaissance of the High Sierra, we come next to the region about the head of the Mokelumne, to reach which we followed up the road from Murphy's, by the Calaveras Group of Big Trees, to Silver Mountain, which is not only the name of one of the higher peaks of the range, but is also that of a mining town, where there was, in 1863, considerable mining and prospecting going on, in what was supposed by many to be an important silver district. A good wagon-road was then constructing from the Big Trees across to the town of Silver Mountain, and which was to connect with the mining districts near Aurora and Virginia City. The region about Silver Mountain was formerly included within the counties of Amador and Calaveras, there being some uncertainty in regard to its real position with reference to the county lines; it has since been set off as a separate organization, and called Alpine County.

Mr. Wackenreuder has been engaged in making for the Survey a topographical reconnaissance of the region from Silver Mountain northwards, as far as the Downieville Buttes, and his map has just been completed, but not in time to allow of its being consulted in the preparation of this abstract of the geology of the region. The information contained on Mr. Wackenreuder's map will be incorporated in our map of Central California, now in process of construction at the office of the Geological Survey.

The road to Silver Mountain passes through the famous grove of the Big Trees of Calaveras County, which is about twenty miles from Murphy's, and 2550 feet above that mining town, the elevation of the floor of the hotel at the Big Trees being 4759 feet above the sea, and that of Sperry's Hotel, at Murphy's, 2201 feet.

The Calaveras Grove is the one chiefly visited by tourists, on account 
of its proximity to the settled part of the State, and because there are good arcorimodations for trareller's, which is not the case at any other locality where these trees are growing. It is now well known, from information collected by the Survey, that instead of there being only a few isolated groves of Big Trees in the State, there is a belt of them dotted along at intervals on the western slope of the Sierra, from Tulare to Calaveras County, and at an elevation of from 5000 to 7000 feet. The species is undoubtedly very limited in its range, and is strictly confined to the State of California. Specimens of it may be found in every stage of growth; and, as before noticed, the smaller ones are sawn up for lumber at Thomas's Mill, above Visalia.

The Big Trees are, indeed, among the greatest wonders of California, and require no exaggeration to make them attractive. Full particulars in regard to their growth, habits, and dimensions, will be given in the botanical volume of the Geological Report; it need only be added that the age of the tree which was cut down in the Calaveras Grove, and which, at six feet above the ground, has a diameter of twenty-three feet inside the bark, was found to be about 1300 years. It was easy to count the annual rings, and they amounted to 1255 in number; but there being a small space, about a foot in diameter, at the centre of the tree, from which the wood was decayed away, it would be a reasonable estimate to call the age of this particular tree about 1300 years. The difference in the rapidity of its growth, at different ages, may be inferred from the fact that the width occupied by a hundred rings at the centre of the tree was thirteen inches, and next to the bark was only three.

The more time one spends among these trees, the more their grand proportions and colossal size become impressed on the mind. The extraordinary dimensions of the other species which are associated with the Big Trees, especially of the Sugar Pine-a tree of which the beauty and majesty can hardly be exaggerated-make it difficult to realize that these are really so large as exact measurements prove them to be. Could one of them be suddenly transported to Washington and placed beside the Capitol, its summit towering far above the statue which surmounts the dome of that noble structure, the effect produced would be overwhelming. 
The rocks about the Caliveras Grove are granitic, overlain with masses of rolcanic strata in places, especially towards the north end of the sheltered valley in which the trees are inclosed. From the Big Trees to Silver Valley, a distance of about twenty-two miles, the road keeps on the granite, with a gentle ascending grade, there being no change in the aspect of the country, except such as is due to the rise in elevation affecting the character of the forests. At Silver Valley we have risen to 7323 feet above the sea-level, having had on the south side of the road fiequent glimpses of a region of granite capped with voleanic tables, extending to the south of the Stanislaus, our road having been along the north side of that river and at a distance of three or four miles from it.

At Silver Valley we first see evidences of glacial action, the rocks being polished and grooved, wherever the surface has not been exposed and the markings become obliterated by the weather. In this vicinity we meet also with heavy masses of volcanic materials resting on the granite. A steep hill, at least a thousand feet high, two or three miles south, was ascended and found to be made up exclusively of rudelystratified ashes and breccia. This forms an isolated mass, entirely surrounded by granite, and all the prominent points in the vicinity are capped with the same kind of volcanic ejections, chiefly a very coarse conglomerate of angular fragments of every variety of lava, cemented by a material of the same kind, only more finely comminuted.

Between Silver Valley and the Stanislaus Meadows a ridge is crossed, . having an elevation of 8089 feet, and another one 8216 feet high, between the meadows and Hermit Valley (also called Holden's or Ritchie's Station). Here the Mokelumne River is struck. The rock is granite, capped with a volcanic breccia, excepting on the ridge crossed just before reaching the river, where there is a narrow belt of metamorphic slate, hardly more than a hundred yards wide. These slates are highly altered and much contorted, portions of the mass dipping to the northeast, and other portions in the opposite direction. They are also intersected by veins of granite, varying from a few inches to several rods in thickness. These slates are very hard, and exhibit very distinct marks of former glacial action. Being of a very dark color, they have all been located as' "silver leads." 
Hermit Valley is 7259 feet above the sea-level according to our measurements, and the snow is said to accumulate here in the winter to a very great depth, owing to its great elevation and sheltered position with high mountains on all sides. The road forks at this point, the old emigrant road, by way of the Big Trees to Carson Valley, going off to the north across the "Old Carson Pass" into Hope Valicy; the other road leads over to Silver Mountain. In 1863 this was a simple trail, and it crossed by the route designated on Britton \& Rey's map as "Ebbett's Pass;" this name is, however, one no longer known in that region, as we could find no one who had ever heard of it. In 1863 a new wagon-road was building, by a different route, following up the Mokelumne a short distance, and then striking across the water-shed between that river and a branch of the east fork of the Carson, a little to the east of the old trail. The new pass was stated, by the engineers of the road, to be 1656 feet above Hermit Valley; this would make its elevation above the sea 8915 feet, while the summit of Ebbett's (?) Pass, on the old trail, was found to be 8793 feet above the sea-level.

The crest, along this portion of the Sierra, is of volcanic rock, chiefly a very coarse breccia; but the lower ridges and the valleys, as well as the numerous flats, which are scattered over this region, show the granitic substructure of the mountains. The scenery near the summit of the pass is exceedingly grand; nowhere in the Sierra have we seen the voleanic ridges assuming a more picturesque appearance. The amount - of denudation has been very great, and the masses of rock present a constant succession of sharp pinnacles and fantastic serrated forms, producing an effect hardly inferior to anything seen in the mountains of California. Plate 9 is an attempt to reproduce one of the most striking of these views. The point from which it was taken is near the summit of the road to Silver Mountain, where two of these volcanic overflows are seen, one directly behind, but towering far above, the other. The sketch was taken looking towards the west, near the time of sunset, and the serrated mass in the background, rendered somewhat indistinct by the hazy atmosphere and diffused light of the sun just sinking behind it, had the effect of a reflection of the lower ridge in the sky, or of a kind of mirage, which curious deception was aided by the accidental resemblance in the outlines of the two 


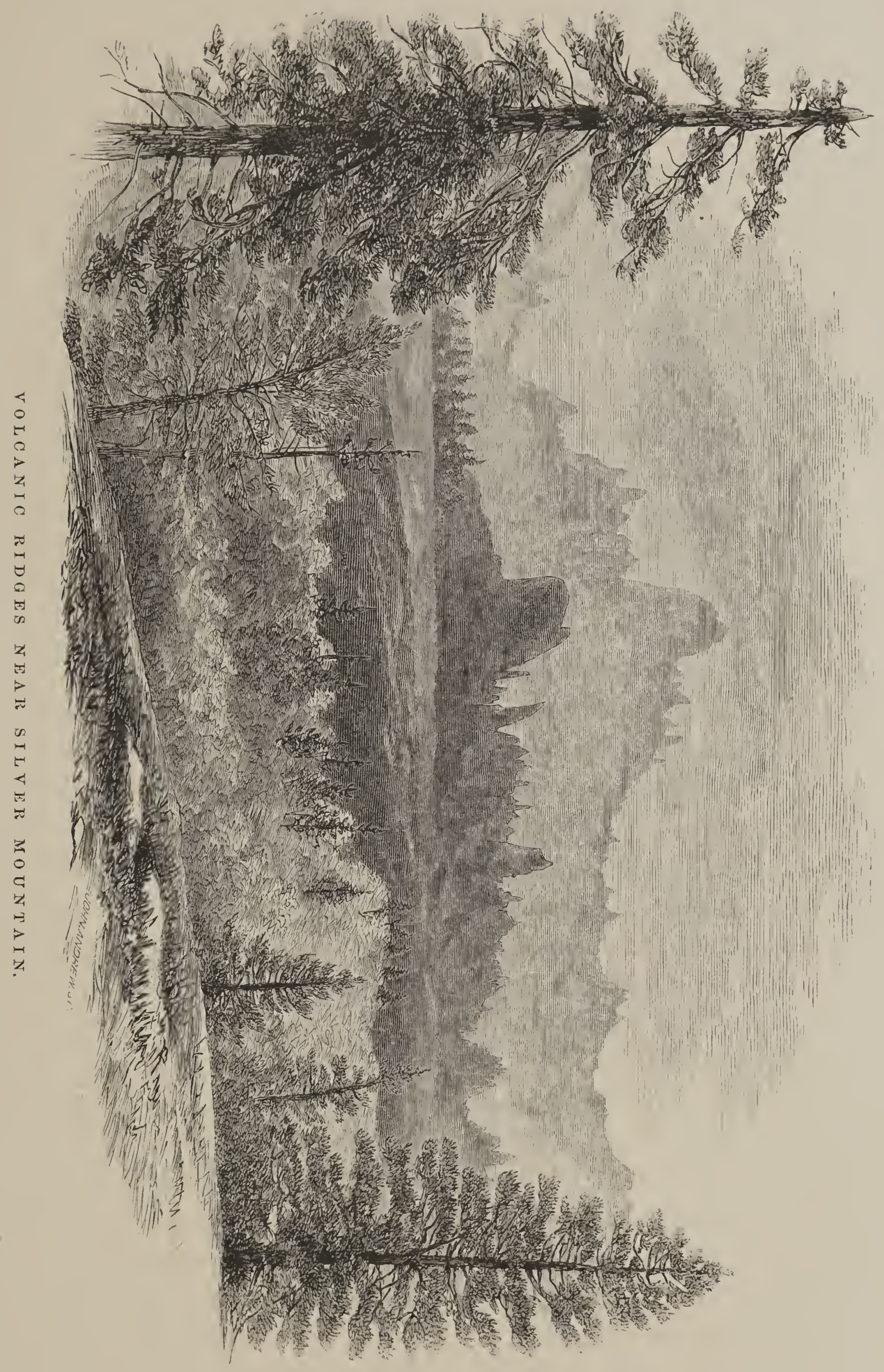




\section{LIBRARY \\ OF THE \\ UNIVERSITY OF ILLINOIS}


ridges, and the very dark color of the one in the foreground. In the wood-cut, an attempt has been made to give this effect of light and shade, but there is no exaggeration of the serrated and pinnacled forms of the masses of rock.

Near the summit of the pass there is an excellent opportunity for examining the relations of the lava to the granitic rocks. At one point a little east of the line of the new road, on the very crest of the ridge, the basaltic masses are seen resting on the granite in the manner illustrated in the annexed wood-cut (Fig. 76), which represents a section of a ridge about 300 feet high, on the north side of which the beds of lava rest, with a steep inclination away from the underlying granitic mass, and a heavy accumulation of fragments of volcanic rock on the opposite side. The granite is seen to be very much altered in character for a considerable distance from the lava; it is both softened and reddened, and

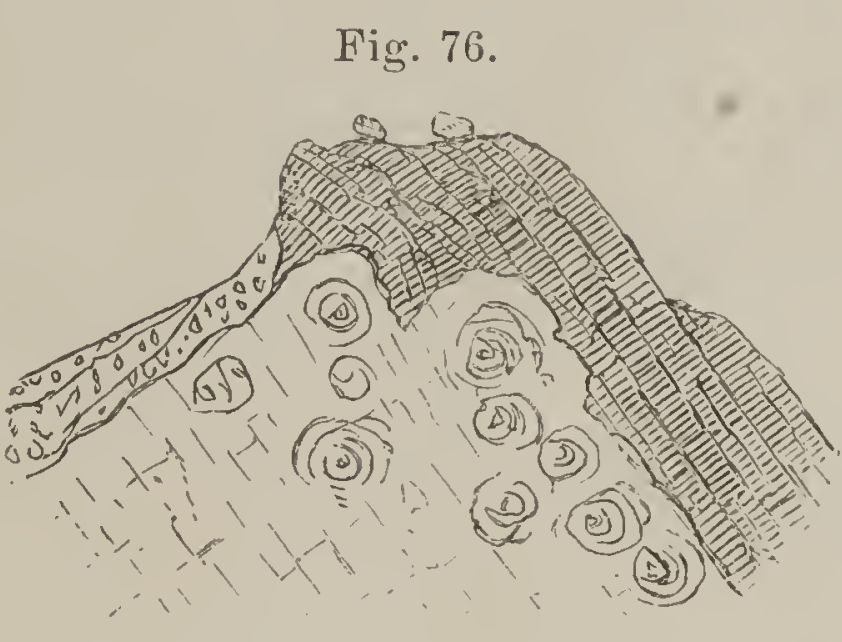

LAVA ON GRANITE. has a concentric structure developed in it, as indicated in the figure. Perched on the summit of the lava are a few very large blocks of granite, evidently carried there by glaciers, and one of the many indications of the immense thickness of the ice in former times, and a striking proof of the wonderful changes which have been wrought in the outline of the surface, within a recent period (speaking geologically), by denudation.

A little below the summit of the pass, on the old trail, there is a very well-marked cone rising to the height of about 800 feet, and entirely surrounded by granite. One side of it is broken away, as represented in the annexed wood-cut (Fig. 77), which is from a sketch taken high up on the side of Silver Mountain, a grand range of volcanic materials forming the background. This cone, as seen from the west, in descending on the trail to Silver Mountain town, appears to be made up of a dark basaltic lava, in very heavy beds, inclining at an angle of about $30^{\circ} \mathrm{in}$ all directions from the centre. It is a picturesque and interesting locality, as it is not often that we are able to see so clearly that the 
volcanic material must have been erupted through a hole in the granite, which rock here surrounds the cone, on all sides, with a smooth

Fig. 77.

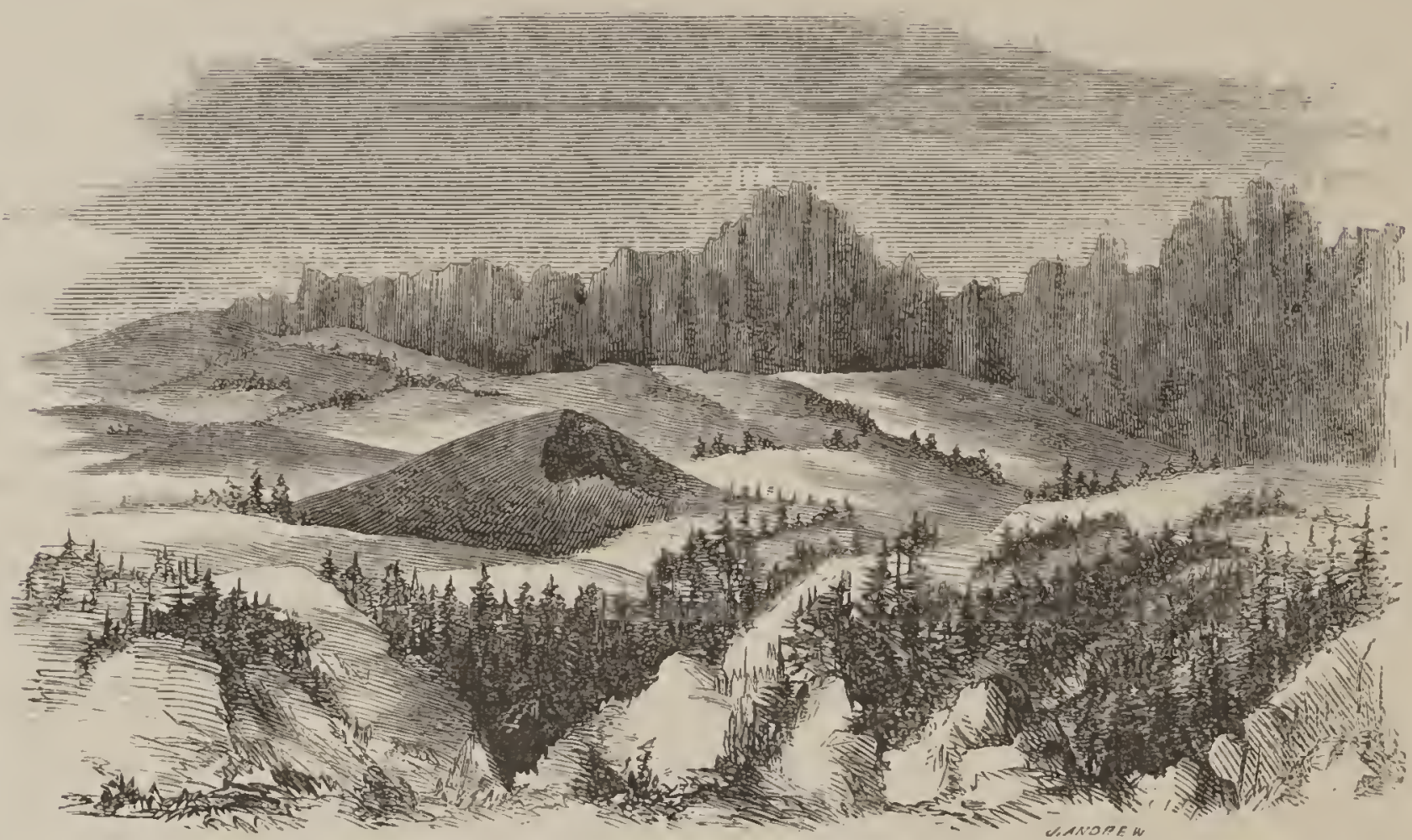

VOLCANIC CONE AND RIDGE NEAR SILVER MOUNTAIN.

and unbroken surface. Indeed, there is hardly any part of the Sierra where the eruptive rocks may be studied to so great advantage as in the vicinity of Silver Mountain.

The traces of ancient glaciers become very abundant as we descend from the summit on the east side, until we come within about two miles of the town, when we strike the volcanic rocks in the cañon. But we noticed in many places blocks of granite perched high up on the slopes of volcanic materials, in positions which they could hardly have attained without the aid of ice.

The town of Silver Mountain lies at the foot of the lofty peak of the same name, and on a branch of the east fork of the Carson. It is 6516 feet above the sea, and the summit of the mountain is 4418 higher, or 10,934 feet above tide. This peak is higher than any one to the north, until we reach Mount Shasta, having an elevation nearly 400 feet greater than that of Wood's Peak, which is the next high point in that direction. The view from the sumnit is very fine, commanding the Sierra in all directions, and extending orer the wide area, covered by volcanic ridges, which lies between the head-waters of the Carson and 
Walker's Rivers. Some points seen in this direction are as high as Silver Mountain itself, and the aspect of the conntry is extremely forbidding firom its roughness and dryness.

The mass of Silver Mountain is made up of volcanic materials, with a great variety of structure and composition, and which we have had no opportunity to examine with care. There is perhaps no locality in the State where so great a number of different kinds of lava might be collected, within the same area, as in this vicinity. Light-colored trachytes, dark basalts, and the curious rhyolites, especially the variety called by Richthofen "Nevadite," are abundant. There are also at the base of the mountain heavy accumulations of stratified materials, which might be called shales, and which have evidently resulted from the decomposition of the volcanic rocks. These shales once occupied the whole valley in which Silver Mountain town is situated, covering it to a depth of at least 750 feet; but the larger portion of the deposit has been removed by denudation. In these sedimentary beds, numerous remains of stems and leaves of plants were discovered.

The name of "Silver Mountain" has supplanted the original one of "Kongsberg," given by the Norwegian miners, who in 1862 commenced prospecting for silver in this region. In 1863 there was a great excitement in this vicinity, and many mining camps were built up, several districts opened, roads constructed, and there were all the external indications of the development of an important mining region, excepting such as could be gathered from the examination of the lodes themselves. In these, so far as the Silver Mountain district itself is concerned (not professing to have any opinion in regard to the adjacent ones, which we had no time to examine), the indications were of a very discouraging character. A large number of specimens were collected and assayed, but none of them were found to contain a workable quantity of silver, while the majority were entirely destitute of that or any other valuable metal.

The "leads," as they were called, were in the form of very irregular" masses of quartz, sometimes of great size, but never distinctly defined, so far as we could observe. The metalliferous portions of these lodes consisted of very fine particles of pyrites, with occasionally some galena, and here and there a little sulphuret of silver, as was supposed, GEOL. YOL. I. - 57 
although the quantity of this latter was always too small to constitute a workable ore, nor can anything more be stated with certainty than that some portions of the rock do contain traces of silver. Many clains were taken up, where we could discover no indications of ore or metal of any kind, and where there was certainly nothing like a vein or lode.

Before entirely condemning this region, however, it should be visited again, and the other districts lying to the north and east of Silver Mountain should be examined, as these were thought by some to present much more favorable indications of mineral wealth than the one we have just noticed.

We here close, for the present, our observations on the High Sierra. Enough has been said in this chapter to give an idea of the geological and scenographical character of this great range of mountains, and the limits of this volume forbid our continuing the description any farther. After, or at the time of, the publication of our map of Central California, and after a more minute survey of the very important routes across the Sierra, between the Big Tree road and Beckworth's Pass, we shall be in a position to do much more ample justice to this portion of the State, in our future volumes of Geology and Physical Geography. We pass now, therefore, to a consideration of the eastern slope of the Sierra.

\section{CHAPTER XI.}

THE EASTERN SLOPE.

\section{Section 1.-Mono Lake and its Vicinity.}

Mono Lake lies in a depression or basin occupying a portion of an elevated plateau of desert land situated at the eastern base of the Sierra Nevada, and between the headwaters of Owen's and Walker's Rivers. Some of the branches of Owen's River head within five miles of the lake, which is chiefly supplied with water from the streams 
rising in the Sierra between Mount Dana and Castle Peak, and they descend very rapidly, as between these two mountains, the distance from the summit of the range to the lake-shore is only about six miles, and the difference of elevation is over 6000 feet. On all other sides except towards the Sierra the lake is surronnded by a wide belt of desert region, there being an area of perhaps as much as 400 square miles embraced within the basin.

Mono Lake is about fourteen miles long from east to west, and nine wide from north to south, in its broadest portion; but it has formerly been much more extensive than it now is, the terraces which indicate its ancient shores being very conspicuous. They may be traced entirely round the lake, although broken in some places; but they can be best measured on the western side, where the hills rise steeply. On this side there is a very distinct terrace 385 feet above the water, and the highest well-defined one is about 680 feet above the present surface of the lake. On the northern, eastern, and southeastern sides they are numerous, and stretch back on the more gradually sloping ground for many miles. The annexed wood-cut (Fig. 78) will serve to give an idea of the appearance of these terraces as seen at Black Point on the northwestern side of the lake.

Fig. 78.

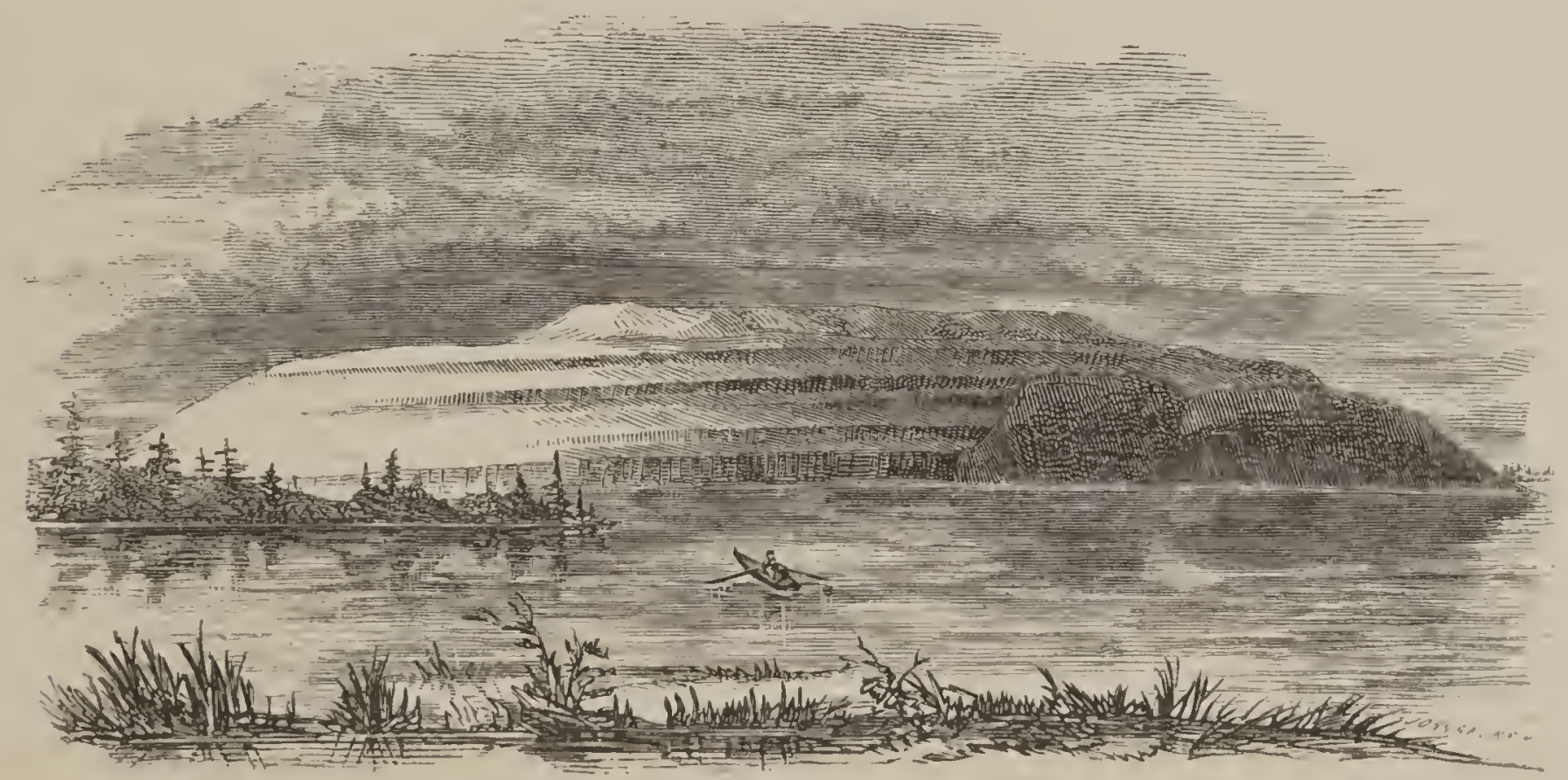

TERRACES ON BLACK POINT, MONO TAKE.

On the southeast side, between the Sierra and the first volcanic chain, an arroyo lias cut through the sandy desert from sixty to a hundred feet deep, and along this in places five well-marked terraces can 
be seen. The old mountaineers say, that at a former period the lake was high enough to pass through a gap to the northeast, and connect with Walker's Iake. If this be true, there must have been a sheet of water here more than fifty miles long from east to west; but of what its form and extent may have been we know too little of the topography of this region to give any clear idea. As the level of the water was once certainly more than 600 feet above its present stage, this great interior lake may have connected with the valleys of the Carson and Humboldt, and have formed a more conspicuous feature in the geography of the country than the present "Great Salt Lake" does. Whatever cause gave rise to the immense body of ice, in the form of glaciers, which, as we have seen, formerly covered the summit of the Sierra in this region and extended down for 5000 feet or more from the crest, this would undoubtedly have been sufficient to supply water enough to raise the lake to the height which the terraces about it show that it must once have had.

The water of the lake is of a high specific gravity and intensely saline. It has not yet been accurately analyzed. It undoubtedly contains a large amount of common salt and of carbonate of soda, as it removes grease and washes as well, or better, than soap-suds. Its surface is not easily thrown into waves, but is generally smooth and glassy; from a distance, it has an oily appearance. It contains some biborate of soda (borax), but the amount has not been determined. It also holds considerable lime in solution, as is evident from the fact that large quantities of calcareous tufa have been deposited along the shore and on the terraces far above the present level of the water; it is this tufa which has been repeatedly mistaken for coral, and has thus given rise to a belief that the lake must in former times have had some connection with the sea. Near the north shore there are springs, holding much lime in solution, which have made extensive deposits of tufa in the lake, some of which rise in fantastic shapes like pillars, or gigantic fungi, from six to ten feet above the water; these springs are less copious than they formerly were. There are also extensive springs of fresh water, which rise in the lake near its western shore, fed from the mountains on that side.

There are several islands in Mono Lake, two of which are of con- 
siderable size, the largest being two and a half miles long from north to south, and the other about half a mile in length from east to west. To the north of this lies a group of islets. These are all composed of volcanic materials. The largest one is chiefly made up of ashes, or loose eruptive masses, portions of which are stratified, and appear to have been deposited under water. The softer strata have been, in places, broken and contorted since their deposition, and there is every indication that the volcanic action has ceased at a very recent period, or, rather, that it has not yet fully died out. On the southeast comer of the larger island are extensive hot springs and steam jets, covering perhaps thirty acres of land and extending in to the lake. This portion of the island is of hard black basalt, with some scorie and cinders, which materials form the eastern end of the island, the western side being made up of stratified ashes, more or less indurated. The steam and hot gases escape from hundreds of vents, and often with considerable noise. About the orifices of many of these fumaroles there are thin red incrustations which appear to consist of chloride of iron. There is but little smell of sulphur and no deposit of this material. Some of these springs furnish a copious supply of boiling water, and large quantities of it come out at the edge of the lake, raising its temperature very perceptibly for many rods from the shore. In one place a large fissure occurs, caused by the falling in of a portion of the crust, and this must have taken place at quite a recent period, since the bushes which grew on the sunken portion are still to be seen in the rubbish at the bottom. Much steam and hot gases issue from this cavity. There are two well-defined craters, now filled with water, on the northeastern part of the island, in the midst of the hard, black basalt.

The second island in size is entirely of hard basaltic rock, and has at its western end a well-defined volcanic cone, of black basalt and cinders. 'This cone is abont 300 feet high, and is very rough and entirely destitute of vegetation; it appears to be more recent than any cone seen in this State, unless it be those to the north of Lassen's Peak.

Myriads of gulls and other aquatic birds resort to this lake to breed during the summer; but the water is destitute of life, excepting a small fly, of which the larra is a white worm, which occurs in immense 
quantities, and which, when dried, furnishes an important article of food to the Indians of this region, and is called by them "Koo-chah-bee."

Stretching south from Mono Lake, in a north and south direction, is a chain of extinct volcanoes, having a remarkable appearance as secu from the west or north, as illustrated by the annexed wood-cut (Fig. 79). It is a cluster of truncated cones, with very steep sides, chiefly

Fig. 79.

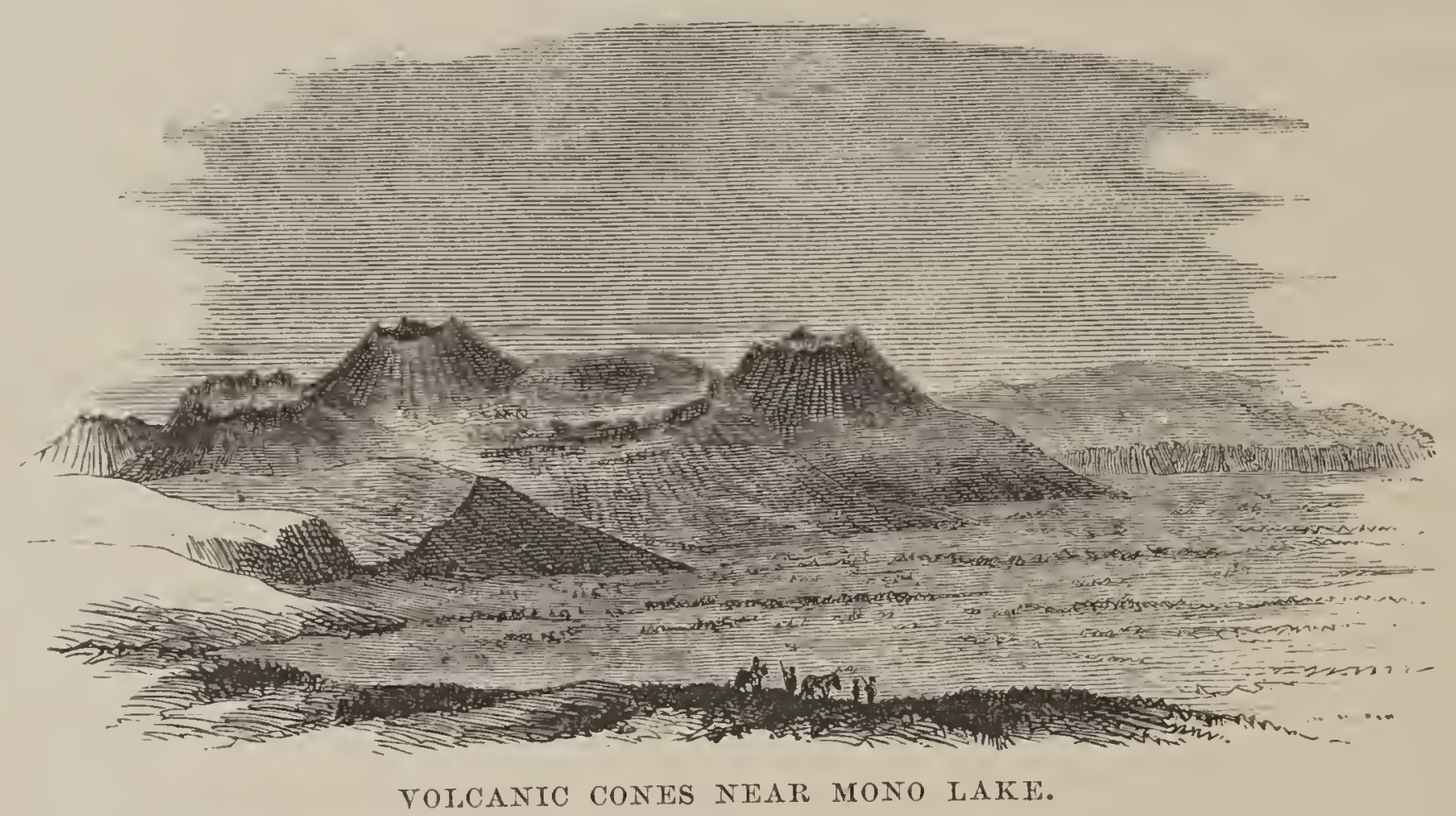

covered with ashes and other loose materials, and having numerous rocky projections rising from their broadly truncated tops. The highest of these was ascended, and its sides found to be covered with loose ashes, lying at as steep an angle as the material would allow, mixed with fragments of volcanic rock of various kinds, especially of trachyte. The broad top was found to be of a light-gray trachyte, with about twelve sharp knobs rising around the outside, apparently the remains of the lip of the ancient crater. Obsidian and pumice are abundant on the top and sides of the cone and over the plain beneath. The soil or ashes of all these cones is intensely dry and pulverulent, so that a man sinks into it, at every step, over the ankles, yet it supports in places a stinted growth of trees and shrubs, and even of herbaceous plants. It is evident that but little rain ever falls here, as the sides of these cones are so little washed, the material of which they are composed being of 
such a character that they could not long retain their present form, except in a very dry climate.

These cones rise to the height of from 9200 to 9300 feet above the sea-level, and the highest is about 2750 feet above the level of Mono Lake. Ths belt of volcanic rock stretches to the south, and appears to enter the Sierra and to extend entirely to the summit, the crest being there considerably lower, as if from the denudation of the softer voleanic materials. From the sumnit of the cone ascended, a similar volcanic range was seen about twenty-five miles farther to the east, apparently parallel with the one examined. In fact, all through this region, between the heads of Walker's and Owen's Rivers, the volcanic formations predominate.

At the summit and within the crater of the cone ascended, several boulders of rose-colored granite were observed mixed with the volcanic ashes, pumice and other erupted materials. Their origin is a curious problem, as it is difficult to suppose that any flow of water or mass of glacier-ice could ever have reached anything like this height above the valley. Indeed, had there been such, the cones of this region could hardly, by any possibility, have retained their peculiarly regular outline; they would certainly have exhibited marks of subaqueous erosion. The most plausible supposition in regard to these boulders is, that they were ejected from the craters by the same force which brought the other materials of which the cones are composed to the surface. They must, in this case, have been torn off from the underlying granite through which the eruptive matter has forced its way, as is seen everywhere in the Sicrra.

\section{Section II.—OWen's Valley.}

Owen's Valley is a narrow basin between extremely lofty mountains; it is about 140 miles in length north and south, and its average width is about ten miles. Along its western edge it is bordered by the Sierra Nevada, which presents an almost unbroken wall in this part of its course, rising in its highest peaks, which are just opposite Owen's Lake, to 15,000 feet, and having no pass across it of less than 11,000 
feet in elevation. Opposite Owen's Lake the descent from the summit of the Sierra to the valley must average fully 1000 feet per mile, the distance being ten or eleven miles, and the difference of level in that part of the range between the highest points and the valley being from 10,500 to 11,000 feet. This would seem to be one of the steepest mountain profiles in the country.

This portion of the Sierra, as seen from the valley, is peculiarly grand; the steep slopes rise from the desert plain, and are everywhere naked and destitute of forests, the only trees being the pines in the cañons, and the scattered nut-pines, which are scrubby and small, and extend up to about 8000 or 9000 feet, the rest of the ridges being made up of patches of bare soil, with exceedingly steep slopes of naked gray rock or snow. From this side the mountains look desolate, forbidding, and immensely high, so much so that it is a wonder it had never been surmised that this was the most elevated portion of the Sierra, until the visit of the Geological Survey to this region in 1864.

On the eastern side of the valley the mountains are more broken, but almost as high and grand as those on the western, and apparently forming one continuous range, as far as known from any topographical information yet published; but it must be remembered that, up to this time, there has never been any instrumental exploration made of the region in question, and so barren and forbidding is it, that it is hardly possible to look forward to a time when the country between Owen's Valley and the Colorado will be known in anything more than the rudest outlines of its topography and geology. It is, beyond a doubt, the most difficult region to explore within our territory. At present it is reserved by the Indians as a sort of stronghold, or last resort. The range on the eastern side of Owen's Valley is called the Inyo Mountains towards the south end, and the White Mountains farther north; but there does not appear to be any especial reason for thus dividing the chain, as it is a continuous one.

These mountains are very dry and desert-like, not a single stream of any size flowing from them into Owen's Valley, which is exclusively supplied with water by the melting of the snow stored away during the winter on the upper part of the eastern slope of the Sierra. The quantity of rain which falls in the valley must be exceedingly small at 
all times, and during the years 1863 and 1864 it was, as reported, almost null. The White and Inyo Mountains are destitute of forest vegetation, excepting a few scattering, scrubby pines, mostly the nutpine, or Pimus Fremontiana.

Owen's Rirer rises in the Sierra Nevada, not far from the head of the San Joaquin, and near the south end of the valley sinks in the lake of the same name, which is about twenty miles long. The tributaries which this river receives from the Sierra are small streams; but these will be of the greatest importance to the settlers, when used for the purposes of irrigation, as they must be in case the mines become permanently valuable. These streams, as they issue from the mountain cañons, flow out upon great piles of detritus, or "washes," consisting of coarse and fine debris brought by the stream from the mountains and piled up on the plain with a gradual slope into the valley. This slope of detritus extends along the whole base of the mountains, but is highest where the streams come out, so that the latter often separate into several branches, as they flow down it, thus making irrigation quite easy, and giving rise to a considerable expanse of meadow along. the various channels.

Our party, under the charge of Professor Brewer, passed hastily up the valley in July, 1864, having erossed the Sierra by the King's River Pass, in order to get north, so as to reach the head of the San Joaquin River by recrossing the mountains. The weather was intensely hot, the thermometer standing all the time at from $100^{\circ}$ to $104^{\circ}$ in the shade, and the party suffered the more, as they had been long enough among the snows of the High Sierra to have become almost acclimated there.

The first day's ride was to the Black Rocks, twenty-two miles, the road passing along on the west side of the river, over the desert slope; but grass is abundant along the river, and where the streams come down from the Sierra; even the desert, when irrigated, as near Fort Independence, produces well. Except in the vicinity of the volcanic rocks, all the boulders seen in the valley were of granite. The Black Rocks form a table of lava, descending from the Sierra by a comparatively gentle slope, very rough and uneven in its details; but, as seen from a distance so that the minor irregularities disappear, it GEOL. VOL. I. -58 
appears as regular and uniform in its descent as a great wash or enbankment of gravel. This mass of lava lies nearly opposite to the Palisades, a ridge of volcanic materials which forms the crest of the Sierra, as noticed in the description of this part of the mountains. The lava of the Black Rocks seems to have issued from the granite at a point about half way up the slope of the mountains, or at an altitude of 8000 or 9000 feet. A similar stream came from the other side of the valley, from the Inyo Mountains, so that the two nearly meet together, leaving only a narrow strip of bottom-land between. From beneath the lava, on the west side of the river, issue copious springs of clear fresh water, of which the largest is known as Fish Springs; this forms a stream several feet deep and ten or twelve yards wide. Several other's of the same character were seen, and they resemble those which are described in another part of this volume as occurring in the northern part of the State. They originate in the same way, namely, by the water, derived from the melting of the snow high up in the mountains, finding its way under the lava, running thus for miles, and finally issuing from it at its base. The lava of this stream is of that hard, dark-colored, basaltic variety so common in the northern part of the chain. The width of the volcanic mass, on the west side of the valley, is about fifteen miles; on the other, it is about two-thirds as much. All through here, the Sierra is of granite entirely down to the edge of the lava.

The Warm Springs, Camp 185, issue from syenitic granite at the base of the Sierra, and are quite copious; there are several of these close together, which unite to form one stream. The water seemed pure, and had a temperature of $122^{\circ}$ to $125^{\circ}$.

From the Warm Springs to Round Valley, the road leads, for most of the way, over a desert plain, the boulders brought down from the Sierra showing the slopes of the mountains to be made up of granite and lava, the former predominating, and often much reddened and altered by contact with the volcanic rocks. At Bishop's Creek the valley between the Sierra and the White Mountains widens considerably to the north, and is entirely occupied by a table of lava, excepting a nook or circular area which lies between it and the Sierra, and which is called Round Valley. This mass of lava is highest along its centre, 
forming at its sides, as it were, two broad valleys. 'The eastern one of these is dry, as no streams come down from the mountains on that side, and it is said to be alkaline and desert, the road to Mono Lake and Aurora passing through it on its eastern edge; the distance to Aurora from Round Valley is called sixty-five miles.

Owen's River flows down on the western side of this lava table, and in places has excavated in it a cañon a hundred feet or more deep. Through here the meadows were finer than any seen in the State, the grass being as high as the horses' backs, and the whole being easily kept irrigated by the streams from the Sierra.

But little is known of the geology of the ranges bordering Owen's Valley on the east side. From Bend City, for twenty-five miles north, their western base and slope seem to be made of slate and other stratified rocks, generally dipping to the southwest, and often much contorted. These slates are said to alternate with beds of limestone. A single fossil was found in these rocks, opposite Camp Independence, by Dr. Horn; it was a species of Goniatite (Goniatites laveridorsatus, Hauer), identical with one found by us in El Dorado Cañon, near Dayton, in Nevada, and which undoubtedly belongs to the Triassic series; this is considered by Mr. Gabb as the same species which has been described by Hauer as occurring in the upper Trias of the Alps. There would appear to be sufficient evidence to justify our considering these strata along the western flanks of the Inyo and White Mountains as identical with the rocks of Washoe, which certainly occupy a geological position closely allied with that of the metalliferous rocks of Owen's Valley.

It is said by explorers that the central portion of the Inyo and White Mountain range is of granite, and that stratified rocks occur on its eastern flank, which dip to the east, forming an anticlinal axis. In some places, the crest of this chain is very rough in outline, and rises in numerous pinnacles. One, like a pillar, on the rery summit of the range, is called the "Pah Ute Monument;" it is conspicuous for a great distance, and is a noted landmark. It is also stated that there are several ranges east of this, in close proximity to each other, with narrow strips of desert valley between, some portions of which are covered with deposits of salt. In 1864 , there was some excitement in regard to the 
alleged discovery of a bed of pure rock-salt, several feet thick, in the second valley east of Bend City. The range east of San Carlos was estimated at about 10,000 feet in height, and it appears to maintain an elevation of as much as 8000 or 9000 feet for some seventy miles to the north; but it sinks to the south, beyond Owen's Lake, forming low and broken ridges in that direction, where it unites with the Coso Mountains. A bout seventy or eighty miles north of San Carlos, there is a high peak called the "White Mountain," which is doubtless 14,000 feet or more in elevation, as it has large patches of snow on its southern side, and it was said by the miners that this snow never entirely disappear's. This peak was levelled to by Mr. King from the summit of Mount Tyndall, and it was thought by him that it was probably about 14,600 feet high, and possibly higher than any peak in the Sierra.* It was also very conspicuous from Mount Dana, opposite Mono Lake.

Deep Spring Valley has been described to us, by Mr. J. E. Clayton, as a remarkable crater-like depression, high up on the flanks of the White Momntain range, with very steep sides, the crest being covered with a dense growth of piñon pines. Mr. Clayton also notices the occurrence of heavy masses of volcanic material along the summit of this range, which would correspond with what is observed farther north on what appears to be its continuation.

Explorers have been actively engaged for some time along the flanks of the Inyo and White Mountain range, and many mineral-bearing lodes have been discovered, of which attractive-looking specimens have been brought to San Francisco. No detailed examination of this region has yet been made by the Survey, and we are unable, therefore, to give any opinion as to its probable value. Troubles with the Indians have, hitherto, made it difficult for our small party to explore the vicinity of Owen's Valley; but it is evidently a very interesting part of the State, and we shall not fail to turn our attention in this direction as soon as it is in our power to do so. 


\section{Section III.-Tine Griati Barin.}

A vast region of desert and mountain extends over the southeastern portion of California. It comprises all that region lying to the northeast of the San Gabriel, San Bernardino, and San Jacinto Mountains, and extending to the Colorado River, which forms the southeastern boundary of the State, while it is limited on the northwest by the range of the Sierra Nevada, as it curves round to meet the Coast Ranges. This region is in intimate comnection with the Great Basin, or the region lying chiefly in Nevada and Utah which has no drainage into the sea. This Great Basin, however, is not by any means a unity; it consists, rather, of a number of independent basins, each one having a system of drainage of its own, but nowhere collecting the water in sufficient quantity to fill up the reservoir, or to cause it to run over and seck an outlet to the ocean. The Colorado flows as a large and navigable stream along the borders of California for more than a hundred and fifty miles; but it does not, in that distance, receive a single tributary, although the mountains are almost everywhere close upon the river ; the fall of rain in this region is not sufficient to give rise to any stream of sufficient size not to lose itself as soon as it enters the plain.

A large part of the Great Basin in California has been hardly explored at all, as yet, and the topography of the most of it is as little known in its details as if it lay in the heart of the continent. It is true that this region is represented in the General Land Office map as subdivided into sections; but there is good reason to believe that a portion, at least, of this work is fraudulent and fictitious; large sums were paid for ruming these lines, but a comparison of the geographical data in our possession with those given in the Land Office map would indicate very strongly that there is more fiction than reality in what is representer thereon.

The principal materials we have for illustrating the geology and topography of the region in question are derived from notes by Dr. Cooper of a journey orer the Mohave trail to Fort Mohave, and a residence of one winter at that post. Besides this, we have Professor Brewer's memoranda of a trip by himself and Mr. Gabb, along the northern edge of the basin, in 1863. Mr. J. E. Clayton has also fur- 
nished some valuable information in regard to the Colorado region, and quite a number of notes and specimens have been sent to the office of the Survey by other explorers. We have also examined the notes of the "United States and California Boundary Commission," in which there is a brief notice of a reconnaissance, made in 1861, through the northern part of the California portion of the Great Basin, from the Colorado River, across, by Death Valley, to Owen's Valley. The geological portion of these manuscripts is of no great value, but the topographical notes by Mr. Biesta and the map by Mr. Van Dorn furnish some important information in regard to a region where but few explorers have penetrated.

The shape of the Great Basin forming the southeastern corner of the State of California is nearly rectangular, the State boundary on the east being about parallel with the ranges of mountains which bound it on the west and separate it from the region traversed by streams flowing into the Pacific; the Colorado on the southeast is also approximately parallel with the range forming the southern termination of the Sierra; as thus linited, the district in question would be about 215 miles long from northwest to southeast, and 125 miles broad in the opposite direction, making an area of not less than 27,000 square miles, or a territory three times as large as the State of Maryland, nearly all of which is comprised in San Bernardino County. The whole of this region may properly be called a desert, so far as its being suited for the residence of a civilized population is concerned; yet it is not entirely destitute of those resources which can be made available for the support of life, when one is driven to do so by necessity, or by the desire of making money. The discovery of very rich and permanent mines might lead to the formation of large settlements, or even the building up of towns or cities, as has already taken place in the adjacent, and not very differently situated, region of Nevada. At present there are no permanent settlements of any considerable size in this part of the State, although a great deal of exploration and prospecting has been done there.*

* In regard to the present condition of the mining interestsin the Colorado region, we have little or no late and reliable information. We propose to make an exploration of this part of the State during the coming winter, if our means permit. 
The mountains which border the region in question on the west, beginning at the San Francisquito Pass, are the San Gabriel Range, the San Bernardino Mountains, the San Jacinto Mountains, and the group to the east of the San Diego. The principal passes which cross these ranges are the Cajon Pass, between the San Gabriel and San Bernardino Mountains; the San Gorgoño, between the San Bernardino and the San Jacinto Ranges; and Warner's Pass, which leads from the plains of San Bernardino, by a circuitous ronte, to the west of the San Jacinto Mountains, into the Colorado Valley. This latter was for some time in daily use as a part of the Overland Stage route, as long as this continued on the southern line from New Mexico to Fort Yuma and thence to Los Angeles. All these passes were surveyed by Lieutenant, now Major, Williamson, or parties under his charge, and a full account of them will be found in the fifth volume of the Pacific Railroad Reports. The Cajon Pass is the one which is in most general use for the travel across the desert to the Upper Colorado, as it leads down the Mohave River by the old Spanish trail to Santa Fe; and from Soda Lake, the sink of the Mohave, it crosses the mountains to Fort Mohave, near the initial point of the boundary line, where the 35th parallel meets the Colorado River. The summit of the Cajon is given by Williamson as 4676 feet above tide; the pass ascends on the Pacific side by a very steep incline, and descends to the Mohave by a much more gentle and uniform one.

The following account of the geology and geography of the Mohave trail is chiefly extracted from the notes of Dr. Cooper, who passed over it twice in the winter of $1860-1$ :

Leaving the Colorado bottom, the road passes for twenty miles over a granitic range, the summit of which is about 2000 feet above the level of the river at the point where the road crosses it, while the peaks on each side rise about 1000 feet higher. This is called the Pah Ute Range. The rock is granitic, containing a large amount of friable feldspar, and is intersected by metalliferous veins. The slopes are very gradual and the surface mostly smooth, covered with fragments of granite forming a coarse gravel; but points and ridges of rock are left standing here and there, and are very rough and precipitous. The valley between this summit and the next is shallow where the road crosses it, its bot- 
tom being marked by a dry, sandy arroyo, through which the mountain torrents run at long intervals; but where no water is commonly to be found, even by digging. This valley, called, as is supposcd, the Galleta Valley, is twelre miles wide, and descends towards the southeast; it was formerly supposed to be the bed of the Mohave River.

The western slope of this valley is covered with fiagments of basaltic lava, fine-grained and resicular, together with obsidian, the fragments being usually small and closely packed together on a surface of granitic sand. Pah Ute Spring, twenty miles from the Colorado, and the first camping ground on the road, is at the foot of a basaltic ridge, about 200 feet high; here the water bursts forth in a fine bold strean from the junction of the lava with the underlying granite. In this vicinity is the first appearance of stratified rocks; these are beds inclining in various directions, without any regularity, of a color varying from white to red, blue, and purple, and having the texture and hardness of burnt pottery or brick, and without a trace of organic remains, so far as could be ascertained. The age of these rocks is not known; Dr. Cooper considers them to be volcanic materials stratified by being ejected into water.

From this spring, there is a steep ascent of about 500 feet to the summit of the basaltic ridge, and a descent of 150 feet on the western side, and then the road rises by a hardly perceptible grade, over a sloping plain of soft volcanic detritus, to Rock Springs, near the summit of the Providence Mountains. This slope is covered with quite a good soil, derived from the decomposition of the volcanic rocks, which produces considerable forage and a variety of vegetation, but which is almost destitute of water. The ascent, although stated by Lieutenant Whipple to be about 2500 feet in twenty miles, appears so slight, that the country looks like a great level plain, the rise of 120 feet to the mile being lost to the eye, in contrast with the steepness of the surrounding mountains. Towards the higher part of the plain, extensive groves of the tree Yucca ( $Y$. baccata) give it a wooded appearance. A view from a photograph taken at Rock Springs, by Mr. L'Heureux, is given here, to illustrate the character of the scenery in this part of the State. (See Fig. 80.)

At Rock Springs, the second watering-place, the rock is granite, form- 
ing a high mountain to the left of the road, while on the right there is another, equally high, of voleanic rocks, in which layers of basalt alter-

Fig. 80.

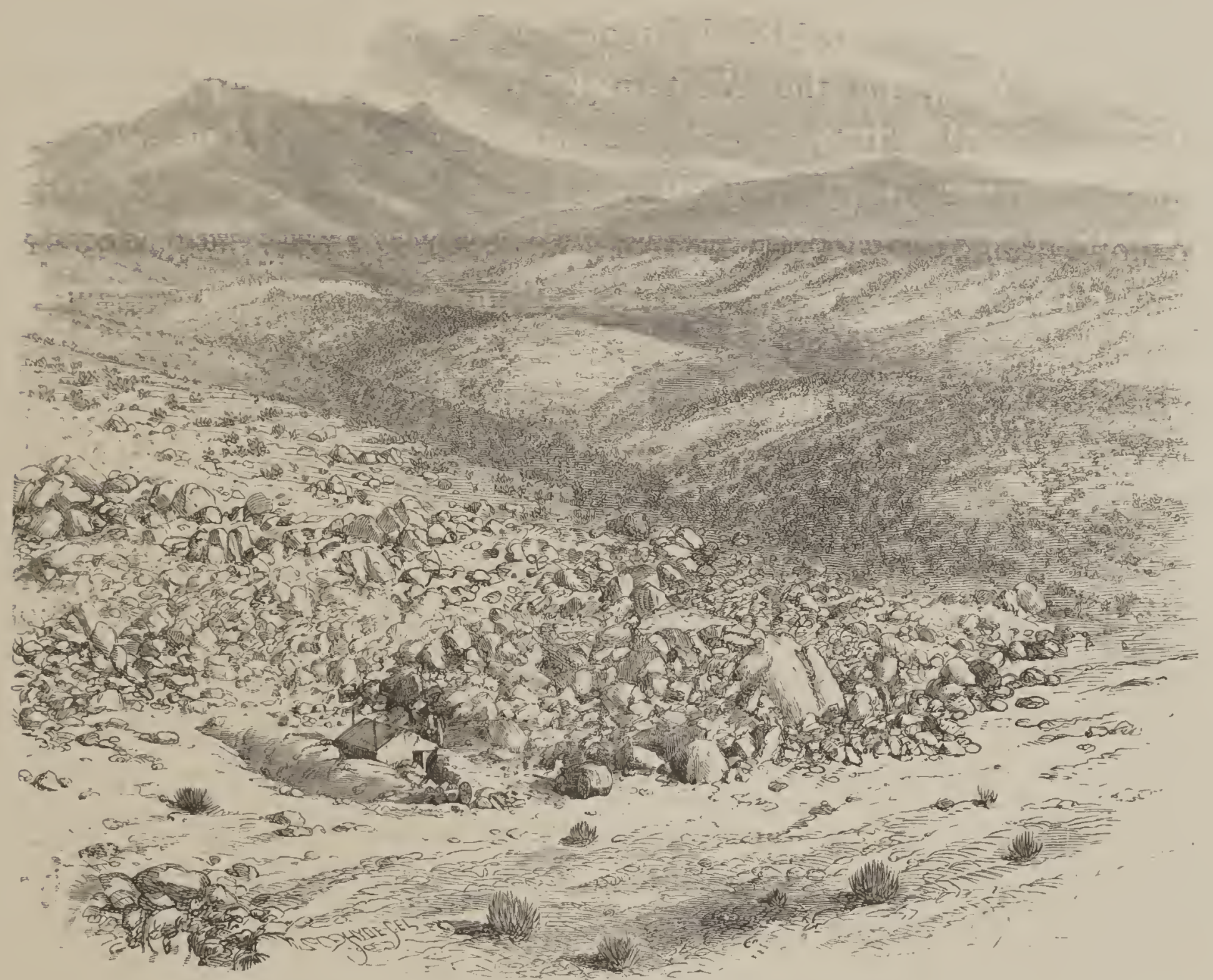

MACEDONIAN VAILEY AND MOUNTAINS, FROM ROCK SPRINGS.

nate with beds of a softer material, like that of the supposed voleanic strata at Pah Ute Spring; these rocks are eroded by the action of water so as to form steep cliff's several hundred feet high. Caves, channels, and rounded boulders of granite indicate that currents of water once swept orer nearly all this range of mountains, to a height of 5000 feet above the sea; while the crests of the ridges, rising 1000 feet higher, with much sharper outlines, indicate that the erosive action did not extend to the summits of the ranges. The effects thus produced are such as we now see on the shores of the ocean, and the fresh appearance of the worn surfaces is remarkable.

From Rock Springs to Chico Spring is three miles, and the ascent is steeper, the spring being at the very summit of the route, but sur-

( $\mathrm{HEOL}$. VOI. I. $-5 !$ 
rounded by higher points. Many plants were found still blooming here which had been in flower two months earlier at Fort Mohave, and which were now entirely dried up at that locality. At this elevation the effect of a more abundant supply of moisture was recognized in the character of the vegetation. Of the more important plants, the small nutpine ( $P$. edulis), and the Western juniper (J. occidentalis), were quite abundant on the higher granite mountains each side of the road, and there was a belt of pretty good grass for a width of about thirty miles. Among the plants collected here by I)r. Cooper was the well-known buffalo grass of the Great Plains; but this was rare, and only found near the summit.

From the camp at Chico Spring, the road led for twenty-two miles down the western slope of the Providence Mountains, passing "Marl Springs" at a distance of sixteen miles. The whole route was over a granitic slope, similar to that west of the Colorado River, equally barren, and producing nearly the same plants. Near Marl Springs a low range of foot-hills of granite seems to act as a sort of dam to the subterranean channels on the west side of the mountain, so that the water rises to the surface in holes dug to retain it; but it rarely overflows. From Marl Springs there is a slight rise, and then a gradual descent for twenty miles, to Soda Lake, the sink of the Mohave, which was four miles wide where it was crossed, a camping ground with water being found on its western margin. Granitic rocks, with gravel and sand, continue all the way down the slope, and fragments of basalt are scattered along the lower half, evidently derived from extensive lava fields which come down to the road on the right hand. Sereral high cones to the north appeared like centres of eruption, but no distinct craters were visible. The lake, as it is called, was entirely dry, and never does contain water, although, in very wet seasons, it is so muddy as to be crossed with difficulty. Its surface is white, with an alkaline crust about one-fourth of an inch thick.

From this the road follows the course of the Mohave River for twelve miles, and then enters a cañon, through which it passes for nine more, when the camping ground called "the Caves" is reached. The first part of the route is over deep drifting sand, approaching more nearly in character to a perfect desert than any portion of the road 
before traversed. The Larrea covers inost of it, and thickets of shrubby mesquit and scattered trees of the beautiful and fragrant Chilopsis show the influence of the moisture which exists in the soil at the depth of from three to six feet beneath the surface. In December, 1860, the Mohave ran in a small stream over this sandy desert nearly to the lake; but this was an unusual occurrence. Soda Lake is the lowest point on the route between the Colorado and Cajon Pass, and according to Lieutenant Whipple is 766 feet above the Colorado at the Mohave crossing, and 1122 feet above the sea. Metamorphic limestone, red granite, and basalt occur at the western end of the lake. In the cañon the first water of the Mohave was met with; but at this season (May) it was unfit for drinking, standing in pools and being very alkaline. The walls of the cañon are generally vertical, about 200 feet high, and consist of a metamorphic rock resembling serpentine, between the spurs of which are heavy beds of detritus, stratified and destitute of fossils. The "Caves" are small, and have been excavated in the metamorphic rock by the river, which, as shown by the marks on the walls, sometimes rises to a height of five feet in the narrowest part of the cañon.

Immediately beyond this cañon, which cuts through a low range of mountains, the valley widens out to a considerable breadth and changes its character entirely. An extensive marsh has been formed here by the obstruction of the mountains, and around it the constant supply of moisture supports a good growth of grass, small willows, mesquit, chilopsis, and cotton-wood. This is the second tolerably good camping. ground in a distance of 110 miles from the Colorado, the summit of Providence Mountains being the other. No water runs beyond this point in the summer, and here the first sea-breeze was met, moderating the intense heat to some extent; up to this point the wind had been constantly from the south.

From this camping ground the distance to Fort Cady is fourteen miles, and at this place there is good water and other conveniences. This fort is an adobe structure, built by Major Cady as a refuge for small parties attacked by the Indians, and there is another one of the same kind at Soda Lake. From Fort Cady the valley widens out, improving in the character of its soil and vegetation, although there is a 
want of rumning water in summer throughout this distance, what does exist being in pools which form regular camping grounds at intervals of from six to twenty miles, known as the "Fish Poud," "Sugar Loaf," "Grocely," "Point of Rocks," \&c. ; west of these the water" becomes frequent, and some attempts at cultivation by settlers were making in 1861. At most of the above-mentioned camping grounds, spurs of mountain ranges come down to the river, namely, at Fort Cady, "Forks of roads" (to Salt Lake), Sugar Loaf, Point of Rocks, and Lane's. At all of these the rock is metamorphic, consisting chiefly of grayish slate, with reins of quartz and pyrites. Whether any of these veins contain valuable ores remains to be investigated. In the intervals between the mountain ranges are extensive level tracts of stratified detritus, in which no fossils have been discovered, and of which it camnot be stated with certainty whether they are of Tertiary or Post-Tertiary age. For about forty miles west of Fort Cady they seem to consist of volcanic materials chiefly, and in one place, at least, are interstratified with volcanic matter. It is known that volcanic mountains and well-formed craters occur in the desert and within no great distance of the Mohave trail (see Williamson's Report, P. R. R. Reports, Vol. 5, p. 31).

The San Gorgoño Pass leads from the valley of San Bernardino between the grand masses of the San Bernardino and San Jacinto Mountains, into the Coahuila Valley, which connects by a gradually descending slope with the desert and the Colorado Basin. The Pass was explored by Lieutenant Parke, under authority of Lieutenant Williamson, in 1854. The elevation of the pass was given by him at 2800 feet, and it was so uniform in its ascent and descent as to be pronounced "the best pass in the Coast Ranges." On the north of the pass and of the Coabuila Valley is a grand ridge of granite mountains, which, so far as known, have never been explored at all, and the same may be said of the San Jacinto Group, which lies on the other side. This group embraces nearly a thousand square miles of mountain ridges, which look very grand and high as.seen from the summit of the Santa Anna Range. The culminating point we estimated at 10,000 feet. The mountain range of San Bernardino appears to extend in one nearly mubroken mass almost to the Colorado River, coming out is 
little above fort Yuma. This range is probably chiefly granitie; but there are some slates and other metamorphic rocks; and gold washings, ats well as quartz-mines, are worked on the north side of San Bepratrdino, but not to any considerable extent. The farther one goes south on this range the more difficult of exploration it becomes, as it is at last absolutely destitute of water. Of the region between this range and the Mohave trail, the same may be said now that was in 1854 , by Williamson: "I have never heard of a white man who had penetrated it." The United States Linear Surveyor's have given no information about the topography of the country; and, as the whole of their work in this region is of an excessively mythical character, it would not be safe to draw any inferences from the published Land Office map.

For information in regard to the region southwest of this range, or the continuation of the Coahuila Valley into what is called the Colorado Descrt, reference may be made to the Pacific Railroad and Mexican Boundary Reports.

We close what we have to say in this volume of the geology and topograply of the Great Basin, by appending a few extracts from the manuscripts of the United States and California Boundary Commission, which throw some light on a region of great geological interest, and which we are extremely desirous of exploring whenever circumstances will permit us to do so. As a characteristic illustration of the scenery near the Colorado, we append a wood-cut (Fig. 81) which is from a photograph, by Mr. L'Heureux, of the mountain ranges in the vicinity of El Dorado Cañon; the exact locality we are unable to state, as there is no map of that region.

The following remarks are taken from a manuscript report by Dr. J. R. N. Owen to the Commissioner of the United States and California Boundary Survey, dated April 15, 1861. It relates to the district traversed by the exploring party sent out to examine the region in the vicinity of the boundary line rumning from the initial point on the Colorado northwest. The party intended to traverse this line and reach Lake Bigler, but was obliged to turn off the route and make their way to Owen's Valley, and thence to Visalia, in consequence of the great difficulties encountered, and especially the absence of water. Dr. Owen says: 
"In crossing the San Bernardino Mountains from Los Angeles, and coming into the country to the eastward of that range and the Sierra

Fig. 81 .

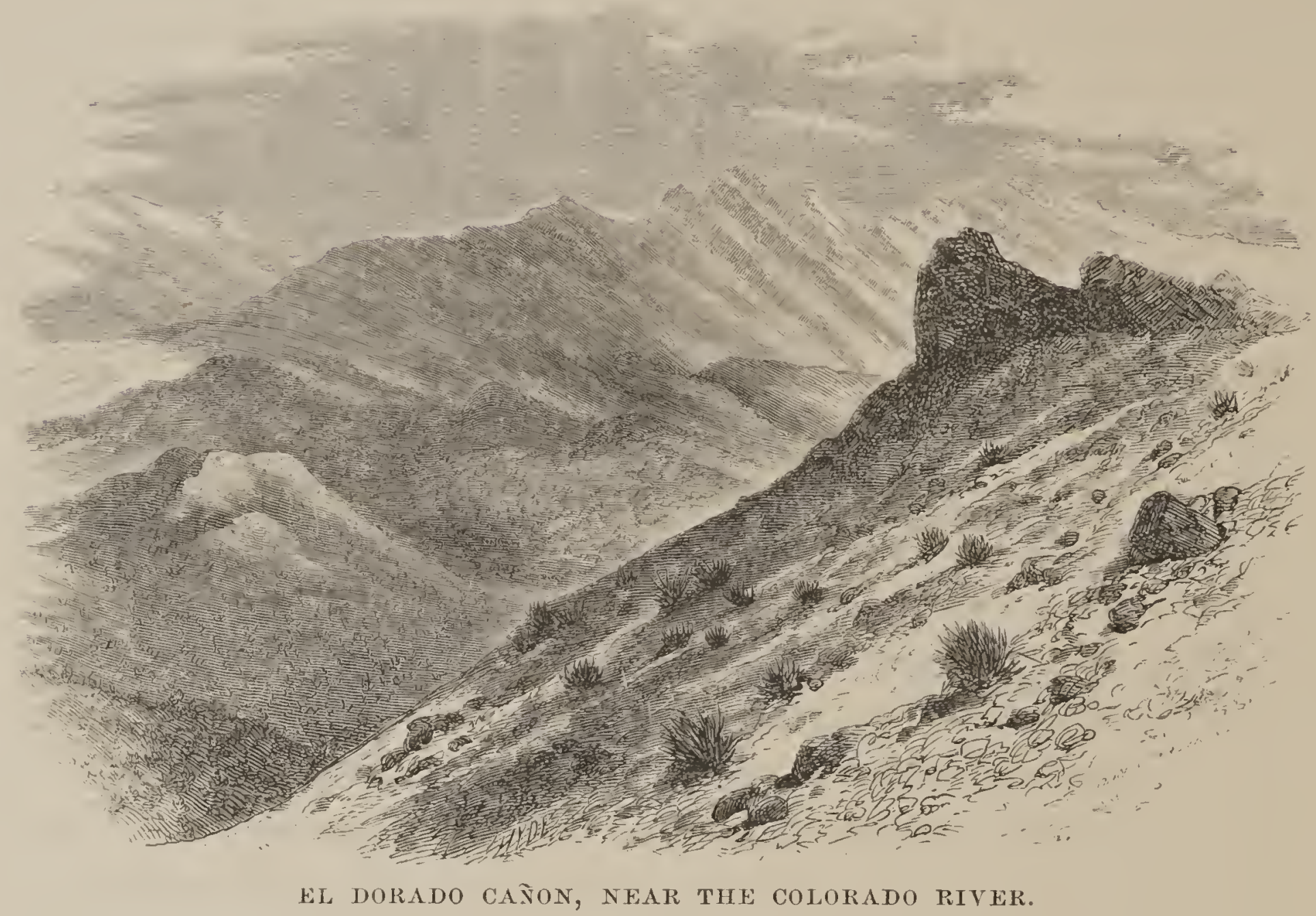

Nevada, one is immediately impressed with its aspect of sterility and drouth, as well as with the numerous indications of its essentially volcanic character, which present themselves in almost every direction in the shape of scorix and lavas of almost every variety and date. Many of the hills which are scattered about in its desert plains appear to be nothing more than masses of lava or basaltic trap-rock that have been forced up through fissures in the surface of the plain, during subterranean disturbances; while others that have been formed by the upheaval of the ruptured crust of the earth show, in the metamorphosed condition of the rocks composing them, unmistakable evidences of intense igneous action, at some period in a geological sense not very remote.

"As far as the Colorado this country still preserves its volcanic aspect, and in the few opportunities which I had to examine its rocks in situ, I recognized only some of the older sandstones, and these were 
very much modified by the immediate vicinity of voleanic products, which everywhere surrounded them.

"Crossing the Pah Ute Hills in our route northwestward, and reaching the Providence Mountains, we found in that range gneiss and granite presenting through the later formations, just as I had observed to be the case in the same range to the sonthward of the Los Angeles road. Leaving this range and proceeding northwestward across a low valley to the next range, we enter a district in which limestone is not only the prevailing rock, but appears to form entire ranges of lofty and boldly-defined mountains, among which are comprised the Kingston Spring, Mountain Spring, and Las Vegas ranges, the latter extending farther to the northward. It is in this Mountain Spring Range that the Potosi mines, which are now exciting considerable attention (1861), are situated, a few miles south of the present Salt Lake road, on the western slope of the mountain, and several hundred feet above the level of the plain."

The Potosi mines are on veins of argentiferons galena, of which nothing definite has been ascertained, except that they have been abandoned. It is reported, however, that there are numerous, welldefined, and large lead veins in this region; but the locality is one so distant and difficult of access, that it seems hardly possible that mines, unless extremely rich in the precious metals, could be worked there with success at present. The existence of an extensive region of limestone formations, as reported by $\mathrm{Dr}$. Owen, with metalliferous veins occurring in it, is a fact of great scientific interest at least, and one cannot but wish that it might be more fully explored, especially since this is the only district, so far as known, on or near the Pacific coast, where limestone extends over any considerable region of country. Mr. Biesta, another member of the expedition, reports having seen fine and pure specimens of alabaster and gypsum in this region.

After examining the Potosi mines, the party turned west, and crossing the northern spur of the Kingston Mountains, called on the MS. map of the expedition by A. Van Dorn, the "Damask Mountains," they struck the Amargosa River; this they followed up for some distance, and entered the range of the same name, which they erossed and descended into Death Valley. The mountains in the rieinity of Amar- 
gosa Valley, on the east side, near Resting Spring, are described by Mr. Biesta as "steep and utterly barren, and all its rocky stratifications in a perfect mass of confusion." The rocks are described as being made up of limestone beds, fifty to sixty feet thick, with slate, lava, and basalt; numerous quartz veins are also mentioned. As this is an interesting region, and one of which nothing definite is known, we subjoin all that Dr. Owen says of it.

"Crossing the plain of Potosi and a spur of the Kingston Mountains (Resting Spring Mountains), on its western border, we next come to the Amargosa Range which here forms the western limit of this limestone district. Looking to the westward of this range, the whole country between it and the Panamint Mountains appears depressed, and the different ranges of hills which are embraced in the great bend of the Amargosa seem to rise, as it were, from the depression of a basin. As we descend into this basin we see on the western slope of the Amargosa Mountains the schists and sandstones of an earlier date, showing out boldly from under the limestone which forms the crest and covers the eastern slope of the mountains. From this point these, with only occasional masses of limestone and conglomerate, continue to characterize the country until we reach Owen's Mountains, where we again encounter granite, gneiss, crystalline marble, and other rocks of this kind."

The Amargosa River rises far to the north, among utterly unknown and unexplored regions, and flows southward, crossing the boundary line in about latitude $36^{\circ} 30^{\prime}$, of course being like all other rivers in this region, rather a channel in which a river might run than one in which it does; in about latitude $35^{\circ} 30^{\prime}$ it makes a great bend and turns and runs northward for about thirty miles, and then enters Death Valley, which is, in fact, the sink of this river. This valley is one of the most interesting features of the topography of the State, as it is beyond a doubt depressed below the level of the sea, and the only area on this continent, at any considerable distance from the coast, which is thus depressed. The valley is entirely surrounded by very ligh and precipitons mountains, having the Anargosa Range on the east, and the Panamint Mountains on the west; it is said to be from eight to ten miles in width, and from thirty-tive to forty miles in length. It 
lies in a direction parallel with the mountain chains in this region, or about N. $20^{\circ}$ E.-S. $20^{\circ} \mathrm{W}$. The formations surrounding Death Valley are described as being to a large extent volcanic, obsidian being noticed in abundance on the west slope of the Amargosa. The whole aspect of the valley is one of the utmost desolation; the mountains surrounding it are naked, arid, of dark color, and of imposing grandeur of form; the valley itself is a sort of marsh in the winter, at least towards the centre. It is covered with a white efflorescence of alkali, from which the rays of the sun are reflected with such power as almost to blind the eyes. The name, ominous of evil, is said to have originated from the fact that a party of emigrants perished here from thirst and starvation, as early as 1849; and it is said by Dr. Owen in his notes, that he followed the marks of their wagon-wheels all the way from Furnace Creek, and that he camped on the same spot they had occupied eleven years before, the remains of their fires and the iron of their wagons being perfectly preserved during the eleven years that had elapsed since the unfortunate party attempted to make their way through this inhospitable region. From this it is evident that but little if any rain had fallen in this valley for several years. Dr. Owen remarks in his manuscript that this fact, taken in connection with the circumstance that on every hand the traces of tremendous washes, of apparently recent origin, are to be seen in the mountains, is one well calculated to excite surprise.

The barometrical observations taken in Death Valley by the California and United States Boundary Commission, and which are the only ones as yet made in that region, are but few in number, and, although they would have indicated a depression of the valley below the level of the sea as probable, they would not have been sufficient to make it certain, had there not been a stationary barometer observed at the time, at no great distance and at a point whose height was pretty accurately known. The observations were taken at the northern end of the valley and at a distance of 180 miles from the initial point on the Colorado where the corresponding observations were made by Lieutenant Tres. Unfortunately only three observations were taken in the bottom of the valley, and three more at the camp close by. All the observations were carefully investigated and computed by Major WilGEOL. VOL. I. -60 
liamson, by whom also the barometer used on this reconnaissance was by good luck, examined and compared with his own standard after the return of the party, so that one source of uncertainty is thus entirely got rid of. Major Williamson, in an elaborate manuscript paper which he has placed in our hands, comes to the final conclusion that Death Valley is certainly over 100 feet below the sea-level, and that it may be as much as 250 feet below it, the mean of all the observations giving, as the approximate result, 175 feet. It may be noticed that this depression of the continent is in the same latitude as the very highest elevations, or at least of the highest mass of mountains of which we have any knowledge, in North America. Only about sixty miles due west from the north end of the valley the culminating points of the Sierra Nevada rise to the height of 15,000 feet above the sea, and 10,000 feet above the intervening plain of Owen's Valley.

From Death Valley to Owen's Valley the distance in a straight line is about fifty miles, and there appear to be three parallel ranges of mountains, running in a N.W.-S. E. course through the region, with narrow valleys between. The Panamint Mountains extend for 150 miles or more, from far in the north towards the sink of the Mohave, terminating before crossing the Salt Lake trail; these form the western border of Death Valley, and of their geology little is known except that the rocks are erystalline and metamorphic. The Coso Mountains lie along the eastern border of the road from Walker's Pass to Owen's Lake. They are made up of granite and gneissoidal rocks, and have been much prospected for gold and silver. In 1861 quite a number of persons were established there, and the erecting of mills was talked of. Nothing seems to have resulted, however, from these attempts; and the inference is, that the veins are not rich enough to pay for working in a region so remote and difficult of access. 


\section{APPENDIX A.}

\section{T A B U L A R S T' A T M E T}

OF THE OPERATIONS OF 'THE PRINCIPAL QUARTZ MLLLS RUNNING IN CALIFORNIA IN 1861.

BY W. ASHBURNER.

\begin{tabular}{|c|c|c|c|c|c|c|c|c|c|c|c|c|c|c|c|c|}
\hline $\begin{array}{c}\text { NAME AND Locality } \\
\text { OF MiLi. }\end{array}$ & 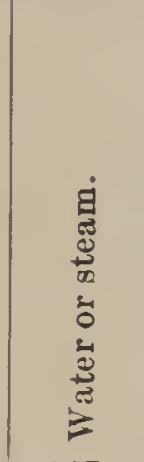 & $\mid \begin{array}{l}\dot{0} \\
\vec{a} \\
\tilde{z} \\
\tilde{w} \\
0 \\
\overrightarrow{0} \\
\dot{0} \\
\dot{z}\end{array}$ & 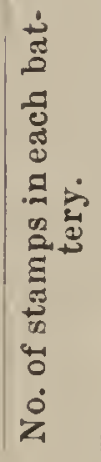 & 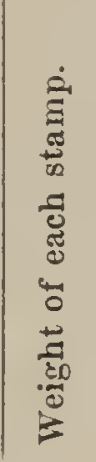 & 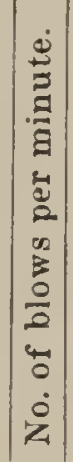 & 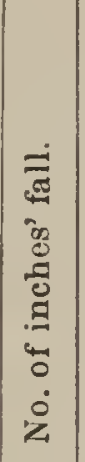 & 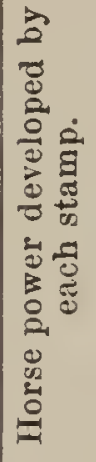 & 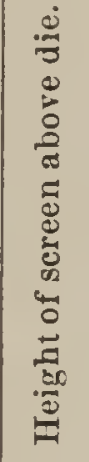 & 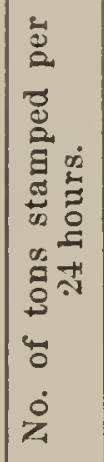 & 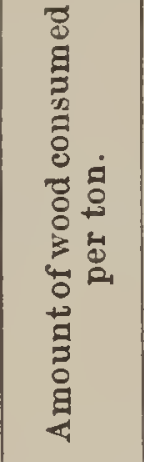 & 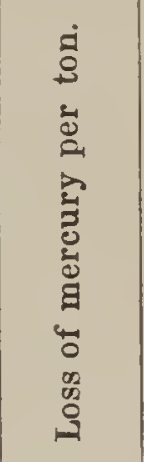 & 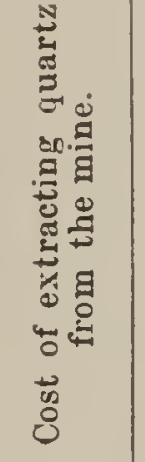 & 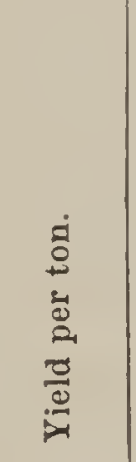 & 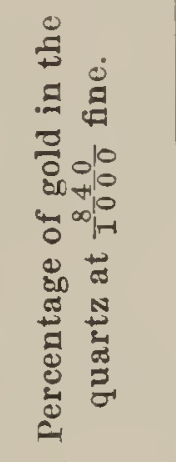 & 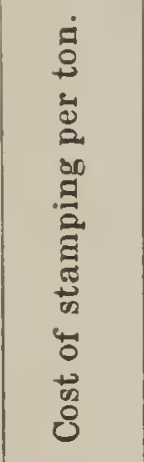 & 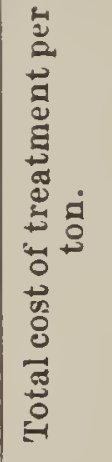 \\
\hline $\begin{array}{l}\text { Mariposa Co. } \\
\text { Benton, . . . . }\end{array}$ & water & 64 & 4 & $\begin{array}{l}\text { Ibs. } \\
550\end{array}$ & 60 & $\begin{array}{c}\text { ins. } \\
12\end{array}$ & 1.00 & ins. & $\begin{array}{c}\text { tons } \\
80\end{array}$ & cords. & $\begin{array}{l}\text { lbs. } \\
0.0027\end{array}$ & $\$ 353$ & $\$ 898$ & $\begin{array}{l}\text { per et. } \\
0.00177\end{array}$ & $\$ 0.559$ & $\$ 104$ \\
\hline Bear Valley, . & steam & 8 & 4 & 1000 & 65 & 12 & 1.97 & & 20 & 0.158 & 0.007 & $\begin{array}{ll}6 & 0 \\
0\end{array}$ & $25 \quad 24$ & 0.00498 & 1.618 & 310 \\
\hline Mt. Ophir, & steam & 24 & 4 & 500 & 56 & 10 & 0.71 & & 26 & 0.176 & 0.019 & $\begin{array}{ll}6 & 00\end{array}$ & 1694 & 0.00334 & 1.909 & 296 \\
\hline Princeton, . . . . & steam & 12 & 4 & 600 & 60 & 14 & 1.27 & 5 & 23 & 0.118 & 0.026 & $\begin{array}{ll}5 & 43\end{array}$ & 2742 & 0.00541 & 1.423 & 318 \\
\hline Tuolumne Co. & & & & & & & & & & & & & & & & \\
\hline Union, . . . . & water & 20 & 5 & 500 & 60 & 13 & 0.98 & & 20 & & 0.031 & 1300 & 5000 & 0.00987 & 3.145 & 381 \\
\hline Platt, . . . & steam & 10 & 5 & 500 & 58 & 13 & 0.95 & & $8 \frac{1}{3}$ & 0.130 & 0.030 & $\begin{array}{ll}5 & 0\end{array}$ & 2536 & 0.00501 & 2.820 & 283 \\
\hline Lomberdo's, . & water & 8 & 4 & 650 & 58 & 14 & 1.33 & & 15 & & 0.016 & 800 & 2000 & 0.00395 & 1.243 & 164 \\
\hline Eureka, . . & water & 20 & 5 & 600 & 65 & 11 & 1.08 & & 40 & & & 233 & 1200 & 0.00237 & & 103 \\
\hline Confidence, & steam & 10 & 5 & 480 & 54 & 12 & 0.78 & 9 & 10 & 0.175 & & 150 & 1000 & 0.00197 & 2.204 & 229 \\
\hline Telegraph, . & water & 10 & 5 & 475 & 62 & & & 10 & 8 & & & 300 & 3000 & 0.00593 & & 200 \\
\hline Knox \& Co., . & water & 5 & 5 & & & & & & 6 & & & $\begin{array}{ll}6 & 00\end{array}$ & 2000 & 0.00395 & & 125 \\
\hline Yaney (Dry), . & water & 6 & 3 & 800 & & & & & 4 & & & & & & & \\
\hline Calaveras Co. & & & & & & & & & & & & & & & & \\
\hline Crystal (Dry), & steam & 12 & 4 & 600 & 60 & 10 & 0.91 & 6 & 8 & 0.500 & 0.128 & 150 & 8000 & 0.01580 & 3.916 & \\
\hline Angels Q. M. Co & steam & 16 & 3 & 490 & 50 & & 0.62 & 10 & 24 & 0.130 & 0.125 & 200 & $\begin{array}{ll}500 \\
\end{array}$ & 0.00098 & 1.827 & 203 \\
\hline Blue Wing (Dry), & steam & 24 & & & & & & & 8 & & & & & & & \\
\hline
\end{tabular}

(Tilble continued. 


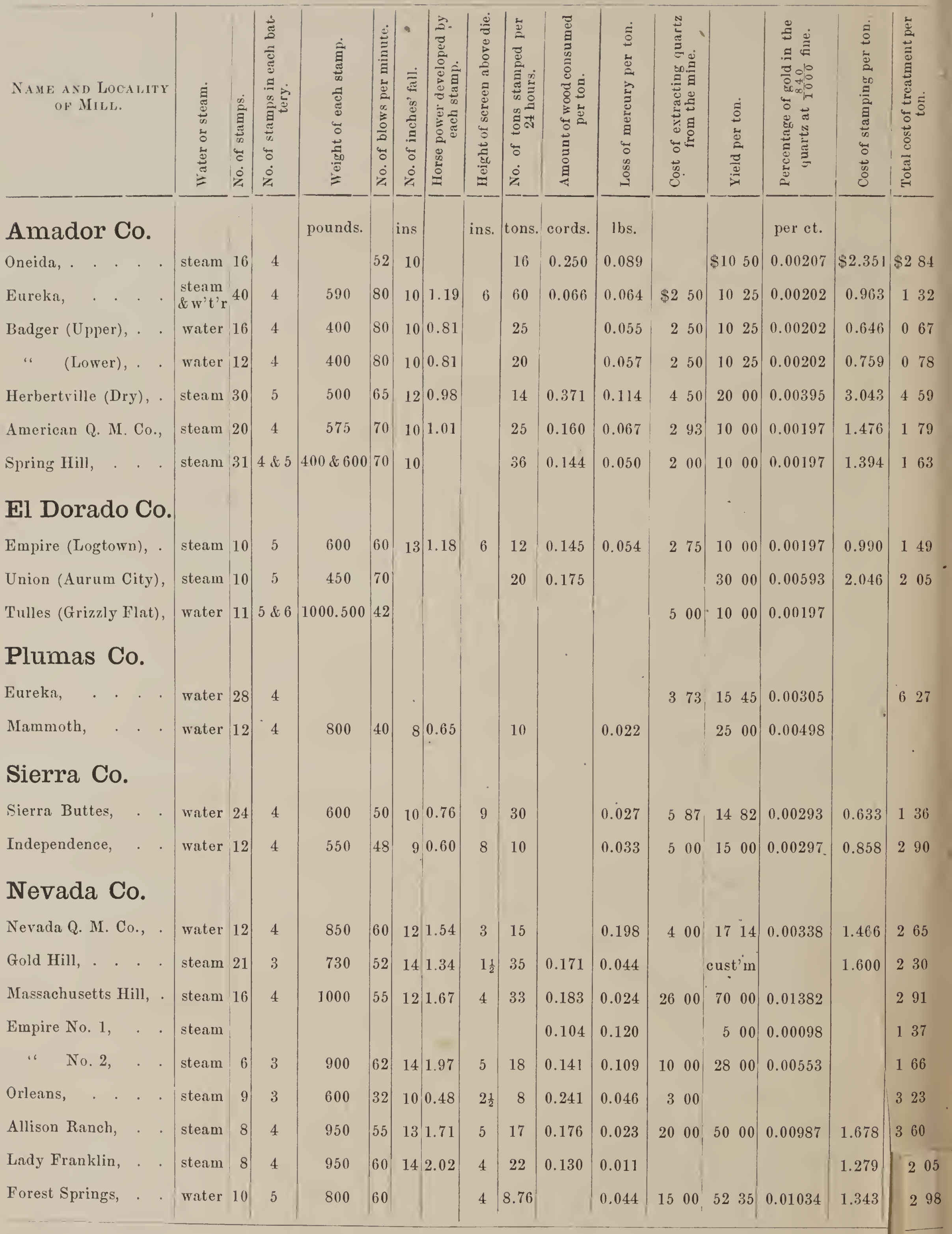




\section{N D E X.}

Note.-Look for names beginning with San (S.), or Santa (Sta.), under the letter next following these words.

Actinolite, $16,55,88$.

Age of Calaveras Big Trees, 444.

of detrital deposits under Table Mountain, 250.

Alabaster. near Potosi Mines, 471.

Alameda Cañon, 19, 33.

Albany Hill, 262.

Alcatraz Island, fossil on, 77.

Alisos Creek, 191.

Allison Ranch Mine, 291.

Almaden Coal Mine, 37, 38.

Alps, and Sierra Nevada, the vegetation of, compared, 338.

Alta copper-mining district, 362. copper mine, 362 .

Altaville, 363.

Alum Rock, 51.

Amador, 273.

Amador County, 269.

Amador Quartz Mining Co., 274.

Amargosa River, 471.

American River, cañon of, 285.

American Valley, 307.

Ammoniacal salts, in water, 100 .

Anacapa Islands, 185.

Andreas (S.), limestone near, 74.

Angel's Camp, 261.

mills near, 262.

Quartz Mining Company, 262.

Animal life on Sta. Barbara Island, 183.

Anita (Sta.) Cañon, 173.

Anna (Sta.) Range, 175.

Antimony, sulpluret of, 92, 189.

Antisell, Dr., cited, 115.

Antonio (S.), Hills of, 150.

Antonio (S.) Mountrin, 173.
Antonio (S.) River, 145.

Argentiferous lodes, near Silver Mountain, 449.

Arroyo Grande, 139.

Arroyo del Puerto, 42.

Cretaceous strata near, 43.

Arroyo Seco, 155.

Arsenical pyrites, near Kcysrille, 2:21

Artesian wells, probable success of in Salinas Valley, 151.

Ashburner, W., cited, 238, 261, 271, 275, $276,282,290,291,298,300,301,305$.

Asphaltum, 114, 116, 132, 137, 189, 174. and Petroleum compared, 118.

Auriferous slates, geological age of, 210 , $226,234,280$.

in Calaveras County, 254, 258.

in El Dorado County, 279, 283.

in High Sierra, 368, 406.

in Nevada County, $2: 8$.

in northern counties, 321.

in Plumas County, 306.

in Sierra County, 299.

in Tuolumne County, 232.

in Trinity County, 323.

on west slope of Sierra, 212.

Auriferous quartz, on Merced River, 230.

Auriferous deposits, under Table Mountain, 246.

Auriferous veins, character of, in Nerada County, 290.

on Mariposa estate, 226.

Aurum City, quartz mill at, 282.

Aurora Mine, 58.

Avalanches, 433 .

Axial line of California, 5. 
Bache, Mount, 62, 65.

Badger Mine, 272.

Bald Hills, 320.

Bald Mountain, 369.

Balley, Mount, 323-4.

Barbara (Sta.), 130.

Barbara (Sta.) Island, 182.

Barometer, on Mount Shasta, 345 .

Basin, the Great, 461.

Land Office Map of, fictitious, 461.

Bass's Ranch, 326 .

Bay of San Francisco, topographical map of region adjaccnt to, 6 .

geology of region north of, 80 .

Bear Mountains, 253.

Bear Valley, Mariposa, 224.

Beckworth Pass, 305.

Benicia, Cretaceous strata near, 100.

Benito (S.) River, terraces on, 53.

Benton Mill, 228.

Bielawski, Mount, 70 .

Big Meadows, 370.

Plumas County, 310.

Big Oak Flat, 237.

Big Trees, near Tlıomas's mill, 368.

near Crane Flat, 407.

Calaveras, 443.

age of, 444.

Bishop's Creek, 458.

Bison, fossil remains of, 252.

Bituminous slate formation, 117.

Bituminousslate in Monte Diablo Range, 56 on peninsula of San Francisco, 73, 74. at Pioncer Mine, 90.

south of Monterey, 122-155. near Monterey, 161, 165.

Black Butte, 314.

Black Mountain, 65.

Black Point, MIono Lake, 451.

Black's Ranch, 406.

Black Rocks, 457.

Bloody Cañon, 436.

Bluc Lead, 295, 302.

Blue Wing Mill, 260.

Boiling Lake, Lassen's Peak, 311.

Booker's, 53.

Borax, in Mono Lake, 452.

Borax Lake, 97.

Borax Company, 98.

Boulders, volcanic, 267.

Bower Cave, 235.
Branch's, asphaltum near, $139^{\circ}$.

Brea, 174.

Brewer, Mount, 3ิ7s.

view from, 380,383 .

ascent of, 379.

views of, 380,381 .

Brewer, W. H., cited, 11, 36, 39, 40, 43, 49, $96,110,124,140,151,153,18 \%, 191,30$. $308,313,315,317,334,350,356,362,365$, $366,383,391,397,401,404,414,431,43 \bar{i}$, $457,461$.

Bridal Veil Fall, 410.

Broderick, Mount, 418.

Bruno (S.) MLountain, 62.

Buckeye Tunnel, 247.

Buckeye Valley, 271.

Buenaventura (S.), 124.

Bull Creek, 406.

Bullet Chup, 323.

Bullion, Mount, 225.

Bushy Knob, 33.

Buttes, near San Luis Obispo, 139, 141. near Downicville, 300 .

Cajalco Mine, 181.

Cajon Pass, 463.

Calaveras Creek, 48-52.

County, 253.

placer mines of, 264 .

Calcareous tufa, near Montc Diablo, 25. in San Ramon Vallcy, 25.

at Tuscan Springs, 208.

near Aurora, 438.

at Mono Lake, 452.

Campo Seco, 257.

Camptonville, 299.

Cañada de Pala, 48, 50.

Cañon of King's River, sublime view in, 379.

Cañon of San Joaquin, 400.

Cañons of American River, 285.

Cañors of Smith's River, 361.

Cañons, very deep in northern counties, 358 .

Capel Valley, 105.

Carboniferous fossils, near Pence's Ranch, 210.

in Genesee Valley, 309.

at Bass's Ranch, 327.

Carboniferous rocks of California, their relations to those of the East, 328 . 
Carlos (S.) Peak, 9, 57.

Carlos (S.) Mine, 5s.

Carmelo Bay, attractions of, 165.

Carmelo Mission, 154.

Carmelo Point, 157.

Carpenter, P. P., 134.

Carpinteria, 125.

Carquines, Straits of, 12.

Carson Hill, 262.

Cascade Range, volcanic peaks of 344.

Casteca Lakes, 194.

Castle Peak, 43 ǰ.

Castlc Range, 330.

Catalina (Sta.) Island, 183.

Cathedral Rock, 410.

Cathedral Peak, 425.

Caves in limestonc, 235, 261.

Caves, Elk Valley, 351.

Cave in voleanic rocks, ncar Hurd's Ranch, 351.

Cave Point, 27.

Cayeguas Ranch, 123.

Central California, map of, 366 .

Chalk Bluffs, 296.

Chelone, Mount, 159.

Chico Creek, fossils at, 209.

Chili Gulch, 268.

Chisnantuck, Mount, 66.

Chromic iron, near New Idria, 59. near Crimea House, 233. in northern counties, 361.

Cincinnati Mine (quicksilver), 89.

Cinnabar, near Monte Diablo, 24.

at New Idria, 58.

at Picacho, 60.

on peninsula of San Francisco, 72, 78. south of Monterey, 114.

near Coulterville, 230.

near Murphy's, 260.

deposits of, in Pope Valley, 91.

with gold, in Bear Valley, 92.

Clara (Sta.), of Santa Barbara County, 1.24.

Clark Mine, 28.

Clatyton, J. E., cited, 429, 461.

Clear Lake, 96,

Clemente (S.) Island, 184.

Climate of California, changes in, 423.

Coahuila Valley, 468.

Coal, near Martiñez, 12. near Monte Diablo, 27. of Bellingham Bay, 30 .
Coal of Nanaimo, 30

in Lone Tree Cañon, 40.

near Corte de Madera Ranch, 71.

north of Benicia, 106.

near Petaluma, 107.

in San Rafael Mountains, 136.

on Cow Creek, 204.

near Pence's Ranch, 211.

near Ione Valley, 270.

near Buckeye Valley, 271.

in Sicrra County, 303.

on Cottonwood Creek, $32($ ).

Coal mines, near Monte Diablo, 27-38.

produce of, 29.

quality of, 29.

analyses of, 30 .

near Santa Barbara, 129.

Coast Ranges, definition of, 1 .

separation of, from Sierra Nevada, 2,

$167,317$.

difficulty in studying geology of, 5 .

south of Montercy Bay, 108.

map of, 109.

explorations of, 109.

vegetation of 113.

as seen from the San Joaquin Plain, 367.

Coast Range coal mine, 37 .

Cobb, Mount, 88.

Columbia, limestone quarries near, 237.

Cone Mountain, 345.

Cone, volcanic, near Battle Creek, 205.

near Mount Sliasta, 345.

near Silver Mountain, 447.

near MLono Lake, 454.

Conical form of Mount Shasta, 313 .

Conifer , forests of, near Mount Shasta, 335.

Contra Costa Hills, 9, 11.

Cooper, Dr. J. G., cited, 182, 183, 184, 185 , $461,463,466$

Copper mines, near Campo Seco, 257.

near Low Divide, Del Norte County, 361.

of Del Norte County, 363.

Copper mine, Alta, 362.

Diamond, 362 .

Copper, native, at mines of Del Norte County, 362.

Copperopolis, 2.54 .

Copper ore, near Monte Diablo, 24.

in Penitencia Cañon, 51.

in San Gabriel Cañon, 173. 
Copper ore, in Soledad Pass, 196.

at Soulsby Vein, 238.

in Calaveras County, 25t, 26t, $26 t$.

in Amador County, 278.

in Nevada County, 294.

in Gencsee Valley, 309.

ncar TValdo, 360.

shipments from Alta Mine, 363.

shipments of, from Calaveras County, $256-7$.

shipments of, from Del Norte County, 363.

Copper, traces of, near San Antonio, 19, 158.

near Murphy's, 260.

Corral Hollow, 34.

Corte de Madera Raneh, geology near, 71.

Coso Mountains, 474.

Cotopaxi, slope of, 314.

Cotter, asecnt of Mount Goddard, 399.

Cottonwood Crcek, 218, 353.

Coyotc Creck, course of, 48 .

Crane Flat, 407.

Crescent City, road to, from Sailor Diggings, 360.

Creseent City, 363.

Cretaceous fossils, near Martiñez, 12.

on Bagley Creek, 23.

in Curry's Cañada, 26.

in Montc Diablo group, 35.

near San Luis Gonzaga Ranch, 46.

near Benicia, 101.

near Fort Téjon, 191.

near Texas Flat, 203.

on Cow Creek, 204.

at Tuscan Springs, 207.

at Chico Creek, 209.

near Pence's Ranch, 210.

on Cottonwood Creek, 320.

at Horsetown, 321.

ncar Yreka, 352.

Cretaceous rocks, near Martiñez, 11, 12.

at Walnut Creek House, 15.

near Redwood Peak, 18.

at Suñol Valley, 18.

metamorphic, near Monte Diablo, 22.

unaltered, near Monte Diablo, 25.

near Corral Hollow, 35.

in Lone Tree Cañon, 40.

in Hospital Cañon, 41.

in Arroyo del Puerto, 42.
Cretaceous rocks, in Orestimba Cañon, 44. near San Luis Gonzaga Ranch, 45.

in Panoche Valley, 56.

near New Almaden, 68.

on peninsula of San Francisco, 62, - $76-7$.

in Marin County, 83, 94, 97.

ncar Benicia, 100, 101.

near Rockville, 103.

in Pelevo Hills, 104.

section of, on Puta Creek, 105.

lignite in, 106.

near Petaluma, 107.

in San Emidio Cañon, 187-9.

ncar Cañada de las Uvas, 190.

in foot-hills of Sicrra, 201.

in Tcxas Flat, 202.

on Cow Creek, 204.

at Tuscan Springs, 206.

at Chico Creck, 209.

near Pence's Ranch, 210.

in northern counties, 318-24, 352-4.

Cruikshank \& Adams' Minc, 28.

Cruikshank Mine, 362.

Cruz, Santa, 165.

Cruz (Sta.) Island, 185.

Cruz (Sta.) Range, 62.

Crystal Mill, 261.

Crystal Springs, rocks ncar, 74, 75.

Cumberland Minc, 29.

Curry's Cañada, fossils in, 26.

Cuyamas Range, 112, 135.

Cypress Point, 161.

Damask Mountains, 471.

Dana, Mount, 435.

ascent of, recommended, 404.

Dana, J. D., cited, 344.

Dead Broke, quicksilver minc, 89.

Dcath Valley, 472.

Deep Spring Valley, 460.

Deer Creek Cañon, 208.

Denver Claim, quicksilver, 91.

Dcpression, below sea-level, of Death $\mathrm{Val}-$ ley, 473.

Destruction River, 326.

Detrital deposits, Tuolumne County, 241

Devil's Acres, 337.

Diamond Copper Mine, 362.

Diamonds, found near Volcano, 276. 
Divide, between forks of King's River, 370. Fall River, 350.

Denudation, example of, at Abby's Ferry, Fan-structure in auriferous slates, 286. 265.

in northern countics, 358 .

of river cañons, 244.

Dog Creek, 329.

Dome Mountain, 371.

Domes of granite, 401.

Dome-strueture of granite, 375.

Douglas City, 323.

Douglas Flat, 259.

Downey, Mount, 177.

Downieville Buttes, 300.

Dust columns, raised by whirlwinds, 366 .

Dykcs, false, in Lone Trec Cañon, 40.

in Pleasant Valley, 106.

in granite, Mariposa, 226.

in limestonc, near Sonora, 236.

at Voleano, 275.

at Bass's Raneh, 326.

near Yreka, 352.

in Illinois Vallcy, 360.

in Rockland District, 36?.

Dyke Ridge, 370.

Fernando (S.) Valley, 122.

Fish, fossil, 66.

Fish Springs, 458.

Folded strat on Arroyo Seeo, 155.

Folsom, Cretaeeous rocks near, 202.

Forests, on road to Yosemite, 407.

of High Sierra, 371.

near Mount Shasta, 334.

of White and Inyo Mountains, 457.

of Yosemite Valley, 420.

silicified, 296.

Fort Cady, 467.

Fort Crook, 350.

Fort Hill, 266.

Fort Téjon, 193.

Four Creeks, 367.

Foxin's Raneh, 137.

Franeiseo (S.) Geology of vicinity of, 76 .

Peninsula of, 61.

Francisquito (S.) Pass, 195.

Frémont's Pass, 216.

Gabb, Mount, 397.

Eagle Point, 21.

Earthquakes, cffects of, 15, 137.

Ebbett's Pass, 446.

El Capitan, Tosemite, 410.

El Dorado, Mount, 187.

El Dorado County, 279.

auriferous detritus of, 283.

Elephant, fossil, 242, 252.

Elevation, effects of, on the system, 341 .

Elkhorn Peak, 103.

Elk Valley, 350.

Emidio (S.) Cañon, 187.

Encino Raneh, hot spring near, 119.

Engelmann, Dr., cited, 348.

Enriquita (quieksilver) Mine, 68.

Enterprise Mine, 360.

Eocene strata, 31, 35, 57.

Eruptive rocks, near San Rafuel, 82.

Estero San Antonio, 83.

Estrella division of Coast Ranges, 9.

Eureka Consol. Mg. Co. (copper), 295.

Eureka (gold) Mine, Tuolumne County, 238.

Amador County, 272.

Excelsior (quicksilver) Mine, 92.

Excelsiur (gold) Mine, 240.

Gabb, W. M., cited, $11,14,31,35,39,57$, $71,79,121,124,134,135,171,186,191$, 201, 203, 210, 279, 309, 328, 459, 461.

Gabriel (S.) Cañon, 172.

Gabriel (S.) Range, 171.

Galena, in Tuolumue County, 237-8.

near Volcano, 276.

in El Dorado County, 282.

at Silver Mountain, 449.

Galena, argentiferous, near Monterey, 114.

at Arroyo Seco, 158.

near Nevada, $; 293$.

in Potosi Mountains, 471.

on Sta. Catalina Island, 183.

Galleta Valley, 464.

Gap in the Sicrra, between Carson and Walker's Passes, 402.

Gardner, J. T., cited, 365, 366, 381, 383, 396, $405,420,421,422$.

Gardner, Mount, 392.

Gavilan Peak, 160.

Gavilan Range, 159.

Genesee Valley, 308.

Geysers, 93.

origin of, 95.

GEOL. VOL. I. -62 
Gifford's Ranch, 308.

Gilson Mill, 238.

Glaciers, ancient, at head of Kern and

King's Rivers, 372, 375, 377, 378.

at head of San Joaquin, 396, 398, 401.

near Lake Tenaya, 425.

near Lassen's Peak, 316.

neur Mount Dana, 435, 436.

near Mount Lyell, 432.

about Mount Shasta, 351.

on Sonora Pass, 440, 442.

at Silver Valley, 445.

near Silver Mountain, 447, 448.

at Soda Springs, 429.

in Yosemite Valley, 422

Goddard, Mount, 382.

ascent of, 399 .

Gold, in Monte Diablo Group, 24.

near Sta. Cruz, 64, 72.

at Tamalpais, 81.

near S. Rafael, 83.

in Sta. Lucia Range, 158.

in San Gabriel Cañon, 173.

in San Francisquito Cañon, 196.

in Chiquito S. Joaquin, 403.

Goniatite, in auriferous slates, 234.

in Inyo Mountains, 459.

at Spanish Flat, 279.

Gorgoño (S.) Pass, 468.

Granite, near Big Meadows, 370.

boulders of, on lava ridges, 442 .

at Carmelo Bay, 155, 158.

of Castle Rock range, 331 .

dome-structure of, $371,375$.

on High Sierra, 394.

on Kaweah River, 389.

on Mariposa Estate, 225, 227.

junction with sandstone near Pescadero, 162.

at Point Pinos, 161.

relations of to lava, on Silver Mountain road, 447.

in Sierra Sta. Monica, 168.

in San Gabriel Range, 172.

in San Emidio Cañon, 187, 189.

near Téjon, 193, 195.

on western slope, 215, 232, 269, 281, 288, 323, 329, 330 .

in Siskiyou Range, 357, 358.

near Temescal, 178, 179.

near Tomales Point, 84, 85.
Granite, on Sonora Pass, 439.

at summits of volcanic cones, 455 .

on Yosemite trail, 406.

Grass Valley, 289.

Gray Mountains, 326.

Gray's Peak, in Rocky Mts., 348.

Greenliorn Creek, 356.

Greenhorn MLuntain, 221.

Green Rock Ledge, 260.

Griswold's Ranch, 56.

Grizzly Flat, mills near, 282.

Guadelupe Largo, 138.

Guadelupe (quicksilver) Mine, 69.

Guadelupe Ranch, 152.

Half Dome, Yosemite, 415.

Hambre, Cañada del, 14.

Hamilton (quicksilver) M g. Co., 91.

Hamilton, Mount, 43. ascent of, 50 .

Hamilton, Mount, Group, 9, 39.

Hancock's Cañon, 168.

Happy Camp, 358.

Helena (Sta.) Mountain, 85-7.

Hell Hollow, 226.

Henry, Mount, 86.

Herbertville Quartz Mg. Co., 273.

Hermit Valley, 445.

High Sierra, remarks on, 364.

Hill's Ranch, 134.

Hoar, Mount, 125.

Hoffmann, C. F., cited, 6, 11, 39, 87, 109, $365,366,372,376,381,383,405,431$.

Hoffmann, Mount, 424.

Hog-wallows, 367.

Hollenbeck's Rock, 47.

Honey Lake Valley, 305.

Hood, Mount, height of, compared with thut of Mount Shasta, 348.

Hope Mine, 263.

Hospital Cañon, 41.

Horn, Dr., cited, 191, 280, 459. fossils discovered by, 459 .

Horse, fossil, 102, 242, 251, 252, 253.

Hot Springs, near Sta. Barbara, 128. in Napa Valley, 87. east of Clear Lake, 95, 97, 99. at Encino Ranch, 119. in Sta. Iñez Range, 128. near Lassen's Peak, :311, 312. on Walker's River, 438. 
Hurd's Ranch, Cave near, :351.

Hydraulic washings, in Tahichipi Valley, 217.

in Placer County, 285.

in Nevada County, 295.

near Nevada City, 296.

in Sierra County, 299.

near North S. Juan, 297.

on Trinity River, 323.

Ice, former thickness of, in the Sierra, during the ice period, 442.

Illilouette, 413.

Inclined strata, near Sta. Monica Cañon, 170 .

Independence Mine, 301.

Indians, favorite resort of, 397. their last retreat, 456.

Indian Valley, 310.

Iñez (Sta.) Range, 110, 127.

Inyo Mountains, 456, 459. mineral indications of, 460 .

Ione City, copper mines near, 278.

Ione Valley, 269. coal near, 270.

Iron ore, near San Antonio, 19. south of Mouterey, 114.

in and near San Emidio Cañon, 189, 194.

in Soulsby Vein, 238.

near Ione, 270.

at Grizzly Flat, 282.

near Auburn, 284.

near Murphy's, 259.

near Shasta City, 322.

Islands of Southern California, 182. volcanic, in Mono Lake, 453.

Italian's Vein, 276.

Jacinto (S.) Mountain, 468.

Jackson Butte, 277.

Jackson, quartz mines near, 271.

Jasper, near Corral Hollow, 35.

near Monte Diablo, 21, 23.

in Mount Hamilton Group, 40, 41, 46. near New Almaden, 66.

in Marin County, 82 .

Joaquin (S.), Cañon of, 400.

Joaquin (S.), plains of, 366 .

Jolon, 148.

Josephine Mine, 227.
Juniper Ridge, 224 .

Jurassic fossils, in Genesee Valley, 308. on Mariposa Estate, 226. near Spanisli Flat, 279.

description of, by F. B. Meek, Appendix $B$.

Kaweall River, 388.

Kern River, head of, 365.

Kettle, the, 374.

Keystone Mine, 257.

Keysville, 219, 221.

Kincaid Flat, 236.

King, C. R., cited, 224, 225, 226, 305, 308, $313,314,317,350,356,365,366,382,384$, $387,388,390,391,405,409,410,411,414$, $420,421,422,425,460$.

King, Mount, 392.

King's River, 370.

Cañon of South Fork of, 391.

region at head of, 365 .

Klamath River, 357.

Knight's Valley, 88.

Knox \& Co.'s Mills, 240.

Koo-chah-bee, 454.

Lakes, produced by moraines, 437. at eastern base of Sierra, 4.

Lake (quicksilver) Mine, 92.

Lambert's, rocks near, 74.

Lancha Plana (copper) Mine, 258.

Lassen's Peak, 311. ascent of, 313 .

Last Chance (copper) Mine, 295.

Leandro (S.), 18.

Leaves, fossil, in Monte Diablo Group, 31, 38,56 .

in peninsula of San Francisco, 71 .

near Oroville, 211.

under Table Mountain, 250.

near Ione, 270.

at Yankee Jim's, 287.

at Chalk Bluffs, 296.

at Silver Mountain, 449.

Leidy, Dr. J., cited, 252.

Leviathan Vein, 276.

Lexington, rocks near, 69

Lick Springs, 206.

Liebre Ranch-house, 195.

Limestone, at Abby's Ferry, 265.

at Bass's Ranch, 326 
Limestone, at Bower Cave, 406.

in Calaveras County, 259.

near Cave City, 260.

in El Dorado County, 281.

near Fort Téjon, 193.

in Genesee Valley, 328.

in Great Basin, 471.

in granite, on Kaweah River, 388.

at Kincaid Flat, 236.

at Murphy's, 259.

in Nevada County, 288.

at Pence's Ranch, 209.

placer mines on, 241.

near Sta. Cruz, 166.

near Sonora, 236.

in Tuolumne County, 234.

near Volcano, 275.

Little Geysers, 95.

Livermore Pass, 32.

Logtown, quartz veins near, 282.

Lomberdo's Mill, 238.

Lone Tree Cañon, 40.

Los Angeles, 174.

Los Gatos Creek, 70.

Los Ojitos Ranch, 149.

Louisiana Claim, 238.

Low Divide, 361.

Lucia, Sierra Sta., 111, 143, 157. section across, 144 .

Luis Gonzaga (S.) Ranch, Cretaceous fossils at, 45 .

Luis Obispo (S.), 139.

Luis Obispo (S.) Valley, 139.

Lyell, Mount, 431.

Macedonian $\nabla$ alley, 465.

MacLane's Pass, 434.

Magnesia, carbonate of, 49 .

Magnesia minerals, near New Idria, 59.

Maine Boy's Tunnel, 247.

Mammoth Ledge, near Keysville, 221.

Mammoth Tunnel, 266.

Mammoth Mountain, 401.

Mammalian remains, near Benicia, 102. in Tuolumne County, 232, 242, 250, 251. near Volcano, 276.

Man contemporaneous with Mastodon, 252.

Manganese, oxide of, near San Francisco, 78.

Maps in preparation by Survey, 6, 19, 78, $109,155,164,366,443$
Maragua Valley, 15.

Marble Valley, 281.

Margarita (Sta.) Valley, $14 t$.

Margarita (Sta.) River, 176.

Maria (Sta.) River, 137.

Marin County, geology of, 81.

Mariposa Estate, 223.

Mariposa County, 223.

Mariposa Peak, 47.

Mariposa Vein, 229.

Marl Springs, 466.

Martiñez, geology of vicinity of, 11 .

Massachusetts Hill, 292.

Master's Hill, 50.

Mastodon, remains of, 102, 135, 242, 252, 276.

Mateo (S.), Section from, to Spanishtown, 74.

Mathewson, E., cited, 12.

McAlpine's Lode, 231.

McCartysville, rocks near, 69.

McCloud River, 326.

Meadows on Walker's River, 438.

Meek, F. B., cited, 210, 226, 308, 327. description of Jurassic fossils, Appen$\operatorname{dix} B$

Merced and Tuolumne Rivers, head of, 403 .

Metamorphic action, instances of, $16,22,51$, $78,94,104,138,153,162,163,355,447$.

Metamorphic rocks, passim.

Meyer's, 363.

Middletown, 322.

Middle Yuba, Cañon of, 307.

Miguel (S.) Islands, 185.

Mill, Allison Ranch, 292.

Amador Q. Mg. Co.'s, 274.

Angel's Q. Mg. Co.'s, 262.

Badger, 273.

Benton, 228.

Blue Wing, 260.

Confidence, 239.

Cornish, 262.

Crystal, 261.

Eureka, 273.

Foster \& Co.'s, 262.

Independence, 301.

Knox \& Co.'s, 240.

Lomberdo's, 238.

Mountain Quartz, 276.

Oneida, 271.

Pirate, 241. 
Mill, Platt, 238

Preston's, 240.

Snyder's, 240.

Sower's, 239.

Sierra Buttes, 301.

Spring Hill, 274.

Street \& Co.'s, 239.

Telegraph, 239.

Union, 282.

Yaney, 240.

Mill Vein, 264.

Milpitas Ranch, rocks near, 52.

Mine, Peacock (coal), 28.

Clark (coal), 28, 29.

Cumberland (coal), 29.

Black Diamond (coal), 29.

Cruikshank \& Adams (coal), 29.

Pacific (coal), 36.

Almaden (coal), 37.

$\mathrm{New}$ Idria (quicksilver), 58.

San Carlos (quicksilver), 58.

Aurora (quicksilver), 58.

Guadelupe (quicksilver), 66.

New Almaden (quicksilver), 68.

Enriquita (quicksilver), 69.

Pioneer (quicksilver), 90.

Lake (quicksilver), 92.

Excelsior (quicksilver), 92.

Union (copper), 255-6.

Keystone (copper), 256-7.

Lancha Plana (copper), 258 .

Copper Hill (copper), 258.

Newton's (copper), 278.

Cosmopolitan (copper), 309.

Diamond (copper), 362.

Cruikshank (copper), 362.

Alta (copper), 362.

Enterprise (gold), 360.

Pine Tree (gold), 227.

Josephine (gold), 227.

Princeton (gold), 228.

Soulsby (gold), 238.

Platt (gold), 238.

Eureka (gold), 239.

Excelsior (gold), 240.

Blue Wing (gold), 260.

Stanislaus (gold), 253.

Hope (gold), 263.

Enterprise (gold), 263.

Oneida (gold), 271.

Eureka (gold), 272.
Mine, Badger (gold), 272.

Herbertville (gold), 273.

Allison Ranch (gold), 291.

Massachusetts Hill (gold), 292

Pacific Quartz (gold), 292.

North Star (gold), 292.

Nevada Quartz (gold), 293.

Sneath, Clay \& Co.'s (gold), 293.

Sierra Buttes (gold), 300.

Independence (gold), 301.

Potosi (silver), 471.

Mines, in Coast Ranges, probable value of, 114.

near West Point, 264.

near Amador, 274.

near Volcano, 275.

in El Dorado County, 282.

near Zine House, 294.

Miocene fossils, near New Idria, 57.

near Lambert's, 72 .

at Pigeon Point, 73

near Spanish Town, 75 .

on Najohui Ranch, 135.

on Nascimiento River, 146.

near Monterey, 154.

in Sta. Monica Range, 171.

in Sta. Anna Range, 176.

in foot-hills of Sierra, 201 .

Miocene rocks, north of Munte Diablo, 31 .

in Sta. Cruz Range, 63.

on the peninsula of S. Francisco, 71-75.

in Marin County, 84.

in Sta. Susanna Range, 121.

in San Fernando Valley, 122.

in Sta. Iñez Chain, 127.

in Palo Scrito Hills, 158.

in Gavilan Range, 160.

near Monterey Bay, 162.

near Los Angeles, 173.

near S. Emidio Cañon, 188.

Missions in Southern California, 112.

Mission Soledad, 151.

Mission Carmelo, 154.

Mitchell's Cañon, 24.

Mohave Trail, Dr. Cooper's notes on, 463.

Mokelumne Hill, 266.

Mokelumne River, head of, 443.

Monica (Sta.), 119.

Monica (Sta.) Cañon, 169.

Monica (Sta.) Range, 110, 168.

Mono Lake, 450. 
Mono Lake, former extension of, 452.

Mono Pass, 433.

Monte Diablo, geology of, 21.

map of, 19.

riew from, 20.

coal near, 27.

Monte Diablo Range, description of, 8. height of passes and peaks, 10 . order of explorations in, 10. south of Pacheco's Pass, 52.

Monterey, Bay of, 160.

Monterey, map of vicinity of, 164.

Moore, G. E., analysis of Borax Lake water, 98, 99.

Moraines, on King's River, 378-9.

in: Yosemite Valley, 422.

near Soda Springs, 429.

around Mount Dana, 437.

Morgan Claim, 263.

Moro Rock, 141.

Mountain Spring Range, 471.

Mount Ophir, 225.

Mount Ophir Vein, 229.

Mountain Quartz Vein, 276.

Murphy's, 259.

Myers \& Easton Vein, 264.

Najohui Ranch, 135.

Napa Springs, 87.

Napa Valley, 85.

Nascimiento River, 145.

Natividad Ranch, 160.

Nelson's Point, 307.

Nevada Quartz Mg. Co., 293.

Nevada County, 287.

Nevada Fall, 418.

Nevadite, 315, 449.

New Almaden Mine, 68.

Newberry, Dr. J. S., cited, 250.

New Idria Mine, 58.

Newton's Copper Mine, 278.

New Year's Point, 73.

Nicolas (S.) Island, 184.

Nipoma Ranch, 138.

North Dome, Yosemite, 417.

North San Juan, 297.

North Star Mining Co., 292.

Oakland, geology near, 16. Obelisk Group, 425.
Oil from asphaltum, 175.

Oil wells near San Pablo, 13.

Ojo de Agua de la Coche, 49.

Ojitos (Los) Ranch, 149.

Oneida Mine, 271.

Orestimba Cañon, 44.

Oso, Mount, 41.

Osos, Cañada de los, 141.

Owen, Dr. J. R. N., cited, 469, 472, 473.

Owen's River, 457.

Owen's Valley, 455.

mountains east side of, 456 .

route of our party up, 457.

Oysters, fossil, gigantic, 38, 72, 140.

Oyster beds near Benicia, 102.

Pablo (S.) Creek, 12.

Pablo (S.), metamorphic rocks near, 16.

Pacheco's Pass, 45.

Pacheco's Peak, 47.

Pacific Quartz Mg. Co., 292.

Pacific Mine, coal (section), 36.

Pah Ute Spring, 464.

Pah Ute Range, 463.

Pah Ute Monument, 459.

Pajaro River, 159.

Palisades, the, 393.

Palo Scrito Hills, 152.

Panoche division of Coast Ranges, 9 .

Palloche Plain, 55.

Panoche Grande, 367.

Panamint Mountains, 472.

Parry, C. C., cited, 348.

Paso el Roble, 145.

Pass, highest of the Sierra, 396.

Peacock coal mine, 28.

Peaks in Rocky Mountains, probable eleva. tion of, 349.

Pelevo Hills, 104.

Peñon Blanco, 231.

Pence's Ranch, 209.

Penitencia Creek and Cañon, 51.

Penitencia Creek, 48.

Pescadero Ranch, 163.

Petaluma, 82. geology near, 107.

Petroleum excitement, 115.

Petroleum, flowing wells of, probability of finding them, 116.

mode of occurrence of, 117 . 
Petroleum swindling companies, 115.

Picacho, cinnabar near, 60.

Pigreon Poirst, rocks at, 73.

Photographs of Yosemite, 408.

Pilgrim Camp, 351.

Pilot Peak, 306.

Pine Tree Mine, 227.

Pine Mountain, 88.

Pinos, Mount, 187, 194.

Pioneer quicksilver claim, 90.

Pike's Peak, 348.

Pitt, Mount, 355.

Pittsburg quicksilver claim, 90.

Placer County, 283.

Placers, in Klamath Kiver, 357.

Placer mines, in Tuolumne County, $2+1$.

on western slope of Sierra, in northern counties, 321-3, 326, 330, 356, 359, 360 .

oll Bull Creek, 406.

near Sonora, 443.

in San Bernardino Range, 469.

Plants, fossil, on Cottonwood Creek, 353.

Platt Mine, 238.

Pleasant Valley, 106.

Pliocene, fossils of, near Kirker's Pass, 32. near Livermore's Pass, 38. near San Francisco, 79. near Cayeguas Ranch, 124. at Sta. Barbara, 134.

at Atascadero Ranch, 144.

under Table Mountain, 250, 251.

Pliocene strata, near San Francisco, 79.

in Pleasant Valley, 106.

in Sta Susanna Range, 121, 122.

at Pence's Ranch, 211.

near Ione, 270.

Plumas County, 304.

Pluto's Cave, 351.

Point San Pedro, rocks near, 76.

Pope Valley, quicksilver mines in, 91 .

Porcupine Flat, 424.

Porphyry, near Temescal, 179.

Portugruese Flat, 330.

Post-Pliocene deposits, near San Pablo, 13. near Kirker's Puss, 32.

at Booker's, 54.

near Mereed Lake, 79. .

near Benicia, 102.

about Sta. Barbara, 132, 137.

on Sta. Barbara Island, 183.
Post-Pliocene fauna, 252.

Post-Tertiary detritus, elevated at Booker's, 53.

Post-Tertiary near Benicia, 102.

in San Emidio Cañon, 187.

Pratt's Hill, 269.

Princeton vein, 228.

Process for saving gold, 294

Providence Mountains, 464.

Punta de los Reyes, 85.

Puta Creek, 105.

Quartz Mining, in Mariposa County, 227.

in Tuolumne County, 237.

in Calaveras County, 261.

in Amador County, 271.

in El Dorado County, 282.

in Placer County, 285.

in Nevada County, 289.

in Sierra County, 300.

in Siskiyou Range, 359.

in San Bernardino Range, 469.

Quartz Vein, the Great, 230, 239, 261, 262.

Quicksilver, geological position of its ores, 68.

production of, at New Almaden, 68.

exports of, from California, 69.

mines of, in Napa County, 89.

native, at Pioneer Mines, 89, 90.

prospecting for, at Corte de Madera Ranch, 71.

Quicksilver rock, 16, 19, 83, 89.

Rafael (S.), geology near, 82.

Rafael (S.) Range, 112, 135.

Rag Cañon, 105.

Railroad Flat, 266.

Ramon (S.) River, 14.

Valley, 15.

Rathgeber Vein, 264.

Red Bluff, 319.

Red Bluffs, Mount Shasta, 339.

Red Dog, hydraulic washings near, 296.

Red snow, on Mount Shasta, 338.

Redwood groves, near Sta. Cruz, 64.

Redwood Peak, 18.

Reed Lode, 255.

Reeve's Ranch, 35T.

liémond, A., cited, 79, 101, 106, 234, 269, $275,317,346$. 
Resting Spring Mountain, 472.

Rhinoceros, remains of, $251,268$.

Rhyolitc, 315.

Kincon, Cañada del, 166.

Ritchie's Station, 445.

Robinson's Ranch, 156.

Rockland cuprifcrous district, 362 .

Rock Springs, Mohave trail, 464.

Rockville, 103.

Rocky Mound, 16.

Rocky Mountains, height of peaks in, 348

Rodeo Valley, 12.

Rosa (Sta.) Island, 185.

Round Valley, Owen's Valley, 458.

Ruby Claim, 362.

Ruined City, near Sta. Cruz, 63.

Sacramento Valley, 319.

Salinas Valley, 109, 145, 150.

Sailor Diggings, 359 .

Salmon Mountains, 356.

Salt, near Cañada de las Uvas, 186.

west of Owen's Valley, 460.

Sand, for glass, 161.

Sandstone, for architectural purposes, 202.

Sciad Valley, 357.

Scorpion Hills, 120.

Scott's Bar, 356.

Scott Valley, 356.

Sea of Ice, in San Juaquin Valley, 401.

Scarsville, geology near, 71 .

Sections, geological, described and figured,

$14,36,3 \overline{7}, 106,121,123,128,129,130$,

$132,134,135,138,141,144,147,149,15 \%$,

162, 170, 189, 203, 207, 211, 247, 248, 354 .

Sections across Yosemite Valley, 409, 416.

Sentinel Dome, 412.

Sentinel Rock, 412.

Serpentine, in Contra Costa Hills, 19.

in Monte Diablo Group, 22, 24, 59

in Mount Harnilton Group, 49.

near San Francisco, 67, 74, 78.

north of San Francisco Bay, 82, 83, 86, $88,90,92,93,105$.

south of Monterey Bay, 136, 142, 143, $149,160$.

in Mariposa County, 225.

in Tuolumne County, 233.

in Calaveras County, 256.

in Placer County, 284, 285.
Serpentine, in Plumas County, 306.

on western slope, northern counties, $359,360,361,363$.

Shasta City: 322.

Shasta, Mount, view of from Soda Springs, 332.

ascent of, 333 .

forests near, 334

view from, 341.

regular conical form of, 343 .

determination of height of, 345 .

view of: from Elk Vallcy, 350 .

view of, from N. E. side, 351.

Shasta Valley, 352.

Sheep on Sta. Barbara Island, 185.

Sheep Rock, 390.

Sheldon, H. H., cited, 257, 293.

Sielra County, 298.

Sierra Buttes Quartz Mining Co , 300 .

Sicrra Nevada, rcmarks on, 2, 4, 317, 364. appearance of, from Owen's Valley, 456.

Sierra, the High, 364. explorations in, 365 .

Silliman, Mount, 376.

Silver mines, at Arroyo Seco, 158.

in Coast Ranges, 114.

in San Gabriel Cañon, 173.

near San Emidio Cañon, 194.

about Genesee Valley, 309.

at Silver Mountain, 449.

Silvcr Mountain Pcak, 448.

Siskiyou Mountains, 355, 361.

Sisson, J. H., guidc, 332.

Size of Big Trees, 444.

Slates, auriferous, on Mariposa Estate, 225.

on Cottonwood Creek, 353.

west of Yrcka, 356.

on Klamath River, 359.

near Waldo, 359.

in Del Nortc County, 361.

near Crescent City, 363.

nearly unaltered, Upper Sacramento

Valley, 329.

Slate Creek, 330.

Slates at summit of the Sierra, 396.

Slates, metamorphic; sce Geology of Sierra

Nevada, passim.

Slate Peaks, 397.

Slate Rangc, 221.

Slopes of mountains, exaggerated by travellers and artists, 344 . 
Sneath, Clay d ('o.'s Mill, 298.

Soda Lake, 466.

Soda Springs, near MLount Shasta, 331.

Soda Springs, on Mono trail, 427-8.

Soledad, mission of, 151.

Soledad Pass, 195.

Solfatara, on Mount Shasta, 340 .

Sonora Pass, 437.

South Dome, Yosemite, 419.

Sower's' Mill, 239.

Soulsby Vein, 238. .

Soulsbyville, 238. 253.

Spanishtown, 75.

Spring Hill Mills, 274.

Springs, Tuscan, 208. mineral, at Alum Rock, 51. on Upper Sacramento River, 331. in volcanic regions, 350.

Stanislans River, 243. head of, 440.

Steamboat Spring, 311.

Stone's Ferry, 329.

Strawberry Flat, 332.

Sugar Loaf, 296.

Sugar Loaf Rock, 377.

Sugar Pine Mining District, 240, 442.

Sugar Pine, size of, 336.

Suisun Marble, 104.

Sulphur, near Borax Lake, 99. on San Buenaventura River, 125. at Boiling Lake, 312.

Sulphur Banks, 94, 99.

Sulphur Peak, 93.

Summit of Mount Shasta, character of, 337. Suñol Valley, 18.

Susannu (Sta.) Range, 110, 120.

Sweetbrier Ranch, 330.

Tuble Mouritain, Marin County, 81. Tuolumne County, 243.

Tahichipi Valley, 216.

'T'amalpais, 81.

Tapir, fossil, 252.

Tar Springs, near Los Angeles, 174.

Téjon Pass, 192.

Reservation, 191.

Telegraph Mill, 239.

Tellurides of Silver, 263.

Temescrl Range, 178.

Tenaya, Lake, 425.
Terraces in Monte Diablo Range, 53, 54, 56. at Pigeon Point, 73.

south of Monterey Bay, 147, 150, 151, 165.

in Santa Monica Cañon, 169.

on San Nicolas and Sian c'lemente Islands, 184.

on Walker's River, 438. around Mono Lake, 451.

Tertiary deposits, in Contra Costa Hill, $12,14,15$.

in Monte Diablo Group, 27, 31, 3:3, 35, 38.

in Mount Hamilton Group, 44. 50.

in Monte Diablo Range, 52, 56, 57.

on peninsula of San Francisco, $62.2,17 \%$, $69,70,79$.

north of San Francisco Bay, 82, 102, 103.

south of Los Angeles, 167, 170, 173.

near Cañada de las Uvas, 187, 188, 191, 194.

in foot-hills of Sierra, 201, 211 .

on west slope of Sierra. 269, 271, 303.

Texas Flat, 202, 242.

Thomas's Mill, 368.

Three Brothers, Yosemite, 411.

Three Devils, 357.

Thurston's Lake, 97.

Tin, in Temescal Range, 181. near Weaverville, 181.

'Todd's Talley, 287.

Tomales Bay, 83.

Topography of California, simplicity of, 3 . Tower Rocks, near Monte Diablo, 27.

Trap dylies in limestones, 326.

Trask, Di. J. B., cited, 202, 203, 280, $327^{\circ}$.

Tres Pinos, 53.

Triassic fossils near Gifford's Ranch, 280, 309.

near Spanish Flat, 279.

Triassic rocks, in Inyo Mountains, 459.

Trinity Mountains, 323, 331.

Trinity River, fossils in, 324 .

Triunfo Ranch, 123.

Tufa, calcareous, near Monte Diablo, 25. at Texas Flat, 242.

Tulare Talley, 187. south end of, 192.

Tulé River, 222.

Tunnels in Table Mountain, 248. 
'Tuolumne County, 232.

River, 426.

Valley, Upper, risit to, reconmended, 404.

Tuscan Springs, 206. section at, 207.

Tuttletown, mills near, 239.

Tutucanula, 410.

Twin Sisters, 104.

Tyndall, Mount, 382.

ascerit of, 384 .

view from, 386.

Unaltered strata at base of Sierra Nevada, 199, 329 .

Unicorn Peak, 427.

Union Mine, 256.

Upheaval, systems of, in southern Coast Ranges, 110.

Upper Tuolumne Valley, 427.

Uvas, Cañada de las, 190.

Vacca Mountains, 104.

Vallejo, rocks near, 102.

Van Dorn's map, 462.

Veatch, Dr. J. A., cited, 98, 99, 207.

Vegetation at hot springs, 96 . near Téjon, 197.

Vein, great quartz, in Tuolumne County, 237.

Vernal Fall, 418.

Volcanic deposits, in Monte Diablo Group, 32.

in Mount Hamilton Group, 47.

at and about Mt. St. Helena, 86, 87, 95, $100,103,104$.

near Sonoma, 107.

on Sta. Catalina Island, 183.

near Téjon, 191, 195.

in foot-hills of Sierra, 205, 208.

on western slope of Sierra, 214, 232, $241,244,253,254,258,265,266,277$, $278,283,286,296,299,301,306,307$, $310,314,317,319,330,344,350$.

in High Sierra, 397, 400, 439, 441, 445, $446,449,453,454,458,460,468$.

Volcanic action, instances of, 95, 97, 174, $315,340,448,453$.

Volcano, 275.

quartz mine near, 275 .

Wackenreuder's topographical work, 288, 443.

Waldo, 359.

Walker's Basin, 218.

Walker's Pass, 220.

Walnut Creek, geology of region near, 13.

Warm Springs, Owen's Valley, 458.

Washes from the Sierra, 457.

Water-falls, Bridal Veil, 410.

Yosemite, 413.

Vernal and Nevada, 418.

Water of Mono Lake, 452.

Watkins, C. E., photographs of Yosemite, 408.

Waugh's Ferry, 325, 326.

Well Lode, 294.

West Point, 264.

Whale, bones of, 137 .

White Mountains, 387, 456.

White Mountain peaks, probable height of, 460.

White River, 201.

Whitman Vein, 275.

Whitney, Mount, 382. ascent of, 390 .

Williamson, Najor, U. S. E., cited, 195, $217,347,382,473,474$.

Williamson, Mount, 382, 386.

Wilson's Ranch, fossil oysters near, 140.

Wood, fossil, in Monte Diablo Group, 31, 38. under Table Mountain, 249.

in Calaveras County, 265.

in Placer County, 287.

in Nevada County, 296; 297.

in northern counties, $320,353$.

Wooden Valley, 105.

Wosnessensky, 86.

Yalloballey, 325.

Yaney Mill, 240.

Yankee Jim's, 287.

Yreka, scenery on road to, 325.

roads to, from Shasta City, 325.

Yosemite Fall, 413.

Yosemite Valley, description of, 407.

Gardner and King's map of, 405, 421

origin of, 421.

photographs of, 408.

sections across, 409, 416.

Zine, sulphuret of, 238, 282.

Zinc House, copper ores near, 294. 




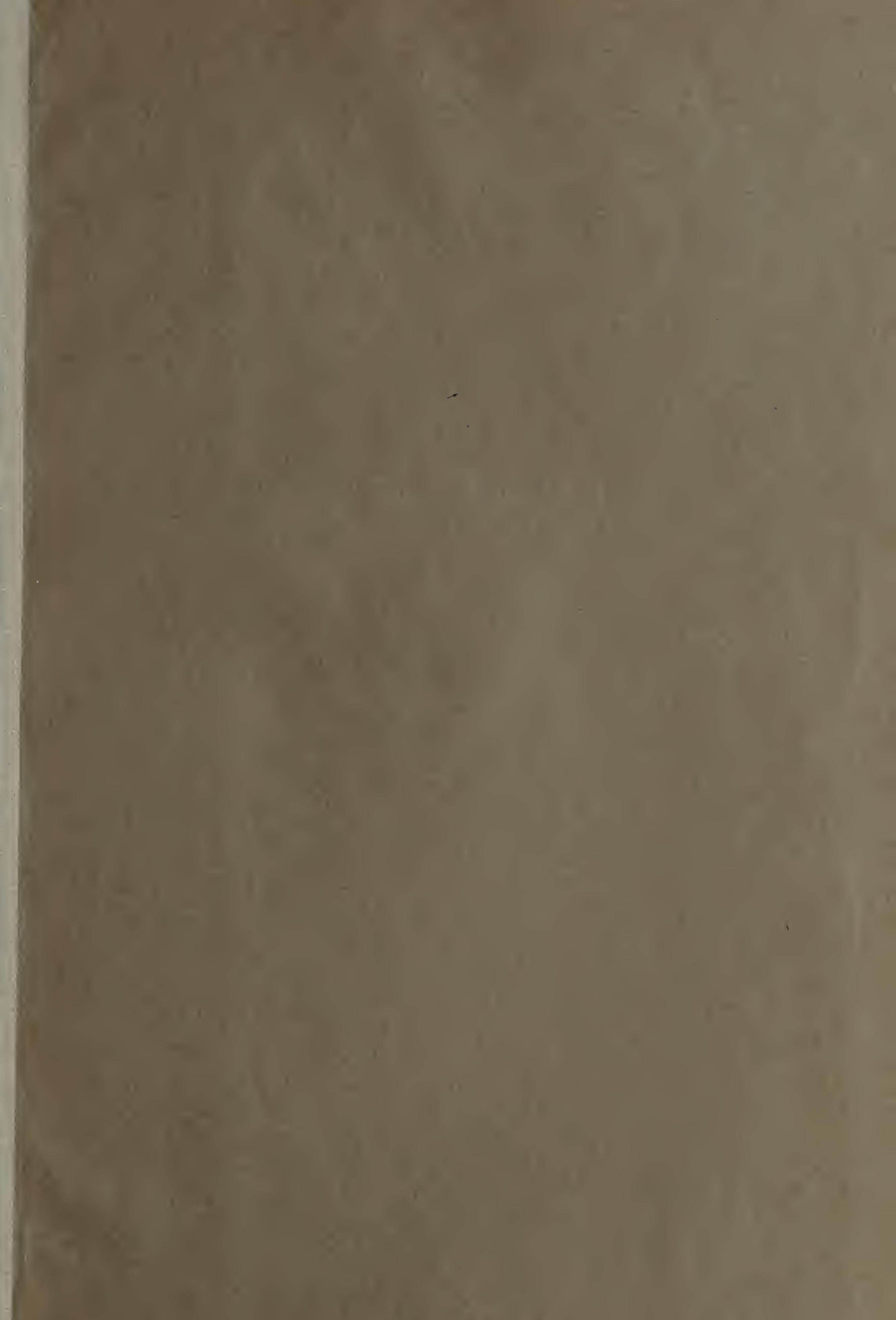




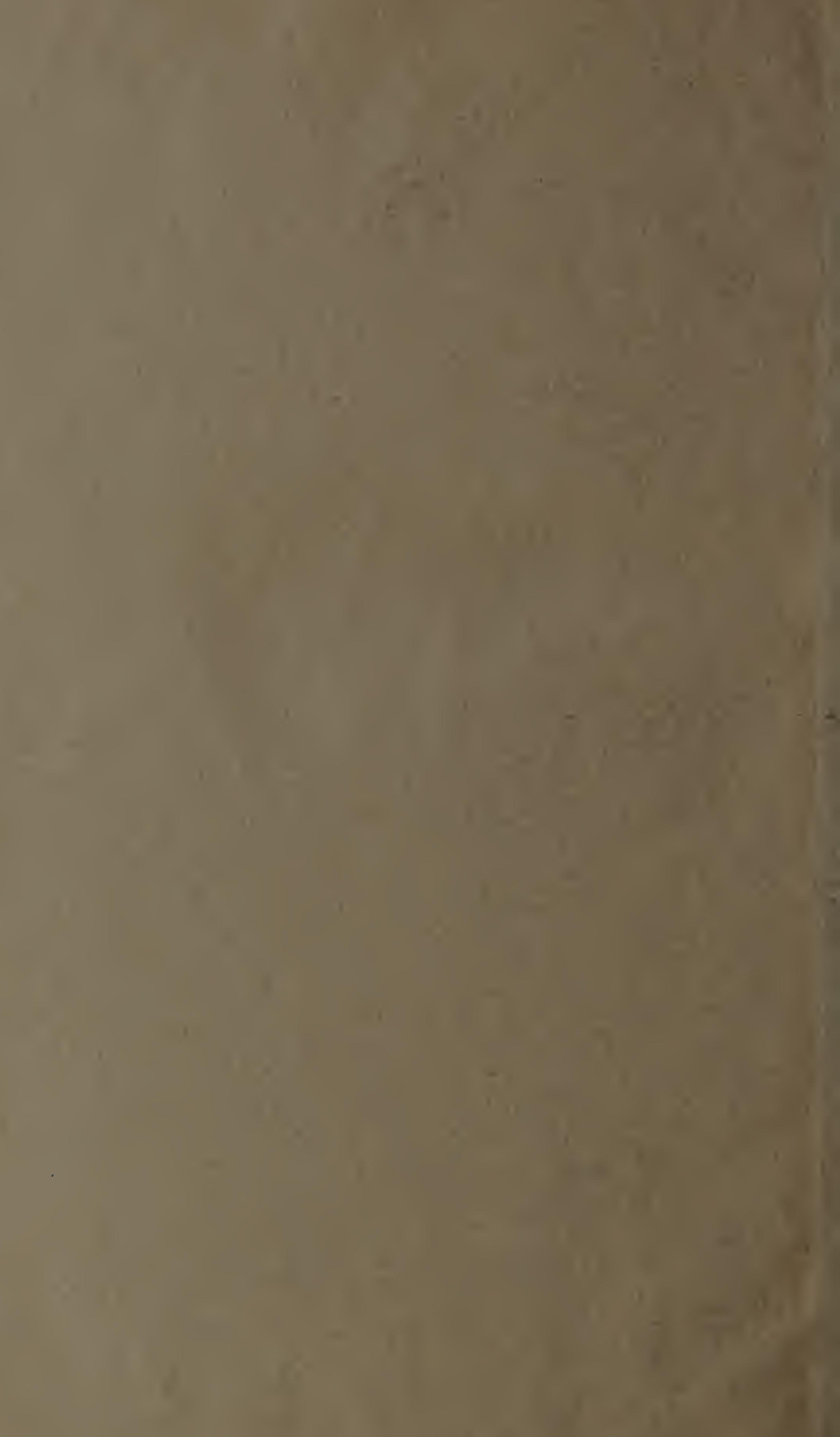




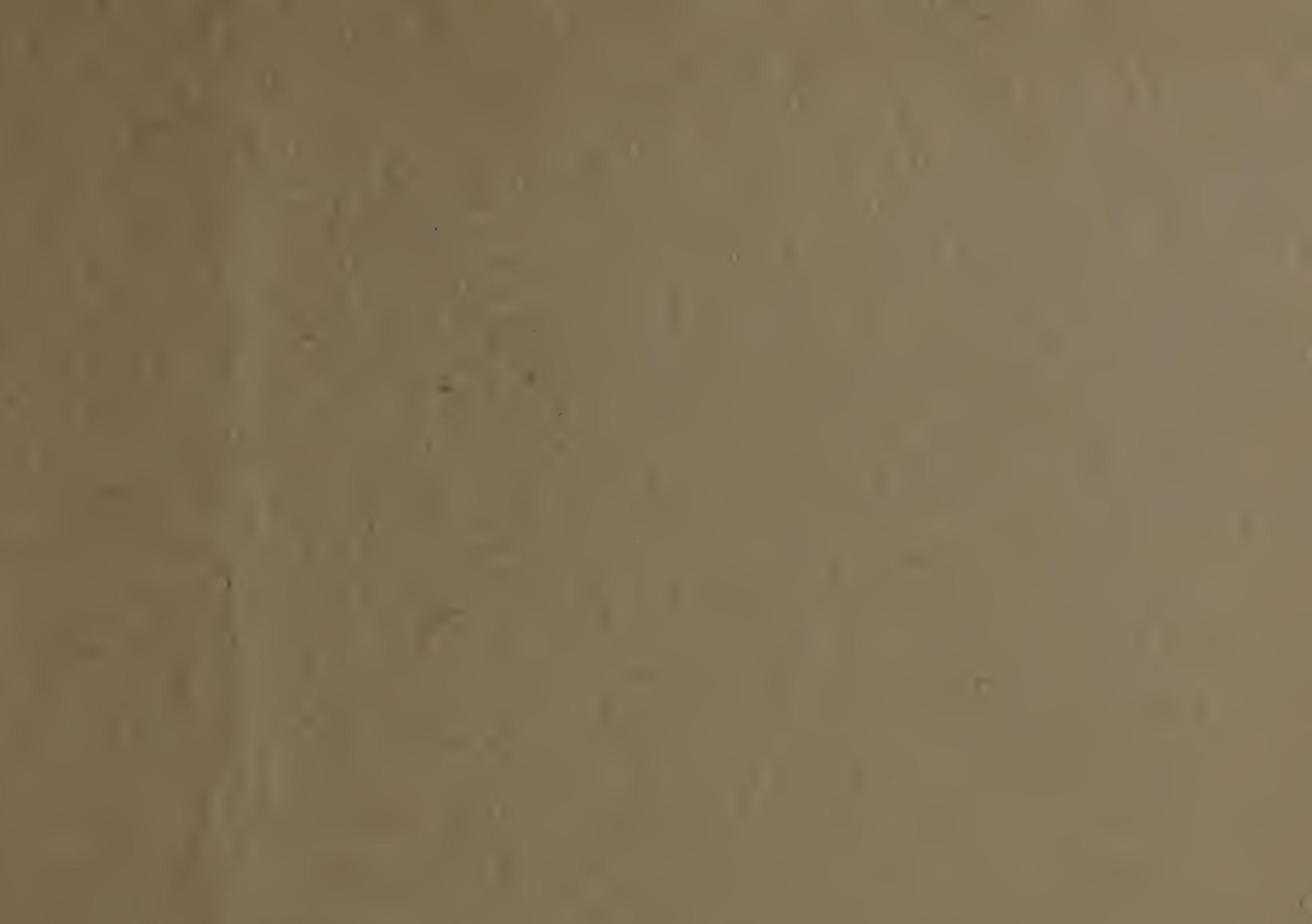

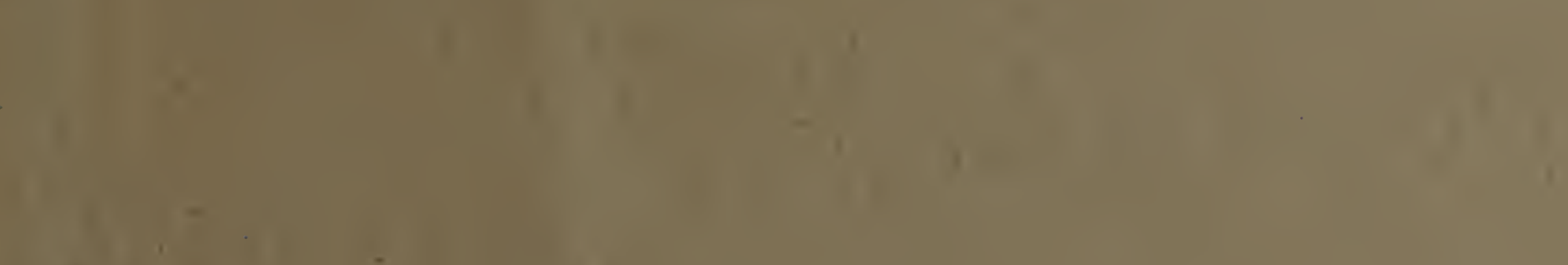

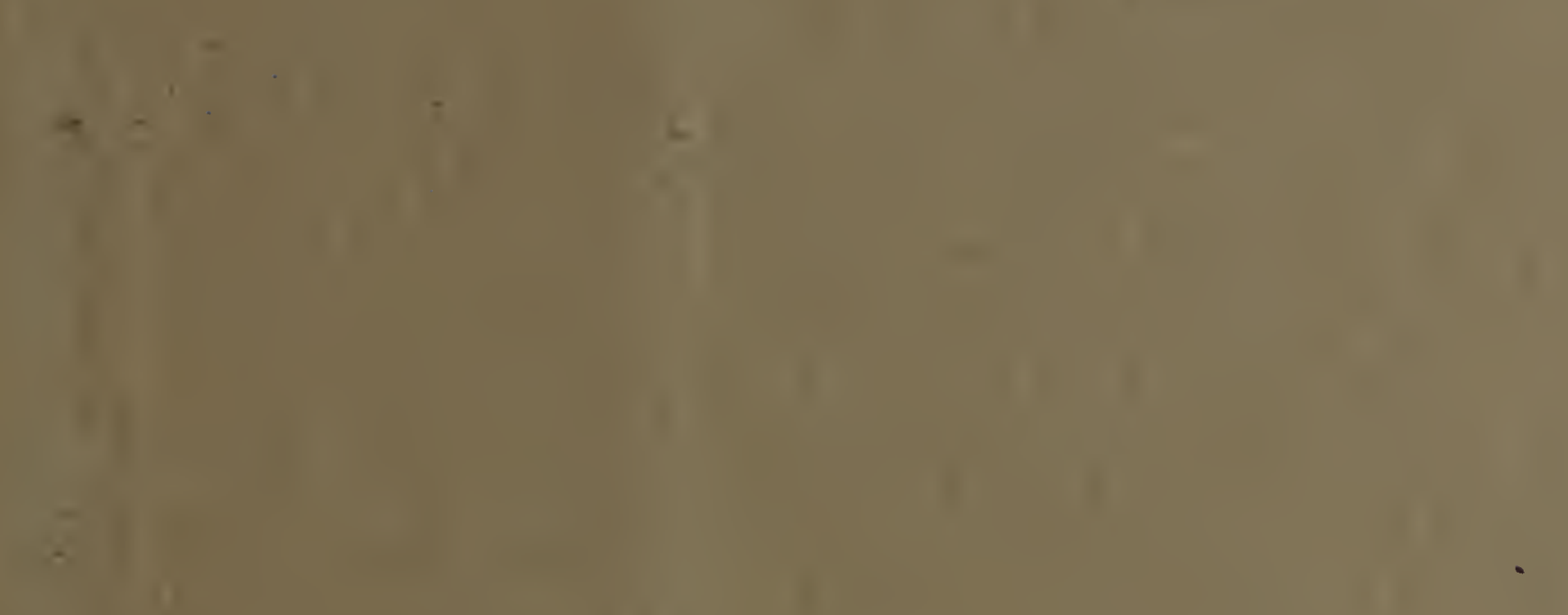

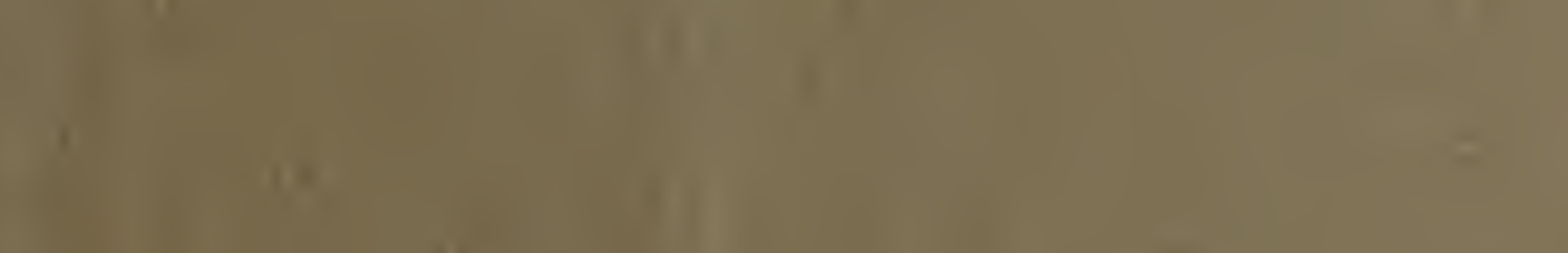

(1)

1

1.:1 $1=$

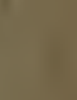

1.11:

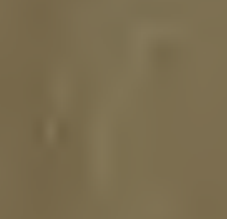

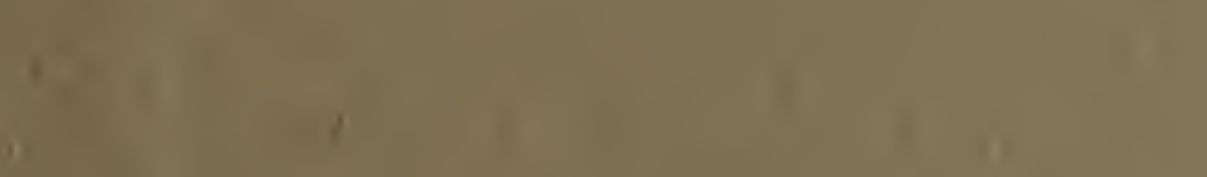

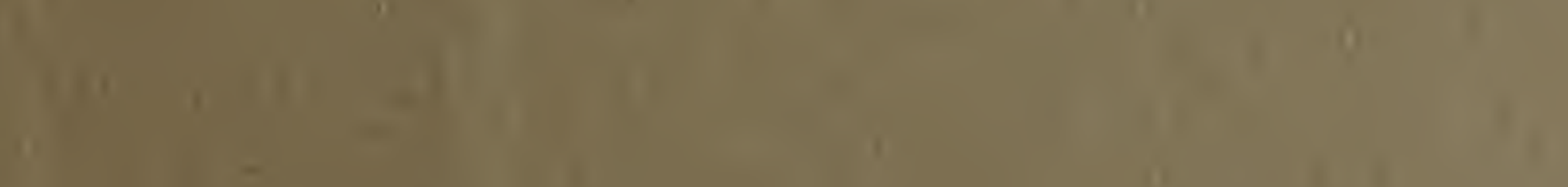

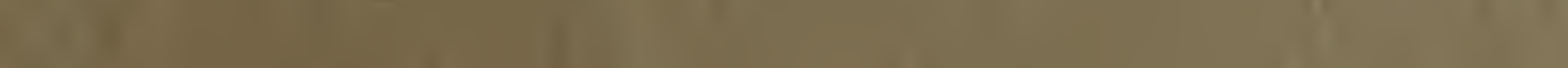


UNIVERSITY OF ILLINOIS-URBANA

|| || || || ||| || || || || || |||||||||||||||||||||||||||||

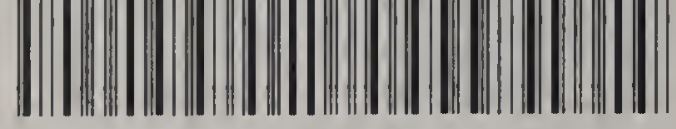

30112032285790 